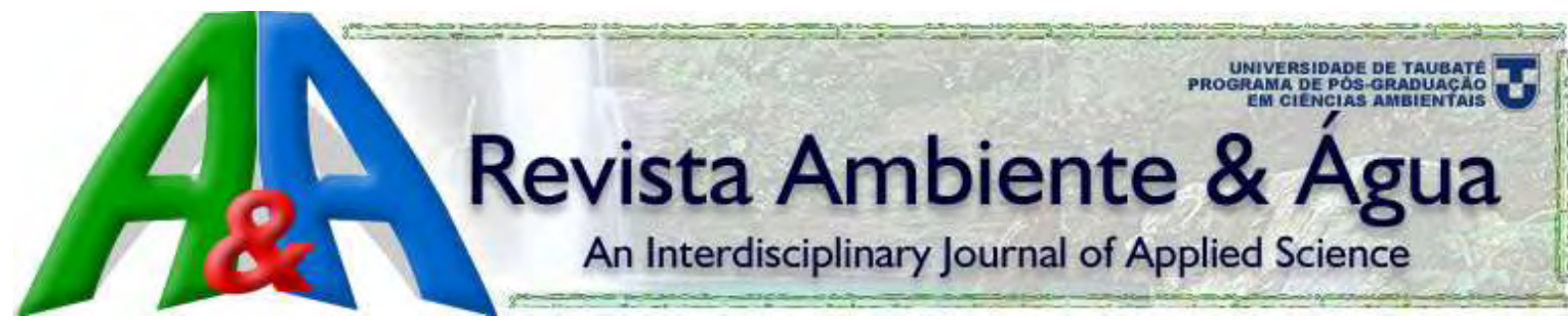

(a)

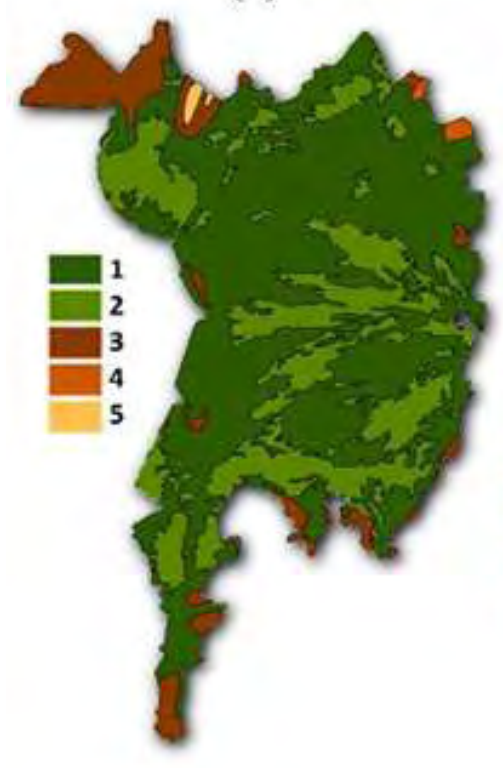

(b)

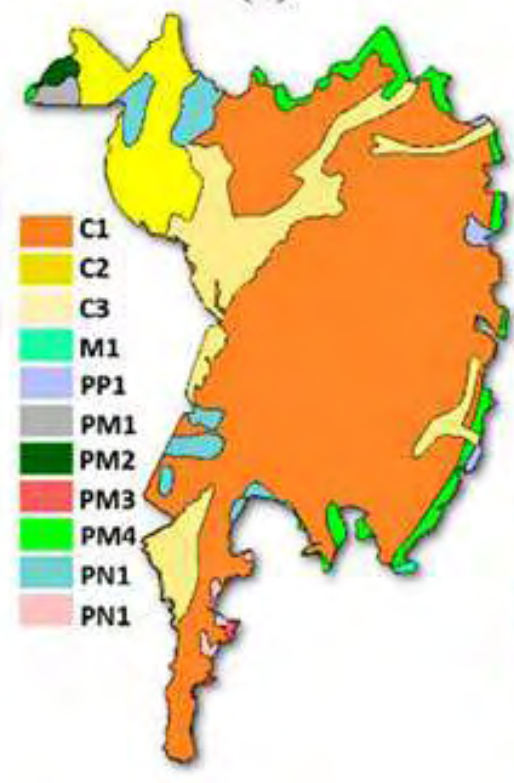

(c)

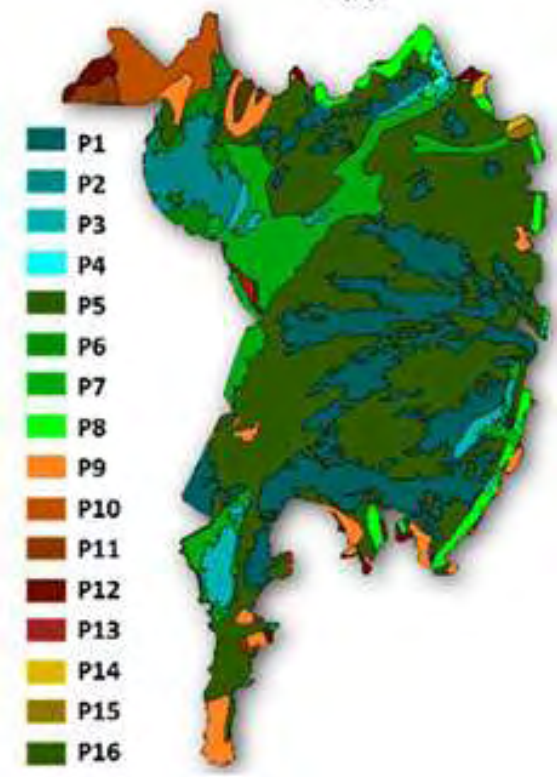

ISSN = 1980-993X (Online)

www.ambi-agua.net

Edição 18 da Revista Ambiente \& Água - An Interdisciplinary Journal of Applied Science, Taubaté, v. 7, n. 1, p. 1-280, Abril 2012. (doi:10.4136/ambi-agua.v7.n1) 


\section{EDITORIAL BOARD}

\section{Editor}

\section{Getulio Teixeira Batista}

Instituto de Pesquisas Ambientais em Bacias Hidrográficas (IPABHi), Brasil

\section{Associate Editors}

Amaury Paulo de Souza

Universidade Federal de Viçosa (UFV), Brasil

\section{Antonio Evaldo Klar}

Universidade Estadual Paulista Júlio de Mesquita Filho, UNESP, Brasil

\section{Dar Roberts}

Universityof Califórnia at Santa Barbara, US

Hans Raj Gheyi

Universidade Federal de Campina Grande (UFCG), Brasil

\section{Hélio Nóbile Diniz}

Instituto Geológico, Secretaria do Meio Ambiente do Estado de São Paulo (IG/SMA), Brasil

\section{João Vianei Soares}

Instituto Nacional de Pesquisas Espaciais (INPE), Brasil

\section{Editorial Section \\ Portuguese Text Editor \\ Text (EN e ES) Editors \\ Reference Editor \\ Layout Editors \\ Technical Support}

Luis A. Bartolucci

Florida International University (FIU), EUA

Marcelo dos Santos Targa

Universidade de Taubaté (UNITAU), Brasil

Nelson Wellausen Dias

Universidade de Taubaté (UNITAU), Brasil

Paul W. Mausel

Indiana State University (ISU), EUA

Paulo Renato Schneider

Universidade Federal de Santa Maria (UFSM), Brasil

\section{Sebastião do Amaral Machado}

Universidade Federal do Paraná (UFPR), Brasil

\section{Silvio Jorge Coelho Simões}

Universidade Estadual Paulista Júlio de Mesquita Filho (UNESP), Brasil

Yosio Edemir Shimabukuro

Instituto Nacional de Pesquisas Espaciais (INPE), Brasil

Nelson Wellausen Dias, PPGCA, UNITAU, Brasil

Maria de Jesus Ferreira Aires, GELP, UNITAU, Brasil

Getulio T. Batista, UNITAU \& Nelson W. Dias IBGE, BR

Liliane Castro, Biblioteca ECA/Civil, UNITAU, Brasil

Vera L. F. Batista, IPABHi \& Getulio T. Batista, UNITAU, BR

Tiago dos Santos Agostinho, LAGEO, UNITAU, Brasil

Library catalog entry by

SIBi - Sistema Integrado de Bibliotecas / UNITAU

Revista Ambiente \& Água - An Interdisciplinary Journal of

Applied Science / Instituto de Pesquisas Ambientais em

Bacias Hidrográficas. Taubaté. v. 7, n. 1 (2006)-

Taubaté: IPABHi, 2012.

Quadrimestral

ISSN 1980-993X.

1. Ciências ambientais. 2. Recursos hídricos. I. Instituto de Pesquisas Ambientais em Bacias Hidrográficas. III. Título.

$$
\begin{aligned}
& \text { CDD - 333.705 } \\
& \text { CDU - (03)556.18 }
\end{aligned}
$$




\section{ÍNDICE}

\section{CAPA}

Mapa de unidades morfométricas (a); Mapa da geologia (b); e Mapa das unidades de Paisagem (c) para o Bioma Pantanal.

Fonte: PEREIRA, G.; CHÁVEZ, E. S.; SILVA, M. E. S. O estudo das unidades de paisagem do bioma Pantanal. Ambi-Agua, Taubaté, v. 7, n. 1, p. 89-103, 2012. (http://dx.doi.org/10.4136/ambi-agua.826)

\section{EDITORIAL}

Reflections on the prospects for evaluation and qualified production of graduate programs in the Environmental Sciences (doi:10.4136/ambi-agua.879)

Marcelo dos Santos Targa

\section{ARTIGOS}

Nitrogen dynamics in soils cultivated with maize and fertilized with pig slurry (doi:10.4136/ambi-agua.782)

Denise de Freitas Silva; Camilo L. T. Andrade; Álvaro Vilela Resende; Clério Hickmann; Tales Antônio Amaral; Maria Emília Borges Alves

Changes in rainfall patterns in the eastern area of La Pampa province, Argentina (doi:10.4136/ambi-agua.692)

Silvia Pérez; Eduardo Sierra

Modeling annual discharge of six Mexico's northern rivers (doi:10.4136/ambi-agua.705)

Jose Návar

Groundwater chemistry of the Oban Massif, South-Eastern Nigeria (doi:10.4136/ambiagua.812)

Azubuike S. Ekwere; Aniekan E. Edet; Solomon J. Ekwere

Hydro-geochemical evaluation of groundwater quality in Akoko North West local government area of Ondo State, Nigeria (doi:10.4136/ambi-agua.851)

Temitope D. T. Oyedotun; Opeyemi Obatoyinbo

The effect of indigenous probiotics on egg hatchability and larval viability of Clarias gariepinus (doi:10.4136/ambi-agua.712)

Caroline N. Ariole; Gideon C. Okpokwasili

O estudo das unidades de paisagem do bioma Pantanal (doi:10.4136/ambi-agua.826)

Gabriel Pereira; Eduardo Salinas Chávez; Maria Elisa Siqueira Silva

Remoção dos corantes Reactive Blue 21 e Direct Red 80 utilizando resíduos de sementes de Mabea fistulifera Mart. como biossorvente (doi:10.4136/ambi-agua.854)

Julieta de Jesus da Silveira Neta; Carlos Juliano da Silva; Guilherme Costa Moreira; César Reis; Efraim Lázaro Reis

Utilização de lâmpadas germicidas na desinfecção de esgoto sanitário (doi:10.4136/ambiagua.845)

Patrícia Bilotta; Luiz Antonio Daniel

Sulfate and dissolved sulfide variation under low COD/Sulfate ratio in Up-flow Anaerobic Sludge Blanket (UASB) treating domestic wastewater (doi:10.4136/ambi-agua.849)

Eduardo Lucas Subtil; Sérvio Túlio Alves Cassini; Ricardo Franci Gonçalves 
Valores anômalos de metais pesados em solo de cemitério (doi:10.4136/ambi-agua.838)

Pedro Daniel da Cunha Kemerich; Willian Fernando de Borba; Rodrigo Ferreira da Silva;

Guilherme Barros; Ademir Eloi Gerhardt; Carlos Eduardo Balestrin Flores

Avaliação da integridade ecológica de rios em áreas do zoneamento ecológico econômico do complexo hidrográfico Guapiaçu-Macacu, RJ, Brasil (doi:10.4136/ambi-agua.762)

Priscilla da Silva Pereira; Lia Amorim Chaves Fernandes; Jaime Lopes da Mota Oliveira; Darcilio Fernandes Baptista

Caracterização geo-pedológica das áreas de nascentes na bacia hidrográfica do rio Piauitinga, Sergipe, Brasil (doi:10.4136/ambi-agua.767)

Leila Thais Soares Magalhães; João Bosco Vasconcelos Gomes; Anderson Nascimento do Vasco; Antenor de Oliveira Aguiar Netto; Robério Anastácio Ferreira

Conservação e reúso de águas usando o método Diagrama de Fontes de Água para processos em batelada: estudo de casos (doi:10.4136/ambi-agua.565)

Reinaldo Coelho Mirre; Shaula Christine Leal Ferreira; Aline Rodrigues Dias; Fernando Luiz Pellegrini Pessoa

Tratamento do lixiviado de aterro sanitário usando destilador solar (doi:10.4136/ambiagua.815)

Lidiane Freire de Sá; José Fernando Thomé Jucá; Maurício A. da Motta Sobrinho

Uso del modelado de nicho ecológico como una herramienta para predecir la distribución potencial de Microcystis sp (cianobacteria) en la Presa Hidroeléctrica de Aguamilpa, Nayarit, México (doi:10.4136/ambi-agua.607)

José L. Ibarra-Montoya; Gabriel Rangel-Peraza; Fernando A. González-Farias; José De Anda; Enrique Martínez-Meyer; Humberto Macias-Cuellar

Bacterias resistentes a antibióticos en aguas grises como agentes de riesgo sanitario (doi:10.4136/ambi-agua.638)

Lidia Nuñez; Carina Tornello; Noel Puentes; Juan Moretton

Qualidade da água de chuva armazenada em cisterna utilizada na dessedentação de suínos e bovinos de corte (doi:10.4136/ambi-agua.822)

Julio Cesar Pascale Palhares; Antônio Lourenço Guidoni

Avaliação de eventos de inundação na Região Norte Fluminense, Rio de Janeiro, utilizando imagens de sensores remotos (doi:10.4136/ambi-agua.817)

José Carlos Mendonça; Ramon Morais de Freitas; Yosio Edemir Shimabukuro; Valdo da Silva Marques

Modelagem do balanço hídrico em povoamentos de eucalipto sob diferentes manejos como auxílio ao gerenciamento do impacto hidrológico da atividade (doi:10.4136/ambi-agua.810)

Rosane Barbosa Lopes Cavalcante; Carlos André Bulhões Mendes 


\begin{tabular}{|c|} 
ISSN = 1980-993X - doi:10.4136/1980-993X \\
www.agro.unitau.br/ambi-agua \\
E-mail: ambi-agua@agro.unitau.br \\
Phone.: +55 (12) 3625-4212
\end{tabular}

\title{
Reflections on the prospects for evaluation and qualified production of graduate programs in Environmental Sciences
}

(doi:10.4136/ambi-agua.879)

\author{
Marcelo dos Santos Targa \\ Professor of the Master Degree Program in Environmental Sciences of the University of Taubaté \\ e-mail: mtarga@unitau.br
}

\begin{abstract}
In this editorial, we reflect on the evaluation criteria that is under discussion to be adopted for the assessment of CAPES (Brazilian Federal Agency for the Support and Evaluation of Graduate Education) Environmental Sciences area - CACiamb. This criteria aims to increase qualified production by simulating CAPES quality strata A1, A2, B1 and B2 production of Academic Master Degree Programs with 12 permanent professors based on the criteria established by the Interdisciplinary Area Committee - CAInter in 2007. As well as expectations for the adoption of periodic assessment of free access bases, along with fostering the use of scientific journals published online by Graduate Programs.
\end{abstract}

Keywords: Production, Master Degree; environment.

\section{Reflexões sobre as perspectivas de avaliação e produção qualificada dos programas de pós-graduação na área das ciências ambientais}

\section{RESUMO}

No presente editorial procurou-se refletir sobre os critérios de avaliação, em discussão, para serem adotados para área de avaliação Ciências Ambientais - CACiamb da CAPES, visando o aumento da produção qualificada por meio da simulação da produção nos extratos A1, A2, B1 e B2 de um Programa de Mestrado Acadêmico composto de 12 docentes permanentes com base nos critérios estabelecidos pelo Comitê da Área Interdisciplinar CAInter, em 2007, e as expectativas de adoção de bases livres no processo de avaliação de periódicos, bem como da maior utilização de revistas científicas on-line pelos Programas de Pós-Graduação.

Palavras-chave: Produção; mestrado; ambiente.

\section{INTRODUCTION}

The Graduate Program Evaluation System was deployed by the Coordination for the Improvement of Higher Education Personnel - CAPES in 1976 (CAPES, 2012a). Its Interdisciplinary Area (CAInter), in 2006, was organized into four Thematic Chambers: I Environment and Agriculture; II - Social and Humanities; III - Engineering, Technology and Management; and IV - Biology \& Medicine. Recognizing the complexity of environmental science, CAPES created, by the Ordinance 081 of June 6, 2011 (CAPES, 2011), the Area of Environmental Sciences - CACIAmb in Thematic Chamber I, that was effectively installed in the $1^{\text {st }}$ ReNaCiamb (CAPES, 2012c). 
TARGA, M. S. Reflections on the prospects for evaluation and qualified production of graduate programs in the Environmental Sciences. Ambi-Agua, Taubaté, v. 7, n. 1, p. 4-8, 2012. (http://dx.doi.org/10.4136/ambiagua.879)

All graduate programs have to submit information annually to CAPES using the Data Collection Platform. This information, once treated and consisted, allows the issuance of reports used in the evaluation process. Thus, CAPES makes public on the web a page containing a set of 11 reports for each program: 1.Teses and Dissertations; 2. Bibliographic Production; 3. Technical Production; 4. Artistic Production; 5. Faculty, Enrollment and Graduation; 6. Disciplines; 7. Research Thematic Focus; 8. Research Project; 9. Proposed Program; 10. Teaching Performance; and 11. Faculty Production (CAPES, 2012b).

The evaluation form consists of program indicators with different weights according to the degree of their importance. The main indicators measure the quality of both faculty and student participation in the activities of the Post-Graduate and related Undergraduate programs. The major indicator in most cases is the number of permanent faculty members. CAPES establishes the need for a strong and solid ties of the institution's faculty to the program, because production of collaborative teaching staff is counted only when there is joint production with permanent faculty members and students.

The $1^{\text {st }}$ ReNaCiamb (CAPES, 2012c) rose in the Environmental Sciences Area, the need to broaden the discussion of the evaluation procedure for this new Post-Graduation area to allow dialogue and community participation in the definition of parameters and criteria. However, as a first step, it is very natural and appropriate that the criteria previously used by the interdisciplinary area would be also used for the new environmental area, and particularities of this new area are to be incorporated progressively as discussions are settled.

The evaluation criteria for the Interdisciplinary Program Area (CAInter) are given in Table 1 (CAPES, 2009). It can be observed that for a program with grade 3 to improve its grade, criterion 3 (Student Body, Thesis and Dissertations) and 4 (Intellectual Production) must reach at least the "good" concept. The major difficulty faced by the programs refers to the joint qualified production of faculty and students, especially in scientific journals. Some of the reasons that have been reported by the coordinators of the programs are: a) lack of perseverance of the graduated students to follow the later stages after an article was submitted to a journal; b) non-academic professional performance of graduates hampers the co-authored production; and, c) the long time between submission and publication in a qualified scientific journal.

Table 1. Summary of program evaluation criteria of CAPES Interdisciplinary Area.

\begin{tabular}{ccccc|c}
\hline $\begin{array}{c}\text { 1. Program } \\
\text { Proposal }\end{array}$ & $\begin{array}{c}\text { 2. Faculty } \\
\mathbf{( 2 0 \% )}\end{array}$ & $\begin{array}{c}\text { 3. Student Body, } \\
\text { Theses and } \\
\text { Dissertations } \\
\text { (35\%) }\end{array}$ & $\begin{array}{c}\text { 4. Intellectual } \\
\text { production } \\
(\mathbf{3 5 \% )}\end{array}$ & $\begin{array}{c}\text { 5. Social } \\
\text { Inclusion } \\
(\mathbf{1 0 \%})\end{array}$ & Grade \\
\hline $\mathrm{VG}$ & $\mathrm{VG} / \mathrm{G}$ & $\mathrm{VG}$ & $\mathrm{VG}$ & $\mathrm{VG} / \mathrm{G}$ & 5 \\
$\mathrm{G}$ & $\mathrm{G} / \mathrm{R}$ & $\mathrm{G}$ & $\mathrm{G}$ & $\mathrm{G} / \mathrm{R}$ & 4 \\
$\mathrm{G} / \mathrm{R}$ & $\mathrm{R}$ & $\mathrm{R}$ & $\mathrm{R}$ & $\mathrm{R} / \mathrm{P}$ & 3 \\
$\mathrm{P}$ & $\mathrm{R} / \mathrm{P}$ & $\mathrm{P}$ & $\mathrm{R} / \mathrm{P}$ & $\mathrm{P}$ & 2 \\
$\mathrm{D}$ & $\mathrm{D}$ & $\mathrm{D}$ & $\mathrm{D}$ & $\mathrm{D}$ & 1 \\
\hline
\end{tabular}

Note: VG-Very Good G-Good, R-Regular, P-Poor, D-Deficient.

Source: CAPES (2009), adapted by the author.

We emphasize the importance of the criteria 3 and 4 , both with $35 \%$ weight in the program evaluation concept (Table 1). Within criterion 3, Student Body, Thesis and Dissertation, the item 3.3, that refers to the quality of thesis and the production of graduate and undergraduate students authorship, has $50 \%$ weight in this criterion and reflects the measure of the proportion of students who are authors of full articles in relevant scientific 
TARGA, M. S. Reflections on the prospects for evaluation and qualified production of graduate programs in the Environmental Sciences. Ambi-Agua, Taubaté, v. 7, n. 1, p. 4-8, 2012. (http://dx.doi.org/10.4136/ambiagua.879)

journals and conferences, as well as books and book chapters and technological production based on the relevant indicators IndAut and IndQual (CAPES, 2009).

The IndAut is a relative measure of the number of postgraduate students that are authors of full articles in journals or annals of scientific meetings, of relevant books or book chapters, and of relevant technological/artistic production. While the IndQual is a relative measure of average intellectual production of the permanent professor staff with the participation of graduate students, including those graduated up to three years after graduation.

The fourth criterion, Intellectual Production (Table 1), includes an item 4.1. that refers to qualified publications by the permanent faculty members with a weight of $55 \%$ and it is measured by the IndProd (Equation 1) that reflects the qualified production in journal articles, books, book chapters and of technology products by the permanent teaching staff of the program (CAPES, 2009). There is a clear induction by CAPES to foster joint publications in high qualified journals. This brings a lot of pressure and responsibility on professors and students, as already stated by Silva (2009).

$\operatorname{IndProd}=(1.0 * \mathrm{~A} 1 * \mathrm{~A} 2+0.85+0.55+0.7 * \mathrm{~B} 1 * \mathrm{~B} 2 * \mathrm{~B} 3+0.25+0.4+0.1 * \mathrm{~B} 4 * \mathrm{~B} 5+\mathrm{B}+\mathrm{BC}+\mathrm{Tec}) /$ (number of permanent staff)

where:

A1, A2, B1, B2, B3, B4, and B5 = number of articles published in journals of CAPES Qualis A1, $\mathrm{A} 2, \mathrm{~B} 1, \mathrm{~B} 2, \mathrm{~B} 3, \mathrm{~B} 4$, and B5 for all teachers of the program;

$\mathrm{B}$ and $\mathrm{BC}=$ number of books $(\mathrm{B})$ and Book Chapters $(\mathrm{BC})$ published by all professors of the program;

Tec $=$ Number of Tec Products Technology $(\mathrm{Tec})$ published by all teachers of the Program

The performance indicator of the average annual scientific production of the Interdisciplinary Area for academic post-graduate programs is shown in Table 2, which clearly spells out the minimum scores to achieve an attribute concept. The scores have to be distributed to all permanent professors.

Table 2. Performance indicators of the average annual scientific production of Interdisciplinary Area for academic post-graduate programs.

\begin{tabular}{c|l}
\hline Attribute & \multicolumn{1}{|c}{ Production Indicator (IndProd) annual average } \\
\hline VG & $\begin{array}{l}\text { IndProd }=1.2 \text { - Distribution by faculty }>\text { Scientific production and } \\
50 \% \text { for permanent teaching must necessarily be } \geq 1.0\end{array}$ \\
\hline G & $\begin{array}{l}\text { IndProd }=0.8 \text { - Distribution by faculty> Scientific production and } \\
50 \% \text { for permanent teaching must necessarily be } \geq 0.7\end{array}$ \\
\hline $\mathrm{R}$ & $\begin{array}{l}\text { IndProd }=0.5 \text { - Distribution by faculty }>\text { Scientific production and } \\
50 \% \text { for permanent teaching must necessarily be } \geq 0.4\end{array}$ \\
\hline $\mathrm{P}$ & $\begin{array}{l}\text { IndProd }=0.3 \text { - Distribution by faculty> Scientific production and } \\
50 \% \text { for permanent teaching must necessarily be } \geq 0.25\end{array}$ \\
\hline $\mathrm{D}$ & None of the indices is achieved \\
\hline
\end{tabular}

Note: VG- Very Good, G-Good, R-Regular, P-Poor, D-Deficient.

Source: CAPES (2009) adapted by the author.

A simulation of production score values in journals with CAPES Qualis A1, A2, B1 and B2 using Equation 1 to calculate the IndProd for a Master Degree Academic Program that has 12 teachers is presented in Table 3. It can be observed that if they produce only 12 Articles in one year, the professor production score, IndProd, will be equal to 0.59 and it will not pass the Regular (R) concept, even if the production concentrates in the most qualified journals. Thus 
it is clear the need to increase production to a minimum of two articles per each member professor, in the same extracts, in order for the IndProd to achieve a Good $(G)$ concept, for a Very Good (VG) concept, the production of the program would have to be tripled.

Table 3. Simulation Values of IndProd for an academic master's program.

\begin{tabular}{c|c|c|c|c|c}
\hline \multirow{2}{*}{$\begin{array}{c}\text { CAPES Qualis } \\
\text { of journals }\end{array}$} & \multicolumn{5}{|c}{ Number of articles } \\
\cline { 2 - 6 } & $\mathbf{1 2}$ & $\mathbf{1 2}$ & $\mathbf{1 2}$ & $\mathbf{2 4}$ & $\mathbf{3 2}$ \\
\hline A1 & 2 & 0 & 1 & 2 & 3 \\
A2 & 1 & 2 & 2 & 3 & 2 \\
B1 & 5 & 12 & 4 & 10 & 8 \\
B2 & 0 & 2 & 5 & 10 & 18 \\
Average /Professor & 1 & 1 & 1 & 2 & 2.66 \\
IndProd & 0.51 & 0.58 & 0.59 & 1.01 & 1.25 \\
Grade & $\mathrm{R}$ & $\mathrm{R}$ & $\mathrm{R}$ & $\mathrm{G}$ & $\mathrm{VG}$ \\
\hline
\end{tabular}

Note: R-Regular, G-Good, VG- Very Good.

Source: CAPES (2009) adapted by the author.

The Qualis System was designed to improve the process of journal classification, so far lacking systematization and produced by artisanal and non-uniform means (Souza and Paula, 2002). In this sense, the evaluation criteria, proposed in the $1^{\text {st }}$ ReNaCiamb for Qualis Scientific Periodicals, was to take into account A1 to B5 layers and JCR and SciELO indexed journals, and other indexing databases such as BIOISIS, CAB, EconLit, FSTA, GEOREF, INDEX-PSI, LILACS, MATHSCI, MEDLINE, MLA, Philosopher, PYSCINFO, PUBMED, and SPORT DISCUS. It takes into account also if the journal is in the CAPES portal, if it has qualified and recognized editorial board, well established peer review procedure, and if it is edited by a scientific society, university or a research institution (CAPES, 2011).

\section{FINAL REMARKS}

Most indexing databases in adoption by CACiamb (environment), along with CAInter (interdisciplinary), emphasize only the Health area and, therefore, do not adequately cover the entire subject of most graduate courses that are grouped in his new area, which focuses in more comprehensive environmental research than just Health. Thus, the use of indices with greater scope and preferably freely accessible bases is recommended, as they would allow the analysis of all journals in an equal basis without leaving out emerging journals (Dias and Batista, 2010).

Online publication of scientific journals should be encouraged by CAPES, because they reduce the time for publication and have additional benefits when the access is free, such as facilitating research findings, maximizing the interaction between research groups, optimizing efforts, and increasing the efficiency of research funding, in addition to the improved visibility and increase in the number of citations, as previously observed (Lawrence, 2001; Batista, 2007). 


\section{REFERENCES}

BATISTA, G. T. Scientific journal indexing. Ambi-Agua, Taubaté, v. 2, n. 2, p. 3-6, 2007. (http://dx.doi.org/10.4136/ambi-agua.22).

COORDENAÇÃO DE APERFEIÇOAMENTO DE PESSOAL DE NÍVEL SUPERIOR CAPES. Avaliação da pós-graduação. 2012a. Available in: <http://capes.gov.br/ avaliacao/avaliacao-da-pos-graduacao>. Access in: April 2012.

COORDENAÇÃO DE APERFEIÇOAMENTO DE PESSOAL DE NÍVEL SUPERIOR CAPES. Cadernos de indicadores. 2012b. Available in: <http://conteudoweb.capes. gov.br/conteudoweb/CadernoAvaliacaoServlet>. Access in: April 2012.

COORDENAÇÃO DE APERFEIÇOAMENTO DE PESSOAL DE NÍVEL SUPERIOR CAPES. Minuta do documento de área 2011. In: Ciências ambientais. 2011. p. 1-50. Available in: <http://www.capes.gov.br/component/content/article/44-avaliacao/ 4688-ciencias-ambientais>. Access in: April 2012.

COORDENAÇÃO DE APERFEIÇOAMENTO DE PESSOAL DE NÍVEL SUPERIOR CAPES. Reunião de coordenadores PPG In: Ciências ambientais. 2012c. Available in: http://www.capes.gov.br/component/content/article/44-avaliacao/4688ciencias-ambientais>. Access in: April 2012.

COORDENAÇÃO DE APERFEIÇOAMENTO DE PESSOAL DE NÍVEL SUPERIOR CAPES. Documento de área - 2007-2009. In: Interdisciplinar. 2009. p. 1-122. Available in: <http://www.capes.gov.br/component/content/article/44-avaliacao/4674interdisciplinar>. Access in: April 2012.

DIAS, N. W.; BATISTA, G. T. As revistas científicas da base SciELO, seus indicadores de impacto e a posição relativa da Ambiente \& Água. Ambi-Agua, Taubaté, v. 5, n. 3, p. 4-9, 2010. (http://dx.doi.org/10.4136/ambi-agua.151).

LAWRENCE, S. Online or invisible? Nature, v. 411, n. 6837, p. 521, 2001.

SILVA, M. G. M. A produção docente e a avaliação dos programas de pós-graduação: um estudo na pós-graduação da UFMT. R. Educ. Públ., Cuiabá, v. 18, n. 37, p. 383-401, maio/ago. 2009.

SOUZA, E. P.; PAULA, M. C. S. Qualis: a base de qualificação dos periódicos científicos utilizada na avaliação CAPES. InfoCAPES, v. 10, n. 2, p. 6-24, 2002. 


\begin{tabular}{ccc|} 
ISSN = 1980-993X - doi:10.4136/1980-993X \\
www.ambi-agua.net \\
E-mail: ambi-agua@agro.unitau.br \\
Tel.: (12) 3625-4212
\end{tabular}

\title{
Nitrogen dynamics in soils cultivated with maize and fertilized with pig slurry
}

\author{
(http://dx.doi.org/10.4136/ambi-agua.782)
}

\author{
Denise de Freitas Silva ${ }^{1}$; Camilo L. T. Andrade ${ }^{1}$; Álvaro Vilela Resende ${ }^{1}$; Clério \\ Hickmann²; Tales Antônio Amaral $^{3}$; Maria Emília Borges Alves ${ }^{4}$ \\ ${ }^{1}$ Embrapa Maize and Sorghum, Sete Lagoas, MG \\ e-mail: denisefreitassilva@ oi.com.br; camilo@cnpms.embrapa.br; \\ alvaro@cnpms.embrapa.br; \\ ${ }^{2}$ Universidade Federal de Lavras, Lavras, MG \\ e-mail: clerioh@gmail.com; \\ ${ }^{3}$ Universidade Federal de Pelotas, Pelotas, RS \\ e-mail: tales_aamaral@yahoo.com.br; \\ ${ }^{4}$ National Agriculture Confederation, Brasília, DF \\ e-mail: mebalves@hotmail.com
}

\begin{abstract}
The proper disposal of pig manure is of great importance because, when mishandled, it can contaminate water resources. This study aimed to evaluate the nitrogen dynamics in a Cerrado Oxisol and its absorption, over time, by a maize crop managed with pig slurry associated with mineral fertilization (N P K). The study was conducted at a private farm, in the region of Sete Lagoas, Minas Gerais, Brazil. The maize crop was able to recover $62 \%$ of the mineral nitrogen that entered the soil-plant system, while $9 \%$ leached as nitrate and, to a lesser amount, as ammonium. The maximum average content of nitrate and ammonium of 92 $\mathrm{kg} \mathrm{ha}^{-1}$ and $43 \mathrm{~kg} \mathrm{ha}^{-1}$, respectively, was observed in the 0 to $0.3 \mathrm{~m}$ soil layer during the early crop development stage. A minimum content of $5.8 \mathrm{~kg} \mathrm{ha}^{-1}$ of nitrate and $9.0 \mathrm{~kg} \mathrm{ha}^{-1}$ of ammonium, respectively, was measured at the end of the cycle. In addition, the nitrate content at that soil layer, at the end of the maize cycle, remained below the values measured at the native Cerrado, indicating that the agricultural use of the land poses no additional risk to the nitrate accumulation and leaching into the soil profile.
\end{abstract}

Keywords: environmental contamination; leaching; maize yield; Zea mays L..

\section{Dinâmica do nitrogênio em Latossolo cultivado com milho e adubado com dejetos líquidos de suínos}

\section{RESUMO}

A destinação adequada dos dejetos suínos é de grande relevância, pois quando mal manejada, pode provocar contaminação de recursos hídricos. Este trabalho teve como objetivo avaliar a dinâmica do nitrogênio no perfil de um Latossolo sob Cerrado e a sua absorção, ao longo do tempo, pela cultura do milho, manejada com uso de dejetos líquidos de suínos, associado à adubação mineral (N P K). O estudo foi realizado em uma propriedade particular da região de Sete Lagoas, MG, Brasil. A cultura recuperou $62 \%$ do nitrogênio mineral que entrou no sistema solo-planta, enquanto $9 \%$ lixiviou na forma de nitrato e, em menor quantidade, na forma de amônio. Teores médios máximos de nitrato e amônio de $92 \mathrm{~kg} \mathrm{ha}^{-1} \mathrm{e}$ de $43 \mathrm{~kg} \mathrm{ha}^{-1}$, respectivamente, foram observados na camada 0-0,3 $\mathrm{m}$ no início do 
SILVA, D. F; ANDRADE, C. L.T.; RESENDE, A. V.; HICKMANN, C.; AMARAL, T. A.; ALVES, M. E. B. Nitrogen dynamics in soils cultivated with maize and fertilized with pig slurry. Ambi-Agua, Taubaté, v. 7, n. 1, p. 9-23, 2012. (http://dx.doi.org/10.4136/ambi-agua.782)

desenvolvimento da cultura. Conteúdos mínimos de $5,8 \mathrm{~kg} \mathrm{ha}^{-1}$ de nitrato e de $9,0 \mathrm{~kg} \mathrm{ha}^{-1}$ de amônio, foram medidos no final do ciclo. Além do mais, os teores de nitrato naquela camada, ao final do ciclo da cultura do milho, mantiveram-se abaixo dos valores observados do Cerrado nativo, indicando que o uso agronômico da terra não ofereceu risco adicional de acúmulo e lixiviação de nitrato no perfil do solo.

Palavras-chave: contaminação ambiental; lixiviação; produtividade de milho; Zea mays L..

\section{INTRODUCTION}

Brazilian swine production has risen sharply in recent decades, as a result of effective use of technologies associated with animal breeding, balanced feeding, and management in various forms of animal confinement. As a result, productivity has increased, resulting in large concentrations of animals per unit area, along with large accumulations of organic wastes. These are of great importance from a technical and environmental point of view since, when mishandled, animal manure can cause water resource contamination (Seidel et al., 2010). Recently, the Brazilian Ministry of Agriculture launched an incentive program for lowcarbon agriculture, with proper treatment and disposal of pig slurry as one of its priorities (Brasil, 2010).

The use of pig slurry as fertilizer is one of the correct destinations of this waste, because it allows nutrient cycling within the production unit, making the system sustainable. The fertilizer potential of pig slurry is often attributed to its different concentrations and amounts of nutrients, especially nitrogen (Ceretta, 2003; Giacomini and Aita, 2008; Giacomini et al., 2009). This makes it a promising fertilization alternative for crops, such as maize, that demand large amounts of nitrogen. However, it should be used with caution, as factors related to the imbalance between soil nutrient availability and plant demand can cause some ionselective accumulation in the soil (Ceretta, 2003). The rate of slurry to be applied to the field depends on the pig slurry's fertilizer value, on the soil characteristics and chemical tests, and on crop nutrient requirements. However, when there has been no previous chemical analysis of the manure, Konsen (2003) recommends using 40 to $90 \mathrm{~m}^{3} \mathrm{ha}^{-1}$ for conventionally managed maize, and 50 to $100 \mathrm{~m}^{3} \mathrm{ha}^{-1}$ for the no-tillage maize grown in Cerrado soils.

In Brazil, information about soil organic matter content and previous crop biomass have been used as the main indication of nitrogen release from the soil during the crop cycle, assuming that the $\mathrm{N}$ present in soil organic matter and in the previous crop biomass will be mineralized in time to be absorbed by the current crop (Amado et al., 2002).

Nitrate $\left(\mathrm{NO}_{3}{ }^{-}\right)$leaching is considered the main loss of $\mathrm{N}$ in cultivated soils, and it is directly influenced by the factors that determine the soil water flow and the $\mathrm{NO}_{3}{ }^{-}$ concentration in the soil solution (White, 1987). The greater the soil-water storage capacity, the lower the water's deep percolation and, therefore, the lower the $\mathrm{NO}_{3}{ }^{-}$leaching (Bortolini et al., 2000).

Another important factor in the dynamics of nutrients is related to the soil's physicochemical properties, which affect the balance of charges and the specific surface of clay particles in the subsurface soil layers. The adsorption of $\mathrm{N}^{-N_{3}}{ }^{-}$in variable-charged soils tends to increase with depth. This phenomenon is associated with the increased number of positive electrical charges in this direction (Dynia et al., 2006), a typical characteristic of the highly weathered Oxisols that dominate the Brazilian Cerrado region. Oliveira et al. (2000) observed that the adsorption of $\mathrm{N}$ species increased with soil profile depth and was higher in soils under native Cerrado vegetation as compared to cultivated soils.

Some studies were conducted to try to predict nitrogen supplement requirements for some crops, taking into consideration the nitrate and mineral nitrogen contents in the soil 
SILVA, D. F; ANDRADE, C. L.T.; RESENDE, A. V.; HICKMANN, C.; AMARAL, T. A.; ALVES, M. E. B. Nitrogen dynamics in soils cultivated with maize and fertilized with pig slurry. Ambi-Agua, Taubaté, v. 7, n. 1, p. 9-23, 2012. (http://dx.doi.org/10.4136/ambi-agua.782)

before and during the crop cycle. Some soil tests have been developed to guide the nitrogen recommendations for maize. These tests, discussed in detail by Rambo et al. (2004), are divided into a pre-sowing test (TPS), a pre-application of nitrogen test (TPNC), and a postharvest test (TPC). The critical $\mathrm{N}_{-\mathrm{NO}_{3}}{ }^{-}$levels in soil, above which it is considered that there is excess $\mathrm{N}$, are between 15 to $30 \mathrm{mgkg}^{-1}$ (Rambo et al., 2007).

In this sense, the objective of this paper was to evaluate soil mineral nitrogen dynamics in an Oxisol, and its absorption by a maize crop managed with pig slurry associated with conventional mineral fertilization.

\section{MATERIALS AND METHODS}

The study was conducted at a farm located in the region of Sete Lagoas, MG, Brazil $\left(19^{\circ}\right.$ 23' 19" South, 44 32' 33" West, elevation $686 \mathrm{~m})$. The local climate is classified by Köppen as Aw, tropical savanna, with dry winters and an average temperature in the coldest month greater than $18^{\circ} \mathrm{C}$. The average annual temperature and precipitation in the last 60 years were, respectively, $22.1{ }^{\circ} \mathrm{C}$ and $1300 \mathrm{~mm}$, with a well-defined rainy season. A maximum rainfall average of $290 \mathrm{~mm}$ is observed in December, and a minimum average of $8 \mathrm{~mm}$ in August. The soil of the study area is classified as a typical Oxisol, whose major attributes are shown in Table 1.

Table 1. Chemical properties for different soil layers of the study area ${ }^{1}$.

\begin{tabular}{|c|c|c|c|c|c|c|c|c|c|c|}
\hline \multirow{2}{*}{$\begin{array}{c}\text { Layer } \\
(\mathrm{m})\end{array}$} & \multirow{2}{*}{$\begin{array}{r}\mathbf{p H} \\
\left(\mathrm{H}_{2} \mathrm{O}\right) \\
\end{array}$} & $\mathbf{H}+\mathbf{A l}$ & Al & $\mathrm{Ca}$ & Mg & $\mathrm{CTC}_{\text {pot }}$ & $\mathbf{K}$ & $\mathbf{P}$ & \multirow{2}{*}{$\begin{array}{c}\mathbf{M O} \\
\left(\operatorname{dagkg}^{-1}\right)\end{array}$} & \multirow{2}{*}{$\begin{array}{l}\mathbf{V} \\
(\%)\end{array}$} \\
\hline & & \multicolumn{5}{|c|}{$\left(\mathrm{cmol}_{\mathrm{c}} \mathrm{dm}^{-3}\right)$} & \multicolumn{2}{|c|}{$\left(\mathrm{mgdm}^{-3}\right)$} & & \\
\hline $0-0.15$ & 5.6 & 4.98 & 0.00 & 3.31 & 1.02 & 10.08 & 300 & 64 & 3.19 & 51 \\
\hline $0.15-0.30$ & 5.5 & 4.36 & 0.00 & 1.95 & 0.54 & 7.30 & 174 & 12 & 1.59 & 40 \\
\hline $0.30-0.45$ & 5.3 & 3.20 & 0.12 & 1.22 & 0.38 & 5.02 & 85 & 2 & 1.64 & 36 \\
\hline $0.45-0.60$ & 5.4 & 2.96 & 0.12 & 0.98 & 0.33 & 4.45 & 71 & 2 & 1.39 & 34 \\
\hline $0.60-0.90$ & 4.8 & 2.93 & 0.12 & 0.42 & 0.16 & 3.59 & 31 & 1 & 1.07 & 18 \\
\hline $0.90-1.20$ & 4.6 & 2.93 & 0.12 & 0.29 & 0.10 & 3.37 & 21 & 1 & 0.86 & 13 \\
\hline
\end{tabular}

${ }^{1}$ Methods of soil analysis described in Embrapa (1997).

The study area has been cultivated for more than 20 years. In the first 10 years, soil management was based on conventional tillage; later the no-till system was adopted. In the last seven years, due to the occurrence of frequent dry spells, a center pivot irrigation system has been used to irrigate an area of 90 ha. Pig slurry, in combination with mineral fertilizer, has been used in the last seven years as a source of nutrients for maize.

In this study, a 0.5 ha area was randomly selected inside the 90 ha center pivot area. This area was divided into four plots, each plot being considered a replication. Each plot consisted of eight maize rows $10 \mathrm{~m}$ long and $0.68 \mathrm{~m}$ apart. The six central rows were tagged for the final evaluation.

The farmer has adopted an intensive no-till management system, with successive maize sowings, with no crop rotation. In 2008, the single-cross maize hybrid DKB 390YG was sown on October $25^{\text {th }}$. Emergence occurred nine days after sowing (DAS), silking at 63 DAS, and physiological maturity at 133 DAS. Harvest was performed at 136 DAS. Fertilization consisted of $70 \mathrm{~m}^{3} \mathrm{ha}^{-1}$ of pig slurry, biologically stabilized in a bioreactor, applied 17 days before sowing. The pig slurry remained in the bioreactor for 35 days, and was subsequently stored in lagoons until distribution on the plantations. The stable slurry was applied in the 
SILVA, D. F; ANDRADE, C. L.T.; RESENDE, A. V.; HICKMANN, C.; AMARAL, T. A.; ALVES, M. E. B. Nitrogen dynamics in soils cultivated with maize and fertilized with pig slurry. Ambi-Agua, Taubaté, v. 7, n. 1, p. 9-23, 2012. (http://dx.doi.org/10.4136/ambi-agua.782)

field by using a mechanical spreader. This fertilizer was supplemented with $350 \mathrm{kgha}^{-1}$ of the formula 09-33-12 (NPK), placed deeper than the seeds, during the sowing operation. Additionally, $150 \mathrm{kgha}^{-1}$ of urea was side-dressed at 12 and 25 DAS. The chemical composition of the stable pig slurry used is presented in Table 2.

Since sowing was done during the rainy season in Brazil, only two irrigations were applied early in the maize crop cycle. Irrigation management was based on the farm manager's previous experience, and there has been no interference in this procedure.

In order to monitor nitrate and ammonium concentrations along the crop cycle, the soil was sampled using a Dutch auger at the 0 to $0.3 \mathrm{~m}, 0.3$ to $0.6 \mathrm{~m}$, and 0.6 to $1.2 \mathrm{~m}$ layers. No sampling was performed at the 0.60 to $1.2 \mathrm{~m}$ layer on $11,19,26$ DAS because we did not consider it relevant at this early crop stage. The soil was also sampled once, at the same depths, inside the adjacent reserve of Cerrado. This way, we had a baseline to compare with the cultivated area.

Table 2. Nutrient content of pig slurry after being stabilized in a bioreactor for 35 days and just prior to field application ${ }^{1}$.

\begin{tabular}{c|c}
\hline Components & Content $\left(\mathbf{m g L}^{-\mathbf{1}}\right)$ \\
\hline $\mathrm{N}_{\text {total }}{ }^{+}$ & 1179.18 \\
$\mathrm{~N}^{+} \mathrm{NH}_{4}{ }^{-}$ & 957.35 \\
$\mathrm{~N}_{3} \mathrm{NO}^{-}$ & 2.80 \\
$\mathrm{P}$ & 188.35 \\
$\mathrm{~K}$ & 581.88 \\
$\mathrm{Ca}$ & 152.40 \\
$\mathrm{Mg}$ & 72.92 \\
$\mathrm{Zn}$ & 20.30 \\
$\mathrm{Fe}$ & 17.73 \\
$\mathrm{Cu}$ & 8.92 \\
$\mathrm{Mn}$ & 3.21 \\
$\mathrm{Na}$ & 140.00 \\
\hline
\end{tabular}

${ }^{1}$ Methods of analysis described in Embrapa (1997).

The samples were collected in between the crop rows, in three randomly dug holes inside the plot. In the native Cerrado the soil samples were collected at three representative points of the area. The three samples were mixed together to produce one composed representative

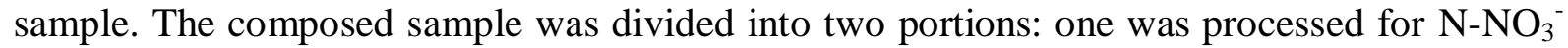
and $\mathrm{N}-\mathrm{NH}_{4}{ }^{+}$determinations, and the other for soil fertility analysis. All methods of analysis are described in EMBRAPA (1997).

The Kjeldahl distillation method was used for soil $\mathrm{N}-\mathrm{NH}_{4}{ }^{+}$and $\mathrm{N}-\mathrm{NO}_{3}{ }^{-}$determinations. Nitrogen extraction was performed with a $\mathrm{KCl} 2 \mathrm{molL}^{-1}$ solution. A $10 \mathrm{~mL}$ extract sample was used in the distillation process. In the first distillation for $\mathrm{N}^{-\mathrm{NH}_{4}}{ }^{+}$determination, $\mathrm{MgO}$ was added and, in the second distillation of the same sample, the Devarda alloy was added for $\mathrm{NO}_{3}{ }^{-}$determination, with subsequent quantification by titration with $\mathrm{H}_{2} \mathrm{SO}_{4}$ (Nogueira and Souza, 2005). The mineral-N content was calculated as the sum of the $\mathrm{N}^{-\mathrm{NO}_{3}}{ }^{-}$and $\mathrm{N}_{-} \mathrm{NH}_{4}{ }^{+}$ content.

The mineral nitrogen dynamics in the 0 to $0.60 \mathrm{~m}$ soil layer was evaluated along the crop cycle. As input to the system, we considered the sum of the mineral nitrogen present in pig slurry, the mineral fertilizer applied at sowing, side-dressings performed, the nitrogen present in the existing soil surface mulching before planting, and the existing soil mineral nitrogen 
SILVA, D. F; ANDRADE, C. L.T.; RESENDE, A. V.; HICKMANN, C.; AMARAL, T. A.; ALVES, M. E. B. Nitrogen dynamics in soils cultivated with maize and fertilized with pig slurry. Ambi-Agua, Taubaté, v. 7, n. 1, p. 9-23, 2012. (http://dx.doi.org/10.4136/ambi-agua.782)

(nitrate plus ammonium) prior to the pig manure application. As output, we considered the nitrogen accumulated in the crop aboveground biomass, the mineral nitrogen presented in the 0 to $0.60 \mathrm{~m}$ soil layer at the end of the crop cycle, and the nitrogen leached below the rooting system, which was regarded as the mineral nitrogen presented in the 0.60 to $1.20 \mathrm{~m}$ soil layer. The amount of $\mathrm{N}$ presented in the roots was neglected.

Maize crop aboveground biomass was sampled at different crop stages and processed separately as leaves, stem + tassel, husks, cobs, and grains. Samples were then taken to an oven, at $65^{\circ} \mathrm{C}$, for dry mass determination. Later on, the maize plant components were milled and stored for subsequent nutrient analysis. Plant tissue nitrogen concentration was determined by the Dumas method, as described by Ribeiro (2010). With dry mass and nutrient concentration data, maize crop element absorption at different stages was estimated. At the end of the crop cycle, grain yield and yield components were evaluated.

Maize crop rooting system distribution was also evaluated. Undisturbed soil samples with $0.0013 \mathrm{~m}^{3}$ thickness were collected at the same soil profile layers used for soil characterization. Samples were washed inside a small mesh sieve to separate roots from soil material. Clean roots were stored in flasks containing a $70 \%$ ethanol solution in order to prevent tissue dehydration. Root length, volume, and diameter were estimated by using the WinRhizo, which consists of a professional scanner model Epson 10000 XL, equipped with an additional light unit (TPU). The procedures for determining the volume of roots per volume of soil are described in Costa et al. (2002).

The data on $\mathrm{N}-\mathrm{NH}_{4}{ }^{+}, \mathrm{N}_{-} \mathrm{NO}_{3}{ }^{-}$and on $\mathrm{N}$-mineral were submitted to analysis of variance using the SISVAR (Ferreira, 2000) program. The effect of time (days after sowing, DAS) on soil ammonium and nitrate content was evaluated using the F test. When significant effects were found, linear equations were fit to soil nitrate and ammonium content as a function of DAS. Regression models were adjusted using the t test with up to $10 \%$ probability. We were not interested in fitting a model that perfectly described the nitrate and ammonium dynamics, but in checking the trend in these ions' behavior, over time, for different soil profile layers, in order to assess their mobility. The soil nitrate and ammonium content data under the Cerrado vegetation were compared with those observed along the crop cycle of the cultivated area.

Soil-water content at different soil profile layers was monitored along the crop cycle. Soil-water storage was calculated to a depth of $0.60 \mathrm{~m}$. Soil material was submitted to laboratory analysis to determine the upper and lower limits of available water so that total soil-water availability to plants could be calculated. The rainfall data were monitored using an automatic weather station installed at the site.

Charts were plotted to facilitate interpretation of data on plant nitrogen absorption and on the dynamics of water, nitrate, and ammonium in the soil. Rooting system distribution was evaluated and inferences were made regarding nitrogen leaching.

\section{RESULTS AND DISCUSSION}

It was observed that the maize rooting system had grown up to $1.20 \mathrm{~m}$ deep (Figure 1). However, the largest concentration of roots per unit of soil volume was observed in the 0 to 0.6 m layer, which is consistent with observations made by Ivo and Mielniczuk (1999). Based on these findings, observed soil-water storage and lab-determined soil-water retention limits were calculated for that layer and plotted versus time. Moreover, the nitrogen amounts presented in the 0.6 to $1.20 \mathrm{~m}$ layer were considered prone to leaching.

We observed that, due to rain and irrigation, soil-water storage in the 0 to $0.60 \mathrm{~m}$ layer remained consistently above $50 \%$ of soil available (Figure 2) water and, therefore, the crop did not suffer severe water stress. 
SILVA, D. F; ANDRADE, C. L.T.; RESENDE, A. V.; HICKMANN, C.; AMARAL, T. A.; ALVES, M. E. B. Nitrogen dynamics in soils cultivated with maize and fertilized with pig slurry. Ambi-Agua, Taubaté, v. 7, n. 1, p. 9-23, 2012. (http://dx.doi.org/10.4136/ambi-agua.782)

Nutrient absorption efficiency has a direct relation with the morphological attributes of the crops rooting system (Horn et al., 2006). An increase in the root volume, when nutrient concentration is the same in the vicinity of the root surface, may lead to greater efficiency in nutrient absorption (Costa et al., 2002).

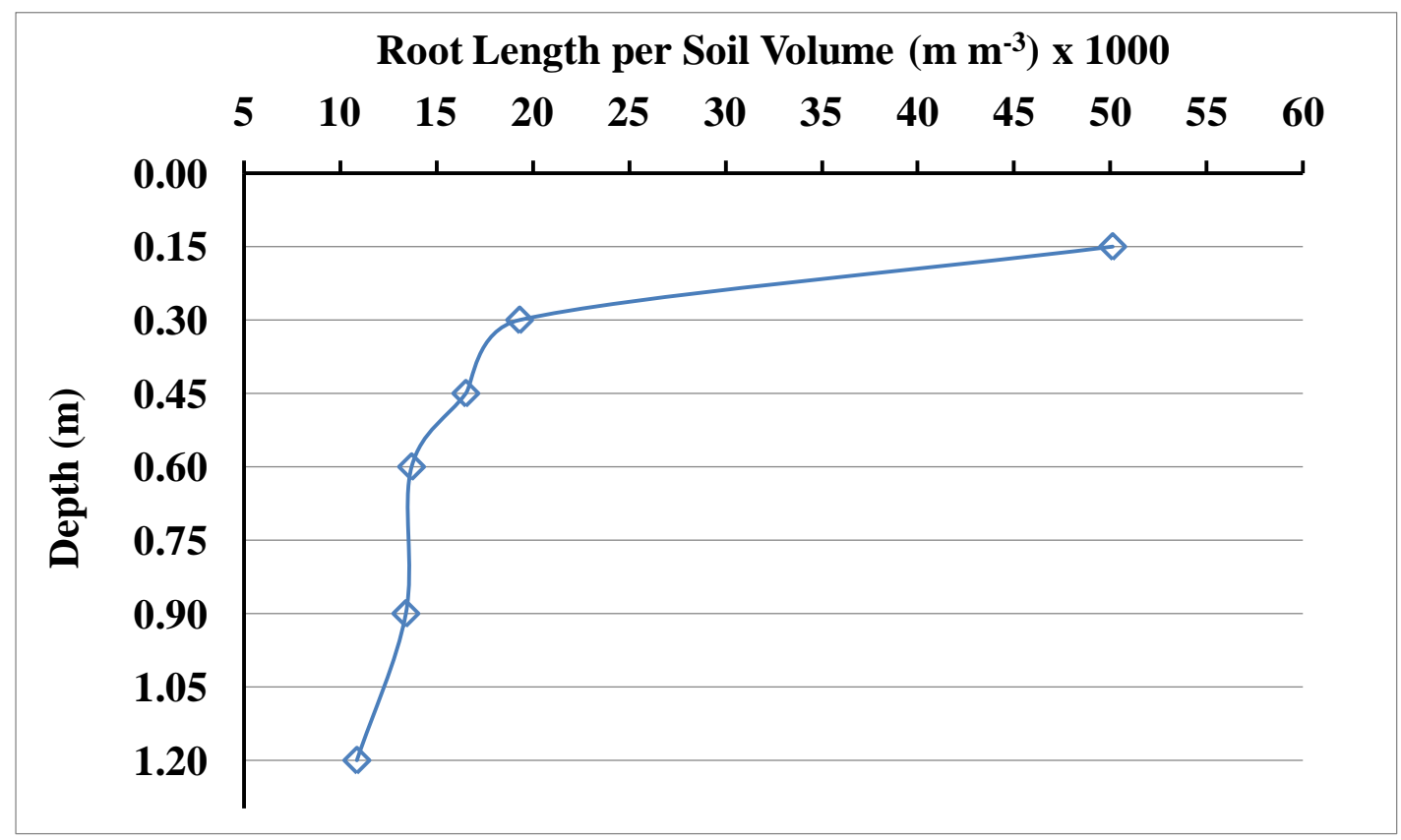

Figure 1. Distribution of root length (meters) per unit volume (cubic meters) of soil $\left(\mathrm{mm}^{-3}\right)$ x 1000 .

Considering the entire crop cycle, out of the $359.0 \mathrm{kgha}^{-1}$ of mineral nitrogen that entered the soil-plant system, the maize plant recovered $221.6 \mathrm{kgha}^{-1}(62 \%), 33.5 \mathrm{kgha}^{-1}$ (9\%) was leached, $51.1 \mathrm{kgha}^{-1}(14 \%)$ was retained in the 0 to $0.60 \mathrm{~m}$ soil layer, and $52.7 \mathrm{kgha}^{-1}(15 \%)$ was not recovered, meaning it was either volatilized or immobilized by the soil. The system outputs accounted for $306.3 \mathrm{kgha}^{-1}$ of mineral N. Similar results were obtained by Coelho et al. (1991), while Gava et al. (2006), studying soil-plant system nitrogen balance in a no-till maize field, observed that $44.5 \mathrm{kgha}^{-1}(45 \%)$ of $\mathrm{N}$-fertilizer was recovered by the plant, 34 $\mathrm{kgha}^{-1}(35 \%)$ was retained in the soil, and $20 \mathrm{kgha}^{-1}(20 \%)$ was not recovered.

Duete et al. (2008), working with various sources of nitrogen fertilizer applied to a maize crop grown in an Oxisol, observed that, regardless of the source, the plants extracted an average of $130 \mathrm{kgha}^{-1}$. According Peoples et al. (2004), on average, $19 \%$ to $38 \%$ of the fertilizer applied to a conventional tillage maize cropping system remained in the soil after harvest, and $25 \%$ of the nitrogen was not recovered. The discrepancy between mineral $\mathrm{N}$ values observed in the studies is justified by differences in the ability of the soil to supply mineral $\mathrm{N}$, the amount of nitrogen added to the system, and the crop biomass production and $\mathrm{N}$ uptake capacity of the maize genotypes employed.

As might be expected in a production system that makes continued use of considerable doses of pig slurry as a supplementary source of fertilizer, the concentrations of nitrate, ammonium, and mineral nitrogen (nitrate + ammonium) observed in the soil profile were high early in the crop cycle (Figures 3, 4 e 5), decreasing with time. High initial mineral nitrogen content, between 55 and $92 \mathrm{kgha}^{-1}$ was observed in the 0 to $0.30 \mathrm{~m}$ layer, due to the slurry application on the soil surface and shallow mineral fertilizer incorporation at sowing. The highest rates of decrease in the mineral $\mathrm{N}$ over time were observed in the 0 to $0.30 \mathrm{~m}$ layer, where most of the maize rooting system is located (Figure 1). The $\mathrm{N}_{-} \mathrm{NO}_{3}{ }^{-}$content in the 0 to $0.30 \mathrm{~m}$ layer at 11 days after sowing (DAS) was $55.74 \mathrm{kgha}^{-1}$, as a result of the first side- 
SILVA, D. F; ANDRADE, C. L.T.; RESENDE, A. V.; HICKMANN, C.; AMARAL, T. A.; ALVES, M. E. B. Nitrogen dynamics in soils cultivated with maize and fertilized with pig slurry. Ambi-Agua, Taubaté, v. 7, n. 1, p. 9-23, 2012. (http://dx.doi.org/10.4136/ambi-agua.782)

dressing. This amount is within the range of 52.65 to $105.3 \mathrm{kgha}^{-1}$ considered critical, as reported by Rambo et al. (2007).

As a result of maize growth and development, the nitrate content in the 0 to $0.30 \mathrm{~m}$ layer decreased rapidly over time, reaching $12.16 \mathrm{kgha}^{-1}$ at $116 \mathrm{DAS}$. In turn, the reduction in nitrate content over time in the 0.60 to 1.20 m layer was slower. The amount of this element in that layer stabilized at $11.86 \mathrm{kgha}^{-1}$ at 102 DAS (Figure 3). Nitrate content in the layers 0 to 0.30 and 0.60 to $1.20 \mathrm{~m}$ at the end of the crop cycle was below $52.65 \mathrm{kgha}^{-1}$, the critical level reported by Rambo et al. (2007).

The greatest reductions in nitrate, ammonium, and $\mathrm{N}$-mineral contents in the 0 to 0.30 and 0.30 to $0.60 \mathrm{~m}$ layers, where the largest roots volumes were concentrated (Figure 1), occurred between 0 to 102 DAS. This phase coincides with the period of the greatest nitrogen demand by a maize crop. França et al. (1994) showed that maize $\mathrm{N}$ uptake is most intense between 40 and 60 DAS.

Analyzing the nitrate content data of the 0.6 to $1.2 \mathrm{~m}$ soil layer (Figure 3 ), we observed a decreasing trend until 137 DAS, as expressed by the curve fitted to the values (Table 3). Certainly, the reduction in nitrate levels in this layer until 137 DAS was due to leaching, fostered by the intense rainfall regime that occurred in that period (Figure 2). A cumulative depth of $1163 \mathrm{~mm}$ of rain was recorded between 0 and 137 DAS, which corresponded to an average of 8.49 mmday $^{-1}$.

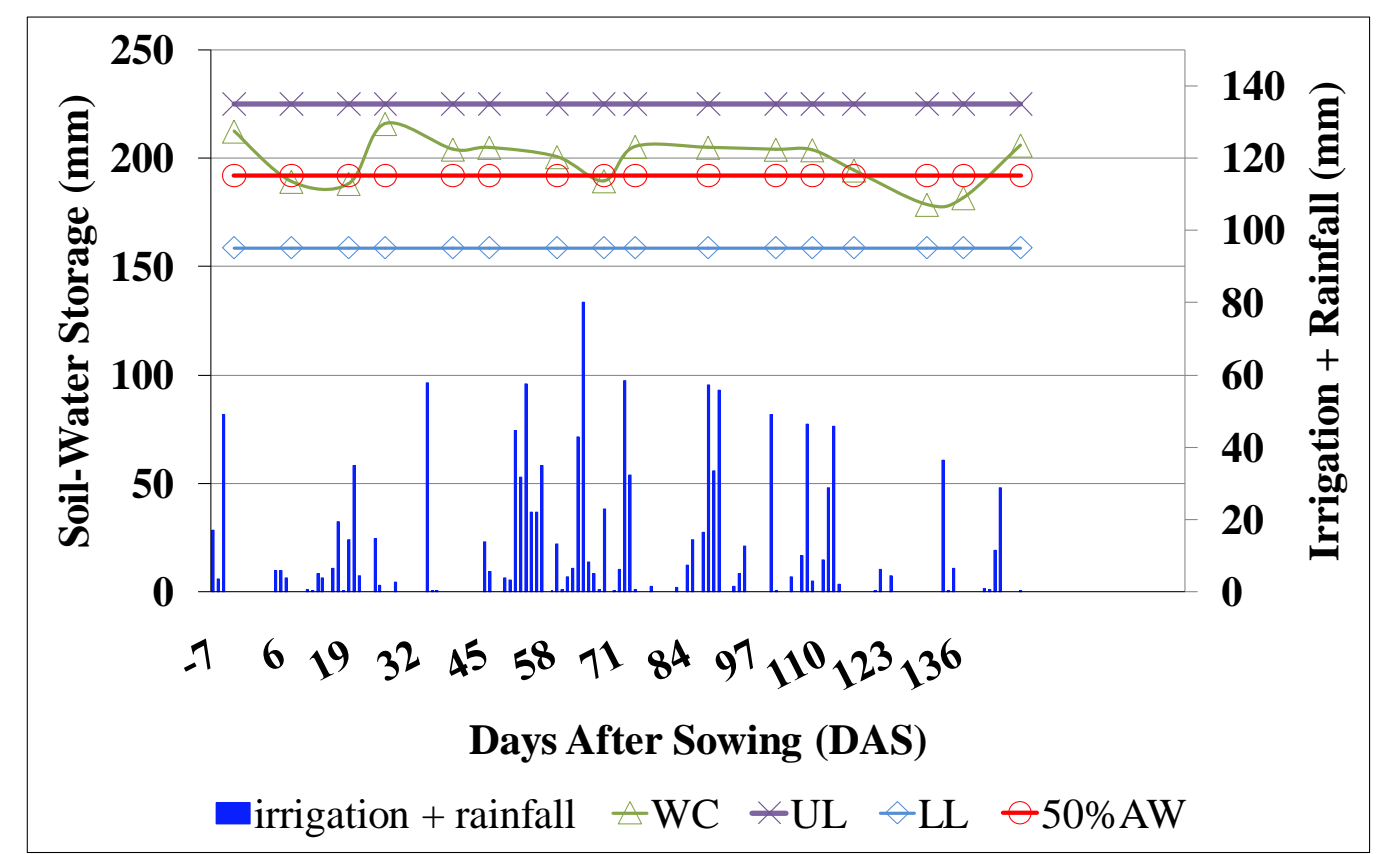

Figure 2. Water depths received by the crop (irrigation + rainfall), soil-water stored in the 0 to $0.60 \mathrm{~m}$ layer at the water content (WC) and upper (UL) and lower (LL) limit of available water and at $50 \%$ of available water (AW) for the 2008/2009 crop season.

The nitrate accumulation in the 0.6 to $1.2 \mathrm{~m}$ layer, relative to other layers, was high at 102 to 137 DAS period, since the crop was at its final grain-filling phase and the nitrogen demand drops. In addition, less nitrate leaching occurs as a consequence of no irrigation and less rain received in this stage (Figure 2). The mineralization of crop residues and of current crop abscised leaves can also contribute to nitrogen supply to the soil, and when there is no plant uptake, this element tends to leach and accumulate in the deep layers, where its adsorption is greater (Torres et al., 2005). 
SILVA, D. F; ANDRADE, C. L.T.; RESENDE, A. V.; HICKMANN, C.; AMARAL, T. A.; ALVES, M. E. B. Nitrogen dynamics in soils cultivated with maize and fertilized with pig slurry. Ambi-Agua, Taubaté, v. 7, n. 1, p. 9-23, 2012. (http://dx.doi.org/10.4136/ambi-agua.782)

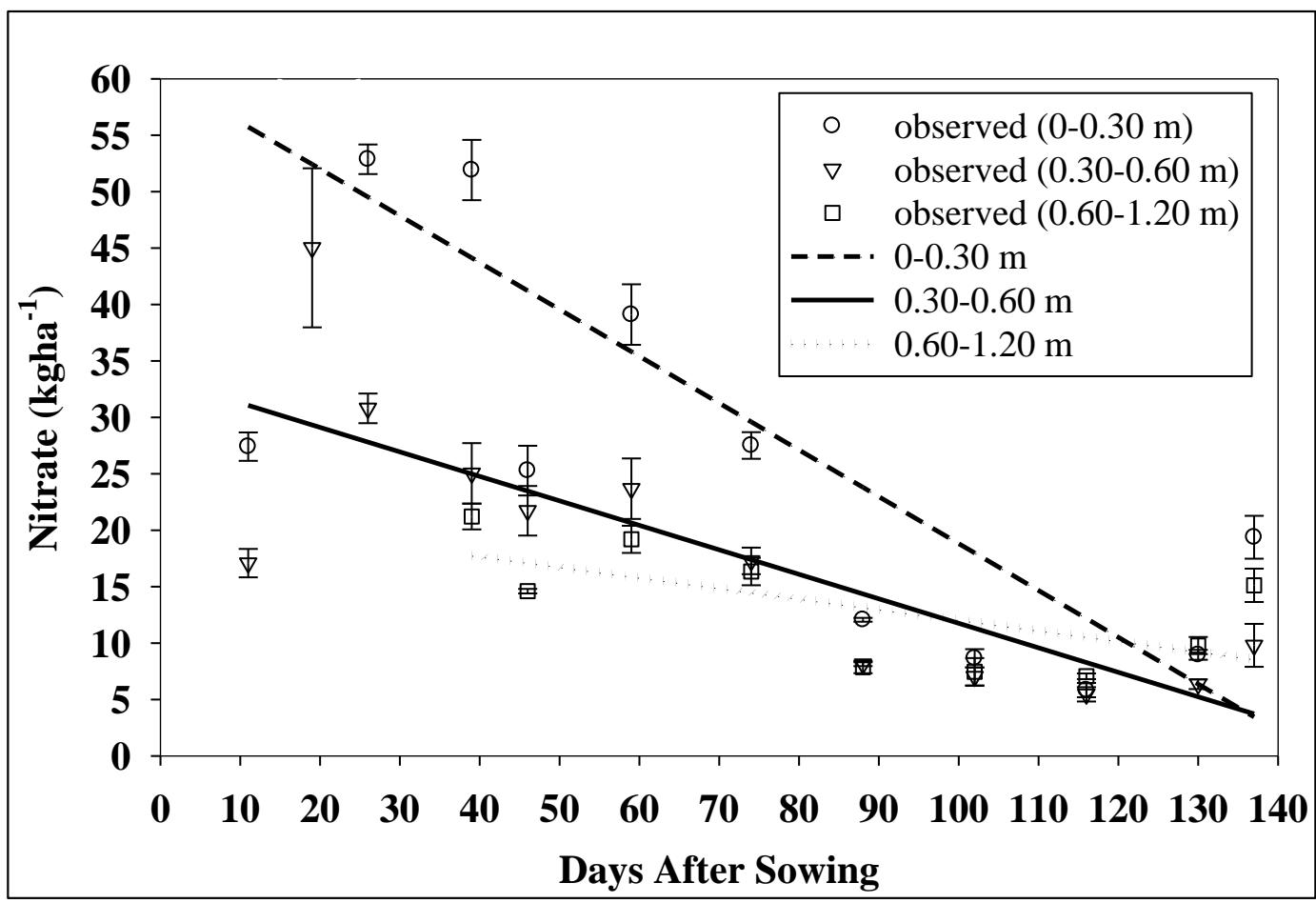

Figure 3. Soil nitrate content in the layers 0 to $0.30,0.30$ to 0.60 , and 0.60 to $1.20 \mathrm{~m}$, along the cycle of a maize crop, grown in an Oxisol managed with pig slurry and with mineral fertilization. Vertical bars are the standard error above and below the average.

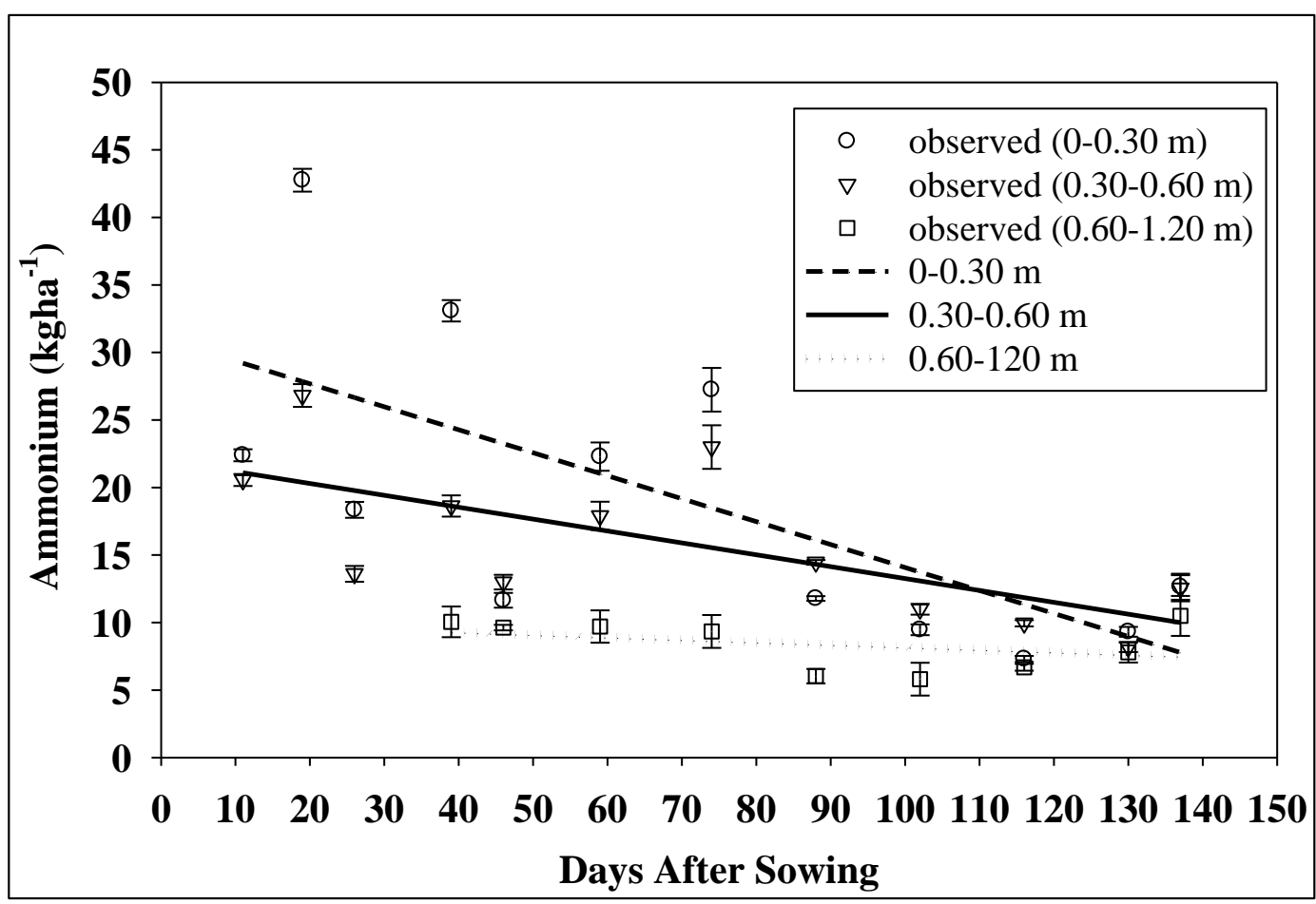

Figure 4. Soil ammonium content in the layers 0 to $0.30,0.30$ to 0.60 , and 0.60 to 1.20 $\mathrm{m}$, along the cycle of a maize crop, grown in an Oxisol managed with pig slurry and with mineral fertilization. Vertical bars are the standard error above and below the average. 
SILVA, D. F; ANDRADE, C. L.T.; RESENDE, A. V.; HICKMANN, C.; AMARAL, T. A.; ALVES, M. E. B. Nitrogen dynamics in soils cultivated with maize and fertilized with pig slurry. Ambi-Agua, Taubaté, v. 7, n. 1, p. 9-23, 2012. (http://dx.doi.org/10.4136/ambi-agua.782)

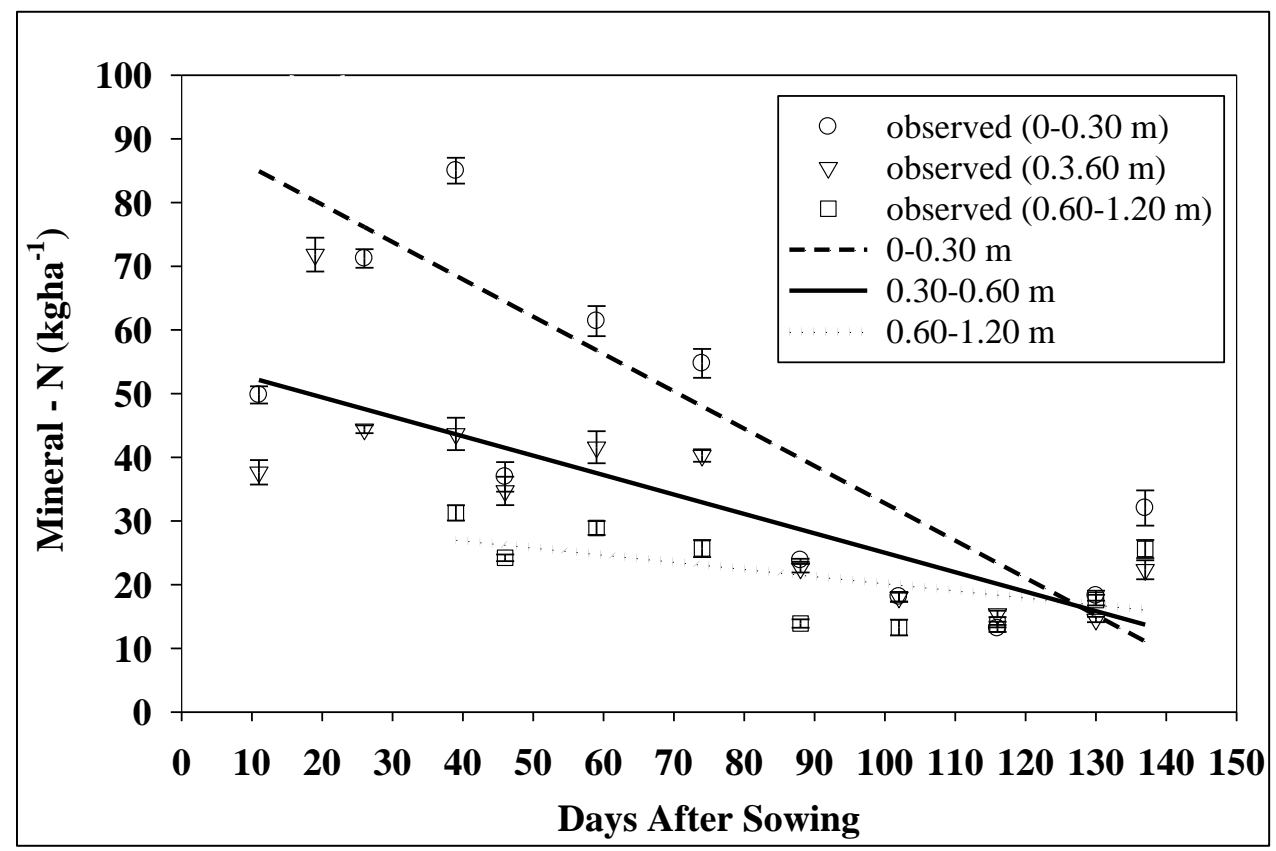

Figure 5. Soil mineral-N content in the layers 0 to $0.30,0.30$ to 0.60 , and 0.60 to $1.20 \mathrm{~m}$, along the cycle of a maize crop, grown in an Oxisol managed with pig slurry and with mineral fertilization. Vertical bars are the standard error above and below the average.

Table 3. Linear regression equations fitted to nitrate $\left(\mathrm{N}^{-N_{3}}{ }^{-}\right)$, ammonium $\left(\mathrm{N}^{-} \mathrm{NH}_{4}{ }^{+}\right)$, and to mineral nitrogen (mineral-N) as a function of days after sowing (DAS).

\begin{tabular}{|c|c|c|c|}
\hline Nutrients & Layer $(\mathbf{m})$ & Equation & $\mathbf{R}^{2}(\%)$ \\
\hline \multirow{3}{*}{$\mathbf{N}-\mathrm{NO}_{3}^{-}$} & $0-0.30$ & $\mathrm{~N}^{-\mathrm{NO}_{3}}{ }^{-}=-0.415 \mathrm{DAS}^{*}+60.309$ & 52.60 \\
\hline & $0.30-0.60$ & $\mathrm{~N}-\mathrm{NO}_{3}{ }^{-}=-0.217 \mathrm{DAS}^{*}+33.455$ & 63.91 \\
\hline & $0.60-1.20$ & $\mathrm{~N}^{-\mathrm{NO}_{3}}{ }^{-}=-0.0938 \mathrm{DAS}^{*}+21.430$ & 40.26 \\
\hline \multirow{3}{*}{$\mathbf{N}-\mathrm{NH}_{4}^{+}$} & $0-0.30$ & $\mathrm{~N}-\mathrm{NH}_{4}{ }^{+}=-0.170 \mathrm{DAS}^{*}+31.070$ & 46.84 \\
\hline & $0.30-0.60$ & $\mathrm{~N}-\mathrm{NH}_{4}{ }^{+}=-0.088 \mathrm{DAS}^{*}+22.060$ & 47.91 \\
\hline & $0.60-1.20$ & $\mathrm{~N}^{-\mathrm{NH}_{4}}{ }^{+}=-0.018 \mathrm{DAS}^{*}+10.013$ & 13.06 \\
\hline \multirow{3}{*}{ mineral-N } & $0-0.30$ & mineral- $\mathrm{N}=-0.586 \mathrm{DAS}^{*}+91.378$ & 53.31 \\
\hline & $0.30-0.60$ & mineral- $\mathrm{N}=-0.305 \mathrm{DAS}^{*}+55.514$ & 66.50 \\
\hline & $0.60-1.20$ & mineral- $\mathrm{N}=-0.112 \mathrm{DAS}^{*}+31.445$ & 33.20 \\
\hline
\end{tabular}

* significant at $5 \%$ probability by t test.

The dynamic of $\mathrm{N}^{-} \mathrm{NH}_{4}{ }^{+}$(Figure 4) in the soil profile showed a pattern similar to $\mathrm{N}-\mathrm{NO}_{3}{ }^{-}$ (Figure 3), although ammonium content in the soil profile, and reduction rates over time, were lower. With the crop growth and development, $\mathrm{N}$ uptake (Figure 6) increased and, therefore, the $\mathrm{N}-\mathrm{NH}_{4}{ }^{+}$quantities presented in the soil profile were reduced (Figure 4). Concomitantly, 
SILVA, D. F; ANDRADE, C. L.T.; RESENDE, A. V.; HICKMANN, C.; AMARAL, T. A.; ALVES, M. E. B. Nitrogen dynamics in soils cultivated with maize and fertilized with pig slurry. Ambi-Agua, Taubaté, v. 7, n. 1, p. 9-23, 2012. (http://dx.doi.org/10.4136/ambi-agua.782)

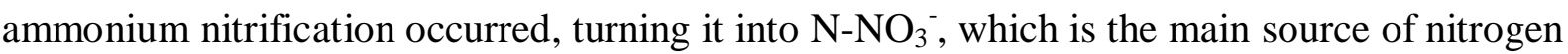
assimilated by crops, although it is more readily leachable. The low $\mathrm{pH}$ and CEC values of soil subsurface layers (Table 1) favored leaching of that cation below the root zone. As occurred with the $\mathrm{N}-\mathrm{NO}_{3}{ }^{-}$, the $\mathrm{N}-\mathrm{NH}_{4}{ }^{+}$content stabilized around $7.88 \mathrm{kgha}^{-1}$ at $116 \mathrm{DAS}$ (Figure 4).

It can be seen in Figure 4 and in the equation in Table 3 that at 11 DAS the highest N$\mathrm{NH}_{4}{ }^{+}$values were observed in the upper layer, while at 110 DAS the highest concentrations were measured at the 0.30 to $0.60 \mathrm{~m}$ layer, indicating that this element moved vertically in the soil profile, possibly due to the ammonification of organic $\mathrm{N}$ contributing to the increase of $\mathrm{N}-\mathrm{NH}_{4}{ }^{+}$content in that layer. Gonçalves et al. (2001) and Oliveira et al. (2001), studying the ammonium behavior in the soil, observed the presence of this element at the subsurface layers, thus demonstrating its movement in tropical soils. Cabezas and Souza (2008), in an trial to evaluate the combined use of gypsum and urea in a maize crop observed a higher

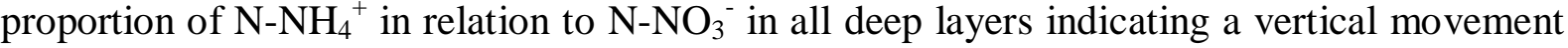
of ammonium favored by the presence of gypsum. According to Scherer et al. (2010), organic fertilizers have, in general, a greater residual effect on the soil as compared to mineral fertilizers. This pattern is explained by the slow mineralization of organic compounds making the nutrients available in a longer time frame. Thus these nutrients are less subject to chemical reactions in the soil unlike the mineral fertilizers.

The content of mineral $\mathrm{N}$ in the cultivated soil decreases with depth and over time as can be seen in Figure 5, following the same pattern of nitrate and ammonium. Cardoso Neto et al. (2006), evaluating different nitrogen sources, found that the highest concentrations of mineral $\mathrm{N}$ was observed in the topsoil following a decrease in concentrations with depth; the same occurring with ammonium and nitrate. Similar results were also found by Silva et al. (2005) and Ceretta et al. (2002).

The $\mathrm{N}^{-\mathrm{NO}_{3}}{ }^{-}$content at layers 0 to $0.3,0.3$ to 0.6 and 0.6 to $1.2 \mathrm{~m}$ of the soil profile under the native Cerrado was $31.1,30.9$ and $48.7 \mathrm{kgha}^{-1}$, respectively. The $\mathrm{N}_{-} \mathrm{NH}_{4}{ }^{+}$content were $60.1,34.5$ and $65.8 \mathrm{kgha}^{-1}$ in the same layers. Both nitrate and ammonium quantities were higher than those observed in the cultivated area (Figures 3 and 4). This behavior is due to the constant recycling of nutrients observed in the natural environment which is in a dynamic equilibrium.

In the cultivated soil, the process of soil organic matter decomposition becomes faster because of the acidity corrections and constant soil fertilization providing favorable conditions for the development of nitrifying microorganisms. Adding to this, the crop nutrient uptake caused a decrease in soil $\mathrm{N}$ content.

It can be seen in Figure 6 that the maximum accumulation of nitrogen was $132 \mathrm{kgha}^{-1}$ in the grain and $240 \mathrm{kgha}^{-1}$ in the aboveground maize biomass. The $\mathrm{N}$ uptake by a maize crop with a potential to yield 3 to $12 \mathrm{tha}^{-1}$ is in the range of 84 to $336 \mathrm{kgha}^{-1}$ (Cantarella, 2007). We noted that the $\mathrm{N}$ accumulation observed in this study is in the range considered normal for the maize crop.

From 21 to 90 DAS, $\mathrm{N}$ was absorbed by maize crop at an average rate of approximately $3.28 \mathrm{kgha}^{-1}$ day $^{-1}$. Absorption was more intense from 21 to 40 DAS, when it reached an average rate of $6.0 \mathrm{kgha}^{-1} \mathrm{day}^{-1}$ (Figure 6). Despite the nutritional requirements being lower in the early growth stages, research indicates that high $\mathrm{N}$ concentrations in the rooting zone are beneficial in promoting a rapid initial plant growth and in increasing yield (Varvel et al., 1997). According to Arnon (1975), nitrogen requirements vary considerably with the different maize crop stages. A minimal amount is required in the early stages, rising with increasing growth rate and reaching a peak from flowering to early grain formation phases. 
SILVA, D. F; ANDRADE, C. L.T.; RESENDE, A. V.; HICKMANN, C.; AMARAL, T. A.; ALVES, M. E. B. Nitrogen dynamics in soils cultivated with maize and fertilized with pig slurry. Ambi-Agua, Taubaté, v. 7, n. 1, p. 9-23, 2012. (http://dx.doi.org/10.4136/ambi-agua.782)

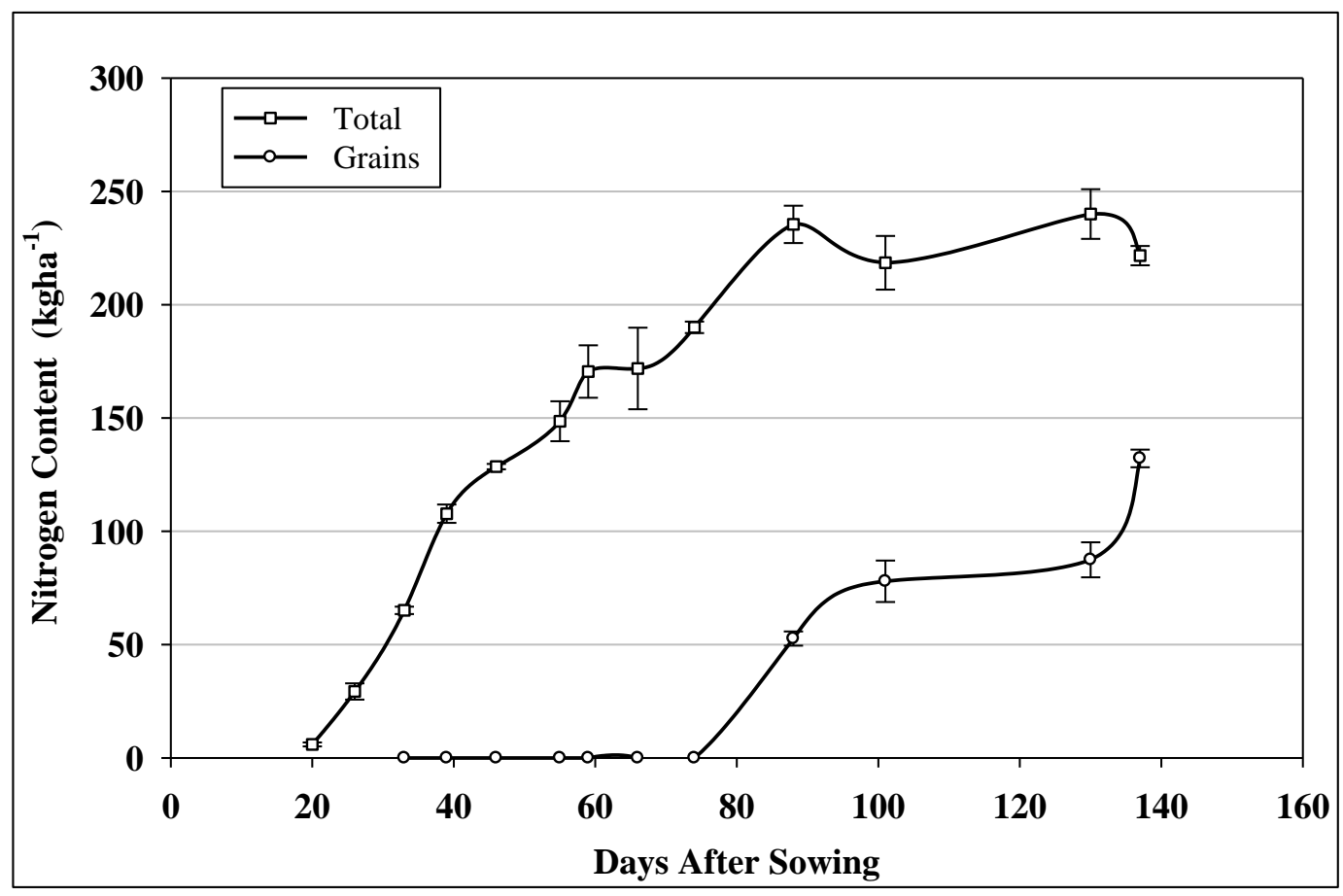

Figure 6. Nitrogen content in the biomass and grain along the maize crop cycle. Vertical bars are standard error above and below the average.

The average crop yield was $10.817 \mathrm{kgha}^{-1}$ of grain with $13 \%$ humidity, which is a high yield as compared to the average figure for the Minas Gerais State, which is $5.118 \mathrm{kgha}^{-1}$ (Agrianual, 2011). The average yield of the DKB 390YG hybrid varies from 8.414 to 8.659 $\mathrm{kgha}^{-1}$ (DEKALB, 2011). Evans et al. (1977), studying the performance of maize fertilized with pig slurry at a rate of 636 tha $^{-1}$ (fresh weight) for two successive years and monitored for two more years, observed that the average grain yield was $7.100 \mathrm{kgha}^{-1}$, whereas for mineral fertilization treatments this value was $6.880 \mathrm{kgha}^{-1}$. In studies reported by Konzen and Alvarenga (2002), the yield of a trial in which maize was fertilized with pig slurry was between 5.200 and $7.600 \mathrm{kgha}^{-1}$.

\section{CONCLUSIONS}

The crop was able to recover $62 \%$ of the mineral nitrogen that entered the soil-plant system, and we estimated that $9 \%$ leached as nitrate and, to a lesser amount, as ammonium.

The maximum average content of nitrate and ammonium in the 0 to $0.3 \mathrm{~m}$ layer was 92 $\mathrm{kgha}^{-1}$ and $43 \mathrm{kgha}^{-1}$, respectively, in the early crop stage, and a minimum of $5.8 \mathrm{kgha}^{-1}$ of nitrate and $9.0 \mathrm{kgha}^{-1}$ of ammonium, at the end of the crop cycle.

The nitrate content at the 0.60 to $1.20 \mathrm{~m}$ soil layer at the end of the crop cycle remains below the values observed in the native Cerrado, indicating that the current agricultural use of the land poses no additional risk of nitrate accumulation and leaching.

\section{ACKNOWLEDGMENTS}

To CNPq, for the financial support given to projects $\mathrm{n}^{\circ} 559065 / 2008-6$ and $\mathrm{n}^{\circ}$ 476169/2008-9. To Embrapa's Maize and Sorghum staff for help with collecting and analyzing the data. To the farmer who allowed the development of this study on his farm. 
SILVA, D. F; ANDRADE, C. L.T.; RESENDE, A. V.; HICKMANN, C.; AMARAL, T. A.; ALVES, M. E. B. Nitrogen dynamics in soils cultivated with maize and fertilized with pig slurry. Ambi-Agua, Taubaté, v. 7, n. 1, p. 9-23, 2012. (http://dx.doi.org/10.4136/ambi-agua.782)

\section{REFERENCES}

AGRIANUAL - Anuário da agricultura brasileira. São Paulo: Instituto FNP, 2011. 482 p.

AMADO, T. J. C.; MIELNICZUK, J.; AITA, C. Recomendação de adubação nitrogenada para o milho no RS e SC adaptada ao uso de culturas de cobertura do solo, sob plantio direto. Revista Brasileira de Ciência do Solo, Viçosa, MG, v. 26, n. 1, p. 241-248, 2002 .

ARNON, I. Mineral nutrition of maize. Bern: International Potash Institute, 1975. 452 p.

BORTOLINI, C. G.; SILVA, P. R. F.; ARGENTA, G.; FORSTHOFER, E. L. Sistemas de aplicação de nitrogênio e seus efeitos sobre o acúmulo de $\mathrm{N}$ na planta de milho. Revista Brasileira de Ciência do Solo, Viçosa, MG, v. 26, n. 3, p. 361-366, 2000.

BRASIL. Ministério da Agricultura, Pecuária e Abastecimento. Programa ABC. Agricultura de baixo carbono: plante sustentabilidade, colha resultados. Brasília, 2010. Disponível em: 〈http://www.agricultura.gov.br/abc>. Acesso em: 22 set. 2011.

CABEZAS, W. A. R. L.; SOUZA, M. A. Volatilização de amônio, lixiviação de nitrogênio e produtividade de milho em resposta à aplicação de mistura de uréia com sulfato de amônio ou com gesso agrícola. Revista Brasileira de Ciência do Solo, Viçosa, MG, v. 32, n. 4, p. 2331-2342, 2008.

CANTARELlA, H. Nitrogênio. In: NOVAIS, R. F.; ALVAREZ V.V. H.; BARROS, N. F. de; FONTES, R. L. F.; CANTARUTTI, R. B.; NEVES, J. C. L. (Ed.). Fertilidade do solo. Viçosa, MG: Sociedade Brasileira de Ciência do Solo, 2007. p. 375-470.

CARDOSO NETO, F.; GUERRA, H. O. C.; CHAVES, G. L. H. Nitrogênio residual em solo adubado com diferentes fontes e intervalos de aplicação de nitrogênio. Revista Caatinga, Mossoró, v. 19, n. 2, p. 161-168, 2006.

CERETTA, C. A. Características químicas de solo sob aplicação de dejeto líquido de suínos em pastagem natural. Pesquisa Agropecuária Brasileira, Brasília, v. 38, n. 6, p. 729735, 2003.

CERETTA, C. A.; BASSO, C. J.; FLECHA, A. M. T.; PAVINATO, P. S.; VIEIRA, F. C. B.; MAI, M. E. M. Manejo da adubação nitrogenada na sucessão aveia preta/milho, no sistema plantio direto. Revista Brasileira de Ciência do Solo, Viçosa, MG, v. 16, n. 1, p. 163-171, 2002.

COELhO, A. M.; FRANÇA, G. E.; BAHIA, A. F. C.; GUEDES, G. A. A. Balanço de nitrogênio(15N) em um Latossolo Vermelho escuro, sob vegetação de cerrado, cultivado com milho. Revista Brasileira de Ciência do Solo, Viçosa, MG, v. 15, n. 2, p. 187-193, 1991.

COSTA, C.; DWYER, L. M.; ZHOU, X.; DUTILlEUL, P.; HAMEL, C.; REID, L. M. et al. Root morphology of contrasting maize genotypes. Agronomy Journal, Madison, v. 94, n. 1, p. 96-101, 2002. http://dx.doi.org/10.2134/agronj2002.0096

DEKALB. Semente híbrida de milho safrinha 2007 DKB 390. Disponível em: <http://www.dekalb.com.br/produto_milho_safrinha.aspx?id=34>. Acesso em: 26 abr. 2011. 
SILVA, D. F; ANDRADE, C. L.T.; RESENDE, A. V.; HICKMANN, C.; AMARAL, T. A.; ALVES, M. E. B. Nitrogen dynamics in soils cultivated with maize and fertilized with pig slurry. Ambi-Agua, Taubaté, v. 7, n. 1, p. 9-23, 2012. (http://dx.doi.org/10.4136/ambi-agua.782)

DUETE, R. R. C.; MURAOKA, T.; SILVA, E. C.; TRIVElin, P. C. O.; AMBROSANO, E. J. Manejo da adubação nitrogenada e utilização nitrogênio (15N) pelo milho em Latossolo Vermelho. Revista Brasileira Ciência do Solo, Viçosa, MG, v. 32, n. 1, p. 161-171, 2008.

DYNIA, J. F.; SOUZA, M. D.; BOEIRA, R. C. Lixiviação de nitrato em Latossolo cultivado com milho após aplicações sucessivas de lodo de esgoto. Pesquisa Agropecuária Brasileira, Brasília, v. 41, n. 5, p. 855-862, 2006.

EMBRAPA. Centro Nacional de Pesquisa de Solos. Manual de métodos de análise de solo. 2. ed. Rio de Janeiro, 1997. 212 p. (EMBRAPA- CNPS. Documento, 1).

EVANS, S. D.; GOODRICH, P. R.; MUNTER, R. C. Effects of solid and liquid beef manure and liquid hog manure on soil characteristics and on growth, yield and decomposition of corn. Journal Environ Quality, Madison, v. 6, n. 2, p. 361-368, 1977. http://dx.doi.org/10.2134/jeq1977.00472425000600040006x

FERREIRA, D. F. Manual do sistema SISVAR para análise estatística. Lavras: UFLA, 2000. 63 p.

FRANÇA, G. E.; COELHO, A. M.; RESENDE, M.; BAHIA FILHO, A. F. C. Parcelamento da adubação nitrogenada em cobertura na cultura do milho irrigado. In: EMBRAPA. Centro Nacional de Pesquisa de Milho e Sorgo. Relatório técnico anual do Centro Nacional de Pesquisa de Milho e Sorgo: 1992-1993. Sete Lagoas, 1994. p. 28-29.

GAVA, G. J. C.; TRIVELIN, P. C. O.; OLIVEIRA, M. W.; HEINRICHS, R.; SILVA, M. A. Balanço do nitrogênio da uréia $\left({ }^{15} \mathrm{~N}\right)$ no sistema solo-planta na implantação da semeadura direta na cultura do milho. Bragantia, Campinas, v. 65, n. 3, p. 477-486, 2006.

GIACOMINI, S. J.; AITA, C. Cama sobreposta e dejetos líquidos de suínos como fonte de nitrogênio ao milho. Revista Brasileira de Ciência do Solo, Viçosa, MG, v. 32, n. 1, p. 195-205, 2008.

GIACOMINI, S. J.; AITA, C.; JANTALIA, C. P.; URQUIAGA, S.; SANTOS, G. F. dos. Imobilização do nitrogênio amoniacal de dejetos líquidos de suínos em plantio direto e preparo reduzido do solo. Revista Brasileira de Ciência do Solo, Viçosa, MG, v. 33, n. 1, p. 41-50, 2009.

GONÇALVES, J. L. M.; MENDES, K. C. F. S.; SASAKI, C. M. Mineralização de nitrogênio em ecossistemas florestais naturais e implantados do Estado de São Paulo. Revista Brasileira de Ciência do Solo, Viçosa, v. 25, n. 3, p. 601-616, 2001.

HORN, D.; ERNANI, P. R.; SANGOI, L.; SCHWEITZER, C.; CASSOL, P. C. Parâmetros cinéticos e morfológicos da absorção de nutrientes em cultivares de milho com variabilidade genética contrastante. Revista Brasileira de Ciência do Solo, Viçosa, MG, v. 30, n. 2, p. 77-85, 2006.

IVO, W. M. P.; MIELNICZUK, J. Influência da estrutura do solo na distribuição e na morfologia do sistema radicular do milho sob três métodos de preparo. Revista Brasileira de Ciência do Solo, Viçosa, MG, v. 23, n. 1, p. 135-143, 1999. 
SILVA, D. F; ANDRADE, C. L.T.; RESENDE, A. V.; HICKMANN, C.; AMARAL, T. A.; ALVES, M. E. B. Nitrogen dynamics in soils cultivated with maize and fertilized with pig slurry. Ambi-Agua, Taubaté, v. 7, n. 1, p. 9-23, 2012. (http://dx.doi.org/10.4136/ambi-agua.782)

KONZEN, E. A. Fertilização de lavoura e pastagem com dejetos de suínos e cama de aves. Sete Lagoas: Embrapa Milho e Sorgo, 2003. 3 p. (Embrapa Milho e Sorgo. Circular Técnica, 31). Disponível em: <http:// http://ainfo.cnptia.embrapa.br/ digital/bitstream/CNPMS/16184/1/Circ_31.pdf>. Acesso em: 26 abril 2011.

KONZEN, E. A.; ALVARENGA, R. C. Monitoramento ambiental do uso de dejetos líquidos de suínos como insumo na agricultura: efeito de doses na produtividade de milho. Revista Brasileira de Ciência do Solo, Viçosa, MG, v. 2, n. 3, p. 123-131, 2002.

NOGUEIRA, A. R. A.; SOUZA, G. B. Manual de laboratórios: solo, água, nutrição vegetal, nutrição animal e alimentos. In: PRIMAVESI, A. C.; ANDRADE, A. G.; ALVES, B. J. R.; ROSSO, C.; BATISTA, E. M.; PRATES, H. T. et al. Métodos de análise de solo. São Carlos: Embrapa Pecuária Sudeste, 2005. p. 67-130.

OLIVEIRA, F. C. Percolação de nitrato em Latossolo Amarelo Distrófico afetada pela aplicação de composto de lixo urbano e adubação mineral. Revista Brasileira de Ciência do Solo, Viçosa, MG, v. 25, n. 3, p. 731-741, 2001.

OLIVEIRA, J. R. A. de; VILELA, L.; AYARZA, M. A. Adsorção de nitrato em solos de cerrado do Distrito Federal. Pesquisa Agropecuária Brasileira, Brasília, v. 35, n. 6, p. 1199-1205, 2000.

PEOPLES, M. B.; BOYER, E. W.; GOULDING, K. W. T.; HEFFER, P.; OCHWOH, V. A.; VANLAUWE, B. et al. Pathways of nitrogen loss and their impacts on human health and the environment. In: MOSIER, A.; SYERS, J. K.; FRENEY, J. R. (Ed.). Agriculture and the nitrogen cycle: assessing the impacts of fertilizer use on food production and the environment. Washington: Island Press, 2004. p. 53-69. (SCOPE report, 65).

RAMBO, L.; SILVA, P. R. F.; BAYER, C; ARGENTA, G.; STRIEDER, M. L.; SILVA, A. A. Testes de nitrato no solo como indicadores complementares da disponibilidade de nitrogênio no solo para o milho. Revista Brasileira de Ciência do Solo, Viçosa, MG, v. 31, n. 1, p. 731-738, 2007.

RAMBO, L.; SILVA, P. R. F.; ARGENTA, G.; BAYER, C. Testes de nitrato no solo como indicadores complementares no manejo da adubação nitrogenada em milho. Ciência Rural, Santa Maria, v. 34, n. 4, p. 1279-1287, 2004.

RIBEIRO, P. E. de A. Implementação de análise de nitrogênio total em solo pelo método de Dumas. Sete Lagoas: Embrapa Milho e Sorgo, 2010. 26 p. (Embrapa Milho e Sorgo. Documentos, 115).

SCHERER, E. E.; NESI, C. N.; MASSOTTI, Z. Atributos químicos do solo influenciados por sucessivas aplicações de dejetos suínos em áreas agrícolas de Santa Catarina. Revista Brasileira de Ciência do Solo, Viçosa, MG, v. 34, n. 2, p. 1375-1383, 2010.

SEIDEL, E. P.; GONÇALVES JUNIOR, A. C.; VANIN, J. P.; STREY, L.; SCHWANTES, D.; NACKE, H. Aplicação de dejetos de suínos na cultura do milho cultivado em sistema de plantio direto. Acta Scientiarum Technology, Maringá, v. 32, n. 2, p. 113$117,2010$. 
SILVA, D. F; ANDRADE, C. L.T.; RESENDE, A. V.; HICKMANN, C.; AMARAL, T. A.; ALVES, M. E. B. Nitrogen dynamics in soils cultivated with maize and fertilized with pig slurry. Ambi-Agua, Taubaté, v. 7, n. 1, p. 9-23, 2012. (http://dx.doi.org/10.4136/ambi-agua.782)

SILVA, E. C.; BUZETTI, S.; GUIMARÃES, G. L.; LAZARINI, E.; SÁ, M. E. Doses e épocas de aplicação de nitrogênio na cultura do milho em plantio direto sobre Latossolo Vermelho. Revista Brasileira de Ciência do Solo, Viçosa, MG, v. 29, n. 3, p. 353-362, 2005.

TORRES, J. L. R.; PEREIRA, M. G.; ANDRIOLI, I.; POLIDORO, J. C.; FABIAN, A. J. Decomposição e liberação de nitrogênio de resíduos culturais de plantas de cobertura em um solo de cerrado. Revista Brasileira de Ciência do Solo, Viçosa, MG, v. 29, n. 3, p. 609-618, 2005.

VARVEL, G. E.; SCHPERS, J. S.; FRANCIS, D. D. Ability for in-season correction of nitrogen deficiency in corn using chlorophyll meters. Soil Science Society of America Journal, Madison, v. 61, n. 4, p. 1233-1239, 1997.

WHITE, R. E. Leaching. In: WILSON, J. R. Advances in nitrogen cycling in agricultural ecosystems. Wallingford: CAB International, 1987. p. 193-211. 


ISSN = 1980-993X - doi:10.4136/1980-993X
www.ambi-agua.net
E-mail: ambi-agua@agro.unitau.br
Tel.: (12) 3625-4212

\title{
Changes in rainfall patterns in the eastern area of La Pampa province, Argentina
}

\author{
(http://dx.doi.org/10.4136/ambi-agua.692) \\ Silvia Pérez; Eduardo Sierra
}

\author{
Faculty of Agronomy, University of Buenos Aires, Buenos Aires, Argentina \\ e-mail: perez@agro.uba.ar; sierra@agro.uba.ar
}

\begin{abstract}
The eastern area of the Province of La Pampa, Argentina lies in a transition zone between the humid temperate climate stretching east and the steppe climate stretching west. The area is very sensitive to changes in precipitation patterns, especially when changes are sudden and there is no time to take adaptive measures to cope with the impacts of climate change. In such cases, agricultural production and the balance of the environment are threatened by potential disaster. In order to determine the long-term occurrence of such phenomena, long-term annual precipitation series (1921-2009) from 14 stations in the study area were analyzed using the procedure of hydrometeorological series segmentation. The results for the study period show a succession of abrupt increases, with annual precipitation increasing by about $30 \%$. Each increase in rainfall can be seen as a fostering factor for the expansion of crop planted area in the following years. However, in recent years, there has been an abrupt and significant decrease in precipitation with a marked return to the conditions that prevailed at the beginning of the period. Because agriculture intensified during the period of increased rainfall, the carrying capacity of the environment could be exceeded if rainfall continues to decrease over a long period of time, causing a decline in production accompanied by environmental degradation.
\end{abstract}

Keywords: Agroclimatology; climatological time series; shift in the mean.

\section{Mudanças no regime de precipitações do este do município La Pampa, Argentina}

\section{RESUMO}

O leste do Município de La Pampa, Argentina está em uma área de transição entre o clima temperado e úmido que estende para o leste e o clima de estepe que estende para o oeste, é muito sensível às mudanças no regime de precipitações, especialmente, quando elas ocorrem de forma abrupta, não dando o tempo necessário para levar a cabo medidas adaptativas, para evitar impactos negativos das mudanças climáticas que afetam a produção agrária e o equilíbrio ambiental. Com objetivo de estudar mudanças no regime de precipitação, foram analisadas séries anuais de precipitação (1921 - 2009) de 14 estações da área de estudo, usando uma metodologia de segmentação de séries hidrometeorológicas. Os resultados indicaram que no período de estudo, aconteceram uma sucessão de mudanças abruptas, de sinal positivo em que a precipitação anual aumentou ao redor de $30 \%$. O incremento das precipitações pode ser considerado uma das causas que explicam a expansão da área cultivada nos anos subsequentes a esses aumentos na precipitação. Não obstante, nos últimos anos, foi observada uma mudança abrupta de sinal negativo que reduziu 
significativamente a precipitação com um retorno marcado para as condições que prevaleceram no início do período analisado. Devido à expansão da agricultura observada no período de incremento das chuvas e, posteriormente, a diminuição dessas chuvas durante um longo período, poderia resultar na queda da produtividade e resultar em uma deterioração ambiental.

Palavras-chave: Agroclimatologia; série climatológica de tempo; mudanças na precipitação.

\section{INTRODUCTION}

Rainfall variability for different regions of South America has been studied by several authors. Garreaud and Aceituno (2001) studied interannual rainfall variability over the South America Altiplano. Paegle and Mo (2002) invested linkage between summer rainfall variability over South America and sea surface temperature anomalies. Pasquini et al. (2006) with statistical and spectral analysis show that there is significant evidence that rainfall has increased in central Argentina since the 2nd half of the 20th century. De la Casa and Nasello (2010) analyzed breakpoints in annual rainfall trends in Córdoba, Argentina in the period 1930-2006, they observed from negative to positive in the 1950s in the north area of the region, while in the other areas the opposite change occurs in the 1970s. More recently Junquas et al. (2011) studied summer precipitation variability over Southeastern South America in a global warming scenario.

According to Köppen's climatic classification as modified by Trewartha (Köppen, 1948; Trewartha, 1968), the western border of Argentina's agricultural area is located in a transition zone between the humid temperate climate (C), which extends eastward, and the steppe climate (BS), which extends westward. For this reason, the agricultural economy of the area is vulnerable to changes in water regime. Changes can produce strong positive or negative impacts on agricultural production (Viglizzo et al., 1995, 1997, 2001; Viglizzo and Frank, 2006).

From the mid 1970s, a sharp increase in rainfall regime provided most of the area with a supply of moisture higher than previously reported (Sierra et al., 1994; Pérez et al., 1999; Forte Lay et al., 2008; Pérez et al., 2011). This led to a strong increase in agricultural activity (Sierra et al., 1995; Solbrig and Viglizzo, 1999; Bernardos et al., 2001; Viglizzo et al., 1995, 1997, 2002, 2003; Manuel-Navarrete et al., 2009).

However, in recent years, the area has suffered from a marked recurrence of drought, which has seriously affected farming (Earth Observatory, 2009; WMO, 2009). Minetti et al. (2003) noted that severe droughts associated with La Niña during the periods 1988-1989 and 1995-1996 had reversed the rainfall trend over much of Argentina. The gradual increase in rainfall during the second half of the twentieth century has given way to a gradual decrease in rainfall during the early years of the 21 st century.

This paper examines changes in annual precipitation in the eastern area of the Province of La Pampa during the period 1921-2009. It assesses the alternation of wet and dry periods and considers whether transitions between periods allow sufficient time for adaptive adjustments or whether transitions are so abrupt that severe impacts are almost unavoidable.

\section{MATERIAL AND METHODS}

\subsection{Data}

We used monthly rainfall data for the period 1921-2009 from 14 localities in the northern, central and southern sub-areas of the eastern area of the Province of La Pampa, Argentina (Table 1, Figure 1). This data were collected with conventional rain gauges, from the official records of the National Weather Service (SMN in Spanish), the National Institute 
PÉREZ, S.; SIERRA, E. Changes in rainfall patterns in the eastern area of La Pampa province, Argentina. Ambi-Agua, Taubaté, v. 7, n. 1, p. 24-35, 2012. (http://dx.doi.org/10.4136/ambi-agua.692)

of Agricultural Technology (INTA) and the Directorate General of Statistics and Censuses (DGEyC) of the Province of La Pampa. The tests were applied to series of annual values obtained by adding together the monthly values for each year.

Table 1. Rain gauges geographical informations.

\begin{tabular}{lccccc}
\hline \multicolumn{1}{c}{ Locality } & $\begin{array}{c}\text { Latitude } \\
(\mathbf{S})\end{array}$ & $\begin{array}{c}\text { Longitude } \\
(\mathbf{W})\end{array}$ & $\begin{array}{c}\text { Altitude } \\
(\mathbf{m s l})\end{array}$ & $\begin{array}{c}\text { Sub } \\
\text { zone }\end{array}$ & $\begin{array}{c}\text { Origin of } \\
\text { the data }\end{array}$ \\
\hline Intendente Alvear & $35^{\circ} 14^{\prime}$ & $63^{\circ} 35^{\prime}$ & 123 & North & DGEyC $^{\text {a }}$ \\
Eduardo Castex & $35^{\circ} 53^{\prime}$ & $64^{\circ} 17^{\prime}$ & 171 & North & DGEyC $^{\text {a }}$ \\
Conhello & $36^{\circ} 01^{\prime}$ & $64^{\circ} 35^{\prime}$ & 201 & North & DGEyC $^{\text {a }}$ \\
Rucanelo & $36^{\circ} 02^{\prime}$ & $64^{\circ} 49^{\prime}$ & 244 & North & DGEyC $^{\text {a }}$ \\
Catrilo & $36^{\circ} 26^{\prime}$ & $63^{\circ} 24^{\prime}$ & 113 & Center & DGEyC $^{\text {a }}$ \\
Lonquimay & $36^{\circ} 28^{\prime}$ & $63^{\circ} 37^{\prime}$ & 136 & Center & DGEyC $^{\text {a }}$ \\
Anguil & $36^{\circ} 31^{\prime}$ & $64^{\circ} 01^{\prime}$ & 152 & Center & INTA $^{\text {b }}$ \\
Santa Rosa & $36^{\circ} 37^{\prime}$ & $64^{\circ} 16^{\prime}$ & 175 & Center & SMN $^{c}$ \\
Macachín & $37^{\circ} 08^{\prime}$ & $63^{\circ} 38^{\prime}$ & 130 & Center & DGEyC $^{\text {a }}$ \\
Doblas & $37^{\circ} 08^{\prime}$ & $64^{\circ} 01^{\prime}$ & 157 & Center & DGEyC $^{\text {a }}$ \\
Perú & $37^{\circ} 37^{\prime}$ & $64^{\circ} 09^{\prime}$ & 200 & South & DGEyC $^{\text {a }}$ \\
Guatraché & $37^{\circ} 40^{\prime}$ & $63^{\circ} 32^{\prime}$ & 169 & South & DGEyC $^{\text {a }}$ \\
Bernasconi & $37^{\circ} 54^{\prime}$ & $63^{\circ} 43^{\prime}$ & 162 & South & DGEyC $^{\text {a }}$ \\
Gral San Martín & $37^{\circ} 58^{\prime}$ & $63^{\circ} 34^{\prime}$ & 164 & South & DGEyC $^{\text {a }}$ \\
\hline
\end{tabular}

${ }^{\text {a} D G E y C ~ D i r e c t o r a t e ~ G e n e r a l ~ o f ~ S t a t i s t i c s ~ a n d ~ C e n s u s e s, ~}$

${ }^{\mathbf{b}}$ INTA National Institute of Agricultural Technology,

${ }^{\mathbf{c}}$ SMN National Weather Service

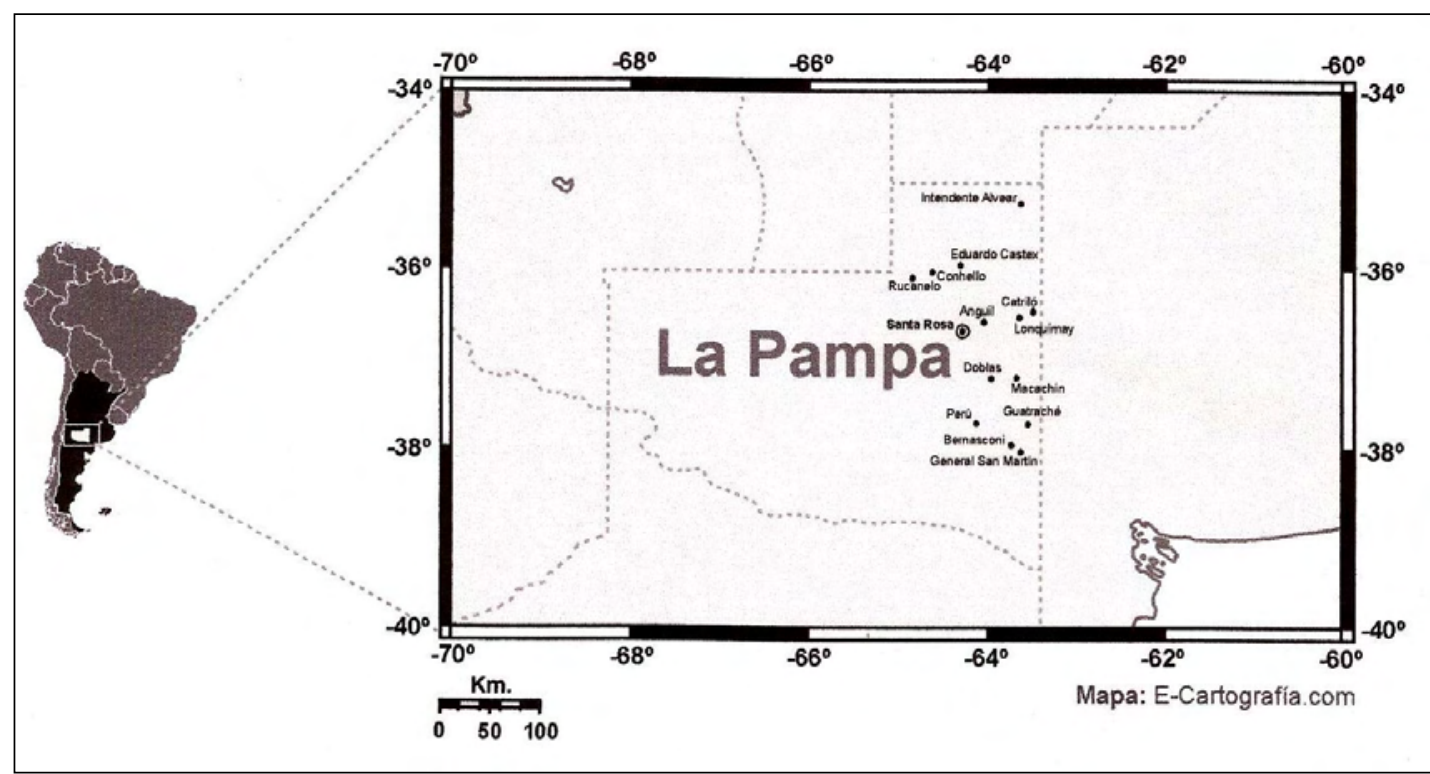

Figure 1. Location map of La Pampa Province, Argentina. 


\subsection{Quality Control}

The data from the 14 selected locations was subjected to a process of quality control in order to control for possible errors.

All data above the third quartile plus three times the interquartile range and located more than five standard deviations from the mean was treated as outliers. These outliers were then contrasted climatographically with readings from nearby stations. If the same reading was labeled as out of range for more than two seasons, the value was considered to be correct.

Months classed as outliers and those without data were treated as gaps. Both types of gaps were filled but no missing data was completed if there were more than three gaps in one year. The missing data were estimated from the records of the nearest stations taking into account the correlation coefficient between the various observation posts on a monthly basis.

\subsection{Homogeneity Test}

The homogeneity of the precipitation series was tested by Alexandersson and Moberg's (1997) Standard Normal Homogeneity Test (SNHT). For this purpose we used AnClim software (Štěpánek, 2006).

We used the series from the National Weather Service' recording station in Santa Rosa as a reference series because it is part of the network of stations reporting daily to the World Meteorological Organization (WMO ID No. 87623).

The SNHT was applied to each of the remaining series. A series of ratios $\left|q_{\mathrm{i}}\right|_{i=1}^{N}$ were estimated between the observed value of the series to which the test was applied and the value of the reference station. The standardized set of ratios $\left|z_{\mathrm{i}}\right|_{i=1}^{N}$ was estimated for which

$$
z_{\mathrm{i}}=\left(q_{\mathrm{i}}-\overline{q_{\mathrm{i}}}\right) / \mathrm{Sq}
$$

where $\overline{q_{\mathrm{i}}}$ and Sq are the mean and sample standard deviation of the series $q_{\mathrm{i}}$,

Let $1 \leq v<N$ and $\mu_{1 \neq} \mu_{2}$ where $\mathrm{N}$ is the number of years of data available,

The aim is to test the null hypothesis: $H_{0}: z_{i} \sim N(0,1) \forall i$

Against the alternative hypothesis: $H_{1}: z_{i} \sim N\left(\mu_{1}, 1\right) i \leq v \quad H_{1}: z_{i} \sim N\left(\mu_{2}, 1\right) i>v$

The null hypothesis states that the average of the standardized set $\mathrm{z}_{\mathrm{i}}$ does not change over time, while the alternative hypothesis states that for a time period $v$ there is a shift in the mean of the series.

The test statistic to determine whether a shift has occurred in the mean of the series $\mathrm{z}_{\mathrm{i}}$ is

$$
T_{0}=\max _{1 \leq v<N}\left\{T_{v}\right\}
$$

where

$$
\mathrm{T} v=v \overline{\mathrm{z}}_{1}^{2}+(\mathrm{N}-\mathrm{v}) \overline{\mathrm{z}}_{2}^{2}
$$

$\bar{z}_{1}$ and $\bar{z}_{2}$ are the sample means of the first $\mathbf{v}$ and last $(\mathrm{N}-\mathbf{v})$ values of the series $\mathrm{z}_{\mathrm{i}}$. If $\mathrm{T}_{0}$ is greater than some critical level for a given level of significance of the test, we can reject the null hypothesis which states that the series is homogeneous. According to Alexandersson (1986), the critical values for the test at significance level $\alpha=0,10$ and $\alpha=0,05$ for a series length $\mathrm{N}=89$ are 7,77 and 9,04 respectively. 


\subsection{Detecting shifts in the mean}

In order to detect shifts in mean annual precipitation we used Hubert's method of segmentation of hydrometeorological time series (Hubert et al., 1989). This method divides the series into $m$ segments $(m>1)$ so that the calculated mean over the entire series is significantly different from the means of neighboring segments.

Segmentation is defined as follows: Any series $x_{i}, i=i_{1}, i_{2}$ with $i_{1} \geq 1$ and $i_{2} \leq N$ where $\left(i_{1}<i_{2}\right)$ is a segment of the initial series of $\left(x_{i}\right), I=1, \ldots, N$

Any division of the initial series into $\mathrm{m}$ segments is an m-order segmentation of this series.

Thus, from a particular m-order segmentation of the initial series, we define:

$$
\begin{aligned}
& i_{k}, k=1,2, \ldots, m \\
& n_{k}=i_{k}-i_{k-1} \\
& \bar{x}_{k}=\left[\sum_{i=i_{k-1}+1}^{i=i_{k}} x_{i}\right] / n_{k} \\
& D_{m}=\sum_{k=1}^{k=m} d_{k} \quad \text { with } \quad d_{k}=\sum_{i=i_{k-1}+1}^{i=i_{k}}\left(x_{i}-\bar{x}_{k}\right)^{2}
\end{aligned}
$$

The segmentation obtained should be such that for a given segment order $\mathrm{m}$, the standard deviation $\mathrm{D}_{\mathrm{m}}$ is minimal. This is a necessary but not a sufficient condition to determine the optimal segmentation. It should be noted that the means of two adjacent segments must be significantly different. This constraint is met by applying the Scheffé test (Dagnélie, 1970).

\section{RESULTS AND DISCUSSION}

\subsection{Homogeneity test}

Twelve of the available annual rainfall series (Table 2) showed a T value smaller than the critical value (Alexandersson, 1986) and can be considered homogeneous at the level of significance $\alpha=0,05$. The other two series had $\mathrm{T}$ values greater than the critical value and were thus considered non- homogeneous. These were eliminated from the analysis.

Table 2. Test results of the Standard Normal Homogeneity Test applied to annual precipitation series from towns in the Province of La Pampa, and the series from the Santa Rosa station are used as a reference.

\begin{tabular}{l|cc}
\hline \multicolumn{1}{c|}{ Locality } & Change year & T value \\
\hline Intendente Alvear & 1969 & 5,513 \\
Eduardo Castex & 2009 & 2,691 \\
Conhelo & 1925 & 8,544 \\
Rucanelo & 2002 & 4,417 \\
Catrilo & 1969 & $9,304^{*}$ \\
Lonquimay & 1988 & $13,488^{*}$ \\
Anguil & $1991 \quad$ Reference series \\
Santa Rosa & 2005 & 3,312 \\
Macachín & 1948 & 2,565 \\
Doblas & 2005 & 5,419 \\
Perú & 2005 & 8,798 \\
Guatraché & 1985 & 3,946 \\
Bernasconi & 1986 & 4,487 \\
Gral. San Martín & & 6,471 \\
\hline
\end{tabular}

* $\mathbf{T}$ value exceeds $95 \%$ 
PÉREZ, S.; SIERRA, E. Changes in rainfall patterns in the eastern area of La Pampa province, Argentina. Ambi-Agua, Taubaté, v. 7, n. 1, p. 24-35, 2012. (http://dx.doi.org/10.4136/ambi-agua.692)

\subsection{Hubert's Hydrometeorological Time Series Segmentation}

Area and sub area means for annual precipitation series in the eastern area of the Province of La Pampa by Hubert's segmentation method (Hubert et al., 1989) are detailed in Table 3.

Table 3. Segmentation of the annual precipitation series for the northern, central, and southern sub-areas of the eastern area of the Province of La Pampa by Hubert's segmentation method (Hubert et al., 1989).

\begin{tabular}{l|rrrc}
\hline \multicolumn{1}{c|}{ Sub area } & Sub-period & Mean & $\begin{array}{c}\text { Standard } \\
\text { deviation }\end{array}$ & $\begin{array}{c}\text { Coefficient } \\
\text { of Variation }\end{array}$ \\
\hline \multirow{2}{*}{ North } & $1921-1971$ & 596,6 & 133,8 & 22,4 \\
& $1972-1998$ & 813,9 & 148,3 & 18,2 \\
& $1999-2001$ & 1179,1 & 189,5 & 16,1 \\
& $2002-2009$ & 657,1 & 199,6 & 30,4 \\
\hline \multirow{2}{*}{ Center } & $1921-1975$ & 583,5 & 151,3 & 25,9 \\
& $1976-2000$ & 788,4 & 177,5 & 22,5 \\
& $2001-2001$ & 1400,0 & 0,0 & 0,0 \\
& $2002-2009$ & 608,6 & 193,4 & 31,8 \\
\hline \multirow{2}{*}{ South } & $1921-1975$ & 544,7 & 141,2 & 25,9 \\
& $1976-2004$ & 728,5 & 184,6 & 25,3 \\
& $2005-2009$ & 420,4 & 137,8 & 32,8 \\
\hline \multirow{2}{*}{ Whole area } & $1921-1972$ & 564,0 & 136,6 & 24,2 \\
& $1973-1995$ & 706,4 & 146,9 & 20,8 \\
& $1996-2002$ & 930,3 & 174,5 & 18,8 \\
& $2003-2009$ & 567,4 & 189,1 & 33,3 \\
\hline
\end{tabular}

The behavior of localities in the northern sub-area was quite homogeneous (Figure 2), making the sub-area average representative of the ensemble.

Only Alvear seemed to show a slightly different behavior, but it was due to its higher rainfall average, and it showed the same abrupt changes as the other localities in the northern sub-area.

All localities in the northern sub-area showed two successive abrupt positive changes (Table 3 and Figure 2). The first was an increase in average annual precipitation from 596,6 mm during the 1921-1971 sub-period, to 813,9 mm during the 1972-1998 sub-period. The second abrupt positive change raised average annual rainfall to $1179,1 \mathrm{~mm}$ during the 1999 2001 sub-period. It is remarkable that, since 2002, after a short wet sub-period lasting just three years, an abrupt negative change reduced the average annual rainfall to $657,1 \mathrm{~mm}$, which is very similar to that of the initial 1921-1971 period. 


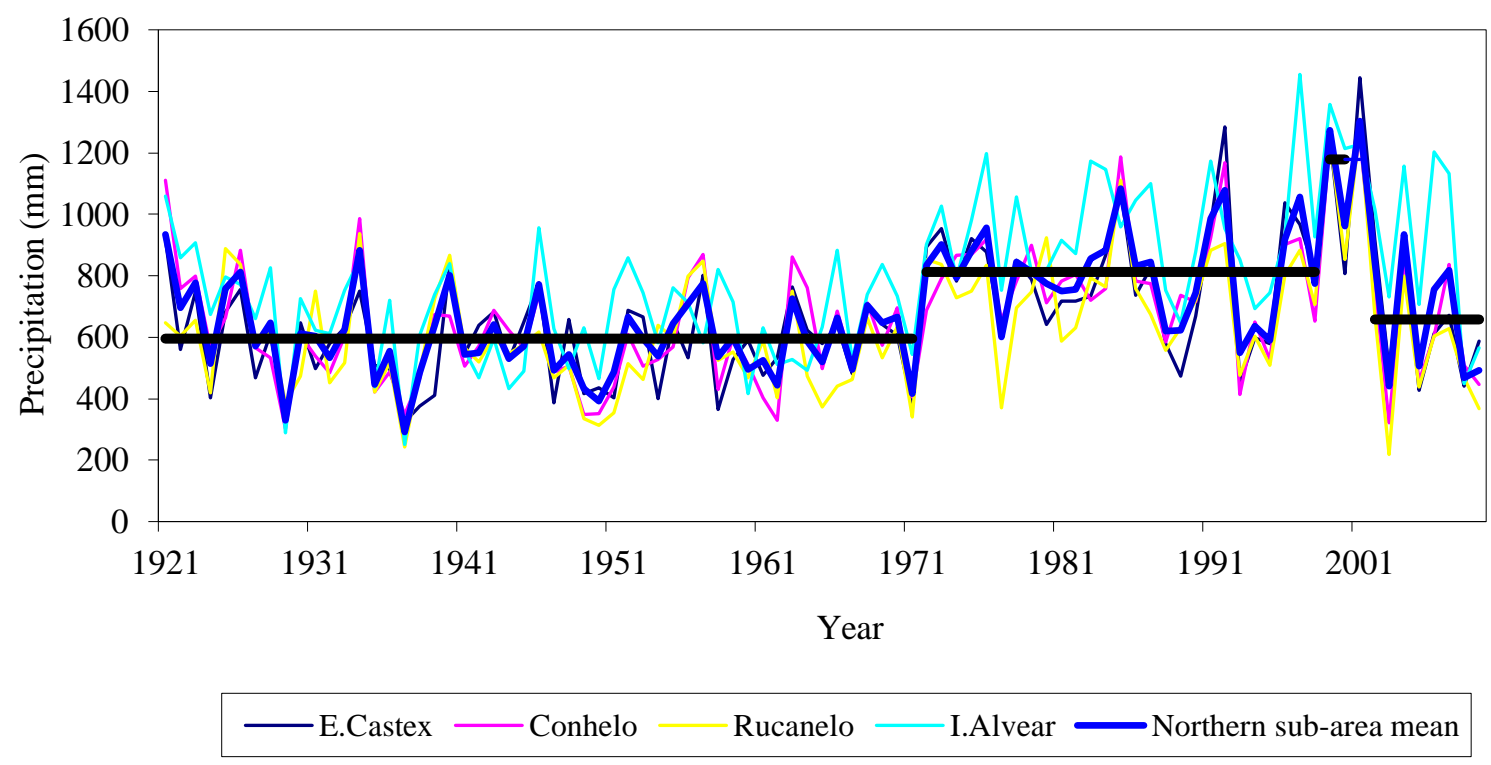

Figure 2. Annual precipitation and means for the sub-periods in the northern sub-area by Hubert's segmentation method.

The behavior of localities in the central sub-area was very homogeneous (Figure 3), making the sub-area average representative of the ensemble.

Although it showed the same abrupt changes than the other localities in the central subarea, Doblas showed slightly more marked behavior, with higher increases in the positive changes, and greater decreases in the negative changes.

The central sub area showed two abrupt positive changes (Table 3 and Figure 3). The first of these brought average annual rainfall from 583,5 mm during the 1921-1975 sub-period to $788,4 \mathrm{~mm}$ during the 1976-2000 sub-period; the second change was an increase in annual rainfall to $1400 \mathrm{~mm}$ in 2001. After this brief wet spell, there was an abrupt negative change in 2002. This lowered the average annual rainfall to $608,6 \mathrm{~mm}$, which is very similar to what it had been during the initial 1921-1975 period.

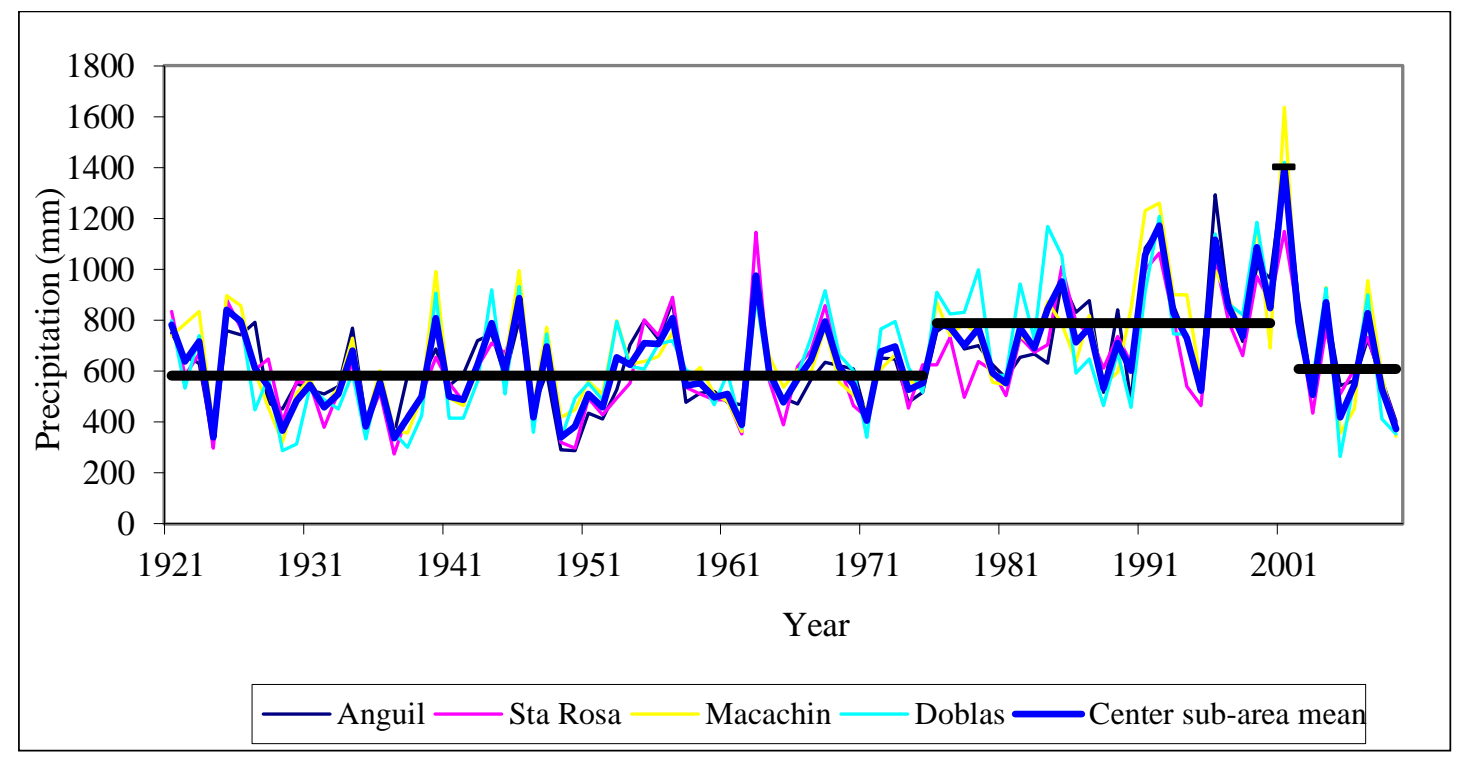

Figure 3. Annual precipitation and means for the sub-periods in the central sub-area by Hubert's segmentation method. 
The behavior of localities in the southern sub-area was very homogeneous (Figure 4), making the sub-area average representative of the ensemble.

Although it showed the same abrupt changes than the other localities in the southern subarea, Guatrache showed higher increases in the positive changes, while the decreases in the negative changes were less marked.

The southern sub-area showed two abrupt changes (Table 3 and Figure 4). The first was positive, with average annual rainfall rising from 544,7 $\mathrm{mm}$ during the sub-period 1921-1975, to $728,5 \mathrm{~mm}$ during the sub-period 1976-2004. The second abrupt change, which began in 2005, was negative. Here average annual rainfall fell to $420,4 \mathrm{~mm}$, which is considerably lower than what it had been during the initial 1921-1975 period.

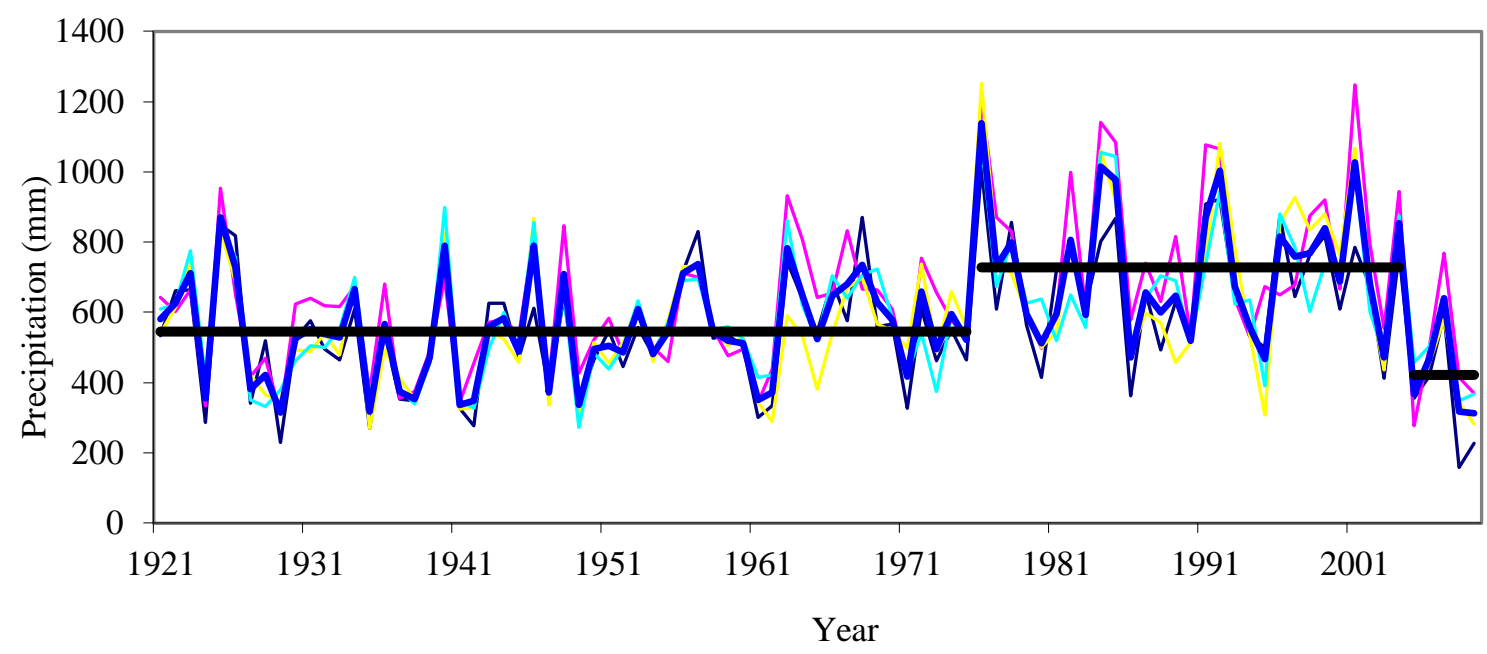

—Perú — Guatraché — Bernasconi —-Gral.San Martín — Southern sub-area mean

Figure 4. Annual precipitation and means for the sub-periods in the southern sub-area by Hubert's segmentation method.

The average for the whole area (Table 3 and Figure 5) showed two successive abrupt positive changes. The first brought average annual precipitation from $564,0 \mathrm{~mm}$ during the 1921-1972 sub-period to 706,4 $\mathrm{mm}$ during the 1973-1995 sub-period. The second abrupt positive change raised average annual rainfall to $930,3 \mathrm{~mm}$ in the $1996-2002$ sub-period. It is noteworthy that after this short wet sub-period of just six years, an abrupt negative change starting in 2003 reduced average annual rainfall to $567,4 \mathrm{~mm}$, which is very similar to the average for the initial 1921-1972 period.

It can be seen that there were always one and sometimes two abrupt positive changes in all the different sub-areas, as well as two abrupt positive changes in the area average in the second half of the twentieth century. Average rainfall increased, favoring the expansion of agriculture (Sierra et al., 1995; Solbrig and Viglizzo, 1999; Bernardos et al., 2001; Viglizzo et al., 1995, 1997, 2002, 2003; Manuel-Navarrete et al., 2009).

The behavior of the sub-areas was quite homogeneous (Figure 5), making the whole area average representative of the ensemble.

Nevertheless some minor differences in the behavior of the sub-areas were observed:

a)The northern sub-area showed higher increases in the positive changes, while the negative changes were of a lesser magnitude.

b) The center sub-area followed a behavior very similar to whole area.

c)The southern sub-area showed the wider range between positive and negative changes. 
Those differences show that abrupt changes are the most dangerous in the southern subarea, where the range of the fluctuations is very marked. This was very evident during the drought which affected the whole area during the 2008/2009 season, causing great damage to crops and cattle.

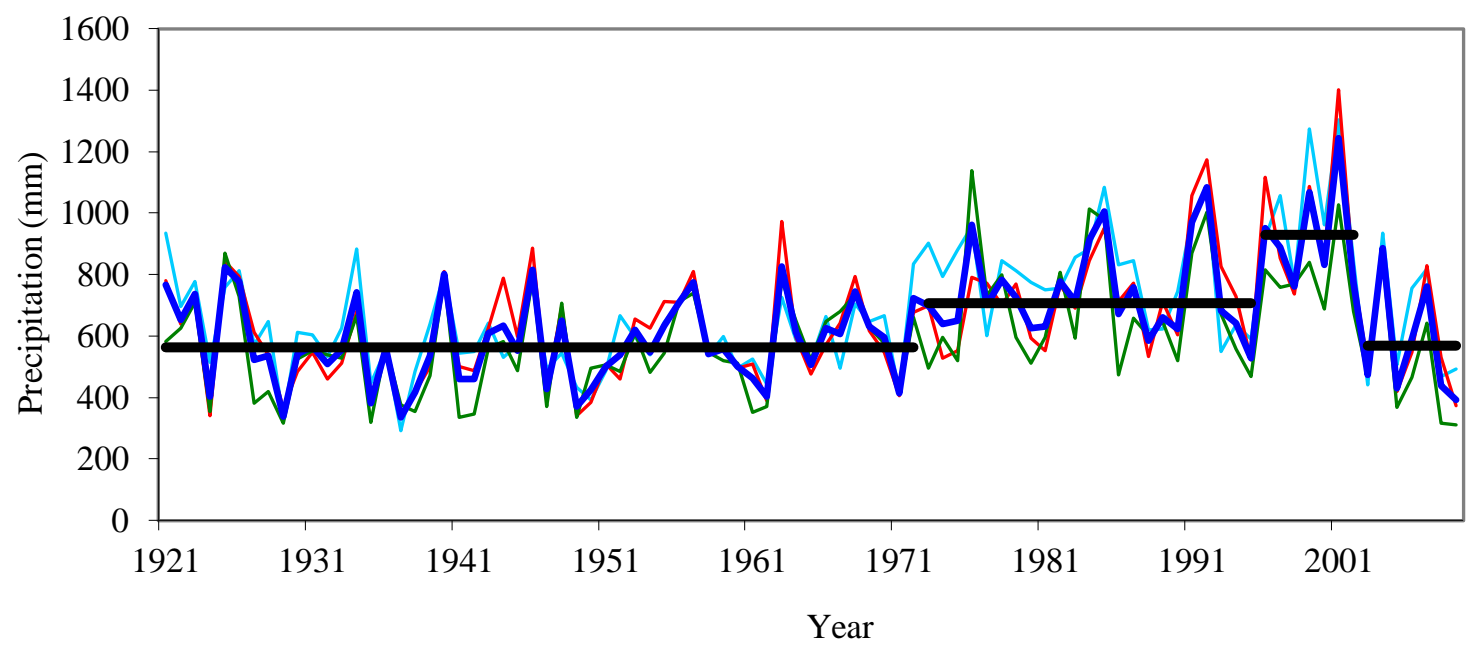

— Northern sub-area mean $\quad$ Center sub-area mean — Southern sub-area mean — Whole area

Figure 5. Annual precipitation and means for the whole area and the sub areas during the sub-periods by Hubert's segmentation method.

In the early years of the 21st century, not only individual locations and sub areas but also the area as a whole showed abrupt negative changes in average annual rainfall with a return to levels similar to the initial values. Thus, although the agricultural aptitude of the land had previously increased, much of it has now been lost again, placing the production and the environment of the area at risk.

\subsection{Possible causes of the as Pacific Decadal Oscillation (PDO) phenomena}

The causes of abrupt changes in rainfall in the eastern area of the Province of La Pampa are possibly associated with a phenomenon known as Pacific Decadal Oscillation (PDO) (Mantua et al., 1997), which has a warm and a cold phase, each lasting about 30 years.

During the warm phase (positive values), the Low Level Jet (low-altitude air current) strengthens. This increases the supply of moist tropical air from the Atlantic Ocean to the South American continent (Vimeux et al., 2005; Vimeux et al., 2009; Garreaud et al., 2009), and causes a corresponding increase in precipitation.

Conversely, during the cool phase (negative values), the Low Level Jet weakens, reducing the supply of moist air to the South American continent and thus reducing rainfall.

The rapid transition from one PDO phase to another is consistent with the abrupt changes in rainfall observed in this study. Specifically, the abrupt increase in rainfall in the area during the 1970s may be associated with the onset of a warm phase PDO at the same time, while the abrupt decrease of rainfall in the same area in the early 21 st century may be related to the simultaneous onset of a cool phase PDO.

If these pairings are correct, one would expect a dry phase in the eastern area of the Province of La Pampa lasting for about 30 years. Another rainy phase could not be expected until the beginning of the next warm phase PDO. 


\section{CONCLUSIONS}

Segmentation of the annual precipitation series for the eastern area of the Province of La Pampa by Hubert's segmentation method (Hubert et al., 1989) revealed that the area is subject to abrupt changes in rainfall.

In the second half of the twentieth century there was a succession of abrupt positive changes, with annual precipitation increasing by about $30 \%$. Increased rainfall can be considered one of the causes behind the crop extension area expansion in the years after the event.

However, it should be noted that in the early years of this century, there was an abrupt negative change. Rainfall was significantly reduced with a marked return to low values. If this regime continues for a long time, the carrying capability of the environment could be exceeded, causing a fall in production and parallel environmental degradation.

\section{REFERENCES}

ALEXANDERSSON, H. A homogeneity test applied to precipitation data. Journal of Climatology, San Francisco, v. 6, p. 661-675, 1986.

ALEXANDERSSON, H.; MOBERG, A. Homogenization of Swedish temperature data. Part I: homogeneity test for linear trends. International Journal of Climatology, London, v. 17, p. 25-34, 1997. http://dx.doi.org/10.1002/(SICI)1097-0088(199701)17:1<25::AID-JOC103>3.0.CO;2-J

BERNARDOS, J. N.; VIGLIZZO, E. F.; JOUVET, V.; LÉRTORA, F. A.; PORDOMINGO, A. J.; CID, F. D. The use of EPIC model to study the agroecological change during 93 years of farming transformation in the Argentine pampas. Agricultural Systems, Netherlands, v. 69, p. 215-234, 2001. http://dx.doi.org/10.1016/S0308-521X(01)00027-0

DE LA CASA, A.; NASELLO, O. Breakpoints in annual rainfall trenes in Córdoba, Argentina. Atmospheric Research, v. 95, p. 419-427, 2010. http://dx.doi.org/10.1016/j.atmosres.2009.11.005

DAGNÉLIE, P. Théorie et Méthodes Statistiques. Gembloux : Les Presses Agronomiques de Gembloux, 1970. 463 p.

EARTH OBSERVATORY. Drought in Argentina. Natural Hazards, 2009. Available in: <http://earthobservatory.nasa.gov/NaturalHazards/view.php?id=37105>. Access in: June 1st. 2011.

FORTE LAY, J.; SCARPATI, O.; CAPRIOLO, A. Precipitation variability and soil content in Pampean Flatlands (Argentina). Geofísica Internacional, México, v. 47, n. 4, p. 341354, 2008.

GARREAUD, R. D.; ACEITUNO, P. Interannual rainfall variability over South America Altiplano. Journal of Climate, v. 14, p. 2779-2789, 2001. http://dx.doi.org/10.1175/1520-0442(2001)014<2779:IRVOTS>2.0.CO;2

GARREAUD, R. D.; VUILlE, M.; COMPAGNUCCI, R.; MARENGO, J. Present-day South American Climate. Palaeogeography, Palaeoclimatology, Palaeoecology, v. 281, p. 180-195, 2009. http://dx.doi.org/10.1016/j.palaeo.2007.10.032 
HUBERT, P.; CARBONNEL, P.; CHAOUCHE, A. Segmentation des séries hydrométriques. Application à des séries de précipitations et de débits de l'Afrique de l'ouest. Journal of Hydrology, Stuttgart, v. 110, p. 349-367, 1989.

JUNQUAS, C.; VERA, C.; LI, L.; LE TREUT, H. Summer precipitation variability over southeastern South America in a global warming scenario. Climatic Dynamics, DOI 10.1007/s00382-011-1141-y, 2011. http://dx.doi.org/10.1007/s00382-011-1141-y

KÖPPEN, W. Climatología. Ciudad de Mexico: Fondo de Cultura Económica, 1948. 478 p.

MANUEL-NAVARRETE, D.; GALLOPÍN, G.; BLANCO, M.; DÍAZ ZORITA, M.; FERRARO, D.; HERZER, H.; et al. Multi-causal and integrated assessment of sustainability: the case of agriculturization in the Argentine Pampas. Environment Development and Sustainability, London, v. 11, n. 3, p. 621-638, 2009. http://dx.doi.org/10.1007/s10668-007-9133-0

MANTUA, N. J.; HARE, S.; ZHANG,Y.; WALlACE, J. M.; FRANCIS, R. C. A Pacific interdecadal climate oscillation with impacts on salmon production. Bulletin of American Meteorological Society, v. 78, p. 1069-1079, 1997. http://dx.doi.org/10.1175/1520-0477(1997)078<1069:APICOW>2.0.CO;2

MINETTI, J. L.; VARGAS, W.; POBLETE, A. G.; ACUÑA, L. R.; CASAGRANDE, G. Non-linear trends and low frequency oscillations in annual precipitation over Argentina and Chile, 1931-1999. Atmósfera, Ciudad de México, v. 16, p. 119-135, 2003.

PAEGLE, N.; MO, K.C. Linkages between summer rainfall variability over South America and sea surface temperature anomalies. Journal of Climate, v. 15, p. 1389-1407, 2002. http://dx.doi.org/10.1175/1520-0442(2002)015<1389:LBSRVO>2.0.CO;2

PASQUINI, A.; LECOMTE, K.; PIOVANO, E.; DEPETRIS, P. Recent rainfall and runoff variability in Central Argentina. Quaternary International, v. 158, p. 127-139, 2006 http://dx.doi.org/10.1016/j.quaint.2006.05.021

PÉREZ, S.; SIERRA, E.M.; CASAGRANDE, G.; VERGARA, G. Incremento de las precipitaciones (1921/1998) en el centro-este de la provincia de La Pampa (Argentina). Revista de Facultad de Agronomía, Buenos Aires, v. 19, n. 2, p. 193-196, 1999.

PÉREZ, S.; SIERRA, E.; LÓPEZ, E.; NIZZERO, G.; MOMO, F.; MASSOBRIO, M. Abrupt changes in rainfall in the Eastern area of La Pampa Province, Argentina. Theoretical and Applied Climatology, Hamburg, v. 103, p. 159-165, 2011. http://dx.doi.org/10.1007/s00704-010-0290-y

SIERRA, E. M.; HURTADO, R.; SPESCHA, L. Corrimiento de las isoyetas anuales medias decenales en la Región Pampeana 1941-1990. Revista de Facultad de Agronomía, Buenos Aires, v. 14, n. 2, p. 139-144, 1994.

SIERRA, E. M.; CONDE PRAT, M.; PÉREZ, S. La migración de cultivos de granos como indicador del cambio climático 1941-93 en la Región Pampeana Argentina. Revista de Facultad de Agronomía, Buenos Aires, v. 15, n. 2-3, p. 171-176, 1995.

ŠTĔPÁNEK, P. AnClim Software for time series analysis. Brno: Dept. of Geography, Faculty of Sciences, Masaryk University. 2006. 
SOLBRIG, O. T.; VIGLIZZO, E. F. Sustainable farming in the Argentine pampas : history, society, economy and ecology. Paper $\mathrm{N}^{\circ}$ 99/00-1 DRCLAS (Working papers on Latin America); Cambridge: Harvard University Cambridge, 1999.

TREWARTHA, G. T. An introduction to climate. 4th. Edition. New York: Mc Graw-Hill, 1968. $408 \mathrm{p}$.

VIGLIZZO, E. F.; ROBERTO, Z. E.; FILIPPIN, M. C.; PORDOMINGO, A. J. Climate variability and agroecological change in the Central Pampas of Argentina. Agriculture Ecosystems and Environment, Zürich, v. 55, p. 7-16, 1995.

VIGLIZZO, E. F.; ROBERTO, Z. E.; LÉRTORA, F.; LÓPEZ GAY, E.; BERNARDOS, J. Climate and land-use change in field-crop ecosystems of Argentina. Agriculture Ecosystems and Environment, Zürich, v. 66, p. 61-70, 1997.

VIGLIZZO, E. F.; LÉRTORA, F.; PORDOMINGO, A. J.; BERNARDOS, J. N.; ROBERTO, Z. E.; DEL VALLE, H. Ecological lessons and applications from one century of low external-input farming in the pampas of Argentina. Agriculture Ecosystems and Environment, Zürich, v. 83, p. 65-81, 2001.

VIGLIZZO, E.; PORDOMINGO, A. J.; CASTRO, M. G.; LÉRTORA, F.; SOLBRIG, O. T. Environmental sustainability of Argentine agriculture: patterns, gradients and tendencies 1960-2000. Working Paper N 01/02-2. Cambridge: Harvard University, The David Rockefeller Center for Latin American Studies, 2002.

VIGLIZZO, E. F.; PORDOMINGO, A. J.; CASTRO, M. G.; LÉRTORA, F. Environmental assessment of agricultura at a regional scale in the Pampas of Argentina. Environmental Monitoring and Assessment, Maine, v. 87, p. 169-195, 2003. http://dx.doi.org/10.1023/A:1024654316879

VIGLIZZO, E. F.; FRANK, F. C. Ecological interactions, feedbacks, thresholds and collapses in the Argentine Pampas in response to climate and farming during the last century. Quaternary International, Canada, v. 158, p. 122-126, 2006.

VIMEUX, F.; GALLAIRE, R.; BONY, S.; HOFFMANN, G.; CHIANG, J. C. H. What are the climate controls on delta $\mathrm{D}$ in precipitation in the Zongo Valley (Bolivia)? Implications for the Illimani ice core interpretation, Earth and Planetary Science Letters, v. 240, P. 205-220, 2005.

http://dx.doi.org/10.1016/j.eps1.2005.09.031

VIMEUX, F.; GINOT, P.; SCHWIKOWSKI, M.; VUILLE, M.; HOFFMANN, G.; THOMPSON, L. G. et al. Climate variability during the last 1000 years inferred from Andean ice cores: A review of methodology and recent results, Palaeogeography, Palaeoclimatology, Palaeoecology, v. 281, P. 229-241, 2009.

http://dx.doi.org/10.1016/j.palaeo.2008.03.054

WORLD METEOROLOGICAL ORGANIZATION - WMO. The warmest decade 20002009. Press Release $\mathrm{N}^{\circ} 869,2009$. Available in: <http://www.wmo.int/pages/ mediacentre/press_releases/pr_869_en.html>. Access in: June 1st 2011. 


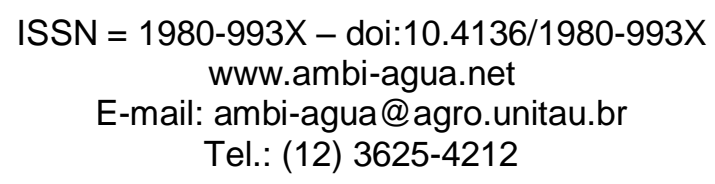

\title{
Modeling annual discharge of six Mexico's northern rivers
}

\author{
(http://dx.doi.org/10.4136/ambi-agua.705)
}

\author{
Jose Návar \\ Natural Resource Management. CIIDIR-IPN Unidad Durango, México \\ e-mail: jnavar@ipn.mx
}

\begin{abstract}
The overall goal of this report was to understand river discharge variability to improve conventional water management practices of Mexico's northern subtropical rivers. This report addresses whether: a) river discharge tendencies, patterns and cycles can be detected with proxy and instrumental records; and b) annual discharge can be forecasted by stochastic models. Eleven gauging stations of six major rivers; three lowland rivers discharging into the Pacific Ocean (Rios Santa Cruz, Acaponeta, and San Pedro); five upland rivers draining into the Pacific Ocean (Rio San Pedro: Peña del Aguila, Refugio Salcido, San Felipe, Vicente Guerrero and Saltito), one river flowing across the interior Basin (Rio Nazas: Salomé Acosta) and two more rivers discharging into the Northern Gulf of Mexico (Rio San Juan: El Cuchillo and Rio Ramos: Pablillos) were statistically analyzed. Instrumental recorded daily discharge data (1940-1999) and reconstructed time series data (1860-1940) using dendrochronological analysis delivered annual discharge data to be modeled using autoregressive integrated moving average, ARIMA models. Spectral density analysis, autocorrelation functions and the standardized annual discharge data evaluated annual discharge frequency cycles. Results showed ARIMA models with two autoregressive and one moving average coefficient adequately project river discharge for all gauging stations with four of them showing significant declining patterns since 1860. ARIMA models in combination with autocorrelation and spectral density techniques as well as standardized departures, in agreement with present (2002-2010) observations, forecast a wet episode that may last between 9 and 12 years thereafter entering again into a dry episode. Three dry-wet spell cycles with different time scales (1-2 years; 4-7 years; 9-12 years) could be discerned from these analyses that are consistent for all three northern Mexico's river clusters that emerged from a multivariate analysis test.
\end{abstract}

Keywords: Cycles; patterns; tendencies; spectral density; drought and wet episodes.

\section{Modelagem da vazão anual de seis rios do norte do México}

\section{RESUMO}

O objetivo geral deste trabalho foi a modelagem da variabilidade da vazão de rios para melhorar a gestão convencional das águas dos rios subtropicais do norte do México. Este artigo abordou as seguintes hipóteses: a) tendências das vazões do rio, padrões e ciclos podem ser detectados com base em registros de dados simulados e de instrumentos, e b) vazão anual pode ser prevista por modelos estocásticos. Onze estações hidrométricas de seis grandes rios; três rios de planície que drenam diretamente para o Oceano Pacífico (Rios Santa Cruz, Acaponeta, e San Pedro), cinco localizados nos trechos superiores desses rios (Rio San Pedro: Peña del Aguila, Refugio Salcido, San Felipe, Vicente Guerrero e Saltito) que drenam para bacia interior (Río Nazas: Salomé Acosta) e os dois últimos que drenam para o norte do Golfo 
México (Rio San Juan: El Cuchillo e Rio Ramos: Pablillos) foram analisadas estatisticamente. Dados armazenados de vazões diárias observadas (1940-1999) e dados reconstituídos a partir de série dendrocronológica histórica (1860-1940) resultou em dados de vazão anual a serem modelados usando médias móveis auto-regressivas integradas (modelos ARIMA). A análise de densidade espectral, funções de autocorrelação e os dados padronizados de vazão anual permitiram a avaliação dos ciclos de frequência anual de vazão. Os resultados mostraram que os modelos ARIMA com dois coeficientes e média móvel autorregressiva foram adequados para modelar a descarga do rio para todas as estações, em que quatro deles apresentaram tendências significativas de redução da vazão a partir de 1860. Modelos ARIMA em combinação com técnicas de autocorrelação e densidade espectral, bem como observações dos dados de vazão atuais (2002-2010), indicam que o norte do México está em um ciclo de cheias que pode durar de 9 a 12 anos antes de passar novamente por um período de seca. As estatísticas utilizadas mostraram a presença de três ciclos (anos 1-2, 4-6 e 9-12) consistentes para os três grupos de estações que surgiram a partir da análise multivariada.

Palavras-chave: ciclos; padrões; tendências; densidade espectral; episódios de seca e cheias.

\section{INTRODUCTION}

Mexico's freshwater availability is high with an average of $474.9 \mathrm{Km}^{3}$ year $^{-1}$ that equates to $4,749 \mathrm{~m}^{3}$ inhabitant $^{-1}$ year $^{-1}$ (México, 2005). Overall only $18 \%$ of water resources are pumped out from rivers and aquifers for consumptive use, totaling 78,000 $\mathrm{M} \mathrm{m}^{3} \mathrm{y}^{-1}$. This volume supplies agriculture (78\%), urban-public (12\%), industry $(8 \%)$, and livestock $(2 \%)$ (México, 2001). Mexico's irrigated area total 6.3 M ha, of which 3.4 M ha are irrigated with surface water and the remaining $2.9 \mathrm{M}$ ha with primarily groundwater (México, 2005).

In Mexico, as in many other places, water resources are not evenly distributed in time neither in space. For example, per capita water availability is steadily declining since it was close to $18,000 \mathrm{~m}^{3}$ inhabitant $^{-1}$ year $^{-1}$ in the 1950's (México, 2007). On the other side, the country's most productive central-northern portion has only $31 \%$ of renewable freshwater (México, 2009). Currently, several Mexico's northern watersheds already show signs of water scarcity to cope with increased conventional demands. For example, several over-stressed regions by persistent shortages have water pressure indices well above $100 \%$.

Recurrent drought spells control water resources availability since northern Mexico is a climatically sensitive-prone area because of its subtropical location, a region susceptible to changes in precipitation at several temporal and spatial scales. Drought episodes have reliably been well documented by instrumental and reconstructed proxy rainfall and dendrochronological records (O'Hara and Metcalfe, 1997; Stahle et al., 1999; Diaz et al., 2002; Cleaveland et al., 2003; Návar, 2008). However, how reduced rainfall controls surface and groundwater resources is missing elsewhere. Any hydro-climatic model would predict that rainfall variation drives watershed discharge and aquifer recharge, although its magnitude requires further empirical quantification and evidence. Coupling physical modeling with measured rainfall-discharge data would eventually improve predictions. For instance, Návar (1999) proved the river discharge magnification effect by diminished rainfall; e.g., the Mexico's northeastern Rio San Juan discharge was reduced along the main stem by 52\% during the 1950's drought spell on record although annual precipitation declined by only $20 \%$.

Hydro-climate variability drives water availability, pressure and competition and modeling river discharge plays a key role in the decision-making process with the aim to properly manage water resources in places with scarce, erratic hydro-climatic conditions (Postel, 2000). However, discharge cycles, their magnitude and temporal duration must first be understood to be later coupled with reconstructed rainfall data to fit more physically-based 
models. For instrumental records, Návar et al. (2006) for Mexico's northern rivers; Návar (2009) for rivers of Durango, Mexico; Hernández and Návar (2010) for rivers of Michoacán, Mexico found that approximately $40 \%$ of all gauging stations analyzed are presenting statistical oscillations and tendencies; of which approximately $26 \%$ show monotonic reduced annual discharge for the instrumental period of 1940-2000. However, modeling requires information on whether oscillations and tendencies are consistent over longer time series data that can be documented with proxy information to understand sources of inherent intrinsic climatic variability and potential subtle climate shifts.

In light of this information, this research addresses the question whether longer proxy and instrumental river discharge data can be stochastically modeled with the aim to derive oscillations and tendencies. Daily river discharge data for eleven sub-tropical gauging stations for six Mexico's northern large rivers (Acaponeta, San Pedro, San Juan, Nazas, Pablillos, and Santa Cruz) was available to fit ARIMA models; autocorrelation and spectral density analysis. In addition to a cumulative standardized departure aided to understand oscillations and tendencies with the aim to set up better river management guidelines.

\section{MATERIAL AND METHODS}

\subsection{The study area.}

The study area covers the basins of Sinaloa, Presidio-San Pedro, Nazas-Aguanaval, and San Fernando-Soto La Marina and the Rio San Juan. These watersheds are found within the Mexican northern States of Sinaloa, Nayarit, Durango, Chihuahua, Zacatecas, Coahuila, Nuevo Leon, and Tamaulipas. The hydrometric stations spans from $21^{0} 59$ ' 15 ', at the 'Río San Pedro' site to the $25^{\circ} 43^{\prime} 10^{\prime}$ ' of North Latitude at the 'El Cuchillo' site and from $106^{0} 57^{\prime} 10^{\prime}$ ', at the 'Santa Cruz' station in Sinaloa, to $99^{0} 33^{\prime} 20^{\prime}$ ' of West Longitude at the 'Pablillo' site in Nuevo León, Mexico (Figure 1).

A diversity of climates characterizes Northern Mexico's landscapes (México, 2000). Cold climate typifies the highest peaks and uplands of the two main mountain ranges. The central valleys, and mesas of the Cordilleras feature cold-temperate climates. Subtropical and tropical climates are characteristic of the low ranges of the Pacific Ocean and Gulf of Mexico. Dry-warm climates are common in the central Chihuahuan Desert and the southern Great Plains of North America.

Pine, oak, and a mixture of pine-oak forests cover extensive upland areas of the eastern and western Sierras Madre mountain ranges. Montane forests, characterized by thorny shrubs and low, broadleaved trees, distribute widely on the piedmonts of the main mountain ranges. Tropical and subtropical flora dominates plant cover in the plains and low piedmont slopes facing the oceans. Chaparral, dry, xerophytic plant cover is typical at the central Chihuahuan Desert and the southern Great Plains of North America. Tamaulipan thornscrub, acacia and mesquite forests extend into the lowlands of the Pacific Ocean, northern Gulf of Mexico and at several places of the Great Plains of North America. Tropical dry forests are typical of the lowlands of the Pacific Ocean.

Shallow Litosols and Regosols are typical of the main mountain ranges. Deep Regosols, Xerosols, and Yermosols dominate the landscape of the central Chihuahuan Desert. Deep Vertisols characterizes the plains in the lowlands of the Pacific Ocean and the northern Gulf of México. 


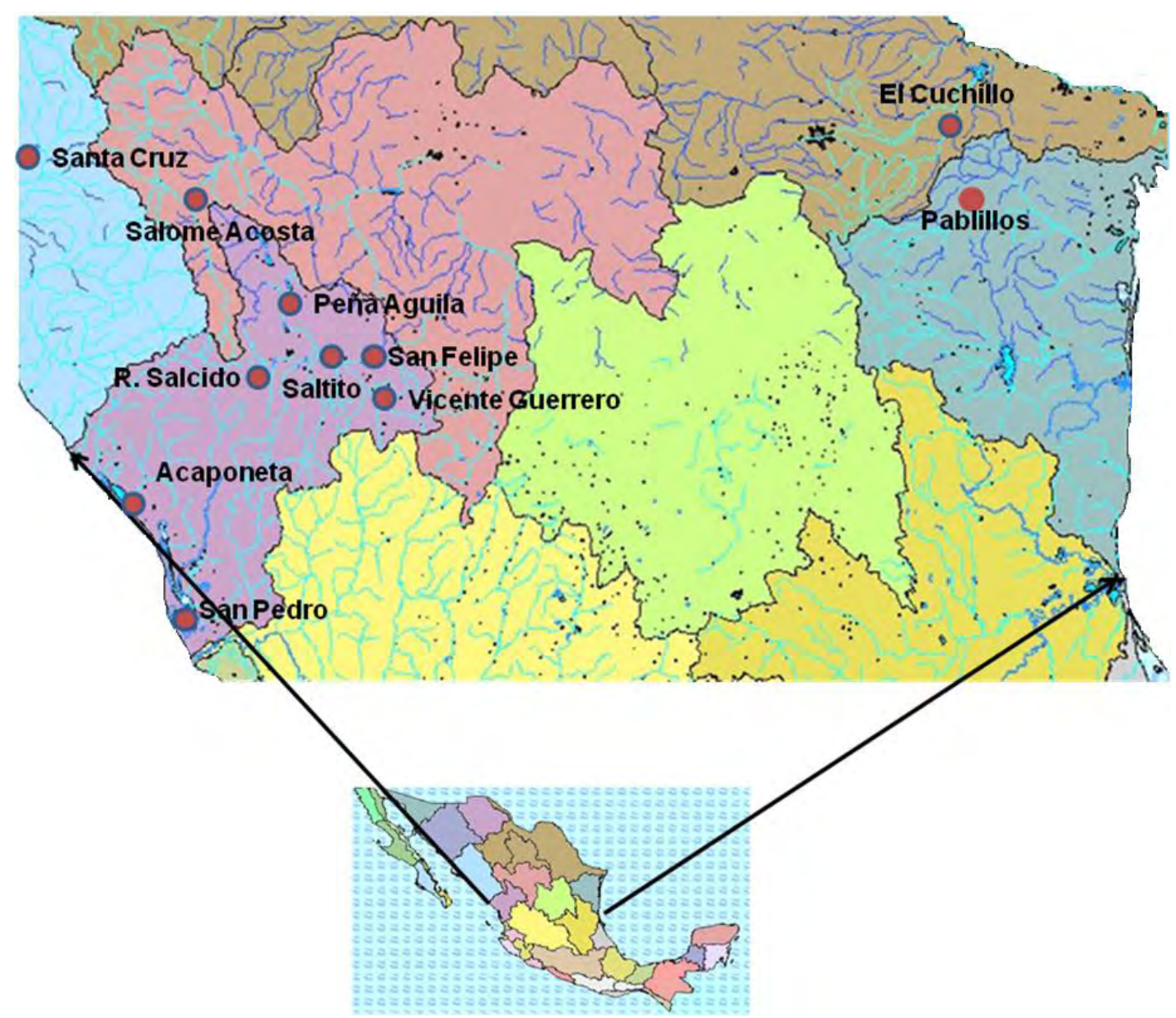

Figure 1. Location of the study area and the eleven hydrometric stations in northern Mexico.

\subsection{Instrumental and reconstructed annual discharge data.}

Annual instrumental discharge data (1940-2000) collected from official records for the gauging stations: Santa Cruz (RH 10); San Pedro (RH 11); Acaponeta (RH 11); Salomé Acosta (RH 36); San Felipe (RH 11); Refugio Salcido (RH 11); Peña del Águila (RH 11); Vicente Guerrero (RH 11); Saltito (RH 11); El Cuchillo (RH 37); Pablillo(RH 25) was reconstructed back to 1860 using dendrochronological analysis reported for the Sierra Madre Oriental and Occidental mountain ranges, SMO and SMW, respectively. A total of six dendrochronologies; three for the SMO (La Marta, El Potosí, and La Encantada) reported by Arreola-Ortiz and Návar-Cháidez (2010) and three for the SMW (El Gato, Banderas, and Las Bayas) reported by González-Elizondo et al. (2005) fitted regression equations with annual discharge as the dependent variable. It is highly likely annual baseflow correlates better with tree ring width since annual discharge is most of the time controlled by heavy downpours lasting a few days in semi-arid and subtropical landscapes. However baseflow information could not be derived at this time for these time series. In general, El Gato data predicted well annual river discharge for most SMW gauging stations and El Potosi dendrochronological data fitted better the El Cuchillo-Pablillos annual river discharge data. Regression equations were statistically significant, with coefficients of determination, $\mathrm{r}^{2}$, between $0.10 \leq \mathrm{r}^{2} \leq 0.40$ and probabilities $<0.05$. 


\subsection{Fitting ARIMA models.}

Autoregressive integrated moving average models, ARIMA, fitted proxy and instrumental time series data. The data was smoothed because of a lack of significant autocorrelation functions on the original discharge time series. Trend and de-trended autoregressive, integrated moving average, ARIMA, models fitted smoothed annual reconstructed and instrumental time series data (1860-2000). Moving average statistic with a time $t=5$ years smoothed data well. I searched for ARIMA models that produced unbiased annual discharge data; accounted for the largest variance (large coefficient of determination and small standard error), had uncorrelated AR or MA coefficients, and that projected consistent patterns and tendencies with the original data source. Autoregressive parameters explain the relationship between current and previous discharge while moving average parameters define better cycles within the time series. ARIMA models can be described as a combination of both parameters with or without a tendency or a seasonal component. A simple ARIMA model with an autoregressive and one moving average parameter with no seasonal pattern is $(1,0,1)$ and explains that the previous discharge is well related to the current discharge and that the time series has one potential cycle. Parameters are often calculated using statistical software. For this analysis the Statistical Analysis System (Sas) was employed.

\subsection{Classifying gauging stations.}

Principal component analysis, a multivariate analysis statistic, classified and ordered all eleven gauging stations using instrumental annual discharge data. The statistical method was conducted on un-transformed data with the correlation option in SAS v 8.0 (Sas, 1997).

\subsection{Magnifying and extracting dry-wet frequency cycles.}

The time series discharge data augmented the resolution by calculating the cumulative standardized $\mathrm{z}$ coefficient value. The standardization procedure contrasts time series data since discharge values are transformed into a compatible $\mathrm{Z}$ statistic. The cumulative standardize $\mathrm{Z}$ coefficient was calculated as follows;

$$
Z=\sum_{z i=1}^{Z n} z_{i}+z_{i+1} \therefore z_{i}=\frac{x_{i}-\bar{x}}{s} \therefore s=\sqrt{\frac{\left(x_{i}-\bar{x}\right)^{2}}{n-1}}
$$

When the $\mathrm{Z}$ coefficient value is plotted as a function of time, $t$, negative $\mathrm{Z}$ values produce downward tendencies indicating the presence of drought spells. In contrast when the cumulative $Z$ coefficient value make upward tendencies it provides indications of wet cycles. Then, the $Z$ coefficient value magnifies drought and wet patterns in the time series data.

\subsection{Identifying wet and dry cycle periodicities.}

Predicted discharge time series by the ARIMA models were statistically analyzed for frequency cycles using spectral density analysis. The autocorrelation, the partial autocorrelation and the inverse autocorrelation, as well as the spectral density functions fitted reconstructed and instrumental time series data. Confidence interval bands $(\alpha=0.05)$ on the correlation and spectral functions furnished preliminary statistical backgrounds on $r$ values $>$ than confidence interval bands. Spectral density analysis and the standardized cumulative $\mathrm{Z}$ index confirmed the cycle frequency as a function of peaks to noise ratios in a spectral band.

\section{RESULTS AND DISCUSSION}

\subsection{Fitting ARIMA models}

Autoregressive, integrated moving average models with a linear tendency fitted better than the autoregressive-moving average models proxy and instrumental data since the mean $\mathrm{r}^{2}$ 
increased from mean values of 0.64 to 0.73 and the mean standard error was reduced on average from 92 to $82 \mathrm{Mm}^{3}$. An example of instrumentally-recorded, reconstructed, smoothed, modeled and projected flows for the Nayarit's gauging station 'San Pedro' is shown in Figure 2. In general, best prediction ARIMA models contain two auto-regressive and one moving average parameters with a linear tendency that adequately project annual discharge, with a coefficient of variation of $12 \%(08 \%)$ of the mean annual discharge (Table 1). Therefore, two previous discharge values are well related to the present discharge and the time series has on the average one cycle. The inter-annual cycle was the most statistically significant. For all ARIMA models, the linear tendency had a negative slope but only four (San Pedro, Upper Nazas or Salomé Acosta, Pablillos, and Santa Cruz) had statistical significance $(\mathrm{p} \leq 0.05)$. That is, in this report, the linear decreasing discharge tendency is accepted for four out of eleven studied gauging stations; in 36\% of the studied rivers the downward tendency extends to the period of 1860-1940 (Table 1). Surprisingly these results are consistent with findings for other rivers of Mexico's northern and central watersheds. Most models predict well smoothed annual discharge since coefficients of determination, $\mathrm{r}^{2}$, larger than 0.69 and standard errors of less than $40 \%$ were observed in these models. Most second order autoregressive parameters show negative signs stressing the stochasticity of these time series. The up and down tendencies can be noted in Figure 2 as well.

In seven out of nine hydrometric stations analyzed, discharge monotonically reduces in northern Mexico (Návar, 2009). Hernández and Návar (2010) found that 24\% of all Michoacan State's gauging stations analyzed also present discharge downward tendencies. Návar et al. (2006) calculated that 26\% of Mexico's northern 175 gauging stations studied are also presenting reduced instrumental discharge. That is, between 20 and $40 \%$ of river discharge data analyzed for instrumental records show monotonically reduced discharge tendencies that are consistent with the percentage of proxy discharge tendencies as well.

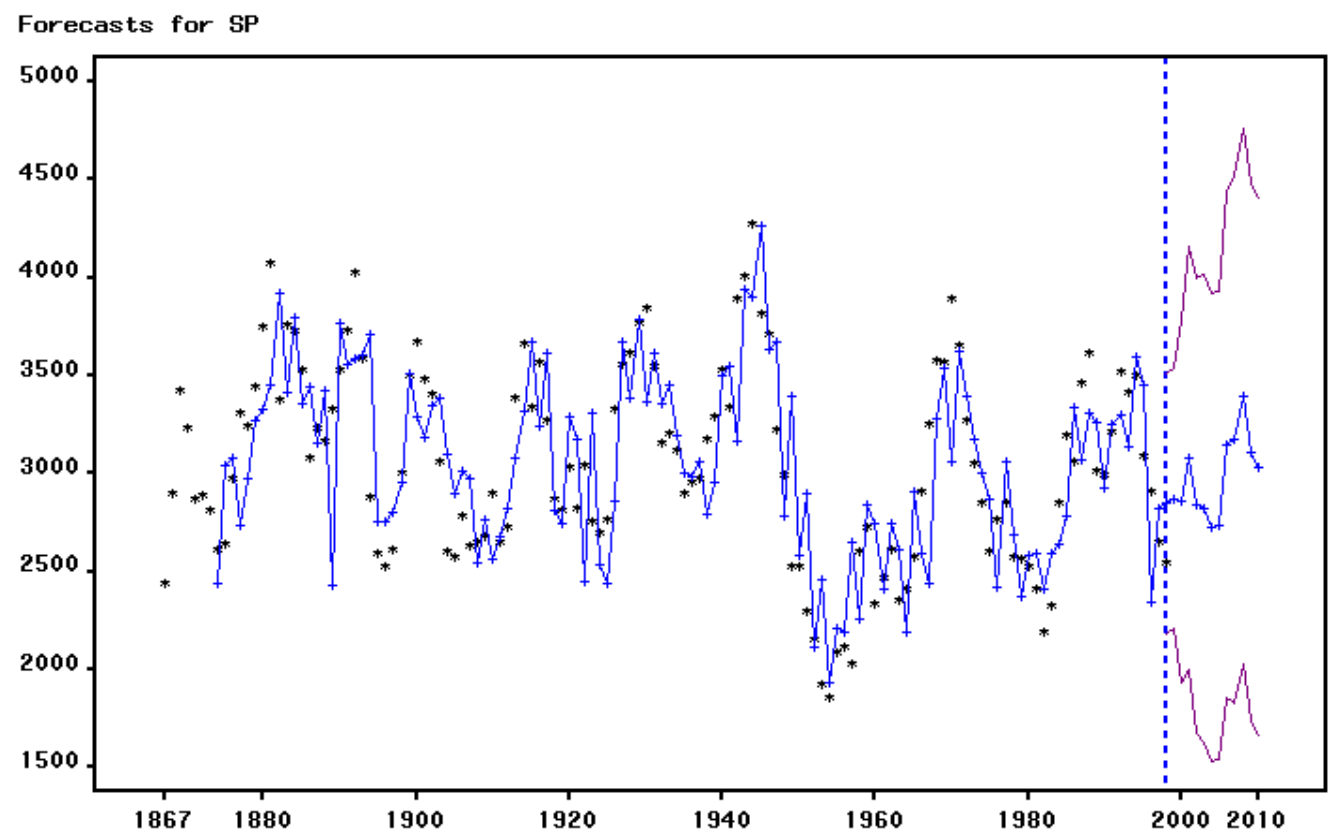

Figure 2. Smoothed annual instrumental and reconstructed discharge data fitted with an ARIMA model $(2,0,1)$ with a linear tendency for the gauging station 'San Pedro' in Nayarit, Mexico.

All ARIMA models project consistently increased river flow for the period of 2002-2004 to 2010-2012 as it has been the case for instrumental and visual observations for all of these rivers for this time period. Unfortunately, discharge data is not yet publically available to 
validate stochastic models for the last period (2000-2010) of instrumental records. Good correlations were found between discharge predictions by ARIMA models reported in Table 1 for all eleven gauging stations.

Table 1. ARIMA models for predicting annual smoothed discharge for Mexico's northern eleven gauging stations from six rivers.

\begin{tabular}{l|lll|ll|l|l|c}
\hline \multicolumn{1}{c|}{ Gauging Station } & Model & MA(1) & MA(2) & AR(1) & AR(2) & $\begin{array}{l}\text { Linear } \\
\text { Trend }\end{array}$ & $\mathbf{S x}$ & $\mathbf{R}^{2}$ \\
\hline Acaponeta & $(2,0,1)$ & 0.63 & & 1.60 & -0.73 & -2.20 & 142.63 & 0.71 \\
San Pedro & $(2,0,1)$ & 0.48 & & 1.51 & -0.64 & $\mathbf{- 2 . 3 6}$ & 262.31 & 0.73 \\
El Cuchillo & $(2,0,2)$ & 0.65 & -0.45 & 1.35 & -0.62 & -2.80 & 134.04 & 0.70 \\
Salomé Acosta & $(2,0,2)$ & -1.32 & -0.44 & -0.24 & 0.64 & $\mathbf{- 0 . 9 5}$ & 84.59 & 0.69 \\
Pablillos & $(2,0,0)$ & & & 1.04 & -0.19 & $-\mathbf{0 . 3 9}$ & 22.99 & 0.79 \\
Vicente Guerrero & $(2,0,1)$ & 0.41 & & 1.42 & -0.61 & -0.10 & 7.02 & 0.70 \\
San Felipe & $(2,0,1)$ & 0.36 & & 1.47 & -0.65 & -0.36 & 18.81 & 0.75 \\
Refugio Salcido & $(2,0,0)$ & & & 1.16 & -0.39 & -0.22 & 13.41 & 0.76 \\
Peña del Aguila & $(2,0,2)$ & 0.56 & -0.59 & 1.33 & -0.62 & -0.44 & 25.18 & 0.75 \\
Saltito & $(2,0,0)$ & & & 1.05 & -0.26 & -1.01 & 56.91 & 0.73 \\
Santa Cruz & $(2,0,1)$ & 0.50 & & 1.50 & -0.62 & $\mathbf{- 2 . 1 2}$ & 186.69 & 0.72 \\
\hline
\end{tabular}

Note: bold numbers are statistically significant $(\mathrm{p}<0.05)$

\subsection{Classifying gauging stations.}

Three principal components accounted for by $90 \%$ of the total annual discharge variance. The first two are graphed in Figure 3 and they accounted for by $75 \%$ of the total annual discharge variance. The first principal component divides data into large (Santa Cruz, Acaponeta, San Pedro and El Cuchillo) and small (R. Salcido, Pablillos, San Felipe, P. Águila, V. Guerrero, Salomé Acosta, Saltito) discharge station values. The second principal component dissects data into Pacific Ocean, the Interior basin draining- river and the uplandwatershed gauging stations with intermediate northern Gulf of Mexico gauging stations. As expected, three main clusters emerged quite well from this multivariate analysis. The first one makes up by rivers that drain into the Pacific Ocean (San Pedro, Santa Cruz, and Acaponeta) with reported high internal series' correlation coefficients $(r>0.87)$. The second cluster separated well and conformed rivers draining into the northern Gulf of Mexico (El Cuchillo and Pablillos) that also reported high internal series' $r$ values $(r>0.67)$. The third cluster contained rivers discharging into interior basins (Salome Acosta) together with uplandwatershed rivers that drain into the Pacific Ocean (Vicente Guerrero, Peña del Aguila, R. Salcido, El Saltito), which reported also large internal correlation coefficient values ( $r>0.72)$. However, small correlation values were found for any of these three river clusters. 
Climatically-driven rainfall patterns that produce river discharge; e.g., bimodal type of rainfall originated from easterlies of the Atlantic Ocean are typical of Mexico's northeastern watersheds (El Cuchillo and Pablillos). Monsoonal, uni-modal summer rainfalls originated from Pacific Ocean easterlies appear to feature basins RH 10; RH 11 and RH 36. Geology consisting on Shales and Limestones of Upper Cretacic origin along with recent sedimentary deposits dominate the landscape of the Sierra Madre Oriental mountain range that gives life to Rios San Juan and Pablillos as well as to many other smaller rivers. Volcanic rocks of the Cenozoic era characterize the geology of the Sierra Madre Occidental mountain range. Lower andesitic and upper rhyolitic units of different age composed the volcanic rocks.

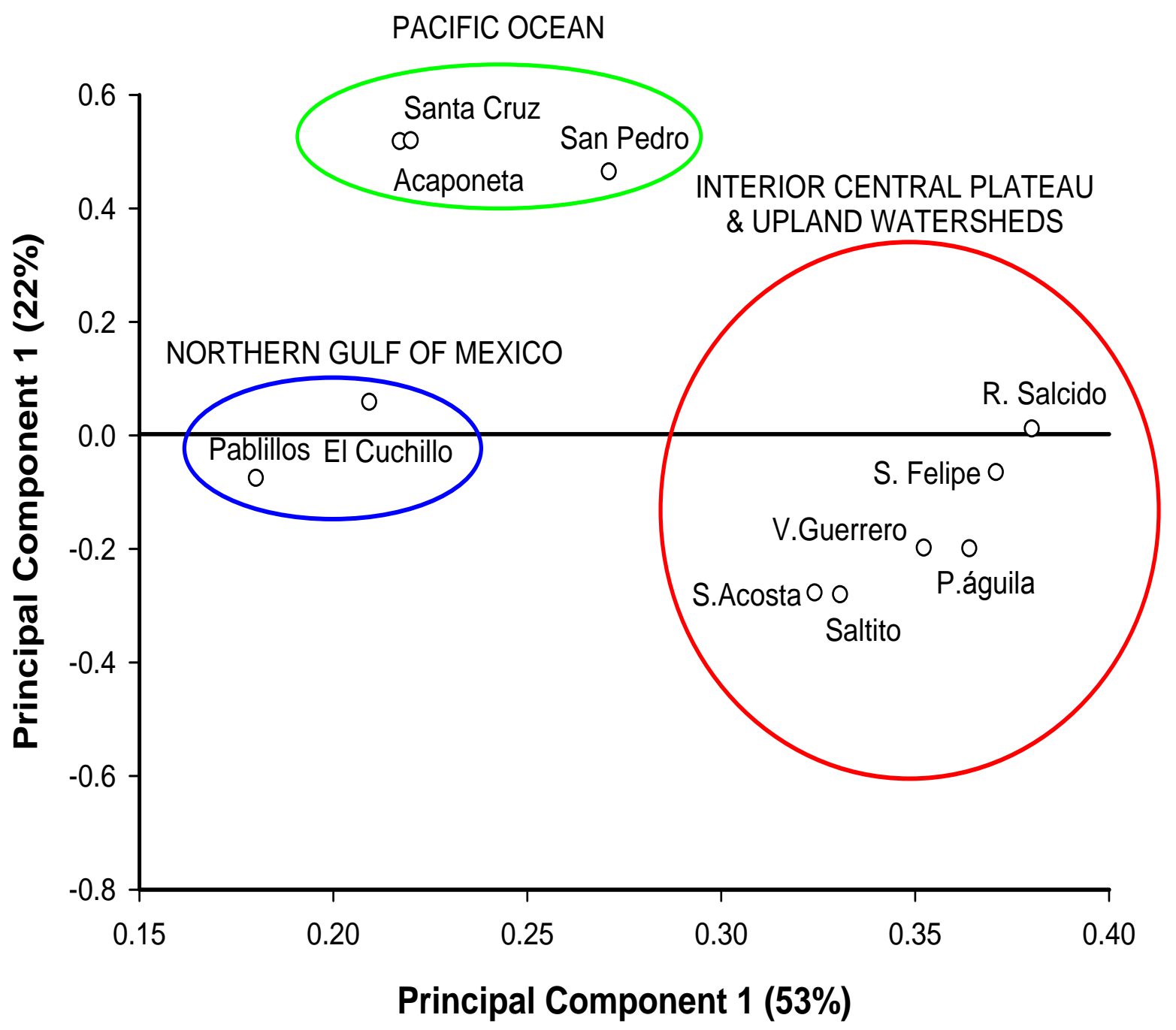

Figure 3. Principal component analysis for instrumental and reconstructed annual discharge data for eleven Mexico's northern rivers.

\subsection{Dry-wet cycles}

The time series data, the ARIMA models and the standardized cumulative departures show well dry and wet cycles. Below-average river discharge for several time periods indicates dry spells and above-average river discharge annual values are classified as wet episodes. Dry and wet spells can be noted for each river cluster in Figures (4 and 5), respectively. 


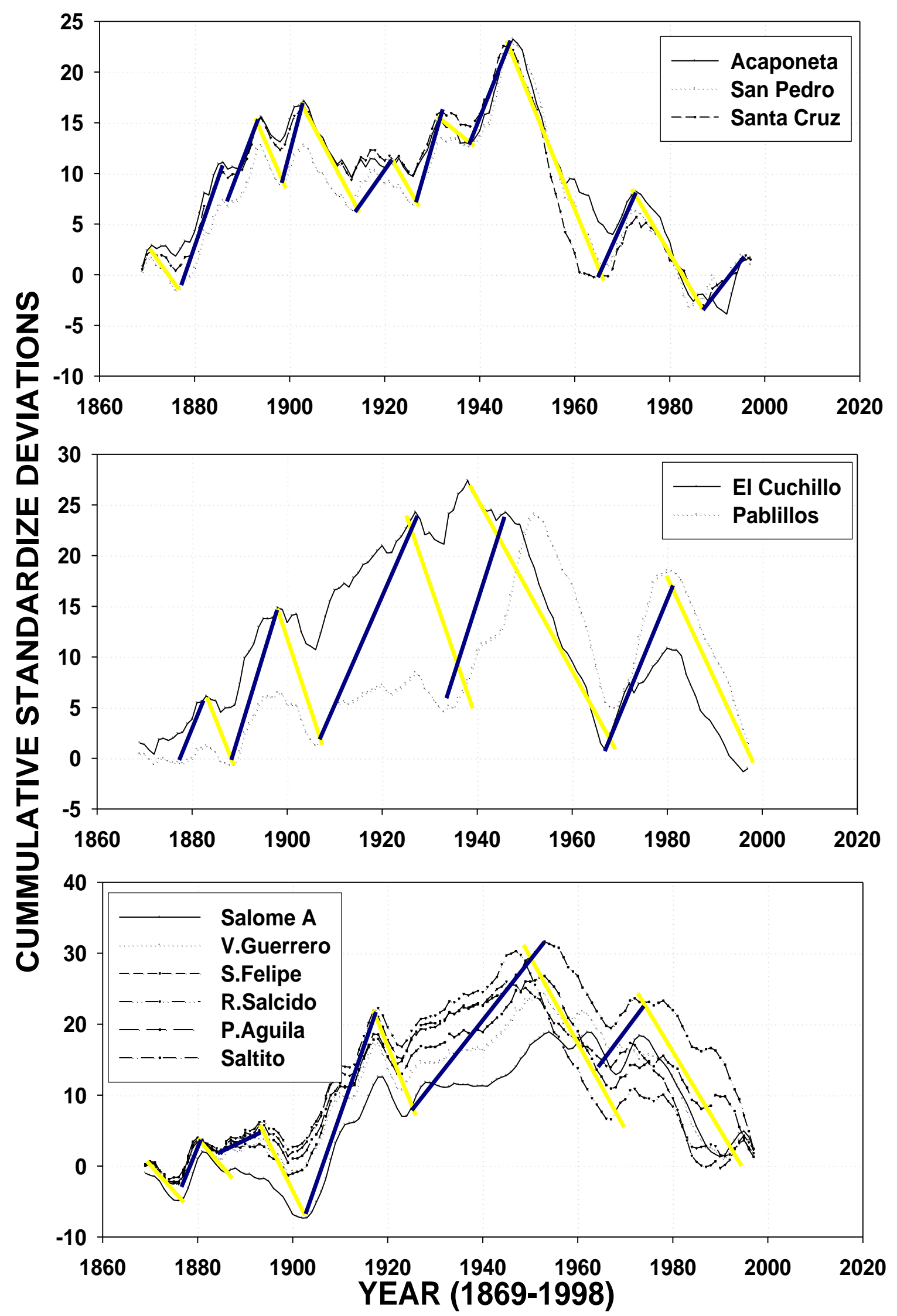

Figure 4. Dry-wet (yellow-blue lines) cycles depicted in standardized annual discharge deviations for all reconstructed and instrumental records for each Physiographic Region. 
All reconstructed and instrumental time series are intrinsically and consistently synchronized due to the large internal correlation coefficients and dry and wet cycles are also consistent between hydrometric stations and therefore between physiographic regions. Drywet cycles randomly oscillate with different durations and magnitudes; e.g., quasi-decadal dry cycles are noted for the 1870's; early 1900's; the 1930's; the 1950's; the 1980's and the 1990 's. Wet quasi-decadal cycles were present during the 1880's; peaking during the 1920's; peaking between the 1940 and 1950's and the last important one peaking in the 1970's. These cycles are also consistent with those reported earlier by Díaz et al. (2002) for Chihuahua, Mexico; by Cook et al. (1999) for the southern portion of the US and by Cleaveland et al. (2003) and Stahle et al. (1999) for Durango, México. Rainfall and discharge patterns for the last century for Puerto Rico reported by Larsen (2000) also show some consistency with drywet cycles detected in this study.

Cyclones, hurricanes or tropical depressions notably increase annual discharge for Mexico's northern rivers. Discharge caused by these climatic phenomena may account for up to four times the long-term annual discharge average. For rivers of the Mexican State of Nuevo Leon, Návar (2003) projected the presence of an average of 2 (with confidence bounds of between 1 and 4) cyclones moving into the State for the period of 2004-2013. This prediction has come true so far since 'Emily' and 'Alex' swept across the State pouring heavy rains with consequently heavy discharge rates for most northeastern rivers during 2005 and 2010, respectively. For proxy discharge data, the 1909 hurricane has been well documented for northeastern Mexico. There is also information on heavy rains producing notable discharge rates across northern Mexico in the 1880's and during the 1890's. These wet episodes must be confirmed with other sources of information to be reliable documented.

Dry-wet episodes present frequencies with different time periods. However, in general, three major cycles could be consistently detected in the spectral density analysis. These findings are consistent with the magnified standardized cumulative $\mathrm{Z}$ coefficients and the autocorrelation functions for all time series; these cycles are: (i) 1-2 years; (ii) 4-7 years; and (iii) 9-11 years. The last quasi-decadal cycle does have statistical significance but only at $\mathrm{p}=0.10$. The small number of decadal cycles in the time series may explain the lack of potential statistical significance. ARIMA models also project dry and wet spells, in agreement with the spectral density analysis on predicted discharge values, lasting from 1-2; 4-7; and longer periods that last between 9 to 11 years that are consistent in time (1880's, 1900's, 1920's, 1950's, and 1990's).

O'Hara and Metcalfe (1997); Stahle et al. (1999) and Návar (2008), using primary and secondary historical sources of information and dendrochronological data coupled with instrumental records reconstructed Mexico's northern seasonal precipitation. These authors found quasi decadal drought spells during 1450-1500; 1550's, 1600's, 1695-1720, 1750-1820; $1870-1880,1895-1910 ; 1930$ 's, 1950's, 1990's. For the study period in this report, both sources of hydro-climatic data matches well drought episodes and show the 1950's and 1990 s' dry oscillations are the worst on record for this part of the country since late 1880's.

The inter-annual discharge variability requires additional sources of information in order to be more explicitly described. The annual migration of the Bermuda High in the North Atlantic Ocean combined with the seasonal displacement of the Inter-tropical Convergence Zone, ITCZ may partially explain the inter-annual variability. The second dry-wet cycle (4-7 years) correlates well with indices of El Niño/Southern Oscillation, ENSO (Cavazos and Hastenrath, 1990; Stahle et al., 1999; Méndez-González et al., 2008) that exhibit statistically significant spectral peaks in the ENSO frequency band near periods of 4 years (Stahle et al., 1999). The ENSO causes severe and prolonged summer droughts and wet winters in northern Mexico (González-Elizondo et al., 2005) with total reduced annual rainfall and it has an indirect control on river discharge as well. The third quasi decadal discharge dry-wet variability is evident in all ARIMA models, spectral density analysis, as well as in 
reconstructed Durango's seasonal precipitation (Stahle et al., 1999; Návar, 2008). The reconstructed Mexico's climate variability using historic sources also shows this variability (O’Hara and Metcalfe, 1997).

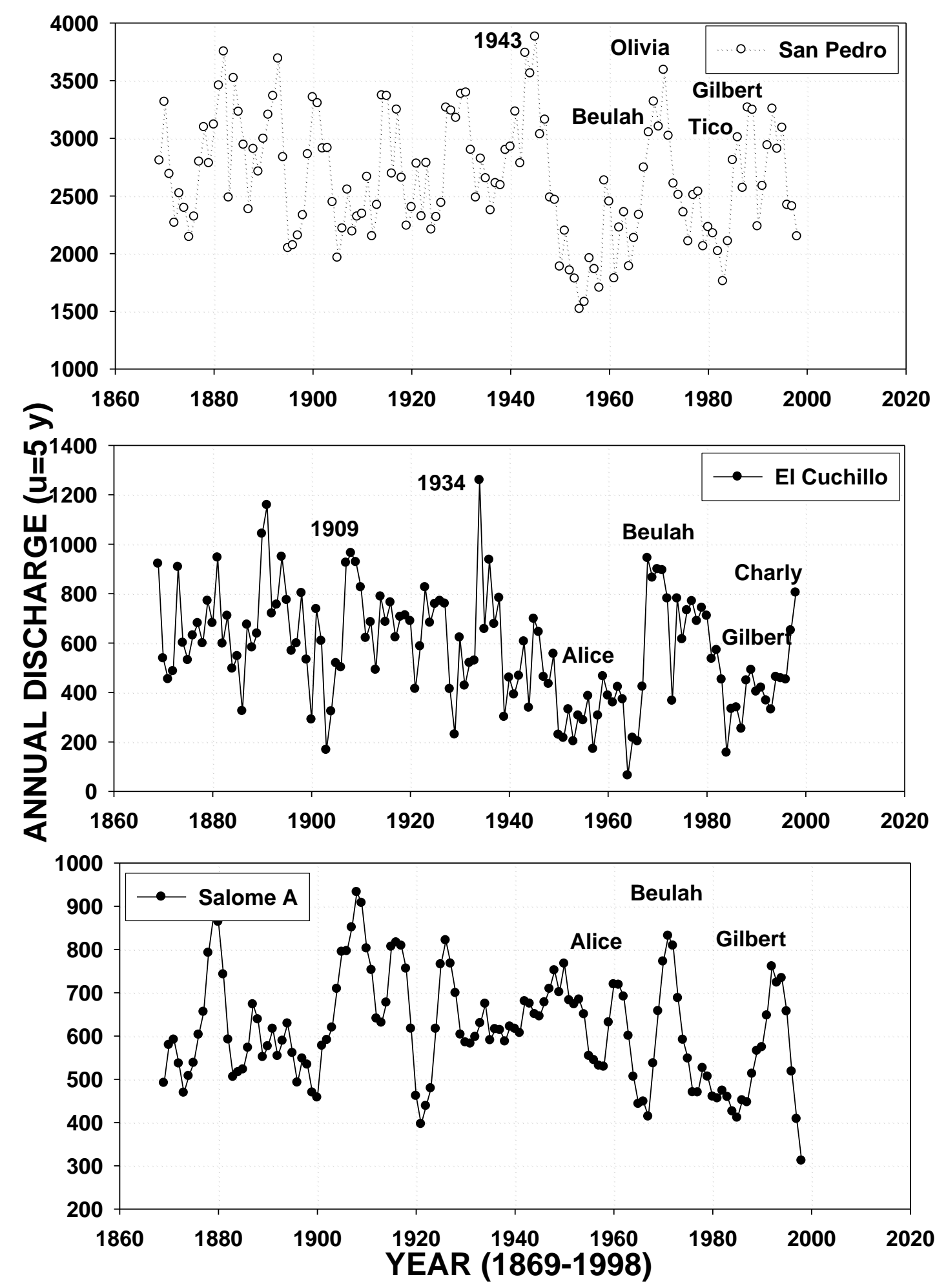

Figure 5. Cyclones, hurricanes, and tropical depressions causing floods and increasing annual flow for three Mexico's northern Rivers. 
The northeastern Pacific Ocean cooling - warming cycle, called the Pacific Decadal Oscillation, PDO, appears to be related to this phase for northern Mexico (Jones, 2003). Quasi-decadal sequences repeated in the time series and ARIMA models during the 1880's, 1900's, 1920's, 1930's, 1950's, 1980's and 1990's. The cooling of the northeastern Pacific Ocean surface waters brings below average rainfall and discharge to northern Mexico. The PDO effect has also been related to surface runoff in Utah although its control is not consistent over time and appears insignificant during periods of instrumental recorded data (Tingstad and MacDonald, 2010). Weak associations between annual discharge and PDO variability can be explained since the latter manifests mostly in the North Pacific region and can persist over several decades. Mantua et al. (1997) described periods of 15-25 years and 50-70 years and dry spells last at the most 15 years (1950's) for this time series data.

The Atlantic Multidecadal Oscillation, AMO, is a recurring pattern of SST anomalies in the North Atlantic with a recurring period of 65-80 years (Knight et al., 2006). Positive AMO index values have been associated with drought in the continental U.S. during the $20^{\text {th }}$ Century (Enfield et al., 2001). This cycle appears to control river discharge when looking at the cumulative $\mathrm{Z}$ index time series data (Figure 4). For rivers draining into the northern Gulf of Mexico, this cycle started, peaked and ended in the 1880's, the late 1940's and the early 1960 's, respectively. For rivers draining into the Pacific Ocean, this cycle started, peaked and ended during the 1990's, the 1950's and the late 1990's, respectively. However, proxy and instrumental discharge data is not sufficient to statistically correlate this tendency.

Longer time cycles of close to 300 years are discussed in O'Hara and Metcalfe's (1997) historical and Stahle's et al. (1999) dendrochronological datasets. The period 1345-1640 appeared to have been relatively wet; the period of 1640-1915 appeared to be relatively dry and since 1915 there has been a shift towards somewhat wetter conditions in Mexico. Due to the reconstructed short time series data to build the ARIMA models, the AMO and Little Ice Age dry-wet sequences are absent in future projections. The 1640-1915 dry episode appeared to have been dominated by the prolonged blocking of the monsoon and an increase of the 'nortes' frequency that coincides with the Little Ice Age (O'Hara and Metcalfe, 1997). The monsoon suppression, the Bermuda High lying well to the east and the southwards displacement of the Intertropical Convergence Zone, ITCZ, appear to control dry periods (Jauregi and Klaus, 1976; Jauregi, 1979); since two major features of atmospheric circulation the Trade winds and the sub-tropical high pressure belt influence Mexico's present day precipitation.

The reported longest dry-wet cycles (300 years) would point at a monotonic increasing discharge trend for all studied river gauging stations, since it appears it started during early the $20^{\text {th }}$ century. Likewise the smaller, quasi decadal discharge tendencies would also tip at an increasing pattern unlike the ENSO cycle that was hitting northern Mexico in 2009. Since a negative discharge pattern is common in all ARIMA models as well as for other studied rivers, discharge variation must be controlled by other sources of perturbation that should be observed, measured, modeled and projected.

The potential climate change effect on annual river discharge cannot be derived by this statistical analysis. Cycles and tendencies are consistent for both proxy and instrumental discharge data. The declining river discharge pattern noted in all ARIMA models is probably associated to an increase of human control over water resources. Although, Mulholland et al. (1997) projected using climate change models that river discharge would diminish between 5 to $20 \%$ in semi-arid, subtropical Mexican eco-regions by climate change; climate variability appears to govern river discharge over other human-induced perturbations such as land use change, increased water demands from rivers and aquifers, and potential climate change. However, the latter control deserves more attention. By looking into the rainfall patterns, depth, duration, intensity parameters that drive river discharge may offer some insights into the climate change phenomenon. This is also a matter of further studies. 


\section{CONCLUSIONS}

This research shows that variability of river discharge could be detected in proxy and instrumental discharge records as well as that ARIMA models with a linear tendency predicted well the reconstructed and instrumental time series data. Therefore, discharge variability is under the influence of synoptic climatic events of several temporal scales. Interannual, ENSO, PDO, AMO, and Little Ice Ages control individually or in combination Mexico's northern discharge patterns and tendencies. Monotonic reduced discharge for four hydrometric stations partially stresses the indirect evidence of human control over surface water resources. Therefore, this study calls for: a) extending and modeling discharge time series to explore the time cycles controlled by longer climate variability patterns; b) further understanding other major sources of variation that would better explain the downward river discharge trend; and c) combining AMO, PDO, ENSO, Little Ice Age climate events to better understand discharge variability across Mexico's northern watersheds with the aim to sustainable manage water resources in the region. Land-use changes, increasing irrigated area, human and industrial demands over time, as well as potential, temporal subtle climate changes could also explain discharge drifts. This is a matter of further studies.

\section{ACNOWLEDGEMENTS}

The author of this report thanks many anonymous reviewers for the technical and language improvements of this manuscript. The author is COFAA scholar.

\section{REFERENCE}

ARREOLA-ORTIZ, M. A.; NÁVAR-CHÁIDEZ, J. J. Análisis de sequía y productividad con cronologías de Pseudotsuga menziesii Rob. \& Fern. Y su asociación con El Niño en el nordeste de México. Investigaciones geográficas, v. 71, p. 7-20, 2010.

CAVAZOS, T.; HASTENRATH, S. Convection and rainfall over Mexico and their modulation by the Southern Oscillation. International Journal of Climatology, v. 10, p. 377-386, 1990. http://dx.doi.org/10.1002/joc.3370100405

CLEAVELAND, M. K.; STAHLE, D. W.; THERRELL, M. D.; VILLANUEAVA-DIAZ, J.; BURNS, B. T. Tree-ring reconstructed winter precipitation in Durango, Mexico. Climatic Change, v. 59, p. 369-388, 2003. http://dx.doi.org/10.1023/A:1024835630188

COOK, E. R.; MEKO. D. M.; STAHLE, D. W.; CLEAVELAND, M. K. Drought reconstructions for the continental United States. Journal of Climate, v. 12, p. 11451162, 1999. http://dx.doi.org/10.1175/1520-0442(1999)012<1145:DRFTCU>2.0.CO;2

DÍAZ, S. C.; THERRELL, M. D.; STAHLE, D. W.; CLEAVELAND, M. K. Chihuahua (Mexico) winter-spring precipitation reconstructed from tree rings, 1647-1992. Climate Research, v. 22, p. 237-244, 2002. http://dx.doi.org/10.3354/cr022237

EINFIELD, D. B.; MESTAS-NUÑEZ, A. M.; TRIMBLE, P. J. The Atlantic Multidecadal Oscillation and its relationship to rainfall and river flows in the continental U.S. Geophysical Research Letters, v. 28, n. 10, p. 2077-2080, 2001. http://dx.doi.org/10.1029/2000GL012745 
GONZÁLEZ-ELIZONDO, M.; JURADO, E.; NÁVAR, J.; GONZÁLEZ-ELIZONDO, M. S.; VILLANUEVA, J.; AGUIRRE, O. et al. Tree-rings and climate relationships for Douglas-fir chronologies from the Sierra Madre Occidental, México: a 1681-2001 rain reconstruction. Forest Ecology \& Management, v. 213, p. 39-53, 2005.

HERNÁNDEZ-RODRÍGUEZ, H.; NÁVAR-CHÁIDEZ, J. J. Tendencias de los caudales en ríos de Michoacán, México. Tecnología y Ciencias del Agua, v. 1, p. 139-145, 2010.

JÁUREGUI, E.; KLAUS, D. Some aspects of climate fluctuations in Mexico in relation to drought. Geofisica Internacional, v. 16, n. 1, p. 45-61, 1976.

JÁUREGUI, E. Algunos aspectos de las fluctuaciones pluviométricas en México en los Últimos 100 años. (Aspects of rainfall fluctuations in Mexico during last 100 years). B. Int. de Geogr. UNAM, n. 9, p. 39-64, 1979.

JONES, D. L. El Niño, PDO, climatic cycles and drought in the Sierra Nevada. Shingle Springs: El Dorado County Water Agency, Water Resources Development and Management Plan, 2003. Available in: <http://www.co.el-dorado.ca.us/ water/water _plan_pdfs/Appendix_G.pdf>. Access in: 16 Jan. 2012.

KNIGHT, J. R.; FOLLAND, C. K.; SCAIFE, A. A. Climate impacts of the Atlantic multidecadal oscillation. Geophysical Research Letters, v. 33, n. LI7706, 2006. doi: 10.1029/2006GL026242. http://dx.doi.org/10.1029/2006GL026242

LARSEN, M. C. Analysis of 20th Century rainfall and streamflow to characterize drought and water resources in Puerto Rico. Physical Geography, v. 21, p. 494-521, 2000.

MANTUA, N. J.; HARE, S. R.; ZHANG, Y.; WALLACE, J. M.; FRANCIS, R. C. A Pacific interdecadal climate oscillation with impacts on salmon production. Bulletin of the american Meteorological Society, v. 78, p. 1069-1079, 1997.

http://dx.doi.org/10.1175/1520-0477(1997)078<1069:APICOW>2.0.CO;2

MÉNDEZ-GONZÁLEZ， J.; NÁVAR-CHÁIDEZ， J. J.; GONZÁLEZ-ONTIVEROS， V. Análisis de tendencias de precipitación (1920-2004) en México. Investigaciones Geográficas, v. 65, p. 38-55, 2008.

MÉXICO. Comision Nacional Del Agua - CONAGUA. Estadísticas hidrológicas de México. México, DF, 2000.

MÉXICO. Comision Nacional Del Agua - CONAGUA. Estadísticas hidrológicas de México. México, DF, 2001.

MÉXICO. Comision Nacional Del Agua - CONAGUA. Síntesis de las estadísticas del agua en México. Mexico, DF, 2005.

MÉXICO. Comision Nacional Del Agua - CONAGUA. Estadísticas del Agua en México. México, DF, 2009.

MÉXICO. Instituto Nacional de Estadística, Geografia e Informática - INEGI. Censos de población y vivienda. México, DF, 2007.

MULHOLLAND, P. J.; BEST, G. R.; COUTANT, C. C.; HORNBERGER, G. M.; MEYER, J. L.; ROBINSON P. J. et al. Effects of climate change on freshwater ecosystems of United States and the Gulf of Mexico. Hydrological Processes, v. 11, p. 949-970, 1997. http://dx.doi.org/10.1002/(SICI)1099-1085(19970630)11:8<949::AID-HYP513> 3.0.CO;2-G 
NÁVAR, J. Agua y desarrollo sustentable en la cuenca baja del Río Bravo-San Juan. Ciencia UANL, v. 2, n. 4, p. 356-362, 1999.

NÁVAR, J. Probabilidades y estadísticas aplicadas al manejo de recursos naturales y medio ambiente. Linares: Facultad de Ciencias Forestales, 2003. Inédito.

NÁVAR, J.; HERNÁNDEZ, H.; RÍOS, J. C. Temporal tendencies of river discharge of five watersheds of northern México. In: USDA Forest Service. Proceedings RMRS-P42CDN. 2006. Available in: < http://www.treesearch.fs.fed.us/pubs/24524>. Access in: 16 Jan. 2012.

NÁVAR, J. Reconstrucción de las sequías en los últimos 10 mil años en el norte de México. AGROFAZ, v. 8, p. 41- 53, 2008.

NÁVAR, J. Tendencias espacio-temporales de variables climáticas en el estado de Durango. AGROFAZ, v. 9, p. 95-110, 2009.

O'HARA, S. L.; METCALFE, S. E. The climate of Mexico since the Aztec period. Quaternary International, v. 43/44, p. 25-31, 1997.

http://dx.doi.org/10.1016/S1040-6182(97)00017-7

POSTEL, L. S. Entering an era of water scarcity: the challenges ahead. Ecological Applications, v. 10, n. 4, p. 941-948, 2000. http://dx.doi.org/10.1890/1051-0761(2000)010[0941:EAEOWS]2.0.CO;2

STATISTICAL ANALYSIS SYSTEM - SAS. V. 8.0. Raleigh, 1997.

STAHLE, D. W.; CLEAVELAND, M. K.; THERRELL, M. D.; VILLANUEVA-DIAZ, J. Tree ring reconstruction of winter and summer precipitation in Durango, Mexico, for the past 600 years. In: SYMPOSIUM GLOBAL CHANGE STUDIES, 10., 10-15 Jan. 1999, Dallas. Proceedings... Dallas: American Meteorological Society, 1999. p. 205211.

TINGSTAD, A. H.; MACDONALD, G. M. Long-term relationships between ocean variability and water resources in northeastern Utah. Journal of the American Water Resources Association, v. 46, n. 5, p. 987-1002, 2010. http://dx.doi.org/10.1111/j.1752-1688.2010.00471.x 


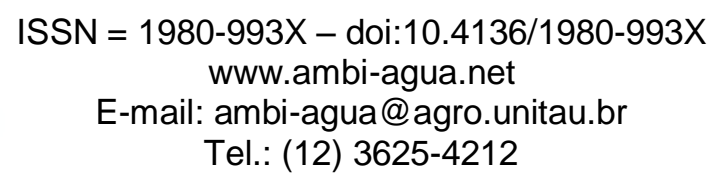

\title{
Groundwater chemistry of the Oban Massif, South-Eastern Nigeria
}

\author{
(http://dx.doi.org/10.4136/ambi-agua.812)
}

\author{
Azubuike S. Ekwere; Aniekan E. Edet; Solomon J. Ekwere \\ Department of Geology, University of Calabar, Calabar, Nigeria \\ e-mails: zerratta77@yahoo.com; aniekanedet@yahoo.com; \\ zerratta78@blackplanet.com
}

\begin{abstract}
Hydrogeochemical study of the fractured/weathered basement of the Oban Massif, southeastern Nigeria has been carried out. Results indicated that concentrations of major cations and anions exhibited the following order of abundance: $\mathrm{Ca}>\mathrm{Na}>\mathrm{Mg}>\mathrm{K}$ and $\mathrm{HCO}_{3}>\mathrm{SO}_{4}>\mathrm{Cl}$, respectively, with minor variations across sampling seasons. Ca-Na-Cl-SO and $\mathrm{Ca}-\mathrm{Mg}-\mathrm{HCO}_{3}$ water types have been identified as major facies, resultant from congruent influences of weathering (mainly silicates), ion exchange processes, and water mixing.
\end{abstract}

Keywords: groundwater; cation; anion; weathering; ion exchange; Oban massif; Nigeria.

\section{Química das águas subterrâneas do Maciço Oban, Sudeste da Nigéria}

\section{RESUMO}

Estudo hidrogeoquímico do embasamento fraturado / intemperizado do Maciço Oban, sudeste da Nigéria foi realizado. Os resultados indicaram que as concentrações de cátions e ânions apresentaram a seguinte ordem de ocorrência: $\mathrm{Ca}>\mathrm{Na}>\mathrm{Mg}>\mathrm{K}$ e $\mathrm{HCO}>\mathrm{SO} 4>\mathrm{Cl}$, respectivamente, com pequenas variações entre as estações de amostragem. Os tipos de água $\mathrm{Ca}-\mathrm{Na}-\mathrm{Cl}-\mathrm{SO} 4$ e Ca-Mg-HCO3 têm sido identificados como os principais fácies, resultantes de influências congruentes de desgaste (principalmente silicatos), processos de permuta iónica e água de mistura.

Palavras-chave: água subterrânea; catiônica; ânion; intemperismo; troca iônica; Oban maciço; Nigéria.

\section{INTRODUCTION}

The ability to estimate the rate and extent of water-rock interaction and chemical transport depends on the quantitative understanding of the physical and chemical properties of the rocks and fluids participating in reactive transport properties in natural systems (Oelkers, 1996).

Composition of sub-surface waters in basement areas is a function of many variables, which include; composition of recharge water, petrologic and mineralogic composition of sub-surface rocks and hydrogeologic properties of the rocks, which influence water-rock reactions and groundwater flow velocities. According to Caritat et al. (2004), generally chemical quality of groundwater from basement bedrock is often very different from waters from superficial deposits. Bedrock groundwater is often more mature more basic, more 
reducing, and more sodium rich and contains more of most minor/trace elements than groundwater from shallow aquifers.

Variations in physical and chemical composition of basement groundwater may also be due to mixing with shallow groundwater from the overburden. Present increases of population with higher demands for water resources are typical in most developing Sub-Saharan countries. This has led to water scarcity and increasing water stress in most of these regions. Nigeria belongs to this equatorial region with most of its harnessed water resources being of surface and sub-surface origin.

The Oban Massif lies in the southeastern part of Nigeria and it is considered the most important groundwater reservoir in Cross River state (Nigeria), providing water to the various cottage industries and communities in the area. The rock types are mostly gneisses, granodiorites, and schist. Groundwater extraction is mainly through shallow wells and hand pump fitted boreholes and in some cases surface water.

Natural geochemical processes play an important role in groundwater quality. The aim of this work is to characterize the chemical processes occurring in the water-bearing horizon.

Previous studies in the area have been on the geology, petrology, and geochemical aspects of the massif. This study therefore forms the first ever study on the hydrochemical evolution of groundwater in the area.

\section{DESCRIPTION OF STUDY AREA}

The Oban Massif lies between Longitudes $8^{0} 00^{\prime} \mathrm{E}$ and $8^{0} 55^{\prime} \mathrm{E}$ and Latitudes $5^{0} 00^{\prime} \mathrm{N}$ and $5^{0} 45^{\prime} \mathrm{N}$ covering an area of about 8,740 square kilometers (Edet et al., 1998), Figure 1. The crystalline basement complex lies at an average height of about $150 \mathrm{~m}$, rising gradually from the south northwards and falls away towards the Cross River to the North (Ayi, 1987). Fractures and joints control drainage within the massif. The massif is well drained with a network of rivers and associated streams, actively engaged in erosion of channels (juvenile stage). The area is characterized by a tropical climate with two distinct seasons viz wet and dry. The wet season spans from May to October, while the dry season lasts from November to April. The average monthly temperature in the area ranges from $29-34^{0} \mathrm{C}$. Mean annual rainfall of about $2,300 \mathrm{~mm}$ have been reported for the area, with annual mean daily relative humidity and evaporation of $86 \%$ and $3.85 \mathrm{~mm} /$ day respectively (CRBDA, 2008).

The Oban Massif is described as being underlain by highly deformed Precambrian crystalline basement rocks, mainly migmatites, granites, gneisses, and schists (Ekwueme and Ekwere, 1989; Ekwere and Ekwueme, 1991). These rocks exhibit varying degrees of weathering across the massif. They are intruded by pegmatites, granodiorites, diorites, tonalites, monzonites, charnokites and dolerites (Ekwueme, 1990).

\section{MATERIALS AND METHODS}

Seventy-four water samples, covering both dry and wet seasons were collected. The dry season samples were collected in the month of February and those for the wet in the July of 2009. The sample locations straddled the various geologic units within the study area. The water samples were obtained from motorized and hand pump fitted boreholes, open wells, and stream channels.

Three samples were collected from each location in $75 \mathrm{cl}$ polyethylene bottles. The sample bottles were soaked in $10 \% \mathrm{HNO}_{3}$ for 24 hours and rinsed several times with deionized water prior to use. At the sampling locations, the bottles were thoroughly rinsed with aliquots of the sampled waters, prior to collection. 
One sample from each location was preserved by acidifying to $\mathrm{pH}$ ca. 2 with $0.5 \mathrm{ml}$ of concentrated $\mathrm{HNO}_{3}$ acid before analysis for trace metals. All samples were packaged (airtight), labeled and stored in coolers for onward transportation to the laboratory for analysis.

Measurements of temperature, conductivity, TDS, $\mathrm{pH}$, Eh were carried out in the field using standard field equipment (PHT-027 multi-parameter). Prior to measurement of $\mathrm{pH}$, the electrode was calibrated using $\mathrm{pH} 6.88$ and 4.01 buffer solutions at a similar temperature to the water samples. The same meter and an ionodes ORP electrode were used to measure Eh. Calcium, magnesium, sodium, and potassium contents were determined with reference to the APHA (1995) method. Major and trace element contents were determined by atomic absorption spectrophotometer (AAS), model UNICAM 939. The anion contents of samples were determined by colorimetric method using UNICAM UV2 spectrophotometer. All instrumental analyses were carried out in the laboratories of the Aluminum Smelting Company of Nigeria (ALSCON), Ikot Abasi, Nigeria.

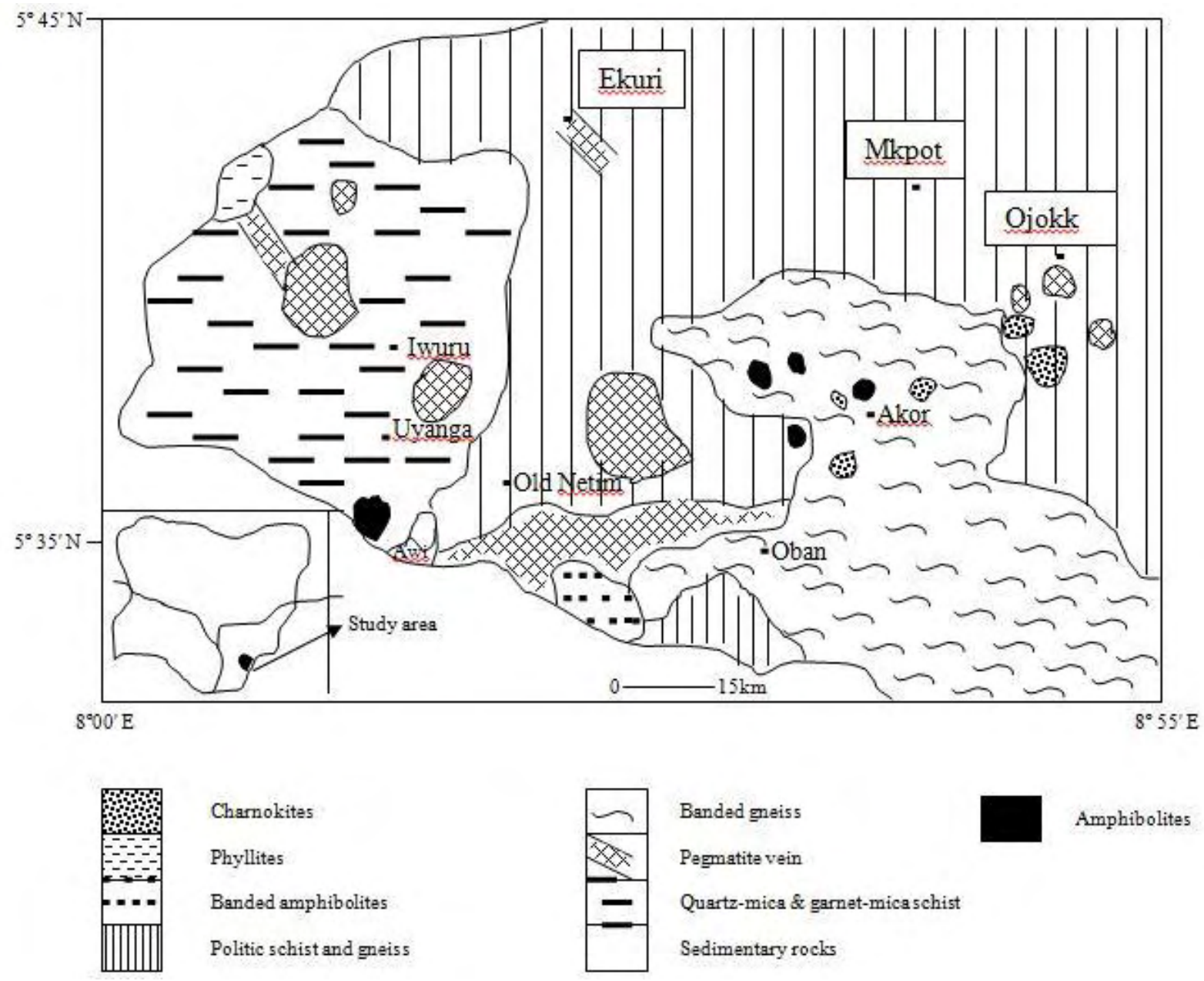

Figure 1. Geologic map of the study area (Oban massif): insert map of Nigeria (modified from Ekwueme, 2003). 


\section{RESULTS AND DISCUSSION}

Compositions of ground and surface waters in the wet and dry seasons within the Oban massif are given in Tables 1 and 2. Statistical summary shows the water is slightly acidicalkaline (5.08 - 8.65), fresh with total dissolved solids (TDS) $<1000 \mathrm{mg} / \mathrm{l}$.

The cations were in the order $\mathrm{Ca}^{2+}>\mathrm{Na}^{+}>\mathrm{Mg}^{2+}>\mathrm{K}^{+}$and the anions generally showed $\mathrm{HCO}_{3}{ }^{2-}>\mathrm{Cl}^{-}>\mathrm{SO}_{4}{ }^{2-}>\mathrm{NO}_{3}{ }^{-}$.

\subsection{Seasonal variation of ions}

The analytical results show the slightly acidic nature of water in the dry season as $\mathrm{pH}$ ranged from $5.08-6.86$. The waters tended to be slightly acidic to alkaline in the wet season with $\mathrm{pH}$ range of $5.88-8.65$. The $\mathrm{pH}$ values of the dry season fall within the 4.5-7.0 range. This range represents a weak acidic activity, usually that of carbonic acid and smaller amounts of organic acid such as fulvic acid (Langmuir, 1997). Lower $\mathrm{pH}$ values of (5.08, 5.40 and 5.12) were recorded at locations with high human population density and can be attributed to low buffer capacity of the regolith in such settings (Edet et al, 2005; Edet and Ekpo, 2008). The $\mathrm{pH}$ values however increased markedly in the wet season reflecting the effects of dissolved salts. Sources of such salts may be from weathering of silicates, carbonates, evaporites and sulphide minerals, atmospheric contribution (cyclic salts) as well as anthropogenic inputs (Berner and Berner, 1996).

The electrical conductivity (EC) which expresses ionic strength of solution, varied between $20.9 \mu \mathrm{s} / \mathrm{cm}$ to $622 \mu \mathrm{s} / \mathrm{cm}$ in the dry season and $60-800 \mu \mathrm{s} / \mathrm{cm}$ in the wet season. Statistical analysis of results reveals a minimum average electrical conductivity value of $199 \mu \mathrm{s} / \mathrm{m}$ in the dry season and a high of $243 \mu \mathrm{s} / \mathrm{cm}$ in the wet season. Somewhat high values within the dry season are reflective of increase in ionic strength and could be related to evaporation effects witnessed during this low water level period and aided by an elevated temperature regime in the area.

The water in the massif exhibited low mean values of total dissolved solids (TDS) concentration of $121 \mathrm{ppm}$ in the dry season and $265 \mathrm{ppm}$ in the wet season. The data shows that electrical conductivity and TDS concentration values were lower in the dry season with an increase in the wet season.

An assessment of data shows a general decrease in cation concentration from the dry to wet seasons. Calcium $\left(\mathrm{Ca}^{2+}\right)$ was the most dominant accounting for about $78 \%$ and $61 \%$ of total cation in the dry and wet seasons respectively. Concentration of $\mathrm{Ca}^{2+}$ recorded ranges of $7.27 \mathrm{mg} / \mathrm{l}-135.2 \mathrm{mg} / \mathrm{l}$ in the dry season and $6.04-97.14 \mathrm{mg} / \mathrm{l}$ in the wet season. This dominance of $\mathrm{Ca}^{2+}$ may reflect the process of chemical weathering of silicates and the common occurrence of calcium carbonate (Langmuir, 1997). Water-rock reactions of mineral phases such as plagioclase, calcite, aragonite, anhydrite and dolomite from basement and the sedimentary terrain lying in close proximity to the study area can be adjudged from this.

Sodium $\left(\mathrm{Na}^{+}\right)$was next in dominance with concentration ranges of $1.2-9.0 \mathrm{mg} / \mathrm{l}$ and 1.8 $-7.0 \mathrm{mg} / \mathrm{l}$ in the dry and wet seasons respectively. The lower mean value for $\mathrm{Na}^{+}, 3.98 \mathrm{mg} / \mathrm{l}$ was recorded in the dry season and the higher of $4.35 \mathrm{mg} / \mathrm{l}$ in the wet season.

The other cations, magnesium $\left(\mathrm{Mg}^{2+}\right)$ and potassium $\left(\mathrm{K}^{+}\right)$ranged between $0.4-5.4 \mathrm{mg} / \mathrm{l}$ and $0.5-5.9 \mathrm{mg} / \mathrm{l}$ respectively in the dry season. In the wet season, ranges were $0.3-3.7 \mathrm{mg} / \mathrm{l}$ for $\mathrm{Mg}$ and $0.2-32.18 \mathrm{mg} / \mathrm{l}$ for $\mathrm{K}$. Potassium exhibited the lowest concentration levels relative to other cations. This is common in natural waters due to its tendency to be fixed by clay minerals and precipitate in the formation of secondary minerals (Matthess, 1982). However, $\mathrm{K}^{+}$recorded the highest concentration mean of $13.97 \mathrm{mg} / \mathrm{l}$ next to calcium (23.09 $\mathrm{mg} / \mathrm{l})$ in the wet season. Potassium shows a reverse trend marked by an increase from the dry to wet season. This increase could be attributed to agricultural practice by the use of fertilizers 
for farming by the local populace. Increased surface run-off in the wet season washes these fertilizers, which $\mathrm{K}^{+}$is a major component and subsequently percolates into the sub-surface water reservoirs. However, the decrease in concentration levels of cations in the wet season reflects the impacts of dilution by surface run-off percolating into the sub-surface reservoirs.

Table 1. Descriptive statistics of parameters as measured in the dry season.

\begin{tabular}{|c|c|c|c|c|c|c|c|c|c|c|c|c|c|}
\hline Source & Statistics & $\underset{(\mathrm{C})}{\text { Temp }}$ & pH & $\begin{array}{c}\mathbf{E C} \\
(\mu \mathrm{s} / \mathrm{cm})\end{array}$ & $\begin{array}{c}\text { TDS } \\
(\mathbf{p p n}\end{array}$ & Ca & Mg & $\mathrm{Na}$ & $\mathbf{K}$ & $\mathrm{SO}_{4}$ & $\mathrm{NO}_{3}$ & $\mathrm{HCO}_{3}$ & Cl \\
\hline \multirow{4}{*}{$\begin{array}{c}\text { Ground } \\
\text { water }\end{array}$} & Min & 26.0 & 5.1 & 24.8 & 15.9 & 7.3 & 0.5 & 1.2 & 0.5 & 0.6 & 0.0 & 18.3 & 0.9 \\
\hline & Max & 28.0 & 6.9 & 622.0 & 398.7 & 135.2 & 5.3 & 4.6 & 5.9 & 117.9 & 45.9 & 122.3 & 93.0 \\
\hline & Mean & 27.1 & 6.0 & 300.7 & 180.2 & 39.5 & 3.7 & 3.9 & 3.2 & 40.9 & 15.6 & 45.6 & 23.5 \\
\hline & SD & 0.8 & 0.5 & 255.6 & 169.7 & 43.1 & 1.7 & 0.9 & 1.7 & 32.8 & 15.8 & 29.1 & 28.7 \\
\hline \multirow{4}{*}{$\begin{array}{c}\text { Surface } \\
\text { water }\end{array}$} & Min & 26.0 & 5.1 & 34.6 & 22.2 & 12.3 & 0.4 & 2.0 & 0.8 & 1.1 & 0.0 & 12.3 & 2.5 \\
\hline & Max & 32.0 & 6.3 & 250.0 & 209.0 & 122.1 & 5.4 & 9.0 & 3.5 & 564.1 & 47.5 & 97.6 & 57.0 \\
\hline & Mean & 27.8 & 5.7 & 96.4 & 61.8 & 34.8 & 3.0 & 4.1 & 2.0 & 80.8 & 12.2 & 49.3 & 15.3 \\
\hline & SD & 1.8 & 0.4 & 92.3 & 59.2 & 30.7 & 2.1 & 1.8 & 1.0 & 158.8 & 15.2 & 35.2 & 16.2 \\
\hline $\begin{array}{l}\text { WHO } \\
(2001)\end{array}$ & & & $6.5-8.5$ & 1400 & 1000 & 100 & 50 & 200 & 12 & 400 & 50 & & 250 \\
\hline
\end{tabular}

Table 2. Descriptive statistics of parameters as measured in the wet season.

\begin{tabular}{c|l|r|r|r|r|r|r|r|r|r|r|r|r}
\hline Source & Statistics & $\begin{array}{c}\text { Temp } \\
(\mathbf{(} \mathbf{c})\end{array}$ & $\mathbf{p H}$ & $\begin{array}{c}\mathbf{E C} \\
(\mathbf{\mu s} / \mathbf{c m})\end{array}$ & $\begin{array}{c}\mathbf{T D S} \\
(\mathbf{p p m})\end{array}$ & $\mathbf{C a}$ & $\mathbf{M g}$ & $\mathbf{N a}$ & $\mathbf{K}$ & $\mathbf{S O}_{\mathbf{4}}$ & $\mathbf{N O}_{\mathbf{3}}$ & $\mathbf{H C O}_{\mathbf{3}}$ & $\mathbf{C l}$ \\
\hline & Min & 27.0 & 5.9 & 80.0 & 60.0 & 6.0 & 0.3 & 2.5 & 1.0 & 13.6 & 0.2 & 12.1 & 22.1 \\
$\begin{array}{c}\text { Ground } \\
\text { water }\end{array}$ & Max & 30.0 & 7.7 & 580.0 & 890.0 & 97.1 & 3.4 & 7.0 & 32.2 & 471.7 & 11.7 & 67.0 & 308.7 \\
& Mean & 28.0 & 6.8 & 285.9 & 333.8 & 23.1 & 1.7 & 4.7 & 14.0 & 97.2 & 2.7 & 55.0 & 97.2 \\
& SD & 0.9 & 0.5 & 176.3 & 262.6 & 24.4 & 1.0 & 1.5 & 13.8 & 107.7 & 3.4 & 88.9 & 79.2 \\
\hline & Min & 26.0 & 6.3 & 60 & 40.0 & 7.5 & 0.3 & 1.8 & 0.2 & 25.0 & 0.1 & 24.2 & 50.6 \\
Surface & Max & 30.4 & 8.7 & 430 & 570.0 & 60.1 & 3.7 & 5.7 & 4.7 & 839.6 & 10.0 & 213.5 & 596.6 \\
water & Mean & 28.1 & 7.2 & 200 & 196.2 & 19.5 & 1.5 & 3.9 & 1.8 & 148.6 & 2.6 & 84.9 & 164.5 \\
& SD & 1.1 & 0.7 & 124 & 149.6 & 16.3 & 1.1 & 1.5 & 1.5 & 224.9 & 3.1 & 59.5 & 146.2 \\
\hline $\begin{array}{l}\text { WHO } \\
(\mathbf{2 0 0 1})\end{array}$ & & & $\mathbf{6 . 5 - 8 . 5}$ & $\mathbf{1 4 0 0}$ & $\mathbf{1 0 0 0}$ & $\mathbf{1 0 0}$ & $\mathbf{5 0}$ & $\mathbf{2 0 0}$ & $\mathbf{1 2}$ & $\mathbf{4 0 0}$ & $\mathbf{5 0}$ & & $\mathbf{2 5 0}$ \\
\hline
\end{tabular}

Anion concentration levels generally increased from the dry to the wet seasons. Chloride exhibited a marked increase along this seasonal trend. Sulphate and bicarbonate were the dominant anions within the dry season with mean concentration values of $61 \mathrm{mg} / \mathrm{l}$ and 48 $\mathrm{mg} / \mathrm{l}$ respectively. In the wet season, chloride was most dominant with an average concentration value of $130.5 \mathrm{mg} / \mathrm{l}$. Sulphate had a mean value of $123 \mathrm{mg} / \mathrm{l}$ and bicarbonate, 70 $\mathrm{mg} / \mathrm{l}$. Nitrate was least with mean values of $14 \mathrm{mg} / \mathrm{l}$ and $2.7 \mathrm{mg} / \mathrm{l}$ in the dry and wet seasons respectively.

\subsection{Spatial variations of ions}

Spatial variations for measured parameters across the massif are presented in Table 3. The differences are reflective of degree of regolith development and lithologic characteristics. The western sector of the massif is composed mainly of granodiorites, granites, granitic gneisses and schists and characterized by thick overburden of $29-47 \mathrm{~m}$ as revealed from drilled sections. The eastern sector on the other hand is mainly of migmatites, amphibolites and schists with thinner overburden of $6-12 \mathrm{~m}$. The lineament density, higher for western and 
lower for eastern sectors, as reported by Edet et al., (1994), supports the trend in overburden variability.

Electrical conductivity values across the massif exhibited a lower mean value of 191.42 $\mu \mathrm{s} / \mathrm{cm}$ for the eastern sector and $216.21 \mu \mathrm{s} / \mathrm{cm}$ for the western sector. A lower mean TDS value of $226.9 \mathrm{ppm}$ was recorded for the eastern sector of the massif while a mean value of $296.70 \mathrm{ppm}$ was recorded for the western sector. This shows an increase of TDS and EC from the east to the west of the massif. This is probably due to the depth of the weathered profile as revealed by litho-logs from both sectors and an expected increase of TDS along flow path of groundwater as groundwater flows from the east to west.

The mean value of $\mathrm{pH}$ for the western sector was 6.23 and 6.84 was deduced for the eastern flank. Relatively lower $\mathrm{pH}$ mean value for the western sector may be attributed to sub surface run-off, inputs of organic waste and other anthropogenic inputs due to higher human population density on this flank while higher values for the eastern flank may be due to decrease in dissolved solute (Ekwere, 2010).

The concentration of mobile cations were higher on the western sector of the massif as these are products of mineral dissolution as water flows through the more porous sub-surface media from the eastern to the western sector. Anions Cl-, HCO3- and SO42- however, showed higher mean values on the eastern arm of the massif. This could be attributed to accumulation and concentration of soluble salts in the aquifers as a function of topographic alternation within this axis of the Oban massif (Ekwere, 2010). However, mean values of nitrates were higher on the western sector. This is related to high concentrations of communities and attendant increase in human activity.

Table 3. Mean variations of parameters across western and eastern sectors of the massif.

\begin{tabular}{|c|c|c|}
\hline Parameter & Western Sector & Eastern Sector \\
\hline Temp. $\left({ }^{0} \mathrm{c}\right)$ & 27.7 & 27.9 \\
\hline $\mathbf{p H}$ & 6.2 & 6.8 \\
\hline Conductivity $(\mu \mathrm{s} / \mathrm{cm})$ & 216.2 & 191.4 \\
\hline TDS (ppm) & 296.7 & 226.9 \\
\hline SWL (m) & 2.8 & 3.1 \\
\hline Yield $\left(\mathbf{m}^{3} \mathbf{h r}^{-}\right)$ & 6.1 & 6.2 \\
\hline $\mathbf{C a}$ & 31.7 & 15.6 \\
\hline Mg & 2.7 & 1.5 \\
\hline $\mathbf{N a}$ & 4.3 & 3.6 \\
\hline $\mathbf{K}$ & 6.9 & 1.4 \\
\hline $\mathrm{SO}_{4}$ & 71.6 & 159.9 \\
\hline $\mathrm{NO}_{3}$ & 9.1 & 4.7 \\
\hline $\mathrm{HCO}_{3}$ & 59.4 & 92.4 \\
\hline $\mathbf{C l}$ & 67.1 & 106.6 \\
\hline $\mathrm{PO}_{4}$ & 1.3 & 0.2 \\
\hline $\mathrm{SiO}_{2}$ & 2.0 & 6.9 \\
\hline Lithology & $\begin{array}{l}\text { Gneiss, quartzite, schist, } \\
\text { granodiorite, pegmatite, } \\
\text { gneissic-granite. }\end{array}$ & $\begin{array}{l}\text { Migmatites, schists, } \\
\text { amphibolites, quartzite, } \\
\text { syenites. }\end{array}$ \\
\hline
\end{tabular}




\subsection{Hydrochemical processes controlling water characteristics}

Dissolved species and their relations with each other can reveal the origin of solutes and the processes that generated the observed composition of water. Cross plots and ionic ratios have been used as tools for interpretation of groundwater composition in the study area.

Gibbs (1970) proposed a simple explanation for the general chemistry of both surface and sub-surface waters. He showed that: (1) rainfall (rain dominated), (2) rock-weathering reactions (rock-dominated) and (3) evaporation-crystallization or a combination of these influences, determine the chemistries of surface and ground waters. The plot of TDS against weight ratio of $\mathrm{Na} / \mathrm{Na}+\mathrm{Ca}$ (Figure 2), indicates the mechanisms that determined the major ion composition of sampled waters. Rock dominance appears to be the major controlling factor of the chemistry of sampled waters from the wet season. The plot reveals about $86 \%$ of the sampled waters to be within the rock dominance field. Majority of the waters from the dry season $(72 \%)$, plot within the rainfall/precipitation dominance field. This can be explained by effects of evaporation, giving less time for water-rock reactions and dissolution. The waters are of relatively less resident times and their chemistry is of the recharge source (rainfall). The remaining $28 \%$ of the waters plot within the rock dominance field, reflecting some form of structural control leading to higher resident times and effective mineral dissolution processes.

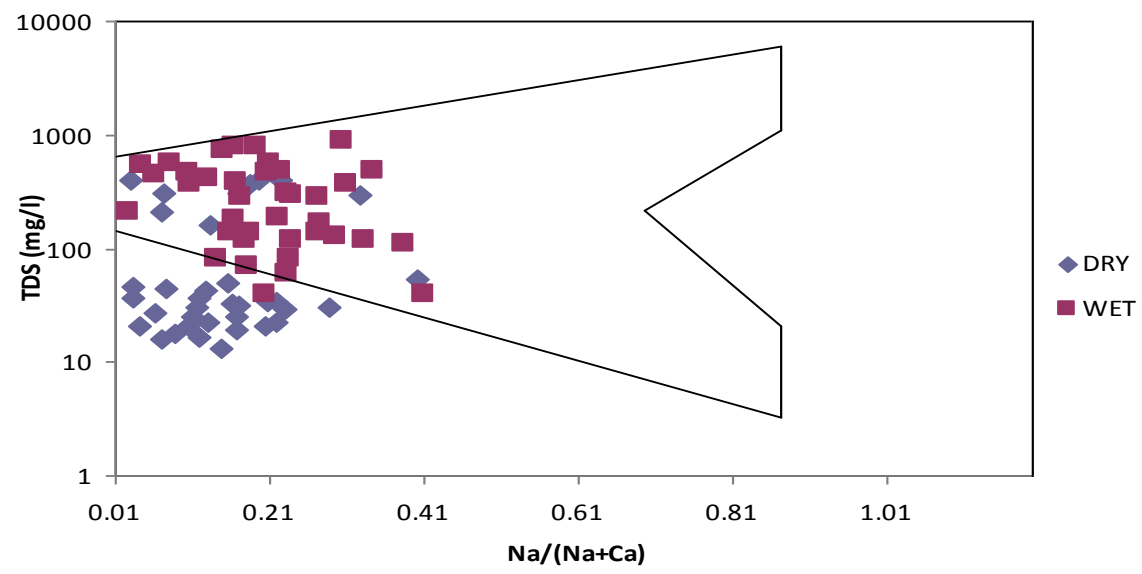

Figure 2. Plot of TDS versus weight ratio of $\mathrm{Na} /(\mathrm{Na}+\mathrm{Ca})$ for sampled waters across seasons.

Plots of $\mathrm{Na}$ versus $\mathrm{Cl}$ have been used to identify the mechanism for acquiring salinity and saline intrusions in aquifers (Zhu et al., 2008; Singh et al., 2005). Generally, evaporation causes an increase in the concentrations of chemical species in water. If the evaporation process is dominant, and no mineral species are precipitated, the $\mathrm{Na}^{+} / \mathrm{Cl}^{-}$ratio is unchanged (Jankowski and Acworth, 1997). Thus, a plot of $\mathrm{Na}^{+} / \mathrm{Cl}^{-}$versus EC would give a horizontal line, which would indicate concentration by evaporation and transpiration (Figure 3a). If simple dissolution of halite is responsible for sodium, then $\mathrm{Na}^{+} / \mathrm{Cl}^{-}$molar ratio would be approximately one. Mean ratios of $\mathrm{Na} / \mathrm{Cl}$ in the dry season was 1.261 and 0.076 for the wet season, Ekwere (2010). Plot of $\mathrm{Na}$ versus $\mathrm{Cl}$ (Figure 3b) shows an excess of $\mathrm{Cl}$ to $\mathrm{Na}$, particularly for samples from shallow and deep aquifers as well as surface waters from the wet season. Most samples of the shallow and deep aquifers also plot below the equiline. Few shallow aquifer and surface water samples from the dry season plot above the equiline reflecting excess of $\mathrm{Na}$ to $\mathrm{Cl}$. The excess of sodium for point plots suggests background levels of $\mathrm{Na}$ that originate from weathering of Na-silicate minerals (e.g. sodium plagioclase) from the crystalline basement. Chloride excess over $\mathrm{Na}^{+}$suggests other sources contributing $\mathrm{Cl}^{+}$to groundwater. A possible source of the excess $\mathrm{Cl}$ in the waters could be saline water from sedimentary rocks adjacent to the crystalline basement. Such saline waters are believed to be 
probably of primitive marine origin (Michard et al., 1996). Ca-Cl water type has been reported from the area, (Ekwere, 2010) and this water type is a result of reverse cation exchange due to the removal of $\mathrm{Na}$ out of solution for bound $\mathrm{Ca}$.

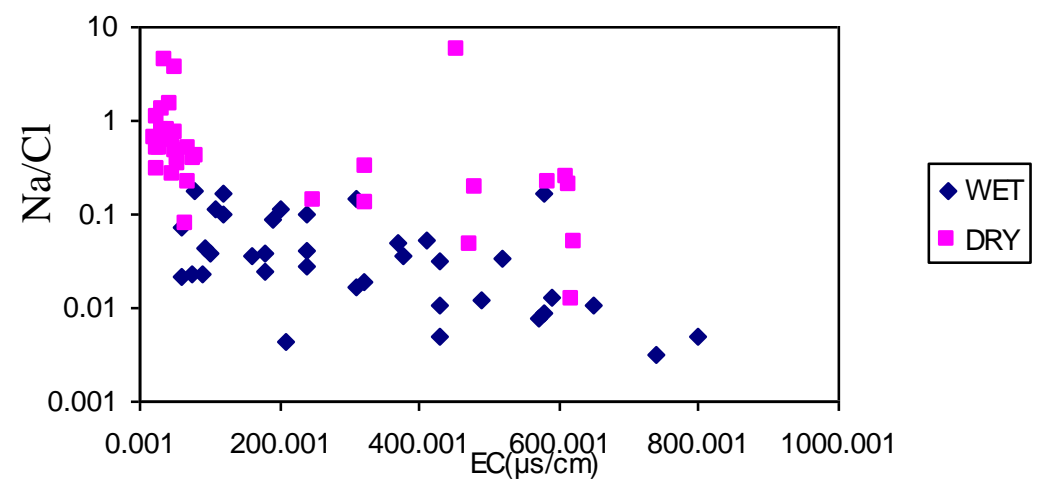

Figure 3a. Plot of $\mathrm{Na} / \mathrm{Cl}$ versus electrical conductivity (EC) for sampled the waters.

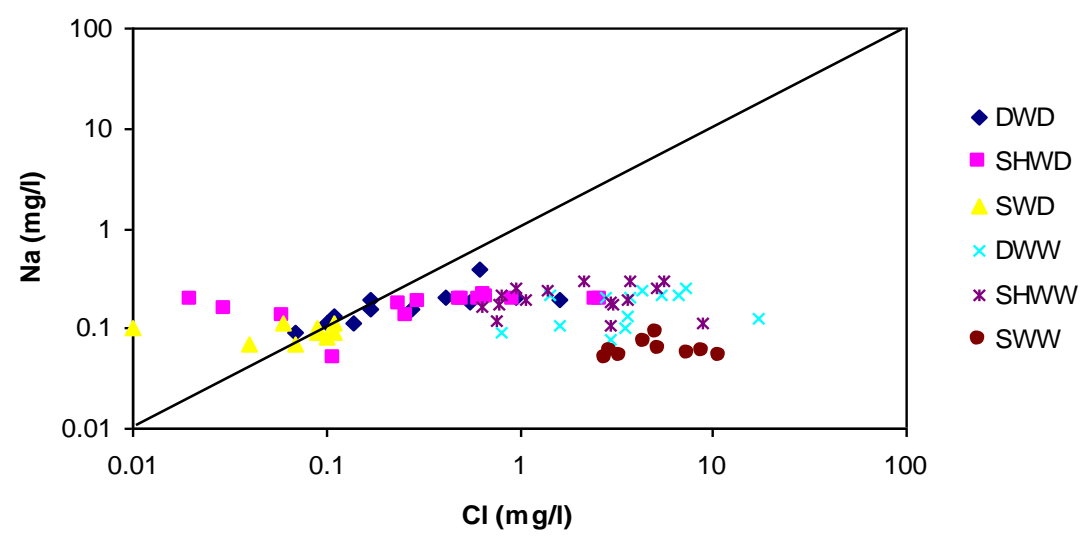

Figure 3b. Plot of $\mathrm{Na}$ versus $\mathrm{Cl}$ for sampled waters.

Note: DWD- deep well dry season; SHWD-shallow well dry season;

SWD-surface water dry season; DWW- deep well wet season;

SHWW- shallow well wet season; SWW- surface water wet season.

$\mathrm{Ca}-\mathrm{Cl}$ type waters could also be a result of the process of mixing between younger, fresher water with more saline older water (Adams et al., 2001). Increased water in aquifers, resultant from recharge levels in the wet season, leads to higher groundwater flow. This supports interaction of water from the adjacent sedimentary terrain with the basement through porous sub-surface media. Another possible source is cation ion exchange processes. Zhu et al. (2008) have shown that low $\mathrm{Na} / \mathrm{Cl}$ ratio of groundwater probably results from ion exchange of $\mathrm{Na}$ for $\mathrm{Ca}$ and $\mathrm{Mg}$ in clay. This is evident in the ratios of these pairs of ionic species from the sampled waters (Ekwere, 2010).

A plot of $\mathrm{Ca}+\mathrm{Mg}$ versus $\mathrm{HCO}_{3}$ (Figure 4) shows that about $81 \%$ of sampled waters plot above the 1:1 equiline, for groundwater from both sampling seasons. This indicates an excess of $\mathrm{Ca}+\mathrm{Mg}$ to $\mathrm{HCO}_{3}$. The remaining fraction, plot around the equiline showing a good correlation between these two factors. This indicates congruent dissolution of silicates (feldspars) and calcite. Surface water samples from the wet season plot below the equiline reflecting excess bicarbonate relative to $\mathrm{Ca}+\mathrm{Mg}$. The excess of $\mathrm{Ca}+\mathrm{Mg}$ over bicarbonate in the waters indicates some extra source of these ions, and a demand that part of these excess 
positive charges has to be balanced by other anions like $\mathrm{SO}_{4}{ }^{2-}$ and/or $\mathrm{Cl}^{-}$. Asides carbonate weathering, silicate weathering (chiefly plagioclase and feldspar), evaporite dissolution can be possible sources of $\mathrm{Ca}^{2+}$ and $\mathrm{Mg}^{2+}$ in water (Ettazarini, 2005; Singh et al., 2005).

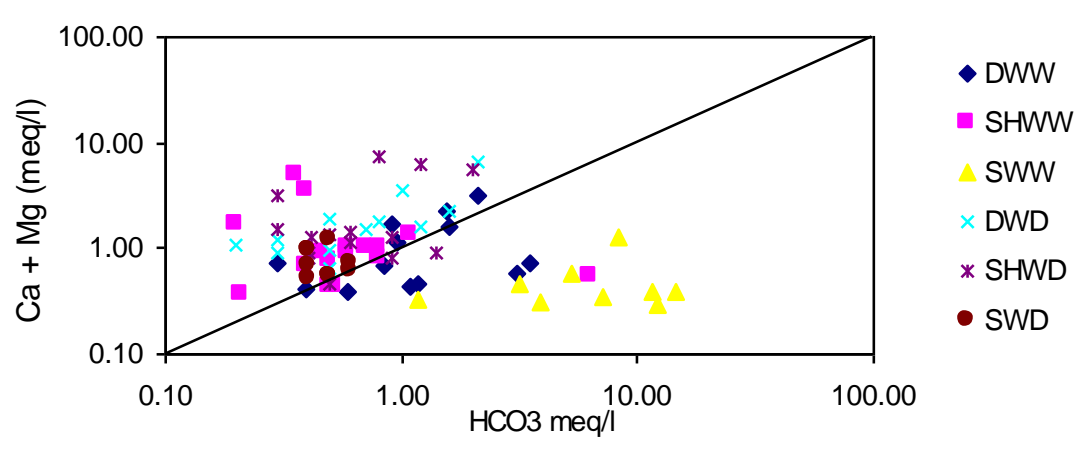

Figure 4. Plot of $\mathrm{Ca}+\mathrm{Mg}$ versus $\mathrm{HCO}_{3}$ for sampled waters across seasons.

The excess of bicarbonate over $\mathrm{Ca}+\mathrm{Mg}$ for samples from the wet season requires that part of the alkalinity should be balanced by alkalis $(\mathrm{Na}+\mathrm{K})$. This bicarbonate excess may be from hydrolysis of carbonate rocks from the Cretaceous sedimentary terrain lying adjacent to the basement complex.

Evidence of silicate weathering and cation exchange can be adjudged by plots of $\mathrm{Ca}+$ $\mathrm{Mg}$ against $\mathrm{HCO}_{3}+\mathrm{SO}_{4}$ (Garcia et al., 2001). This reflects the amount of $\mathrm{Ca}^{2+}$ and $\mathrm{Mg}^{2+}$ gained or lost relative to that provided by the dissolution of $\mathrm{Ca}^{2+}$ and $\mathrm{Mg}^{2+}$ bearing minerals.

Figure 5 shows a plot of this ratio, with most of the points falling below the equiline, a greater percentage being the samples from the wet season. A few samples plot, evolving around the equiline, while a greater percentage of those from the dry season plot above. This demands a portion of the $\mathrm{HCO}_{3}+\mathrm{SO}_{4}$ be balanced by the alkalis $\mathrm{Na}+\mathrm{K}$. Points on and around the equiline correspond to simultaneous calcite and feldspar dissolution. If $\mathrm{Ca}^{2+}, \mathrm{Mg}^{2+}$, $\mathrm{HCO}_{3}{ }^{-}$and $\mathrm{SO}_{4}{ }^{2-}$, were derived from simple dissolution of calcitic minerals and feldspars, then a charge balance should exist between the cations and anions. An ion exchange process is characterized by $\mathrm{HCO}_{3}+\mathrm{SO}_{4}$ excess over $\mathrm{Ca}+\mathrm{Mg}(86 \%$ of the wet season samples and about $17 \%$ of the dry season samples), while the reverse ion exchange is marked by $\mathrm{Ca}+\mathrm{Mg}$ excess over $\mathrm{HCO}_{3}+\mathrm{SO}_{4}$, largely for the dry season samples (Cerling et al., 1989; Fisher and Mullican, 1997; Ettazarini, 2005).

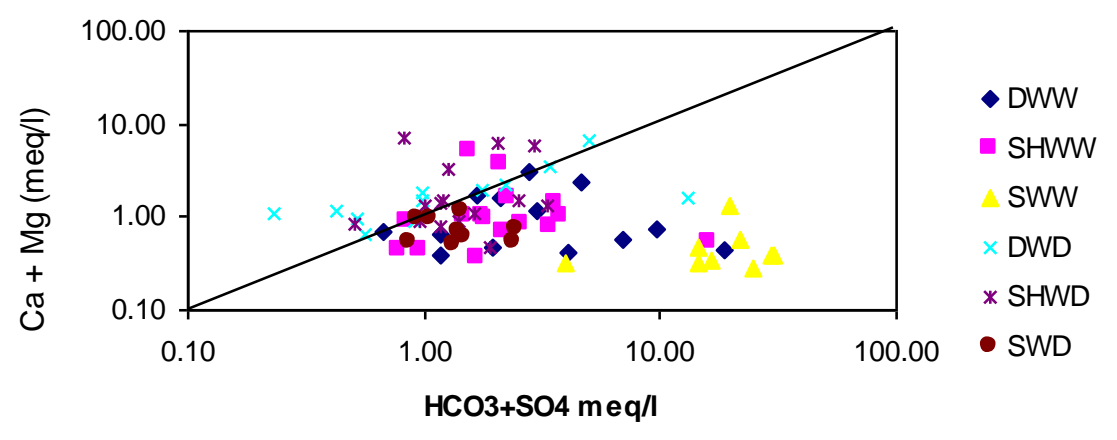

Figure 5. Plot of $\mathrm{Ca}+\mathrm{Mg}$ versus $\mathrm{HCO}_{3}+\mathrm{SO}_{4}$ for sampled waters across seasons. 
A plot of $(\mathrm{Ca}+\mathrm{Mg})$ versus TC (total cation) for samples from both seasons shows that all the points plot along and close to the equiline in a linear spread, Figure 6a. The average ratio of $[\mathrm{Ca}+\mathrm{Mg}] / \mathrm{TC}$ were 0.86 and 0.76 for the dry and wet seasons respectively. Plot of $\mathrm{Na}+\mathrm{K}$ against TC (Figure 6b) shows that, all points plot below the equiline for both seasons. The average ratios of $(\mathrm{Na}+\mathrm{K}) / \mathrm{TC}$ are 0.14 and 0.24 for the dry and wet seasons respectively. Calcium and magnesium are the dominant cations across seasons. Evaporation and $\mathrm{Ca}^{2+}$ precipitation alongside $\mathrm{Mg}^{2+}$ is responsible for the dominance of these ionic species in the dry season (Ekwere, 2010). The degree of dominance however decreases from the dry to the wet seasons. The ratio of $\mathrm{Na}+\mathrm{K}$ to $\mathrm{TC}$ increases from the dry to the wet seasons. This indicates an increasing contribution of alkalis with increase in dissolved solids (Singh et al., 2005).

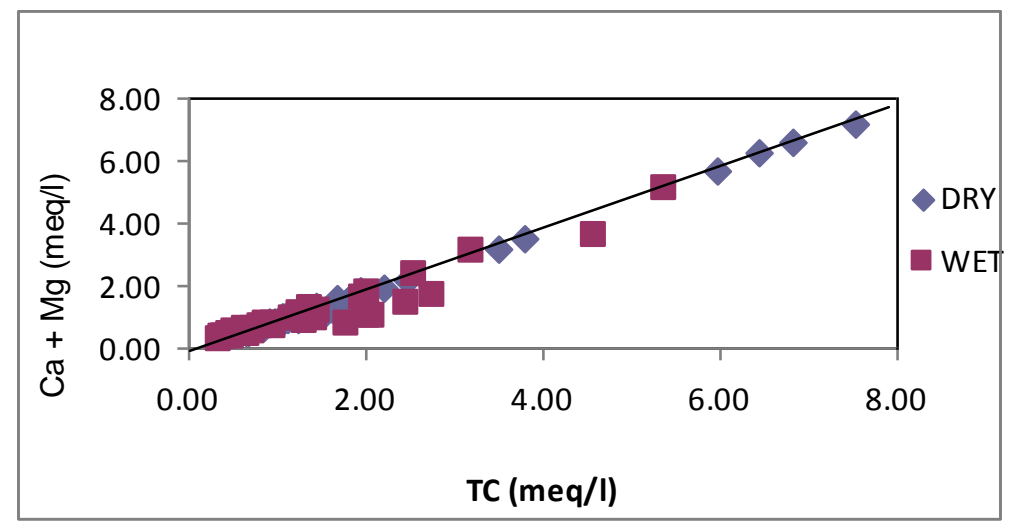

Figure 6a. Plot of $\mathrm{Ca}+\mathrm{Mg}$ versus total cation (TC) sampled waters across seasons.

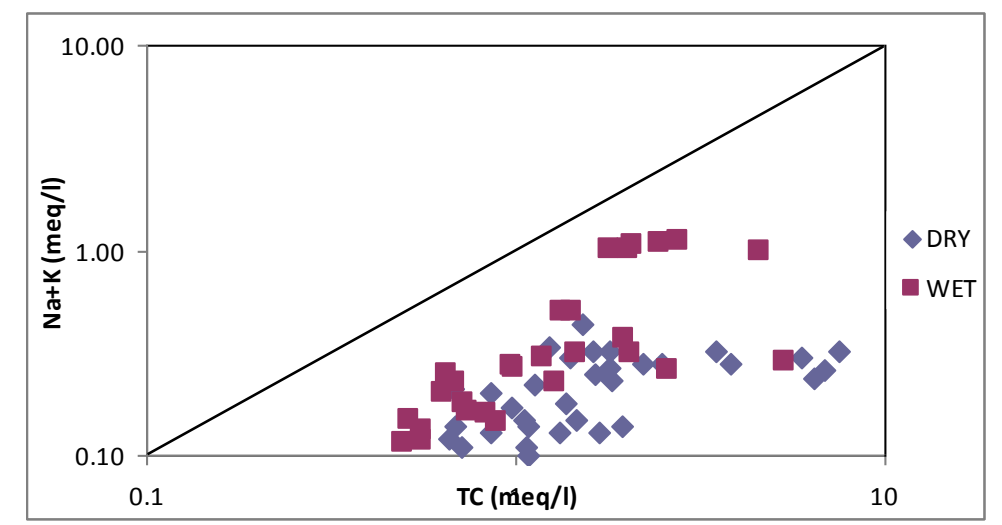

Figure 6b. Plot of $\mathrm{Na}+\mathrm{K}$ versus total cation (TC) for sampled waters across seasons.

\subsection{Factor analysis}

Factor analysis is a multivariate statistical technique that is widely used to aid interpretation of geochemical data and enhances subtle but significant single-element anomalies (Garret and Nichol, 1969). In other words, factor analysis has the simple objective of revealing an underlying relation that is presumed to exist within a set of multivariate observation, (Davies, 1986). By so doing, the structure of the underlying system that produced the data is well understood. Factor analyses were employed in this study to process data and determine the sources of incipient ionic species relative to physical parameters as well as factors controlling such. Results of R- mode factor analyses for both seasons of sampling are summarized in factor matrix Tables 4 and 5. 
EKWERE, A. S.; EDET, A. E.; EKWERE, S. J. Groundwater chemistry of the Oban Massif, South-Eastern Nigeria. Ambi-Agua, Taubaté, v. 7, n. 1, p. 51-66, 2012. (http://dx.doi.org/10.4136/ambi-agua.812)

Table 4. Factor loading for dry season.

\begin{tabular}{|c|c|c|c|c|}
\hline \multicolumn{5}{|c|}{ FACTOR } \\
\hline Variables & 1 & 2 & 3 & 4 \\
\hline Temp. & -0.004 & 0.020 & -0.034 & -0.927 \\
\hline EC & 0.944 & -0.036 & 0.030 & -0.046 \\
\hline TDS & 0.944 & -0.036 & 0.030 & -0.046 \\
\hline pH & -0.458 & 0.117 & -0.401 & 0.298 \\
\hline $\mathbf{N a}$ & 0.573 & 0.184 & 0.382 & 0.231 \\
\hline $\mathbf{K}$ & 0.806 & 0.425 & 0.042 & 0.050 \\
\hline $\mathbf{C a}$ & 0.233 & 0.824 & 0.052 & 0.096 \\
\hline Mg & 0.767 & 0.576 & 0.079 & 0.153 \\
\hline Cl & 0.584 & 0.211 & 0.436 & 0.203 \\
\hline $\mathrm{HCO}_{3}{ }^{-}$ & -0.001 & 0.921 & 0.144 & -0.086 \\
\hline $\mathrm{SO}_{4}{ }^{2-}$ & -0.131 & 0.105 & 0.877 & -0.083 \\
\hline $\mathrm{NO}_{3}{ }^{-}$ & 0.332 & 0.147 & 0.734 & 0.227 \\
\hline Eigenval & 4.949 & 1.704 & 1.390 & 1.088 \\
\hline$\%$ Variance & 41.242 & 14.198 & 11.586 & 9.064 \\
\hline Cumul. Eigenv. & 4.949 & 6.653 & 8.043 & 9.131 \\
\hline \% Cumul. & 41.242 & 55.440 & 67.026 & 76.090 \\
\hline
\end{tabular}

On inspection, a four and three factor models were recognized for the dry and wet seasons respectively. Only variables with loadings greater than 0.50 , were considered significant members of a particular factor.

In the dry season, factor one (EC, TDS, $\mathrm{Na}, \mathrm{K}, \mathrm{Mg}$ and $\mathrm{Cl}$ ) accounted for $41.2 \%$ of total data variance and was interpreted as related to geogenic processes; infiltration of surface runoff and other sub-surface fluids, dissolution processes, mixing of waters and cation exchange processes.

The second factor $\left(\mathrm{Ca}, \mathrm{Mg}, \mathrm{HCO}_{3}\right)$, with $14.2 \%$ data variance, was interpreted to be related to natural weathering of $\mathrm{Ca}$ and $\mathrm{Mg}$ bearing minerals and lesser extents of carbonate dissolution processes within the porous sub-surface media. The main cation exchange elements $\mathrm{Ca}^{2+}$ and $\mathrm{Mg}^{2+}$ relative to $\mathrm{HCO}_{3}{ }^{-}$correlated positively indicating the influence of the geological matrix.

Factor $3\left(\mathrm{SO}_{4}\right.$ and $\left.\mathrm{NO}_{3}\right)$ accounted for $11.6 \%$ data variance and was interpreted to be reflective of biogenic reactions. Organic activities within the soil profile affects infiltrating water, Langmuir (1997). Impacts of land use practices could also be inferred due to the presence of the biochemical $\mathrm{NO}_{3}$, which is a principal plant nutrient (Adams et al, 2001). The fourth factor, which is temperature, shows its effects on the series of processes that control the chemistry of sampled waters.

Results from R-mode factor analysis for the wet season shows factor $1(\mathrm{Na}, \mathrm{K}, \mathrm{Ca}$ and $\mathrm{Mg}$ ) accounts for $36.2 \%$ of data variation, reflecting natural weathering from water-rock interactions in geo-matrix of the basement. Factor 2, (EC, TDS, $\mathrm{HCO}_{3}, \mathrm{SO}_{4}$ ), exhibits loading that accounts for about $18.9 \%$ of data variance. This factor is believed to be related to 
weathering and water-rock reactions. Inputs of mobile phases of ionic species $\left(\mathrm{SO}_{4}{ }^{2-}\right.$ and $\left.\mathrm{HCO}_{3}{ }^{-}\right)$from dissolution and cation exchange are evident in conductivity levels. Factor $3(\mathrm{pH}$, $\mathrm{NO}_{3}$ ) accounts for $11.7 \%$ of data variance and similar to factor three of the dry season, it indicates the effects of organic activities controlled by varying $\mathrm{pH}$ conditions as well as effects of land use practices.

\subsection{Chemical types and trends of groundwater}

In order to ascertain the groundwater types and visualize the trends of chemistry, the Piper trilinear diagram was used (Figures $7 \mathrm{a}$ and $7 \mathrm{~b}$ ). These show the relative concentrations of the different ionic species for the individual sample type based on average values across the sampling seasons. Calcium is the dominant cation across both seasons. Bicarbonate is the dominant anion for the water types in the wet season, while chloride is for the dry season. The recognizable water types are; $\mathrm{Ca}-(\mathrm{Mg})-\mathrm{HCO}_{3}$ and $\mathrm{Ca}-(\mathrm{Na})-\mathrm{Cl}-\mathrm{SO}_{4}$.

The $\mathrm{Ca}-(\mathrm{Mg})-\mathrm{HCO}_{3}$ water type is defined as the normal alkaline group of water. Amadi (1987) describes this type of water of being typical of Nigerian basement terrain with limited mixing, perhaps reflecting a primary stage of evolution of its groundwater system. Similar water type has been reported for the western basement complex of Nigeria by Elueze et al. (2004) and Tijani (1994). The chemical composition of this water type is said to be due to the dissolution of silicate minerals in the bedrock and aluminosilicates in the weathered regolith, Tijani (1994).

The $\mathrm{Ca}-\mathrm{Na}-\mathrm{Cl}-\mathrm{SO}_{4}$ association is defined as a major constituent of atmospheric precipitation (Davis and De Weist, 1966). Elueze et al. (2004) reports occurrence of such water type in the western sector of the Nigerian basement complex. The chemistry of this water type is therefore influenced by precipitation.

Table 5. Factor loading for wet season.

\begin{tabular}{|c|c|c|c|}
\hline \multicolumn{4}{|c|}{ FACTOR } \\
\hline VARIABLE & 1 & 2 & 3 \\
\hline Temp. & 0.405 & -0.385 & -0.207 \\
\hline EC & -0.135 & 0.945 & 0.072 \\
\hline TDS & 0.132 & 0.884 & -0.125 \\
\hline $\mathbf{p H}$ & -0.285 & -0.221 & 0.821 \\
\hline $\mathbf{N a}$ & 0.849 & -0.278 & -0.117 \\
\hline $\mathbf{K}$ & 0730 & -0.040 & 0.071 \\
\hline $\mathbf{C a}$ & 0.631 & 0.164 & -0.009 \\
\hline Mg & 0.879 & -0.035 & -0.028 \\
\hline Cl & -0.124 & 0.447 & 0.137 \\
\hline $\mathrm{HCO}_{3}^{-}$ & -0.500 & 0.691 & 0.154 \\
\hline $\mathrm{SO}_{4}{ }^{2-}$ & -0.499 & 0.591 & 0.462 \\
\hline $\mathrm{NO}_{3}{ }^{-}$ & 0.254 & 0.301 & 0.792 \\
\hline Eigenval & 4.339 & 2.272 & 1.409 \\
\hline$\%$ Variance & 36.155 & 18.934 & 11.742 \\
\hline Cumul. Eigenv. & 4.339 & 6.611 & 8.020 \\
\hline \% Cumul. & 36.155 & 55.089 & 66.831 \\
\hline
\end{tabular}


EKWERE, A. S.; EDET, A. E.; EKWERE, S. J. Groundwater chemistry of the Oban Massif, South-Eastern Nigeria. Ambi-Agua, Taubaté, v. 7, n. 1, p. 51-66, 2012. (http://dx.doi.org/10.4136/ambi-agua.812)

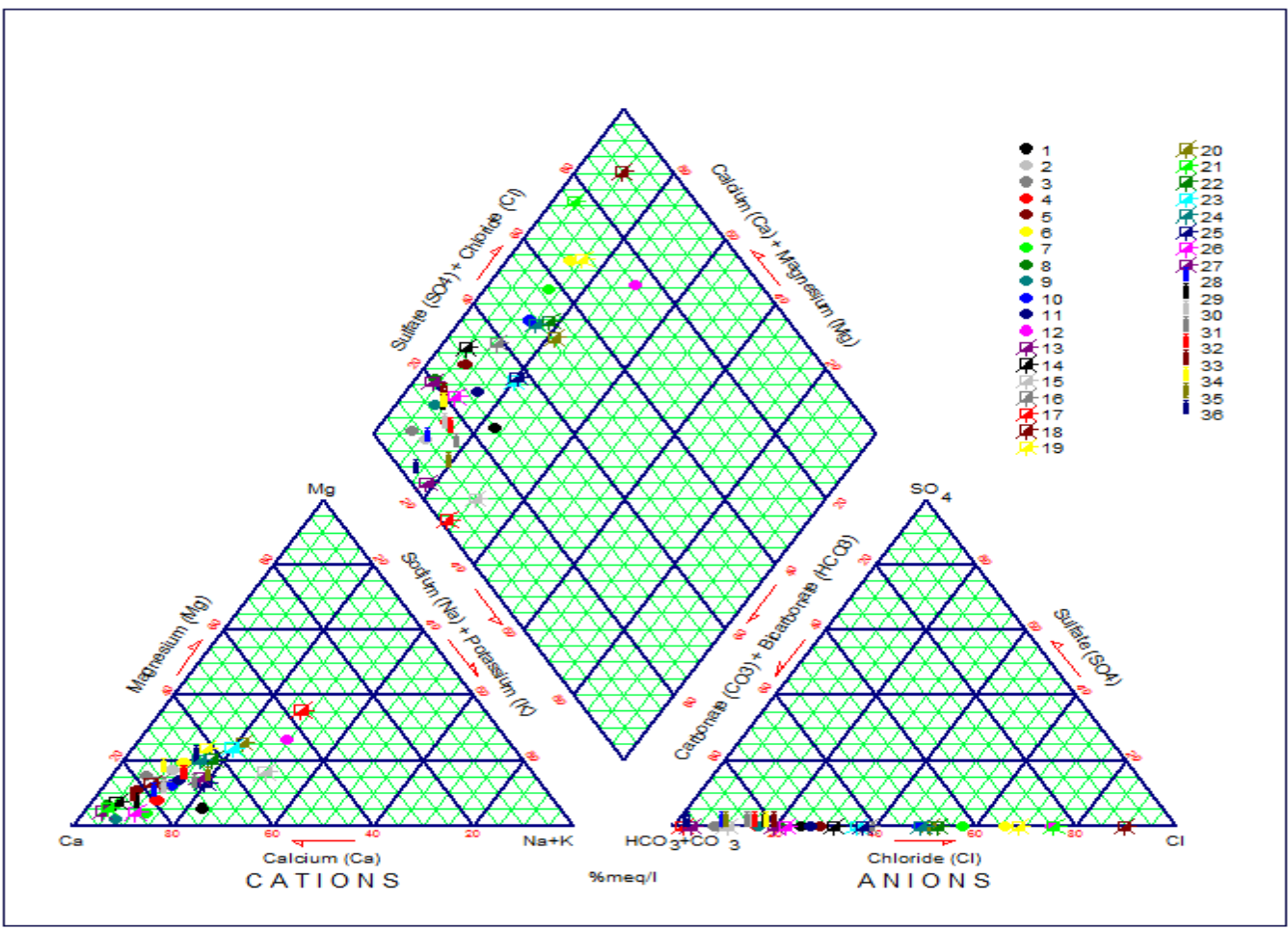

1-12 boreholes; 13-27 open wells; 28-36 surface streams

Figure 7a. Trilinear diagram plot of water samples from the dry season.

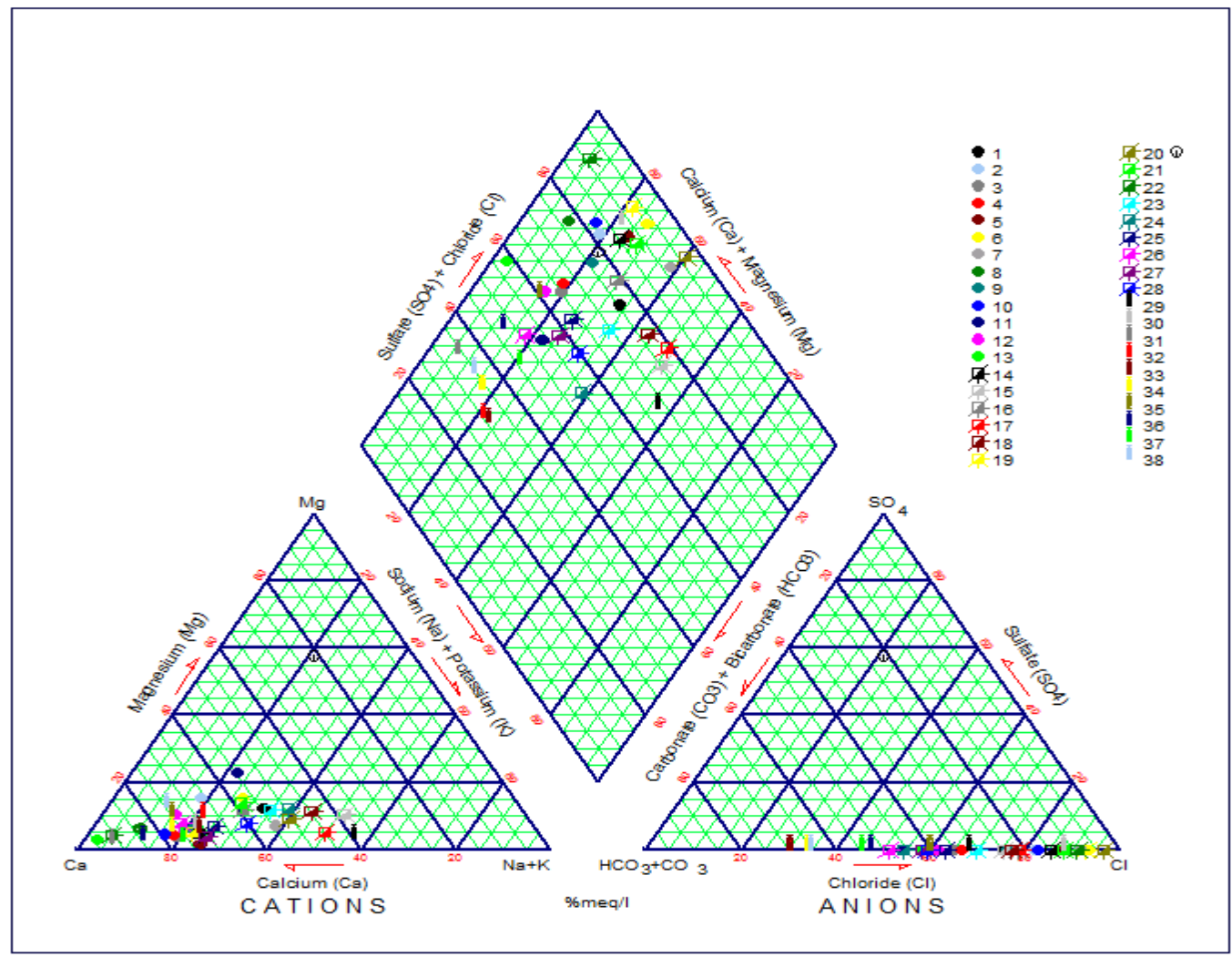

1-13 boreholes; $14-28$ open wells; 29-38 surface streams

Figure 7b. Trilinear diagram plot of water samples from the wet season. 


\section{CONCLUSIONS}

The present hydrochemical status of the study area shows concentration levels of ionic species to be controlled by geogenic processes. Geologic and hydrogeologic features affect the chemistries as exhibited by groundwater. Order of abundance of major chemical species was $\mathrm{Ca}>\mathrm{Na}>\mathrm{Mg}>\mathrm{K}$ and $\mathrm{HCO}_{3}>\mathrm{SO}_{4}>\mathrm{Cl}$ with minor spatial variations across the sampling seasons. Deductions from ionic ratios cross plots and factor analysis support interrelations between ionic species that can be explained by geologic processes. These adjudged natural processes include weathering of mineral phases (mainly silicates), water mixing (from adjacent sedimentary terrain), and ion exchange reactions. This broad spectrum of hydrochemical dynamics is indicated by two dominant hydrochemical facies; $\mathrm{Ca}-(\mathrm{Na})-\mathrm{Cl}-\mathrm{SO}_{4}$ and $\mathrm{Ca}-(\mathrm{Mg})-\mathrm{HCO}_{3}$ water types in the study area.

\section{REFERENCE}

ADAMS, S. S.; TITUS, R.; PIETERSEN, K.; TREDOUX, G.; HARRIS, C. Hydrochemical characteristics of aquifers near Sutherland in Western Karoo, South Africa. Journal of Hydrology, v. 241, p. 91-103, 2001 http://dx.doi.org/10.1016/S0022-1694(00)00370-X

AMERICAN PUBLIC HEALTH ASSOCIATION - APHA. Standard methods for the examination of water and wastewater. $19^{\text {th }}$ ed. Washington, 1995.

AYI, N. E. Geology and geochemistry of the eastern part of the Oban massif. 1987. Thesis (M.Sc in Geology) - Dept. of Geology, University of Calabar, Calabar, 1987.

BERNER, E. K.; BERNER, R. A. Global environment: water, air and geochemical cycles. Upper Saddle River: Prentice Hall, 1996.

CARITAT, P. de; KIRSTE, D.; CARR, G.; McCULLOCH, M. Groundwater in Broken Hill region, Australia: recognizing interaction with bedrock and mineralization using $\mathrm{S}, \mathrm{Sr}$ and Pb isotopes. Applied Geochemistry, v. 20, p. 767-787, 2004.

http://dx.doi.org/10.1016/j.apgeochem.2004.11.003

CERLING, T. E.; PEDERSON, B. L.; DAMM, K. L. V. Sodium-Calcium ion exchange in the weathering shales. Implications for global weathering budgets. Geology, v. 17, p. 552554, 1989. http://dx.doi.org/10.1130/0091-7613(1989)017<0552:SCIEIT>2.3.CO;2

CROSS RIVER BASIN DEVELOPMENT AUTHORITY - CRBDA. Hydrogeological survey of lower Cross River Basin: final report. Calabar, 2008. 158p.

DAVIS, S. N.; De WEIST, R. J. M. Hydrogeology. New York: John Wiley \& Sons, 1966.

DAVIES, J. C. Statistics and data analysis in geology. $2^{\text {nd }}$ ed. New York: Wiley and Sons, 1986.

EDET, A. E.; TEME, S. C.; OKEREKE, C. S.; ESU, E. O. Linearment analysis for groundwater exploration in Precambrian Oban massif and Obudu Plateau, SE Nigeria. Journal of Mining and Geology, v. 30, n. 1, p. 8-95, 1994.

EDET, A. E.; OKEREKE, C. S.; TEME, S. C.; ESU, E. O. Application of remote-sensing data to groundwater exploration: a case study of the Cross River State, SE Nigeria. Hydrogeology Journal, v. 6, p. 394-404, 1998.

http://dx.doi.org/10.1007/s100400050162 
EDET, A. E.; OKEREKE, C. S. Hydrogeological and hydrochemical character of the regolith aquifer, northern Obudu Plateau, Southern Nigeria. Hydrogeology Journal, v. 13, p. 391-415, 2005. http://dx.doi.org/10.1007/s10040-004-0358-9

EDET, A. E.; EKPO, B. O. Hydrogeochemistry of a fractured aquifer in the Ogoja/Obudu area of SE Nigeria. In: ADELANA, S.; MacDONALD, A. Applied groundwater studies in Africa. Boca Raton: Taylor and Francis, 2008. p. 391-403. (Selected Papers on Hydrogeology, 13)

EKWERE, S. J.; EKWUEME, B. N. Geochemistry of precambrian gneisses in the eastern part of the Oban massif, southeastern Nigeria. Geolgie en Mijnbouw, v. 70, p. 105-114, 1991.

EKWERE, A. S. Hydrogeological and hydrogeochemical framework of the Oban Massif, south-eastern Nigeria. 2010. Thesis (Ph.D.) - Dept. of Geology, University of Calabar, Calabar, 2010.

EKWUEME, B. N. Rb-Sr ages and petrologic features of Precambrian rocks from the Oban massif, south-eastern Nigeria. Precambian Research, v. 47, p. 271-286, 1990. http://dx.doi.org/10.1016/0301-9268(90)90042-O

EKWUEME, B. N. The Precambrian geology and evolution of the Southeastern Nigerian basement complex. University of Calabar Press 135p, 2003.

EKWUEME, B. N.; EKWERE, S. J. The geology of the eastern sector of Oban massif, southeastern Nigeria. Journal Mining and Geology, v. 25, n. 1/2, p. 317-329, 1989.

ELUEZE, A. A.; OMIDIRAN, J. O.; NTON, M. E. Hydrogeochemical investigation of surface water and groundwater around Ibokun, Ilesha area, southwestern Nigeria. Journal Mining and Geology, v. 40, n. 1, p. 57-64, 2004.

ETTAZARINI, S. Processes of water-rock interaction in the Turonian aquifer of Oum ErRabia Basin, Morocco. Environmental Geology, v. 49, p. 293-299, 2005. http://dx.doi.org/10.1007/s00254-005-0088-x

FISHER, R. S.; MULLICAN, W. F. Hydrochemical evolution of sodium-sulfate and sodiumchloride groundwater beneath the Northern Chihuahua Desert, Trans-Pecos, Texas, USA. Hydrogeology Journal, v. 5, n. 2, p. 4-16, 1997. http://dx.doi.org/10.1007/s100400050102

GARCIA, M. G.; HIDALGO, M. V.; BLESA, M. A. Geochemistry of groundwater in the alluvial plain of Tucuman province, Argentina. Hydrogeology Journal v. 9, p. 597 610, 2001. http://dx.doi.org/10.1007/s10040-001-0166-4

GARRET, R. G.; NICHOL, I. Factor analysis as an aid in the interpretation of regional geochemical streams sediment data. Golden: Colorado School of Mines, 1969. p. 245264.

GIBBS, R. J. Mechanism controlling world water chemistry. Science, v. 170, n. 10, p. 88- 90, 1970.

JANKOWSKI, J.; ACWORTH, R. I. Impact of debris-flow deposits on hydrogeochemical processes and the development of dry land salinity in the Yass River catchment, New South Wales, Australia. Hydrogeology Journal, v. 5, n. 4, p. 71-88, 1997. http://dx.doi.org/10.1007/s100400050119 
LANGMUIR, D. Aqueous environmental geochemistry. Upper Saddle River: Prentice Hall, 1997.

MATTHESS, G. The properties of groundwater. New York: Wiley, 1982.

MICHARD, G.; PEARSON JR., F. J.; GAUTSCHI, A. Chemical evolution of waters during long term interaction with granitic rocks in Northern Switzerland. Applied Geochemistry, v. 11, p. 757-774, 1996. http://dx.doi.org/10.1016/S0883-2927(96)00014-5

OELKERS, E. H. Physical and chemical properties of rock and fluids for chemical mass transport calculation. Reviews in Mineralogy and Geochemistry, v. 34, p. 131-191, 1996.

SINGH, A. K.; MONDAL, G. C.; SINGH, P. K.; SINGH, S.; SINGH, T. B.; TEWARY, B. K. Hydrochemistry of reservoirs of Damodar River Basin, India: weathering processes and water quality assessment. Environmental Geology, v. 48, p. 1014-1028, 2005. http://dx.doi.org/10.1007/s00254-005-1302-6

TIJANI, M. N. Hydrochemical assessment of groundwater in Moro area, Kwara State, Nigeria. Environ. Geol. Vol 24. pp. 194 - 202, 1994. http://dx.doi.org/10.1007/BF00766889

ZHU, G. F.; SU, Y. H.; FENG, Q. The hydrochemical characteristics and evolution of groundwater and surface water in the Heihe River Basin, northwest China. Hydrogeology Journal, v. 16, p. 167-182, 2008. http://dx.doi.org/10.1007/s10040-007-0216-7 


\begin{tabular}{ccc|} 
ISSN = 1980-993X - doi:10.4136/1980-993X \\
www.ambi-agua.net \\
E-mail: ambi-agua@agro.unitau.br \\
Tel.: (12) 3625-4212
\end{tabular}

\title{
Hydro-geochemical evaluation of groundwater quality in Akoko North West local government area of Ondo State, Nigeria
}

\author{
(http://dx.doi.org/10.4136/ambi-agua.851)
}

\author{
Temitope D. T. Oyedotun ${ }^{1}$; Opeyemi Obatoyinbo ${ }^{2}$ \\ ${ }^{1}$ Department of Geography and Planning Sciences, Faculty of Social Sciences, \\ Adekunle Ajasin University, P. M. B. 001, Akungba-Akoko, Ondo State, Nigeria. \\ e-mail: oyedotuntim@yahoo.com; \\ ${ }^{2}$ Department of Geology, Faculty of Science, Adekunle Ajasin University, \\ P. M. B. 001, Akungba-Akoko, Ondo State, Nigeria. \\ e-mail: obatope2@yahoo.com
}

\begin{abstract}
A sudden geometric increase in population of Akoko North West Local Government Area of Ondo State has led to an increase in demand for water and harnessing of subsurface water reserve. A total of twenty six water samples obtained from both boreholes and hand-dug wells were analyzed for their physico-chemical characteristics with the aim of assessing their quality, usability and also to determine the level of their contamination in the local government which is dominated by granite gneisses, charnockites, and augen gneisses as the main rock types. The following physico-chemical properties were analyzed for in the samples collected: electrical conductivity (EC), $\mathrm{pH}$, total alkalinity (TA), total dissolved solids (TDS), total suspended solids (TSS), acid neutralizing capacity (ANC) with major cations $\left(\mathrm{Na}^{+}\right.$, $\left.\mathrm{Mg}^{2+}, \mathrm{Ca}^{2+}\right)$, anions $\left(\mathrm{PO}_{4}{ }^{3-}, \mathrm{HCO}_{3}{ }^{-}, \mathrm{SO}_{4}{ }^{3-}\right)$ and several heavy metals $\left(\mathrm{Zn}^{2+}, \mathrm{Fe}^{2+}, \mathrm{As}^{+}, \mathrm{Ni}^{+}\right.$, $\left.\mathrm{Pb}^{2+}, \mathrm{Cd}^{+}, \mathrm{Cu}^{2+}\right)$. The following results were obtained from the analysis: $\mathrm{Zn}^{2+}(0.109-0.437$ ppm), $\mathrm{Fe}^{2+}(0.216-0.726 \mathrm{ppm}), \mathrm{As}^{+}(0.01-0.03 \mathrm{ppm}), \mathrm{Ni}^{+}(0.036-0.074), \mathrm{Pb}^{2+}(0.003-$ $0.010), \mathrm{Cd}^{+}(0.002-0.007), \mathrm{Cu}^{2+}(0.086-0.241)$ with appreciable abundances of $\mathrm{PO}_{4}{ }^{3-}, \mathrm{Cd}^{+}$, $\mathrm{Fe}^{2+}$ and $\mathrm{Ni}^{+}$some exceeding while some others are below the WHO acceptable level for drinking water, thereby making it a serious source of concern as it indicates varying levels of faecal contamination (from leaky septic tanks, interception with pit latrines) and heavy metal liberation into the water consumed by the residents. It was also noticed that the water was fresh based on the analysis of the Total Dissolved Solids and the $\mathrm{Pb}^{2+}$ concentrations almost exceeded the standard permissible limit. Generally, it was concluded that the overall quality of the ground water is averagely good physico-chemically.
\end{abstract}

Keywords: water samples; physico-chemical properties; water quality.

\section{Avaliação hydrogeoquímica da qualidade da água subterrânea na área Akoko North West do governo local do estado Ondo, Nigéria}

\section{RESUMO}

Um aumento geométrico e repentino da população da área de Akoko North West do Governo Local do Estado de Ondo levou a um aumento pela procura de água e aproveitamento de reserva de água subterrânea. As características físico-químicas de vinte e seis amostras de água obtidas de poços perfurados e cavados à mão foram analisadas com a 
OYEDOTUN, T. D. T.; OBATOYINBO, O. Hydro-geochemical evaluation of groundwater quality in Akoko North West local government area of Ondo State, Nigeria. Ambi-Agua, Taubaté, v. 7, n. 1, p. 67-80, 2012. (http://dx.doi.org/10.4136/ambi-agua.851)

finalidade de avaliar sua qualidade, usabilidade e determinação de seu nível de contaminação na área do governo local, que é dominado principalmente pelas rochas de granito, gnaisses, charnockitos e augen gnaisse. As seguintes propriedades físico-químicas das amostras coletadas foram analisadas: condutividade elétrica (CE), $\mathrm{pH}$, alcalinidade total (AT), sólidos totais dissolvidos (TDS), sólidos suspensos totais (SST), a capacidade de neutralização de ácido (CNA), com os principais cátions $\left(\mathrm{Na}^{+}, \mathrm{Mg}^{2+}, \mathrm{Ca}^{2+}\right)$, ânions $\left(\mathrm{PO}_{4}{ }^{3-}, \mathrm{HCO}_{3-}, \mathrm{SO}_{4}{ }^{3}\right)$ e vários metais pesados $\left(\mathrm{Zn}^{2+}, \mathrm{Fe}^{2+}, \mathrm{As}^{+}, \mathrm{Ni}^{+}, \mathrm{Pb}^{2+}, \mathrm{Cd}^{+}, \mathrm{Cu}^{2+}\right)$. Os seguintes resultados foram obtidos: $\mathrm{Zn}^{2+}(0,109-0,437 \mathrm{ppm}), \mathrm{Fe}^{2+}(0,216-0,726 \mathrm{ppm}), \mathrm{As}^{+}(0.01-0.03 \mathrm{ppm}), \mathrm{Ni}^{+}$ $\left(0,036\right.$ - 0,074), $\mathrm{Pb}^{2+}(0,003-0,010), \mathrm{Cd}^{+}(0,002-0,007), \mathrm{Cu}^{2+}(0,086-0,241)$, com concentrações apreciáveis de $\mathrm{PO}_{4}{ }^{3-}, \mathrm{Cd}^{+}, \mathrm{Fe}^{2+} \mathrm{e} \mathrm{Ni}^{+}$algumas superiores, enquanto outras abaixo do nível aceitável da WHO para água potável, fato que se constitui em grande preocupação, pois indica níveis variáveis de contaminação fecal (de vazamento de fossas sépticas e de latrinas) e contaminação de metais pesados na água consumida pelos moradores. Também foi observado que a água era doce com base na análise dos sólidos totais dissolvidos e que as concentrações de $\mathrm{Pb}^{2+}$ quase ultrapassaram o limite padrão estabelecido. Observou-se que a qualidade físico-química global da água do solo é medianamente boa.

Palavras-chave: amostras de água; propriedades físico-químicas; qualidade da água.

\section{INTRODUCTION}

Water is a very important component of the earthly environment. Throughout the history of man, water has always been sustaining life and serving communities. The importance of the quality of available water cannot, however, be over-emphasised. As far as Nigeria is concerned, there is abundant of surface and groundwater resources, particularly in the SouthWestern region which is entirely within the tropical rainforest zone (Obatoyinbo and Oyedotun, 2011). Rijswijk (1981) estimated the groundwater resources at $0-50 \mathrm{~m}$ depth in Nigeria to be $6 \times 10^{6} \mathrm{~km}^{3}\left(6 \times 10^{6} \mathrm{~m}^{3}\right)$. However, from the eight mega regional aquifers in Nigeria which Akujieze et al., (2003) estimated, the deposit of the total groundwater yields additional groundwater resources of 7.2 times Rijswijk's figure, the total of which is estimated to be 50 million trillion 1/year (Akujieze et al., 2003). Earlier, Hanidu (1990) has estimated the surface water resources in Nigeria to be 224 trillion 1/year. Hence, with the available surface water resources of 224 trillion litre per year (1/year) and about 50 million trillion 1/year as groundwater resources, there is an assured water abundance in Nigeria. Any shortfall in meeting the rising population needs is principally due to harnessing, distribution, delivery and quality (Hanidu, 1990; Akujieze et al., 2003).

Through the International Drinking Water Supply and Sanitation Decade (1980 - 1990), the NPC (2006) recommended and proposed water for all by the year 2000. For this to be achieved, Nigeria launched a National Borehole Programme, which included 760 boreholes with only $228(30 \%)$ being productive (Akujieze et al., 2003). The failure of this project may be due to poor knowledge of groundwater disposition in Nigeria, the bureaucratic nature of government projects or the attitude of new political government officials to discard their predecessors initiated projects, resulting in those ventures to be white-elephant projects. With the view and understanding that groundwater is much more of high quality than surface water (which are exposed to all sorts of pollution), individuals have been embarking on digging wells in their neighbourhood and apartments to meet their growing water needs for their multifarious purposes.

However, the quality of groundwater depends upon several factors such as lithology and conditions prevailing within formation, quantum of water available in the aquifer and its rate of circulation. Apart from these factors, the activities of microorganisms, temperature and pressure are also responsible for the chemical characteristic of groundwater (Ramanathan, 
OYEDOTUN, T. D. T.; OBATOYINBO, O. Hydro-geochemical evaluation of groundwater quality in Akoko North West local government area of Ondo State, Nigeria. Ambi-Agua, Taubaté, v. 7, n. 1, p. 67-80, 2012. (http://dx.doi.org/10.4136/ambi-agua.851)

2004). Therefore, groundwater is not entirely pure water because it usually contains dissolved mineral ions (Okagbue, 1988). The type and concentration of these dissolved minerals can affect the usefulness of groundwater for different purposes (Boyle, 1988). If certain mineral constituent are present in excessive amounts, some type of treatment may be necessary to either change or remove the dissolved mineral before the water can be used for the intended purpose. The major cations found in groundwater include calcium $\left(\mathrm{Ca}^{2+}\right)$, magnesium $\left(\mathrm{Mg}^{2+}\right)$, sodium $\left(\mathrm{Na}^{+}\right)$, potassium $\left(\mathrm{K}^{+}\right)$and anions such as bicarbonate $\left(\mathrm{HCO}_{3}{ }^{-}\right)$, sulphates $\left(\mathrm{SO}_{4}{ }^{2-}\right)$, chloride $\left(\mathrm{Cl}^{-}\right)$with non-ionic constituents like oxides, phenols, synthetic detergents, dissolved gases e.g. oxygen $\left(\mathrm{O}_{2}\right)$ and carbon dioxide $\left(\mathrm{CO}_{2}\right)$ (Tijani, 1994). These constituents result in the good quality of groundwater when they are present in optimum concentrations.

A sudden geometric increase in the population of Akoko North West Local Government of Ondo State, Nigeria which has reached 213,792 (UN, 2006) has led to an increase in the demand for water and harnessing of subsurface water reserve. This paper investigates the possible infiltration of dissolved mineral (either from weathered rock or anthropogenic sources) into subsurface water in the area (basement complex rocks), and comparing the mineral level with the set standard for quality water by the World Health Organization (WHO). The main objectives of this study are: to determine the suitability of the water in the study area for human consumption from WHO established standard, and to determine the level as well as source of contaminants where applicable. Physical tests and chemical tests for several parameters were also carried out using specific set of scientific experimental standard (Omotoyinbo and Okafor, 2008).

\subsection{The Study Area}

The study area (Akoko North West) is one of the eighteen Local Governments that made up Ondo State in the South-Western Region of Nigeria. It falls within latitudes $7^{\circ} 30^{\prime}$ and $7^{\circ} 35^{\prime} \mathrm{N}$ and longitudes $5^{\circ} 43^{\prime}$ and $5^{\circ} 49^{\prime} \mathrm{E}$. The area is accessible by roads and footpaths and it occupies about $0.83 \mathrm{~km}^{2}$ in aerial extent (Figure 1). Topographically, the area is characterised by a relatively rugged, undulating, topography with outcrops of charnockites, migmatite gneiss with other gneissic rocks as highlands which range between 600 and 1500 feet above sea level. It is situated within the Precambrian Basement Complex with the outcrops which are predominantly gneiss and migmatite (Figure 2). With this type of rock types, their ability to serve as aquifers compared to sedimentary aquifers is very minimal with limited small amount of groundwater storage within the crystalline basement. The failure rate of the new boreholes in the study area is as high as $80 \%$ (Edet et al., 1998), which is as a result of the geological configurations of the study area. The groundwater availability is, however, limited to fracture zones and areas of deep weathering. The topography of Ikare (the capital of the Local Government) is high with undulating relief of about $200 \mathrm{~m}$ to more than $1500 \mathrm{~m}$ high. There are knolls, ridges and flat lying exposures observed in the area. The western part is characterized by a conical hill relief - outcrops of batholiths is scattered in the southern part of the area towards Ikare and Okeagbe. Eastward, the area is featured by lowland outcrops and sparsely characterized with gneissic ridges. The major road runs from southwest to northwest.

The climate can be said to be subequatorial with two peaks of rainfall. The first peak comes up between April and July while the second peak comes up between late August and late October. These two peaks are marked by heavy rainfall and the mean annual rainfall is $1500-2000 \mathrm{~mm}$ with a relative humidity of about $75-95 \%$. Since the climate is sub equatorial, temperature could sometimes be severe. The mean annual temperature is $23-26^{\circ} \mathrm{C}$ (Duze and Ojo, 1982). 
OYEDOTUN, T. D. T.; OBATOYINBO, O. Hydro-geochemical evaluation of groundwater quality in Akoko North West local government area of Ondo State, Nigeria. Ambi-Agua, Taubaté, v. 7, n. 1, p. 67-80, 2012. (http://dx.doi.org/10.4136/ambi-agua.851)

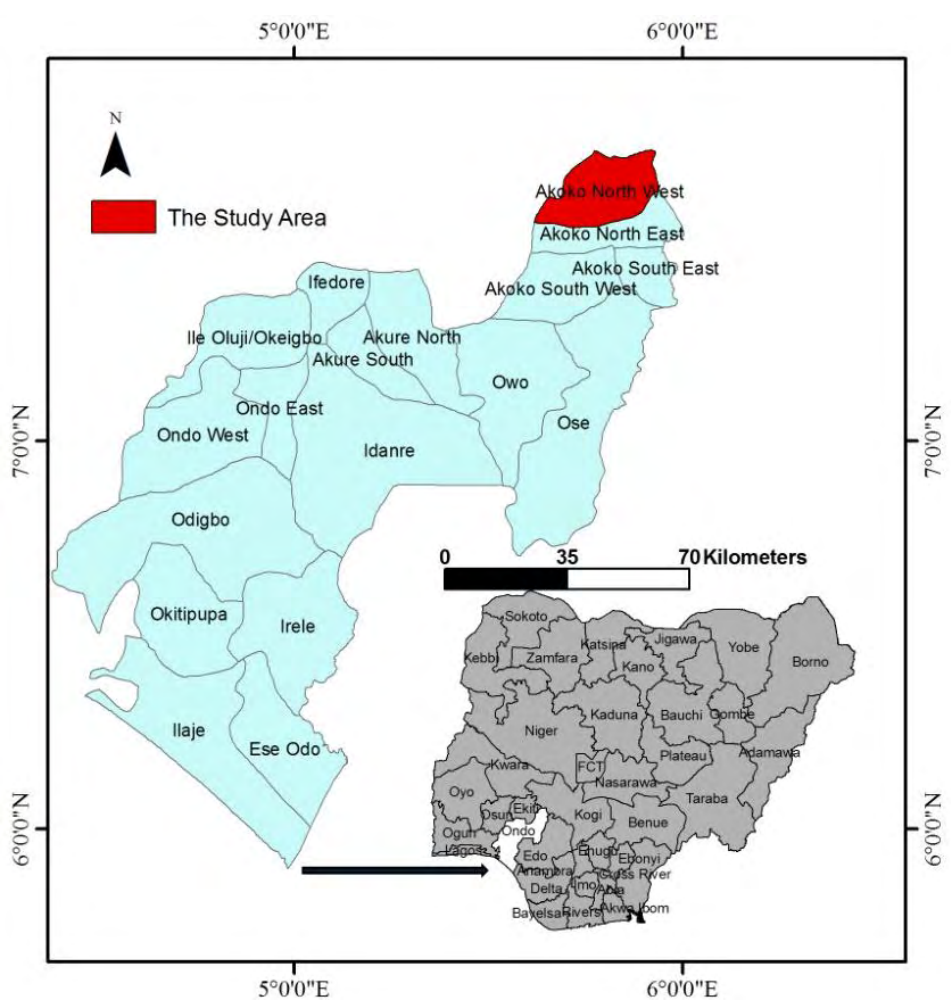

Figure 1. Map of Ondo State Showing the study area. Inset: Map of Nigeria showing Ondo State.

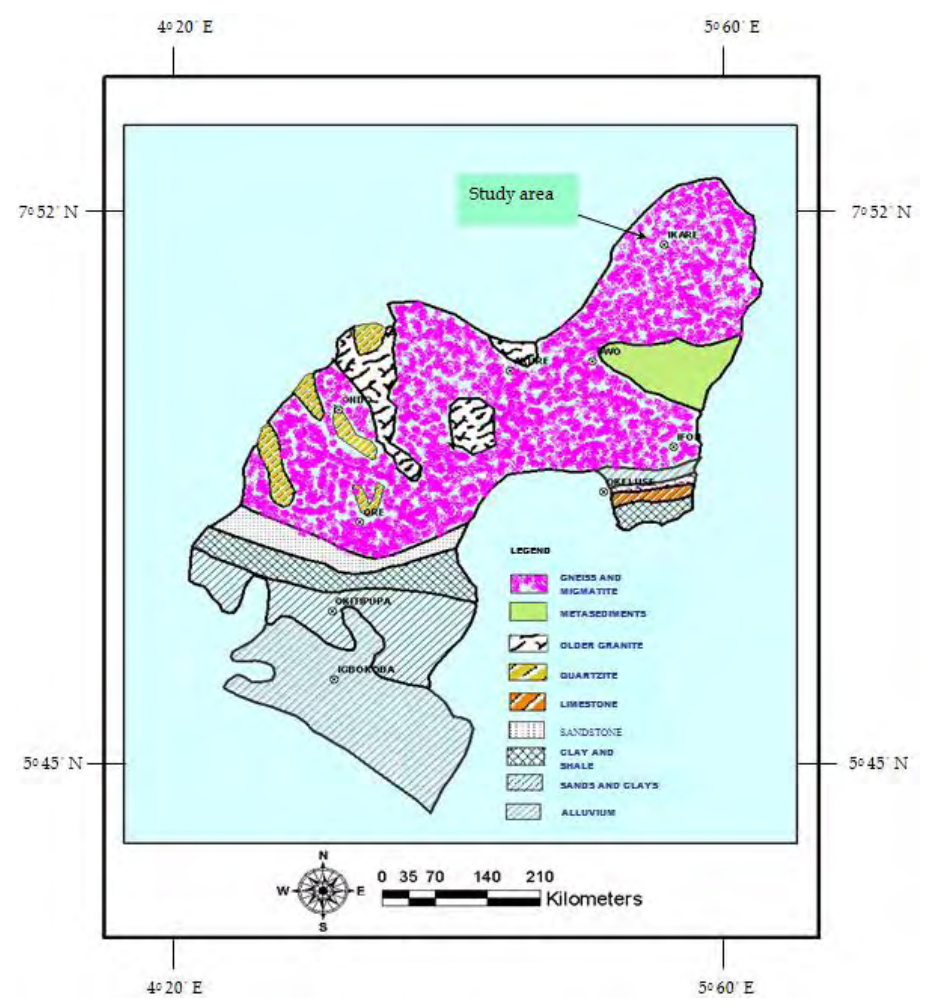

Figure 2. Geologic Map of Ondo State showing Geology and the location of the study area.

Source: Geological Survey Nigeria, Ondo State.

The area under study is situated in the deciduous rain forest area within south-western Nigeria. It has evergreen vegetation and urban settlement. The vegetation of this area reflects 
OYEDOTUN, T. D. T.; OBATOYINBO, O. Hydro-geochemical evaluation of groundwater quality in Akoko North West local government area of Ondo State, Nigeria. Ambi-Agua, Taubaté, v. 7, n. 1, p. 67-80, 2012. (http://dx.doi.org/10.4136/ambi-agua.851)

the rainforest and Guinea Savannah's vegetation, which is characterized by different plants and trees which may reach a height of $5 \mathrm{~m}$ and even more. They consist of light forests, shrubs and scattered cultivation.

There are areas where rocks are covered by vegetation which is also an indication of the porosity of the rocks and function of the grain size. Trees and plants like timber, oil palm, kolanut, rubber, cocoa and citrus are very prominent in these areas. A high forest zone is found in the north while the southern part is mostly Sub-Savannah due to the farming activities in the area, which had actually reduced the thickly vegetated area.

\section{MATERIAL AND METHODS}

Groundwater samples were collected from the hand-held boreholes, Solar powered boreholes and hand-dug wells at various locations and different depths in the study area. The details of the sampling site and depths are given in Table 1 below. The samples were then taken to the International Institute for Tropical Agriculture (IITA), Ibadan, Oyo State of Nigeria for the analysis of all the parameters (physico-chemical parameters, cations, anions and the heavy metals), after which relevant statistical packages were also used to analyse the data and their level of significance was determined.

Table 1. Summary of the derivations from the GPS readings from sample collection and other readings.

\begin{tabular}{|c|c|c|c|c|c|c|c|c|}
\hline $\mathbf{S} / \mathbf{n}$ & $\begin{array}{l}\text { Sample } \\
\text { number (from } \\
\text { selected } \\
\text { locations) }\end{array}$ & Date & Time & $\begin{array}{c}\text { Water } \\
\text { Source }\end{array}$ & $\begin{array}{c}\text { Depth } \\
\text { (m) }\end{array}$ & $\begin{array}{c}\text { Elevation } \\
\text { (m) }\end{array}$ & Longitude & Latitude \\
\hline 1 & $\mathrm{I}_{1}$ & $20-02-10$ & $12: 58$ & HDW & 6.1 & 393 & $05^{\circ} 46^{\prime} 15^{\prime \prime} \mathrm{E}$ & $07^{\circ} 32^{\prime} 37^{\prime \prime} \mathrm{N}$ \\
\hline 2 & $\mathrm{I}_{2}$ & $20-02-10$ & $1: 31$ & HDW & 6.1 & 392 & $05^{\circ} 46^{\prime} 07^{\prime \prime} \mathrm{E}$ & $07^{\circ} 32^{\prime} 12^{\prime \prime} \mathrm{N}$ \\
\hline 3 & $\mathrm{I}_{3}$ & $20-02-10$ & $1: 49$ & HDW & 5.5 & 396 & $05^{\circ} 45^{\prime} 52^{\prime \prime} \mathrm{E}$ & $07^{\circ} 32^{\prime} 03^{\prime \prime} \mathrm{N}$ \\
\hline 4 & $\mathrm{I}_{4}$ & $20-02-10$ & 2:01 & HDW & 6.1 & 405 & $05^{\circ} 45^{\prime} 45^{\prime \prime} \mathrm{E}$ & $07^{\circ} 32^{\prime} 00^{\prime \prime} \mathrm{N}$ \\
\hline 5 & $\mathrm{I}_{6}$ & $20-02-10$ & $2: 45$ & HHBH & ND & 409 & $05^{\circ} 45^{\prime} 37^{\prime \prime} \mathrm{E}$ & $07^{\circ} 31^{\prime} 59^{\prime \prime} \mathrm{N}$ \\
\hline 6 & $\mathrm{I}_{7}$ & $20-02-10$ & $3: 18$ & SBH & ND & 421 & $05^{\circ} 45^{\prime} 34^{\prime \prime} \mathrm{E}$ & $07^{\circ} 31^{\prime} 44^{\prime \prime} \mathrm{N}$ \\
\hline 7 & $\mathrm{I}_{8}$ & $20-02-10$ & $3: 36$ & HHBH & ND & 405 & $05^{\circ} 46^{\prime} 12^{\prime \prime} \mathrm{E}$ & $07^{\circ} 31^{\prime} 30^{\prime \prime} \mathrm{N}$ \\
\hline 8 & $\mathrm{I}_{9}$ & $20-02-10$ & $3: 46$ & HHBH & ND & 417 & $05^{\circ} 45^{\prime} 33^{\prime \prime} \mathrm{E}$ & $07^{\circ} 31^{\prime} 29^{\prime \prime} \mathrm{N}$ \\
\hline 9 & $\mathrm{I}_{10}$ & $20-02-10$ & 4:03 & HHBW & ND & 450 & $05^{\circ} 45^{\prime} 22^{\prime \prime} \mathrm{E}$ & $07^{\circ} 31^{\prime} 21^{\prime \prime} \mathrm{N}$ \\
\hline 10 & $\mathrm{I}_{11}$ & $20-02-10$ & $4: 48$ & HDW & ND & 452 & $05^{\circ} 44^{\prime} 57^{\prime \prime} \mathrm{E}$ & $07^{\circ} 31^{\prime} 18^{\prime \prime} \mathrm{N}$ \\
\hline 11 & $\mathrm{I}_{13}$ & $20-02-10$ & $5: 28$ & HHBH & ND & 462 & $05^{\circ} 44^{\prime} 51^{\prime \prime} \mathrm{E}$ & $07^{\circ} 30^{\prime} 00^{\prime \prime} \mathrm{N}$ \\
\hline 12 & $\mathrm{~A}_{1}$ & $19-02-10$ & $12: 15$ & HDW & 6.7 & 363 & $05^{\circ} 46^{\prime} 43^{\prime \prime} \mathrm{E}$ & $07^{\circ} 33^{\prime} 04^{\prime \prime} \mathrm{N}$ \\
\hline 13 & $\mathrm{~A}_{3}$ & $20-02-10$ & $11: 29$ & HDW & 6.1 & 410 & $05^{\circ} 46^{\prime} 50^{\prime \prime} \mathrm{E}$ & $07^{\circ} 33^{\prime} 12^{\prime \prime} \mathrm{N}$ \\
\hline 14 & $\mathrm{~A}_{4}$ & $19-02-10$ & $12: 46$ & HDW & 9.2 & 407 & $05^{\circ} 46^{\prime} 48^{\prime \prime} \mathrm{E}$ & $07^{\circ} 33^{\prime} 10^{\prime \prime} \mathrm{N}$ \\
\hline 15 & $\mathrm{~A}_{6}$ & $19-02-10$ & $1: 12$ & HDW & 6.1 & 403 & $05^{\circ} 46^{\prime} 42^{\prime \prime} \mathrm{E}$ & $07^{\circ} 33^{\prime} 07^{\prime \prime} \mathrm{N}$ \\
\hline 16 & $\mathrm{~A}_{7}$ & $19-02-10$ & $1: 36$ & HDW & 5.5 & 402 & $05^{\circ} 46^{\prime} 28^{\prime \prime} \mathrm{E}$ & $07^{\circ} 33^{\prime} 08^{\prime \prime} \mathrm{N}$ \\
\hline 17 & $\mathrm{~A}_{9}$ & $19-02-10$ & $1: 54$ & HDW & 7.3 & 393 & $05^{\circ} 46^{\prime} 17^{\prime \prime} \mathrm{E}$ & $07^{\circ} 33^{\prime} 11^{\prime \prime} \mathrm{N}$ \\
\hline 18 & $\mathrm{~A}_{10}$ & $19-02-10$ & $2: 55$ & HHBH & ND & 403 & $05^{\circ} 45^{\prime} 46^{\prime \prime} \mathrm{E}$ & $07^{\circ} 33^{\prime} 48^{\prime \prime} \mathrm{N}$ \\
\hline 19 & $\mathrm{~A}_{11}$ & $19-02-10$ & $3: 21$ & HDW & 9.8 & 404 & $05^{\circ} 46^{\prime} 01^{\prime \prime} \mathrm{E}$ & $07^{\circ} 33^{\prime} 38^{\prime \prime} \mathrm{N}$ \\
\hline 20 & $\mathrm{~A}_{13}$ & $19-02-10$ & $4: 03$ & HDW & 6.7 & 397 & $05^{\circ} 46^{\prime} 06^{\prime \prime} \mathrm{E}$ & $07^{\circ} 33^{\prime} 12^{\prime \prime} \mathrm{N}$ \\
\hline 21 & $\mathrm{~A}_{14}$ & $19-02-10$ & $4: 25$ & HDW & 7.3 & 396 & $05^{\circ} 46^{\prime} 06^{\prime \prime} \mathrm{E}$ & $07^{\circ} 32^{\prime} 52^{\prime \prime} \mathrm{N}$ \\
\hline 22 & $\mathrm{~A}_{15}$ & $19-02-10$ & $4: 44$ & HDW & 7.3 & 389 & $05^{\circ} 46^{\prime} 12^{\prime \prime} \mathrm{E}$ & $07^{\circ} 32^{\prime} 46^{\prime \prime} \mathrm{N}$ \\
\hline 23 & $\mathrm{M}_{2}$ & $20-02-10$ & $11: 03$ & HDW & 6.7 & 410 & $05^{\circ} 46^{\prime} 35^{\prime \prime} \mathrm{E}$ & $07^{\circ} 32^{\prime} 57^{\prime \prime} \mathrm{N}$ \\
\hline 24 & $\mathrm{M}_{3}$ & $20-02-10$ & $11: 13$ & HDW & 7.9 & 410 & $05^{\circ} 46^{\prime} 37^{\prime \prime} \mathrm{E}$ & $07^{\circ} 33^{\prime} 02^{\prime \prime} \mathrm{N}$ \\
\hline 25 & $\mathrm{M}_{4}$ & $20-02-10$ & $12: 03$ & HDW & 9.7 & 408 & $05^{\circ} 46^{\prime} 27^{\prime \prime} \mathrm{E}$ & $07^{\circ} 32^{\prime} 48^{\prime \prime} \mathrm{N}$ \\
\hline 26 & $\mathrm{M}_{6}$ & $20-02-10$ & $12: 18$ & HDW & 7.3 & 405 & $05^{\circ} 46^{\prime} 30^{\prime \prime} \mathrm{E}$ & $07^{\circ} 32^{\prime} 41^{\prime \prime} \mathrm{N}$ \\
\hline
\end{tabular}

Note: $\mathrm{I}=$ Ikare; $\mathrm{A}=$ Arigidi; $\mathrm{M}=$ Ministry Area; $\mathrm{HHBH}=$ Hand - held Borehole; $\mathrm{SBH}=$ Solar Borehole; HDW $=$ Hand - dug well; $\mathrm{ND}=$ No Data. 
OYEDOTUN, T. D. T.; OBATOYINBO, O. Hydro-geochemical evaluation of groundwater quality in Akoko North West local government area of Ondo State, Nigeria. Ambi-Agua, Taubaté, v. 7, n. 1, p. 67-80, 2012. (http://dx.doi.org/10.4136/ambi-agua.851)

Magellan SporTrak® handheld Global Positioning System (GPS) Receivers device with 12-channel tracking and differential correction capability was used to determine and identify location where the water samples are selected, especially with the aid of a topographical map covering the study area. The SporTrak Map GPS used can track up to 12 satellites at any time out of the current constellation, and it fully supports the Wide Area Augmentation System (WAAS) with the accuracy within 3 metres or better depending on the line of sight to the satellite. Tape rule and sample bottles are other materials made use of in the field.

Twenty six water samples were collected from various locations in the Local Government Area on the 19th and 20th of February 2010 and the samples were used for the assessment of water quality which comprise nineteen hand dug wells and seven boreholes (examples of which are shown in Figure 3 below). These constitute the major sources of water for the inhabitants. About 20 millilitres of water samples were collected from both the hand dug wells and boreholes into clean plastic containers. The samples were then labelled and preserved (in the refrigerator) until they were taken to the laboratory for chemical analysis. The water samples were analyzed for electrical conductivity (EC), $\mathrm{pH}$, total alkalinity (TA), total dissolved solids (TDS), total suspended solids (TSS), acid neutralizing capacity (ANC) with major cations $\left(\mathrm{Na}^{+}, \mathrm{Mg}^{2+}, \mathrm{Ca}^{2+}\right)$, anions $\left(\mathrm{PO}_{4}{ }^{3-}, \mathrm{HCO}_{3}{ }^{-}, \mathrm{SO}_{4}{ }^{3-}\right)$ and several heavy metals $\left(\mathrm{Zn}^{2+}, \mathrm{Fe}^{2+}, \mathrm{As}^{+}, \mathrm{Ni}^{+}, \mathrm{Pb}^{2+}, \mathrm{Cd}^{+}, \mathrm{Cu}^{2+}\right)$ using the Buck Model 205 Atomic Absorption Spectrophotometer and flame photometer for the cations.

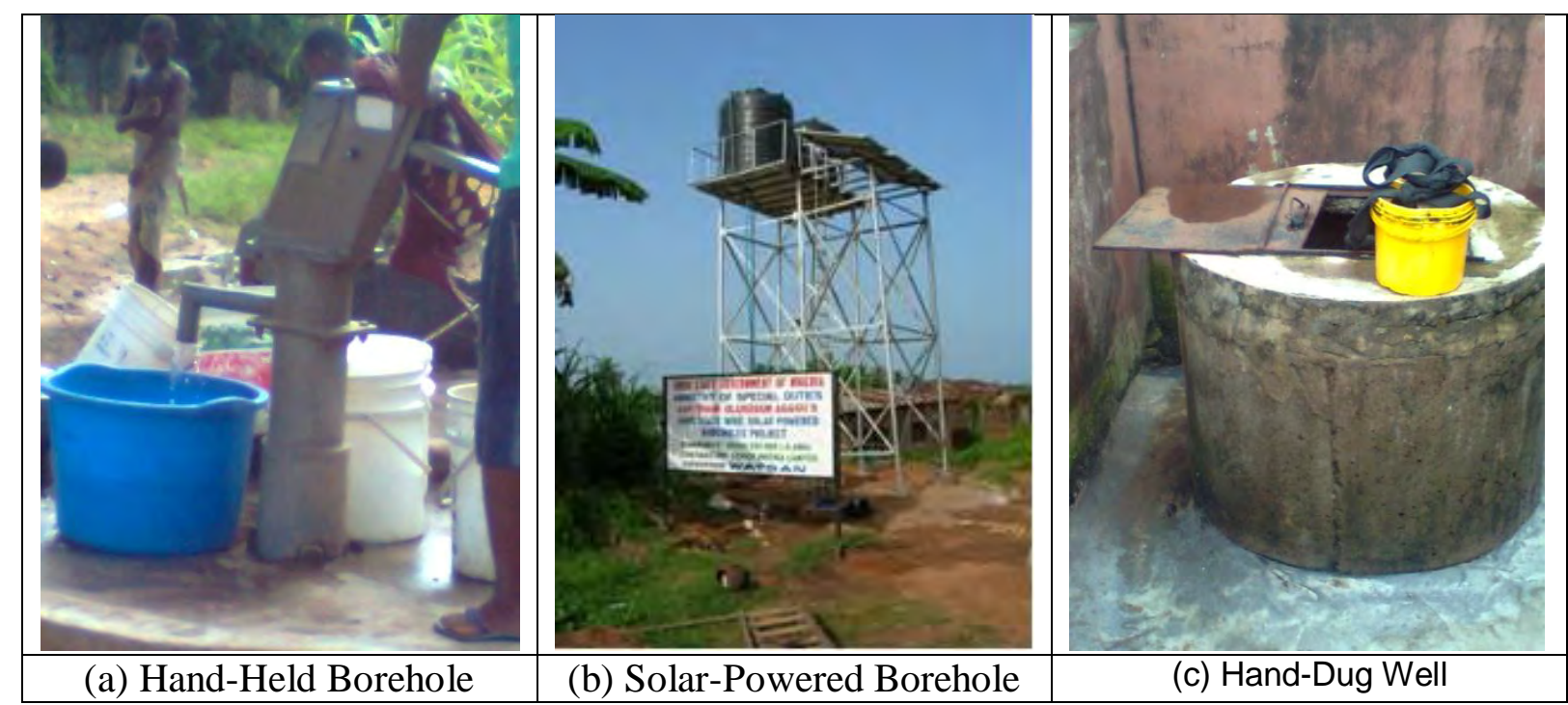

Figure 3. Example of (a) Hand Held Borehole, (b) Solar Powered Borehole and (c) Hand-dug well in the study area.

The chemical character of any water determines its quality and utilization. The quality is a function of the physical, chemical and biological parameters and could be subjective since it depends on a particular intended use (Tijani, 1994). Hence, there are different water quality standards and are generally based on two main criteria. These include the presence of objectionable taste, odour and colour plus the availability of substances with adverse physiological health effects (Tijani, 1994).

The quality of water, whether it is used for drinking, irrigation or recreational purposes is significant for health in both developing and developed countries worldwide. Water quality can have a major impact on health, either through outbreaks of waterborne diseases or by contributing to the background rates of the diseases. Accordingly, countries develop water quality standards to protect public health (Ramanathan, 2004).

The WHO has developed a series of normative guidelines for assessment of health risk and hazards through water. These principal guidelines are intended to assist countries in 
OYEDOTUN, T. D. T.; OBATOYINBO, O. Hydro-geochemical evaluation of groundwater quality in Akoko North West local government area of Ondo State, Nigeria. Ambi-Agua, Taubaté, v. 7, n. 1, p. 67-80, 2012. (http://dx.doi.org/10.4136/ambi-agua.851)

establishing effective national or regional strategies and standards. The physical parameters such as $\mathrm{pH}, \mathrm{EC}$, TDS etc and chemical parameters such as $\mathrm{Ca}^{2+}, \mathrm{Mg}^{2+}, \mathrm{Na}^{+}, \mathrm{Fe}^{2+}, \mathrm{Cl}^{-}, \mathrm{SO}_{4}{ }^{2-}$ with other heavy metal concentrations should be within the WHO acceptable standards. Therefore, the findings from the analyses are compared with WHO set standard to evaluate the groundwater quality in the local government (the study area). The World Health Organization (WHO, 1984) recommended a standard for drinking water quality. Table 2 below gives the example of these recommendations.

Table 2. Summary of Physical and Chemical Characteristics and WHO (1984) standards for drinking water.

\begin{tabular}{|c|c|c|c|c|c|c|}
\hline $\begin{array}{l}\text { Measured } \\
\text { Parameter }\end{array}$ & Range & GW* & $\mathbf{S W}^{*}$ & $\begin{array}{c}\text { Overall } \\
\text { mean }\end{array}$ & $\begin{array}{c}\text { Acceptable } \\
\text { Level }\end{array}$ & $\begin{array}{c}\text { Maximum } \\
\text { Permissible } \\
\text { Level }\end{array}$ \\
\hline Temperature $\left({ }^{\circ} \mathrm{C}\right)$ & $24.20-28.20$ & 27.17 & 24.96 & 26.37 & & \\
\hline $\mathrm{pH}$ (pH Unit) & $7.10-9.10$ & 7.91 & 7.70 & 7.83 & 6.6 & 8.5 \\
\hline $\mathrm{EC}(\mathrm{ms} / \mathrm{cm})$ & $6.00-12.72$ & 437.59 & 106.00 & 318.22 & - & 1400.00 \\
\hline $\mathrm{TH}\left(\mathrm{mgL}^{-1}\right)$ & $1.21-65.36$ & 16.14 & 3.84 & 11.71 & - & \\
\hline $\mathrm{TDS}\left(\mathrm{mgL}^{-1}\right)$ & $10.32-763.20$ & 250.98 & 46.50 & 177.40 & & 1000.00 \\
\hline $\operatorname{SAR}\left(\mathrm{mgL}^{-1}\right)$ & $0.15-3.89$ & 0.56 & 0.99 & 0.77 & & \\
\hline $\mathrm{Ca}^{2+}\left(\mathrm{mgL}^{-1}\right)$ & $1.00-130$ & 45.75 & 4.39 & 30.86 & & 200.00 \\
\hline $\mathrm{Mg}^{2+}\left(\mathrm{mgL}^{-1}\right)$ & $1.10-9.72$ & 4.58 & 3.97 & 4.36 & & \\
\hline $\mathrm{Na}^{+}\left(\mathrm{mgL}^{-1}\right)$ & $1.40-28.00$ & 11.61 & 7.46 & 10.11 & & 200.00 \\
\hline $\mathrm{K}^{+}\left(\mathrm{mgL}^{-1}\right)$ & $2.0-65.0$ & 19.08 & 7.17 & 14.79 & & \\
\hline $\mathrm{Fe}^{2+}\left(\mathrm{mgL}^{-1}\right)$ & $0.05-0.60$ & 0.19 & 0.14 & 0.17 & 0.3 & 1.00 \\
\hline $\mathrm{HCO}_{3}^{-}\left(\mathrm{mgL}^{-1}\right)$ & $3.05-97.6$ & 31.71 & 25.82 & 29.59 & & \\
\hline $\mathrm{Cl}^{-}\left(\mathrm{mgL}^{-1}\right)$ & $2.84-60.35$ & 29.91 & 18.13 & 26.67 & & 250.00 \\
\hline $\mathrm{SO}_{4}^{2-}\left(\mathrm{mgL}^{-1}\right)$ & $0.01-5.93$ & 1.40 & 1.64 & 1.49 & 200.00 & 400.00 \\
\hline $\mathrm{PO}_{4}{ }^{3-}\left(\mathrm{mgL}^{-1}\right)$ & $0.01-0.03$ & 0.01 & 0.01 & 0.01 & & \\
\hline $\mathrm{NO}_{3}^{-}\left(\mathrm{mgL}^{-1}\right)$ & $1.00-7.46$ & 3.81 & 6.39 & 4.74 & & 10.00 \\
\hline
\end{tabular}

$\mathrm{GW}^{*}=$ Groundwater; EC = Electrical Conductivity; TH = Total Hardness; SAR = Sodium Absorption Ratio; $\mathrm{SW}^{*}=$ Surface water (mean concentration) for each group; TDS = Total Dissolved Solid.

Source: World Health Organization $(1984,1997)$

\section{RESULTS}

The analysis of the findings, which is centred on laboratory test of the water samples collected from both (mechanical and solar powered) boreholes and hand-dug wells and are termed to be ideal for human consumption, are compared with the WHO standards for drinking waters.

The analysis is presented by plotting the concentration of the analytical values of each element and the WHO standard in $\mathrm{mgL}^{-1}(\mathrm{ppm})$ with the twenty - six sample locations so as to have an overview of the concentration of each element and its probable effect on the quality of the water. The results of the analysis are presented in Tables $3-4$. The derived results from the analysis are then plotted in comparison with the WHO stand values, the bar chart of which are presented in Figures 4 - 6. The elements analyzed are $\mathrm{Ca}, \mathrm{Mg}, \mathrm{Na}, \mathrm{As}, \mathrm{Fe}$, $\mathrm{Zn}, \mathrm{Cu}, \mathrm{Cd}, \mathrm{Pb}$ and $\mathrm{Ni}$. 
OYEDOTUN, T. D. T.; OBATOYINBO, O. Hydro-geochemical evaluation of groundwater quality in Akoko North West local government area of Ondo State, Nigeria. Ambi-Agua, Taubaté, v. 7, n. 1, p. 67-80, 2012. (http://dx.doi.org/10.4136/ambi-agua.851)

Table 3. The concentrations of Anion, Cation and heavy metal from the water samples at the study area.

\begin{tabular}{|c|c|c|c|c|c|c|c|c|c|c|c|c|c|}
\hline \multirow{2}{*}{$\begin{array}{c}\text { Sample } \\
\text { Particulars }\end{array}$} & \multicolumn{13}{|c|}{$\mathrm{mgL}^{-1}$} \\
\hline & $\mathrm{Ca}^{2+}$ & $\mathrm{Ni}^{+}$ & $\mathrm{Fe}^{2+}$ & $\mathrm{Cu}^{2+}$ & $\mathrm{Zn}^{2+}$ & $\mathbf{C d}^{+}$ & $\mathbf{A s}^{+}$ & $\mathbf{P b}^{2+}$ & $\mathrm{Mg}^{2+}$ & $\mathrm{Na}^{+}$ & $\mathrm{HCO}_{3}{ }^{-}$ & $\mathrm{SO}_{4}{ }^{2-}$ & $\mathrm{PO}_{4}{ }^{2-}$ \\
\hline $\mathrm{I}_{1}$ & 11.117 & 0.071 & 0.521 & 0.106 & 0.169 & 0.006 & 0.002 & 0.008 & 5.011 & 21.081 & 0.018 & 0.026 & 0.041 \\
\hline $\mathrm{I}_{2}$ & 9.856 & 0.056 & 0.561 & 0.136 & 0.248 & 0.005 & 0.001 & 0.009 & 4.220 & 19.322 & 0.015 & 0.029 & 0.039 \\
\hline $\mathrm{I}_{3}$ & 11.327 & 0.066 & 0.521 & 0.098 & 0.165 & 0.007 & 0.003 & 0.008 & 5.026 & 20.056 & 0.019 & 0.031 & 0.044 \\
\hline $\mathrm{I}_{4}$ & 12.170 & 0.053 & 0.513 & 0.241 & 0.388 & 0.007 & 0.002 & 0.007 & 5.716 & 18.716 & 0.021 & 0.026 & 0.042 \\
\hline $\mathrm{I}_{6}$ & 9.986 & 0.066 & 0.608 & 0.161 & 0.297 & 0.005 & 0.002 & 0.009 & 4.218 & 21.732 & 0.017 & 0.029 & 0.037 \\
\hline $\mathrm{I}_{7}$ & 10.771 & 0.059 & 0.613 & 0.217 & 0.402 & 0.005 & 0.003 & 0.007 & 4.761 & 20.156 & 0.019 & 0.018 & 0.039 \\
\hline $\mathrm{I}_{8}$ & 10.350 & 0.049 & 0.512 & 0.206 & 0.351 & 0.004 & 0.002 & 0.010 & 4.113 & 21.520 & 0.013 & 0.029 & 0.041 \\
\hline $\mathrm{I}_{9}$ & 9.988 & 0.056 & 0.518 & 0.116 & 0.306 & 0.006 & 0.002 & 0.008 & 4.216 & 19.116 & 0.015 & 0.031 & 0.042 \\
\hline $\mathrm{I}_{10}$ & 11.731 & 0.058 & 0.498 & 0.224 & 0.437 & 0.006 & 0.003 & 0.009 & 5.005 & 21.681 & 0.013 & 0.026 & 0.043 \\
\hline $\mathrm{I}_{11}$ & 10.156 & 0.058 & 0.601 & 0.185 & 0.372 & 0.004 & 0.002 & 0.010 & 4.371 & 17.115 & 0.014 & 0.036 & 0.041 \\
\hline $\mathrm{I}_{13}$ & 12.001 & 0.061 & 0.533 & 0.177 & 0.298 & 0.005 & 0.002 & 0.008 & 5.296 & 19.781 & 0.016 & 0.028 & 0.083 \\
\hline $\mathrm{A}_{1}$ & 8.176 & 0.036 & 0.351 & 0.111 & 0.167 & 0.002 & 0.001 & 0.005 & 3.005 & 14.216 & 0.011 & 0.017 & 0.019 \\
\hline $\mathrm{A}_{3}$ & 8.151 & 0.041 & 0.314 & 0.132 & 0.121 & 0.002 & 0.001 & 0.004 & 3.256 & 16.081 & 0.010 & 0.014 & 0.021 \\
\hline $\mathrm{A}_{4}$ & 9.086 & 0.039 & 0.298 & 0.091 & 0.136 & 0.003 & 0.002 & 0.005 & 1.986 & 13.713 & 0.012 & 0.021 & 0.024 \\
\hline $\mathrm{A}_{6}$ & 10.722 & 0.044 & 0.341 & 0.106 & 0.203 & 0.002 & 0.001 & 0.005 & 2.013 & 12.118 & 0.010 & 0.015 & 0.018 \\
\hline $\mathrm{A}_{7}$ & 9.165 & 0.043 & 0.288 & 0.116 & 0.213 & 0.003 & 0.001 & 0.005 & 1.965 & 11.811 & 0.009 & 0.017 & 0.022 \\
\hline $\mathrm{A}_{9}$ & 8.986 & 0.039 & 0.216 & 0.092 & 0.167 & 0.004 & 0.002 & 0.004 & 2.850 & 13.381 & 0.013 & 0.014 & 0.021 \\
\hline $\mathrm{A}_{10}$ & 8.932 & 0.041 & 0.306 & 0.086 & 0.143 & 0.003 & 0.002 & 0.006 & 2.117 & 12.156 & 0.012 & 0.021 & 0.019 \\
\hline $\mathrm{A}_{11}$ & 9.006 & 0.036 & 0.281 & 0.095 & 0.147 & 0.004 & 0.002 & 0.003 & 2.658 & 13.118 & 0.012 & 0.020 & 0.022 \\
\hline $\mathrm{A}_{13}$ & 9.156 & 0.039 & 0.269 & 0.089 & 0.132 & 0.003 & 0.001 & 0.004 & 2.134 & 14.218 & 0.013 & 0.017 & 0.020 \\
\hline $\mathrm{A}_{14}$ & 8.111 & 0.042 & 0.325 & 0.106 & 0.211 & 0.003 & 0.002 & 0.005 & 3.216 & 12.116 & 0.011 & 0.015 & 0.018 \\
\hline $\mathrm{A}_{15}$ & 8.635 & 0.046 & 0.341 & 0.093 & 0.123 & 0.004 & 0.002 & 0.004 & 3.186 & 13.148 & 0.012 & 0.019 & 0.020 \\
\hline $\mathrm{M}_{2}$ & 12.167 & 0.041 & 0.726 & 0.113 & 0.109 & 0.007 & 0.003 & 0.009 & 7.114 & 26.081 & 0.017 & 0.031 & 0.053 \\
\hline $\mathrm{M}_{3}$ & 13.151 & 0.069 & 0.691 & 0.094 & 0.120 & 0.008 & 0.003 & 0.009 & 7.215 & 24.115 & 0.015 & 0.029 & 0.049 \\
\hline $\mathrm{M}_{4}$ & 11.328 & 0.074 & 0.688 & 0.121 & 0.307 & 0.007 & 0.002 & 0.008 & 6.932 & 25.168 & 0.019 & 0.033 & 0.048 \\
\hline $\mathrm{M}_{6}$ & 14.715 & 0.073 & 0.701 & 0.091 & 0.140 & 0.008 & 0.003 & 0.010 & 7.910 & 27.108 & 0.017 & 0.034 & 0.151 \\
\hline
\end{tabular}

Table 4. The concentrations of physical parameters from the water samples at the study area TDS $\left(\mathrm{mgL}^{-1}\right)$; TSS $\left(\mathrm{mgL}^{-1}\right)$.

\begin{tabular}{|c|c|c|c|c|c|c|}
\hline $\begin{array}{c}\text { Sample } \\
\text { Particulars } \\
\end{array}$ & $\mathbf{p H}$ & TA & ANC & $\mathrm{EC}(\boldsymbol{\mu S} / \mathbf{c m})$ & TDS $\left(\mathrm{mgL}^{-1}\right)$ & $\operatorname{TSS}\left(\mathrm{mgL}^{-1}\right)$ \\
\hline $\mathrm{I}_{1}$ & 6.3 & 0.011 & 0.121 & 29.33 & 12.411 & 6.74 \\
\hline $\mathrm{I}_{2}$ & 6.1 & 0.009 & 0.133 & 31.18 & 13.086 & 7.02 \\
\hline $\mathrm{I}_{3}$ & 5.9 & 0.010 & 0.107 & 26.72 & 11.917 & 5.99 \\
\hline $\mathrm{I}_{4}$ & 6.5 & 0.011 & 0.206 & 29.75 & 14.086 & 6.36 \\
\hline $\mathrm{I}_{6}$ & 5.8 & 0.117 & 0.126 & 32.68 & 15.137 & 6.41 \\
\hline $\mathrm{I}_{7}$ & 5.7 & 0.092 & 0.096 & 31.77 & 12.929 & 7.22 \\
\hline $\mathrm{I}_{8}$ & 6.1 & 0.106 & 0.086 & 29.84 & 13.756 & 7.14 \\
\hline $\mathrm{I}_{9}$ & 5.7 & 0.006 & 0.132 & 27.56 & 15.225 & 5.89 \\
\hline $\mathrm{I}_{10}$ & 6.5 & 0.011 & 0.141 & 29.72 & 17.986 & 7.02 \\
\hline $\mathrm{I}_{11}$ & 6.8 & 0.009 & 0.126 & 32.08 & 14.756 & 6.41 \\
\hline $\mathrm{I}_{13}$ & 5.6 & 0.006 & 0.134 & 31.11 & 15.090 & 5.88 \\
\hline $\mathrm{A}_{1}$ & 4.7 & 0.011 & 0.109 & 21.15 & 9.750 & 4.71 \\
\hline $\mathrm{A}_{3}$ & 5.0 & 0.008 & 0.113 & 19.85 & 10.332 & 5.05 \\
\hline $\mathrm{A}_{4}$ & 4.7 & 0.009 & 0.121 & 23.66 & 9.851 & 4.93 \\
\hline $\mathrm{A}_{6}$ & 4.9 & 0.010 & 0.097 & 20.11 & 11.033 & 4.67 \\
\hline $\mathrm{A}_{7}$ & 5.3 & 0.007 & 0.113 & 21.56 & 9.748 & 5.13 \\
\hline $\mathrm{A}_{9}$ & 6.0 & 0.010 & 0.086 & 23.35 & 8.996 & 5.04 \\
\hline $\mathrm{A}_{10}$ & 5.9 & 0.009 & 0.114 & 21.65 & 10.826 & 4.79 \\
\hline $\mathrm{A}_{11}$ & 6.1 & 0.008 & 0.106 & 19.84 & 11.047 & 4.82 \\
\hline $\mathrm{A}_{13}$ & 5.3 & 0.009 & 0.114 & 22.31 & 10.251 & 5.36 \\
\hline $\mathrm{A}_{14}$ & 5.5 & 0.010 & 0.098 & 18.56 & 8.744 & 7.21 \\
\hline $\mathrm{A}_{15}$ & 4.9 & 0.007 & 0.097 & 19.74 & 10.256 & 6.84 \\
\hline $\mathrm{M}_{2}$ & 6.9 & 0.013 & 0.023 & 36.08 & 14.117 & 9.35 \\
\hline $\mathrm{M}_{3}$ & 7.1 & 0.012 & 0.021 & 39.75 & 16.032 & 8.96 \\
\hline $\mathrm{M}_{4}$ & 6.6 & 0.013 & 0.019 & 35.11 & 15.056 & 9.44 \\
\hline $\mathrm{M}_{6}$ & 6.5 & 0.011 & 0.021 & 40.08 & 14.136 & 10.13 \\
\hline
\end{tabular}

TSS $=$ Total Suspended Solids; ANC $=$ Acid Neutralizing Capacity; EC $=$ Electrical Conductivity; TA $=$ Total Alkalinity; TDS = Total Dissolved Solid. 
OYEDOTUN, T. D. T.; OBATOYINBO, O. Hydro-geochemical evaluation of groundwater quality in Akoko North West local government area of Ondo State, Nigeria. Ambi-Agua, Taubaté, v. 7, n. 1, p. 67-80, 2012. (http://dx.doi.org/10.4136/ambi-agua.851)

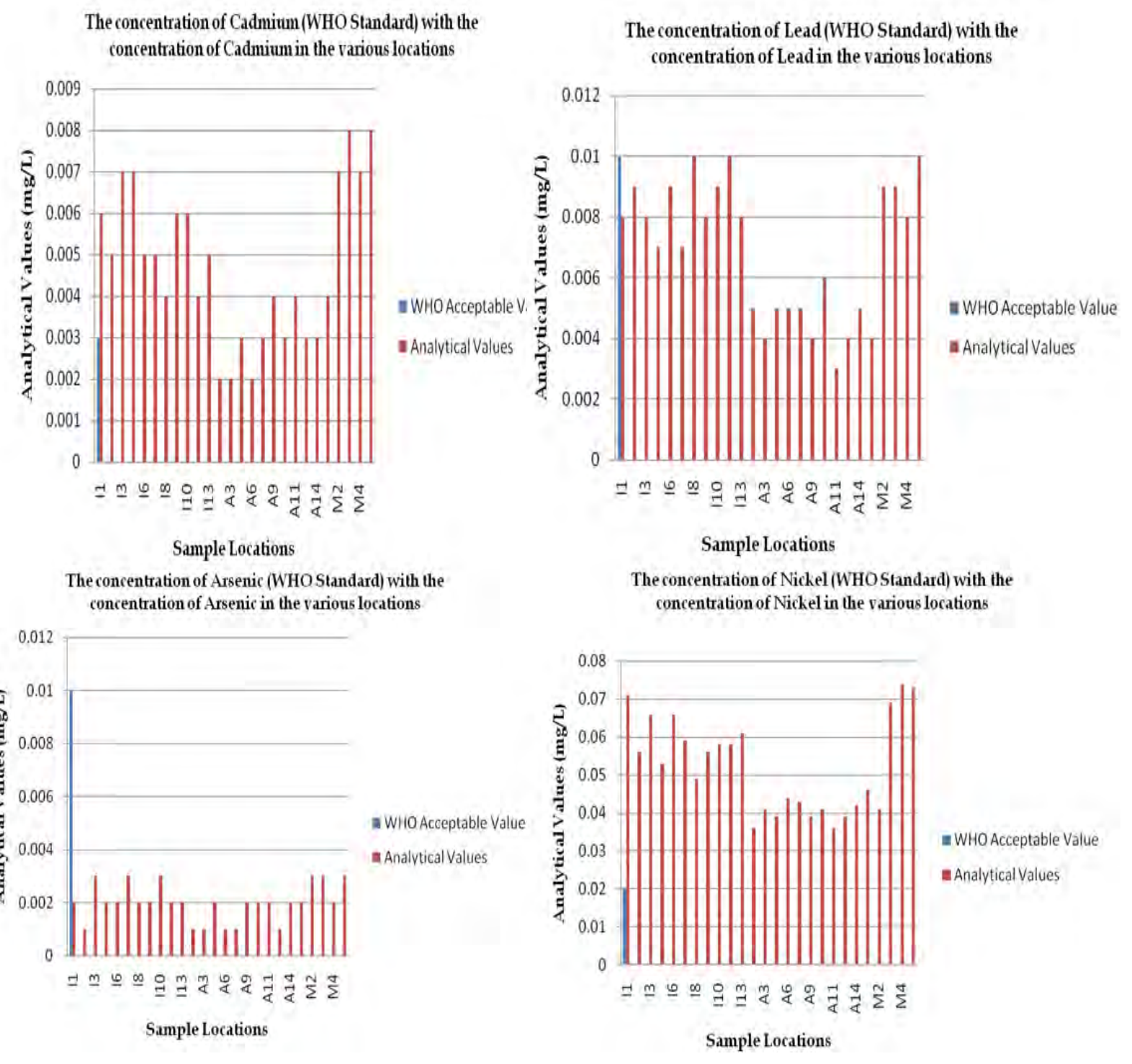

The concentration of Iron (WHO Standard) with the concentration of Iron in the various locations

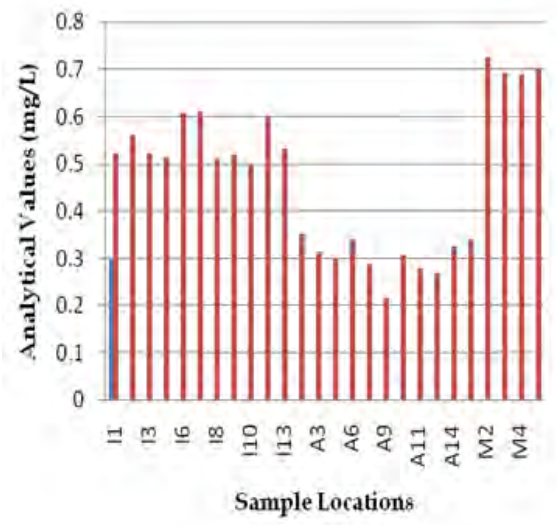

-WHO Acceptable Value

- Analytical Values

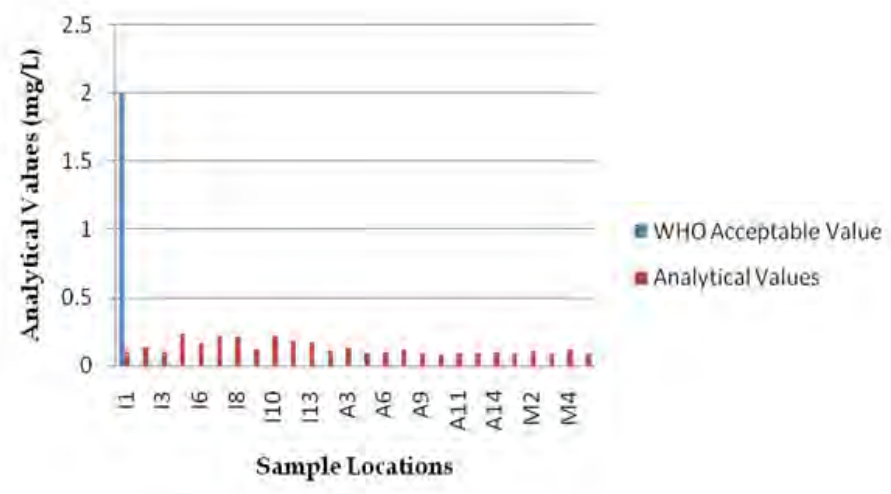

Figure 4. Graph of physico-chemical analytical values of groundwater samples with WHO Acceptable Value. (i) Cadmium (ii) Lead (iii) Arsenic (iv) Nickel (v) Iron and (vi) Cooper. 
OYEDOTUN, T. D. T.; OBATOYINBO, O. Hydro-geochemical evaluation of groundwater quality in Akoko North West local government area of Ondo State, Nigeria. Ambi-Agua, Taubaté, v. 7, n. 1, p. 67-80, 2012. (http://dx.doi.org/10.4136/ambi-agua.851)
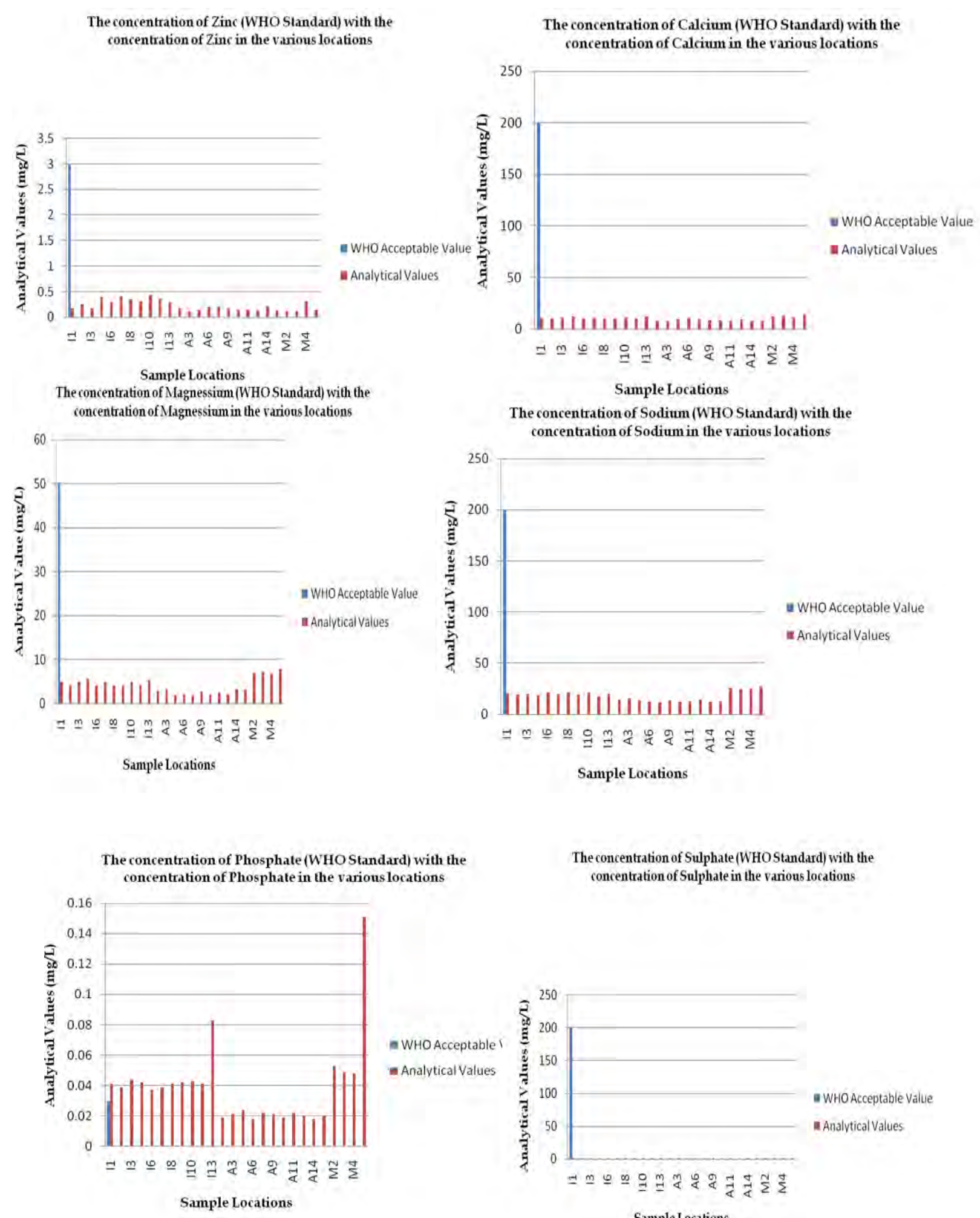

The concentration of Sulphate (WHO Standard) with the concentration of Sulphate in the various locations

Figure 5. Graph of physico-chemical analytical values of groundwater samples with WHO Acceptable Value. (i) Zinc (ii) Calcium (iii) Magnesium (iv) Sodium (v) Phosphate and (vi) Sulphate. 
OYEDOTUN, T. D. T.; OBATOYINBO, O. Hydro-geochemical evaluation of groundwater quality in Akoko North West local government area of Ondo State, Nigeria. Ambi-Agua, Taubaté, v. 7, n. 1, p. 67-80, 2012. (http://dx.doi.org/10.4136/ambi-agua.851)

The concentration of Bicarbonate (WHOStandard) with the concentration of Bicarbonate in the varions locations
The concentration of $\mathrm{pH}$ (WHO Standard) with the concentration of $\mathrm{pH}$ in the various locations
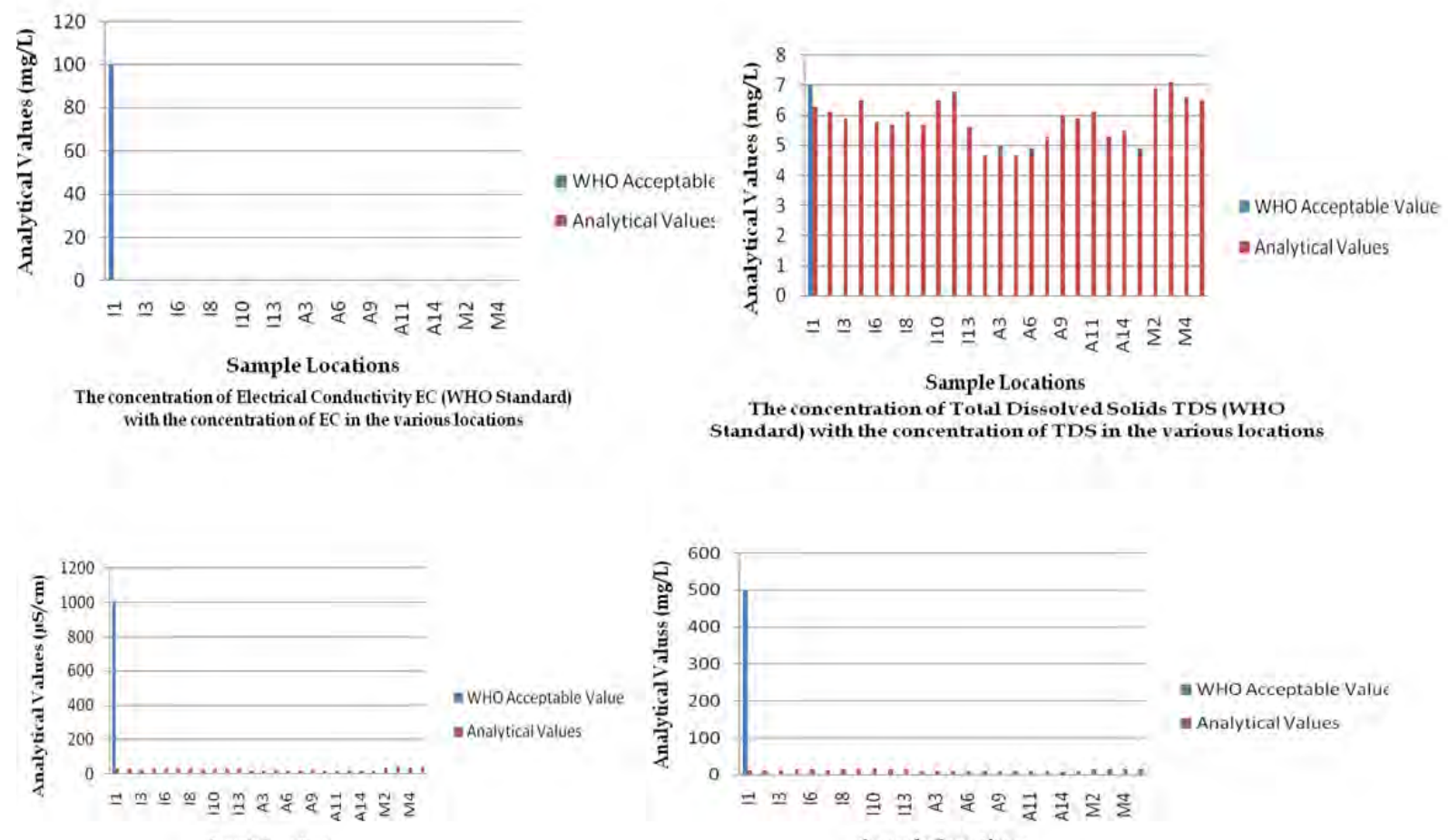

Sample Locations

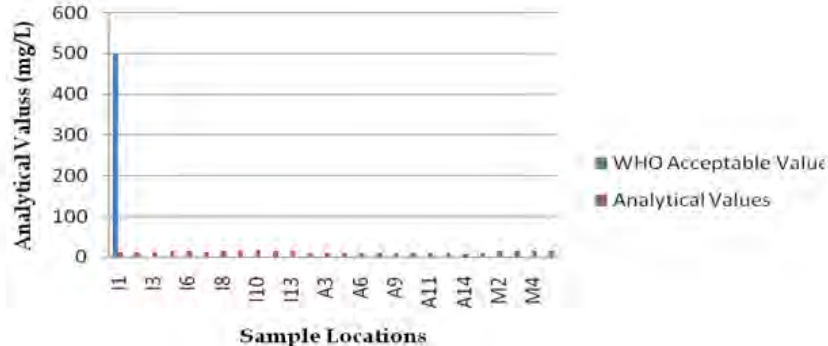

Figure 6. Graph of physico-chemical analytical values of groundwater samples with WHO Acceptable Value (i) Bicarbonate (ii) $\mathrm{pH}$ (iii) Electrical Conductivity (EC) and (iv) Total Dissolved Solids.

\section{DISCUSSION}

The characteristics of each element varies from one sample point to the other and this indicates the difference in the quality of the water sample collected from that particular point. The WHO acceptable values are then compared with the various values to determine and compare the suitability and effect of continual consumption of such water.

The Figures 4, 5 and 6 above indicate the comparison of the analysed values for the groundwater parameters in Akoko North West Local Government of Ondo State with the WHO established standard. For cadmium concentrations, the analyzed values of the samples taken at Arigidi-Akoko are the only ones within the WHO permissible range $\left(0.003 \mathrm{mgL}^{-1}\right)$ Figure 4(i), in other areas, the difference are less than the acceptable WHO standard concentration $\left(0.003 \mathrm{mgL}^{-1}\right)$, and are still assumed to be okay for domestic use except for two peaks at locations 9 and 11 in Arigidi. On the other hand, the analyzed values of the samples taken at Ikare and the Ministry area are far above the permissible concentration. It can therefore be concluded that the concentration of cadmium in these areas are anomalous and as such geological.

For the lead concentrations (Figure 4(ii)), the analyzed values fall within the permissible range for lead concentration based on WHO standard concentration $\left(0.01 \mathrm{mgL}^{-1}\right)$. It can therefore be concluded that though the concentration of the various sample locations have a concentration between the range, the lead intake of the residents within the study area is lesser than the acceptable which is what it ought to be since lead intake is hazardous to the health of man. Nevertheless care should be taken at the three locations $\left(\mathrm{I}_{8}, \mathrm{I}_{11}\right.$ and $\left.\mathrm{M}_{6}\right)$ that have the 
OYEDOTUN, T. D. T.; OBATOYINBO, O. Hydro-geochemical evaluation of groundwater quality in Akoko North West local government area of Ondo State, Nigeria. Ambi-Agua, Taubaté, v. 7, n. 1, p. 67-80, 2012. (http://dx.doi.org/10.4136/ambi-agua.851)

same lead concentration as the WHO standard overtime so that it does not exceed the acceptable values.

The WHO guideline value for arsenic in drinking water is currently $0.01 \mathrm{mgL}^{-1}$ although the Nigerian National Standard is $0.05 \mathrm{mgL}^{-1}$. Few data are so far available for arsenic in groundwater from Nigeria (Smedley and Kinniburgh, 2002). However, from the Figure 4(iii), the analyzed values for the samples fall within the permissible range $\left(0.001 \mathrm{mgL}^{-1}\right.$, Table 2$)$ for arsenic concentration but it is far less than the acceptable WHO standard concentration $\left(0.01 \mathrm{mgL}^{-1}\right)$. However, it should be noted the overall concentration which is lesser than the permissible value for arsenic is acceptable because too much arsenic intake is hazardous to human's health.

The overall analysis of the values for the groundwater sampled (See Tables 3 and 4, as well as Figures 4, 5 and 6) in comparison with the WHO acceptable standard (See Table 2) indicates that Copper (Figure 4(vi)), Zinc (Figure 5(i)), Calcium (Figure 5(ii)), Magnesium (Figure 5(iii)), Sodium (Figure 5(iv)), Sulphate (Figure 5(v)), Bicarbonate (Figure 6(i)), Electrical Conductivity - EC (Figure 6(iii)) and Total Dissolved Solids (Figure 6(iv)) are far lesser than the WHO acceptable standard(quality) for drinking water. The magnitude of the values for Nickel (Figure 4(iv)), Iron (Figure 4(v)) and Phosphate (Figure 5(v)) are, however, higher than the WHO established standard. The only groundwater quality parameter from the samples analysed for the study which is generally of WHO standard is the $\mathrm{pH}$ value (Figure 6(iv)).

Clear differences are observable in all the sampled groundwater from the Hand Held Boreholes, Solar-Powered Boreholes and Hand-Dug wells in the local government area. The summary of the effects of these variations to the human health is presented in Table 5 below. The major threats to the groundwater quality in the study area are from agricultural effluents seepage, septic tank and soak-away pits leakages, water table's interception with latrines and other various other impacts of human encroachment which do affect the physical and chemistry of the groundwater component in the area. Major anomalies are seen in the concentrations of some of the heavy metals in the area.

Table 5. The likely effect of metal ingestion above/below acceptable level.

\begin{tabular}{|c|c|c|}
\hline $\begin{array}{l}\text { Measured } \\
\text { Parameters }\end{array}$ & $\begin{array}{l}\text { Acceptable } \\
\text { Level }\end{array}$ & Effect above/below level \\
\hline Total dis.solids (TDS) & Max 1000 & Stomach discomfort \\
\hline Cadmium & $0.003 \mathrm{mgL}^{-1}$ & Kidney damage \\
\hline Copper & $2.0 \mathrm{mgL}^{-1}$ & Gastrointestinal, liver or kidney damage \\
\hline Temperature & $25^{\circ} \mathrm{C}$ & Bone disease (pain and tenderness of the bones); Children may get \\
\hline Arsenic & 0.01 & Skindamage or problems with circulatory systems, and may have \\
\hline Total hardness & Max 500 & Increase in blood pressure \\
\hline Chlorite & 1.0 & Anemia; infants \& young children: nervous system effects \\
\hline Turbidity & $\operatorname{Max} 25$ & Nausea, cramps, diarrhea, and associated headaches. \\
\hline Chlorine & $\operatorname{Max} 200 \mathrm{mgL}^{-1}$ & Eye/nose irritation; stomach discomfort \\
\hline Calcium & $\operatorname{Max} 200 \mathrm{mgL}^{-1}$ & Indigestibility of fat in the body \\
\hline Magnesium & $\operatorname{Max} 150 \mathrm{mgL}^{-1}$ & Gastrointestinal, liver or kidney damage \\
\hline Potassium & $\operatorname{Max} 50$ & Effect on blood pressure \\
\hline Lead & $0.01 \mathrm{mgL}^{-1}$ & Infants and children: Delays in physical or mental development; children \\
\hline $\mathrm{pH}$ & $6.5-8.5$ & Rusting, cancer \\
\hline Aluminium & $0.2 \mathrm{mgL}^{-1}$ & Minor kidney changes \\
\hline Nickel & $0.02 \mathrm{mgL}^{-1}$ & Cancer of lungs, nose, bone and dermatitis \\
\hline Conductivity & $\operatorname{Max}$ & Anemia; liver, kidney or spleen damage; changes in blood \\
\hline Iron & $0.30 \mathrm{mgL}^{-1}$ & Rusting, cancer \\
\hline Sulphate & $\operatorname{Max} 400 \mathrm{mgL}^{-1}$ & Allergic dermatitis \\
\hline Sodium & $\operatorname{Max} 200 \mathrm{mgL}^{-1}$ & Increased risk of cancer \\
\hline Zinc & $3.0 \mathrm{mgL}^{-1}$ & Nausea, cramps, diarrhea, and associated headaches. \\
\hline
\end{tabular}


OYEDOTUN, T. D. T.; OBATOYINBO, O. Hydro-geochemical evaluation of groundwater quality in Akoko North West local government area of Ondo State, Nigeria. Ambi-Agua, Taubaté, v. 7, n. 1, p. 67-80, 2012. (http://dx.doi.org/10.4136/ambi-agua.851)

\section{CONCLUSION}

It can be concluded that the sampled groundwater are in most cases not suitable for human consumption judging by the various concentrations of the physicochemical parameters analyzed from the samples. Because of the total reliance of the entire population in the study area on groundwater for their various uses, there is the need to carry out a research on the link between quality of water intake and the health conditions of the populace in the study area. It was also observed that some of the heavy metals, anions and cations, with the physical parameters are much higher than the WHO acceptable standard for drinking water. Although there were also cases where in some of the analyzed samples, the range and the concentration were within the WHO acceptable standard for drinking water. Most of the high concentrations in the analyzed groundwater are generally from anthropogenic sources and not natural or geological.

The following are hereby recommended as possible solutions to the groundwater quality problems in the study area:

i. that waters in such areas where the physic-chemical constituents are lower than the acceptable standards of the WHO are unsafe for human consumption and domestic use, and therefore should be treated to reduce or ameliorate the problems;

ii. that further work should be carried out to ascertain the specific anthropogenic contaminants in the analyzed waters so as to determine the level of contamination and be able to proffer appropriate remediation;

iii. that in areas where the cationic and anionic concentrations are far below the WHO acceptable levels, supplements should be advised to the residents of such areas or such be distributed so as to make up for the minimal intake recommended for domestic use by the World Health Organization;

iv. that further investigation of the entire area is necessary to determine the specific causes for the chemistry observed and to establish hypotheses on reasons for some of the abnormalities;

v. for the research approach, a larger number of samples should be taken to allow the optimization of a more routine study in the area; and,

vi. the startling statistics from this research work should, therefore, serve as a wake-up call for urgent remedial action from both the Local and State Governments, if the residents in these areas are to continually live healthily. They should be properly orientated on the need not to dump untreated/raw sewage into flowing surface waters and the environments so as to reduce the increasing rate of fecal contamination of both the surface and groundwater bodies from where majority of domestic water supply come from.

\section{ACKNOWLEDGEMENT}

The authors would like to appreciate and acknowledge the supervisory assistance and guidance of Prof Ogunbajo, M. I. and Prof. Oyinloye, A. O. in this research work.

\section{REFERENCES}

AKUJIEZE, C. N.; COKER, S. J. L.; OTEZE, G. E. Groundwater in Nigeria- a millennium experience - distribution, practice, problems and solutions. Hydrogeology Journal, v. 11, n. 2, p. 259-74, April 2003. http://dx.doi.org/10.1007/s10040-002-0227-3 
OYEDOTUN, T. D. T.; OBATOYINBO, O. Hydro-geochemical evaluation of groundwater quality in Akoko North West local government area of Ondo State, Nigeria. Ambi-Agua, Taubaté, v. 7, n. 1, p. 67-80, 2012. (http://dx.doi.org/10.4136/ambi-agua.851)

BOYLE, D. R. Application of groundwater geochemistry in mineral exploration. In: BERRY, M. J. (Ed.). Current activities forum 1988, program with abstracts. Dartmouth: Geological Survey of Canada, 1988.

DUZE, M.; OJO, A. Senior school atlas. Lagos: Macmillan Educational,1982. 113p.

EDET, A. E.; OKEREKE, C. S.; TEME, S. C.; ESU, E. O. Application of remote sensing data to groundwater exploration: a case study of the Cross River State, South-eastern Nigeria. Hydrogeology Journal, v. 6, n. 3, p. 394-404, 1998. DOI: 10.1007/s100400050162 http://dx.doi.org/10.1007/s100400050162

HANIDU, J. A. National growth, water demand and supply strategies in Nigeria in the 1990s. Water Resource Journal of Nigerian Association of Hydrogeologists, v. 2, n. 1, p. 16, 1990.

NATIONAL POPULATION COMMISSION - NPC. National population and housing census. [S.1.], 2006.

OBATOYINBO, O.; OYEDOTUN, T. D. T. Microbial/bacteriological analysis of water resources in Ikare and Arigidi Akoko of Ondo State, Nigeria. In: EIT International Conference on Water Resources Engineering, 1., 18 -19 August 2011, Cha-Am. Proceedings... p. 279-84. Available in: <http://eitwre2011.fiet.kmutt.ac.th /theme_en/8WQ_E.pdf>. Accessed 23 Apr. 2012.

OKAGBUE, C. O. Hydrology and chemical characteristics of surface and groundwater resources of the Okigwi area and environs, Imo State, Nigeria. In: OFOEGBU, C.O. (Ed.). Groundwater and mineral resources of Nigeria. Braunschweig: Vieweg and Sohn, 1988. p. 3-16.

OMOTOYINBO, O. S.; OKAFOR, F. C. Influence of rock mineralogy on subsurface water in Ado-Ekiti, Nigeria. African Research Review, v. 2, n. 2, p. 175-86, 2008. http://dx.doi.org/10.4314/afrrev.v2i2.41049

RAMANATHAN, A. L. Water quality: guidelines and assessment of risk. New Delhi: School of Environmental Sciences, 2004. p. 110-67.

RIJSWIJK, K. Small community water supplies. The Hague: IRC, 1981. (Technical Paper, n. 18).

SMEDLEY, P. L.; KINNIBURGH, D. G. A review of the source, behaviour and distribution of arsenic in natural waters. Applied Geochemistry, v. 17, p. 517-68, 2002.

http://dx.doi.org/10.1016/S0883-2927(02)00018-5

TIJANI, M. N. Hydrogeochemical assessment of groundwater in Moro area, Kwara state, Nigeria. Environmental Geology, v. 24, n. 3, p. 194-202, 1994. DOI: 10.1007/BF00766889 http://dx.doi.org/10.1007/BF00766889

WORLD HEALTH ORGANIZATION - WHO. Guidelines for drinking-water quality. Vol. 1: recommendations. Geneva, 1984.

WORLD HEALTH ORGANIZATION - WHO. Guidelines for drinking-water quality. 2. ed.. Vol. 3: surveillance and control of community supplies. Geneva, 1997 


ISSN = 1980-993X-doi:10.4136/1980-993X
www.ambi-agua.net
E-mail: ambi-agua@agro.unitau.br
Tel.: (12) 3625-4212

\title{
The effect of indigenous probiotics on egg hatchability and larval viability of Clarias gariepinus
}

(http://dx.doi.org/10.4136/ambi-agua.712)

\author{
Caroline N. Ariole ${ }^{1}$; Gideon C. Okpokwasili \\ Department of Microbiology, University of Port Harcourt, \\ P.M.B. 5323, Port Harcourt, Rivers State, Nigeria \\ e-mail: cnariole@yahoo.com; ${ }^{2}$ e-mail: gidsilman@yahoo.com
}

\begin{abstract}
The effect of a mixture of four indigenous bacterial genera composed of Bacillus, Pseudomonas, Acinetobacter and Flavobacterium on egg hatchability and larval viability of Clarias gariepinus was investigated. The fertilized eggs were distributed into glass Petri dishes (100 mm diameter) containing $50 \mathrm{ml}$ of water at graded level of mixed indigenous probiotics ranging from $0-10^{8}$ cells $/ \mathrm{ml}$. The incubation time increased from 17 hours at 0 $\mathrm{cfu} / \mathrm{ml}$ to 22 hours at $10^{8} \mathrm{cfu} / \mathrm{ml}$. The mean hatching rate increased from $8.70 \%$ at $0 \mathrm{cfu} / \mathrm{ml}$ to $53.85 \%$ at $10^{8} \mathrm{cfu} / \mathrm{ml}$. The highest larval survival of $71.43 \%$ recorded at $10^{8} \mathrm{cfu} / \mathrm{ml}$ where the highest hatching rate was observed, was significantly higher than the larval survival rate observed at the other concentrations. All yolk sac larvae at 0 and $10^{1} \mathrm{cfu} / \mathrm{ml}$ died before the end of yolk sac period. These results imply that the incubation time, hatching rate and larval survival of Clarias gariepinus increased with increase in bacterial load of water up to $10^{8}$ cells $/ \mathrm{ml}$, the highest dose employed. Further investigations are needed to establish the optimal and threshold doses.
\end{abstract}

Keywords: Clarias eggs; incubation; rearing; indigenous probiotics; yolk sac larvae.

\section{O efeito dos probióticos naturais sobre a eclodibilidade de ovos e viabilidade das larvas de Clarias gariepinus}

\section{RESUMO}

O efeito de uma mistura de quatro géneros bacterianos naturais compostos de Bacillus, Pseudomonas, Acinetobacter e Flavobacterium sobre a eclodibilidade dos ovos e viabilidade das larvas de Clarias gariepinus foi investigado. Os ovos fertilizados foram distribuídos em placas de Petri de vidro (100 mm de diâmetro) contendo $50 \mathrm{ml}$ de água, adicionando-se probióticos naturais mistos que variaram de $0-10^{8}$ células $/ \mathrm{ml}$. O tempo de incubação aumentou de 17 horas a $0 \mathrm{ufc} / \mathrm{ml}$ para 22 horas a $10^{8} \mathrm{ufc} / \mathrm{ml}$. A taxa de eclosão média aumentou de $8,70 \%$ a $0 \mathrm{ufc} / \mathrm{ml}$ para $53,85 \%$ a $10^{8}$ ufc $/ \mathrm{ml}$. A maior taxa de sobrevivência das larvas foi de $71,43 \%$ observada em $10^{8} \mathrm{ufc} / \mathrm{ml}$, significativamente mais elevada do que a taxa de sobrevivência das larvas observada nas outras concentrações. Todas as larvas em fase embrionária na concentração de 0 e $10^{1} \mathrm{cfu} / \mathrm{ml}$ morreram antes do final do período embrionário da gema. Estes resultados implicam que o tempo de incubação, a taxa de eclosão e a sobrevivência das larvas de Clarias gariepinus apresentaram os melhores resultados com a concentração bacteriana na água de até $10^{8}$ 
ARIOLE, C. N.; OKPOKWASILI, G. C. The effect of indigenous probiotics on egg hatchability and larval viability of Clarias gariepinus. Ambi-Agua, Taubaté, v. 7, n. 1, p. 81-88, 2012. (http://dx.doi.org/10.4136/ambi-agua.712)

células/ml, ou seja, com a dose mais elevada utilizada. Investigações adicionais são necessárias para estabelecer as doses ótimas e os níveis limites.

Palavras-chave: Ovos de Clarias; incubação; criação; probióticos naturais; larvas de gemas embrionárias.

\section{INTRODUTION}

The African catfish Clarias gariepinus is distributed throughout Africa. It is of growing economic value in the African aquaculture industry (Goda et al., 2007; Osman et al., 2007; Aldelhamid, 2009). In Nigeria, Clarias gariepinus is very well accepted by fish farmers and consumers and are therefore very indispensable to the sustainability of aquaculture. One of the limiting factors in fish production is mortality due to microbial infections and hatcheries and nurseries are known to be point sources of infection (Delince et al., 1987). Disease reduces hatchery efficiency and production which in turn, increases costs and reduces profit. There is, therefore, an urgent need to control the microbiota in hatching incubators by alternative means, since the use of antibiotic has to be minimal. In fact, the use of antibiotics does not allow microbial control and may result in an unfavorable alteration of the microbiota (Hansen et al., 1992; Olafsen, 1998). The introduction of microbial control practices by means of probiotics may have a beneficial effect on the cultures (Olafsen, 1998).

The development of non - antibiotic and friendly agents is one of the key factors for health management in aquaculture. This is because the use of expensive chemotherapeutants for controlling diseases have been widely criticized for their negative impacts (Sahu et al., 2008). The development and spread of antimicrobial resistant human pathogens (motile Aeromonas spp., E. tarda, E. coli, V. vulrificus, V. para haemolyticus, $V$. cholerae etc.) were well- documented (WHO, 1999). Aquatic bacteria can also develop resistance genes as a consequence of exposure to antimicrobial agents (Smith et al., 1994; Kim et al., 2004; S Ørum, 2006). Also, the occurrence of antimicrobial residues in products of aquaculture threat human health (WHO, 2006).

Probiotics which can be administered by direct addition of the organisms to the tanks, or by incorporation of the organisms into live or formulated feed is yet to gain popularity in aquaculture of Nigeria. The research of probiotics in aquaculture in Nigeria is still in its early stage. At present data about the effect of probiotics on tropical freshwater fish hatchery system is still lacking. Therefore, the aim of this investigation was to study the effect of graded level of a mixture of indigenous bacteria previously isolated from fish hatchery environment (Molokwu and Okpokwasili, 2002) on egg hatchability and larval viability of Clarias gariepinus as a part of a long term investigation into screening new probiotic strains from local aquaculture rearing unit to suit the specific requirement in Nigeria.

\section{MATERIALS AND METHODS}

The eggs of Clarias gariepinus were obtained from the hatchery at the African Regional Aquaculture centre (ARAC) Aluu, Port Harcourt, Nigeria by artificial breeding of the brood fish as described by Delince et al. (1987). Final maturation followed by ovulation was induced in female spawners with hormone treatment. The riped eggs were procured by stripping and milt was procured by dissection of a male donor. Few drops of milt solution were added onto the eggs and the sexual products mixed by gentle shaking of the bowl. The eggs were taken to the laboratory within 10 minutes of collection and 
ARIOLE, C. N.; OKPOKWASILI, G. C. The effect of indigenous probiotics on egg hatchability and larval viability of Clarias gariepinus. Ambi-Agua, Taubaté, v. 7, n. 1, p. 81-88, 2012. (http://dx.doi.org/10.4136/ambi-agua.712)

fertilized by adding approximately the same volume of clean water. The water and egg mass were thoroughly mixed by gently shaking the bowl.

The fertilized eggs were distributed into glass Petri dishes (100 $\mathrm{mm}$ diameter) containing $50 \mathrm{ml}$ of water at different concentrations of mixed indigenous probiotics. Four bacterial genera (Bacillus, Pseudomonas, Acinetobacter and Flavobacterium) previously isolated from fish hatchery systems (Molokwu and Okpokwasili, 2002) were grown at $30^{\circ} \mathrm{C}$ in nutrient broth for 24 hours. The bacterial cells were then harvested by centrifugation at 5,000 rpm for 20 minutes at room temperature $\left(28^{\circ} \mathrm{C}\right)$. The cells were washed twice, resuspended in $10 \mathrm{~mL}$ of sterile normal saline $(0.85 \% \mathrm{NaCl})$ and added to the Petri dishes at a final concentration ranging from $10^{1}-10^{8} \mathrm{cfu} / \mathrm{ml}$. The dilution water (borehole water) with physico-chemical characteristics as shown in Table 1 was used as control. Each treatment had three replicates.

Table 1. Physico-chemical characteristics of borehole water used for dilution.

\begin{tabular}{l|r}
\hline \multicolumn{1}{c|}{ Parameters } & Values \\
\hline $\mathrm{pH}$ & 6.50 \\
Total alkalinity $\left(\mathrm{mg} / \mathrm{L} \mathrm{CaCO}_{3}\right)$ & 9.00 \\
Total Hardness $\left(\mathrm{mg} / \mathrm{L} \mathrm{CaCO}_{3}\right)$ & 10.00 \\
$\mathrm{SO}_{4}{ }^{2-}-\mathrm{S}(\mathrm{mg} / \mathrm{L})$ & 0.00 \\
$\mathrm{NH}_{3}-\mathrm{N}(\mathrm{mg} / \mathrm{L})$ & 0.02 \\
$\mathrm{PO}_{4}{ }^{3-}-\mathrm{P}(\mathrm{mg} / \mathrm{L})$ & 0.00 \\
Salinity $(\mathrm{ppt})$ & 0.00 \\
Phenolphthalein alkalinity $\left(\mathrm{mg} / \mathrm{L}\right.$ as $\left.\mathrm{CaCO}_{3}\right)$ & 0.00 \\
\hline
\end{tabular}

The initial number of fertilized eggs in each Petri dish was noted. Dead eggs and larvae were removed with forceps. The duration of incubation time (from fertilization to first hatch) was recorded for each treatment. The hatched eggs were counted and the percentage determined for each treatment.

During larval rearing, incubation remnants, dead larvae and waste matter were siphoned off every day to avoid any form of stress and $50 \%$ of the water in each Petri dish was replaced. Three development periods were defined - the egg period, the hatching period and the yolk-sac period. The egg period began from the time of placement and ended when the eggs began to hatch. The hatching period began when first eggs hatched and ended when all eggs had hatched. The yolk-sac period extended from the end of the hatching period until the yolk-sac of the fry were absorbed (yolk-sac absorption was determined visually). The percentage survival of eggs and larvae at the end of each developmental period was determined. Data on hatchability and larval survival were analyzed using one-way analysis of variance (ANOVA) and Duncan multiple Range Test (DMRT). Significance was established at the 0.05 level.

\section{RESULTS AND DISCUSSION}

The effects of graded levels of a mixture of indigenous probiotics on incubation period presented in Figure 1 revealed that the incubation time increased from 17 hours at 0 $\mathrm{cfu} / \mathrm{ml}$ to 22 hours at $10^{8} \mathrm{cfu} / \mathrm{ml}$. The mean hatching rate increased from $8.70 \%$ at $0 \mathrm{cfu} / \mathrm{ml}$ to $53.85 \%$ at $10^{8} \mathrm{cfu} / \mathrm{ml}$, the highest concentration employed (Figure 2). 
ARIOLE, C. N.; OKPOKWASILI, G. C. The effect of indigenous probiotics on egg hatchability and larval viability of Clarias gariepinus. Ambi-Agua, Taubaté, v. 7, n. 1, p. 81-88, 2012. (http://dx.doi.org/10.4136/ambi-agua.712)

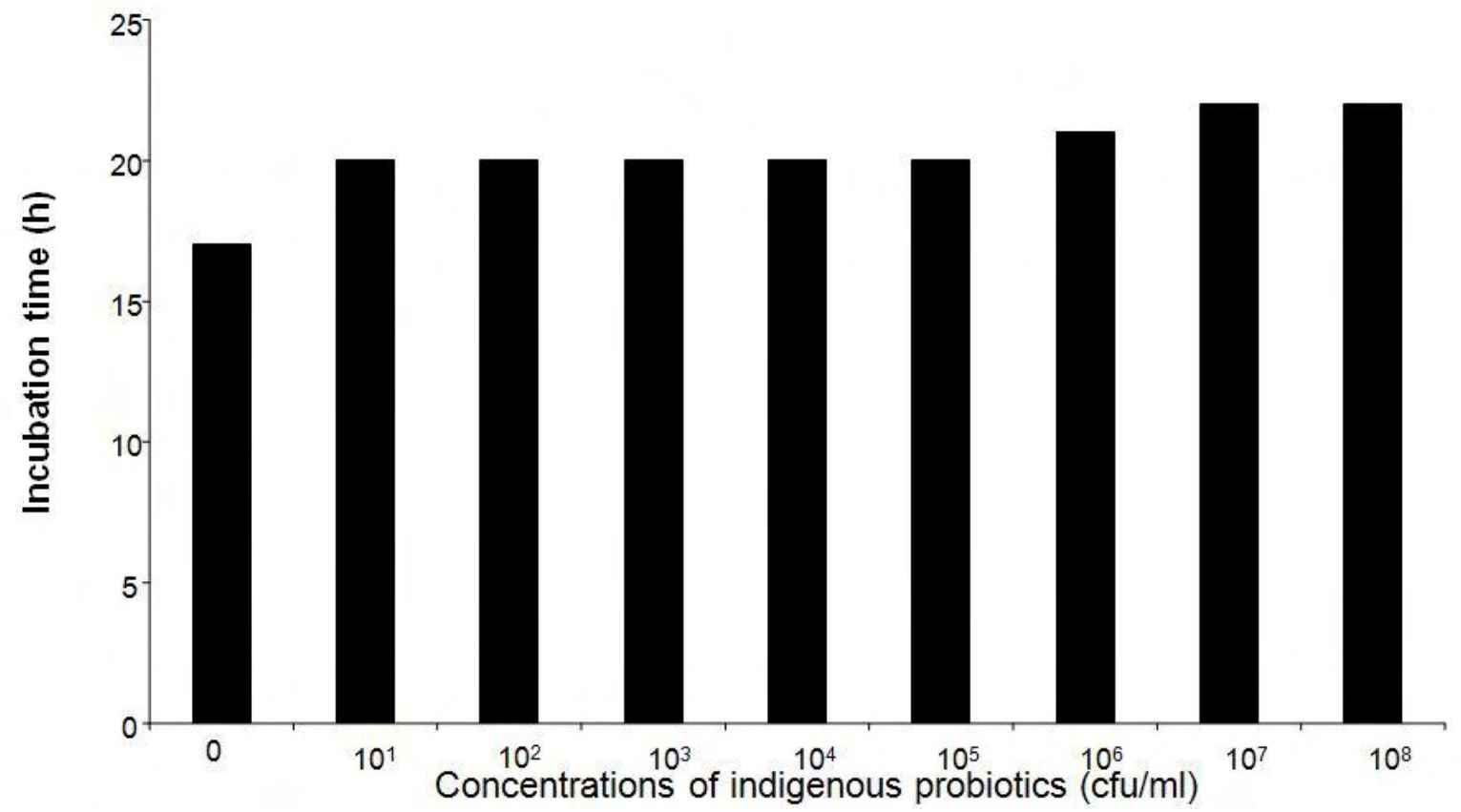

Figure 1. Incubation time to hatching of Clarias gariepinus egg exposed to different concentrations of indigenous probiotics.

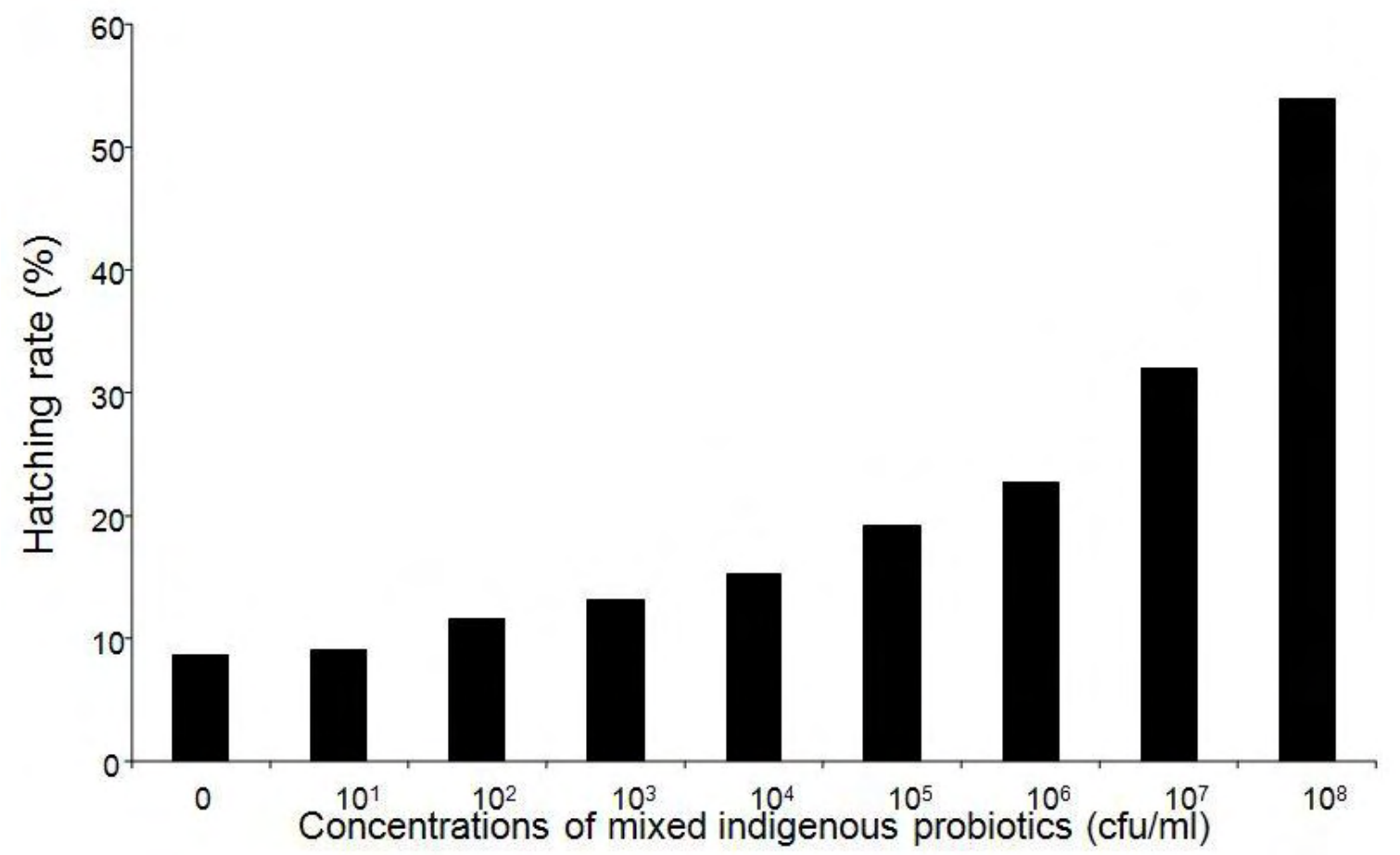

Figure 2. Hatching rate of Clarias gariepinus eggs exposed to different concentrations of mixed indigenous probiotics. 
ARIOLE, C. N.; OKPOKWASILI, G. C. The effect of indigenous probiotics on egg hatchability and larval viability of Clarias gariepinus. Ambi-Agua, Taubaté, v. 7, n. 1, p. 81-88, 2012. (http://dx.doi.org/10.4136/ambi-agua.712)

Table 2. Survival (mean \pm SD) of Clarias gariepinus eggs and larvae exposed to different mixed indigenous probiotics.

\begin{tabular}{|c|c|c|c|c|c|c|c|c|}
\hline \multirow[b]{2}{*}{$\begin{array}{l}\text { Concentration } \\
\text { of indigenous } \\
\text { probiotics } \\
\text { (cfu/ml) }\end{array}$} & \multicolumn{3}{|c|}{ Egg period } & \multicolumn{2}{|c|}{ Hatching period } & \multicolumn{3}{|c|}{ Yolk sac period } \\
\hline & $\begin{array}{c}\text { Initial } \\
\text { number } \\
\text { of eggs }\end{array}$ & $\begin{array}{c}\text { Survivors } \\
\text { to } \\
\text { hatching } \\
\text { period }\end{array}$ & $\begin{array}{c}\text { Egg } \\
\text { survival } \\
(\%)\end{array}$ & $\begin{array}{c}\text { Survivors } \\
\text { to end of } \\
\text { hatching } \\
\text { period }\end{array}$ & $\begin{array}{c}\text { Survival } \\
\text { from end of } \\
\text { egg period } \\
(\%)\end{array}$ & $\begin{array}{l}\text { Survivors } \\
\text { to end of } \\
\text { yolk sac } \\
\text { period }\end{array}$ & $\begin{array}{c}\text { Survival } \\
\text { from end of } \\
\text { hatching } \\
\text { period }(\%)\end{array}$ & $\begin{array}{c}\text { Survival } \\
\text { from end } \\
\text { of egg } \\
\text { period } \\
(\%)\end{array}$ \\
\hline 0* & 23 & 2 & $8.70 \pm 0.42$ & 2 & $100.00 \pm 0.00$ & 0 & $0 \pm 0.00$ & $0 \pm 0.00$ \\
\hline $10^{1 *}$ & 33 & 3 & $9.09 \pm 0.81$ & 3 & $100.00 \pm 0.00$ & 0 & $0 \pm 0.00$ & $0 \pm 0.00$ \\
\hline $10^{2}$ & 69 & 8 & $11.59 \pm 0.53$ & 8 & $100.00 \pm 0.00$ & 3 & $37.5 \pm 0.11$ & $37.5 \pm 0.91$ \\
\hline $10^{3}$ & 38 & 5 & $13.16 \pm 0.62$ & 4 & $80.00 \pm 0.23$ & 2 & $50.00 \pm 0.23$ & $40.00 \pm 0.82$ \\
\hline $10^{4}$ & 33 & 5 & $15.15 \pm 0.72$ & 4 & $40.00 \pm 0.59$ & 2 & $50.00 \pm 0.90$ & $40.00 \pm 0.73$ \\
\hline $10^{5}$ & 26 & 5 & $19.23 \pm 0.94$ & 4 & $80.00 \pm 0.61$ & 2 & $50.00 \pm 0.81$ & $40.00 \pm 0.51$ \\
\hline $10^{6}$ & 44 & 10 & $22.73 \pm 0.12$ & 8 & $80.00 \pm 0.72$ & 5 & $62.5 \pm 0.72$ & $50.00 \pm 0.22$ \\
\hline $10^{7}$ & 25 & 8 & $32.00 \pm 0.12$ & 5 & $62.5 \pm 0.83$ & 4 & $80.00 \pm 0.89$ & $50.00 \pm 0.33$ \\
\hline $10^{8}$ & 26 & 14 & $53.85 \pm 0.33$ & 12 & $85.71 \pm 0.91$ & 10 & $83.33 \pm 0.14$ & $71.43 \pm 0.97$ \\
\hline
\end{tabular}

* All the yolk sac larvae at these concentrations died before the end of yolk sac period.

These results imply that Clarias gariepinus developing embryos were quite sensitive to higher bacterial load since the incubation time and hatching rate increased with increase in bacterial load.

All yolk- sac larvae at 0 and $10^{1} \mathrm{cfu} / \mathrm{ml}$ died before the end of yolk - sac period (Table 2). Table 3 revealed that the hatching rate observed at $0 \mathrm{cfu} / \mathrm{ml}$ (dilution water) was significantly lower than all the other hatching rates observed at the other concentrations. Furthermore, the highest larval survival of $71.43 \%$ recorded at $10^{8} \mathrm{cfu} / \mathrm{ml}$ where the highest hatching rate was observed, was significantly higher than larval survival rate observed at the other concentrations.

Table 3. Mean ( $\pm \mathrm{SD})$ Comparison for Clarias gariepinus egg hatchability and larval survival at different levels of mixed indigenous probiotics.

\begin{tabular}{c|c|c}
\hline $\begin{array}{c}\text { Concentration of mixed } \\
\text { indigenous probiotics } \\
(\mathbf{c f u} / \mathbf{m l})\end{array}$ & $\begin{array}{c}\text { Hatchability } \\
(\boldsymbol{\%})\end{array}$ & $\begin{array}{c}\text { Larval survival } \\
(\boldsymbol{\%})\end{array}$ \\
\hline $\mathbf{0}$ & $8.70^{\mathrm{m}} \pm 0.42$ & $0^{\mathrm{m}}$ \\
$\mathbf{1 0}^{\mathbf{1}}$ & $9.09^{\mathrm{d}} \pm 0.81$ & $0^{\mathrm{m}}$ \\
$\mathbf{1 0}^{\mathbf{2}}$ & $11.59^{\mathrm{e}} \pm 0.53$ & $37.50^{\mathrm{a}} \pm 0.91$ \\
$\mathbf{1 0}^{\mathbf{3}}$ & $13.16^{\mathrm{a}} \pm 0.62$ & $40.00^{\mathrm{b}} \pm 0.82$ \\
$\mathbf{1 0}^{\mathbf{4}}$ & $15.15^{\mathrm{b}} \pm 0.72$ & $40.00^{\mathrm{b}} \pm 0.73$ \\
$\mathbf{1 0}^{\mathbf{1 0}}$ & $19.23^{\mathrm{x}} \pm 0.94$ & $40.00^{\mathrm{b}} \pm 0.51$ \\
$\mathbf{1 0}^{\mathbf{7}}$ & $22.73^{\mathrm{y}} \pm 0.12$ & $50.00^{\mathrm{e}} \pm 0.22$ \\
$\mathbf{1 0}^{\mathbf{8}}$ & $32.00^{\mathrm{z}} \pm 0.12$ & $50.00^{\mathrm{e}} \pm 0.33$ \\
\hline
\end{tabular}

Note: Mean values within each column which do not have the same superscript letter are significantly different $(\mathrm{p}<0.05)$.

The higher egg and larval survival with increase in bacterial load is probably due to the fact that they were used as sources of exogenous carbon and energy or had an otherwise beneficial effect on survival. It has been observed that survival of halibut (Hippoglossus hippoglossus) larvae in the first 2 weeks after hatching is affected by 
ARIOLE, C. N.; OKPOKWASILI, G. C. The effect of indigenous probiotics on egg hatchability and larval viability of Clarias gariepinus. Ambi-Agua, Taubaté, v. 7, n. 1, p. 81-88, 2012. (http://dx.doi.org/10.4136/ambi-agua.712)

incubation with indigenous bacteria isolated from fish (Olafsen, 1998). Probiotics are known to confer a healthy effect on the host as significant microbial food supplements in the field of prophylaxis (Geovanny et al., 2007). A relatively dense, non pathogenic and diverse adherent microbiota present on the eggs would probably be an effective barrier against colony formation by pathogens on fish eggs (Hansen et al., 1992; Olafsen, 1998).

Several experiments and observations suggest that poor survival, growth and quality of larvae to a large extent can be explained by microbial conditions during egg and yolk sac stages (Bergh and Hjelmert, 1990 ; Salvesen et al., 1991; Lein et al.,1992) and during first feeding (Gatesoupe, 1991). But the bacteria used in challenging the egg and larval culture were non-pathogens previously isolated from the eggs and larvae as normal flora. However, a high load of organic matter and bacteria as well as substantial variation in the environmental conditions of the bacteria may change the normal interaction between bacteria and larvae to one that is detrimental (Vadstein et al., 1993).

Therefore, further investigation is needed in order to establish the threshold concentration of the bacterial load in water as well as those colonizing the eggs and larvae that will inhibit hatching and larval survival in the hatchery.

\section{CONCLUSIONS}

From the results of this experiment, it can be concluded that a mixture of indigenous bacteria composed of Bacillus, Pseudomonas, Acinetobacter and Flavobacterium previously isolated from aquatic environment has a beneficial impact on survival of eggs and larvae of Clarias gariepinus. The hatching rate and larval survival increased with increasing bacterial load up to $10^{8}$ cells $/ \mathrm{ml}$, the highest dose employed. Therefore, further investigations are needed to demonstrate the optimal and threshold doses.

\section{ACKNOWLEDGEMENTS}

The authors wish to acknowledge the assistance of the management and staff of African Regional Aquaculture centre (ARAC) Aluu, Port-Harcourt, during the course of the experiments.

\section{REFERENCES}

ABDELHAMID, A. M. Recent trends in fish culture. Alexandria: New University office, 2009.

BERGH, $\varnothing$.; HJELMERT, A. Antibacterial treatment of eggs of halibut (Hippoglossus hippoglossus L.). ICES report, v. 39, 1990.

DELINCE, G. A.; CAMPBELL, D.; JANSEN, J. A. L.; KUTTY, M. N. Seed production. Port-Harcourt : African Regional Aquaculture Centre (ARAC), Aluu, 1987.

GATESOUPE, F. J. The use of probiotics in fish hatcheries: Results and prospect. ICES report, v. 37, 1991.

GEOVANNY, G. R.; LUIS, B. J.; SHEN, M. A. Probiotics as control agents in aquaculture. J. Ocean Univ. China, v. 6, p. 76-79, 2007.

http://dx.doi.org/10.1007/s11802-007-0076-8 
ARIOLE, C. N.; OKPOKWASILI, G. C. The effect of indigenous probiotics on egg hatchability and larval viability of Clarias gariepinus. Ambi-Agua, Taubaté, v. 7, n. 1, p. 81-88, 2012. (http://dx.doi.org/10.4136/ambi-agua.712)

GODA, A. M. A. S.; El -HAROUN, E. R.; CHOWDHURY, M. A. K. Effects of totally or partially replacing of fish meal by alternative protein sources on growth of Africa catfish Clarias gariepinus (Burchell, 1822) reared in concrete tanks. Aquacult. Res. v. 38, p. 279-287, 2007. http://dx.doi.org/10.1111/j.1365-2109.2007.01663.x

HANSEN, G. H.; STR $\varnothing$ M, E.; OLAFSEN, J. A. Effects of deferent holding regimens on the intestinal microflora of herring (Clupea harengus) larvae. Appl. Environ. Microbiol. v. 58, p. 461-470, 1992.

KIM, S.; NONAKA, L.; SUZUKI, S. Occurrence of tetracycline resistance genes tet (M) and tet $(\mathrm{S})$ in bacteria from marine aquaculture sites. FEMS Microbial. Lett. v. 237, p. 147-156, 2004. http://dx.doi.org/10.1111/j.1574-6968.2004.tb09690.x

LEIN, I.; GULBRANDSEN, J.; HOLMEFJORD, I.; REFSTIE, T.; BOLLA, S.; OLSEN, Y. et al. Progress in larviculture of the Atlantic halibut Hippoglossus hippoglossus. Med. Fac. Landbouww. Univ. Gent., v. 57, n. 46, p. 2099-2110, 1992.

MOLOKWU, C. N.; OKPOKWASILI, G. C. Microbial flora of Clarias gariepinus in the early stages of development. Tropical Freshwater Biology, v. 11, p. 91-100, 2002.

OLAFSEN, J. A. Interactions between hosts and bacteria aquaculture. In: US-EC WORKSHOP ON MARINE MICROORGANISMS: RESEARCH ISSUES FOR BIOTECHNOLOGY, 1998, Brussels. Proceedings... Brussels: European Commission, 1998. p. 127-145.

OSMAN, A. G. M.; WUERTZ, S.; MEKKAWY, I. A. A.; EXNER, H.; KIRSCHBAUM, F. Embryo -toxic effects of lead nitrate of the African catfish Clarias gariepinus (Brurchell 1822). J. Ichthyol, v. 23, p. 48-58, 2007.

SAHU, M. K.; SWARNAKUMAR, N. S.; SIVAKUMAR, K.; THANGARADJOU, T.; KANNAN, L. Probiotics in aquaculture: Importance and future perspectives. Indian J. Microbiol. v. 48, p. 299 -308, 2008. http://dx.doi.org/10.1007/s12088-008-0024-3

SALVESEN, I.; JØRGENSEN, L.; VADSTEIN, O. Evaluation of four chemicals for surface disinfection of marine fish eggs. European Aquaculture Society, Special Publication, n. 15, p. 406-408, 1991.

SMITH, P.; HINEY, M. P.; SAMUELSEN, O.B. Bacterial resistance to antimicrobial agents used in fish farming: a critical evaluation of method and meaning. Annu. Rev. Fish. Dis. v. 4, p. 273-313, 1994. http://dx.doi.org/10.1016/09598030(94)90032-9

SØRUM, H. Antimicrobial drug resitance in fish pathogens. In: AARESRUP, F. M. (Ed.). Antimicrobial resistance in bacteria of animal origin. Washington DC.: ASM Press, 2006. p. 213-238.

VADSTEIN, O.; ØIE, G.; OLSEN, Y.; SALVESEN, I.; SKJERMO, J.; SKJA K-BRAEK, G. A. Strategy to obtain microbial control during larval development of marine fish. In: REINERTSEN, H.; DAHLE, L. A.; JØRGENSEN, L.; TVINNEREIM, K. (Eds.). Fish farming technology. Rotterdam: Balkema, 1993. p. 69-75.

WORLD HEALTH ORGANIZATION - WHO. Joint FAO/NACA/WHO studying group on food safety issues associated with products from aquaculture. Technical Report Series, n. 883, 1999. 
ARIOLE, C. N.; OKPOKWASILI, G. C. The effect of indigenous probiotics on egg hatchability and larval viability of Clarias gariepinus. Ambi-Agua, Taubaté, v. 7, n. 1, p. 81-88, 2012. (http://dx.doi.org/10.4136/ambi-agua.712)

WORLD HEALTH ORGANIZATION - WHO. Report of a Joint FAO/OIE/WHO expert consultation on antimicrobial use in aquaculture and antimicrobial resistance: Seoul, Republic of Korea, 13-16 June, 2006. Available in: <http://www.who.int/topics/foodborne_diseases/aquaculture_rep_13_16june2006\%2 0.pdf>. Access in: 23 Feb. 2011. 


ISSN = 1980-993X - doi:10.4136/1980-993X
www.ambi-agua.net
E-mail: ambi-agua@agro.unitau.br
Tel.: (12) 3625-4212

\title{
O estudo das unidades de paisagem do bioma Pantanal
}

(http://dx.doi.org/10.4136/ambi-agua.826)

\author{
Gabriel Pereira $^{1,3}$; Eduardo Salinas Chávez ${ }^{2}$ : Maria Elisa Siqueira Silva ${ }^{3}$ \\ ${ }^{1}$ Instituto Nacional de Pesquisas Espaciais - DSR, INPE - Brasil \\ e-mail: gabriel@dsr.inpe.br \\ ${ }^{2}$ Universidad de la Habana - Cuba. \\ e-mail: esalinas@geo.uh.cu \\ ${ }^{3}$ Universidade de São Paulo - FFLCH, USP - Brasil \\ e-mail: gabrielpereira@usp.br; elisasiq@usp.br
}

\section{RESUMO}

A observação geoecológica da paisagem permite a análise da fragmentação dos geossistemas em pequenas áreas ou mesmo um diagnóstico de um determinado ambiente ou bioma. Esta abordagem geossistêmica permite alcançar um nível superior de integração dos elementos que compõe o meio, abrangendo a análise da interação e interdependência dos elementos ambientais e sociais. O presente estudo teve como objetivo principal elaborar um mapa de unidades de paisagem e um modelo de ocupação e uso para o Bioma Pantanal, utilizando os dados provenientes do Instituto Brasileiro de Geografia e Estatística (IBGE) correspondentes às informações de unidades morfométricas de relevo, geologia, solos e potencial agrícola; o mapa de uso e cobertura da terra desenvolvido pela Empresa Brasileira de Pesquisa Agropecuária (EMBRAPA) e os mapas de áreas alagadas do bioma Pantanal e de variabilidade espacial das inundações. A partir do cruzamento entre as variáveis altimetria, declividade, mapa de variabilidade espacial e geologia, foram identificadas 16 unidades de paisagem. Ainda, a análise da vulnerabilidade ambiental das unidades de paisagem do Bioma Pantanal aos diferentes tipos de fitofisionomias, unidades morfométricas e solos mostrou que grande parte do Pantanal apresenta uma média fragilidade ambiental, localizada principalmente na região de deposição aluvial do leque do Rio Taquari e em planícies não inundáveis com altitude entre 50 e 250 metros.

Palavras-chave: Pantanal; estudo da paisagem; inundações periódicas.

\section{The study of landscape units in Pantanal biome}

\begin{abstract}
The geoecological landscape observation allows the analysis of geosystems fragmentation in small areas or a diagnosis of a particular environment or biome. This geosystemic approach permits the integration of elements that constitutes the environment, allowing the interaction and interdependence analysis of social and ecological elements. The main goal of this work was to elaborate a map of landscape units and a territorial planning for Pantanal biome, using data generated by the Brazilian Institute of Geography and Statistics (IBGE) corresponding to morphometric relief units, geology, soils and agricultural capability; the land cover and land use map developed by the Brazilian Agricultural Research Corporation (EMBRAPA) and the maps of flooded areas and spatial variability of the Pantanal biome. From the crosstab between altitude, slope, spatial variability map and geology we identified 16 landscape units.
\end{abstract}


Additionally, the analysis of Pantanal biome environmental vulnerability of the landscape units considering different types of vegetation, topography and soils units showed that Pantanal has an intermediate environmental fragility, located mainly in the alluvial deposition areas of the Taquari river and in flood plains with altitude between 50 and 250 meters.

Keywords: Pantanal; landscape; periodic flooding regime.

\section{INTRODUÇÃO}

Anualmente vastas extensões da superfície terrestre são submetidas a processos de degradação ambiental, ocasionando, desta forma, alterações significativas no uso e cobertura da terra. No Brasil, as modificações das fisionomias naturais em áreas antrópicas estão relacionadas com a constante expansão agrícola e pecuária. Consequentemente, o Pantanal, localizado em uma faixa de contato e de grande interação entre ecossistemas terrestres e aquáticos, é considerado um espaço de tensão ecológica e de grande importância socioeconômica.

O Pantanal é uma das maiores planícies sujeitas a inundações periódicas do globo. Localizado na região central da América do Sul, está localizado principalmente nas áreas dos Estados brasileiros do Mato Grosso e Mato Grosso do Sul, na Bolívia e no Paraguai. Este bioma possui fronteira com a Floresta Amazônica, ao norte, e com o platô do Brasil central, a leste, e ocupa aproximadamente $160.000 \mathrm{~km}^{2}$ do território brasileiro. As principais feições fitoecológicas presentes são compostas pela Savana Arborizada, Savana Florestada, Savana Gramíneo-lenhosa, Pastagem e Floresta Estacional Semi-decidual Aluvial (Brasil, 2010).

Localizado na bacia hidrográfica do Alto Paraguai, o bioma Pantanal é caracterizado por apresentar baixos valores hipsométricos com pequenas variações no gradiente topográfico, (Figura 1), e por uma ampla área de planícies que alagam durante a estação chuvosa, porém, sendo comum encontrar cordões arenosos que não são afetados pelas grandes inundações (Assine, 2005). Nestas planícies alagáveis, é comum a ocorrência de feições geomorfológicas de erosão e deposição que constituem a paisagem pantaneira. Entre os principais processos geomorfológicos, podem-se citar as deposições aluviais e lacustres atuais, assim como deposições aluviais antigas e paisagens formadas por processos eólicos (Assine e Soares, 2004).

O regime pluviométrico no pantanal apresenta duas estações bem definidas: uma chuvosa que ocorre entre os meses de outubro e março e outra seca, entre abril e setembro. Segundo a classificação de Köppen, o Bioma Pantanal está inserido no grupo de Clima tropical com estação seca ou clima de savana (Aw) e exibe temperaturas médias mensais superiores a $18^{\circ} \mathrm{C}$ com um dos meses com precipitação média inferior a $60 \mathrm{~mm}$. Entre os principais mecanismos de precipitação destacam-se as chuvas convectivas, ocasionadas pelo aquecimento da superfície durante o dia.

No Pantanal Brasileiro, o ciclo de alagamento anual abrange, segundo Cardozo et al. (2010), $26 \pm 7 \%$ da área total do bioma $\left(42.700 \pm 11.719 \mathrm{~km}^{2}\right)$. O efeito da mudança de cobertura atua significativamente nessa dinâmica alterando o balanço de energia, a temperatura da superfície e do ar e, consequentemente, o ciclo hidrológico regional (Pereira et al., 2010b). Tradicionalmente, os recursos naturais (bióticos e abióticos) podem ser classificados em renováveis e não renováveis, dependendo de sua taxa de regeneração no tempo e de sua utilização. Desta forma, a exploração destes recursos devem ser embasados em inventários ambientais e em zoneamentos econômico-ecológicos, onde o principal objetivo é permitir um melhor aproveitamento e gerenciamento do meio ambiente. Para atingir tal objetivo, a cartografia digital e o sensoriamento remoto apresentam-se como uma alternativa eficaz, pois essas técnicas permitem detectar, localizar e representar de maneira eficiente os recursos naturais existentes em determinada região e promover a organização do espaço (Priego et al., 2008). 
A visão geoecológica da paisagem permite estudar desde a fragmentação dos objetos em pequenas áreas até a análise sistêmica de um dado ambiente ou bioma. Esta abordagem permite alcançar um nível superior de integração dos elementos que compõe o meio-ambiente, incluindo a análise da interação e interdependência dos elementos sociais e ambientais. O estudo da paisagem ainda pode originar ordenamentos territoriais para determinadas regiões ou áreas com base nos seus atributos físicos e sociais.

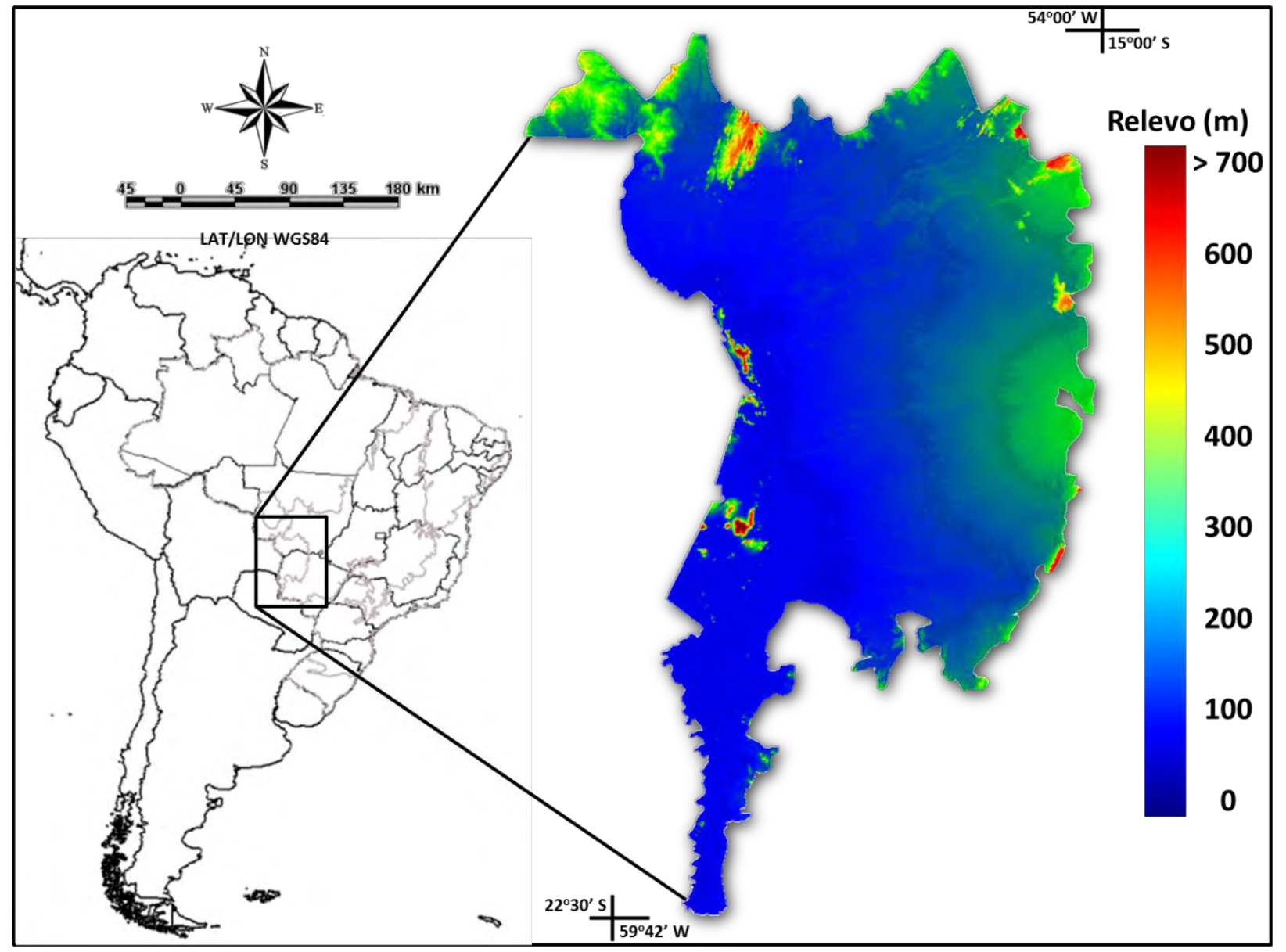

Figura 1. Localização da área de estudo.

Todavia, segundo Salinas e Middleton (1998), para propor um ordenamento territorial e analisar a sustentabilidade de diferentes regiões, torna-se necessário o conhecimento prévio dos diferentes elementos que formam a paisagem como, por exemplo, as condições climáticas, as características do relevo, as potencialidades dos solos para os diferentes usos, os distintos processos geomorfológicos que atuaram na superfície terrestre e determinaram as relações ecogeográficas, além das estruturas fitoecológicas presentes na área de estudo. Portanto, o auxílio da ecologia da paisagem, que possui um caráter holístico, apresenta-se como uma ferramenta poderosa para integrar os elementos físicos, bióticos e antrópicos que atuam no meioambiente de maneira integrada (Salinas e Quintela, 2000).

Neste contexto, o presente trabalho tem como objetivo principal analisar os principais elementos que formam a paisagem do Bioma Pantanal. Desta forma, devem-se analisar as diferentes componentes que atuam na área de estudo, integrando mapas de hipsometria, declividade, geologia, aptidão ao uso agrícola, unidades morfométricas e informações de uso e cobertura da terra para obter o mapa de Paisagem e propor um uso sustentável para a área em questão. 


\section{MATERIAIS E MÉTODO}

\subsection{Valores altimétricos e declividade}

Para a obtenção dos valores altimétricos da área de estudo utilizou-se o modelo digital de terreno (MDT) derivado de imagens interferométricas do Shuttle Radar Topography Mission (SRTM). Este dado possui como características principais a resolução espacial de 90 metros e cobertura global. Ressalta-se que os valores altimétricos foram adquiridos durante a campanha de 11 dias do ano de 2000 a partir de um sistema-radar de abertura sintética que operava nas bandas $\mathrm{C}$ e $\mathrm{X}$ na região do espectro eletromagnético referente às micro-ondas. Os dados globais de MDT derivados pelo SRTM possuem a acurácia de aproximadamente 16 metros, porém, podem-se obter erros de aproximadamente 6 metros para escalas locais, que variam de 50 a 100 km (Rabus et al., 2003).

A partir dos dados de MDT, estimou-se a declividade de cada ponto de grade do modelo. Esta etapa foi realizada no SPRING, um programa de gerenciamento e processamento de dados geográficos, desenvolvido pelo Instituto Nacional de Pesquisas Espaciais (INPE). A declividade pode ser definida como a medida de inclinação de determinado ponto do MDT em relação ao plano horizontal. De uma maneira geral, a declividade pode ser estimada a partir da equação (SPRING, 2005):

$$
\text { Declividade }=\arctan \sqrt{\frac{\partial z^{2}}{\partial x^{2}}+\frac{\partial z^{2}}{\partial y^{2}}}
$$

em que: $\mathrm{z}$ representa o valor altimétricos, $\mathrm{x}$ e y as coordenadas do ponto.

\subsection{Informações Ambientais}

Para delimitar as unidades morfológicas do Pantanal, utilizaram-se dados vetoriais provenientes do Instituto Brasileiro de Geografia e Estatística - IBGE (2011) correspondentes às informações de: a) unidades morfométricas de relevo, que apresenta as características geomorfológicas e sua relação com o domínio morfoestrutural do bioma Pantanal; b) geologia; c) solos; e d) potencial agrícola, que relaciona as componentes físicas como características morfológicas, topografia e fertilidade.

O mapa de uso e cobertura da terra utilizado neste trabalho foi originado pela EMBRAPA (2004). Este mapa foi confeccionado a partir da aplicação de segmentação (critério de crescimento de região) em imagens do sensor Thematic Mapper (TM) do satélite Landsat 5 e interpretação visual dos segmentos gerados pelo processamento da imagem. Embora o mapa tenha sido confeccionado em diversas classes de fisionomias vegetais e usos, optou-se por agrupá-lo nas classes Ecótono, Formações Pioneiras, Formações Florestais, Áreas Urbanas, Hidrografia, Agricultura/Pecuária e Savana. Ressalta-se que o mapa das áreas alagadas do bioma Pantanal, para os anos de 2000 a junho de 2010, foram extraídos de Cardozo et al. (2010), e o mapa da variabilidade espacial das inundações, obtidos a partir da realização por componentes principais, foi extraído de Pereira et al. (2010a).

\subsection{Metodologia}

Os dados vetoriais e matriciais dos produtos acima mencionados foram inseridos no SPRING. Desta forma, alguns procedimentos (transformação e compatibilização de diferentes dados, extração de atributos, entre outros) foram realizados na Linguagem Espacial para Geoprocessamento Algébrico (LEGAL). A Figura 2 mostra o fluxograma da metodologia adotada para se obter o mapa de Paisagem do Bioma Pantanal, assim como, o modelo de ocupação e uso para o Bioma Pantanal estimado a partir das unidades morfométricas, geologia, uso e cobertura da terra, potencial agrícola e solos. 
A primeira etapa da metodologia consistiu em agrupar todos os dados necessários para o estudo (I) e posterior extração de atributos e conversões para o formato matricial (II) e (III). A quarta etapa (IV) consistiu no cruzamento de diversos planos de informação para originar os mapas de unidades morfométricas e, decorrente deste, o mapa de unidades de paisagem. Esta etapa consistiu no cruzamento de diversas informações, como, por exemplo, os dados de variabilidade espacial das áreas alagadas, altimetria, declividade, unidades de relevo, geologia, solos e uso/cobertura vegetal (Ramon et al., 2009).

A Etapa V constitui na atribuição do grau de fragilidade para cada componente do Bioma Pantanal, relacionados com o tipo de vegetação, relevo, declividade e solo predominantes em cada unidade de paisagem. Desta forma, o mapa final originou-se da ponderação das fragilidades de cada componente (Muito Alta, Alta, Média, Baixa e Muito Baixa). A última etapa (VI) referese ao cruzamento de todos os elementos que constituem o Bioma Pantanal. Nesta etapa, os mapas de unidades morfométricas, unidades de paisagem, fragilidade, uso e cobertura do solo e potencial agrícola foram ponderados de acordo com a aptidão para a conservação, urbanização, agricultura/pecuária, indicando ao final o potencial primário e secundário, originando o modelo de ocupação e uso (Salinas, 2008).

(I)

(II)

(III)

(IV)

(V)

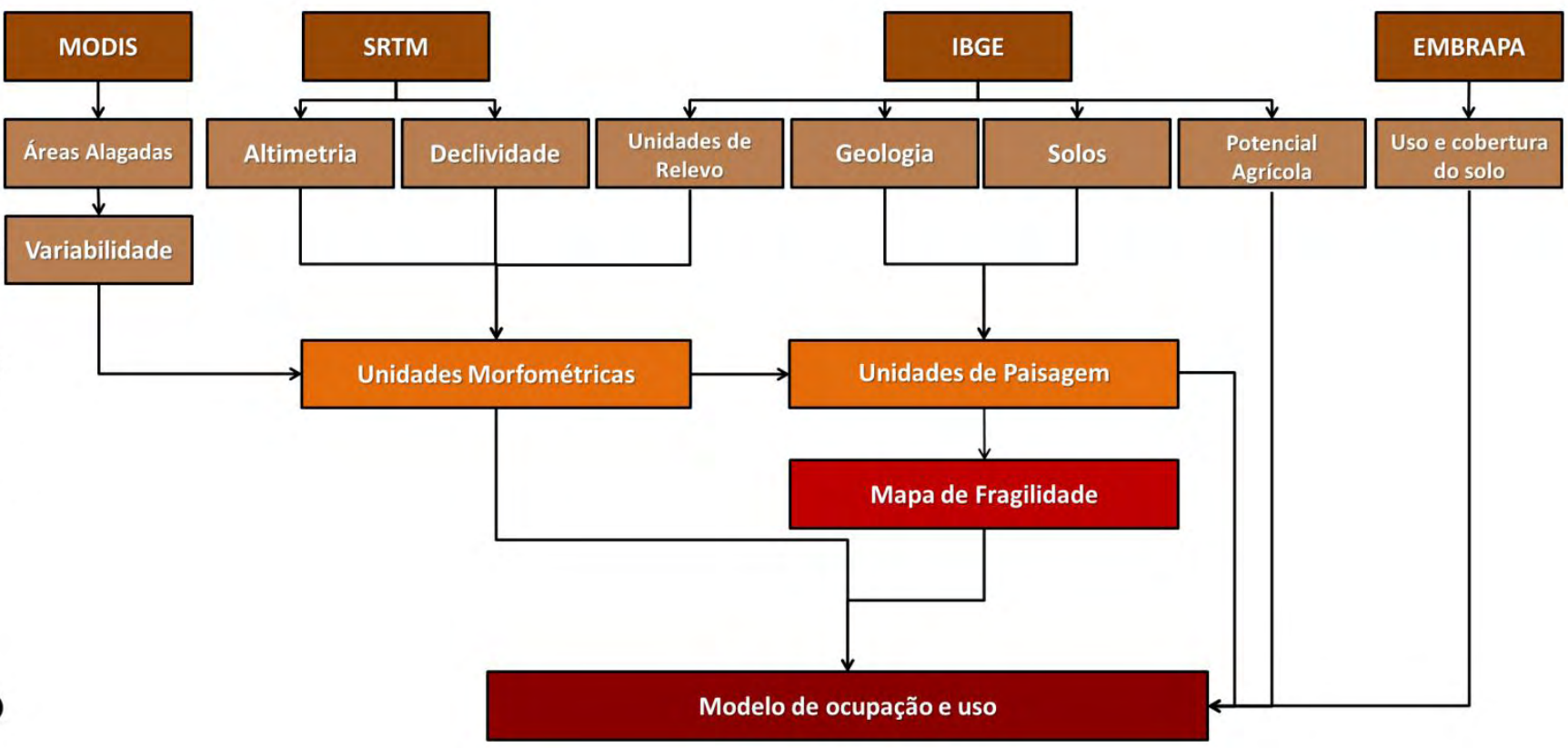

Figura 2. Fluxograma da metodologia.

\section{RESULTADOS E DISCUSSÃO}

De acordo com Cardozo et al. (2010), o ciclo de alagamento anual no Bioma Pantanal abrange $42.700 \pm 11.719 \mathrm{~km}^{2}$. Segundo estes autores, as maiores áreas alagadas ocorreram no ano de 2000, seguidas do ano de 2007, 2006 e 2008, possuindo $58.490 \mathrm{~km}^{2}, 55.250 \mathrm{~km}^{2}, 54.490$ $\mathrm{km}^{2}$ e $54.320 \mathrm{~km}^{2}$, correspondendo a 36,55\%, 34,53\%, 34,05\% e 33,95\% da área total, respectivamente. Pode-se dizer que o Bioma Pantanal apresenta grande dinâmica intra e interanual, fato observado pela variação das inundações que ocorreram por todo o bioma entre os anos de menor e maior alagamento, com diferenças superiores a 57\%. 
No Pantanal, o regime das inundações determina os principais processos bióticos e abióticos, bem como as composições específicas das unidades da paisagem (Adamoli, 1995). Todo o bioma é influenciado pelas alterações no regime de inundações, causando mudanças na cobertura vegetal.

A Figura 3 mostra as segundas componentes principais (PC2) geradas a partir dos dados de NDVI (índice de vegetação por diferença normalizada) e reflectância NIR/SWIR, respectivamente, provenientes da série temporal disponibilizada pelos dados do sensor MODIS (Justice et al., 2002) a bordo do satélite Terra. Nestas componentes podemos visualizar a dinâmica interanual da vegetação (Figura 3a) e a variação das áreas alagadas no decorrer dos anos (Figura 3b). Percebe-se uma diversificada dinâmica ocasionada pela época chuvosa e pela resposta da vegetação ao stress hídrico que ocorre na vegetação do pantanal. Na Figura 3b as regiões com tons de vermelho são cobertas por lâminas d'água na estação chuvosa, resultando em lagos temporários extensos, que inundam a vegetação existente. Após a inundação a vegetação volta a ficar exposta, ocupando a área.
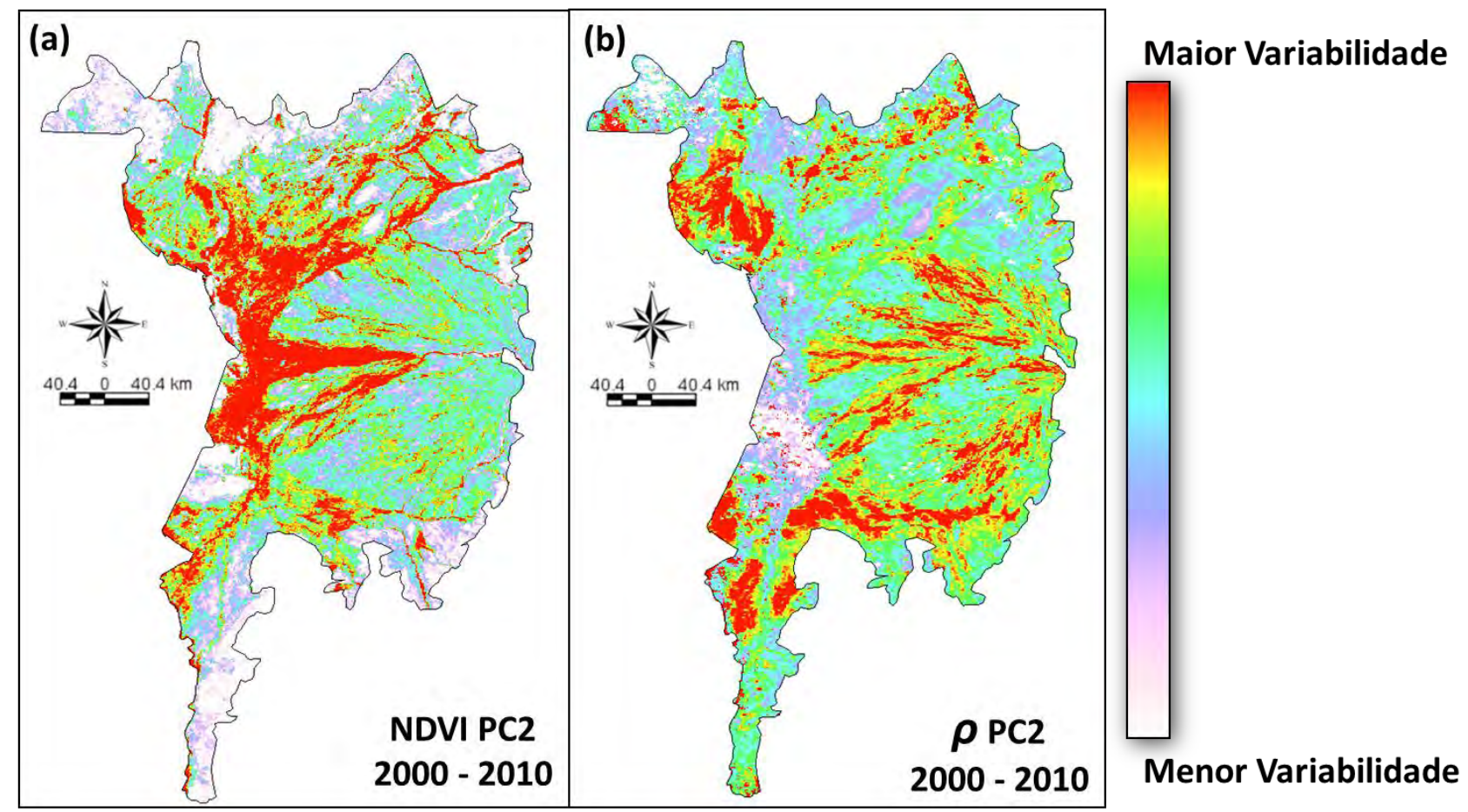

Figura 3. Mapa da variabilidade obtida a partir da componente principal CP2 das imagens NDVI (à esquerda) e de reflectância ( $\rho)$ NIR/SWIR (à direita).

Fonte. Adaptado de Pereira et al. (2010a).

A Figura 4 mostra o mapa hipsométrico, o mapa de declividade e as unidades morfométricas de relevo para a área de estudo. Para o Bioma Pantanal, aproximadamente $83 \%$ da área possui plana a baixa declividade (0-2.5\%) e altitude entre 50-150 metros. Além disto, $14 \%$ da área de estudo apresentam baixa a média declividade (2.5-12\%) e altitude predominante entre 50-150 metros, sendo que apenas $3 \%$ da área apresentam um relevo com média a alta declividade (12$50 \%$ ) ou declividade muito alta $(>50 \%)$. Desta forma, optou-se por separar as unidades morfométricas em quatro grandes regiões, adotando-se a nomenclatura oficial do Instituto Brasileiro de Geografia e Estatística (IBGE). A Figura 4c mostra a distribuição destas unidades: em (1) a classe correspondente à Depressão dos Altos Rios Paraguai/Guaporé; em (2) os Pantanais Mato-grossenses, referentes à planície de inundação; em (3) o Planalto dos Guimarães, 
com topos suaves e moderados; e (4) referentes aos Planaltos e Serras dos Altos Rios Paraguai/Guaporé.
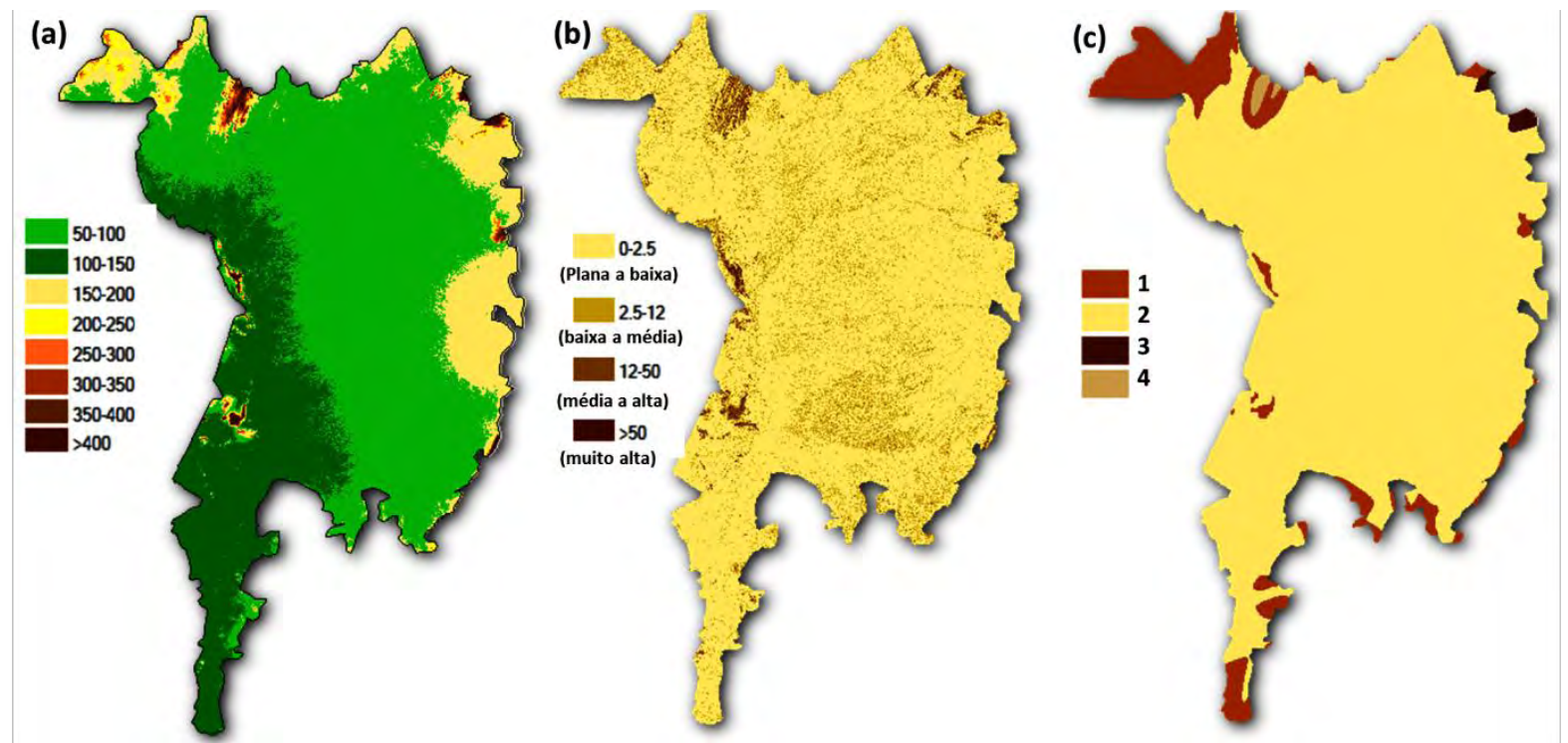

Figura 4. (a) Mapa hipsométrico extraído do SRTM; (b) Mapa da declividade; e (c) Mapa de unidades morfométricas provenientes do IBGE (2011).

A Figura 5a mostra o mapa das unidades morfométricas, com o acréscimo das áreas de alta variabilidade para o Bioma Pantanal, obtido a partir da análise por componentes principais da região do espectro eletromagnético referente ao NIR/SWIR (como visualizado na Figura 3b). Desta forma, as cinco classes referentes às unidades morfométricas representam: (1) Planícies aluviais não inundáveis (50-100 m) de plana a média declividade (0-12\%); (2) Planícies Aluviais inundáveis $(50-100 \mathrm{~m})$ de plana a baixa declividade (0-2,5\%); (3) Depressão dos Altos Rios Paraguai/Guaporé $(150-250 \mathrm{~m})$ com baixa a média declividade (2,5-12\%); (4) Planalto dos Guimarães (250-600 m) com declividade muito alta (>50\%); e (5) Planaltos e Serras dos Altos Rios Paraguai/Guaporé $(>400 \mathrm{~m})$ com declividade muito alta $(>50 \%)$. A Tabela 1 mostra as unidades geológicas para da área de estudo.

(a)

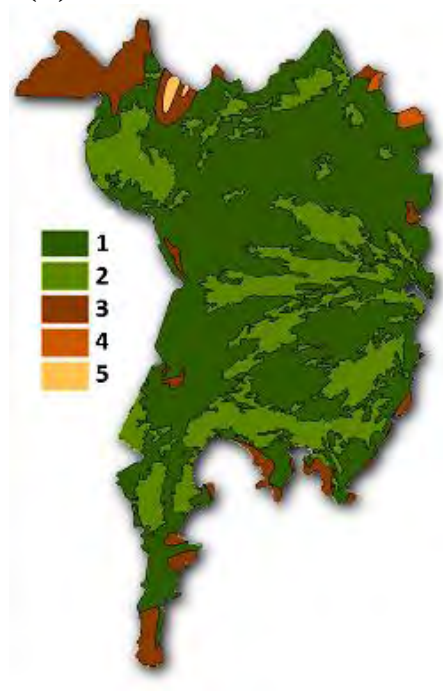

(b)

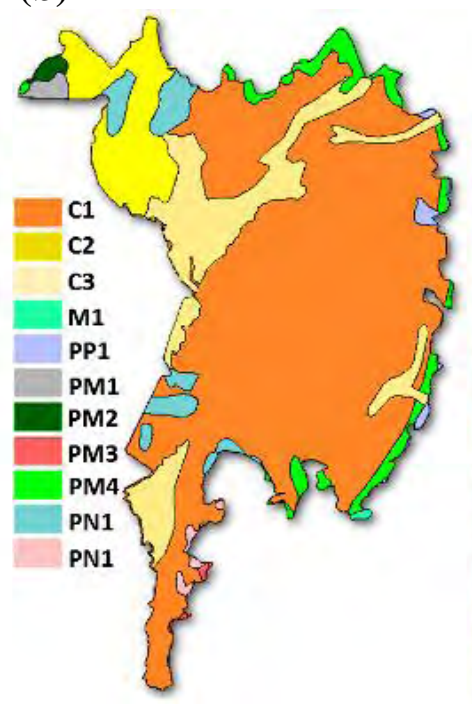

(c)

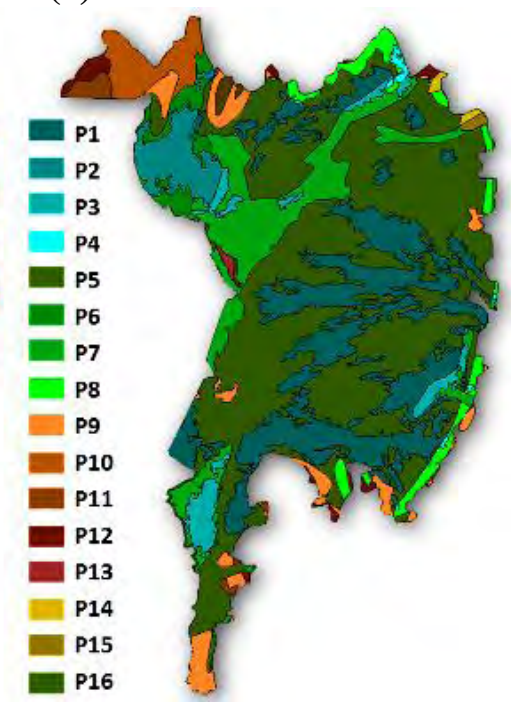

Figura 5. (a) Mapa de unidades morfométricas com a área de alta variabilidade; (b) Mapa da geologia para o Bioma Pantanal extraído de IBGE (2011); e (c) Mapa das unidades de Paisagem para o Bioma Pantanal. 
A partir do mapa de unidades morfométricas com áreas de alta variabilidade e o mapa de geologia obtido a partir do IGBE, originou-se o mapa de unidades de Paisagem. A Figura 5b representa as classes geológicas para a área de estudo, em que cada código na legenda representa:

Tabela 1. Unidades geológicas para a área de estudo.

\begin{tabular}{|c|c|}
\hline $\mathrm{C} 1$ & $\begin{array}{l}\text { Sedimentos arenosos e argilosos, podendo incluir níveis carbonosos do } \\
\text { Terciário. }\end{array}$ \\
\hline $\mathrm{C} 2$ & Sedimento arenoso do Pleistoceno. \\
\hline $\mathrm{C} 3$ & Sedimentos relativos à aluviões atuais e terraços mais antigos do Holoceno. \\
\hline PN1 & Sedimentos arenosos e argilo-carbonáticos de grau metamórfico fraco a médio. \\
\hline PM1 & $\begin{array}{l}\text { Rochas gnáissicas de origem magmática e/ou sedimentar de médio grau } \\
\text { metamórfico. }\end{array}$ \\
\hline PM2 & $\begin{array}{l}\text { Sequências sedimentares e vulcanossedimentares de grau metamórfico baixo a } \\
\text { médio. }\end{array}$ \\
\hline PM3 & $\begin{array}{l}\text { Associações de rochas de origem vulcânica e plutônica e composição félsica até } \\
\text { máfica. }\end{array}$ \\
\hline PM4 & $\begin{array}{l}\text { Sequências sedimentares, principalmente psamíticas, podendo incluir } \\
\text { piroclásticas. }\end{array}$ \\
\hline M1 & Sedimentos argilosos, arenosos e cascalhos. \\
\hline PP1 & $\begin{array}{l}\text { Rochas gnáissicas de origem magmática e/ou sedimentar de médio grau } \\
\text { metamórfico e rochas graníticas desenvolvidas durante o tectonismo. }\end{array}$ \\
\hline
\end{tabular}

A Figura 5c mostra o mapa das unidades de Paisagem obtidas a partir do cruzamento entre as variáveis altimetria, declividade, mapa de variabilidade espacial e geologia. Para a área de estudo, foram identificadas 16 unidades de paisagem (Tabela 2). 
PEREIRA, G.; CHÁVEZ, E. S.; SILVA, M. E. S. O estudo das unidades de paisagem do bioma Pantanal. AmbiAgua, Taubaté, v. 7, n. 1, p. 89-103, 2012. (http://dx.doi.org/10.4136/ambi-agua.826)

Tabela 2. Unidades de Paisagem para o Bioma Pantanal.

\begin{tabular}{|c|c|}
\hline P1 & $\begin{array}{l}\text { Planície aluvial sujeita a inundações periódicas }(50-150 \mathrm{~m}) \text { com predominância de declividade plana a } \\
\text { baixa }(0-2,5 \%) \text { com sedimentos arenosos e argilosos, podendo incluir sedimentos argilo-carbonáticos e } \\
\text { cascalhos, com solo predominantemente do tipo Espodossolo Ferrocárbico, com Savana/Pastagem. }\end{array}$ \\
\hline $\mathbf{P 2}$ & $\begin{array}{l}\text { Planície aluvial sujeita a inundações periódicas }(50-150 \mathrm{~m}) \text { com predominância de declividade plana a } \\
\text { baixa }(0-2,5 \%) \text { com sedimentos arenosos do Pleistoceno, com solo predominantemente do tipo } \\
\text { Plintossolo Háplico, com Savana/Savana Lenhosa. }\end{array}$ \\
\hline P3 & $\begin{array}{l}\text { Planície aluvial sujeita a inundações periódicas }(50-150 \mathrm{~m}) \text { com predominância de declividade plana a } \\
\text { baixa }(0-2.5 \%) \text { com sedimentos relativo à aluviões atuais e terraços mais antigos do Holoceno, com } \\
\text { solo predominantemente do tipo Planossolo Hidromórfico, com Savana/Savana Lenhosa. }\end{array}$ \\
\hline P4 & $\begin{array}{l}\text { Planície aluvial sujeita a inundações periódicas }(50-150 \mathrm{~m}) \text { com predominância de baixa a média } \\
\text { declividade }(2,5-12 \%) \text { com sequências sedimentares, principalmente psamíticas, podendo incluir } \\
\text { piroclásticas, com solo predominantemente do tipo Plintossolo Háplico, com Savana/ Floresta } \\
\text { Estacional. }\end{array}$ \\
\hline P5 & $\begin{array}{l}\text { Planície aluvial não inundável }(50-150 \mathrm{~m}) \text { com predominância de declividade plana a baixa }(0-2,5 \%) \\
\text { com sedimentos arenosos e argilosos, podendo incluir sedimentos argilo-carbonáticos e cascalhos, com } \\
\text { solo predominantemente do tipo Espodossolo Ferrocárbico, com Savana/Floresta Estacional. }\end{array}$ \\
\hline P6 & $\begin{array}{l}\text { Planície aluvial não inundável }(50-150 \mathrm{~m}) \text { com predominância de declividade plana a baixa }(0-2,5 \%) \\
\text { com sedimentos arenosos do Pleistoceno, com solo predominantemente do tipo Plintossolo Háplico, } \\
\text { com Savana/ Floresta Estacional. }\end{array}$ \\
\hline P7 & $\begin{array}{l}\text { Planície aluvial não inundável }(50-150 \mathrm{~m}) \text { com predominância de declividade plana a baixa }(0-2,5 \%) \\
\text { com sedimentos relativo à aluviões atuais e terraços mais antigos do Holoceno, podendo incluir } \\
\text { sequências sedimentares e vulcanossedimentares de grau metamórfico baixo a médio, com solo } \\
\text { predominantemente do tipo Gleissolo Háplico, com Floresta Estacional /Savana Lenhosa. }\end{array}$ \\
\hline P8 & $\begin{array}{l}\text { Planície aluvial não inundável }(50-150 \mathrm{~m}) \text { com predominância de baixa a média declividade }(2,5-12 \%) \\
\text { com sequências sedimentares, principalmente psamíticas, podendo incluir piroclásticas, com solo } \\
\text { predominantemente do tipo Argissolo Vermelho-Amarelo, com Savana/Savana Lenhosa. }\end{array}$ \\
\hline P9 & $\begin{array}{l}\text { Depressão dos Altos Rios Paraguai/Guaporé }(150-250 \mathrm{~m}) \text { com predominância de baixa a média } \\
\text { declividade }(2,5-12 \%) \text { com sedimentos arenosos e argilosos, podendo incluir sedimentos argilo- } \\
\text { carbonáticos e cascalhos, com solo predominantemente do tipo Argissolo Vermelho-Amarelo, com } \\
\text { Savana/Savana Lenhosa. }\end{array}$ \\
\hline P10 & $\begin{array}{l}\text { Depressão dos Altos Rios Paraguai/Guaporé }(150-250 \mathrm{~m}) \text { com predominância de baixa a média } \\
\text { declividade }(2,5-12 \%) \text { com sedimentos arenosos do Pleistoceno, com solo predominantemente do tipo } \\
\text { Argissolo Vermelho-Amarelo, com Savana/Agricultura e Pecuária. }\end{array}$ \\
\hline P11 & $\begin{array}{l}\text { Depressão dos Altos Rios Paraguai/Guaporé }(150-250 \mathrm{~m}) \text { com predominância de baixa a média } \\
\text { declividade }(2,5-12 \%) \text { com rochas gnáissicas de origem magmática e/ou sedimentar de médio grau } \\
\text { metamórfico e rochas graníticas desenvolvidas durante o tectonismo, com solo predominantemente do } \\
\text { tipo Planossolo Háplico, com Savana/Savana Lenhosa. }\end{array}$ \\
\hline P12 & $\begin{array}{l}\text { Depressão dos Altos Rios Paraguai/Guaporé }(150-250 \mathrm{~m}) \text { com predominância de baixa a média } \\
\text { declividade }(2,5-12 \%) \text { com sequências sedimentares/vulcanossedimentares e associações de rochas de } \\
\text { origem vulcânica e plutônica, com solo predominantemente do tipo Argissolo Vermelho-Amarelo, } \\
\text { com Savana/Savana Lenhosa. }\end{array}$ \\
\hline P13 & $\begin{array}{l}\text { Depressão dos Altos Rios Paraguai/Guaporé }(150-250 \mathrm{~m}) \text { com predominância de baixa a média } \\
\text { declividade }(2,5-12 \%) \text { com sedimentos relativos à aluviões atuais e terraços mais antigos do Holoceno, } \\
\text { com solo predominantemente do tipo Argissolo Vermelho-Amarelo, com Savana Lenhosa/Pastagem. }\end{array}$ \\
\hline P14 & $\begin{array}{l}\text { Planalto dos Guimarães }(250-600 \mathrm{~m}) \text { com predominância de muito alta declividade }(>50 \%) \text { com } \\
\text { sedimentos relativos à aluviões atuais e terraços mais antigos do Holoceno, com solo } \\
\text { predominantemente do tipo Argissolo Vermelho-Amarelo, com Savana/Agricultura e Pecuária. }\end{array}$ \\
\hline P15 & $\begin{array}{l}\text { Planalto dos Guimarães }(250-600 \mathrm{~m}) \text { com predominância de muito alta declividade (>50\%) com } \\
\text { sequências sedimentares, podendo incluir sedimentos arenosos e argilosos, com solo } \\
\text { predominantemente do tipo Argissolo Vermelho-Amarelo, com Savana Lenhosa/Savana. }\end{array}$ \\
\hline P16 & $\begin{array}{l}\text { Planaltos e Serras dos Altos Rios Paraguai/Guaporé }(>400 \mathrm{~m}) \text { com muito alta declividade }(>50 \%) \text { com } \\
\text { sedimentos arenosos e argilo-carbonáticos de grau metamórfico fraco a médio, com solo } \\
\text { predominantemente do tipo Argissolo Vermelho-Amarelo, com Savana/Savana Lenhosa. }\end{array}$ \\
\hline
\end{tabular}


A Figura 6a mostra o mapa de fragilidade ambiental para o Bioma Pantanal. Este mapa representa a vulnerabilidade ambiental das unidades de paisagem do Bioma Pantanal aos diferentes tipos de fitofisionomias, unidades morfométricas e solos. Percebe-se que grande parte do Pantanal apresenta uma média fragilidade ambiental, localizada principalmente na região de deposição aluvial do leque do Rio Taquari e em planícies não inundáveis com altitude entre 50 e 250 metros. As áreas de baixa fragilidade ambiental estão localizadas em planícies de deposição aluvial com predominância de plana a baixa declividade (0-2,5\%) com sedimentos relativos a aluviões atuais e terraços mais antigos do Holoceno, com predomínio de Savana/Savana Lenhosa. Além disto, áreas de alta e muito alta fragilidade são compostas por regiões de planícies aluviais e regiões montanhosas com média e alta declividade, compostas principalmente por solos do tipo Planossolo Háplico, Gleissolo Háplico e Argissolo VermelhoAmarelo. A Tabela 3 mostra os valores adotados para estimativa do mapa de fragilidade para o Pantanal.

Tabela 3. Valores adotados para estimativa do mapa de fragilidade para o Pantanal.

\begin{tabular}{|c|c|c|c|c|c|}
\hline & Muito Alta & Alta & Média & Baixa & $\begin{array}{l}\text { Muito } \\
\text { Baixa }\end{array}$ \\
\hline Vegetação & $\begin{array}{l}\text { Floresta } \\
\text { Estacional }\end{array}$ & $\begin{array}{l}\text { Savana Lenhosa } \\
\text { Savana } \\
\text { Arborizada }\end{array}$ & Savana & Gramíneas & $\begin{array}{l}\text { Agricultura } \\
\text { Pecuária }\end{array}$ \\
\hline Relevo & $>400 \mathrm{~m}$ & $350-400 \mathrm{~m}$ & $250-350 \mathrm{~m}$ & $150-250 \mathrm{~m}$ & $50-150 \mathrm{~m}$ \\
\hline Declividade & $>50 \%$ & $12-50 \%$ & $6-12 \%$ & $2,5-6 \%$ & $0-2,5 \%$ \\
\hline Solos & $\begin{array}{l}\text { Planossolo } \\
\text { Háplico e } \\
\text { Planossolo } \\
\text { Hidromórfico }\end{array}$ & $\begin{array}{l}\text { Argissolo } \\
\text { Vermelho- } \\
\text { Amarelo, } \\
\text { Gleissolo Háplico } \\
\text { e Plintossolo } \\
\text { Háplico }\end{array}$ & $\begin{array}{l}\text { Espodossolo } \\
\text { Férrico }\end{array}$ & | ------- & \\
\hline
\end{tabular}

A Figura 6 b mostra o mapa do potencial agrícola estimado pelo IBGE. Este mapa caracteriza o Bioma Pantanal de acordo com as potencialidades para o uso agrícola, utilizando fatores ambientais como fertilidade, topografia, principais limitações e características físicas e morfológicas de cada região. Em geral, o Bioma Pantanal apresenta uma aptidão agrícola desfavorável com aproximadamente $76 \%$ da área total $\left(121.170 \mathrm{~km}^{2}\right)$. Entre as principais limitações ao uso agrícola podem-se citar a alta salinidade, a reduzida profundidade do horizonte A e B, presença de pedregosidade ou rochosidade e a textura arenosa. Estes solos ocorrem basicamente nas planícies e regiões sujeitas a inundações periódicas.

No Pantanal, aproximadamente $12 \%$ da área apresenta um potencial agrícola caracterizado como Restrito a Desfavorável devido principalmente ao excesso de sódio e corresponderem a áreas de inundações periódicas e com restrição de drenagem. 


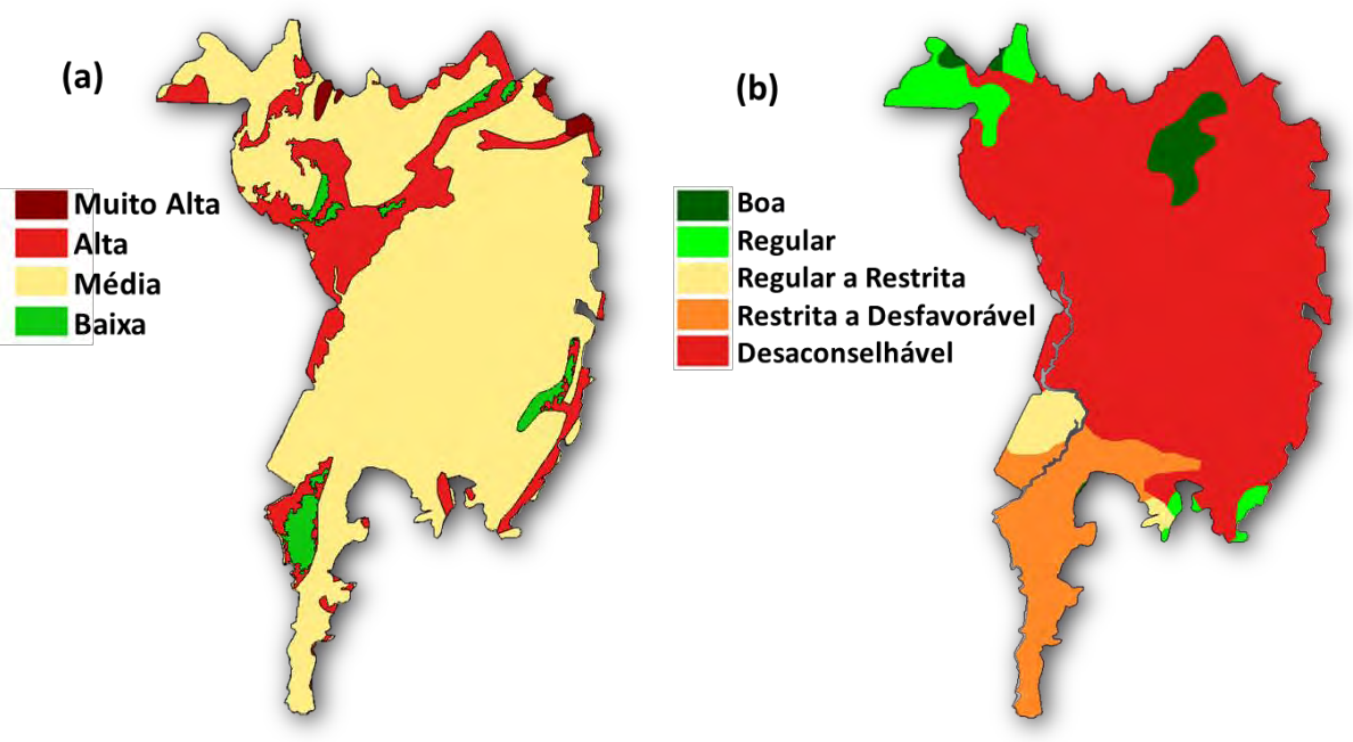

Figura 6.(a) Mapa de fragilidade para o Bioma Pantanal; (b) Mapa de potencial agrícola estimado pelo IBGE (2011).

Ainda, aproximadamente $8 \%$ apresentam uma caracterização considerada Regular a Restrita, estas regiões são caracterizadas por apresentar declives acentuados, pouca profundidade dos horizontes A e B, textura grosseira, baixa disponibilidade de nutrientes e excesso de alumínio. Apenas $4 \%$ de todo o bioma pantaneiro apresenta condições favoráveis para a agricultura com alta fertilidade, características físicas e morfológicas boas e praticamente sem limitações.

A Tabela 4 mostra os cruzamentos entre a altimetria, declividade, solos, vegetação e seus respectivos valores de suscetibilidade adotados para originar o mapa de fragilidade ambiental (Figura 6a). Ainda, pode-se observar a aptidão à conservação ambiental, urbanização e agricultura/pecuária. Estes valores foram adotados para originar a tabela de aptidão primária e secundária, determinando, desta forma, o modelo de ocupação e uso (Figura 7b).

Tabela 4. Valores de suscetibilidade adotados para o mapa de fragilidade, aptidão à conservação, urbanização e agricultura/pecuária e proposta de uso.

\begin{tabular}{|c|c|c|c|c|c|c|c|c|c|c|c|}
\hline \multirow[b]{2}{*}{ Unidade de Paisagem } & \multirow[b]{2}{*}{ Altimetria } & \multirow[b]{2}{*}{ Declividade } & \multirow[b]{2}{*}{ Solo } & \multirow[b]{2}{*}{ Vegetação } & \multirow[b]{2}{*}{ Fragilidade } & \multicolumn{3}{|c|}{ Aptidão } & \multirow[b]{2}{*}{ Aptidão Primária } & \multirow[b]{2}{*}{ Aptidão Secundária } & \multirow[b]{2}{*}{ Proposta de uso } \\
\hline & & & & & & Agric. e Pecuária & Assentamentos & Conservação & & & \\
\hline 1 & Muito Baixa & Baixa & Média & Média & Média & Não-Apto & Não-Apto & Apto & Conservação & $x$ & Conservação \\
\hline 2 & Muito Baixa & Baixa & Alta & Média & Média & Não-Apto & Não-Apto & Apto & Conservação & $x$ & Conservação \\
\hline 3 & Muito Baixa & Muito Baixa & Muito Alta & Média & Baixa & Não-Apto & Não-Apto & Apto & Conservação & $x$ & Conservação \\
\hline 4 & Muito Baixa & Média & Alta & Alta & Alta & Não-Apto & Não-Apto & Apto & Conservação & $x$ & Conservação \\
\hline 5 & Muito Baixa & Baixa & Média & Alta & Média & Não-Apto & Não-Apto & Apto & Conservação & $x$ & Conservação/Urbanização \\
\hline 6 & Muito Baixa & Baixa & Alta & Alta & Alta & Não-Apto & Apto & Apto & Urbanização & Conservação & Urbanização \\
\hline 7 & Muito Baixa & Muito Baixa & Alta & Muito Alta & Alta & Não-Apto & Apto & Apto & Conservação & Urbanização & Conservação \\
\hline 8 & Muito Baixa & Média & Alta & Alta & Alta & Apto & Não-Apto & Apto & Agricultura & Conservação & Conservação \\
\hline 9 & Baixa & Média & Alta & Média & Média & Apto & Não-Apto & Apto & Conservação & Agricultura & Conservação \\
\hline 10 & Baixa & Média & Alta & Baixa & Média & Apto & Não-Apto & Apto & Agricultura & Conservação & Agricultura \\
\hline 11 & Baixa & Média & Muito Alta & Média & Alta & Apto & Não-Apto & Apto & Agricultura & Conservação & Agricultura \\
\hline 12 & Baixa & Média & Alta & Média & Média & Apto & Não-Apto & Apto & Agricultura & Conservação & Agricultura \\
\hline 13 & Média & Muito Alta & Alta & Média & Alta & Não-Apto & Não-Apto & Apto & Conservação & $x$ & Conservação \\
\hline 14 & Muito Alta & Muito Alta & Alta & Alta & Muito Alta & Apto & Nã̃o-Apto & Apto & Conservação & Agricultura & Conservação \\
\hline 15 & Muito Alta & Muito Alta & Alta & Alta & Muito Alta & Apto & Não-Apto & Apto & Conservação & Agricultura & Conservação \\
\hline 16 & Muito Alta & Muito Alta & Alta & Média & Muito Alta & Não-Apto & Não-Apto & Apto & Conservação & $x$ & Conservação \\
\hline
\end{tabular}


A Figura 7a mostra o mapa de uso e cobertura da terra originado pela EMBRAPA (2004).

Pode-se observar que na região do Pantanal, a classe de maior ocorrência é a Savana com $81.773 \mathrm{~km}^{2}$, seguida da classe Ecótono, com $26.000 \mathrm{~km}^{2}$. Na terceira posição encontra-se a classe Pecuária que corresponde a $16.922 \mathrm{~km}^{2}$, seguida pela Savana Estépica com 12.762 km². As classes de menor ocorrência na região são compostas por Floresta Estacional Semi-Decidual $\left(6.453 \mathrm{~km}^{2}\right)$, Formações Pioneiras $\left(6.230 \mathrm{~km}^{2}\right)$, Hidrografia $\left(2.620 \mathrm{~km}^{2}\right)$, Floresta Estacional Decidual $\left(1.518 \mathrm{~km}^{2}\right)$ e Encrave $\left(1.310 \mathrm{~km}^{2}\right)$. As classes restantes foram pouco representativas na área de estudo, possuindo menos de $1000 \mathrm{~km}^{2}$ de extensão.

A Figura 7b mostra o modelo de ocupação e uso sugerido para o Bioma Pantanal. A área de estudo, localizada na porção centro-oeste do Brasil, apresenta quatro patamares bem definidos para o uso e cobertura da terra. O Bioma pantanal possui uma grande área de vegetação nativa, encontrando-se pequenos núcleos habitacionais pela região. Desta forma, com base nas políticas sustentáveis, optou-se por um modelo de desenvolvimento econômico que se baseia nas potencialidades naturais da região, como o ecoturismo e $\mathrm{o}$ turismo de aventura. Consequentemente foram deliberadas, com base nas informações descritas e nas aptidões de cada domínio paisagístico, as áreas potenciais para os seguintes usos: a) as áreas correspondentes à planície aluvial inundável devem ser alvo de uma política ambiental voltada ao turismo ecológico e promovendo a conservação da área em questão; b) as áreas da planície aluvial sem a presença de inundações periódicas e com baixa declividade devem ser voltadas principalmente à conservação, porém, uma política de uso agrícola/pecuária em pequenas unidades pode ser admitida desde que haja uma compensação ambiental; c) as áreas correspondentes à planície aluvial não inundável $(50-150 \mathrm{~m})$ com predominância de declividade plana a baixa $(0-2,5 \%)$ com sedimentos arenosos do Pleistoceno, com solo predominantemente do tipo Plintossolo Háplico devem ser alvo de uma política de planejamento urbano; d) as demais regiões que correspondem a áreas de planalto com solos férteis devem proporcionar a agricultura e pecuária para suprir a demanda regional.

(a)

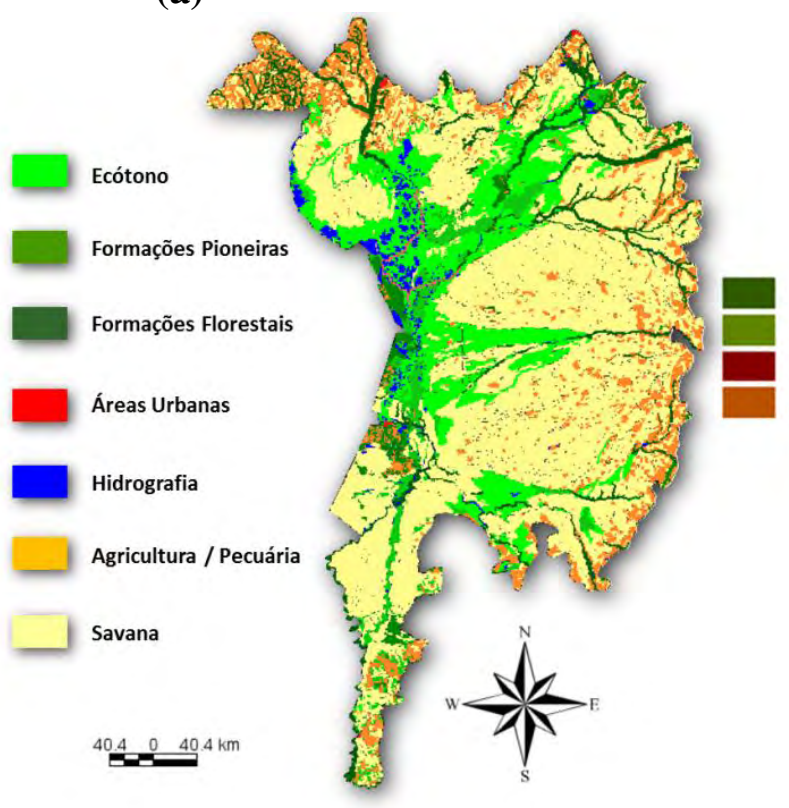

(b)

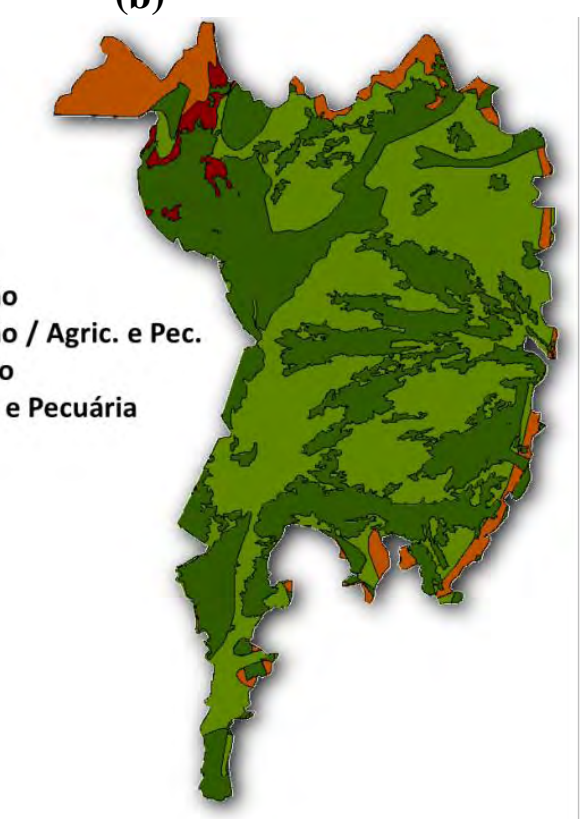

Figura 7. (a) Mapa de uso e cobertura da terra para o Bioma Pantanal (EMBRAPA, 2004); (b) Modelo de ocupação e uso para o Bioma Pantanal estimado a partir das unidades morfométricas, geologia e solos. 
Comparando o mapa de uso e cobertura da terra representado na Figura 7a com o modelo de ocupação e uso para o Bioma Pantanal (Figura 7b) percebe-se uma boa coerência entre o atual e o sugerido uso e cobertura da terra. Aproximadamente $45 \%$ da área total do bioma pantanal foram destinadas à conservação ambiental e para o desenvolvimento de um turismo sustentável. Estas áreas correspondem a áreas de Ecótono, savanas inundáveis e áreas de savana florestada, savana arborizada, savana estépica, entre outras. Aproximadamente $8 \%$ da área total foram destinadas unicamente à agricultura/pecuária, localizadas principalmente na região norte do bioma e em suas extremidades. Para este uso, percebe-se uma grande coerência com o modelo de ocupação e uso proposto, principalmente nas extremidades do bioma e na região norte. Porém, percebe-se uma tendência de crescimento de áreas agrícolas na planície aluvial com e sem inundações periódicas. Consequentemente, o avanço da agricultura requer medidas mitigadoras para prevenir o impacto deste uso na conservação e na biodiversidade.

De acordo com o mapa da EMBRAPA (2004), as áreas urbanas correspondem a $115 \mathrm{~km}^{2}$, ou seja, aproximadamente $0,07 \%$ da área total do bioma. No modelo proposto, destinaram-se aproximadamente $1 \%$ para a ocupação urbana, estas estão localizadas principalmente em áreas próximas ao núcleo agrícola na região norte. A área restante, $44 \%$, foi destinada à conservação e a agricultura/pecuária e correspondem praticamente a regiões de planície aluvial não inundável (50-150 m) com predominância de baixa declividade (0-2,5\%) com sedimentos arenosos e argilosos, podendo incluir sedimentos argilo-carbonáticos e cascalhos, com solo predominantemente do tipo Espodossolo Ferrocárbico. Para o uso agrícola, medidas de correção de solo e rotatividade de culturas devem ser adotadas. Ainda, a pecuária bovina, principalmente, é responsável pela maior incidência de desmatamentos na área de estudo, uma vez que acabam suprimindo áreas de Savana Estépica Florestada, Savana Estépica Arborizada, áreas de Ecótono entre Savana/Floresta Estacional Decidual, entre outras.

\section{CONCLUSÃO}

O estudo geoecológico da paisagem permite o diagnóstico da fragmentação dos geossistemas de um determinado ambiente ou bioma. Esta abordagem permite a integração dos elementos que compõe o meio, compreendendo a análise da interação e interdependência dos elementos ambientais e sociais. Desta forma, os dados de sensoriamento remoto provenientes de plataformas orbitais possibilitam a obtenção de informações multiespectrais com variadas resoluções espaciais e temporais. Estas informações podem ser empregadas para o estudo da variabilidade intra e interanual das áreas alagadas, propiciando a inclusão desta variável no estudo das unidades de paisagem do Bioma Pantanal.

A análise multitemporal dos dados de NDVI e reflectância da superfície, proporcionaram a integração de mapas altimétricos com informações da variabilidade do uso e cobertura da terra para o Bioma Pantanal, originando fragmentações para a área de estudo a partir da separação das planícies aluviais não inundáveis e inundáveis. Consequentemente, a partir do cruzamento de produtos orbitais e cartográficos foram identificadas 16 unidades de paisagem. Destas, as mais importantes destacam-se áreas de planície aluvial sujeita a inundações periódicas com predominância de declividade plana a baixa, compostas por sedimentos arenosos e argilosos e por planícies aluviais não inundáveis com sedimentos arenosos e argilosos, podendo incluir sedimentos argilo-carbonáticos e cascalhos.

Ainda, pode-se concluir que o desenvolvimento socioeconômico da região do Pantanal e em áreas adjacentes permitiu a expansão da fronteira agrícola, introduzindo ao bioma extensas áreas de pecuária e agricultura. Desta forma, o modelo de ocupação e uso pode inferir políticas públicas voltadas à otimização dos recursos naturais e ao desenvolvimento sustentável da região. 


\section{AGRADECIMENTOS}

À Fundação de Amparo à Pesquisa do Estado de São Paulo (FAPESP) pelo apoio (2010/07083-0).

\section{REFERÊNCIAS}

ADAMOLI, J. Zoneamento ecológico do Pantanal baseado no regime de inundações. In: ENCONTRO SOBRE SENSORIAMENTO REMOTO APLICADO A ESTUDOS NO PANTANAL, 1., 1995, Corumbá. Resumos... 1995. p.15-17. Disponível em: <http://mtcm12.sid.inpe.br/col/sid.inpe.br/mtc-m12@80/2006/08.17.11.54/doc/ @ sumario.htm>. Acesso em: 18 abr. 2012.

ASSINE, M. River avulsions on the Taquari megafan, Pantanal wetland, Brazil. Geomorphology, v. 70, n. 3/4, p. 357-371, 2005. doi: 10.1016/j.geomorph.2005.02.013. http://dx.doi.org/10.1016/j.geomorph.2005.02.013

ASSINE, M. L.; SOARES, P. C. Quaternary of the Pantanal, westcentral Brazil. Quaternary International, v. 114, p. 23-34, 2004. http://dx.doi.org/10.1016/S1040-6182(03)00039-9

BRASIL. Ministério do Meio Ambiente. Projeto de monitoramento do desmatamento dos biomas brasileiros por satélite. Monitoramento do bioma Pantanal. Brasília, DF, 30 p. 2010. Disponível em: <http://siscom.ibama.gov.br/monitorabiomas/pantanal/ RELATORIO_PANTANAL_2008_PMDBBS.pdf>. Acesso em: 18 abr. 2012.

CARDOZO, F. S.; PEREIRA, L. O.; MOURA, Y. M.; PEREIRA, G.; KAMPEL, M.; SHIMABUKURO, Y. E. et al. Utilização de parâmetros biofísicos para a estimativa de áreas alagadas no bioma Pantanal. In: SIMPÓSIO DE GEOTECNOLOGIAS NO PANTANAL, 3., 2010, Cáceres. Anais eletrônicos... 2010. p. 809-817. Disponível em: <http://www.geopantanal2009.cnptia.embrapa.br/2010/cd/geopantanal.pdf>. Acesso em: 18 abr. 2012.

EMPRESA BRASILEIRA DE PESQUISA AGROPECUÁRIA - EMBRAPA. Levantamento e mapeamento dos remanescentes da cobertura vegetal do bioma Pantanal, período de 2002 na escala de 1:250.000. Campinas: Embrapa Informática Agropecuária, 2004. p. 43.

INSTITUTO BRASILEIRO DE GEOGRAFIA E ESTATÍSTICA - IBGE. Mapas interativos. 2011. Disponível em: <http://www.ibge.gov.br>. Acesso em: 10 out. 2011.

JUSTICE, C. O.; GIGLIO, L.; KORONTZI, S.; OWENS, J.; MRISETTE, J.; ROY, D. et al. The MODIS fire product. Remote Sensing of Environment, v. 83, p. 244-262, 2002.

http://dx.doi.org/10.1016/S0034-4257(02)00076-7

PEREIRA, L. O.; CARDOZO, F. S.; MOURA, Y. M.; FONSECA, L. M. G.; PEREIRA, G.; MORAES, E. C. Delimitação das áreas alagadas do Pantanal a partir da análise por Componentes Principais e Transformada Wavelet. In: SIMPÓSIO DE GEOTECNOLOGIAS NO PANTANAL, 3., 2010, Cáceres. Anais eletrônicos... 2010a. p. 200-209. . Disponível em: <http://www.geopantanal2009.cnptia.embrapa.br/2010/ cd/geopantanal.pdf $>$. Acesso em: 18 abr. 2012. 
PEREIRA, G. ; SILVA, M. E. S.; MORAES, E. C.; SHIMABUKURO, Y. E.; CARDOZO, F. S.; SILVA, F. B. et al. Impactos climáticos das áreas alagadas no Bioma Pantanal. In: SIMPÓSIO DE GEOTECNOLOGIAS NO PANTANAL, 3., 2010, Cáceres. Anais eletrônicos... 2010b. Disponível em: <http://www.geopantanal2009.cnptia.embrapa.br /2010/cd/geopantanal.pdf>. Acesso em: 18 abr. 2012.

PRIEGO, A.; BOCCO, G.; MENDONZA, M.; GARRIDO, A. Propuesta para la generación semiautomatizada de unidades de paisajes: fundamentos y métodos. 2008. Disponível em: <http://www2.ine.gob.mx/emapas/download/paisaje_unidades_ paisaje.pdf>. Acesso em: 18 abr. 2012.

RABUS, B.; EINEDER, M.; ROTH, A.; BAMLER, R. The shuttle radar topography mission- a new class of digital elevation models acquired by spaceborne radar. ISPRS Journal of Photogrammetry and Remote Sensing, v. 57, n. 4, p. 241-262, 2003. http://dx.doi.org/10.1016/S0924-2716(02)00124-7

RAMON, A. M.; SALINAS, E.; REMOND, R. Diseño metodológico para la elaboración de mapas de paisajes con el uso de los SIG: aplicación a la cuenca alta del río Cauto, Cuba. Geografía y Sistemas de Información Geográfica, ano 1, n. 1, p. 95-108, 2009.

ROSS, J. L. S. Análise empírica da fragilidade dos ambientes naturais e antropizados. RDG Revista do Departamento de Geografia, São Paulo, n. 8, p. 63-74, 1994.

SALINAS CHÁVEZ, E.; MIDDLETON, J. La ecología del paisaje como base para el desarrollo sustentable en América Latina. 1998. Disponível em: <http://www.brocku.ca/tren/EPI/lebk/lopez1.html>. Acesso em: 18 abr. 2012.

SALINAS, E.; QUINTELA, J. Paisajes y ordenamiento territorial: obtención del mapa de paisajes del Estado de Hidalgo en México a escala media con el apoyo de los SIG, Alquibla. Revista de Investigaciones del Bajo Segura, Alicante, n. 7, p.517-527, 2000.

SALINAS ESCOBAR, M. E. (Org.). El ordenamiento territorial: experiencias internacionales. Secretaría del Medio Ambiente y Recursos Naturales. 2008. Disponível em: <http://www2.ine.gob.mx/publicaciones/download/596.pdf>. Acesso em: 18 abr. 2012.

SISTEMA de processamento de informações georreferenciadas - SPRING. Versão 4.3. São José dos Campos: INPE, 2005. 


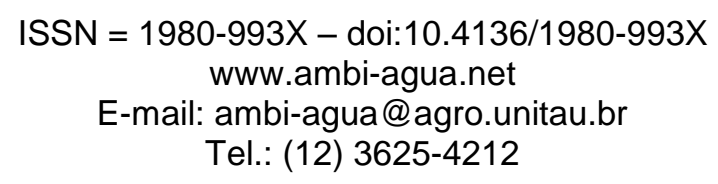

\title{
Remoção dos corantes Reactive Blue 21 e Direct Red 80 utilizando resíduos de sementes de Mabea fistulifera Mart. como biossorvente
}

\author{
(http://dx.doi.org/10.4136/ambi-agua.854)
}

\author{
Julieta de Jesus da Silveira Neta ${ }^{1,2}$; Carlos Juliano da Silva ${ }^{2}$; \\ Guilherme Costa Moreira ${ }^{2}$; César Reis ${ }^{2}$; Efraim Lázaro Reis ${ }^{2}$ \\ ${ }^{1}$ Embrapa Amazônia Oriental, Belém, Pará \\ e-mail: julieta_neta@yahoo.com.br; julieta@cpatu.embrapa.br \\ ${ }^{2}$ Universidade Federal de Viçosa (UFV), Viçosa, Minas Gerais \\ e-mail: carlosjuliano07@yahoo.com.br; songuilherme@yahoo.com.br; \\ cesar@ufv.br; efraim@ufv.br
}

\section{RESUMO}

Neste estudo empregou-se resíduos de Mabea fistulifera Mart. como bioadsorvente para a remoção dos corantes Reactive Blue 21 (RB 21) e Direct Red 80 (DR 80) em soluções aquosas e em amostras de efluentes reais fortificados com estes corantes. Foram investigados os ensaios da influência do $\mathrm{pH}$, cinéticos e adsortivos para a remoção dos corantes por meio de uma série de experimentos de batelada. O bioadsorvente exibiu máxima adsorção em $\mathrm{pH}=2,0$ para ambos os corantes. O tempo de equilíbrio da adsorção foi estabelecido em 300 minutos para o DR 80 e 120 minutos para o RB 21. O modelo de Langmuir descreveu com maior fidelidade o comportamento do sistema sortivo, apresentando coeficiente de determinação $\left(\mathrm{R}^{2}\right)$ superior a 0,98 . Por meio da Isoterma de Langmuir, foi possível obter a capacidade máxima de adsorção dos corantes Direct Red 80 e Reactive Blue 21 pelo bioadsorvente sendo encontrados os valores de 4,92 $\mathrm{mg} \mathrm{g}^{-1}$ e $11,13 \mathrm{mg} \mathrm{g}^{-1}$, respectivamente. O modelo cinético de pseudo-segunda ordem melhor descreveu o processo de adsorção do corante RB 21 sob o bioadsorvente, embora a difusão intra-partícula também esteja envolvida no mecanismo de adsorção. Já para o corante DR 80 o modelo de difusão de Morris e Weber sugeriu que a difusão intra-partícula é predominante em todo o processo de adsorção. Depois de otimizadas as condições adsortivas, o bioadsorvente foi empregado a amostras de efluentes têxteis reais fortificadas com soluções aquosas dos corantes, obtendo-se $85 \%$ de remoção do RB 21 e $94 \%$ de remoção do DR 80 na matriz do efluente.

Palavras-chave: adsorção; Mabea fistulifera Mart.; bioadsorvente; corante.

\section{Removal of the Reactive Blue 21 and Direct Red 80 dyes using seed residue of Mabea fistulifera Mart. as biosorbent}

\section{ABSTRACT}

Residues of Mabea fistulifera Mart. were used in this study as a bioadsorbent for the removal of the Reactive Blue 21 (RB 21) and Direct Red 80 (DR 80) dyes from aqueous solutions and samples of real effluents enriched with these dyes. The influence of $\mathrm{pH}$, kinetic, and adsorptive parameters for the removal these dyes were investigated by conducting a series of batch experiments. The maximum adsorption using this bioadsorbent was observed at $\mathrm{pH}=2.0$ for both dyes. The time of adsorption equilibrium was established at 300 minutes for DR 80 and 120 minutes for RB 21. The Langmuir model stood out because it described the 
behavior of the sorptive system with higher fidelity than the Freundlich model showing the coefficient of determination $\left(\mathrm{R}^{2}\right)$ above 0.98 . It was possible to obtain the maximum adsorption capacity of the bioadsorbent, for the Direct Red 80 and Reactive Blue 21 dyes, using the Langmuir Isotherm; these values were determined as $4.92 \mathrm{mg} \mathrm{g}^{-1}$ and $11.13 \mathrm{mg} \mathrm{g}^{-1}$, respectively. The pseudo-second order kinetic model best described the adsorption process of the RB 21 dye by the bioadsorbent, however, the intra-particle diffusion is also involved in the mechanism of adsorption. The Morris and Weber diffusion model suggested that the intraparticle diffusion is prevalent throughout the process of adsorption for the DR 80 dye. The bioadsorbent was employed on real textile effluent samples enriched with aqueous solutions of these dyes after the adsorptive conditions were optimized; $85 \%$ RB 21 and $94 \%$ DR 80 removal rates were obtained from the effluent's matrix.

Keywords: adsorption; Mabea fistulifera Mart.; biosorbent; dye.

\section{INTRODUÇÃO}

As indústrias são os principais responsáveis pela geração de efluentes contendo compostos fenólicos (Froehner et al., 2009), metais pesados (Ghorbani et al., 2008; Lohani et al., 2008) e corantes (Baek et al., 2010; Brito et al., 2010; Saha, 2010). Estima-se que são utilizados mundialmente mais de 10.000 tipos diferentes de corantes e pigmentos. $\mathrm{Na}$ indústria têxtil, $15 \%$ dos corantes utilizados são perdidos durante o processo de tingimento de tecidos gerando efluentes (Parshetti et al., 2010). Quando tais efluentes são descartados indevidamente em corpos hídricos, os corantes mesmo em concentrações baixas são prejudiciais (Park et al., 2007). Se não forem tratados adequadamente antes de lançados em águas naturais, os efluentes provenientes da indústria de corantes ou de processos envolvendo tintura têxtil podem modificar o ecossistema ou atingir a saúde da população. Alguns corantes como os pré-metalizados, chegam a liberar substâncias tóxicas com altas concentrações de metais pesados. Outros podem ser acumulados por plantas e, consequentemente, passar para a cadeia alimentar, contaminando outros organismos (Zanoni e Carneiro, 2001).

De maneira geral, o processo mais comum utilizado na remoção de corantes de efluentes industriais é a adsorção. Sua maior aplicação industrial está associada ao baixo custo, flexibilidade e simplicidade do processo, facilidade de operação se comparada a outras técnicas de tratamento. Além disso, a adsorção não resulta na formação de substâncias prejudiciais ao meio ambiente, não utiliza solventes orgânicos, bem como pode permitir o reaproveitamento do adsorvente (Achak et al., 2009).

Atualmente o material que apresenta maior capacidade de adsorção, sendo amplamente utilizado para o tratamento de efluentes, é o carvão ativado. Entretanto, devido às perdas durante o processo de recuperação do adsorvente, sua utilização torna-se onerosa (Aktaş e Çeçen, 2007; Ozkaya, 2006). Neste sentido existe um crescente interesse pela busca de materiais alternativos de baixo custo que possam ser utilizados em substituição ao carvão ativado como adsorventes para a eliminação de corantes têxteis, tais como: casca de banana (Achak et al., 2009), casca de nozes (Brito et al., 2010), folhas de Neem (Immich et al., 2009), pó de folhas de abacaxi (Weng et al., 2009), casca de cevada (Robinson et al., 2002), bagaço de cana-de-açucar (Santos et al., 2011), sementes de Moringa oleifera (Viera et al., 2009) e o resíduo de semente de Mabea fistulifera Mart. alvo de nosso estudo. A Mabea pertence à família Euphorbiaceae, é uma planta nativa amplamente encontrada em áreas de transição de Mata para Cerrado, nos estados de Minas Gerais, Rio de Janeiro e São Paulo, muito utilizada para recuperação de áreas degradadas por indústrias de mineração. Árvore de alta importância ambiental e econômica, pois produz pólen e néctar em abundância, e sua semente produz uma quantidade de óleo de aproximadamente $40 \%$ podendo assim utilizada para a produção de 
biodiesel (Pereira, 2007). É popularmente conhecida como canudo-de-pito, sendo considerada uma planta de pequeno porte, com em média 7 metros de altura (Lorenzi, 2000).

Este trabalho visa estudar a eficiência de resíduos de semente de Mabea fistulifera mart. na remoção dos corantes Reactive Blue 21 (RB 21) e Direct Red 80 (DR 80) presentes em efluentes têxteis, bem como verificar a influência de diferentes parâmetros no processo de remoção da cor.

\section{MATERIAIS E MÉTODO}

\subsection{Aparelhagem}

As medidas de absorbância das soluções aquosas dos corantes Direct Red 80 (DR 80) e Reactive Blue 21 (RB 21) foram registradas em um espectrofotômetro (HITACHI, modelo U2000), utilizando-se cubetas de quartzo de $1 \mathrm{~cm}$ de caminho ótico e água deionizada como referência.

\subsection{Preparo da solução estoque de corantes}

Os corantes comerciais Reactive Blue 21 e Direct Red 80 foram cedidos pela Companhia Industrial Itabira do Campo (Itabirito, MG). Informações relevantes sobre as propriedades destes corantes estão dispostos na Tabela 1. As soluções estoque de cada um dos corantes

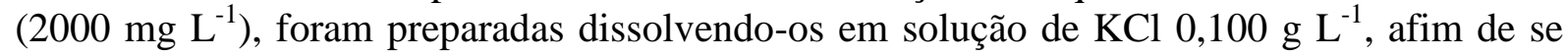
manter a força iônica do meio constante.

Tabela 1. Propriedades do DR 80 e RB 21.

\begin{tabular}{l|cc}
\hline \multicolumn{1}{c|}{ Propriedades } & Direct Red 80 & Reactive Blue 21 \\
\hline$\lambda_{\text {máx }}(\mathrm{nm})$ & 537 & 631 \\
Tipo & Direto & Reativo \\
Peso molecular $(\mathrm{g})$ & $1373,07 \mathrm{~g}$ & $1159,62 \mathrm{~g}$ \\
Fórmula molecular & $\mathrm{C}_{45} \mathrm{H}_{26} \mathrm{~N}_{10} \mathrm{Na}_{6} \mathrm{O}_{21} \mathrm{~S}_{6}$ & $\mathrm{C}_{40} \mathrm{H}_{26} \mathrm{CuN}_{10} \mathrm{O}_{16} \mathrm{~S}_{6}$ \\
Número no Color & 35780 & $12236-86-1$ \\
Index (C.I) & & \\
\hline
\end{tabular}

\subsection{Preparo do adsorvente}

A colheita das sementes da Mabea fistulifera Mart (canudo-de-pito) foi realizada no município de Viçosa MG, antes de seu período de maturação das mesmas. Posteriormente a essa etapa, as sementes foram colocadas sob o sol e cobertas com uma tela, com objetivo de se esperar a deiscência.

O óleo presente nas sementes de Mabea foi extraído e o resíduo das sementes gerado após a extração, foi lavado abundantemente com água destilada. Em seguida, foi conduzido à estufa para secagem a $60{ }^{\circ} \mathrm{C}$ durante seis horas, e peneirado de forma que sua granulometria se mantivesse em 65 mesh $(212 \mu \mathrm{m}$ de diâmetro). Depois de secos e peneirados, os resíduos das sementes foram utilizados para remoção de corantes por processos de adsorção.

\subsection{Caracterização do adsorvente}

A espectroscopia no infravermelho com transformada de Fourier foi utilizada para identificar os principais grupos funcionais, presentes na semente de Mabea. Os espectros do adsorvente foram registrados em espectrofotômetro infravermelho Perkin Elmer - FT - IR 1000, situados na faixa de 400 a $4000 \mathrm{~cm}^{-1}$, a partir de pastilhas de $\mathrm{KBr}$ preparadas com 2,00 mg de amostra. 
Para a determinação do ponto de carga zero (PCZ) do adsorvente, empregaram-se dois tubos de centrífuga, contendo 0, $500 \mathrm{~g}$ dos resíduos da semente. Em cada um dos tubos, foi adicionado $20 \mathrm{~mL}$ de solução de $\mathrm{NaCl}$ em concentrações de 0,1 e $0,015 \mathrm{~mol} \mathrm{~L}^{-1}$. Após a adição das soluções, as misturas foram agitadas durante 30 minutos e mantidas em contato por 72 horas (Egreja Filho et al., 2004).

A amostra do material adsorvente foi submetida a um processo de metalização por meio de recobrimento com ouro utilizando-se um metalizador (Sputtering-Balzeis, modelo FDV010). A visualização desta superfície foi conduzida em um microscópio eletrônico de varredura LEO modelo VP1430, pertencente ao Núcleo de Microscópia e Microanálise (CCBUFV).

\subsection{Ensaios adsortivos em batelada}

\subsubsection{Influência do pH na adsorção}

$\mathrm{O}$ ensaio para avaliação da influência do $\mathrm{pH}$ foi realizado em triplicata abrangendo a faixa de 2,0 a 9,0. Foram adicionados $0,080 \mathrm{~g}$ do adsorvente em tubos de centrífuga e 15,00 $\mathrm{mL}$ de soluções com $\mathrm{pH}$ devidamente ajustados de acordo com a faixa de estudo. $\mathrm{O} \mathrm{pH}$ foi monitorado até atingir sua estabilização, posteriormente os tubos foram centrifugados, 0 sobrenadante descartado e então foram adicionados $15,00 \mathrm{~mL}$ de solução do corante Reactive blue 21 na concentração de $30 \mathrm{mg} \mathrm{L}^{-1}$. O mesmo procedimento foi realizado para o corante Direct Red 80. Os tubos foram agitados por 540 minutos, a $25{ }^{0} \mathrm{C}$. Finalmente, as determinações quantitativas do corante remanescente no sobrenadante foram realizadas por meio de medidas de espectrometria de absorção UV/Vis.

\subsubsection{Estudos cinéticos de adsorção}

$\mathrm{O}$ ensaio cinético de adsorção foi realizado em $\mathrm{pH}$ ótimo $(\mathrm{pH}=2)$, a temperatura de $25{ }^{0} \mathrm{C}$. O estudo foi conduzido em recipiente de $250 \mathrm{~mL}$ devidamente fechado, sendo adicionados, 0,800 g de resíduos da semente de Mabea e $150 \mathrm{~mL}$ da solução dos corantes com concentração $30 \mathrm{mg} \mathrm{L}^{-1}$.

Em intervalos pré-determinados de tempo, foram coletadas alíquotas de 1,00 mL com utilização de uma seringa de vidro acoplada a um sistema filtrante contendo membrana Durapore $0,45 \mu \mathrm{m}$. As leituras das absorvâncias referentes às concentrações dos corantes foram determinadas em espectrofotômetro UV/Vis.

Os modelos de pseudo primeira ordem (Chen et al., 2011), de pseudo segunda-ordem (Ho et al., 1996), e de difusão intrapartícula (Yang et al., 2011) foram empregados para descrever os sistemas adsorvente-adsorbato. A forma linear da equação da pseudo-primeira ordem é dada pela Equação 1.

$$
\log \left(q_{e-} q_{t}\right)=\log q_{e-}\left(K_{1} / 2,303\right) . \mathrm{t}
$$

em que $\mathrm{q}_{\mathrm{e}}$ e $\mathrm{q}_{\mathrm{t}}$ são as quantidades de corante adsorvidas $\left(\mathrm{mg} \mathrm{g}^{-1}\right)$ no equilíbrio e no tempo $\mathrm{t}$ (minutos), respectivamente; $\mathrm{k}_{1}$ é a constante de velocidade de adsorção (minutos ${ }^{-1}$ ).

O modelo linearizado de pseudo-segunda ordem pode ser representado pela Equação 2.

$$
t / q_{t=}\left(1 / K_{2} \cdot q_{e}^{2}\right)+\left(\frac{1}{q_{e}}\right) \cdot t
$$

em que $\mathrm{k}_{2}$ é a constante de velocidade de pseudo-segunda ordem $\left(\mathrm{g} \mathrm{mg}^{-1}\right.$ minutos $\left.{ }^{-1}\right), \mathrm{q}_{\mathrm{e}}$ e $\mathrm{q}_{\mathrm{t}}$ são as quantidades de corante adsorvida $\left(\mathrm{mg} \mathrm{g}^{-1}\right)$ no equilíbrio e no tempo $\mathrm{t}$ (minutos).

Alguns modelos consideram que a cinética de adsorção seja principalmente controlada pela difusão externa como: o modelo de Lagergren (pseudo-primeira ordem) e o modelo de pseudo-segunda ordem (Ho e McKay, 1999a). Tais modelos assumem que a resistência à 
transferência de massa ocorre na camada de difusão próxima à superfície adsorvente. Contudo, o mecanismo do processo de adsorção proposto por Weber e Morris (1963), considera a difusão intrapartícula um fator limitante para a transferência de massa. No modelo proposto, a taxa de agitação é considerada suficientemente alta de modo que transferência de massa intrapartícula limita a difusão. As velocidades iniciais da difusão intraparticula podem ser obtidas pela Equação 3.

$$
q_{t}=R_{i d} \cdot \sqrt{t}
$$

em que $\mathrm{q}_{\mathrm{t}}$ é a quantidade de corante sorvida em $\mathrm{mg} \mathrm{g}^{-1}$ no tempo $\mathrm{t}$ e $\mathrm{R}_{\mathrm{id}}$ é a constante de transporte intraparticula $\left(\mathrm{mg} \mathrm{g}^{-1} \mathrm{~min}^{-1 / 2}\right)$.

\subsubsection{Isotermas de adsorção}

Os ensaios foram realizados a $25{ }^{0} \mathrm{C}$ e em pH ótimo ( $\mathrm{pH}=2$ ), sendo adicionados $0,080 \mathrm{~g}$ de adsorvente em tubos de centrífuga, e $15,00 \mathrm{~mL}$ de solução dos corantes em diferentes concentrações. Posteriormente estes recipientes foram submetidos à agitação durante o tempo necessário para que o sistema atingisse o equilíbrio de adsorção, sendo posteriormente centrifugados a $3000 \mathrm{rpm}(\mathrm{F}=0,1529 \mathrm{~g})$.

A concentração de soluto adsorvido na fase sólida pode ser determinada utilizando a Equação 4.

$$
q e=\frac{\left(C_{o-} C_{e q}\right) \times W}{V}
$$

em que:

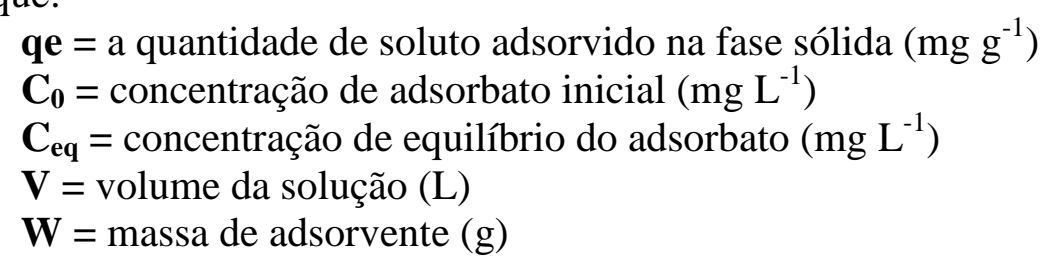

A partir dos dados podem-se obter gráficos de concentração de equilíbrio versus a quantidade adsorvida em $\mathrm{mg} \mathrm{g}^{-1}$ de adsorvente e ajustar os modelos de Langmuir e Freundlich. A isoterma de Langmuir relaciona a quantidade de soluto adsorvido em uma superfície com a concentração de equilíbrio do soluto na solução. A Equação 5 da isoterma de Langmuir é (Ho et al., 2002):

$$
q e=\frac{q_{\text {máx } \times} K_{L \times} C_{e}}{1+K_{L} \times C_{e}}
$$

em que Ce é a concentração do adsorvato na solução após o sistema atingir o equilíbrio (mg $\left.\mathrm{L}^{-1}\right), \mathrm{K}_{\mathrm{L}}$ é a constante de afinidade de Langmuir $\left(\mathrm{L} \mathrm{mg}^{-1}\right)$, $\mathrm{q}_{\text {máx }}$ é a capacidade máxima de adsorção do material $\left(\mathrm{mg} \mathrm{g}^{-1}\right)$ assumindo uma monocamada do adsorvato sobre o adsorvente.

$\mathrm{O}$ modelo de isoterma de Freundlich é uma equação exponencial não sendo possível estimar a capacidade máxima de adsorção. Teoricamente, usando a Equação 6, uma quantidade infinita de adsorção pode ocorrer.

$$
q e=K_{f \times} C_{e}^{1 / n}
$$




\subsubsection{Ensaios adsortivos em amostras de efluente têxtil}

O efluente utilizado neste trabalho foi coletado em uma tinturaria. Aos tubos de centrífuga foram adicionados $0,080 \mathrm{~g}$ de resíduos de sementes de Mabea e $15 \mathrm{~mL}$ de efluente bruto coletado. $\mathrm{O}$ efluente de cada tubo foi fortificado com cada corante separadamente, a concentração final em $30 \mathrm{mg} \mathrm{L}^{-1}$. Posteriormente este efluente teve o $\mathrm{pH}$ ajustado para o valor ótimo $(\mathrm{pH}=2)$. Os sistemas contendo os corantes $\mathrm{DR} 80$ e o RB 21 permaneceram sob agitação a $25{ }^{\circ} \mathrm{C}$ por 300 minutos e 120 minutos, respectivamente. Em seguida estes tubos foram centrifugados a $3000 \mathrm{rpm}(\mathrm{F}=0,1529 \mathrm{~g})$, durante 20 minutos. A concentração dos corantes remanescentes nos sobrenadantes foi determinada por extrapolação da curva analítica construída de $0,1,5,10$ e $15 \mathrm{mg} \mathrm{L}^{-1}$ de cada corante pelo método de adição padrão e as leituras da absorbância feitas por meio de espectrofotometria UV/VIS.

\section{RESULTADOS E DISCUSSÃO}

\subsection{Caracterização do adsorvente}

Verifica-se, de acordo com o espectro IR (Figura 1), que a posição e a forma da banda em aproximadamente $3377 \mathrm{~cm}^{-1}$ é compatível com o estiramento ( $\left.v \mathrm{O}-\mathrm{H}\right)$, referente ao grupo $\mathrm{OH}$ associado, participando de ligação de hidrogênio. A presença de fenóis é confirmada pelo estiramento C-O na faixa de $1220 \mathrm{~cm}^{-1}$ e por meio de uma deformação angular fora do plano $(\gamma \mathrm{O}-\mathrm{H})$ tipicamente alargada em $607 \mathrm{~cm}^{-1}$. Ainda destaca-se o estiramento em $3010 \mathrm{~cm}^{-1}$ referente ao estiramento $(v=\mathrm{CH})$ presente em compostos aromáticos (Silverstein e Webster, 2000). Observa-se no resíduo de semente de Mabea a presença dos grupos funcionais $\mathrm{OH}$ e anéis aromáticos que podem ser potenciais sítios de adsorção.

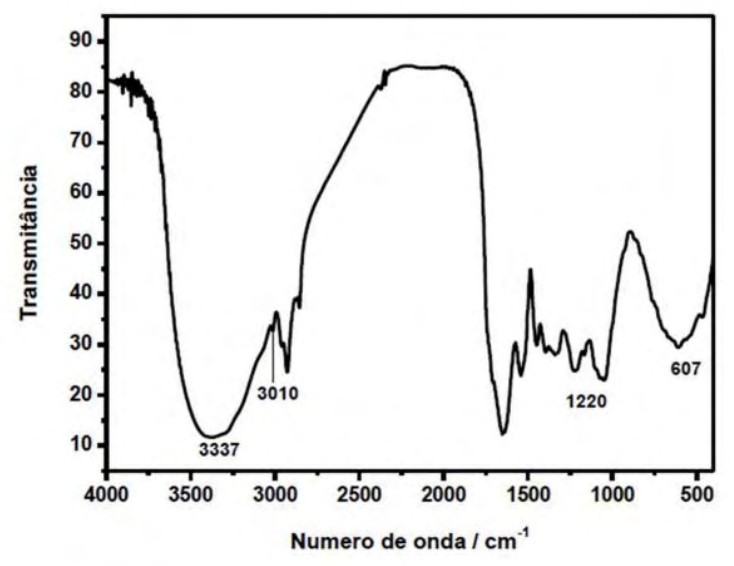

Figura 1. Espectro de IR na faixa de 400$4000 \mathrm{~cm}^{-1}$ em $\mathrm{KBr}$ referente ao resíduo de semente de Mabea fistulifera Mart.

O ponto de carga zero de um adsorvente é definido como o ponto em que a carga total da superfície é zero (neutra). Ele é um importante parâmetro usado para determinar a carga superficial dos adsorventes, uma vez que esta é dependente do $\mathrm{pH}$ da solução do adsorvato. A carga líquida na superfície do adsorvente é positiva para um $\mathrm{pH}$ da solução mais baixo que aquele correspondente ao PCZ ( $\mathrm{pH}$ PZC) e negativa para um $\mathrm{pH}$ da solução maior que o do PCZ (Moreno-Castilla, 2004). Devido à complexidade da estrutura do resíduo de semente de Mabea fistulifera Mart, o valor de PCZ (Figura 2) para este adsorvente abrange a faixa entre 4,73 e 6,00 , isto significa que nesta faixa de valores a carga total da superfície é zero, e para 
SILVEIRA NETA, J. J.; SILVA, C. J.; MOREIRA, G. C.; REIS, C.; REIS, E. L. Remoção dos corantes Reactive Blue 21 e Direct Red 80 utilizando resíduos de sementes de Mabea fistulifera Mart. como biossorvente. AmbiAgua, Taubaté, v. 7, n. 1, p. 104-119, 2012. (http://dx.doi.org/10.4136/ambi-agua.854)

valores de $\mathrm{pH}$ abaixo de 4,73 a superfície do resíduo encontra-se carregada positivamente, já para valores de $\mathrm{pH}$ acima de 6,00 a superfície se encontra carregada negativamente.

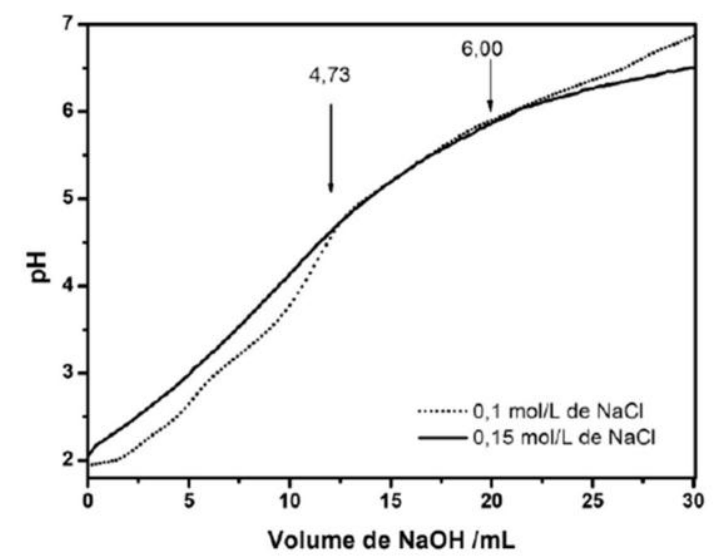

Figura 2. Curvas de titulação do resíduo de semente de Mabea fistulifera Mart. em diferentes concentrações de $\mathrm{NaCl}$

A Figura 3 mostra a superfície dos resíduos de sementes de Mabea predominantemente porosa, devido a fibras presentes em sua composição. Os poros apresentam-se com tamanhos variados, e estes contribuem para aumentar a superfície específica e, consequentemente, para reter maior quantidade de corantes. Estes resíduos foram visualizados no microscópio eletrônico de varredura obtendo-se ampliações de 667 vezes e 992 vezes.
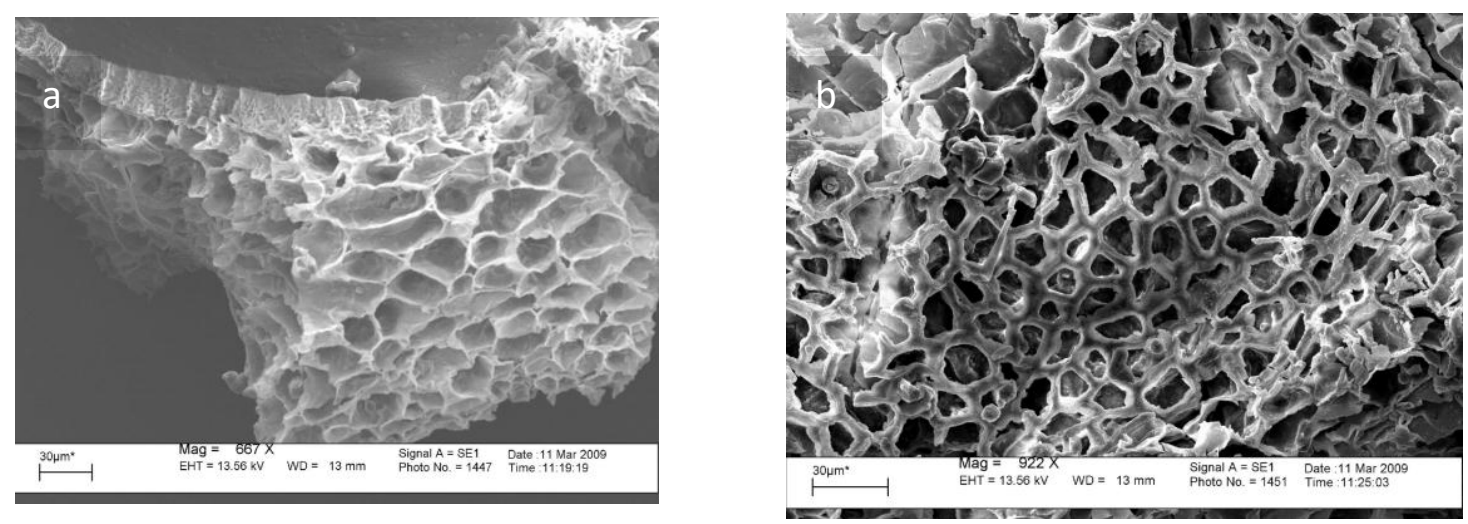

Figura 3. Micrografia da semente de Mabea in natura, com aumentos (a) 667 X (b) 992 X

\subsection{ENSAIOS ADSORTIVOS EM BATELADA}

\subsubsection{INFLUÊNCIA DO pH NA ADSORÇÃO}

A máxima adsorção referente aos corantes Direct Red 80 e Reactive Blue 21, é observada em $\mathrm{pH}$ próximo de 2, para ambos (Figura 4), para valores de $\mathrm{pH}$ superiores a 2 verifica-se uma diminuição na adsorção dos corantes. O meio ácido favorece a adsorção de ambos os corantes por resíduos de sementes de Mabea, pois a superfície do adsorvente adquire carga positiva neste meio, mas os corantes permanecem desprotonados com cargas negativas, por possuírem grupamentos com característica de ácidos fortes, proporcionando a interação. 


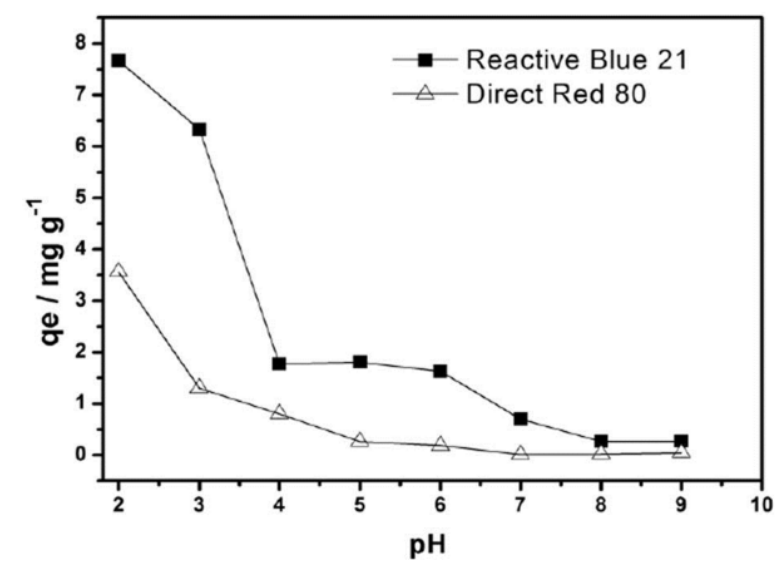

Figura 4. Variação da adsorção do corante por resíduos de sementes de Mabea em função da variação de $\mathrm{pH},(\Delta)$ Direct Red 80, (ロ) Reactive Blue $21\left(\mathrm{C}_{\mathrm{i}}=30 \mathrm{mg} \mathrm{L}^{-1}\right.$, tempo de agitação $=540 \mathrm{~min}, 0,080 \mathrm{~g}$ de adsorvente, $25^{0} \mathrm{C}$ ).

\subsubsection{ESTUDOS CINÉTICOS DE ADSORÇÃO}

As curvas cinéticas de adsorção para ambos os corantes em função do tempo (Figura 5) possibilitam verificar que a adsorção é inicialmente mais rápida e com o passar do tempo fica evidente um aumento da quantidade absorvida, até o momento em que o equilíbrio é atingido. A partir de então, não é observado mais variação da quantidade adsorvida de cada corante em função do tempo. Para DR 80, o equilíbrio é observado aos 300 minutos de agitação, e aos 120 minutos, para o RB 21, esses tempos foram utilizados na obtenção das isotermas de adsorção.

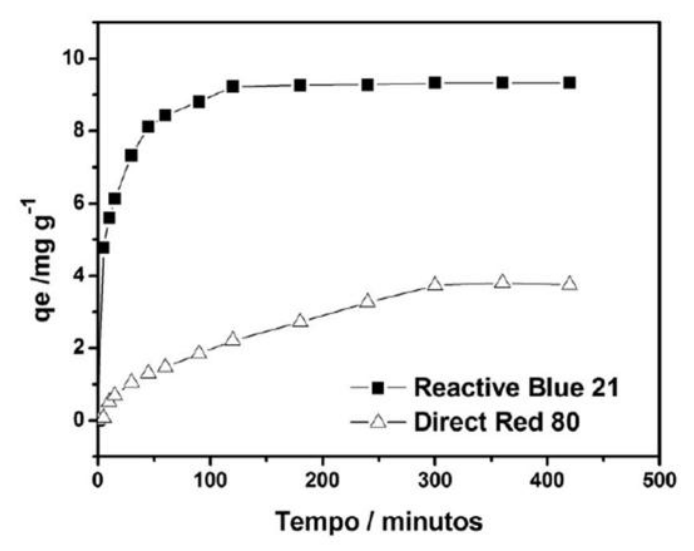

Figura 5. Variação da adsorção do corante por resíduos de sementes de Mabea em função da variação de tempo, $(\Delta)$ Direct Red 80, (- Reactive Blue 21 $\left(\mathrm{C}_{\mathrm{i}}=30 \mathrm{mg} \mathrm{L}^{-1}\right.$, tempo de agitação $=420$ min, $0,080 \mathrm{~g}$ de adsorvente, $25^{\circ} \mathrm{C}$ ).

Para avaliar as mudanças na taxa de adsorção dos corantes com o tempo foi necessário empregar um modelo cinético adequado. Os modelos de pseudo-primeira e pseudo-segunda ordem assumem que a diferença entre a concentração adsorvida em um determinado tempo e 
a concentração da adsorvida no equilíbrio, é a força motriz da adsorção, e a taxa de adsorção global, ou é proporcional à força motriz, no caso da equação de pseudo-primeira ordem, ou é o quadrado da força motriz, para o modelo de pseudo-segunda ordem. Estes modelos assumem ainda que a adsorção é um processo de "falsa" ordem de reação química e a taxa de adsorção pode ser determinada pelas equações de reação de primeira ordem e reação de segunda ordem (Yang e Al-Duri, 2005). Inicialmente, optou-se testar, o ajuste empregando o modelo de pseudo-primeira ordem (Figura 6), para os dados experimentais referentes ao RB 21 e ao DR 80, obtendo-se os coeficientes de determinação $r^{2}$ iguais a 0,9117 e 0,9812, respectivamente. O modelo ajustou-se melhor para a adsorção do corante DR 80. Em muitos casos, a equação de pseudo-primeira ordem não se ajusta a toda faixa de tempo de contato do adsorvato com adsorvente. Geralmente, esta é aplicável em tempos acima de 20 a 30 minutos iniciais do processo de adsorção (Ho e Mckay, 1999b) como observado para o corante RB 21 acima de 25 minutos (Figura 6). Os valores de $-\mathrm{k}_{1}$, obtidos dos coeficientes angulares da reta foram -0,07802 e -0,02210 $\mathrm{min}^{-1}$ para os corantes DR 80 e RB 21, respectivamente, e segundo Baldez et al. (2008), assumem valores negativos indicando que a concentração de solutos na solução diminuem com o aumento da tempo.

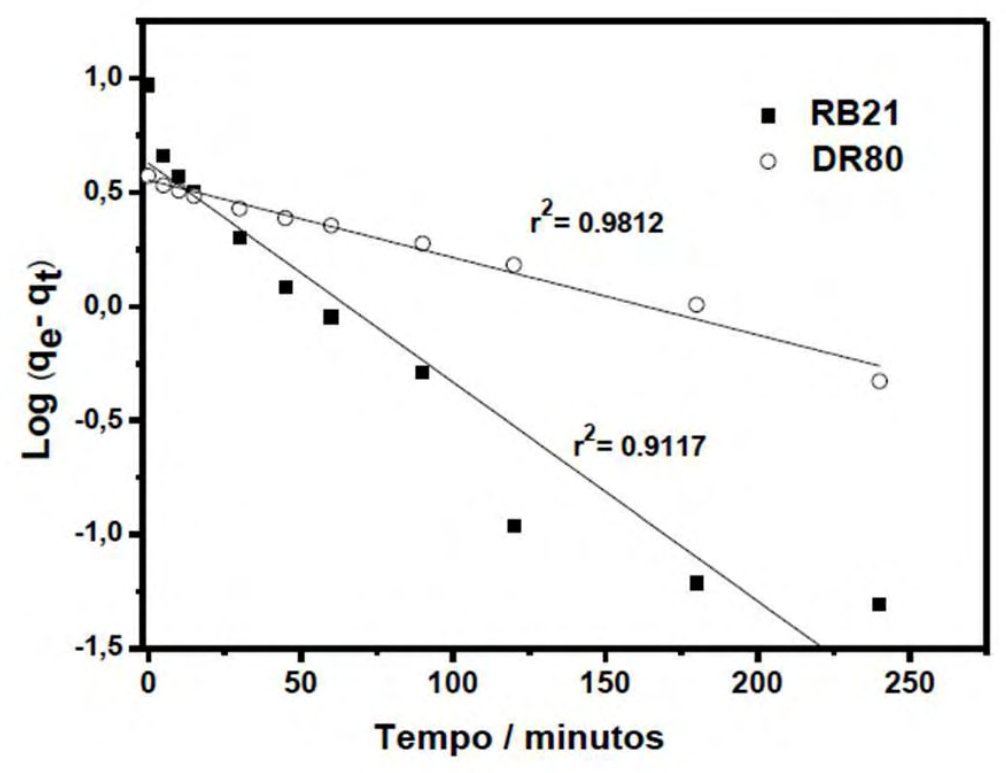

Figura 6. Aplicação do modelo de primeira- ordem para sorção do (匹) RB 21 e do (o) DR 80 pelos resíduos de Mabea Fistulifera mart. $\left(\mathrm{C}_{\mathrm{i}}=30 \mathrm{mg} \mathrm{L} \mathrm{L}^{-1}\right.$, tempo de agitação $=420$ $\min , 0,080 \mathrm{~g}$ de adsorvente, $25^{\circ} \mathrm{C}$ ).

Os valores de $\mathrm{q}_{\mathrm{e}}$ previstos pelo modelo de pseudo-segunda ordem (Figura 7) foram 3,68 $\pm 0,01 \mathrm{mg} \mathrm{g}^{-1}$ para o RB 21 e $9,53 \pm 0,03 \mathrm{mg} \mathrm{g}^{-1}$ para o DR 80, e estão em acordo com os valores de $\mathrm{q}_{\mathrm{e}}$ experimentais de $3,76 \pm 0,11 \mathrm{mg} \mathrm{g}^{-1}$ e 9,29 $\pm 0,07 \mathrm{mg} \mathrm{g}^{-1}$, respectivamente. As constantes de velocidade $\mathrm{K}_{2}$ obtidas foram $0,0017 \mathrm{~g} \mathrm{mg}^{-1}$ minutos ${ }^{-1}$ para o RB 21 e $0,0043 \mathrm{~g}$ $\mathrm{mg}^{-1}$ minutos $^{-1}$ para o DR 80. Já os coeficientes de determinação para o ajuste do modelo foram 0,9998 para RB 21 e 0, 8804 para DR 80. A cinética de pseudo-segunda ordem descreve bem processos de adsorção química, envolvendo doação ou troca de elétrons entre o adsorvato e o adsorvente, como forças covalentes e de troca iônica (Ho e Mckay, 2000), neste tipo de adsorção, as moléculas não são atraídas por todos os pontos da superfície do sólido, mas especificamente para os centros ativos, de maneira a formar uma única camada inicialmente, podendo haver a formação de outras camadas por fisissorção (Coulson and 
Richardson, 1982), O mecanismo de pseudo-segunda ordem se ajusta melhor para o RB 21, sugerindo que a quimisorção seja a forma predominante de adsorção.

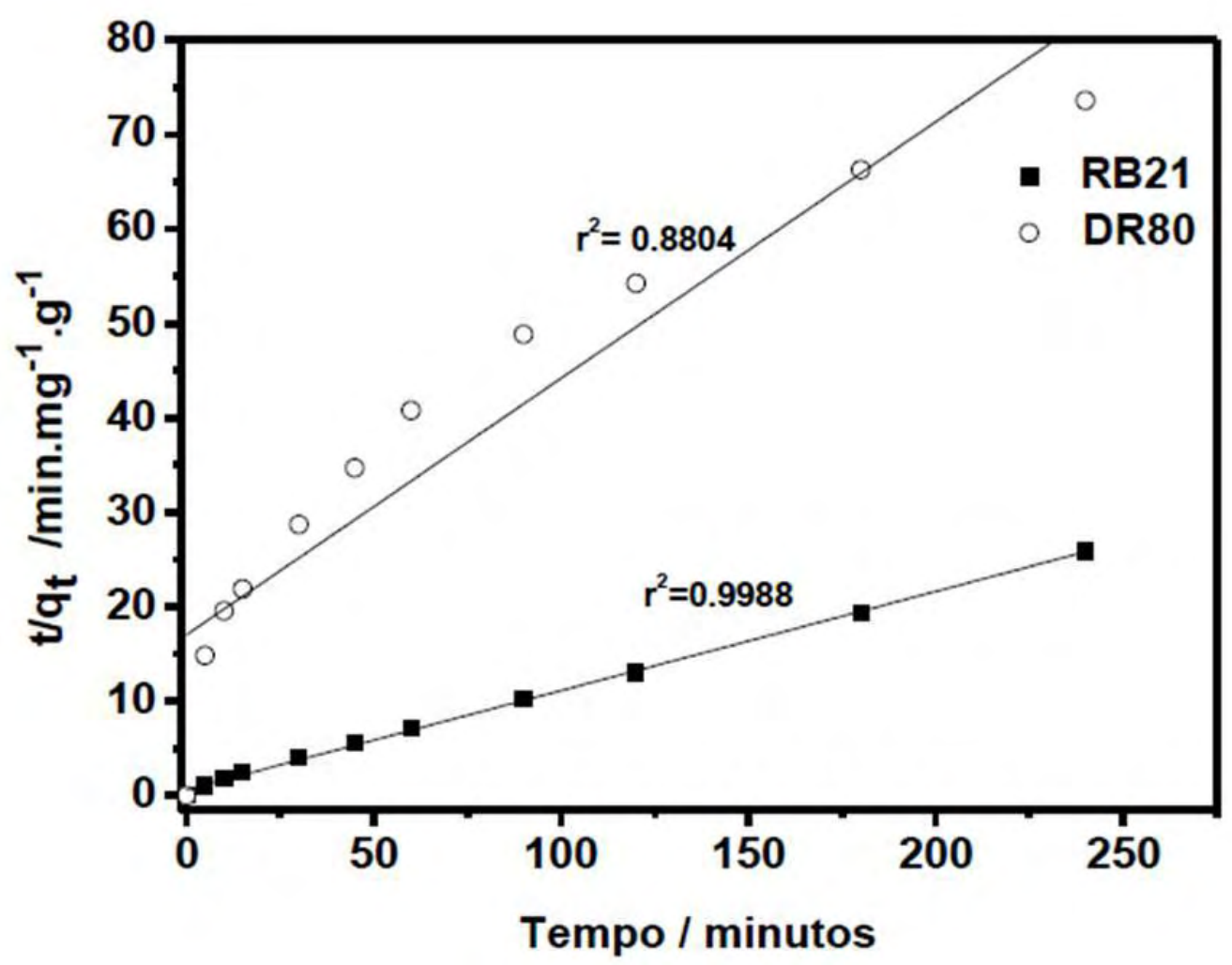

Figura 7. Aplicação do modelo de segunda- ordem para sorção do (ロ) RB 21 e do (०) DR 80 pelos resíduos de Mabea Fistulifera Mart. $\left(\mathrm{C}_{\mathrm{i}}=30 \mathrm{mg} \mathrm{L}^{-1}\right.$, tempo de agitação $=420 \mathrm{~min}, 0,080 \mathrm{~g}$ de adsorvente, $25^{\circ} \mathrm{C}$ ).

Um estudo mecanicista foi realizado com intuito de avaliar a difusão do adsorvato empregando o modelo de Morris-Weber para o sistema em estudo. Nas Figuras 8a e 8b, observa-se a aplicação deste modelo aos dados obtidos na adsorção dos corantes, obtendo-se valores de coeficiente de determinação sempre maiores que 0,9 , indicando boa correlação entre $\mathrm{q}_{\mathrm{t}}$ e $\mathrm{t}^{1 / 2}$ e mostrando que pelo menos parte do fenômeno global de sorção tem relação com a transferência intraparticula, como seria de se esperar dada a natureza porosa do material usado como adsorvente. O gráfico de quantidade adsorvida " $\mathrm{q}_{\mathrm{e}}$ versus $\mathrm{t}$ " $1 / 2$ " (Figura 8b) resulta em uma reta que passa pela origem, o que sugere que o mecanismo intra-partícula é dominante em todo processo de adsorção do corante DR 80 (Özcan et al., 2004). Enquanto que, para o corante RB 21 (Figura 8a), o gráfico não é linear durante todo o processo, sugerindo que o mecanismo de difusão intra-partícula não é dominante. Desta forma, os dados são mais bem representados por três fases lineares, sendo que a fase inicial representa o efeito de camada limite, com transferência de massa externa, em que o corante Reactive Blue 21 é rapidamente adsorvido pelos resíduos de semente de Mabea. Após 25 minutos, a velocidade da adsorção diminui, resultando na segunda fase, que se estende até 120 minutos. Esta etapa se refere à difusão das moléculas para os sítios de adsorção mais internos do adsorvente (Kumar e Porkodi, 2007). Depois de 120 minutos, observa-se o equilíbrio onde a difusão intrapartícula começa a decair devido à baixa concentração de soluto na solução bem como uma menor disponibilidade de sítios para adsorção. 

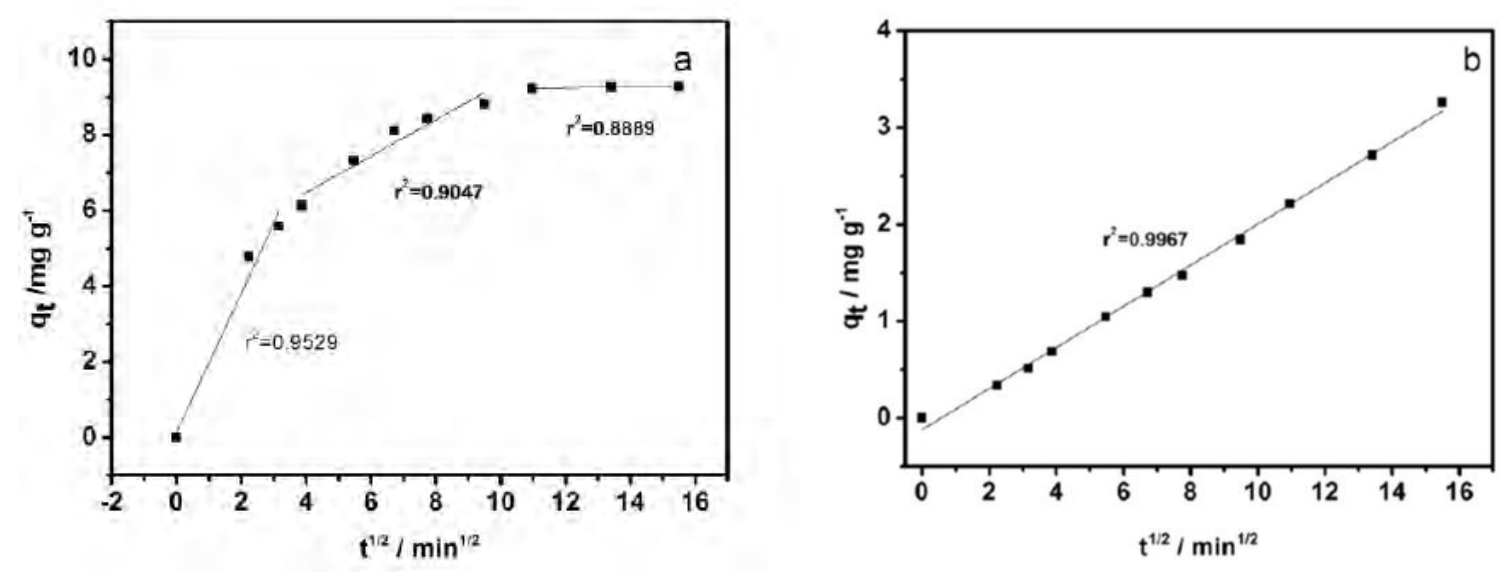

Figura 8. Aplicação do modelo de difusão intrapartícula (Morris-Weber) para sorção do (a) RB 21 e do (b) DR 80 pelos resíduos de Mabea fistulifera Mart. $\left(\mathrm{Ci}=30 \mathrm{mg} \mathrm{L}^{-1}\right.$, tempo de agitação $=420 \mathrm{~min}, 0,080 \mathrm{~g}$ de adsorvente, $25^{\circ} \mathrm{C}$ ).

\subsubsection{Isotermas de adsorção}

Estudos de adsorção dos corantes foram realizados em batelada. A partir dos dados experimentais, foi possível obter as isotermas de adsorção "qe (mg g $\left.{ }^{-1}\right)$ versus $C e\left(\mathrm{mg} \mathrm{L}^{-1}\right)$ " utilizando os modelos de Langmuir e Freundlich que permitiram obter os parâmetros apresentados na Tabela 2.

Tabela 2. Parâmetros obtidos do ajuste dos modelos de Langmuir e Freundlich, para ambos os corantes.

\begin{tabular}{c|ccc|ccc}
\hline \multirow{2}{*}{ Corante } & \multicolumn{3}{|c|}{ Langmuir } & \multicolumn{3}{c}{ Freundlich } \\
\cline { 2 - 7 } & $\mathbf{q}_{\text {máx }}\left(\mathbf{m g ~ g}^{-\mathbf{1}}\right)$ & $\mathbf{K}_{\mathbf{L}}$ & $\mathbf{r}^{\mathbf{2}}$ & $\mathbf{K}_{\mathbf{f}}$ & $\mathbf{n}$ & $\mathbf{r}^{\mathbf{2}}$ \\
\hline DR 80 & $4,92 \pm 0,27$ & $0,03 \pm 0,00$ & 0,9812 & $0,53 \pm 0,08$ & $2,42 \pm 0,03$ & 0,9794 \\
\hline RB 21 & $11,13 \pm 0,73$ & $0,02 \pm 0,00$ & 0,9895 & $0,68 \pm 0,18$ & $1,96 \pm 0,05$ & 0,9621 \\
\hline
\end{tabular}

O modelo de Langmuir (Figura 9 a e Tabela 2) apresentou melhor ajuste $\left(R^{2}>0,98\right)$ quando comparado ao ajuste do modelo de Freundlich para ambos os corantes.

A capacidade máxima de adsorção foi estimada pelo modelo de Langmuir, sendo de 4,91 $\mathrm{mg} \mathrm{g}^{-1}$ para DR 80 , e $11,13 \mathrm{mg} \mathrm{g}^{-1}$ para RB 21 , resultados superiores aos encontrados em outro estudo que trata da adsorção dos corantes RB 21 e DR 80 por espumas de poliuretano (Neta et al., 2011), e para adsorção de azul de metileno por caulinita (Leal et al., 2011).

Para ambos, o processo de adsorção se mostrou favorável, visto que a faixa de variação do valor de RL foi de 0,14 a 0,82 para o DR 80 e de 0,21 a 0,87 para o RB 21. Quando o valor de RL varia entre 0 e 1, significa que a adsorção é favorável (Bhattacharyya e Sarma, 2003).

A partir das isotermas ajustadas pelo modelo Freundlich (Figura 9 b e Tabela 2), foi possível obter os valores da constante de Freundlich (n) para o corante DR 80 é 2,42 e para o corante RB 21 é 1,96, representando também condições de adsorção (Fritz e Schlünder, 1981). 

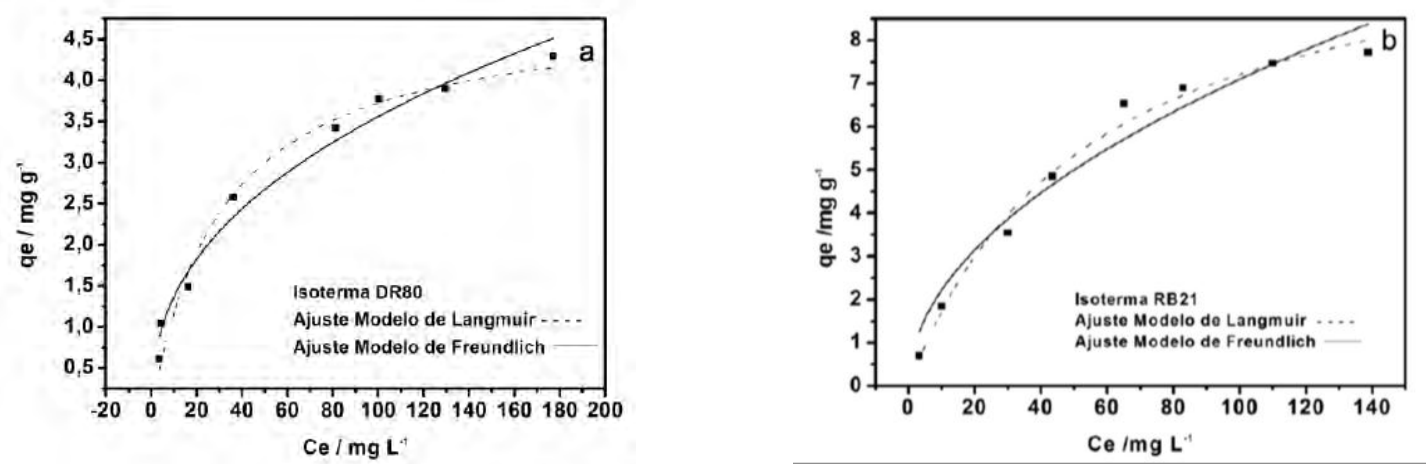

Figura 9. Ajuste da isoterma de Langmuir e Freundlich aos dados da adsorção (a) Direct Red 80, pH $=2$ e tempo de agitação 300 minutos, (b) Reactive Blue 21, $\mathrm{pH}=2$ e tempo de agitação 120 minutos. $\left(\mathrm{Ci}=30 \mathrm{mg} \mathrm{L}^{-1}, 0,080 \mathrm{~g}\right.$ de adsorvente, $\left.25^{\circ} \mathrm{C}\right)$.

\subsubsection{Ensaios adsortivos em amostras de efluente têxtil}

Com o intuito de testar a possibilidade de aplicação da técnica desenvolvida neste trabalho em amostras reais de efluentes industriais, um experimento foi realizado para a remoção de DR 80 e RB 21 de um efluente fortificado com os corantes. Tal teste foi realizado individualmente para cada corante estudado.

As condições experimentais empregadas foram àquelas estabelecidas ao longo do desenvolvimento do trabalho, sendo possível, alcançar uma recuperação de $94 \%$ do corante RB 21 e $85 \%$ para o corante DR 80 .

A evolução da remoção dos corantes RB 21 e DR 80 é apresentada na Figura 10, que mostra os espectros registrados durante procedimento de adsorção. A redução acentuada da intensidade da banda de máxima absorção em $537 \mathrm{~nm}$ para o corante Direct Red 80, e em 631 $\mathrm{nm}$ para o corante Reactive Blue 21 foi observada, evidenciando que os corantes foram removidos dos efluentes por ação dos resíduos de sementes de Mabea fistulifera Mart.

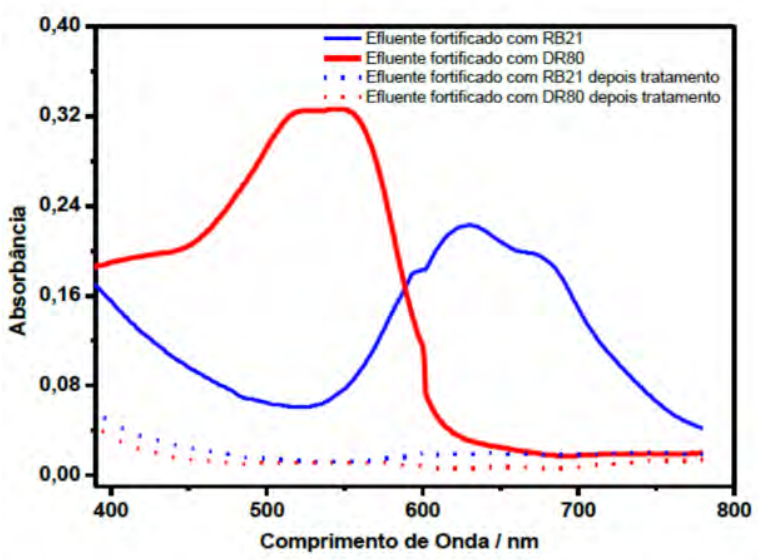

Figura 10. Espectros obtidos de amostra de efluente têxtil fortificado: antes da remoção dos corantes RB 21( - ) e DR 80( - ) e depois da remoção de corantes RB 21 (...) e DR $80(. .$.$) .$ 


\section{CONCLUSÃO}

O estudo da adsorção em batelada dos corantes Direct Red 80 e Reactive Blue 21 por resíduos de Mabea fistulifera Mart. revelou que o processo é fortemente afetado pelo $\mathrm{pH}$, sendo favorecido em meio ácido. A máxima adsorção foi observada em $\mathrm{pH}=2$ para ambos os corantes, neste valor de $\mathrm{pH}$ a superfície do adsorvente se encontra carregada predominantemente com cargas positivas $(\mathrm{pH}<\mathrm{pH}$ PCZ) que interagem com grupamentos das moléculas de corantes carregados negativamente. O tempo de equilíbrio do sistema adsortivo foi estabelecido em 120 minutos para o corante RB21 e 300 minutos para o corante DR80. O modelo de Langmuir se mostrou mais adequado para descrever os sistemas corantesadsorvente, e a capacidade máxima encontrada utilizando este modelo foi de $4,91 \mathrm{mg} \mathrm{g}^{-1}$ para o DR80 e $11,13 \mathrm{mg} \mathrm{g}^{-1}$ para o RB21 em condições de $\mathrm{pH}=2$ e a $25{ }^{0} \mathrm{C}$. O modelo cinético de pseudo-segunda ordem melhor descreveu o processo de adsorção do corante RB21 sob o bioadsorvente, embora a difusão intra-partícula também esteja envolvida no mecanismo de adsorção. Já para o corante DR80 o modelo de difusão de Morris e Weber sugeriu que a difusão intra-partícula é predominante em todo o processo de adsorção.

Depois de estabelecida as condições adsortivas empregando apenas soluções aquosas dos corantes, o processo de tratamento desenvolvido foi aplicado a uma amostra real de efluente industrial fortificado com soluções de $30 \mathrm{mg} \mathrm{L}^{-1}$ de cada corante separadamente. Foi observado um percentual de remoção de $94 \%$ para o RB21 e $85 \%$ para o DR80 empregando os resíduos de Mabea como adsorvente dos corantes presentes no efluente industrial.

Os resíduos de Mabea fistulifera Mart. revelaram elevado potencial para aplicação como bioadsorvente principalmente em efluentes indústrias ácidos, que apresentem em sua constituição os corantes Direct Red 80 e Reactive Blue 21.

\section{AGRADECIMENTOS}

À CAPES (Coordenação de Aperfeiçoamento pessoal de Nível Superior) pelo apoio financeiro.

\section{REFERÊNCIAS}

ACHAK, M.; HAFIDI, A.; OUAZZANI, N.; SAYADI, S.; MANDI, L. Low cost biosorbent "banana peel" for the removal of phenolic compounds from olive mill wastewater: kinetic and equilibrium studies. Journal of Hazardous Materials, v. 166, n. 1, p. 117125, 2009. http://dx.doi.org/10.1016/j.jhazmat.2008.11.036

AKTAŞ, O.; ÇEÇEN, F. Adsorption, desorption and bioregeneration in the treatment of 2chlorophenol with activated carbon. Journal of Hazardous Materials, v. 141, n. 3, p. 769-777, 2007. http://dx.doi.org/10.1016/j.jhazmat.2006.07.050

BAEK, M.; IJAGBEMI, C. O.; SE-JIN, O.; KIM, D. Removal of Malachite Green from aqueous solution using degreased coffee bean. Journal of Hazardous Materials, v. 176, n. 1-3, p. 820-828, 2010. http://dx.doi.org/10.1016/j.jhazmat.2009.11.110

BALDEZ, E. E.; ROBAINA, N. F.; CASSELLA, R. J. Employment of polyurethane foam for the adsorption of Methylene Blue in aqueous. Journal of Hazardous Materials, v. 159, n. 2-3, p. 580-586, 2008. http://dx.doi.org/10.1016/j.jhazmat.2008.02.055

BHATTACHARYYA, K. G.; SARMA, A. Adsorption characteristics of the dye, Brilliant Green, on Neem leaf powder. Dyes Pigments, v. 57, n. 3, p. 211-222, 2003. http://dx.doi.org/10.1016/S0143-7208(03)00009-3 
BRITO, S. M. O.; ANDRADE, H. M. C.; SOARESA, L. F.; AZEVEDO, R. P. Brazil nut shells as a new biosorbent to remove methylene blue and indigo carmine from aqueous solutions. Journal of Hazardous Materials, v. 174, n. 1-3, p. 84-92, 2010. http://dx.doi.org/10.1016/j.jhazmat.2009.09.020

CHEN, G. Q.; ZHANG, W. J.; ZENG, G. M.; HUANG, J. H.; WANG, L.; SHEN, G. L. Surface-modified Phanerochaete chrysosporium as a biosorbent for $\mathrm{Cr}$ (VI)contaminated wastewater. Journal of Hazardous Materials, v. 186, n. 2-3, p. 2138 2143, 2011. http://dx.doi.org/10.1016/j.jhazmat.2010.12.123

COULSON, J. M.; RICHARDSON, J. F. Tecnologia química, Lisboa: Fundação Calouste Gulbenkian, 1982. 746 p.

EGREJA FILHO, F. B; TEÓFILO, R. F.; REIS, E. L.; REIS, C.; FONTES, M. P. F. Determinação do ponto de carga zero por efeito salino (PCZES) em amostras de solos, por titulação contínua. Revista Tecno-Lógica, UNISC, v. 8, n. 2, p. 51-59, 2004.

FRITZ, W.; SCHLÜNDER, E. U. Competitive adsorption of two dissolved organics onto activated carbon - I Adsorption Equilibria. Chemical Engineering Science, v. 36, n. 4, p. 721-730, 1981. http://dx.doi.org/10.1016/0009-2509(81)85088-9

FROEHNER, S.; MARTINS, R. F.; FURUKAWA, W.; ERRERA, M. R. Water remediation by adsorption of phenol onto hydrophobic modified clay. Water, Air \& Soil Pollution, v. 199, n. 1-4, p. 107-113, 2009. http://dx.doi.org/10.1007/s11270-008-9863-0

GHORBANI, F.; YOUNESI, H.; GHASEMPOURI, S. M.; ZINATIZADEH, A. A.; AMINI, M.; DANESHI, A. Application of response surface methodology for optimization of cadmium biosorption in an aqueous solution by Saccharomyces cerevisiae. Chemical Engineering Journal, v. 145, n. 2, p. 267-275, 2008. http://dx.doi.org/10.1016/ j.cej.2008.04.028

HO, Y. S.; HUANG, C. T.; HUANG, H. W. Equilibrium sorption isotherm for metal ions on tree fern. Process Biochemistry, v. 37, n. 12, p. 1421-1430, 2002. http://dx.doi.org/10.1016/S0032-9592(02)00036-5

HO, Y. S; WASE, D. A. J.; FORSTER, C. F. Kinetic studies of competitive heavy metal adsorption by sphagnum moss peat. Environmental Technology, v. 17, n. 1, p. 71-77, 1996. http://dx.doi.org/10.1080/09593331708616362

HO, Y. S.; MCKAY, G. Pseudo-second order model for sorption processes. Process Biochemistry, v. 34, n. 5, p. 451-465, 1999a. http://dx.doi.org/10.1016/S00329592(98)00112-5

HO, Y. S.; MCKAY, G. The kinetics of sorption of divalent metal ions ontos phagnum moss peat. Water Research, v. 34, n. 3, p. 735-742, 2000. http://dx.doi.org/10.1016/S00431354(99)00232-8

HO. Y. S.; MCKAY, G. The Sorption of Lead (II) Ions on Peat. Water Research, v. 33, n. 2, p. 578-584, 1999b. http://dx.doi.org/10.1016/S0043-1354(98)00207-3

IMMICH, A. P. S.; SOUZA, A. A. U; SOUZA, S. M. A. G. U. Removal of Remazol Blue RR dye from aqueous solutions with Neem leaves and evaluation of their acute toxicity with Daphnia magna. Journal of Hazardous Materials, v. 164, n. 2-3, p. 1580-1585, 2009. http://dx.doi.org/10.1016/j.jhazmat.2008.09.019 
KESKINKAN, O.; GOKSU, M. Z. L.; BASIBUYUK, M.; FORSTER, C. F. Heavy metal adsorption properties of a submerged aquatic plant (Ceratophyllum demersum).

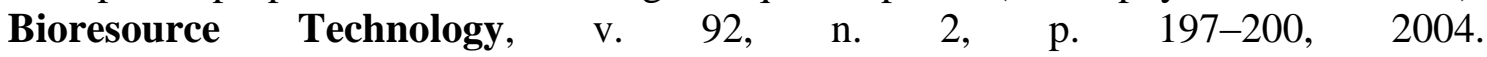
http://dx.doi.org/10.1016/j.biortech.2003.07.011

KUMAR, K. V.; PORKODI, K. Mass transfer, kinetics and equilibrium studies for the biosorption of methylene blue using paspalum notatum. Journal of Hazardous Materials, v. 146, n. 1-2, p. 214-226, 2007. http://dx.doi.org/10.1016/j.jhazmat.2006.12.010

LEAL, P. V. B.; DOS ANJOS, J. P.; MAGRIOTIS, Z. M. Estudo da adsorção do corante azul de metileno em caulinita rosa. Journal of Biotechnology and Biodiversity, v. 2, n. 3, p. 38-42, 2011.

LOHANI, M. B.; SINGH, A.; RUPAINWAR, D. C.; DHAR, D. N. Studies on efficiency of guava (Psidium guajava) bark as bioadsorbent for removal of $\mathrm{Hg}(\mathrm{II})$ from aqueous solutions. Journal of Hazardous Materials, v. 159, n. 2-3, p. 626-629, 2008. http://dx.doi.org/10.1016/j.jhazmat.2008.02.072

LORENZI, H. As árvores brasileiras: manual de identificação e cultivo de plantas arbóreas nativas do Brasil. Nova Odessa: Plantarum, 2000. 322 p.

MORENO-CASTILLA, C. Adsorption of organic molecules from aqueous solutions on carbon materials. Carbon, v. 42, n. 1, p. 83-94, 2004.

http://dx.doi.org/10.1016/j.carbon.2003.09.022

SILVEIRA NETA, J. de J.; MOREIRA, G. C.; DA SILVA, C. J.; REIS, C.; REIS, E. L. Use of polyurethane foams for the removal of the Direct Red 80 and Reactive Blue 21 dyes in aqueous medium. Desalination, v. 281, p. 55-60, 2011.

http://dx.doi.org/10.1016/j.desal.2011.07.041

ÖZCAN, A. SAFA; ÖZCAN, ADNAN. Adsorption of Acid Dyes from Aqueous Solutions Onto Acid-Activated Bentonite. Journal of Colloid and Interface Science, v. 276, n. 1, p. 39-46, 2004. http://dx.doi.org/10.1016/j.jcis.2004.03.043

OZKAYA, B. Adsorption and desorption of phenol on activated carbon and a comparison of isotherm models. Journal of Hazardous Materials, v. B 129, n. 1-3, p. 158-163, 2006. http://dx.doi.org/10.1016/j.jhazmat.2005.08.025

PARK, C.; LEE, M.; LEE, B.; KIM, SW.; CHASE, H.A.; LEE, J.; KIM, S. Biodegradation and biosorption for decolorization of synthetic dyes by Funalia trogii. Biochemical Engineering Journal, v. 36, n. 1, p. 59-65, 2007.

http://dx.doi.org/10.1016/j.bej.2006.06.007

PARSHETTI, G. K.; TELKE, A. A.; KALYANI, D. C.; GOVINDWAR, S. P. Decolorization and detoxification of sulfonated azo dye methyl orange by Kocuria rosea MTCC 1532. Journal of Hazardous Materials, v. 176, n. 1-3, p. 503-509, 2010. http://dx.doi.org/10.1016/j.jhazmat.2009.11.058

PEREIRA, F. E. A. Biodiesel produzido a partir do óleo de sementes de Mabea fistulifera Mart. 2007. 87f. Dissertação (Mestrado em Agroquímica) - Universidade Federal de Viçosa, Viçosa, MG, 2007. 
ROBINSON, T.; CHANDRAN, B.; NAIDU, S. G.; NIGAM, P. Studies on the removal of dyes from a synthetic textile effluent using barley husk in static-batch mode and in a continuous flow, packed-bed, reactor. Bioresource Technology, v. 85, n. 1, p. 43-49, 2002. http://dx.doi.org/10.1016/j.jhazmat.2009.11.058

SAHA, P. Assessment on the removal of methylene blue dye using tamarind fruit shell as biosorbent. Water, Air \& Soil Pollution, v. 213, n. 1-4, p. 287-299, 2010. http://dx.doi.org/10.1007/s11270-010-0384-2

SANTOS, V. C. G.; SOUZA, J. V. T. M.; TARLEY, C. R. T.; CAETANO, J.; DRAGUNSKI, D. C. Copper ions adsorption from aqueous medium using the biosorbent sugarcane bagasse in natura and chemically modified. Water, Air \& Soil Pollution, v. 216, n. 1-4, p. 351-359, 2011. http://dx.doi.org/10.1007/s11270-010-05373

VIEIRA, A. M. S.; VIEIRA, M. F.; SILVA, G. F.; ARAÚJO, A. A.; FAGUNDES-KLEN, M. R.; VEIT M. T. et al. Use of moringa oleifera seed as a natural adsorbent for wastewater treatment. Water, Air \& Soil Pollution, v. 206, n. 1, p. 273-281, 2009. http://dx.doi.org/10.1007/s11270-009-0104-y

WEBER, W. J.; MORRIS, J.C. Kinetics of adsorption carbon from solutions. Journal of the Sanitary Engineering Division, v. 89, n. 2, p. 31-60, 1963.

WENG, C. H.; LIN, Y. T.; TZENG, T. W. Removal of methylene blue from aqueous solution by adsorption onto pineapple leaf powder. Journal of Hazardous Materials, v. 170, n. 1, p. 417-424, 2009. http://dx.doi.org/10.1016/j.jhazmat.2009.04.080

YANG, X; AL-DURI, B. Kinetic modeling of liquid-phase adsorption of reactive dyes on activated carbon. Journal of Colloid and Interface Science, v. 287, n. 1, p. 25-34, 2005. http://dx.doi.org/10.1016/j.jcis.2005.01.093

YANG, Y.; WANG, G.; WANG, B.; LI, Z.; JI, X.; ZHOU, Q.; ZHAO, Y. Biosorption of Acid Black 172 and Congo Red from aqueous solution by nonviable Penicillium YW 01: kinetic study, equilibrium isotherm and artificial neural network modeling. Bioresource Technology, v. 102, n. 2, p. 828-834, 2011. http://dx.doi.org/10.1016/j.biortech.2010.08.125

ZANONI, M. V. B.; CARNEIRO, P. A. O descarte dos corantes têxteis. Revista Ciência Hoje, v. 29, n. 174, p. 61-64, 2001. 


ISSN = 1980-993X - doi:10.4136/1980-993X
www.ambi-agua.net
E-mail: ambi-agua@agro.unitau.br
Tel.: (12) 3625-4212

\title{
Utilização de lâmpadas germicidas na desinfecção de esgoto sanitário
}

\author{
(http://dx.doi.org/10.4136/ambi-agua.845)
}

\section{Patrícia Bilotta; Luiz Antonio Daniel}

\author{
Departamento de Hidráulica e Saneamento (EESC/SHS), Universidade de São Paulo (USP), São Carlos, SP \\ email pb.bilotta@gmail.com; ldaniel@sc.usp.br
}

\section{RESUMO}

O objetivo deste estudo foi investigar a eficiência de lâmpadas germicidas no tratamento terciário de esgoto sanitário no controle de patógenos. O desempenho do reator fotoquímico utilizado nos ensaios foi monitorado em análises microbiológicas para quantificação de $E$. coli (indicador de bactérias), $C$. perfringens (indicador de protozoários) e colifagos (indicador de vírus). Os experimentos foram realizados com efluente proveniente de um reator UASB instalado na ETE-USP campus São Carlos submetido a um filtro biológico submerso aerado e um reator fotoquímico com radiação UV em $254 \mathrm{~nm}$. Os resultados revelaram que os indicadores colifagos e $E$. coli apresentaram a menor resistência à radiação UV, alcançando remoção entre 1,70 a 3,90 log e 1,60 a 5,20 log, respectivamente. $\mathrm{O}$ indicador $C$. perfringens se mostrou bem mais resistente ao efeito das lâmpadas germicidas, atingindo valores entre 0,0 (ausência de inativação) e 1,30 log. Para concentrações de SST acima de 100,0 mg.L $\mathrm{L}^{-1}$, o efeito das lâmpadas germicidas passou a ser menos acentuado. Na prática foi possível notar resultados significativos, mesmo nos ensaios com concentrações de SST de $135,0 \mathrm{mg} . \mathrm{L}^{-1}$. A abordagem experimental forneceu meios para comprovar a eficácia do método combinado para inativar agentes patogênicos normalmente encontrados em esgoto doméstico. Além de atender aos padrões estabelecidos pela legislação brasileira, o efluente final está de acordo com as orientações definidas pela OMS. Portanto, é possível a reutilização do efluente final para irrigação irrestrita, embora haja a necessidade de exames complementares.

Palavras-chave: desinfecção; indicadores patogênicos; radiação UV; esgoto sanitário.

\section{Use of germicidal lamps in the disinfection of sanitary wastewater}

\section{ABSTRACT}

The objective of this study was to investigate the efficiency of germicidal lamps in the tertiary treatment of sewage to control pathogens. The performance of the photochemical reactor used in the tests was monitored by microbiological analyses to quantify $E$. coli (bacteria indicator), $C$. perfringens (protozoa indicator), coliphages (virus indicator). The experiments were performed with effluent from an UASB reactor installed at the WTP- USP São Carlos campus subjected to an aerated submerged biological filter and a photochemical reactor with radiation $U V$ at $254 \mathrm{~nm}$. The results showed that the indicators coliphages and $E$. coli showed the least resistance to UV radiation reaching removal from 1.70 to $3.90 \mathrm{log}$ and 1.60 to $5.20 \mathrm{log}$, respectively. On the other hand, the indicator $C$. perfringens was more resistant to the effect of germicidal lamps reaching values between 0.0 (no inactivation) and $1.30 \mathrm{log}$. For SST concentrations greater than $100.0 \mathrm{mg} . \mathrm{L}^{-1}$, the effect of the germicidal lamps became less pronounced. However, in practice it was possible to notice significant results in tests with TSS concentrations of $135.0 \mathrm{mg} . \mathrm{L}^{-1}$. The experimental approach proved the 
usefulness of the combined method for inactivating pathogens commonly found in domestic sewage. Besides meeting the standards established by the Brazilian regulation, the final effluent is in agreement with the guidelines defined by WHO. This allows the reuse of the final effluent for unrestricted irrigation, although complementary examination must be performed.

Keywords: disinfection; pathogen indicators; UV radiation; wastewater.

\section{INTRODUÇÃO}

A crescente demanda por fontes de água para consumo humano e industrial, aliada ao contínuo comprometimento da qualidade da água em mananciais de abastecimento, tem incentivado a busca por procedimentos mais adequados para reduzir a poluição dos recursos hídricos, com vistas ao desenvolvimento socioeconômico e a sustentabilidade ambiental.

Nesse contexto, a saúde pública é sem dúvida um aspecto de grande importância. $\mathrm{O}$ contato humano com águas contaminadas por esgoto doméstico é apontado pela Organização Mundial da Saúde (OMS) como a principal fonte de proliferação de doenças graves causadas por bactérias, vírus e protozoários. Por essa razão, a etapa de desinfecção do esgoto sanitário, antes de seu lançamento em corpos d'água, é particularmente importante.

Dentre as técnicas utilizadas no controle de microrganismos diversos pode-se destacar o uso de lâmpadas germicidas com emissão de radiação na região ultravioleta. As principais vantagens dessa tecnologia são: a relativa simplicidade de operação e funcionamento, a não formação de subprodutos tóxicos, tais como os compostos halogenados (THM's) comumente gerados durante a cloração, e a possibilidade de instalação do sistema fotoquímico em um espaço físico reduzido (Lazarova et al., 1999; Chin e Berube, 2005; Koivunen e HeinonenTanski, 2005).

Estudos reportam ainda o uso de lâmpadas germicidas em conjunto com a aplicação de desinfetantes químicos, como ozônio, peróxido de oxigênio, cloro, dentre outros, no controle de indicadores microbiológicos, tanto no tratamento de água de abastecimento quanto águas residuárias. Sistemas com mais de um agente de desinfecção juntamente com a radiação UV são particularmente indicados na inativação de microrganismos mais resistentes a um único estágio de desinfecção, como é o caso do protozoário Cryptosporidium. A eficiência da combinação de agentes desinfetantes está associada ao efeito sinérgico desencadeado na primeira etapa de desinfecção, cuja ação potencializa os resultados da segunda etapa de desinfecção, promovendo um incremento na inativação (Lotierzo et al., 2003; Wang et al., 2006; Bilotta e Daniel, 2007, 2010).

$\mathrm{O}$ efeito germicida das lâmpadas UV é devido à energia associada ao comprimento de onda $254 \mathrm{~nm}\left(472,3 \mathrm{~kJ} \mathrm{~mol}^{-1}\right)$, responsável por provocar alterações no DNA e RNA nas células atingidas. As lesões decorrentes de modificações no RNA são menos expressivas, pois o RNA é encontrado no interior da célula na forma de RNA mensageiro, transportador e ribossômico, possibilitando sua reparação (Bitton, 1994; WEF, 1996). Já a unicidade do DNA no interior celular o torna alvo de lesões muitas vezes irreversíveis, provocadas principalmente pela dimerização de bases nitrogenadas, as quais podem originar organismos debilitados e não hábeis à sua replicação e sobrevivência, aumentando a eficiência de inativação de patógenos, tanto no tratamento de água de abastecimento quanto esgoto doméstico (WEF, 1996; USEPA, 1999).

O produto entre a "Intensidade de Radiação" e o "Tempo de Exposição" é definido por "Dosagem de Radiação Aplicada". A literatura científica tem reportado que efluentes secundários e terciários necessitam de dosagens de radiação UV entre 30,0 e 45,0 mW.s.cm ${ }^{-2}$ para garantir redução de 3,0 a 5,0 log no número de coliformes fecais, coliformes totais e 
Streptococcus faecalis sobreviventes. Entretanto, doses maiores podem ser necessárias para efluentes com elevada concentração de sólidos em suspensão (acima de 100,0 mg.L ${ }^{-1}$ ), devido ao efeito de barreira que dificulta a passagem da radiação, ou mesmo para efluentes com elevada contaminação (em termos do número de microrganismos) ou ainda frente a microrganismos mais resistentes à radiação UV (Moreno et al., 1997; Andreadakis et al., 1999; Li et al., 2009).

Segundo Lazarova et al. (1999), bactérias Escherichia coli e Staphylococcus, bem como vírus Coxsackie A2 e poliovírus, apresentaram elevada sensibilidade à radiação UV, enquanto bactérias colifago MS2 são mais resistentes, exigindo dosagens entre 100,0 e 200,0 mW.s.cm ${ }^{-2}$ para reduzir de 3,0 a 5,0 log o número de organismos sobreviventes.

Neste estudo foi avaliado o desempenho de um reator fotoquímico com lâmpadas germicidas para verificar sua capacidade de inativação de bactérias, vírus e protozoários em esgoto sanitário efluente de uma estação de tratamento operada em escala plena.

$\mathrm{O}$ uso de agentes germicidas, em particular de lâmpadas germicidas, no controle de patógenos em esgoto doméstico, além de disponibilizar meios para atender às determinações da legislação ambiental brasileira para descarte do efluente tratado em corpos d'água, com base das resoluções CONAMA 357/2005 e CONAMA 430/2011, também possibilita a adequação da qualidade do efluente final para o seu reuso na irrigação (Liberti e Notarnicola, 1999; Blumenthal et al., 2000; Brasil, 2005; WHO, 2006; Brasil, 2011).

\section{MATERIAIS E MÉTODO}

Para a alimentação da instalação piloto foi utilizado esgoto sanitário efluente de um reator de configuração UASB (Upflow Anaerobic Sludge Blanket), em fluxo contínuo de operação, construído em escala real na Estação de Tratamento de Esgoto da Universidade de São Paulo, campus São Carlos. O tempo de detenção hidráulica no reator anaeróbio foi $12 \mathrm{~h}$. A Figura 1 mostra o fluxograma das etapas de tratamento do efluente nos ensaios com UV.

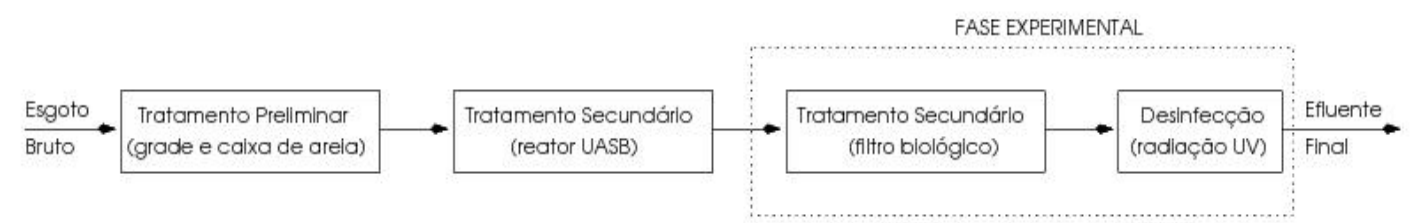

Figura 1. Fluxograma das principais etapas de tratamentos utilizados na pesquisa.

Sendo assim, ao utilizar a configuração indicada na Figura 1 foi possível avaliar o efeito da radiação UV na desinfecção de esgoto sanitário proveniente de uma estação de tratamento em escala plena, com características físico-químicas bastante variáveis (típico de ETE's), de grande valia para a simulação do desempenho do sistema proposto sob condições reais de operação (Bilotta, 2006).

O tratamento secundário é composto por um reator UASB seguido de um filtro biológico submerso mantido sob aeração permanente a $50,0 \mathrm{kPa}$. O biofiltro foi preenchido com carvão ativado granular (porosidade 53,5\%) para otimizar a fixação de biomassa ativa e, assim, favorecer a decomposição da matéria orgânica residual proveniente do reator UASB. O objetivo deste procedimento é minimizar a presença de sólidos em suspensão para reduzir o efeito de bloqueio dessas partículas à incidência da radiação sobre o microrganismo (Bilotta, 2006). A Figura 2 ilustra o biofiltro aeróbio utilizado no tratamento secundário da fase experimental. 


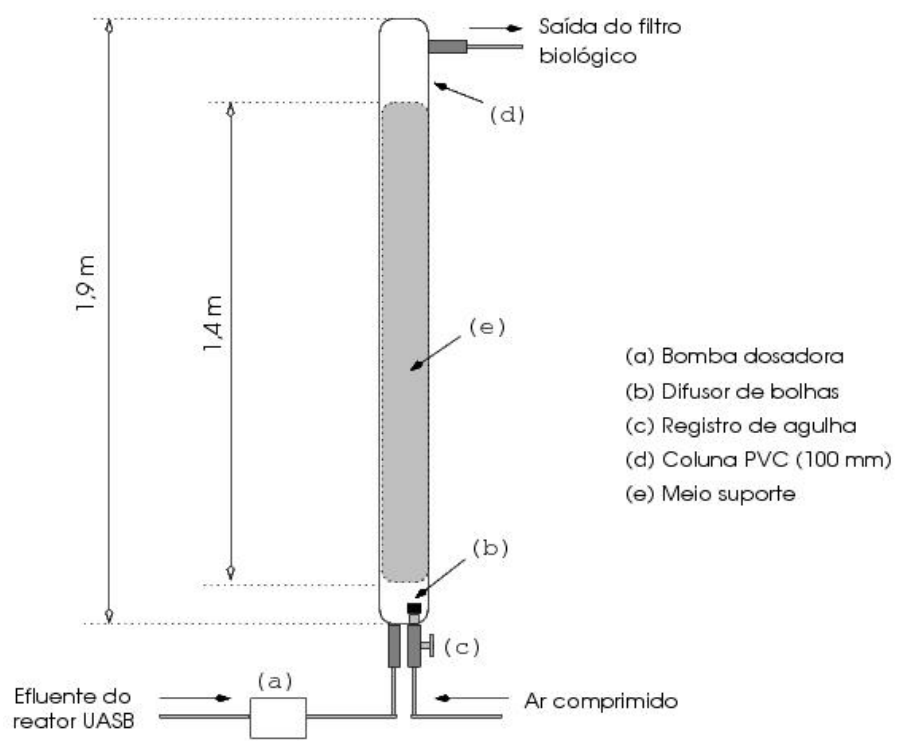

Figura 2. Filtro biológico aeróbio para o tratamento secundário.

A carga orgânica aplicada ao filtro foi de $36,9 \mathrm{~kg}$ DQO. $\mathrm{m}^{-3} \cdot \mathrm{d}^{-1}$. O carvão ativado utilizado como meio suporte possui diâmetro médio de $3,62( \pm 0,38) \mathrm{mm}$ e massa específica de $1,79 \mathrm{~g} . \mathrm{cm}^{-3}$. O filtro biológico foi mantido em regime contínuo de operação durante o período de realização dos experimentos e o tempo de detenção foi estabelecido em 4,6 horas.

Para os ensaios de desinfecção foram utilizadas lâmpadas germicidas Phillips (modelo G15-T8) de longa duração e baixa pressão de vapor de mercúrio (potencial nominal 15,0 W) com 85\% da energia emitida em $254 \mathrm{~nm}$. O reator fotoquímico foi construído em aço inoxidável e está indicado na Figura 3.

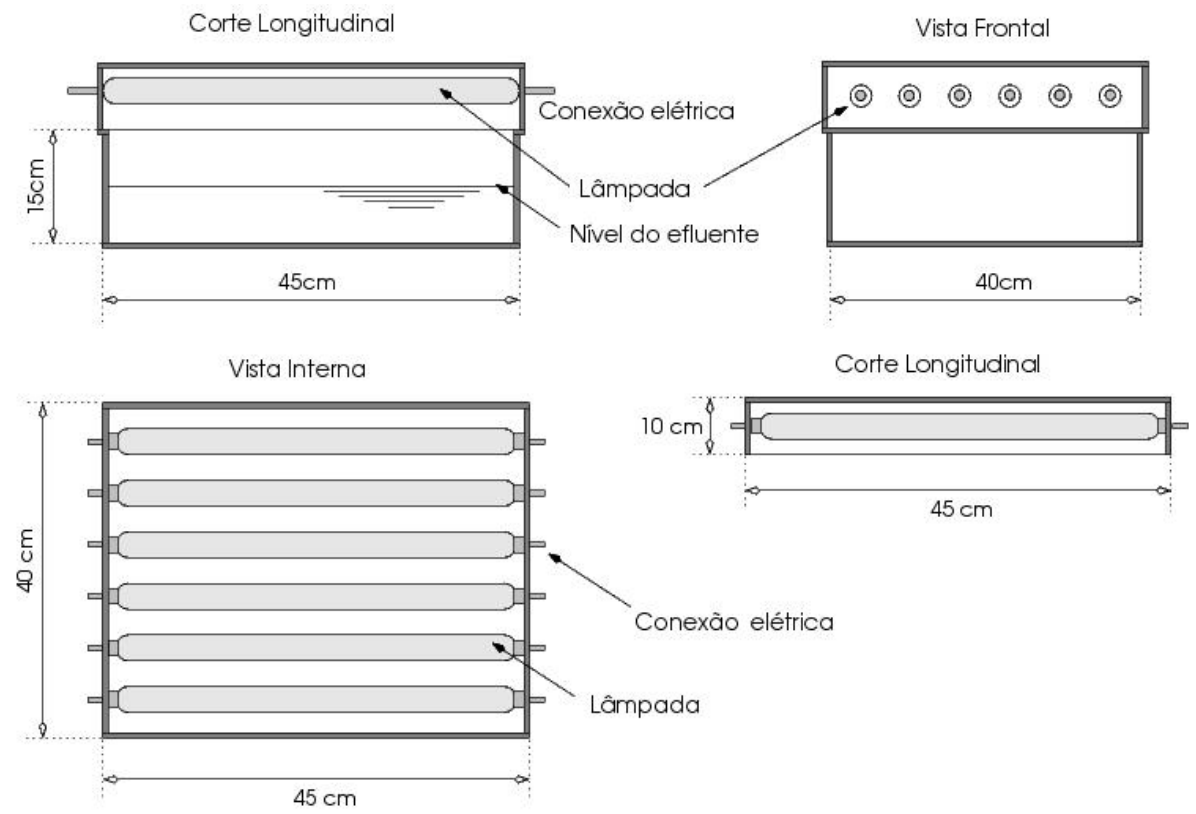

Figura 3. Instalação piloto para os ensaios com as lâmpadas germicidas.

A intensidade média de radiação UV emitida pelo conjunto de lâmpadas foi estimada pelo método radiométrico com equipamento UVX Radiometer, que possui um sensor capaz de quantificar a energia luminosa em $254 \mathrm{~nm}$ (Bilotta, 2006). 
BILOTTA, P.; DANIEL, L. A. Utilização de lâmpadas germicidas na desinfecção de esgoto sanitário. AmbiAgua, Taubaté, v. 7, n. 1, p. 120-129, 2012. (http://dx.doi.org/10.4136/ambi-agua.845)

Os ensaios realizados no filtro biológico aerado foram desenvolvidos em regime de operação contínua, enquanto os ensaios de desinfecção no reator fotoquímico foram executados em batelada. A Tabela 1 mostra as condições operacionais aplicadas a este estudo.

Tabela 1. Condições operacionais utilizadas na fase experimental.

\begin{tabular}{l|l}
\hline \multicolumn{1}{c|}{ Filtro Biológico } & \multicolumn{1}{c}{ Reator Fotoquímico } \\
\hline Tempo de detenção: $4,6 \mathrm{~h}$ & Tempo de contato: 60 e $120 \mathrm{~s}$ \\
Aeração: $50,0 \mathrm{kPa}$ & Intensidade média: $4,5 \mathrm{~mW} . \mathrm{cm}^{-2}$ \\
Vazão de efluente: $6,8 \mathrm{~m}^{3} . \mathrm{h}^{-1}$ & $\begin{array}{l}\text { Dose média efetiva: } 123,0 \text { e } 247,0 \mathrm{~mW} . \mathrm{s} . \mathrm{cm}^{-2} \\
\end{array}$ \\
& Número de lâmpadas: 6 \\
& Volume de efluente: 5,41 \\
& Lâmina líquida: $3,0 \mathrm{~cm}$ \\
\hline
\end{tabular}

Os experimentos foram seguidos de análises físico-químicas e microbiológicos para caracterização qualitativa e quantitativa das amostras coletadas nos seguintes pontos: a) saída do reator UASB, b) saída do filtro biológico, c) após a etapa de desinfecção no reator fotoquímico.

A eficiência do sistema foi monitorada por meio de análises microbiológicas para quantificação de Escherichia coli (indicador de bactérias), Clostridium perfringens (indicador de protozoários) e colifagos (indicador de vírus). A Tabela 2 relaciona as análises e metodologias utilizadas na caracterização das amostras.

Tabela 2. Métodos analíticos para caracterização das amostras.

\section{Procedimentos de Análise ${ }^{\text {[a] }}$}

Demanda Química de Oxigênio (DQO) : Método refluxo fechado (APHA et al., 1995)

Sólidos Suspensos Totais (SST) : Método gravimétrico (APHA et al., 1995)

pH : Método de titulação potenciométrica (APHA et al., 1995)

Clostridium perfringens : Método de tubos múltiplos - CETESB L5.213 (CETESB, 1990)

Colifagos : Método de contagem de placas - CETESB LS.225 (CETESB, 1993)

Escherichia coli : Método membranas filtrantes - Chromocult ${ }^{\circledR}$ (APHA et al., 1995)

Absorbância : Método espectrofotométrico em 254 nm (APHA et al., 1995)

\footnotetext{
[a] Os procedimentos utilizados na análise das amostras coletadas estão detalhadamente descritos nas referências indicadas na Tabela 2 .
}

Nas análises microbiológicas foram utilizadas cepas de E. coli ATCC 11229, além de $C$. perfringens ATCC 13124 e E. coli CIP 55.30 (para os colifagos). Na repicagem e preservação das cepas de E. coli utilizou-se meio de cultura Tryptic Soy Broth (TSB) e para os fagos foram utilizados meios TSB e TSA (Tryptic Soy Agar) modificado. Ainda, para a quantificação de $E$. coli foi utilizada a técnica de filtração em membranas preparadas com meio Chromocult Coliform Agar (Merck n. 1.10426). 


\section{RESULTADOS E DISCUSSÃO}

Com base nos resultados dos exames microbiológicos foi elaborada a Tabela 3. O termo "No" representa o número de microrganismos sobreviventes na saída do tratamento biológico (após o biofiltro), correspondendo à condição inicial, enquanto o termo "N" indica o número de sobreviventes após a aplicação da radiação UV, indicando a condição final.

Tabela 3. Variação da população de Escherichia coli, colifagos e Clostridium perfringens.

\begin{tabular}{|c|c|c|c|c|c|c|c|}
\hline & \multirow{3}{*}{ Ensaio } & \multirow{2}{*}{ Efluente } & \multirow{2}{*}{ Efluente } & \multicolumn{2}{|c|}{ Sobreviventes ${ }^{\text {[a] }}$} & \multicolumn{2}{|c|}{ - $\log$ N/No } \\
\hline & & & & \multicolumn{2}{|c|}{$\mathbf{T}$} & \multicolumn{2}{|c|}{$\mathbf{T}$} \\
\hline & & UASB & Biofiltro & 60 & 120 & 60 & 120 \\
\hline \multirow{5}{*}{$\begin{array}{l}\text { C. perfringens } \\
\text { (NMP/100 ml) }\end{array}$} & 1 & $8,0.10^{2}$ & $8,0.10^{2}$ & 60,0 & 40,0 & 1,12 & 1,30 \\
\hline & 2 & $1,1.10^{3}$ & $1,1.10^{3}$ & $5,0.10^{2}$ & $5,0.10^{2}$ & 0,34 & 0,34 \\
\hline & 3 & $3,3.10^{3}$ & $3,4.10^{3}$ & $8,0.10^{2}$ & $6,0.10^{2}$ & 0,61 & 0,75 \\
\hline & 4 & $1,1.10^{4}$ & $1,7.10^{4}$ & $1,7 \cdot 10^{3}$ & $1,0.10^{2}$ & 0,81 & 2,23 \\
\hline & 5 & $1,0.10^{3}$ & $1,0.10^{3}$ & $1,0.10^{3}$ & $1,0.10^{3}$ & 0,00 & 0,00 \\
\hline \multirow{5}{*}{$\begin{array}{l}\text { Colifagos } \\
\text { (UFP/100 ml) }\end{array}$} & 1 & $1,0.10^{3}$ & $1,0.10^{3}$ & 20,0 & 5,0 & 1,70 & 2,30 \\
\hline & 2 & $7,5.10^{2}$ & $7,0.10^{2}$ & 10,0 & $<1,0$ & 1,87 & 2,84 \\
\hline & 3 & $3,0.10^{2}$ & $3,0.10^{2}$ & $<1,0$ & 20,0 & 2,48 & 1,18 \\
\hline & 4 & $8,1.10^{3}$ & $7,6.10^{3}$ & $<1,0$ & $<1,0$ & 3,90 & 3,88 \\
\hline & 5 & $2,5.10^{3}$ & $2,3.10^{3}$ & $<1,0$ & $<1,0$ & 3,40 & 3,36 \\
\hline \multirow{5}{*}{$\begin{array}{l}\text { E. coli } \\
\text { (UFC/100 ml) }\end{array}$} & 1 & $5,0.10^{5}$ & $1,6.10^{5}$ & $3,0.10^{2}$ & $4,0.10^{3}$ & 3,22 & 1,60 \\
\hline & 2 & $3,2.10^{5}$ & $4,0.10^{4}$ & 20,0 & $1,0.10^{2}$ & 4,20 & 2,60 \\
\hline & 3 & $1,6.10^{5}$ & $1,0.10^{5}$ & $<1,0$ & $<1,0$ & 5,20 & 5,00 \\
\hline & 4 & $1,2.10^{5}$ & $5,4.10^{5}$ & 70 & 100 & 3,23 & 3,73 \\
\hline & 5 & $3,9.10^{5}$ & $5,4.10^{5}$ & 103 & $7,0.10^{3}$ & 3,59 & 1,89 \\
\hline
\end{tabular}

Amostras com número de sobreviventes inferior a 1,0 (Tabela 3) indicam sobrevivência abaixo do limite mínimo de detecção do método analítico utilizado para quantificar atividade metabólica e reprodutiva dos indicadores patogênicos investigados, representando, portanto, ausência de contaminação.

De acordo com a Tabela 3, os indicadores colifagos e E. coli apresentaram a menor resistência ao efeito da radiação UV, alcançando remoção entre 1,70 a 3,90 log e 1,60 a 5,20 $\log$, respectivamente, com dosagens de apenas 123,0 e 247,0 mW.s.cm ${ }^{-2}$, para os tempos de contato de 60 e 120 s. Por outro lado, o indicador $C$. perfringens se mostrou bem mais resistente a ação das lâmpadas germicidas, atingindo valores entre 0,0 (ausência de inativação) e 1,30 log. Sendo assim, para o indicador Clostridium perfringens os resultados apontam para a necessidade de utilizar dosagens mais elevadas de radiação UV (seja pelo aumento do número de lâmpadas ou do tempo de contato) para se obter redução superior aos valores alcançados com a aplicação de $247,0 \mathrm{~mW} . \mathrm{s} . \mathrm{cm}^{-2}$.

Os resultados obtidos estão de acordo os valores descritos por Andreadakis et al. (1999) na inativação de coliformes totais em efluente secundário $(99,99 \%$ de eficiência com dosagem de 120,0 mW.s.cm ${ }^{-2}$ ) e nos resultados relatados por Lazarova et al. (1999) na inativação de coliformes fecais e Streptococcus faecalis $(99,9$ e 99,999\% de eficiência com dosagem de 30,0 e 45,0 mW.s.cm ${ }^{-2}$ ). 
A partir dos resultados apresentados na Tabela 3 foram construídos os gráficos indicados na Figura 4, que descrevem a variação da população de Escherichia coli, colifagos e Clostridium perfringens sobreviventes a ação das lâmpadas germicidas (em termos de Log $\mathrm{N} / \mathrm{No}$ ) para os 5 ensaios nos 2 tempos de contato investigados.

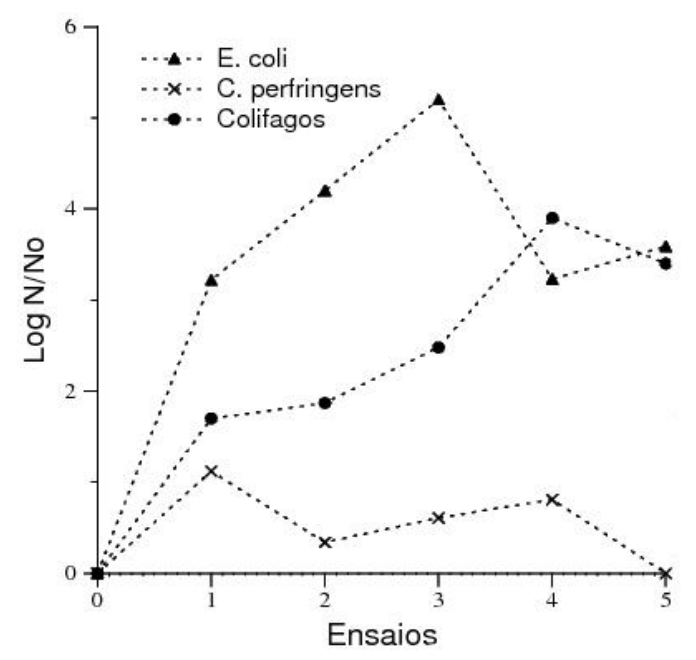

a) Tempo de contato $60 \mathrm{~s}$.

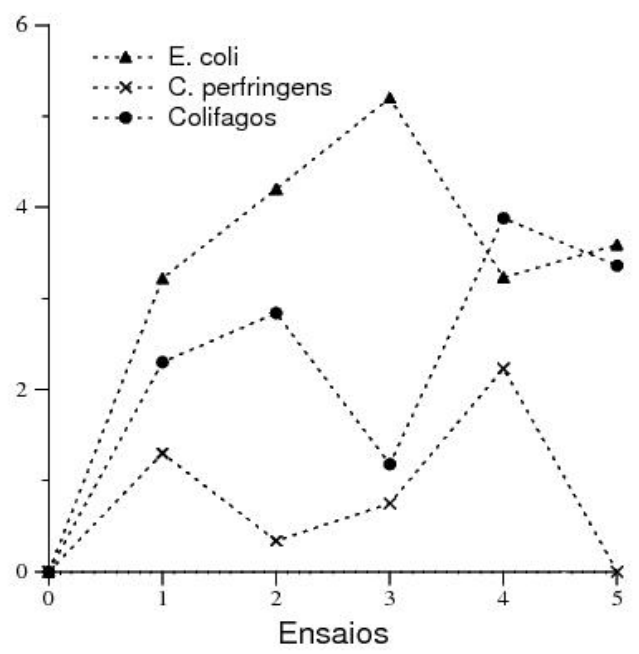

b) Tempo de contato $120 \mathrm{~s}$.

Figura 4. Representação gráfica da variação de microrganismos sobreviventes.

Em relação à dosagem aplicada, pode-se verificar que não houve variação significativa na eficiência de inativação com o aumento do tempo de exposição às lâmpadas germicidas de 60 para 120 s. Nesse sentido, estudos complementares são sugeridos para se investigar a eficiência do reator fotoquímico em dosagens superiores às utilizadas nesta pesquisa (Tabela 1), inclusive para se identificar as condições mais favoráveis para o aumento da eficiência de inativação do indicador de protozoários (Clostridium perfringens).

A Tabela 4 mostra os resultados das análises físico-químicas realizadas a partir das amostras coletadas nos 5 ensaios no reator fotoquímico. A leitura de absorbância das amostras no comprimento de onda $254 \mathrm{~nm}$ revelou os seguintes resultados: $0,254( \pm 0,06)$ para os ensaios com $60 \mathrm{~s}$ de exposição à radiação UV e 0,246 $( \pm 0,07)$ para os ensaios com $120 \mathrm{~s}$. Experimentos realizados por Bilotta (2006) mostram que a eficiência do reator fotoquímico não foi afetada quando a variação da absorbância se manteve entre 0,159 e 0,320, para ensaios combinados com radiação UV e ozônio. Sendo assim, nos ensaios de desinfecção com 60 e 120 s de exposição, a absorbância atingiu valores dentro da faixa aceitável e não interferiu no desempenho do sistema.

Tabela 4. Variação dos parâmetros DQO, concentração de SST e pH.

\begin{tabular}{|c|c|c|c|c|c|c|c|c|c|c|}
\hline \multirow{3}{*}{ Teste } & \multirow{2}{*}{\multicolumn{3}{|c|}{$\begin{array}{c}\text { Efluente } \\
\text { Reator UASB }\end{array}$}} & \multirow{2}{*}{\multicolumn{3}{|c|}{$\begin{array}{c}\text { Efluente } \\
\text { Filtro Biológico }\end{array}$}} & \multicolumn{4}{|c|}{ Efluente Final } \\
\hline & & & & & & & \multicolumn{2}{|c|}{$60(s)$} & \multicolumn{2}{|c|}{$120(s)$} \\
\hline & $\underset{\left(\mathrm{mg}^{2} \mathrm{~L}^{-1}\right)}{\text { DQO }}$ & $\underset{\left(\mathbf{m g} \cdot \mathbf{L}^{-1}\right)}{\text { SST }}$ & $\mathbf{p H}$ & $\underset{\left(\mathbf{m g} . L^{-1}\right)}{\text { DQO }}$ & $\underset{\left(\mathbf{m g} . \mathbf{L}^{-1}\right)}{\mathrm{SST}}$ & pH & $\underset{\left(\mathrm{mg.L}^{-1}\right)}{\text { DQO }}$ & $\underset{\left(\mathbf{m g} . \mathbf{L}^{-1}\right)}{\text { SST }}$ & $\underset{\left(\mathbf{m g} . \mathrm{L}^{-1}\right)}{\text { DQO }}$ & $\underset{\left(\mathbf{m g} . L^{-1}\right)}{\text { SST }}$ \\
\hline 1 & 61 & 149 & 7,1 & 101 & 91 & 7,4 & 125 & 23 & 78 & 106 \\
\hline 2 & 117 & 14 & 6,8 & 85 & 87 & 6,4 & 158 & 73 & 163 & 135 \\
\hline 3 & 47 & 17 & 6,7 & 55 & 20 & 3,6 & 82 & 33 & 49 & 41 \\
\hline 4 & 97 & 60 & 6,0 & 70 & 47 & 6,0 & 128 & 70 & 100 & 68 \\
\hline 5 & 46 & 31 & 7,1 & 43 & 44 & 7,0 & 60 & 27 & 57 & 21 \\
\hline
\end{tabular}


Os resultados físico-químicos indicados na Tabela 4 confirmam a variação da qualidade do efluente secundário em termos dos parâmetros DQO e concentração de sólidos suspensos (DQO: mínimo 49,0 e máximo 158,0 mg.L $\mathrm{L}^{-1}$ e SST: mínimo 23,0 e máximo 135,0 mg.L $\mathrm{L}^{-1}$ ). Portanto, os resultados obtidos com as lâmpadas germicidas revelam a eficiência do sistema fotoquímico mesmo em condições desfavoráveis decorrentes da presença de matéria orgânica em suspensão. Essas partículas agem como barreira e impedem a livre passagem da radiação em direção ao alvo, o microrganismo, reduzindo a eficácia das lâmpadas germicidas.

Para concentrações de SST acima de 100,0 mg.L $\mathrm{L}^{-1}$ o efeito germicida da radiação UV passa a ser menos efetivo (Lazarova et al., 1999; Wang et al., 2006). Além disso, estudos realizados por Li et al. (2009) para verificar o efeito de partículas na eficiência da desinfecção com radiação UV, em efluente secundário de uma ETE, alcançaram inativação de 1,5 log com 24,0 mW.s.cm ${ }^{-2}$ e 1,7 log com 40 mW.s.cm ${ }^{-2}$ para protozoários. Comparando-se os dados das Tabelas 3 e 4 é possível notar resultados significativos mesmo nos ensaios com concentrações de SST de 135,0 mg. $\mathrm{L}^{-1}$, como mostra o ensaio 2 com tempo de contato $120 \mathrm{~s}$.

Assim, as variações observadas entre os 5 ensaios (Tabelas 3 e 4) podem estar conjuntamente associadas aos seguintes aspectos: dificuldade na obtenção de alíquotas absolutamente representativas das amostras analisadas, visto o grande número de diluições requeridas nos exames microbiológicos; variação da qualidade do efluente anaeróbio (particularmente a concentração de sólidos em suspensão), comum em estações de tratamento de esgoto sanitário em escala plena; e oscilações no desempenho do equipamento fotoquímico, em razão de flutuações na energia fornecida pela rede elétrica local.

\section{CONCLUSÃO}

Com base nos resultados e discussões apresentadas, pode-se concluir que o uso de lâmpadas germicidas com emissão de radiação em $254 \mathrm{~nm}$ se mostrou bastante positivo no controle de indicadores patogênicos no tratamento terciário de esgoto doméstico. Os experimentos revelaram a elevada potencialidade técnica do reator fotoquímico para a inativação de colifagos e Escherichia coli, alcançando remoção entre 1,70 a 3,90 log e 1,60 a 5,20 log, respectivamente, com dosagens correspondentes a 123,0 e 247,0 mW.s.cm ${ }^{-2}$.

A espécie Clostridium perfringens, por outro lado, se revelou mais resistente à ação germicida das lâmpadas, considerando-se as condições experimentais aplicadas. Desse modo, estudos complementares são sugeridos no sentido de se verificar o comportamento do indicador Clostridium perfringens para dosagens acima de $247,0 \mathrm{~mW} . \mathrm{s} . \mathrm{cm}^{-2}$ (intensidade das lâmpadas e tempo de contato).

Portanto, a técnica descrita neste trabalho apresenta elevado potencial no tratamento terciário de esgoto sanitário, visando o controle de patógenos, em atendimento à legislação ambiental, para o seu descarte em corpos d'água, e ainda possibilita a adequação do efluente final às diretrizes estabelecidas pela Organização Mundial da Saúde (OMS) para o reuso de água (esgoto tratado) na irrigação, embora a necessidade de exames complementares como a quantificação da presença de helmintos.

\section{AGRADECIMENTOS}

Os autores deste trabalho agradecem o auxílio financeiro concedido pela Fundação de Amparo à Pesquisa do Estado de São Paulo (FAPESP), Processo n.00/00640-5, que tornou possível a realização dessa pesquisa. 


\section{REFERÊNCIAS}

American Public Health Association - APHA; American Water Works Association - AWWA; Water EnvironmenT Federation - WEF. Standard methods for the examination of water and wastewater. 20. ed. New York, 1998.

ANDREADAKIS, A.; MAMAIS, D.; CHRISTOULAS, D.; KABYLAFKA, S. Ultraviolet disinfection of secondary and tertiary effluent in the mediterranean region. Water Science \& Technology, v. 40, n. 4/5, p. 253-260, 1999.

http://dx.doi.org/10.1016/S0273-1223(99)00506-5

BILOTTA, P. Inativação de indicadores patogênicos em sistemas combinados de tratamento e pré-desinfecção de esgoto sanitário. 2006. 180f. Tese (Doutorado em Tratamento de Águas Residuárias) - Departamento de Hidráulica e Saneamento, Universidade de São Paulo, São Carlos, 2006.

BILOTTA, P.; DANIEL, L. A. Sequential application of ozone and UV radiation to eliminate resistant microbiological indicators. In: IWA SPECIALIST CONFERENCE ON WASTEWATER RECLAMATION AND REUSE, 6., 9-12 out. 2007, Antwerp. Proceedings... Antwerp: IWA, 2007.

BILOTTA, P.; DANIEL, L. A. Advanced process of microbiological control of wastewater in combined system of disinfection with UV radiation. Water Science \& Technology, v. 61, n. 10, p. 2469-2475, 2010. http://dx.doi.org/10.2166/wst.2010.155

BITTON, G. Wastewater microbiology. New York: John Wiley \& Sons, 1994. 280p.

BLUMENTHAL, U. J.; MARA, D. D.; PEASY, A.; RUIZ-PALACIO, G.; STOTT, R. Guidelines for the microbiological quality of treated wastewater used in agriculture: recommendations for revising WHO guidelines. World Health Organization, Genébra, v. 78, n. 9, p. 1104-1116, 2000.

BRASIL. Conselho Nacional do Meio Ambiente. Resolução 357 de 18 de março de 2005. Disponível em: <www.gov.br/port/conama/res/res05/res35705.pdf〉. Acesso em: 16 fev. 2012.

BRASIL. Conselho Nacional do Meio Ambiente. Resolução 430 de 13 de maio de 2011. Disponível em: <www.mma.gov.br/port/conama/legiabre.cfm?codlegi=646>. Acesso em: 16 fev. 2012.

COMPANHIA DE TECNOLOGIA EM SANEAMENTO AMBIENTAL - CETESB. Quantificação de colifagos em amostras de água (L5.225). Documento Técnico. São Paulo, 1990.

COMPANHIA DE TECNOLOGIA EM SANEAMENTO AMBIENTAL - CETESB. Clostridium perfringens: determinação em amostras de água pela técnica de tubos múltiplos (L5.213). Documento Técnico. São Paulo, 1993.

CHIN, A.; BERUBE, P. R. Removal of disinfection byproduct precursors with ozone-UV advanced oxidation process. Water Research, v. 39, p. 2136-2144, 2005. http://dx.doi.org/10.1016/j.watres.2005.03.021

KOIVUNEN, J.; HEINONEN-TANSKI, H. Inativation of enteric microorganisms with chemical disinfectants, UV irradiation and combined chemical/UV treatment. Water Research, v. 39, p. 1519-1526, 2005. http://dx.doi.org/10.1016/j.watres.2005.01.021 
LAZAROVA, V.; SAVOYE, P.; JANEX, M. L.; BLATCHLEY, E. R.; POMMEPUY, M. Advanced wastewater disinfection technologies: state of the art and perspectives. Water Science and Technology, v. 40, n. 4/5, p. 203-213, 1999. http://dx.doi.org/10.1016/S0273-1223(99)00502-8

LI, D.; CRAIK, S. A.; SMITH, D. W.; BELOSEVIC, M. The assessment of particle association and UV disinfection of wastewater using indigenous spore-forming bacteria. Water Research, v. 43, n. 2, p. 481-489, 2009. http://dx.doi.org/10.1016/j.watres.2008.10.025

LIBERTI, L.; NOTARNICOLA, M. Advanced treatment and disinfection for municipal wastewater reuse in agriculture. Water Science Technology, v. 40, n. 4/5, p. 235-245, 1999. http://dx.doi.org/10.1016/S0273-1223(99)00505-3

LOTIERZO, M.; FÉLIERS, C.; FAUREL, N.; LE GRAND, L.; SABY, S.; CERVANTES, P. Synergistic effects of sequential treatment by UV irradiation and chemical disinfectant for drinking water disinfection. In: UV WORLD CONGRESS, 2., 03-05 jul. 2003, Vienna. Proceedings... Vienna: IU Light Association, 2003.

MORENO, B.; GONĨ, F; FERNANEDEZ, O.; MARTÍNEZ, J. A.; ASTIGARRAGA, M. The disinfection of wastewater by ultraviolet light. Water Science Technology, v. 35, n. 11/12, p. 233-235, 1997. http://dx.doi.org/10.1016/S0273-1223(97)00264-3

UNITED STATES Environmental Protection Agency - USEPA. Alternative disinfectants and oxidants guidance manual: 815-R-99-014., Washington D.C., 1999. 346p.

WANG, J. L.; WANG, L.; WANG, B. Z.; ZGHAN, J. S.; HUANG, W. Z. Suspended particle effects on ultraviolet light disinfection of effluent and the improvement. Water Practice \& Technology, v. 1, n. 2, 183-192, 2006.

WATER ENVIRONMENT FEDERATION - WEF. Wastewater disinfection: manual of practice. Alexandria, 1996. $230 \mathrm{p}$.

WORLD HEALTH ORGANIZATION - WHO. Guidelines for the safe use of wastewater, excreta and greywater. Vol 2: Wastewater use in agriculture. Genébra, 2006. 


ISSN = 1980-993X - doi:10.4136/1980-993X
www.ambi-agua.net
E-mail: ambi-agua@agro.unitau.br
Tel.: (12) 3625-4212

\title{
Sulfate and dissolved sulfide variation under low COD/Sulfate ratio in Up-flow Anaerobic Sludge Blanket (UASB) treating domestic wastewater
}

(http://dx.doi.org/10.4136/ambi-agua.849)

\author{
Eduardo Lucas Subtil ${ }^{1}$; Sérvio Túlio Alves Cassini ${ }^{2}$; Ricardo Franci Gonçalves ${ }^{2}$ \\ ${ }^{1}$ Centro Internacional de Referência em Reúso de Água, Universidade de São Paulo (USP), \\ ${ }^{2}$ Departamento de Engenharia Ambiental, Universidade Federal do Espírito Santo (UFES), \\ e-mail: ${ }^{1}$ eduardosubtil@gmail.com; ${ }^{2}$ scassini@npd.ufes.br; ${ }^{3}$ franci@npd.ufes.br
}

\begin{abstract}
In this study, the dynamics of sulfate reduction and dissolved sulfide generation $\left(\mathrm{S}^{2-}, \mathrm{HS}^{-}\right.$, $\mathrm{H}_{2} \mathrm{~S}_{\mathrm{aq}}$ ) in liquid phase was evaluated in an UASB reactor treating domestic wastewater with low COD/Sulfate content. The evaluation in the UASB reactor was performed at three sludge heights $(0.25,1.25,2.25$ taps $)$ and effluent of the reactor. Sulfate reduction was verified in the reactor, with an average reduction of $24 \%$ throughout the experiment period. However, the dissolved sulfide concentration in the reactor was not higher than $5.0 \mathrm{mg} \mathrm{S} \mathrm{S}_{\text {diss }} / \mathrm{L}$. The kinetic model of first order showed good fit to describe the sulfate reduction under different $\mathrm{COD} /$ sulfate ratio, with $\mathrm{K}_{1}^{\text {app }}$ between $2.94 \times 10^{-5} \mathrm{~s}^{-1}$ and $1.17 \times 10^{-5} \mathrm{~s}^{-1}$ with correlation coefficients for data over $91 \%$. The maximum rate to sulfate reduction was $18.0 \mathrm{mg} \mathrm{SO} \mathrm{S}^{2-} / \mathrm{L}^{2} \mathrm{~h}^{-1}$ and small variation in $\mathrm{COD} /$ sulfate ratio promotes a significant change both in sulfate and sulfide concentrations.
\end{abstract}

Keywords: COD/sulfate; dissolved sulfide; kinetics; sulfate reduction; UASB reactors.

\section{Variação de sulfato e sulfeto dissolvido sob baixas relações DQO/Sulfato em um Reator Anaeróbio de Manta de Lodo e Fluxo Ascendente (UASB) tratando esgoto sanitário}

\section{RESUMO}

Nesse estudo foi avaliado a dinâmica de redução de sulfato e da geração de sulfeto dissolvido $\left(\mathrm{S}^{2}, \mathrm{HS}^{-}, \mathrm{H}_{2} \mathrm{~S}_{\mathrm{aq}}\right.$ ) na fase líquida de um reator UASB tratando esgoto sanitário tipicamente doméstico com baixa relação DQO/sulfato. Para isso foram coletadas amostras do afluente e efluente, além de três alturas $(0,25 \mathrm{~m}, 1,25 \mathrm{~m}$ e $2,25 \mathrm{~m})$ ao longo do reator. Durante todo experimento foi observada redução de sulfato no reator UASB, com um valor médio de $24 \%$. Entretanto, a concentração de sulfeto dissolvido no efluente do reator não foi maior que $5,0 \mathrm{mg} \mathrm{S}_{\text {diss }} / \mathrm{L}$. O modelo cinético de primeira ordem apresentou um bom ajuste para descrever a redução de sulfato sob diferentes relações DQO/sulfato, com o valor de $\mathrm{K}_{1}{ }^{\text {app }}$ entre $2.94 \times 10^{-5} \mathrm{~s}^{-1}$ e $1.17 \times 10^{-5} \mathrm{~s}^{-1}$ com coeficiente de correlação para os dados superior a $91 \%$. A taxa máxima observada de redução de sulfato foi de $18.0 \mathrm{mg} \mathrm{SO}{ }_{4}{ }^{2-} / \mathrm{L} . \mathrm{h}^{-1}$ e pequenas variações na relação DQO/sulfato promoveu uma mudança significativa tanto na concentração de sulfato como na de sulfeto dissolvido.

Palavras-chave: DQO/sulfato; sulfeto dissolvido; cinética; redução de sulfato; reator UASB 


\section{INTRODUCTION}

Anaerobic treatment of domestic wastewater is not a new concept. However, since the first systems can only partially treat the sewage and, the effluent still contains high concentration of organic matter, suspended solids and nutrients, the interest for sewage treatment was over to aerobic treatment systems. With the advent of high rate anaerobic systems such as Up-flow Anaerobic Sludge Blanket Reactor (UASB), anaerobic contact process, anaerobic filter (AF) or fixed film reactors and fluidized bed reactors, which promote a good contact between the inflow wastewater and the micro-organisms at high concentration and consequently high organic matter removal at short retention times, the strategy for the treatment of sewage was shifted back to anaerobic process which has the advantages of low cost, energy recovery in the form of biogas, operational simplicity, low energy consumption, and low production of digested sludge (Khan et al., 2011; Lettinga, 2008; Chernicharo, 1997). In 1970s, due to the energy crisis and relatively less expensive treatment concept, the UASB process was recognized as one of the most feasible method for the treatment of sewage in developing tropical and sub-tropical countries like India, Brazil and Colombia where financial resources are generally scarce (Khan et al., 2011). Nowadays, it can be considered as an established technology and it is successfully used for the treatment of sewage and many kinds of industrial wastewaters (Lettinga and Hulshoff-Pol, 1991).

Despite the inherent advantages of high rate anaerobic system, the presence of sulfate $\left(\mathrm{SO}_{4}{ }^{2-}\right)$ represent a serious risk for the system, since the Sulfate Reducing Bacteria (SRB) can reduce sulfate to sulfide through a process denominated dissimilatory sulfate reduction (Postgate, 1984; Lens et al., 2001). This process is the main source of odorous compounds, mainly sulfide forms, in air phase during the anaerobic treatment of wastewater. Therefore the sulfate reduction in UASB reactors has been considered a negative side effect, since the production of sulfide causes several problems, such as toxicity (O'flaherty and Colleran, 2000), induced corrosion (Vincke et al., 2001), aggressive odors (Lens et al., 2001), increase of effluent COD and lowering the methane in biogas production (Lens et al., 1998).

Due to very favorable conditions for sulfate reduction in anaerobic reactors, it has been studied specially when the affluent is naturally enriched with sulfate forms (Kalyuzhnyi et al., 1997; Lens et al., 2002). The extent of sulfate reduction and organic matter mineralization depends upon several factors, including the sulfate concentration, wastewater composition, the ratio $\mathrm{COD} / \mathrm{SO}_{4}{ }^{2-}$ and environmental factors such as temperature and $\mathrm{pH}$ (Visser, 1996). Among these factors, the $\mathrm{COD} / \mathrm{SO}_{4}{ }^{2-}$ relationship has been considered one of the key factors when comparing the Methane Producing Microorganisms (MPM) and SRB (Colleran et al., 1995). Until recently, it was considered that a empirical affluent relationship COD/ $\mathrm{SO}_{4}{ }^{2-}>10$ was a strong prerequisite for successful anaerobic treatment because lower relationship values of $\mathrm{COD} / \mathrm{SO}_{4}{ }^{2-}<8$ were potentially inhibitory to methanogenesis and inducing excessive sulfide production in the anaerobic reactor although some authors (Hilton and Archer, 1988; Méndez et al., 1989; Shayegan et al., 2005) have reported a successful anaerobic treatment with $\mathrm{COD} / \mathrm{SO}_{4}{ }^{2-}$ values from 5 to 8 .

Thus, in order to increase the anaerobic wastewater treatment efficiency, with high sulfate concentration, it is necessary to know the dynamics of sulfate reduction in the liquid phase of the anaerobic reactor. The knowledge of kinetic parameters are extreme importance for modeling the biochemical processes allowing the substrate consumption, biomass growth at established conditions and reactor design and treatment efficiency. It should be emphasized that these parameters are not dependent only to sludge characteristics and substrate composition but also of environmental conditions for each biomass and wastewater composition. In this study, the sulfate reduction and dissolved sulfide $\left(\mathrm{S}^{2-}, \mathrm{HS}^{-}, \mathrm{H}_{2} \mathrm{~S}_{\mathrm{aq}}\right.$ ) in 
liquid phase was evaluated under low COD/Sulfate ratio by kinetics studies in an UASB reactor treating domestic wastewater in field scale.

\section{MATERIAL AND METHODS}

\subsection{Location and characteristics of UASB reactor}

The reactor is treating sewage from 800 inhabitants as part of compact treatment system with UASB followed by Submerged Aerobic Biofilter with main operational conditions summarized in Figure 1. The wastewater treatment plant is located at the Federal University of Espirito Santo, which is a mangrove area. This particular characteristic has a direct influence on the sulfate concentration in the wastewater due to infiltration in the sewerage system, causing odor problems in the treatment units (Santos et al., 2006). The UASB reactor in this study has the overall dimensions of $2.3 \times 2.3 \times 5.3 \mathrm{~m}(\mathrm{~L} \times \mathrm{W} \times \mathrm{H})$, with $28 \mathrm{~m}^{3}$ of utile volume and three height taps $(0.25,1.25$ and $2.25 \mathrm{~m})$ for sludge sampling. The wastewater treatment plant has been operating since 1997 and continues working until today. The study was conducted in the summer of 2007 on steady state condition.

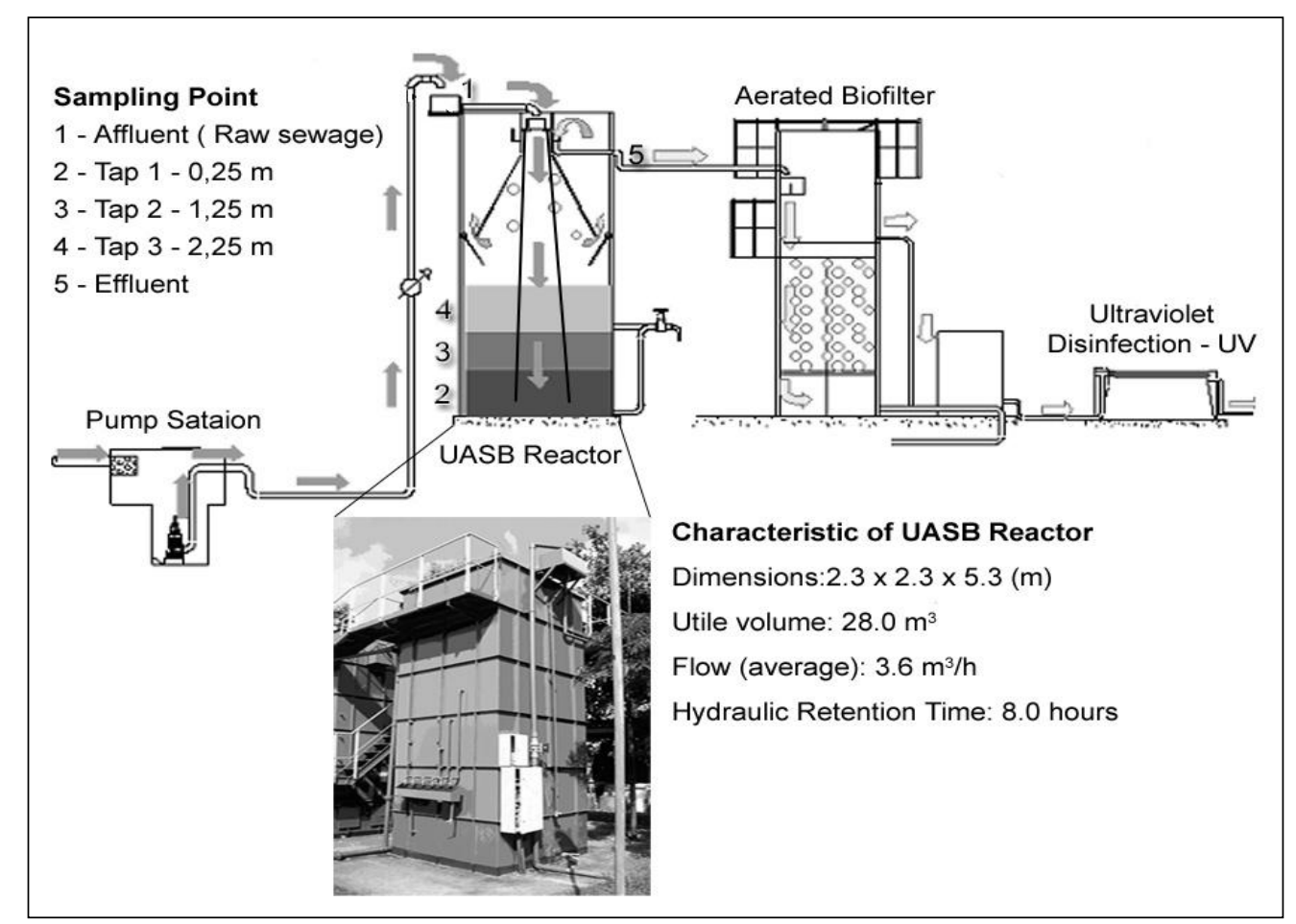

Figure 1. Layout of wastewater treatment plant system with sampling points and mainly characteristic of UASB reactor.

\subsection{Sampling and Analytical Procedures}

Samples were collected at 5 points of UASB reactor as following: 1) wastewater affluent at sand box; sludge samples at the top; 2) $0,25 \mathrm{~m}$; 3) $1,25 \mathrm{~m}$; 4) 2,25 m; and, 5) UASB effluent. The samples were collected considering the Hydraulic Retention Time (HRT) for each sampling point of reactor as shown in Table 1. The experiments were carried out between February and March totaling 20 samples for physical chemical parameters.

The Chemical Oxygen Demand (COD) was measured according to the Standard Methods for COD (APHA et al., 1995). A turbidimetric method was used to measure the concentration of sulfate (APHA et al., 1995). Prior to sulfate determination, suspended solids were removed from the sample by filtration. The absorbance of the sample was measured at a wavelength of 
$420 \mathrm{~nm}$. The absorbance of the sample was used to calculate the concentration of sulfate. For dissolved sulfide iodometric procedure was employed as reported in method 4500-B (APHA et al., 1995). The measured of $\mathrm{pH}$ and temperature was made with a multiparameter in situ.

Table 1: Sampling procedures for UASB reactor.

\begin{tabular}{l|c|l}
\hline \multicolumn{1}{c|}{ Sampling Point } & TDH (hours) & \multicolumn{1}{c}{ Parameters } \\
\hline Influent (Raw sewage) & $\mathrm{t}=0,0$ & $\mathrm{~T}^{\circ} \mathrm{C} ; \mathrm{pH}$; COD $_{\text {total }}$ Sulfate, Sulfide \\
Tap 1 - 0,25 m & $\mathrm{t}=0,4$ & $\mathrm{~T}^{\circ} \mathrm{C} ; \mathrm{pH}$; Sulfate, Sulfide \\
Tap 2-1,25 m & $\mathrm{t}=1,9$ & $\mathrm{~T}^{\circ} \mathrm{C} ; \mathrm{pH}$; Sulfate, Sulfide \\
Tap 3 - 2,25 m & $\mathrm{t}=3,4$ & $\mathrm{~T}^{\circ} \mathrm{C} ; \mathrm{pH}$; Sulfate, Sulfide \\
Effluent & $\mathrm{t}=8,4$ & $\mathrm{~T}^{\circ} \mathrm{C} ; \mathrm{pH}$; COD total, Sulfate, Sulfide \\
\hline
\end{tabular}

\subsection{Kinetics parameters estimation}

The kinetic studies here performed evaluated the sulfate reduction rates and kinetics constant (K1app) under different COD/sulfate ratio. A first-order kinetic model (Equation 1) was found to represent the kinetic behavior in all cases studied. The equation correlates the concentration of sulfate in the liquid phase with time. $\mathrm{K}_{1}{ }^{\text {app }}$ is the first-order apparent kinetic constant. Such a parameter is apparent, because it includes the phenomenon of mass transfer in the liquid and solid phases, besides the sulfate conversion rate.

$$
\left[\mathrm{SO}_{4}^{2-}\right]_{E f l .}=\left[\mathrm{SO}_{4}{ }^{2-}\right]_{\text {Infl. }} \times e^{k_{1}{ }^{a p p} . t}
$$

where:

$$
\begin{aligned}
& {\left[\mathrm{SO}_{4}{ }^{2-}\right]_{\text {Efl. }}=\text { Effluent sulfate concentration }(\mathrm{mg} / \mathrm{L}) ;} \\
& {\left[\mathrm{SO}_{4}{ }^{2-}\right]_{\text {Infl. }}=\text { Influent sulfate concentration }(\mathrm{mg} / \mathrm{L}) ;} \\
& \mathrm{K}_{1}{ }^{\text {app }}=\text { kinetics constant }\left(\mathrm{s}^{-1}\right) ; \\
& \mathrm{t}=\text { Hydraulic Retention Time. }
\end{aligned}
$$

\section{RESULTS AND DISCUSSION}

\subsection{UASB Reactor performance}

The average values of main monitored parameters of UASB reactor are shown in Table 2. Considering the COD values, the raw sewage has a characteristic of weak wastewater but as regard to sulfate concentration it can be concluded that this sewage has higher average values than found for domestic sewage typically in the range of 20 to $50 \mathrm{mg} / \mathrm{L}$ (Metcalf \& Eddy, 2003). The average efficiency or organic matter removal, of UASB reactor, expressed

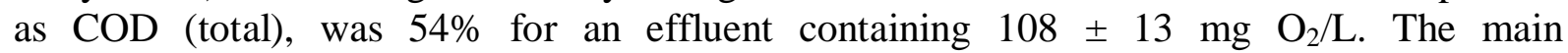
characteristics of raw sewage and UASB reactor effluent used in this study are illustrated in Table 2.

Figure 2 shows the plots of $\mathrm{COD} / \mathrm{SO}_{4}{ }^{2-}$ ratio versus $\mathrm{COD}$ removal efficiency in the continuous UASB system under steady state condition. Based on data presented in Figure 2 it can be observed that the decrease of $\mathrm{COD} / \mathrm{SO}_{4}{ }^{2-}$ ratio had no effect on $\mathrm{COD}$ removal efficiency. This behavior can be attributed to the presence of the numerous of SRB, which can utilize organic carbon for new cells metabolite. Stoichiometrically $1.0 \mathrm{~g}$ COD is required for the reduction of $1.5 \mathrm{~g}$ sulfate and thus both $\mathrm{COD}$ and $\mathrm{SO}_{4}{ }^{2-}$ are removed in the process (Metcalf \& Eddy, 2003). 
SUBTIL, E. L.; CASSINI, S. T. A.; GONÇALVES, R. F. Sulfate and dissolved sulfide variation under low COD/Sulfate ratio in Up-flow Anaerobic Sludge Blanket (UASB) treating domestic wastewater. Ambi-Agua, Taubaté, v. 7, n. 1, p. 130-139, 2012. (http://dx.doi.org/10.4136/ambi-agua.849)

Table 2. Average values of raw sewage and UASB Reactor effluent.

\begin{tabular}{lcc}
\hline Parameter & Raw Sewage & Effluent \\
\hline Temperature $\left({ }^{\circ} \mathrm{C}\right)$ & $31 \pm 1,8$ & $30 \pm 1,5$ \\
pH & $6.9 \pm 0,8$ & $6.7 \pm 0.6$ \\
Total COD $(\mathrm{mg} / \mathrm{L})$ & $235 \pm 27$ & $108 \pm 13$ \\
Sulfate $(\mathrm{mg} / \mathrm{L})$ & $151 \pm 13$ & $114 \pm 8$ \\
Sulfide $(\mathrm{mg} / \mathrm{L})$ & $1.4 \pm 0.3$ & $3.4 \pm 0.7$ \\
\hline
\end{tabular}

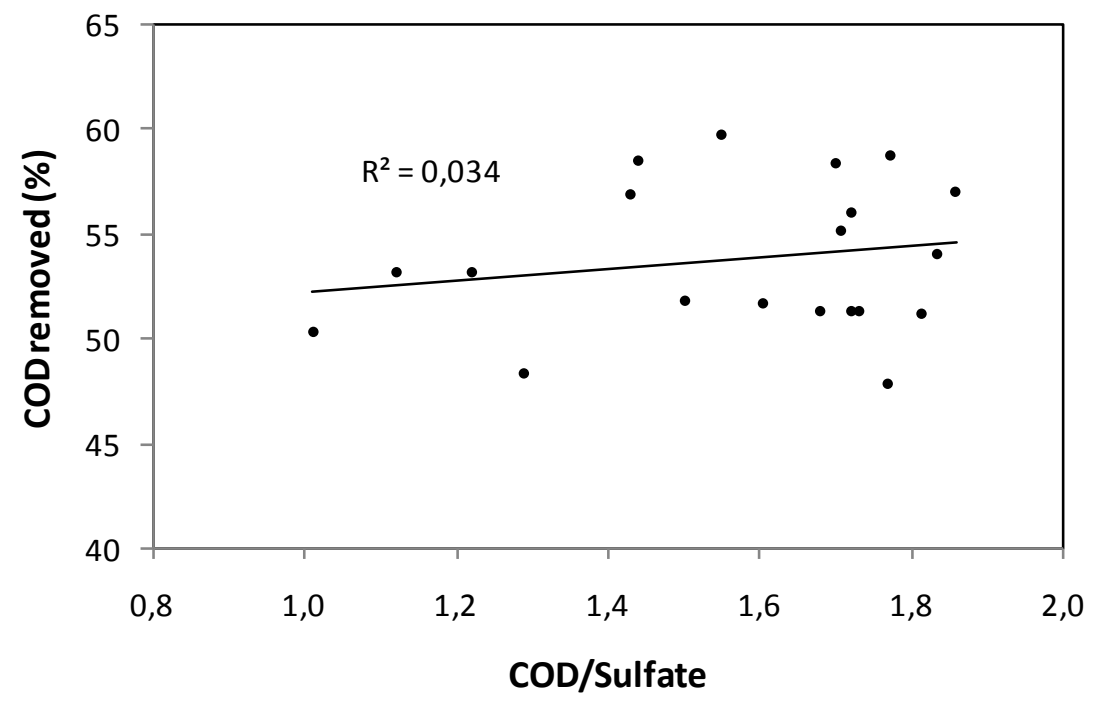

Figure 2. Relationship between COD/SO4 ratio and COD removal.

The sulfate and dissolved sulfide concentration profile along the reactor were evaluated in the 8,0 hours corresponding to the HRT values at each point as showed in Figure 3 . The overall results showed that $24 \%$ of sulfate was reduced in the reactor. In fact, the sulfate reduction appears to be more effective between the reactor heights of $1,25 \mathrm{~m}$ and 2,25 m corresponding to HRT of 1,9 and 3,4 h. Although the sulfide production was apparently linear with the increasing sulfate reduction (Figure 4), the experimental sulfide production differs from the theoretical values, considering the total sulfate remove being converted into sulfide in the liquid phase. The theoretical total conversion of sulfate to sulfide shows a stoichiometry coefficient of $0,33 \mathrm{mg}$ sulfide production per $\mathrm{mg} \mathrm{SO}_{4}{ }^{2-}$ reduced and the evaluated experimental linear regression coefficient was $0,031 \mathrm{mg}$ dissolved sulfide per $\mathrm{mg} \mathrm{SO}_{4}{ }^{2-}$ (Figure 4).

The sulfide produced inside the bioreactor may be present in different forms such as undissociated hydrogen sulfide in liquid and gas phase, $\mathrm{HS}^{-}$and $\mathrm{S}^{2-}$. So the measured hydrogen sulfide, which corresponds to various forms of sulfide in the liquid phase, may not account for the total sulfide produced. Based on these observations, it should be emphasized that sulfate and dissolved sulfide in the UASB reactor can follow different routes and could be lost or non detected (Speece, 1996). In the case of sulfate, it can follow the assimilative route of sulfide becoming a integral part of biomass (organic S). In the dissimilative route the sulfate is released in the medium as sulfide. Thus, the released sulfide can be precipitated by metal ions on liquid phase or accumulating in the sludge blanket (Jong and Parry, 2003) or escaping to aerial phase and apparently lost from aqueous phase. 


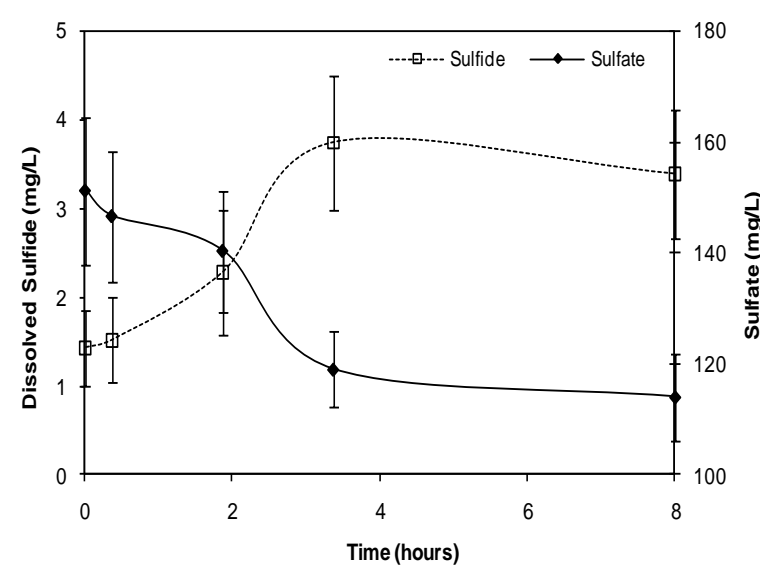

Figure 3. Temporal profile of sulfate and sulfide concentration in UASB reactor.

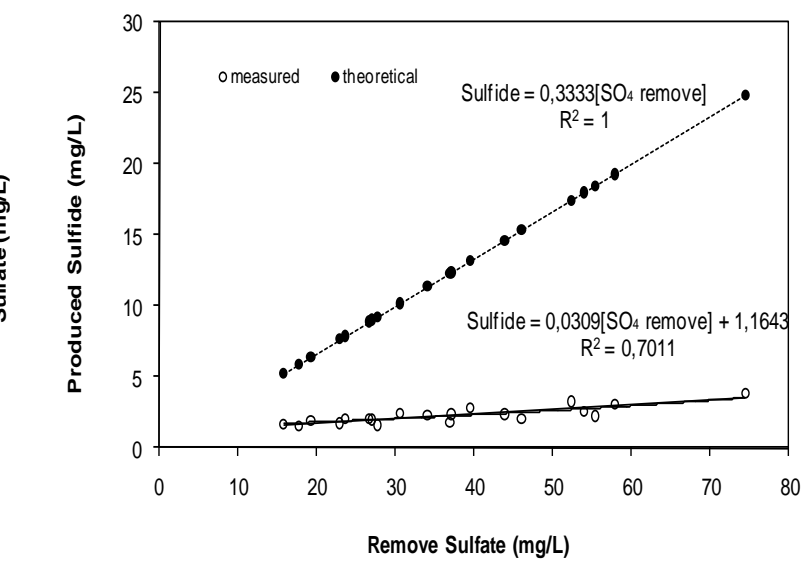

Figure 4. Relationship between sulfate removal $(\%)$ and sulfide production $(\mathrm{mg} / \mathrm{L})$

\subsection{Sulfate reduction at different feed $\mathrm{COD} / \mathrm{SO}_{4}{ }^{2-}$}

Another investigated parameter was the relationship COD/sulfate in the reduction process. A first-order kinetic model was found to represent the kinetic behaviour in all cases studied. Therefore, exponential expressions were adjusted to all the profiles with good correlation coefficient, as showed in Table 3 and Figure 5. The equation correlates the concentration of sulfate in the effluent with time and with the initial concentration of the sulfate in the liquid phase. Can be observed a tendency in $\mathrm{K}_{1}{ }^{\text {app }}$ values with small changes in $\mathrm{COD} /$ Sulfate ratio where the increased of $\mathrm{K}_{1}{ }^{\text {app }}$ was observed with low values of COD/Sulfate (Figure 6). It is shown that a small variation in $\mathrm{COD} /$ sulfate ratio (1.1 to 1.85) promotes a significant change in sulfate reduction as exemplified by the $45 \%$ to $10 \%$ of sulfate removal. Therefore, the overall conversion rates were mainly influenced by the biochemical reactions rates, which need to be considered in the sulfide production in UASB reactor.
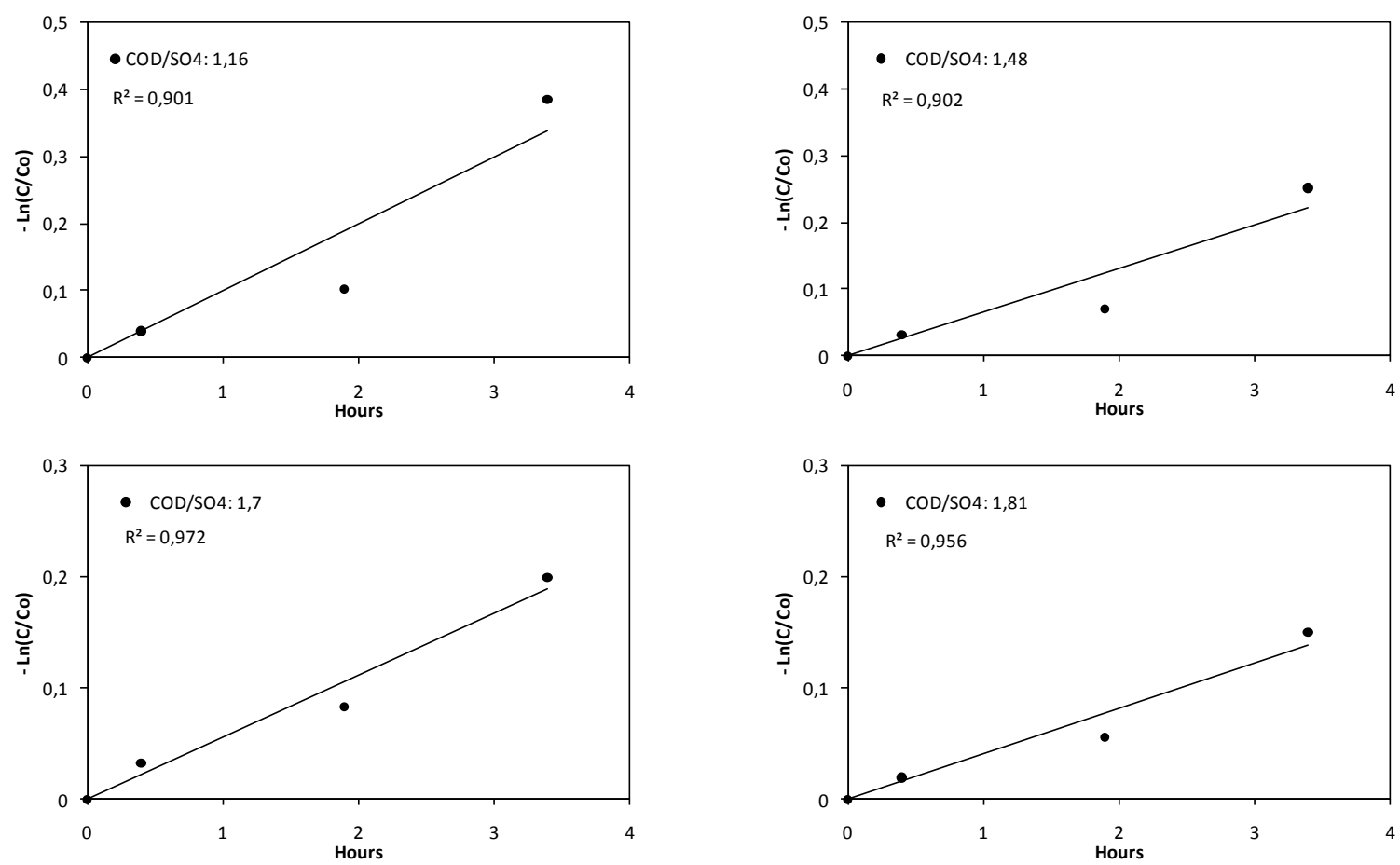

Figure 5. Sulfate reduction in UASB reactor under different COD/Sulfate ratios. 
The influent $\mathrm{COD} / \mathrm{SO}_{4}{ }^{2-}$ ratio has been reported by several authors to significantly affect the metabolic pathways of SRB (Colleran et al., 1995; O'Reilly and Colleran, 2006). At lower $\mathrm{COD} / \mathrm{SO}_{4}{ }^{2-}$ ratios, organic matter degrading SRM might become in competitive advantage with syntrophs, which is generally not the case for high $\mathrm{COD} / \mathrm{SO}_{4}{ }^{2-}$ - ratios (sulfate limitation) (Visser, 1996). Therefore, higher sulfate reduction rates are possible at low COD/ $\mathrm{SO}_{4}{ }^{2-}$ ratios. However, the results presented in the literature on the effect of sulfate reduction on the anaerobic process are quite contradictory. While some reported on the competition between sulfate reducing and methanogenic microorganisms by acetate an hydrogen, other reported synthrophic relations between two groups. Choi and Rim (1991) observed that sulfate reducers and methane producers were very competitive at $\mathrm{COD} / \mathrm{SO}_{4}{ }^{2-}\left(\mathrm{mg} \mathrm{O} 2 / \mathrm{mg} \mathrm{SO}_{4}{ }^{2-}\right.$ ) ratio of 1.7 to 2.7. They also observed that methane producers predominated at high $\mathrm{COD} /$ $\mathrm{SO}_{4}{ }^{2-}$ ratios, while sulfate reducers predominated when the value of this ratio decreased. On the contrary, Prasad et al. (1988) observed that methanogenic bacteria prevailed over sulfate reducing bacteria for $\mathrm{COD} / \mathrm{SO}_{4}{ }^{2-}$ ratio around one.

Besides the $\mathrm{COD} / \mathrm{SO}_{4}{ }^{2-}$ ratio, the $\mathrm{pH}$ holes an important play in the competition between SRB and methanogenic microorganisms. The results obtained from Visser et al. (1993) with the three reactors showed that the amount of organic COD removed via either sulphate reduction or methanogenesis is strongly influenced by the $\mathrm{pH}$ at which the reactor is operated. The removal efficiencies obtained by these authors in the reactors, as a function of the effluent $\mathrm{pH}$, showed it is clear that at $\mathrm{pH}>8$ sulphate reduction becomes predominant, whereas, apparently, at $\mathrm{pH}$ 6.75-7.5 a kind of steady state is established between methane production and sulphate reduction. It may be the cause for a small sulphate reduction in the UASB reactor as a consequence of the low effluent $\mathrm{pH}$ (Table 2).

Table 3. Expressions adjusted to the experimental sulfate profiles for each COD/Sulfate ratio and respective correlation coefficients $\left(\mathrm{R}^{2}\right)$.

\begin{tabular}{ccccc}
\hline COD/Sulfate & First-Order Expression & $\mathbf{R}^{\mathbf{2}}$ & $\begin{array}{c}\mathbf{K}_{\mathbf{1}}{ }^{\text {app }} \mathbf{x 1 0} \\
\left(\mathbf{s}^{-\mathbf{1}}\right)\end{array}$ & $\begin{array}{c}\mathbf{r}_{\text {max. }} \\
\left(\mathbf{m g} / \mathbf{L} \cdot \mathbf{h}^{-\mathbf{1}}\right)\end{array}$ \\
\hline $1.16 \pm 0.06$ & {$\left[\mathrm{SO}_{4}\right]=168.97 . \mathrm{e}^{-0,1059 t}$} & 0.901 & 2.94 & 17.9 \\
$1.48 \pm 0.06$ & {$\left[\mathrm{SO}_{4}\right]=160.79 . \mathrm{e}^{-0,073 \mathrm{t}}$} & 0.902 & 2.03 & 11.7 \\
$1.70 \pm 0.04$ & {$\left[\mathrm{SO}_{4}\right]=147.93 . \mathrm{e}^{-0,056 \mathrm{t}}$} & 0.972 & 1.56 & 8.3 \\
$1.81 \pm 0.04$ & {$\left[\mathrm{SO}_{4}\right]=138.94 . \mathrm{e}^{-0,042 \mathrm{t}}$} & 0.956 & 1.17 & 5.8 \\
\hline
\end{tabular}

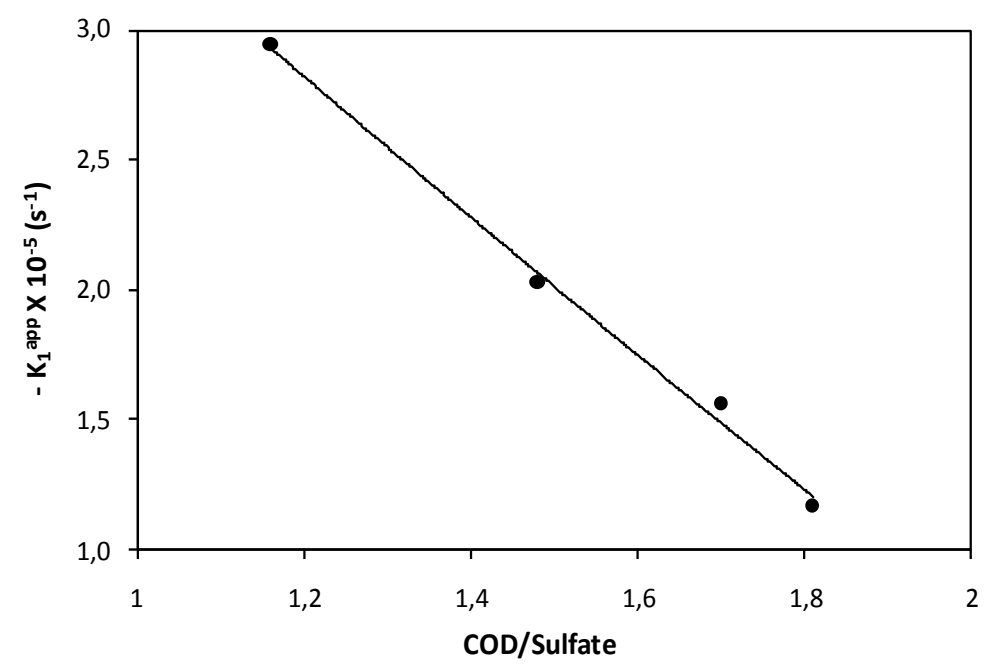

Figure 6. Influence of $\mathrm{COD} /$ Sulfate ratio on the first order kinetics constant $\left(\mathrm{K}_{1}\right)$ of the sulfate reduction. 
Kinetics studies of sulfate reduction with continuous stirring anaerobic reactors and suspended biomass have shown that sulfate reduction process is highly dependent upon the sulfate concentration (Moosa et al., 2002). It is reported that a increase of sulfate initial concentration of 1,0 to $5,0 \mathrm{~g} \mathrm{SO}_{4}{ }^{2-} / \mathrm{L}$ resulted in a significant increase in maximal reduction rate of 0,007 to $0,075 \mathrm{~g} \mathrm{SO}_{4}{ }^{2-} / \mathrm{L} . \mathrm{h}-1$ with no reported values for sulfide concentration in aqueous phase. Kinetic data for anaerobic reduction of sulfate as reported by different researchers are summarized in Table 4. The accurate assessment and comparison of the reported data is rather difficult. This is due to variations in microbial species and strains, experimental conditions such as sulfate concentration, $\mathrm{pH}$, temperature, metal concentrations and employment of different energy sources, as well as differences in configuration of the employed bioreactors.

Table 4: Comparison of kinetic data and manly characteristics of some anaerobic reactor reported by different author.

\begin{tabular}{|c|c|c|c|c|c|c|}
\hline $\begin{array}{c}\text { Temp. } \\
\left({ }^{\circ} \mathrm{C}\right)\end{array}$ & pH & $\begin{array}{c}\text { Flow rate } \\
\left(\mathbf{m}^{3} \cdot h^{-1}\right)\end{array}$ & $\begin{array}{c}\text { Initial sulfate } \\
\text { concentration } \\
(\mathrm{g} / \mathrm{L})\end{array}$ & $\begin{array}{c}\text { HRT } \\
\text { (h) }\end{array}$ & $\begin{array}{c}\text { Reduction } \\
\text { rate } \\
\left(\mathrm{g} / \mathrm{L} \cdot \mathrm{h}^{-1}\right) \\
\end{array}$ & Reference \\
\hline 25 & 4.5 & $1.56 \times 10^{-4}$ & 2.50 & 16.2 & 0.02 & Jong and Parry, 2003 \\
\hline- & 6.46 & - & 3.66 & - & 0.005 & Waybrant et al., 2002 \\
\hline- & 3.2 & & 2.00 & 12.0 & 0.132 & Glombitza, 2001 \\
\hline $23-26$ & 4.2 & $1.8 \times 10^{-4}$ & 0.9 & 6.6 & 0.072 & $\begin{array}{l}\text { Tsukamoto and Miller, } \\
1999\end{array}$ \\
\hline
\end{tabular}

\section{CONCLUSION}

Kinetic studies were found to be a useful tool to assess data of the influence of the $\mathrm{COD} /$ sulphate ratio on the anaerobic conversion process. In this study, the first-order kinetic model adequately represented the sulfate degradation rates. It is shown that a small variation in $\mathrm{COD} /$ sulfate ratio (1.1 to 1.85 ) promotes a significant change in sulfate reduction as exemplified by the $45 \%$ to $10 \%$ of sulfate removal. Furthermore, it was verified that the apparent kinetic parameters $\left(\mathrm{K}_{1}{ }^{\text {app }}\right)$ were affected by altering the COD/Sulfate ratio. The values of $\mathrm{K}_{1}$ app increased with low $\mathrm{COD} /$ sulphate ratios variation and this need to be considered in project of UASB reactor with low COD/sulfate effluent.

\section{REFERÊNCIAS}

American Public Health Association - APHA; American Water Works Association AWWA; Water Environment Federation - wef. Standard methods for the examination of water and wastewater. 20th ed. Washington DC, 1995.

CHERNICHARO, C. A. L. Reatores anaeróbios. Belo Horizonte: DESA/UFMG, 1997. 246p.

CHOI, E.; RIM, J. M. Competition and inibition of sulfate reducers and methane procucers in anaerobic treatment. Water Science \& Technology, v. 23, n. 7, p. 1259-64, 1991.

COLLERAN, E.; FINNEGAN, S.; LENS, P. N. L. Anaerobic treatment of sulphatecontaining waste streams. Antonie van Leeuwenhoek, v. 67, n. 1, p. 29-46, 1995. http://dx.doi.org/10.1007/BF00872194 
GLOMBITZA, F. Treatment of acid lignite mine flooding water by means of microbial sulfate reduction. Waste Management, v. 21, n. 2, p. 197-203, 2001. http://dx.doi.org/10.1016/S0956-053X(00)00061-1

HILTON, M. G.; ARCHER, D. B. Anaerobic digestion of a sulfate rich-molasses wastewater: inhibition of hydrogen sulfide production. Biotechnology and Bioengineering, v. 31, n. 8, p. 885-8, 1988. http://dx.doi.org/10.1002/bit.260310817

JONG, T.; PARRY, D. L. Removal of sulfate and heavy metals by sulfate reducing bacteria in short-term bench scale upflow anaerobic packed bed reactor runs. Water Research, v. 37, p. 3379-89, 2003. http://dx.doi.org/10.1016/S0043-1354(03)00165-9

KALYUZHNYI, S. V.; FRAGOSO, C. De LEON; MARTINEZ, J. R. Biological sulfate reduction in a UASB reactor fed with ethanol as the electron donor. Mikrobiologiya, v. 66, n. 5, p. 562-67, 1997.

KHAN, A. A.; GAUR, R. Z.; TYAGI, V. K.; KHURSHEED, A.; LEWB, B.; MEHROTRA, I. et al. Sustainable options of post treatment of UASB effluent treating sewage: a review. Resources, Conservation and Recycling, v. 55, n. 12, p. 1232-51, 2011. http://dx.doi.org/10.1016/j.resconrec.2011.05.017

LENS, P. N. L.; VISSER, A.; JANSEN, A. J. H.; HULSHOFF-POL, L. W.; LETTINGA, G. Biotechnological treatment of sulphate-rich wastewaters. Critical Reviews in Environmental Science and Technology, v. 28, n. 1, p. 41-88, 1998. http://dx.doi.org/10.1080/10643389891254160

LENS, P. N. L.; KUENEN, J. G. The biological sulfur cycle: novel opportunities for environmental biotechnology. Water Science and Technology, v. 44, n. 8, p. 57-66, 2001.

LENS, P. N. L.; VALLEROL, M.; ESPOSITO, G.; ZANDVOORT, M. Perspectives of sulfate reducing bioreactors in environmental biotechnology. Reviews in Environmental Science and Biotechnology, v. 1, n. 4, p. 311-25, 2002. http://dx.doi.org/10.1023/A:1023207921156

LETTINGA, G.; HULSHOFF-POL, L. W. UASB - Process design for various types of wastewaters. Water Science and Technology, v. 24, n. 8, p. 87-107, 1991.

LETTINGA, G. Towards feasible and sustainable environmental protection for all. Aquatic Ecosystem Health \& Management, v. 11, n. 1, p. 116-24, 2008.

MÉNDEZ, R.; TEN-RUMMELER, E.; HULSHOFF POL, L. W. Start up of UASB reactors treating sucrose-containing substrate with a low cod/sulfate ratio. Environmental Technology Letters, v. 10, n. 1, p. 83-90, 1989. http://dx.doi.org/10.1080/09593338909384721

METCALF \& EDDY INC. Wastewater engineering: treatment, disposal and reuse. 4. ed. New York: McGraw-Hill Books, 2003. 1815p.

MOOSA, S.; NEMATI, M.; HARRISON, S. T. L. A kinetic study on anaerobic reduction of sulphate, part I: effect of sulphate concentration. Chemical Engineering Science, v. 57, p. 2773-80, 2002. http://dx.doi.org/10.1016/S0009-2509(02)00152-5 
O'FLAHERTY, V.; COLLERAN, E. Sulfur problems in anaerobic digestion. In: International Water Association. Environmental technologies to treat sulfur pollution: principles and engineering. London, 2000. p 467-89.

O'REILlY, C.; COLLERAN, E. Effect of influent $\mathrm{COD} / \mathrm{SO}_{4}{ }^{2}{ }^{-}$ratios on mesophilic anaerobic reactor biomass populations: physico-chemical and microbiological properties. FEMS microbiology ecology, v. 56, n. 1, p. 141-53, 2006. http://dx.doi.org/10.1111/j.1574-6941.2006.00066.x

POSTGATE, J. R. The sulphate reducing bacteria. 2nd ed. Cambridge: University Press, 1984.

PRASAD, D.; HENRY, G.; HAIK, S. Role of sulfate reducing bacteria in anaerobic treatment of landfill leachate. In: CSCE Annual Canadian Hydrotechnical Conference, 10., 1988, Vancouver. Proceedings... Vancouver: CSCE, 1988.

SANTOS, J. M.; SÁ, L. M.; REIS JÚNIOR, N. C.; GONÇALVES, R. F.; SIQUEIRA, R. N. Modelling hydrogen sulphide emission in a WWTP with UASB reactor followed by aerobic biofilters. Water Science and Technology, v. 54, n. 9, p. 173-80, 2006. http://dx.doi.org/10.2166/wst.2006.861

SHAYEGAN, J.; GHAVIPANJEH, F.; MIRJAFARI, P. The effect of influent COD and upward flow velocity on the behaviour of sulphate-reducing bacteria. Process Biochemistry, v. 40, n. 7, p. 2305-10, 2005. http://dx.doi.org/10.1016/j.procbio.2004.09.005

SPEECE, R. E. Anaerobic biotechnology for industrial wastewaters. 1. ed. Nashville: Archae Press, 1996. 394p.

TSUKAMOTO, T. K.; MILLER, G. C. Methanol as a carbon source for microbiological treatment of acid mine drainage. Water Research, v. 33, n. 6, p. 1365-70, 1999. http://dx.doi.org/10.1016/S0043-1354(98)00342-X

VINCKE, E.; BOON, N.; VERSTRAETE, W. Analysis of the microbial communities on corroded sewer pipes - a case study. Applied Microbiology and Biotechnology, v. 57, n. 5/6, p. 776-85, 2001. http://dx.doi.org/10.1007/s002530100826

VISSER, A.; GAO, Y.; LETTINGA, G. Effects of $\mathrm{pH}$ on methanogenesis and sulphate reduction in thermophilic $\left(55^{\circ} \mathrm{C}\right)$ UASB reactors. Bioresource Technology, v. 44, n. 2 , 113-21, 1993. http://dx.doi.org/10.1016/0960-8524(93)90184-D

VISSER, A.; HULSHOFF-POL, L. W.; LETTINGA, G. Competition of methanogenic and sulfidogenic bacteria. Water Science and Technology, v. 33, n. 3, p. 99-110, 1996. http://dx.doi.org/10.1016/0273-1223(96)00324-1

WAYBRANT, K. R.; PTACEK, C. J.; BLOWES, D. W. Treatment of mine drainage using permeable reactive barriers: column experiments. Environmental Science and Technology, v. 36, n. 6, p. 1349-56, 2002. http://dx.doi.org/10.1021/es010751g 


\begin{tabular}{ccc|} 
ISSN = 1980-993X - doi:10.4136/1980-993X \\
www.ambi-agua.net \\
E-mail: ambi-agua@agro.unitau.br \\
Tel.: (12) 3625-4212
\end{tabular}

\title{
Valores anômalos de metais pesados em solo de cemitério
}

(http://dx.doi.org/10.4136/ambi-agua.838)

\section{Pedro Daniel da Cunha Kemerich ${ }^{\mathbf{1}}$; Willian Fernando de Borba ${ }^{\mathbf{1}}$; Rodrigo Ferreira da Silva1; Guilherme Barros ${ }^{1}$; Ademir Eloi Gerhardt ${ }^{1}$; Carlos Eduardo Balestrin Flores ${ }^{1}$}

\author{
${ }^{1}$ Universidade Federal de Santa Maria \\ E-mail: eng.kemerich@yahoo.com.br; borba_willian@hotmail.com; rofesil@bol.com.br; \\ Guilherme_barrosp@hotmail.com; adegerhardt@bol.com.br; cadu-fw@hotmail.com
}

\section{RESUMO}

O necrochorume gerado pela decomposição dos corpos humanos apresenta uma carga poluidora elevada e, em virtude do local onde se encontra, poderá atingir e contaminar o solo e os recursos hídricos superficiais e subterrâneos. O problema é agravado quando as necrópoles localizam-se em áreas de vulnerabilidade considerável e a população do entorno faz uso direto dos recursos hídricos sob a influência do mesmo, estando assim sujeita à doenças de veiculação hídrica. O presente trabalho teve como objetivo analisar as concentrações dos metais pesados bário, cobre, cromo e zinco em solo ocupado por necrópole. Para coleta de solo, foram realizadas tradagens em 10 diferentes pontos e profundidades. Para determinação da concentração dos metais foi utilizada a técnica de Fluorescência de Raios-X por Energia Dispersiva e com auxílio do software Surfer 10, foram espacializados os dados gerando-se cartogramas. Os metais bário e cobre apresentaram concentrações que indicaram contaminação do solo em todos os pontos amostrados. Já a concentração do cromo apresentou indícios de contaminação em diversas profundidades entre 0 e $300 \mathrm{~cm}$. O ponto de menor cota topográfica foi o único a ter concentração de zinco acima dos valores de referência, indicando relação do fluxo superficial e sub-superficial da água com a contaminação por esse elemento. Com os resultados obtidos pode-se constatar o potencial de contaminação por metais em solo ocupado por cemitério.

Palavras chaves: Bário; cobre; cromo; necrochorume; zinco.

\section{Anomalous values of heavy metals in soil of cemetery}

\begin{abstract}
The necro chorume generated by the decomposition of human bodies has a high pollution load and depending on its location, it may reach and contaminate the soil, the surface and underground water resources. The problem is critical because the analyzed cemetery is located in a vulnerable area and the surrounding population makes use of the water under the influence of the necro chorume, and therefore, subjected to water carrying diseases. This study aimed to analyze the concentrations of heavy metals barium, copper, chromium and zinc in soil occupied by necropolis. An auger was used to collect soil samples in 10 different sites and depths. For determining the concentration of metals, the technique of fluorescence $\mathrm{X}$-ray Energy Dispersive with the support of the software Surfer 10 was used to spatially generate concentration data maps. The concentrations of barium and copper indicated contamination of the soil in all sampled sites, while the chrome showed evidence of
\end{abstract}


KEMERICH, P. D. C.; BORBA, W. F.; SILVA, R. F.; BARROS, G.; GERHARDT, A. E.; FLORES, C. E. B. Valores anômalos de metais pesados em solo de cemitério. Ambi-Agua, Taubaté, v. 7, n. 1, p. 140-156, 2012. (http://dx.doi.org/10.4136/ambi-agua.838)

contamination at various depths between 0 and $300 \mathrm{~cm}$. The lowest topographic point was the only one to have zinc concentration above reference values, indicating a contamination by this element in the surface flow and sub-surface water. With these results we can confirm the potential of metal contamination in soil occupied by the cemetery.

Keywords: Barium; copper; chromium; necrochorume; zinc.

\section{INTRODUÇÃO}

O uso de águas superficiais se torna cada vez mais problemático em virtude da precariedade dos sistemas de saneamento básico e pelo alto custo de sistemas de tratamento necessários para o atendimento aos padrões de potabilidade (Vendame et al., 2003). Nesse contexto a água subterrânea pode amenizar esse problema, pela sua boa qualidade e o solo funcionar como uma espécie de filtro retendo impurezas nela depositadas.

Em razão do crescimento desenfreado da população e pela contaminação das águas tanto superficiais quanto subterrâneas, o suprimento de água potável em regiões mais desenvolvidas torna-se cada vez mais escasso e de alto custo (Filizola et al., 2002). O solo tem um papel muito importante na retenção dos microrganismos, considerando fatores físicos e químicos, que afetam a infiltração e o carreamento dos microrganismos em direção ao lençol freático (Martins et al., 1991).

Segundo Silva e Malagutti Filho (2008), os cemitérios nunca foram incluídos nas listas de fontes tradicionais de contaminação ambiental, apesar da existência de alguns relatos históricos em Berlim e Paris na década de 70, constatando que a causa de epidemias de febre tifoide estava diretamente relacionada ao posicionamento dos cemitérios à jusante de fontes de água, como aquíferos freáticos e nascentes.

Entretanto, Silva e Malagutti Filho (2010) afirmam que a partir da resolução do Conselho Nacional do Meio Ambiente (Brasil, 2003) no 335 de 3 de abril de 2003, que dispõe sobre o licenciamento ambiental de cemitérios horizontais e verticais a serem implantados no Brasil, esses estabelecimentos passam a ser vistos como fontes de contaminação do ambiente, e sua implantação está sujeita ao atendimento dos critérios legais.

A implantação dos cemitérios, sem levar em consideração os critérios geológicos (características litológicas e estrutura do terreno) e hidrogeológicos (nível do lençol freático), constitui uma das causas de deterioração da qualidade das águas subterrâneas. Anjos (2007) afirmou que a principal causa de poluição nos cemitérios, durante a decomposição dos cadáveres, é um líquido denominado necrochorume. Esta é uma solução com concentração elevada de sais minerais e substâncias orgânicas degradáveis, de tonalidade castanhoacinzentada, viscosa, de cheiro forte e com grau variado de patogenicidade. Deste modo, como os cemitérios são considerados como um depósito de corpos humanos, estes necessitam de uma destinação correta, pois a degradação dos corpos pode se constituir em focos de contaminação.

A disposição dos corpos humanos, de forma inadequada, pode gerar problemas de poluição no aquífero subterrâneo, bem como no solo. Devido à ação das águas superficiais e das chuvas infiltradas nas sepulturas, ou pelo contato dos corpos com as águas subterrâneas, o necrochorume pode entrar em contato e contaminar estas águas (Neira et al., 2008). A toxicidade química do necrochorume diluído na água freática relaciona-se aos teores anômalos de compostos das cadeias do fósforo e do nitrogênio, metais pesados e aminas.

Com base no tema exposto, este trabalho teve como objetivo determinar o potencial de contaminação química do solo por bário, cobre, cromo e zinco em decorrência da ocupação por cemitério. 


\section{MATERIAL E MÉTODOS}

\subsection{Caracterização da área de estudo}

O município de Seberi está situado no noroeste do estado do Rio Grande do Sul (Brasil) na latitude $27^{\circ} 28^{\prime} 4^{\prime \prime} \mathrm{S}$ e longitude $53^{\circ} 24^{\prime} 09^{\prime \prime} \mathrm{O}$, com altitude de 546 metros do nível do mar, abrangendo uma área de $301 \mathrm{Km}^{2}$ e com população de 11098 habitantes, sendo o mesmo pertencente à bacia hidrográfica do Rio Uruguai com clima subtropical úmido (IBGE, 2009). O cemitério municipal São João Batista está situado a $520 \mathrm{~m}$ altitude e foi fundado no ano de 1930, contendo atualmente cerca de 3 mil sepulturas, recebendo em média 7 corpos por mês em uma área de 1,2 hectares, conforme ilustra a Figura 1. Na área estudada, existem basicamente dois tipos de sepulturas, aquelas onde os corpos estão em contato direto com solo e as outras conhecidas como jazigo, estas são construções existentes nos cemitérios executada com placas pré-moldadas onde são sepultados os corpos. Este espaço físico é composto normalmente por "gavetas", onde são depositados os corpos, que ficam normalmente a $1 \mathrm{~m}$ do solo.

\subsection{Localizações dos pontos de amostragem e coleta de amostras}

A tradagem para coleta das amostras foi realizada em função da topografia existente no cemitério e do fluxo preferencial de água superficial, determinado com o auxílio do software Surfer 10 da Golden Software, utilizando-se o método de interpolação matemática Krigagem (Figura 1). Foram considerados 10 pontos de coleta denominados: P1, P2, P3, P4, P5, P6, P7, P8, P9 e P10, conforme mostra a Figura 1, sendo que P1 encontra-se no ponto de maior elevação, sendo considerado o ponto controle. Sendo que a maior cota foi observada no ponto 1 com 522,5 m e o menor no ponto 10 a uma cota de 518,0 m.

A Figura 1 ilustra a área total do cemitério, com os pontos de amostragem e as linhas de fluxo superficial da água.

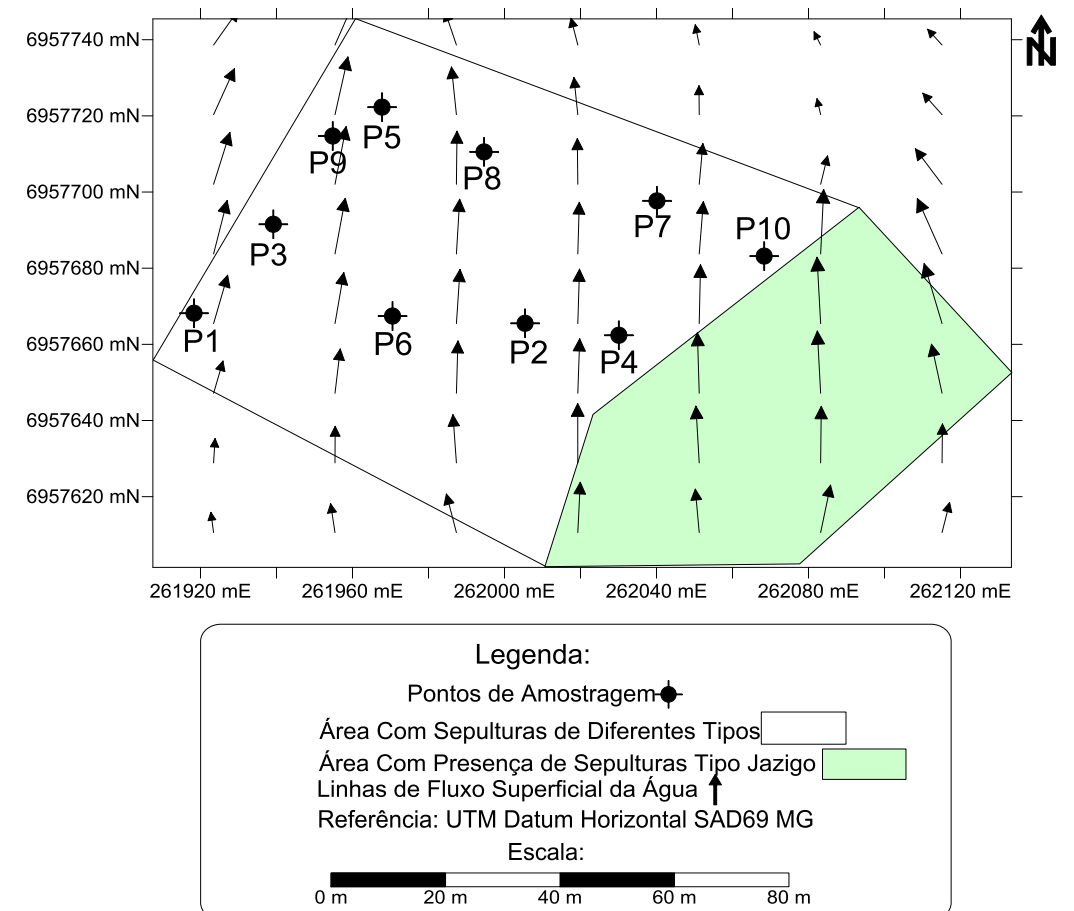

Figura 1. Cartograma da área do cemitério, com linhas de fluxo e pontos de amostragem. 
KEMERICH, P. D. C.; BORBA, W. F.; SILVA, R. F.; BARROS, G.; GERHARDT, A. E.; FLORES, C. E. B. Valores anômalos de metais pesados em solo de cemitério. Ambi-Agua, Taubaté, v. 7, n. 1, p. 140-156, 2012. (http://dx.doi.org/10.4136/ambi-agua.838)

Para a coleta das amostras foi utilizado um trado manual Sonda Terra de $4 \mathrm{~m}$ de comprimento. Cada amostra coletada foi armazenada em sacos plásticos e recebeu identificação correspondendo à localização do ponto de amostragem e a profundidade da coleta. Nos 10 pontos analisados foram coletadas amostras a cada $50 \mathrm{~cm}$ de profundidade, iniciando-se com a amostra superficial em $0 \mathrm{~cm}$ até a profundidade de $300 \mathrm{~cm}$, totalizado 7 amostras por ponto. Para evitar alterações nos resultados o trado era lavado com água destilada ao fim de cada coleta de amostra.

\subsection{Preparo de amostras e determinação de metais}

Foram pesadas $20 \mathrm{~g}$ de solo e encaminhadas para a secagem em estufa à temperatura de $105{ }^{\circ} \mathrm{C}$ por duas horas utilizando-se vidraria básica de laboratório (Becker $50 \mathrm{~mL}$ ) para sua deposição.

Após o quarteamento e a secagem em estufa as amostras foram moídas manualmente em gral com pistilo, objetivando reduzir ao máximo a granulometria da amostra reduzindo os desvios do feixe de Raios-X e assim não influenciando na eficiência das determinações.

As amostras de solo foram então comprimidas em prensa manual em matriz apropriada formando uma pastilha sólida e compacta que foi encaminhada para a análise. A pastilha foi formada usando 10 toneladas de pressão por 10 minutos. Este procedimento aglomera as partículas tornando-as um aglomerado cerâmico cujo resultado analítico reflete-se num padrão ideal para análise por EDXRF.

As análises foram realizadas utilizando um Espectrômetro de Fluorescência de Raios-X por Energia Dispersiva, do modelo Shimadzu EDX-720. As seguintes condições de operação do equipamento foram selecionadas: tensão do tubo de $15 \mathrm{keV}$ ( $\mathrm{Na}$ a $\mathrm{Sc}$ ) e $50 \mathrm{keV}$ (Ti a U) com corrente no tubo $184 \mu \mathrm{A}$ e $25 \mu \mathrm{A}$ respectivamente, colimador de $10 \mathrm{~mm}$, tempo real de integração de 200 segundos tempo morto do detector de $40 \%$ e $39 \%$, sob vácuo e detector de $\mathrm{Si}(\mathrm{Li})$ refrigerado com nitrogênio líquido. $\mathrm{O}$ método analítico usado é denominado método dos Parâmetros Fundamentais (PF) (Bona et al., 2007). Este método permite a obtenção da curva de sensibilidade do equipamento para cada elemento de interesse, quando uma amostra de composição química conhecida é submetida a parâmetros instrumentais bem definidos. A curva de sensibilidade do equipamento relaciona a intensidade fluorescente teórica calculada e a medida para cada elemento (Bona et al., 2007).

Em geral, análise quantitativa por EDXRF é realizada pelo método da curva de calibração. No entanto, para algumas aplicações é difícil obter padrões certificados suficientes, com matrizes semelhantes às amostras e, dessa forma, conseguir uma boa distribuição de pontos de dados sobre a escala de cada elemento a ser determinado. Han et al. (2006) a partir dos resultados da análise experimental de várias e diferentes amostras, comprovaram que resultados de alta precisão podem ser obtidos pelo método de FP, mesmo que apenas amostras de elemento puro sejam utilizadas para calibração. Isso também ilustra claramente que o método FP pode corrigir efetivamente o complicado cálculo do efeito da matriz. Portanto, para análise de rotina em massa, se as amostras de calibração estão ausentes, o método FP pode fornecer resultados relativamente precisos e quantitativos.

Os valores de referência propostos pela CONAMA nº420/2009 (Brasil, 2009) para os metais analisados estão presentes na Tabela 1.

Tabela 1. Valores de referência para solos.

\begin{tabular}{c|c}
\hline Metal & $\begin{array}{c}\text { Valor de referência para solos } \\
\left(\mathbf{m g ~ k g}^{-1}\right)\end{array}$ \\
\hline Bário & 150 \\
Cobre & 60 \\
Cromo & 75 \\
Zinco & 300 \\
\hline
\end{tabular}

Fonte: Adaptado de CONAMA nº 420/2009 (Brasil, 2009). 
KEMERICH, P. D. C.; BORBA, W. F.; SILVA, R. F.; BARROS, G.; GERHARDT, A. E.; FLORES, C. E. B. Valores anômalos de metais pesados em solo de cemitério. Ambi-Agua, Taubaté, v. 7, n. 1, p. 140-156, 2012. (http://dx.doi.org/10.4136/ambi-agua.838)

Foram determinadas as concentrações totais dos metais: bário $\left(\mathrm{Ba}^{+2}\right)$, cobre $\left(\mathrm{Cu}^{+1}\right)$, cromo $\left(\mathrm{Cr}^{+1}\right)$ e zinco $\left(\mathrm{Zn}^{+2}\right)$, que possuem valor de referência propostos pela Resolução CONAMA no 420/2009.

\section{RESULTADOS E DISCUSSÃO}

A Tabela 2 ilustra a concentração dos metais em todos os pontos e profundidades analisadas.

Tabela 2. Concentração dos metais nos pontos de amostragem.

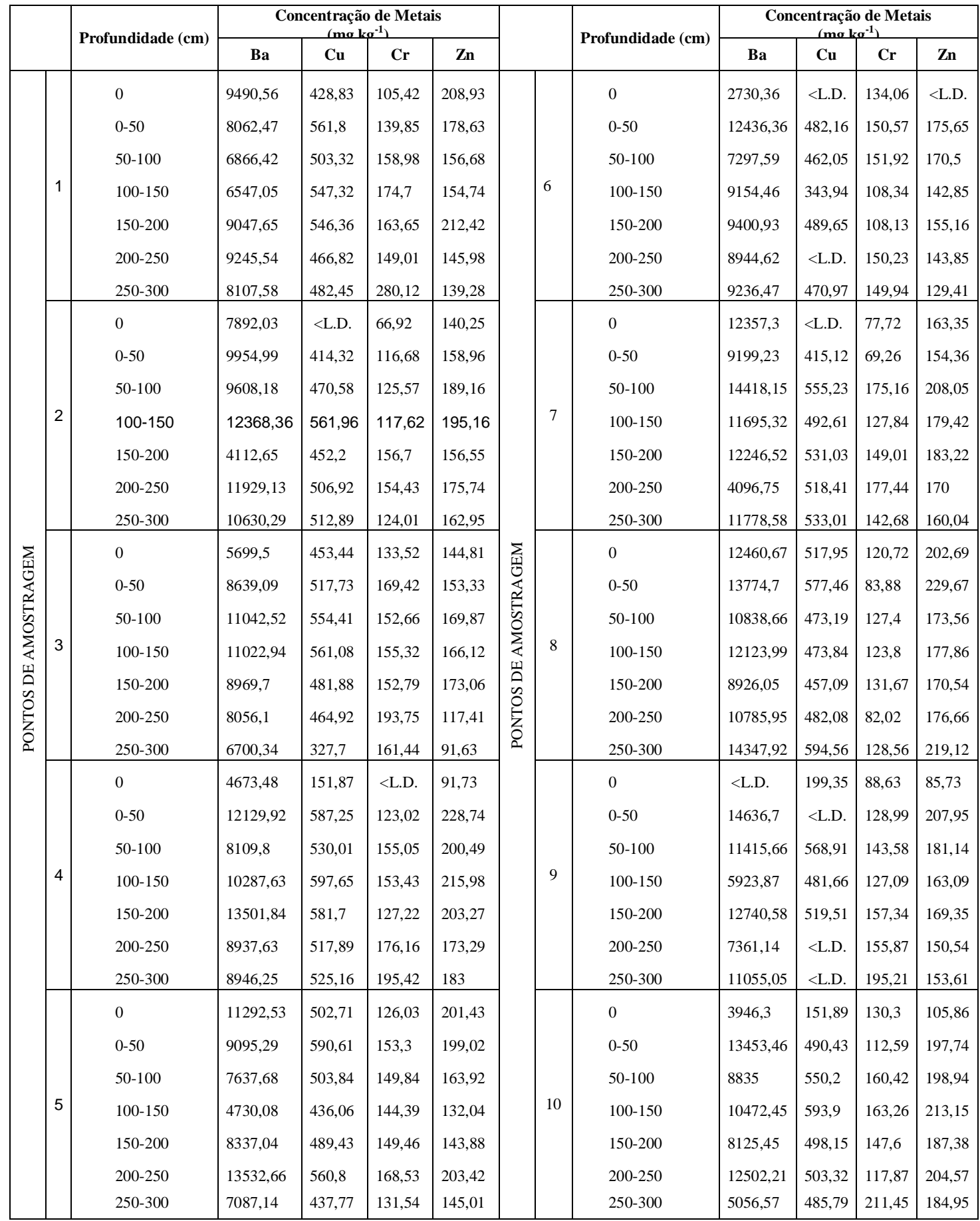


KEMERICH, P. D. C.; BORBA, W. F.; SILVA, R. F.; BARROS, G.; GERHARDT, A. E.; FLORES, C. E. B. Valores anômalos de metais pesados em solo de cemitério. Ambi-Agua, Taubaté, v. 7, n. 1, p. 140-156, 2012. (http://dx.doi.org/10.4136/ambi-agua.838)

\subsection{Bário}

A Figura 2 apresenta o comportamento do Bário na área ocupada pelo cemitério São João Batista nos pontos P1 a P10 nas profundidades 0,50 e $100 \mathrm{~cm}$. Todos os pontos amostrados, com a exceção do ponto 9 na amostra superficial $(0 \mathrm{~cm})$ apresentaram os valores acima do permitido pela Resolução CONAMA no 420 de 28 de dezembro de 2009 que estabelece o valor limite de $150 \mathrm{mg} \mathrm{kg}^{-1}$ de bário para solos. A concentração de Ba no solo, em escala mundial, varia de 19 a $2368 \mathrm{mg} \mathrm{kg}^{-1}$, podendo ser mobilizado em diferentes condições (Kabata-Pendias e Pendias, 1992). Teixeira (2003) diz que este elemento é tóxico e pode matar pela ingestão de apenas meio grama, mas felizmente, sua absorção é lenta. É usado em venenos para ratos, depilatórios, pigmentos para pintura, vidros e cerâmicas. Na medicina é usado em contrastes radiológicos para estômago, vesícula e intestinos.

Na profundidade $0 \mathrm{~cm}$ os maiores valores econtram-se na região nordeste do cartograma entretanto, o ponto 7 apresentou uma concentração semelhante ao observado a 0 e $150 \mathrm{~cm}$ de profundidade. Para a profundidade $50 \mathrm{~cm}$ os maiores valores situam-se a noroeste do cartograma. Já em $100 \mathrm{~cm}$ de profundidade os maiores valores encontram-se na região nordeste. Em $150 \mathrm{~cm}$ os menores valores encontran-se na região oeste, já os maiores valores localizam-se nas regiões nordeste e sudeste.
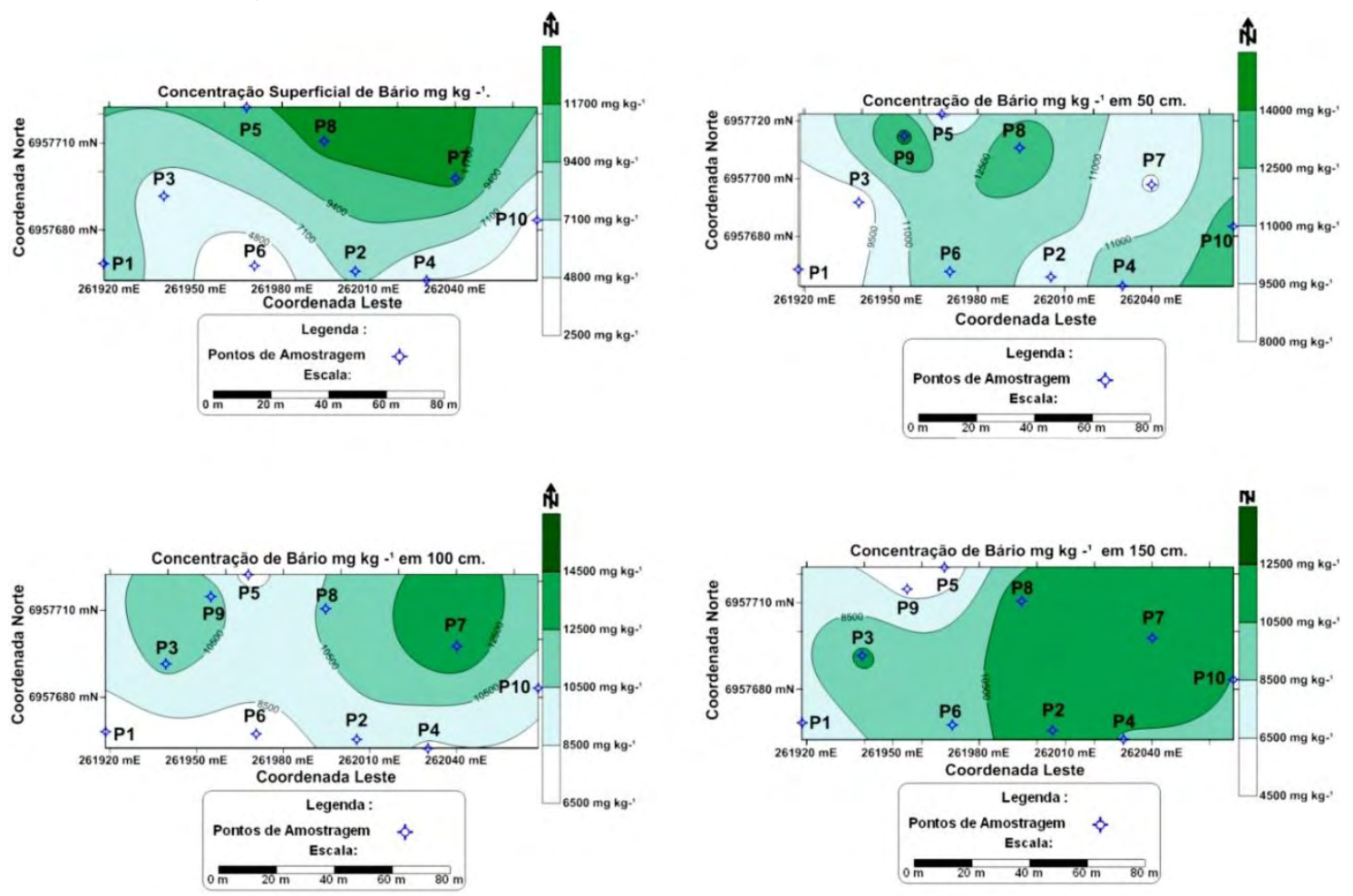

Figura 2. Concentração de Bário no Cemitério São João Batista nas profundidades entre 0 e $150 \mathrm{~cm}$.

A Figura 3 ilustra a concentração de bário nas profundidades variando de 200 a $300 \mathrm{~cm}$, profundidades essas abaixo do local onde geralmente ocorre o sepultamento no cemitério. $\mathrm{Na}$ profundidade de $200 \mathrm{~cm}$ o maior valor encontrado situa-se na região noroeste, leste e sudeste do cartograma, já os menores valores ocorreram na região sul. Na profundidade $250 \mathrm{~cm} \mathrm{o}$ bário apresentou a maior concentração com $13532,66 \mathrm{mg} \mathrm{kg}^{-1}$ no ponto $5 \mathrm{e}$ altitude de $518,738 \mathrm{~m}$, no cartograma os maiores valores estão nas regiões leste e noroeste. Os menores valores situam-se no ponto 7 a uma concentração de $4096,75 \mathrm{mg} \mathrm{kg}^{-1}$ e altitude de 520,655 $\mathrm{m}$, as menores concentrações estão presentes na região nordeste.

Na profundidade $300 \mathrm{~cm}$ tem-se como valor máximo de bário $14347,92 \mathrm{mg} \mathrm{kg}^{-1}$ no ponto 8 a uma altitude de $518,7 \mathrm{~m}$, no cartograma os maiores valores estão localizados na 
KEMERICH, P. D. C.; BORBA, W. F.; SILVA, R. F.; BARROS, G.; GERHARDT, A. E.; FLORES, C. E. B. Valores anômalos de metais pesados em solo de cemitério. Ambi-Agua, Taubaté, v. 7, n. 1, p. 140-156, 2012. (http://dx.doi.org/10.4136/ambi-agua.838)

região norte (Figura 3). A menor concentração de bário em $300 \mathrm{~cm}$ está no ponto $10 \mathrm{com}$ $5056,57 \mathrm{mg} \mathrm{kg}^{-1}$ e uma altitude de 518,0 m, os menores valores estão nas regiões leste e sul. A menor concentração encontrada para bário em todas as profundidades foi no ponto 9 a 0 $\mathrm{cm}$ e a maior no ponto $9 \mathrm{em} 50 \mathrm{~cm}$.
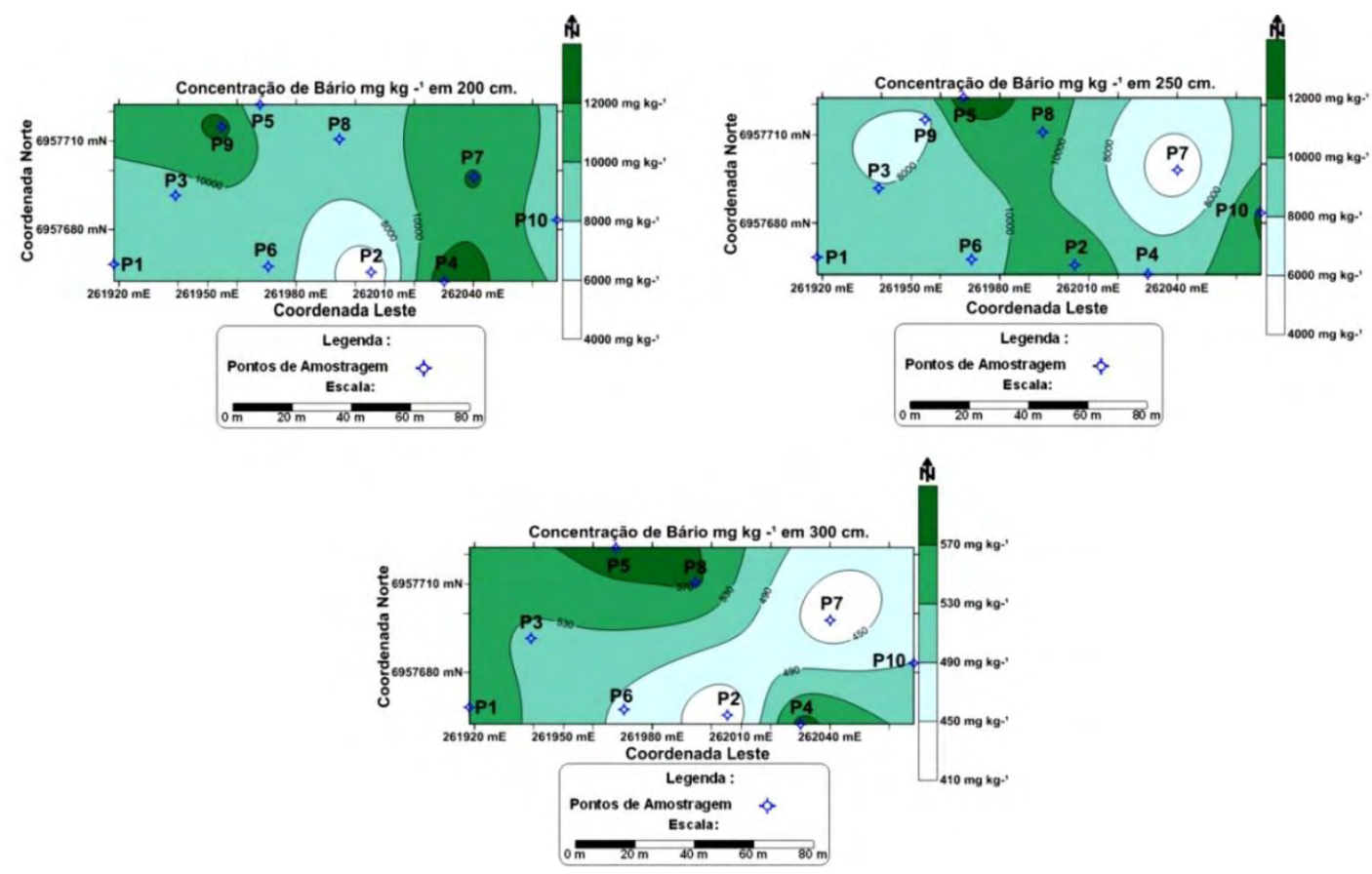

Figura 3. Concentração de Bário no Cemitério São João Batista nas profundidades entre 200 e $300 \mathrm{~cm}$.

A Figura 4 (a) ilustra a concentração média de Bário nos 10 diferentes pontos de amostragem, sendo os maiores valores médios encontrados no ponto $8 \mathrm{com}$ uma concentração que varia de 9500 a $14200 \mathrm{mg} \mathrm{kg}^{-1}$, já os menores valores médios foram encontrados no ponto 1 a uma concentração que varia de 6000 a $10500 \mathrm{mg} \mathrm{kg}^{-1}$. A Figura 4 (b) ilustra a concentração média de Bário em 7 diferentes profundidades, sendo os maiores valores médios presentes na profundidade $50 \mathrm{~cm}$ a uma concentração que varia de 9200 a $14000 \mathrm{mg} \mathrm{kg}^{-1}$, já as menores concentrações médias encontraram-se na profundidade $0 \mathrm{~cm}$ com uma variação de 5000 a $9000 \mathrm{mg} \mathrm{kg}^{-1}$.

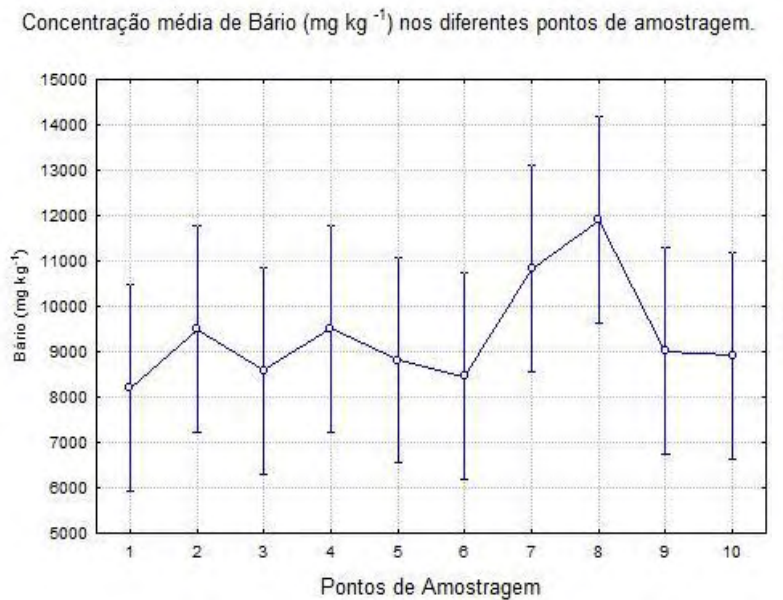

(a)

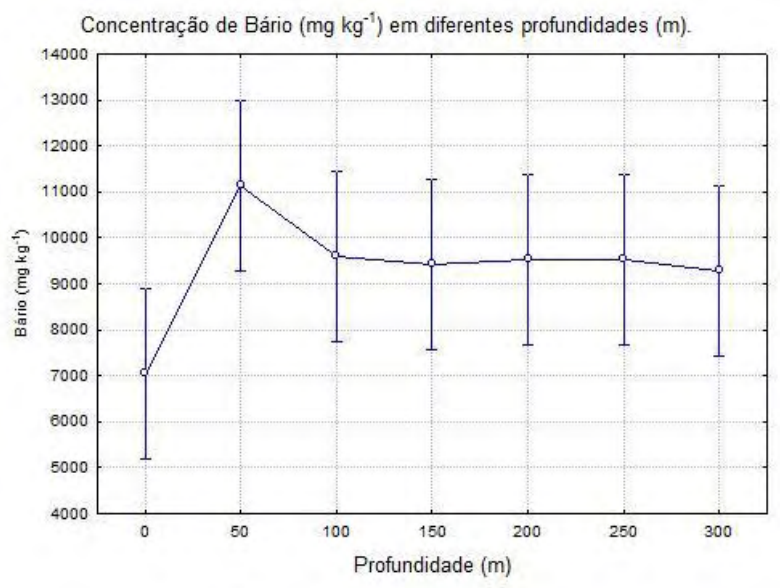

(b)

Figura 4. Concentração média de Bário em 10 pontos de amostragens (a), concentração média de Bário em 7 diferentes profundidades (b). 
KEMERICH, P. D. C.; BORBA, W. F.; SILVA, R. F.; BARROS, G.; GERHARDT, A. E.; FLORES, C. E. B. Valores anômalos de metais pesados em solo de cemitério. Ambi-Agua, Taubaté, v. 7, n. 1, p. 140-156, 2012. (http://dx.doi.org/10.4136/ambi-agua.838)

\subsection{Cobre}

A Figura 5 apresenta os teores de Cobre na área ocupada pelo cemitério São João Batista nos pontos P1 a P10 nas profundidades 0,50 e $100 \mathrm{~cm}$. Todos os pontos amostrados, exceto na amostra superficial $(0 \mathrm{~cm})$ do ponto 4 (em que a concentração foi menor que o Limite de Detecção - L.D), excederam os valores estabelecidos pela Resolução CONAMA no 420/2009, que apresenta $60 \mathrm{mg} \mathrm{kg}^{-1}$ como valor máximo permitido.

O cobre pode ser encontrado na natureza na forma elementar ou na forma de sais, na crosta terrestre ou nos oceanos. A quantidade de cobre encontrada no corpo humano varia de 100 a 150 mg, e sua ingestão diária está entre 2 e 3 mg. Nos seres humanos, Santana (2009) afirmou que a contaminação por cobre causa uma disfunção genética conhecida como Doença de Wilson. O processo de contaminação geralmente ocorre em feto cuja mãe apresenta altas concentrações deste elemento no organismo. A Doença de Wilson provoca um acúmulo excessivo desse elemento essencial no organismo. Em pessoas saudáveis o excesso deste elemento presente em alimentos é eliminado, mas nos doentes de Wilson ocorre uma bioacumulação. No solo é encontrado entre 2 e $100 \mathrm{mg} \mathrm{kg}^{-1}$ de Cobre, já na água potável a concentração dever ser entre 0,01 a $1 \mathrm{mg} \mathrm{L}^{-1}$ (Marques et al., 2003). Contudo, o cobre é considerado um elemento fitotóxico, isso por que é mais tóxico para plantas do que para animais (Costa, 2005).
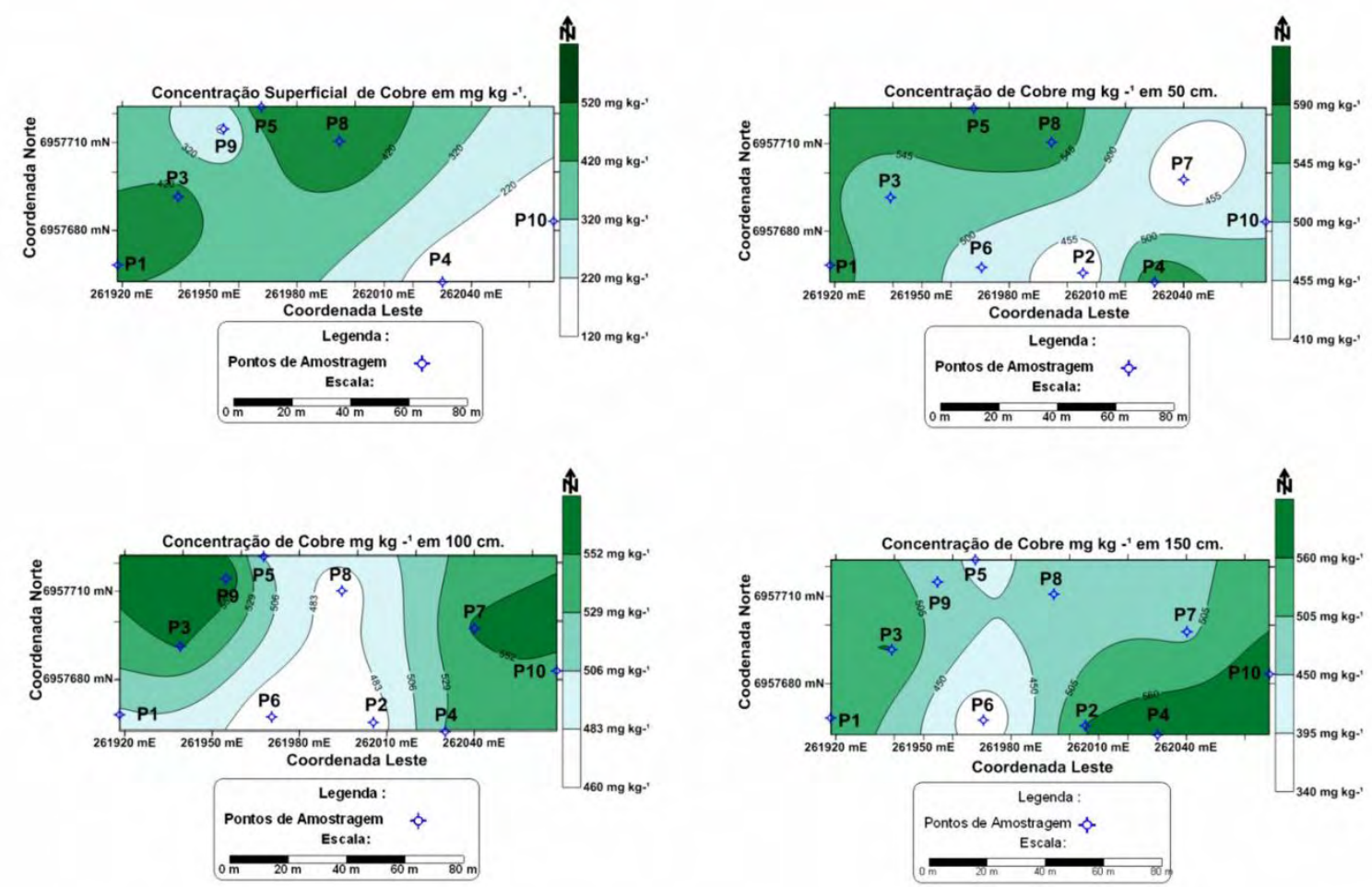

Figura 5. Concentração de Cobre no Cemitério São João Batista nas profundidades entre 0 e $150 \mathrm{~cm}$.

Na profundidade $0 \mathrm{~cm}$, os maiores valores econtram-se na região norte e oeste do cartograma, já os menores estão na região sudeste (Figura 5). Para a profundidade $50 \mathrm{~cm}$, os maiores valores situam-se na região norte do cartograma, e os menores nas regiões leste e sul. Em $100 \mathrm{~cm}$ os maiores valores encontram-se nas regiões leste e noroeste, e as menores concentrações estão nas regiões norte e sul. Em $150 \mathrm{~cm}$, os maiores valores encontram-se na região sudeste do cartograma, e os menores estão na região sudoeste.

A concentração dos metais pesados nas profundidades variando de $200 \mathrm{~cm}$ a $300 \mathrm{~cm}$, sendo essas profundidades encontradas abaixo das sepulturas cavadas no cemitério (Figura 6). 
KEMERICH, P. D. C.; BORBA, W. F.; SILVA, R. F.; BARROS, G.; GERHARDT, A. E.; FLORES, C. E. B. Valores anômalos de metais pesados em solo de cemitério. Ambi-Agua, Taubaté, v. 7, n. 1, p. 140-156, 2012. (http://dx.doi.org/10.4136/ambi-agua.838)

Na profundidade de $200 \mathrm{~cm}$ o maior valor encontrado situa-se na região sudeste do cartograma, já os menores valores ocorreram nas regiões norte e sul. O cobre na profundidade $250 \mathrm{~cm}$ teve o maior valor no ponto 5 a uma concentração de $560,80 \mathrm{mg} \mathrm{kg}^{-1}$ e altitude de 520,887 m, no cartograma as maiores concentrações estão presentes na região noroeste.

Os menores valores encontraram-se no ponto $3 \mathrm{com}$ concentração de $464,92 \mathrm{mg} \mathrm{kg}^{-1} \mathrm{e}$ altitude de 521,5 m, no cartograma estão representados nas regiões oeste e sudoeste.

Na profundidade de $300 \mathrm{~cm}$, os maiores valores de cobre estão no ponto $8 \mathrm{com} 594,56$ $\mathrm{mg} \mathrm{kg}^{-1}$, na altitude de 518,7 m, localizado na região norte da Figura 6 . O menor valor de cobre foi determinado no ponto 9 , esse ponto está a uma altitude de 518,7 m. No cartograma as menores concentrações em $300 \mathrm{~cm}$ encontram-se na região oeste, no ponto 3 . De forma geral, em todas as profundidades avaliadas, o maior valor de cobre foi no ponto 4 a $150 \mathrm{~cm}$.
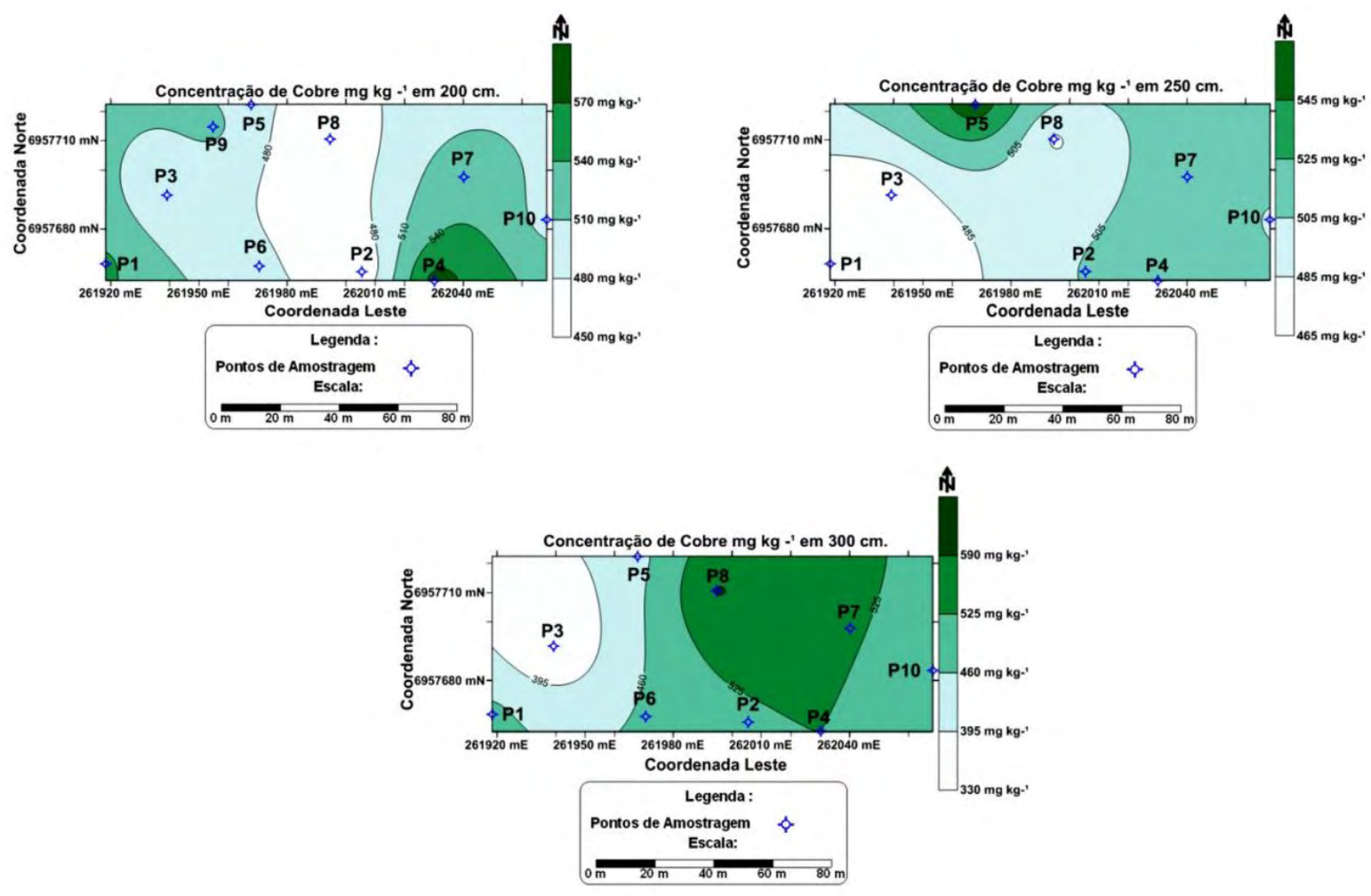

Figura 6. Concentração de Cobre no Cemitério São João Batista nas profundidades entre 200 e $300 \mathrm{~cm}$.

A Figura 7 (a) ilustra a concentração média de Cobre nos 10 diferentes pontos de amostragem, sendo os maiores valores médios encontrados no ponto 8 , coincidindo com o fluxo preferencial da água superficial, cuja concentração varia de 400 a $650 \mathrm{mg} \mathrm{kg}^{-1}$, já os menores valores médios foram encontrados no ponto 9 , com concentração que variou de 150 a $350 \mathrm{mg} \mathrm{kg}^{-1}$. A Figura 7 (b) ilustra a concentração média de Cobre em 7 diferentes profundidades, sendo os maiores valores médios presentes na profundidade $100 \mathrm{~cm}$ a uma concentração que variou de 400 a $600 \mathrm{mg} \mathrm{kg}^{-1}$, já as menores concentrações médias encontraram-se na profundidade $0 \mathrm{~cm}$ com uma variação de 150 a $350 \mathrm{mg} \mathrm{kg}^{-1}$. No intervalo de 100 a $200 \mathrm{~cm}$ estão presentes os maiores valores médios, sendo que os corpos são enterrados entre 200 e $300 \mathrm{~cm}$. 
KEMERICH, P. D. C.; BORBA, W. F.; SILVA, R. F.; BARROS, G.; GERHARDT, A. E.; FLORES, C. E. B. Valores anômalos de metais pesados em solo de cemitério. Ambi-Agua, Taubaté, v. 7, n. 1, p. 140-156, 2012. (http://dx.doi.org/10.4136/ambi-agua.838)

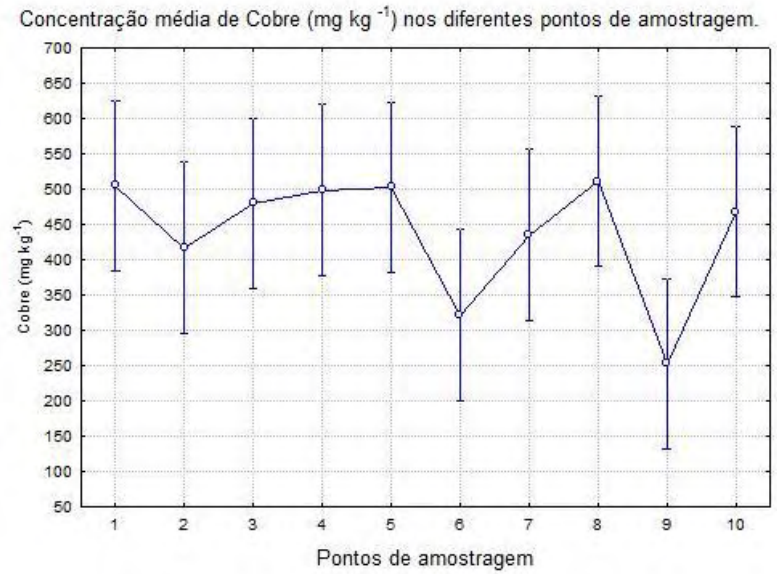

(a)

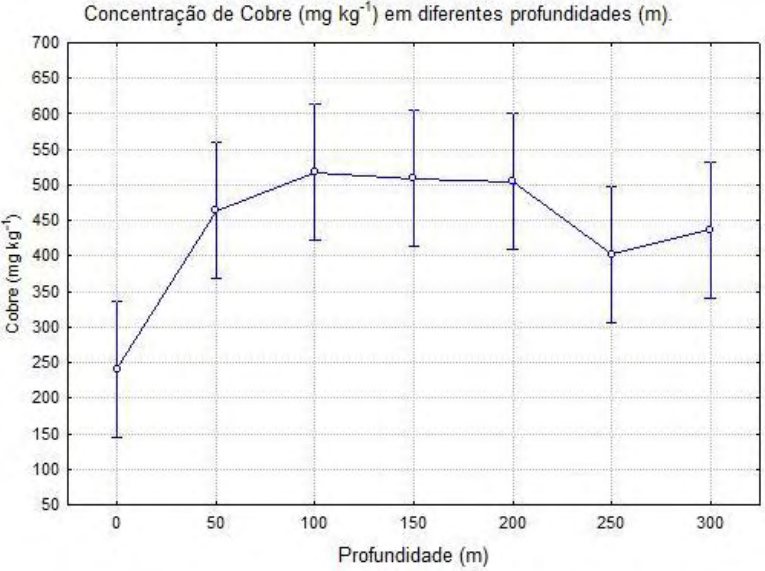

(a)

Figura 7. Concentração média de Cobre em 10 pontos de amostragens (a), concentração média de Cobre em 7 diferentes profundidades (b).

\subsection{Cromo}

A Figura 8 apresenta a variação da concentração de Cromo na área ocupada pelo cemitério São João Batista entre os pontos P1 e P10 nas profundidades 0, 50 e $100 \mathrm{~cm}$. Nessa área apenas amostra superficial do P2 e $50 \mathrm{~cm}$ do P7 não ultrapassaram a concentração permitida pela Resolução CONAMA no $420 / 2009$ para solos $\left(75 \mathrm{mg} \mathrm{kg}^{-1}\right)$.

O cromo é um elemento traço essencial, mas também pode ser tóxico para o ser humano. Este elemento químico é encontrado naturalmente no solo, na poeira e gases de vulcões. No meio ambiente, pode ser encontrado na forma de cromo (0), cromo (III) e cromo (VI), sendo que o cromo (III) tem ocorrência natural no meio ambiente, enquanto cromo (VI) e cromo (0) são geralmente produzidos por processos industriais.

A presença de cromo nas águas subterrâneas está associada à contaminação de origem antrópica, de acordo com sua concentração pode apresentar-se como um elemento essencial e tóxico, ou não. Enquanto o Cr (III) é um elemento essencial e tóxico em nível de traço em animais o $\mathrm{Cr}$ (VI), é não essencial e tóxico em baixas concentrações. Em função dos processos de oxirredução, de transformação de Cr (III) em Cr (VI) e vice-versa, consideramse as atividades antropogênicas que liberam o $\mathrm{Cr}$ (III) ou o $\mathrm{Cr}$ (VI) como indesejáveis, mesmo se Cr (III) seja descarregado no meio ambiente, não há garantia de que ele permanecerá neste estado químico (Mâcedo, 2004).

$\mathrm{O}$ cromo no solo está em sua maioria na forma de óxido insolúvel $\mathrm{Cr}_{2} \mathrm{O}_{3}$ de baixa mobilidade e uma pequena quantidade nas formas solúveis de $\mathrm{Cr}$ (VI) e $\mathrm{Cr}$ (III), portanto de maior mobilidade no solo. A mobilidade destas formas depende das características de adsorção do solo como teor de argila, teor de $\mathrm{Fe}_{2} \mathrm{O}_{3}$ e matéria orgânica (Schirmer et al., 2009)

$\mathrm{O}$ elemento químico cromo é extremamente usado na galvanoplastia e na indústria de curtumes. Todos esses processos geram como consequência, efluentes líquidos, resíduos sólidos e emissões gasosas, com considerável grau de toxicidade e que necessitam de tratamento específico (Mota Sobrinho et al., 2007). 

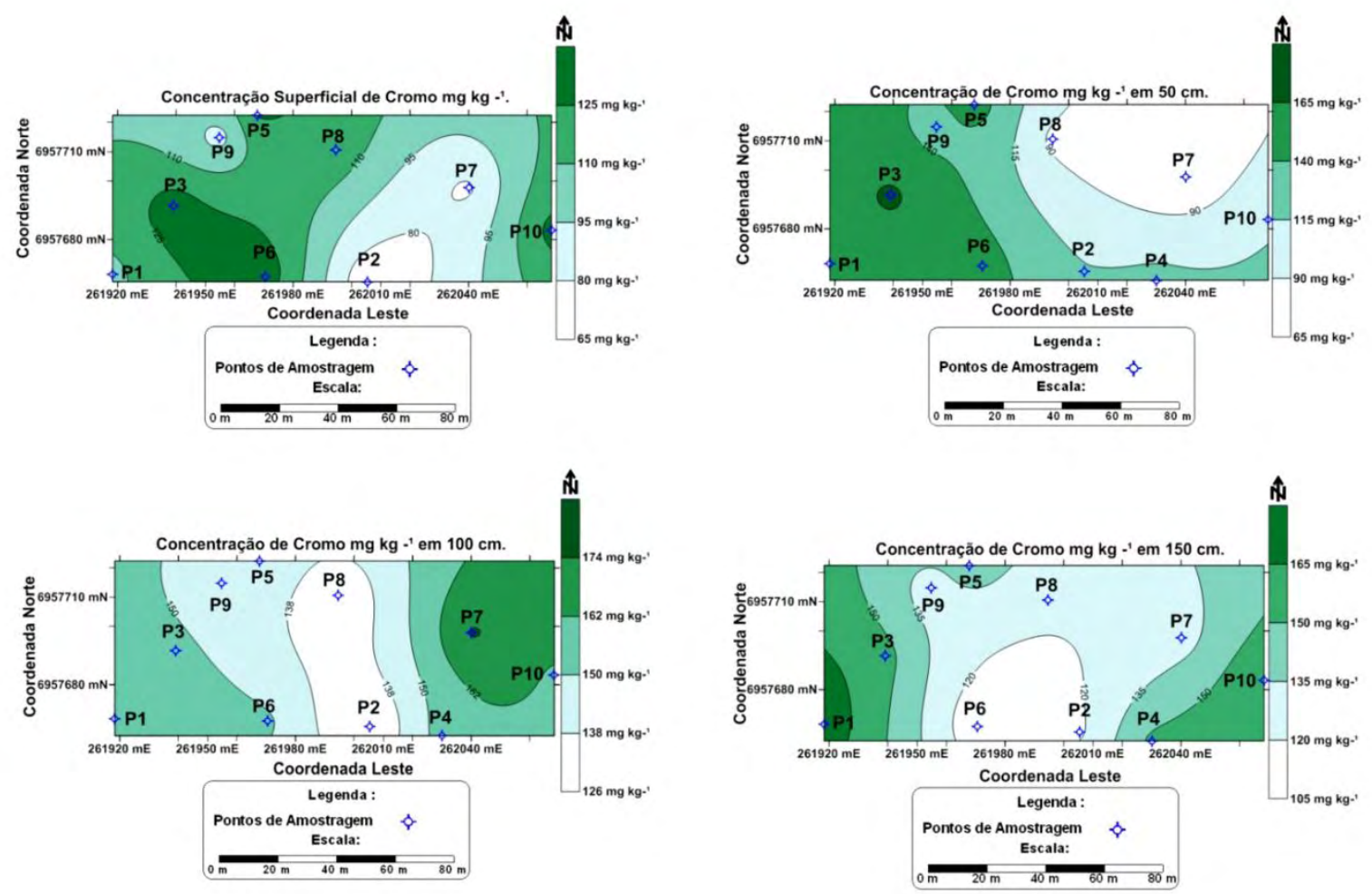

Figura 8. Concentração de Cromo no Cemitério São João Batista nas profundidades entre 0 e $150 \mathrm{~cm}$.

$\mathrm{Na}$ profundidade $0 \mathrm{~cm}$ os maiores valores econtram-se nas regiões sudeste, sudoeste e norte do cartograma, as menores concentrações estão nas regiões leste e sul (Figura 8). Para a profundidade $50 \mathrm{~cm}$ os maiores valores situam-se na região oeste, enquanto que os menores estão representados nas regiões leste e nordeste. Em $100 \mathrm{~cm}$ os maiores valores encontram-se na região nordeste e os menores estão nas regiões central, norte e sul. Em $150 \mathrm{~cm}$ os maiores valores estão na região sudoeste e os menores na região sul.

A Figura 9 ilustra as concentrações de cromo nas profundidades variando de 200 a 300 $\mathrm{cm}$. Na profundidade de $200 \mathrm{~cm}$ os maiores valores estão nas regiões noroeste e oeste, já os menores encontran-se na região sul do cartograma. Na profundidade de $250 \mathrm{~cm}$ o maior valor de cromo foi no no ponto 3 a uma concentração de $193,75 \mathrm{mg} \mathrm{kg}^{-1}$ e altitude de $521,5 \mathrm{~m}$, no cartograma as maiores concentrações de cromo em $250 \mathrm{~cm}$ estão presentes na região noroeste. Os menores valores foram encontrados no ponto 8 com $82,02 \mathrm{mg} \mathrm{kg}^{-1}$ e altitude de $518,7 \mathrm{~m}$, no cartograma encontram-se na região norte.

Na profundidade de $300 \mathrm{~cm}$ o maior valor esteve presente no ponto 1 a uma concentração de $280,12 \mathrm{mg} \mathrm{kg}^{-1}$ e altitude de $522,6 \mathrm{~m}$, no cartograma as maiores concentrações estão na região sudoeste. $\mathrm{O}$ menores valores observados para cromo em $300 \mathrm{~cm}$ foram encontrados no ponto $2\left(124,01 \mathrm{mg} \mathrm{kg}^{-1}\right)$ e altitude de $522,16 \mathrm{~m}$, no cartograma as menores concentrações estão apresentadas nas regiões norte, sul e nordeste. O menor valor de cromo encontrado em todas as profundidades foi na amostra superficial do ponto 4 , já o maior valor foi encontrado no ponto $1 \mathrm{em} 300 \mathrm{~cm}$. 
KEMERICH, P. D. C.; BORBA, W. F.; SILVA, R. F.; BARROS, G.; GERHARDT, A. E.; FLORES, C. E. B. Valores anômalos de metais pesados em solo de cemitério. Ambi-Agua, Taubaté, v. 7, n. 1, p. 140-156, 2012. (http://dx.doi.org/10.4136/ambi-agua.838)
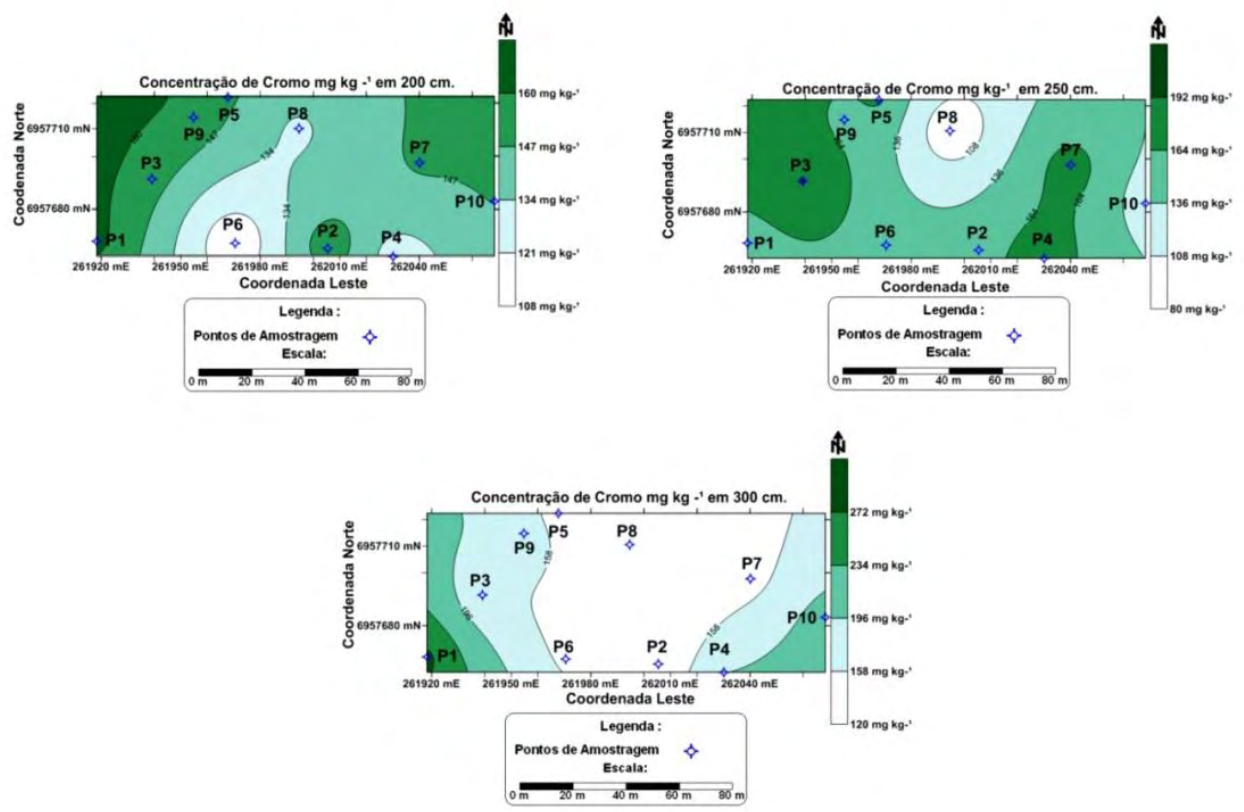

Figura 9. Concentração de Cromo no Cemitério São João Batista nas profundidades entre 200 e $300 \mathrm{~cm}$.

A Figura 10 (a) ilustra a concentração média de Cromo nos 10 diferentes pontos de amostragem, sendo os maiores valores médios encontrados no ponto $1 \mathrm{com}$ concentração que varia de 140 a $190 \mathrm{mg} \mathrm{kg}^{-1}$, já os menores valores médios foram encontrados no ponto 8 cuja concentração variou de 90 a $140 \mathrm{mg} \mathrm{kg}^{-1}$. A Figura 10 (b) ilustra a concentração média de Cromo em 7 diferentes profundidades, sendo os maiores valores médios presentes na profundidade $300 \mathrm{~cm}$ a variando de 150 a $190 \mathrm{mg} \mathrm{kg}^{-1}$, já as menores concentrações médias encontram-se na profundidade $0 \mathrm{~cm}$ com variação de 80 a $120 \mathrm{mg} \mathrm{kg}^{-1}$. O ponto 1 tem um menor influência do fluxo preferencial, pois está localizado no ponto mais alto do terreno, já o ponto 8 está sobre forte influência do escoamento superficial.

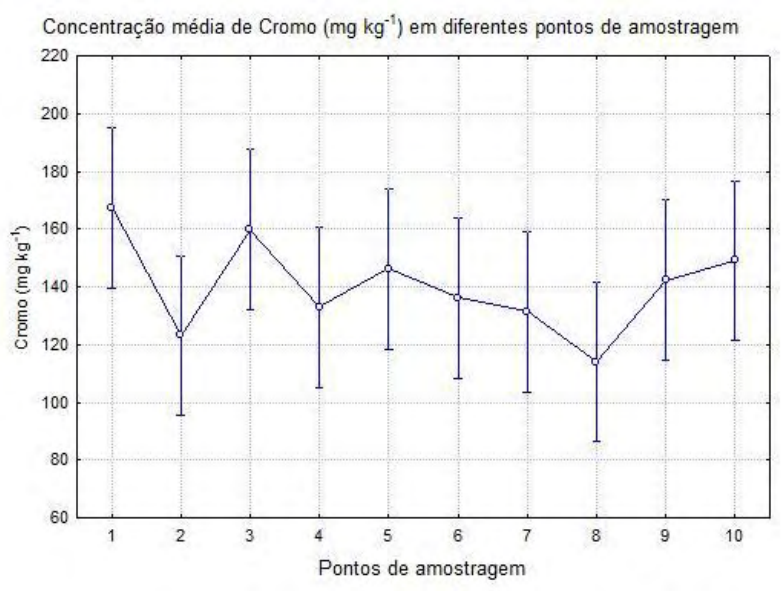

(a)

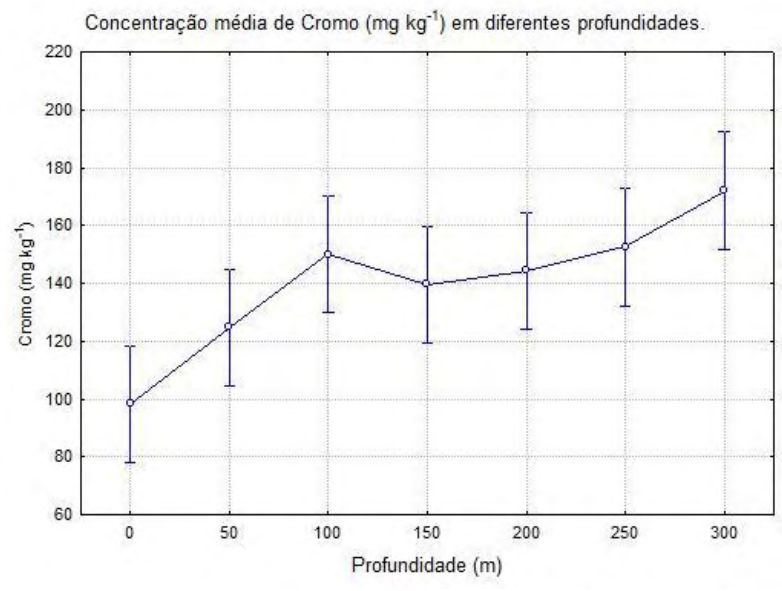

(b)

Figura 10. Concentração média de Cromo em 10 pontos de amostragens (a), concentração média de Cromo em 7 diferentes profundidades (b). 
KEMERICH, P. D. C.; BORBA, W. F.; SILVA, R. F.; BARROS, G.; GERHARDT, A. E.; FLORES, C. E. B. Valores anômalos de metais pesados em solo de cemitério. Ambi-Agua, Taubaté, v. 7, n. 1, p. 140-156, 2012. (http://dx.doi.org/10.4136/ambi-agua.838)

\subsection{Zinco}

A Figura 11 apresenta a variação da concentração de zinco na área ocupada pelo cemitério São João Batista entre os pontos P1 e P10 nas profundidades 0, 50, 100 e $150 \mathrm{~cm}$. $\mathrm{Na}$ área estudada, considerando todos os 10 pontos amostrados, as concentrações dos metais ultrapassaram os valores estabelecidos pela Resolução CONAMA no 420/2009 para solos $\left(300 \mathrm{mg} \mathrm{kg}^{-1}\right)$.

O zinco é considerado o $25^{\circ}$ elemento mais abundante na crosta terrestre, ocorre em vários minerais e em diferentes formas (sulfetos ou carbonatos de $\mathrm{Zn}$ ), seu maior uso é na galvanização de produtos de ferro $(\mathrm{Fe})$, proporcionando uma cobertura resistente à corrosão. É utilizado em baterias, fertilizantes, aros e rodas de veículos, tintas, plásticos, borrachas, em alguns cosméticos como pós e bases faciais e produtos farmacêuticos, como os complexos vitamínicos (Moore e Ramamoorthy, 1984). A absorção excessiva do metal pelo organismo pode levar a um quadro de intoxicação, resultando em sintomas como vômitos, diarréias e cólicas (Bona et al., 2007).

$\mathrm{Na}$ profundidade $0 \mathrm{~cm}$, os maiores valores econtram-se na regiões norte e sudoeste do cartograma, já os menores estão na região noroeste. Para a profundidade $50 \mathrm{~cm}$ os maiores valores situam-se na regiões norte e sudeste, e os menores estão nas regiões leste, sul e oeste. Em $100 \mathrm{~cm}$ os valores de maior concentração estão na região leste, já os de menores estão representados nas regiões oeste e sudeste. Em $150 \mathrm{~cm}$, os maiores valores encontrados estao localizados na região sudeste e os menores nas regiões noroeste e sudeste.
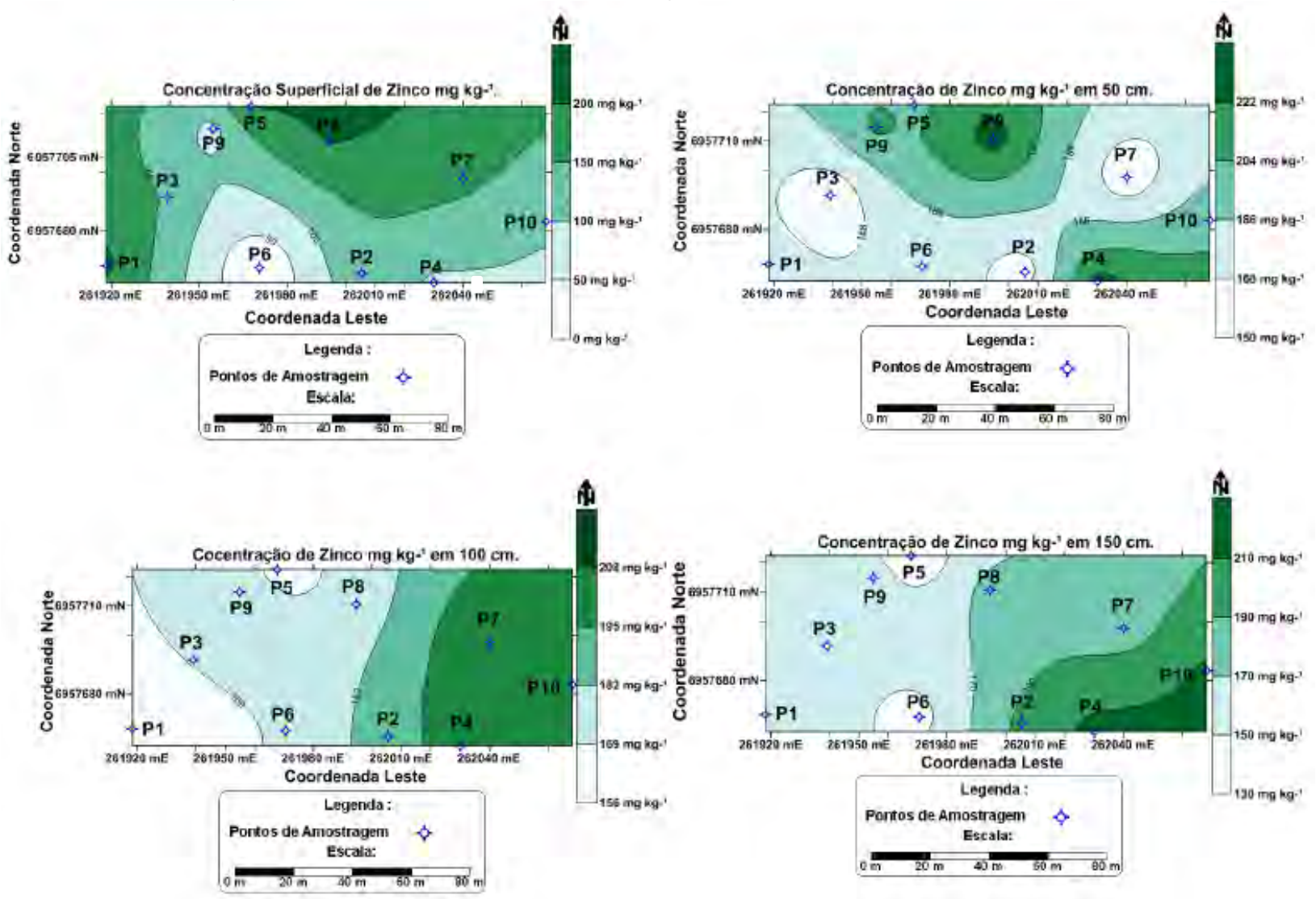

Figura 11. Concentração de Zinco no Cemitério São João Batista nas profundidades entre 0 e $150 \mathrm{~cm}$.

A Figura 12 ilustra a distribuição das concentrações dos metais pesados nas profundidades variando de 200 a $300 \mathrm{~cm}$, profundidades essas abaixo das covas utilizadas para os sepultamentos no cemitério. Na profundidade de $200 \mathrm{~cm}$, os maiores valores encontrados situam-se nas regiões sudeste e sudoeste do cartograma, já os menores valores 
KEMERICH, P. D. C.; BORBA, W. F.; SILVA, R. F.; BARROS, G.; GERHARDT, A. E.; FLORES, C. E. B. Valores anômalos de metais pesados em solo de cemitério. Ambi-Agua, Taubaté, v. 7, n. 1, p. 140-156, 2012. (http://dx.doi.org/10.4136/ambi-agua.838)

ocorreram na região sul. $\mathrm{O}$ zinco na profundidade $250 \mathrm{~cm}$ teve o maior valor no ponto $10 \mathrm{a}$ uma concentração de $204,57 \mathrm{mg} \mathrm{kg}^{-1}$ e altitude de $518,0 \mathrm{~m}$, no cartograma as maiores concentrações estão nas regiões leste e noroeste. $\mathrm{O}$ menor valor encontra-se no ponto 3 com concentração de $117,41 \mathrm{mg} \mathrm{kg}^{-1}$ e altitude de $521,5 \mathrm{~m}$, no cartograma as menores concentrações localizam-se na região oeste.

$\mathrm{Na}$ profundidade $300 \mathrm{~cm}$ tem-se como valor máximo de zinco no ponto $8 \mathrm{com}$ a concentração de $219,12 \mathrm{mg} \mathrm{kg}^{-1}$ e altitude de $518,7 \mathrm{~m}$, no cartograma os maiores valores localizam-se na região norte. O menor valor encontra-se no ponto 3 a uma altitude de $521,5 \mathrm{~m}$ e concentração de $91,63 \mathrm{mg} \mathrm{kg}^{-1}$, no cartograma as menores concentrações estão representadas na região oeste. $\mathrm{O}$ menor valor encontrado para zinco esteve na amostra superficial do ponto 6 , já o maior esteve no ponto 8 , em uma profundidade de $50 \mathrm{~cm}$.

A Figura 13 (a) ilustra a distribuição das concentrações médias de Zinco nos 10 diferentes pontos de amostragem, sendo os maiores valores médios encontrados no ponto $4 \mathrm{e}$ no ponto 8 com concentração que variou de 170 a $210 \mathrm{mg} \mathrm{kg}^{-1}$, já os menores valores médios foram encontrados no ponto 6 a uma concentração que variou de 110 a $160 \mathrm{mg} \mathrm{kg}^{-1}$. A Figura 13 (b) ilustra a concentração média de Zinco em 7 diferentes profundidades, sendo os maiores valores médios presentes na profundidade $50 \mathrm{~cm}$ a uma concentração que varia de 165 a 210 mg kg ${ }^{-1}$, já as menores concentrações médias encontram-se na profundidade $0 \mathrm{~cm}$ com uma variação de 110 a $160 \mathrm{mg} \mathrm{kg}^{-1}$.

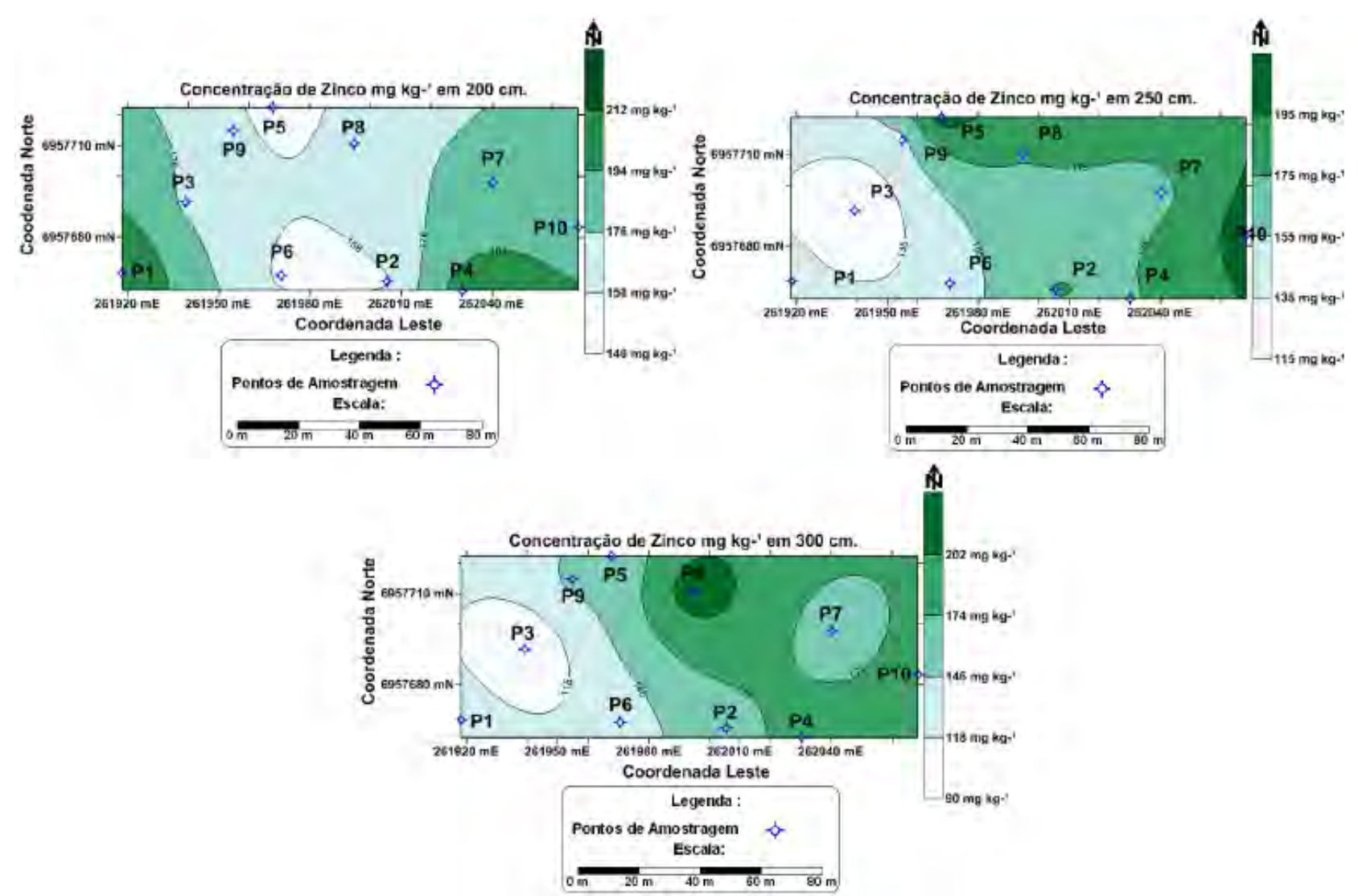

Figura 12. Concentração de Zinco no Cemitério São João Batista nas profundidades entre 200 e $300 \mathrm{~cm}$. 
KEMERICH, P. D. C.; BORBA, W. F.; SILVA, R. F.; BARROS, G.; GERHARDT, A. E.; FLORES, C. E. B. Valores anômalos de metais pesados em solo de cemitério. Ambi-Agua, Taubaté, v. 7, n. 1, p. 140-156, 2012. (http://dx.doi.org/10.4136/ambi-agua.838)

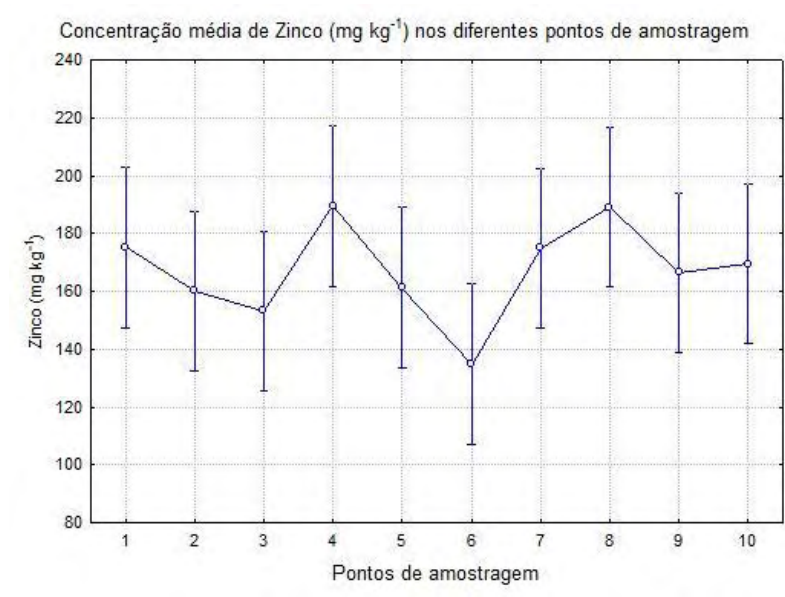

(a)

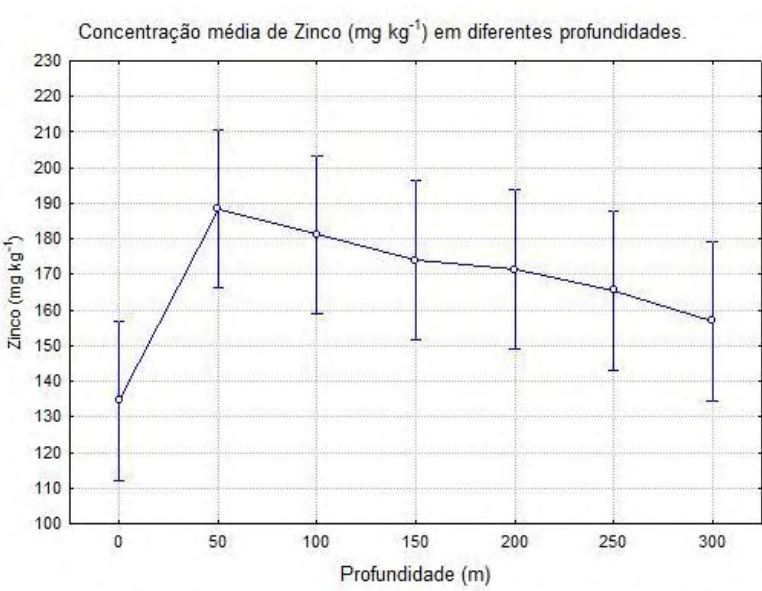

(b)

Figura 13. Concentração média de Zinco em 10 pontos de amostragens (a), concentração média de Zinco em 7 diferentes profundidades (b).

\section{CONCLUSÃO}

Os metais Bário e Cobre apresentaram concentrações elevadas, indicando contaminação do solo em todos os pontos amostrados, já o elemento Cromo apresentou indícios de contaminação nas profundidades variando entre 1 a 3 metros. Para o elemento Zinco os valores ficaram abaixo do valor estabelecido como máximo pela legislação brasileira em todos os pontos amostrados.

\section{REFERÊNCIAS}

ANJOS, R. M. Cemitérios: uma ameaça à saúde humana. In: CONGRESSO BRASILEIRO DE ENGENHARIA SANITÁRIA E AMBIENTAL, 24., 02-07 setembro 2007, Belo Horizonte. Anais... Belo Horizonte: ABES, 2007. 1 CD-ROM.

BONA, I. A. T.; SARKIS, J. E. S.; SALVADOR, V. L. R.; SOARES, A. L. R.; KLAMT, S. L. Análise arqueométrica de cerâmica Tupiguarani da região central do Estado do Rio Grande do Sul, Brasil, usando fluorescência de raios X por disperção de energia (EDXRF). Revista Química Nova, São Paulo, n. 30, p. 785-790, jan./fev. 2007.

BRASIL. Conselho Nacional do Meio Ambiente. Resolução no 420, de 28 de Dezembro de 2009. Dispõe sobre os critérios e valores orientadores de qualidade do solo quanto à presença de substâncias químicas e estabelece diretrizes para o gerenciamento ambiental de área contaminada por essas substâncias em decorrência de atividades antrópicas. Brasília, 2009. Disponível em: <http://homologa.ambiente.sp.gov.br/aquiferos/ CONAMA\%20Resolucao\%202009_420.pdf>. Acesso em: 15 fev. 2011.

BRASIL. Conselho Nacional do Meio Ambiente. Resolução no 335, de 3 de abril de 2003. Dispõe sobre o licenciamento ambiental de cemitérios. Brasília, 2003. Disponível em: <http://www.mma.gov.br/port/conama/res/res03/res33503.xml>. Acesso em: 16 abril 2012.

COSTA, C. das N. Biodisponibilidade de metais pesados em solos do Rio Grande doSul. 2005. 126f. Tese (Doutorado em Ciência do Solo) - Universidade Federal do Rio Grande do Sul, Porto Alegre, 2005. 
KEMERICH, P. D. C.; BORBA, W. F.; SILVA, R. F.; BARROS, G.; GERHARDT, A. E.; FLORES, C. E. B. Valores anômalos de metais pesados em solo de cemitério. Ambi-Agua, Taubaté, v. 7, n. 1, p. 140-156, 2012. (http://dx.doi.org/10.4136/ambi-agua.838)

FILIZOLA, H. F.; FERRACINI, V. L.; SANS, L. M. A.; GOMES, M. A. F.; FERREIRA, C. J. A. Monitoramento e avaliação do risco de contaminação por pesticidas em água superficial e subterrânea na região de Guaira. Pesquisa Agropecuária Brasileira, Brasília, v. 37, n. 5, p. 659-667, maio/jun. 2002.

HAN X. Y.; ZHUO, S. J.; SHEN, R. X.; WANG, P. L.; JI A. Comparison of the quantitative results corrected by fundamental parameter method and difference calibration specimens in x-ray fluorescence spectrometry. Journal of Quantitative Spectroscopy and Radiative Transfer, v. 97, n. 1, p. 68-74, 2006.

http://dx.doi.org/10.1016/j.jqsrt.2004.12.018

INSTITUTO BRASILEIRO DE GEOGRAFIA E ESTATÍSTICA - IBGE. Contagem da população. 2009. Disponível em: <http://www.ibge.gov.br>. Acesso em: 15 maio de 2011.

KABATA-PENDIAS, A.; PENDIAS, H. Trace elements in soil and plants. Boca Raton: CRC Press, 1992. 365 p.

MÂCEDO, J. A. B. Águas \& águas. 2. ed. Belo Horizonte: CRQ-MG, 2004.

MARQUES, J. F.; SKOPURA, L. A.; FERRAZ, J. M. G. Indicadores de sustentabilidade em agroecossistemas. Jaguariuna: Embrapa Meio Ambiente, 2003.

MARTINS, M. T.; PELliZARI, V. H.; PACHECO, A.; MYAKI, D. M.; ADAMS, C.; BOSSOLAN, N. R. S. et al. Qualidade bacteriológica de água subterrânea em cemitérios. Revista Saúde Pública, São Paulo, v. 25, n. 1, p. 47-52, jan./fev. 1991.

MOORE, J. W.; RAMAMOORTHY, S. Heavy metals in natural waters. New York: Springer-Verlag, 1984. http://dx.doi.org/10.1007/978-1-4612-5210-8

MOTA SOBRINHO, M. A. da; OLIVIER, S.; SILVA, V. L. Metodologia para extração de cromo de lodo galvânico. In: CONGRESSO BRASILEIRO DE ENGENHARIA SANITÁRIA E AMBIENTAL, 24., 02-07 setembro 2007, Belo Horizonte. Anais... Belo Horizonte: ABES, 2007. 1 CD-ROM.

NEIRA, D. F.; TERRA, V. R.; SANTOS, R. P.; BARBIÉRI, R. S. Impactos do necrochorume nas águas subterrâneas do cemitério de Santa Inês, Espírito Santo, Brasil. Natureza On Line, Santa Teresa, v. 6, p. 36-41, jan./fev. 2008.

SANTANA, G. P. Contaminação por cobre: a doença de Wilson. 2009. Disponível em: <http://www.cq.ufam.edu.br/Artigos/cobre/contaminacao_cobre.html>. Acesso em: 3 abril 2012.

SCHIRMER, W. N.; DREIFUS, T. V.; QUARTAROLI, L.; BENATTO, G. L.; OLIVEIRA, G. L.; VANZETO, S. A química ambiental do cromo e seus compostos. In: SEMANA DE ENGENHARIA AMBIENTAL, 7., 01-04 junho 2009, Irati. Anais... Irati: EESC/USP, 2009. 1 CD ROM,.

SILVA, R. W. da C.; MALAGUTTI FILHO, W. Emprego do imageamento elétrico no estudo da contaminação por cemitérios. Revista Geociências, Porto Alegre, v. 29, p. 343 354, jan./fev. 2010.

SILVA, R. W. da C.; MALAGUTTI FILHO, W. Cemitérios como áreas potencialmente contaminadas. Revista Brasileira de Ciências Ambientais, Cubatão, v. 9, p. 26-35, mar./abr. 2008. 
KEMERICH, P. D. C.; BORBA, W. F.; SILVA, R. F.; BARROS, G.; GERHARDT, A. E.; FLORES, C. E. B. Valores anômalos de metais pesados em solo de cemitério. Ambi-Agua, Taubaté, v. 7, n. 1, p. 140-156, 2012. (http://dx.doi.org/10.4136/ambi-agua.838)

TEIXEIRA, S. A. Medicina holística: a harmonia do ser humano. Rio de Janeiro: Campus, 2003.

VENDRAME, I. F.; MEDEIROS, G. A.; BRESSAN, M. A. Estudo da poluição de águas subterrâneas em nível local. In: ENCONTRO DE INICIAÇÃO CIENTÍFICA E PÓSGRADUAÇÃO DO ITA, 9., outubro 2003, São José dos Campos. Anais... São José dos Campos: ITA, 2003. v. 1. p. 1. 


ISSN = 1980-993X - doi:10.4136/1980-993X
www.ambi-agua.net
E-mail: ambi-agua@agro.unitau.br
Tel.: (12) 3625-4212

\title{
Avaliação da integridade ecológica de rios em áreas do zoneamento ecológico econômico do complexo hidrográfico Guapiaçu-Macacu, RJ, Brasil
}

\author{
(http://dx.doi.org/10.4136/ambi-agua.762) \\ Priscilla da Silva Pereira ${ }^{1}$; Lia Amorim Chaves Fernandes ${ }^{1}$; Jaime Lopes da Mota \\ Oliveira $^{2}$; Darcilio Fernandes Baptista ${ }^{1}$ e-mail: pris.pereira@ioc.fiocruz.br; lia_acf@ioc.fiocruz.br; e-mail: darcilio@ioc.fiocruz.br;
${ }^{2}$ Departamento de Saneamento e Saúde Ambiental/ENSP/FIOCRUZ e-mail: jaimel@ensp.fiocruz.br. \\ ${ }^{1}$ Laboratório de Avaliação e Promoção da Saúde Ambiental/IOC/FIOCRUZ
}

\section{RESUMO}

Os ecossistemas aquáticos têm sido frequentemente alterados de maneira significativa por múltiplos impactos. O complexo hidrográfico Guapiaçu-Macacu é uma importante bacia do Rio de Janeiro com zonas ecológicas distintas propostas no Zoneamento Ecológico Econômico. Esse estudo avaliou a integridade ecológica em trechos de rios deste Complexo localizados na Zona de Conservação da Vida Silvestre (ZCVS) e Zona de Uso Agropecuário (ZUAP) por meio do Protocolo de Avaliação Visual (PAV) e das variáveis físicas, químicas e microbiológicas. A integração dos resultados mostrou uma diferença significativa entre os pontos de menor grau de contaminação na ZCVS e os trechos com maior grau de impacto na ZUAP. O PAV foi mais sensível que os parâmetros convencionais entre os trechos ecologicamente impactados e os intermediários localizados na ZUAP. Esse tipo de avaliação mostrou ser eficiente no monitoramento ambiental de bacias hidrográficas que tenham um plano de Zoneamento Ecológico Econômico. Portanto, a utilização de métodos físicos, químicos e microbiológicos pode ser complementada com o PAV.

Palavras-chave: Avaliação da qualidade da água; protocolo de avaliação visual; zoneamento ecológico-econômico.

\section{Assessment of water quality in areas of ecological economic zoning of the Guapiaçu-Macacu basin, RJ, Brazil}

\begin{abstract}
Aquatic ecosystems have often been significantly altered by multiple impacts. The Guapiaçu-Macacu Hydrographic Complex is an important basin in Rio de Janeiro characterized by distinct ecological zones that make up an Ecological Economic Zoning. This research evaluated ecological upright in segments of this Complex located in Wildlife Conservation Zone (WCZ) and the Agricultural Use Zone (AUZ) using the Protocol Visual Assessment (PVA) and physical, chemicals and microbiology methods. The results showed a significant difference between the points of lowest contamination degree in WCZ and stretches with a greater impact degree in AUZ. The PVA was more sensible than the conventional parameters in the resolution between segments impacted environmentally and
\end{abstract}


PEREIRA, P. S.; FERNANDES, L. A. C.; OLIVEIRA, J. L. M.; BAPTISTA, D. F. Avaliação da integridade ecológica de rios em áreas do zoneamento ecológico econômico do complexo hidrográfico Guapiaçu-Macacu, RJ, Brasil. Ambi-Agua, Taubaté, v. 7, n. 1, p. 157-168, 2012. (http://dx.doi.org/10.4136/ambi-agua.762)

impacted middle located in AUZ. This type of evaluation proved to be more effective in environmental monitoring the water quality for watersheds that have their Ecological Economic Zoning Plan. Therefore, the use of physical, chemical and microbiological methods must be complemented by the PVA.

Keywords: Assessment of water quality; protocol visual assessment; ecological economic zoning.

\section{INTRODUÇÃO}

Os ecossistemas aquáticos têm sido frequentemente alterados de maneira significativa pelo uso inadequado do solo, podendo provocar a redução na qualidade da água para o consumo humano e integridade biológica (Machado e Klein, 2003; Tundisi, 2003; Pedreira et al., 2009). Uma das principais intervenções ocorre devido à retirada das matas ciliares, aumentando a velocidade da correnteza, o que contribui para o arrasto de sedimentos, acelerando o processo de assoreamento e erosão (Tucci, 2002; Santos e Cardoso, 2007; Sarcinelli et al., 2008, Carvalho et al., 2000). Em geral, a qualidade da água de um rio é determinada pela medição de parâmetros físicos, químicos e microbiológicos (Coradi et al., 2009, Campanha et al., 2010). No entanto, Rodrigues et al. $(2008,2010)$ sugerem a avaliação da paisagem do rio e de seu entorno como ferramenta complementar para um diagnóstico da qualidade do ecossistema aquático por meio da aplicação do Protocolo de Avaliação Visual (PAV).

A ocupação e o manejo do solo e a exploração dos recursos naturais devem adotar como base a biodiversidade, a qualidade e a manutenção dos ecossistemas locais. Para nortear esse processo, normalmente o ambiente é dividido em áreas que compõe um Zoneamento Ecológico Econômico (ZEE). Um ZEE consiste na elaboração do diagnóstico das potencialidades do patrimônio ambiental e sociocultural de um determinado espaço geográfico (Ab'Saber, 1989; Acselrad, 2000). A proposta de ZEE para a bacia GuapiaçuMacacu é composta por sete zonas distintas definidas por um conjunto de regras e orientações para os diferentes usos da terra, produzindo uma sequência de mosaico que fragmentam a paisagem como mostra a Figura 1 (Cabral e Fiszon, 2004). A Zona de Preservação da Vida Silvestre (ZPVS) e a Zona de Conservação da Vida Silvestre (ZCVS) são as áreas de uso mais restritivo da terra por apresentarem unidades de conservação como parques e reservas. As áreas com menor ou nenhuma restrição quanto ao uso da terra são: Zona de Ocupação Controlada (ZOC) onde existem cidades e/ou vilas; Área de Uso Conflitante (AUC) com condições ambientais que favorecem as atividades de desenvolvimento; Zona de Uso Agropecuário (ZUAP) que possui atividades agrícolas e pecuárias; Zona de Uso Especial (ZUE) onde será instalado o Complexo Petroquímico da Petrobras (COMPERJ); e Área Crítica que está composta por uma planície inundável com pequenas atividades agropecuárias.

Desse modo, o monitoramento é fundamental para garantir a integridade ecológica, a manutenção da vida selvagem e a saúde da população usuária dessas águas. Esse estudo teve como objetivo avaliar a integridade ecológica em trechos de rios localizados em duas ZEEs (ZCVS e ZUAP) na sub-bacia do rio Guapiaçu usando as variáveis físicas, químicas, microbiológicas e do Protocolo de Avaliação Visual (PAV). Além disso, foi verificada a importância do emprego do PAV como ferramenta em programas de monitoramento de águas superficiais. 


\section{MATERIAIS E MÉTODOS}

\subsection{Descrição da área de estudo}

O Complexo Hidrográfico Guapiaçu-Macacu possui uma área de drenagem de cerca de $1.640 \mathrm{Km}^{2}$, com uma população do entorno acima de 100 mil habitantes. Suas águas atendem cerca de 2,5 milhões habitantes com irrigação, piscicultura, agropecuária e abastecimento público dos municípios de Cachoeira de Macacu, Guapimirim, Itaboraí, São Gonçalo e Niterói (JICA, 1994; Helder, 1999). Em função da importância deste sistema hidrográfico para o estado do Rio de Janeiro, foi criada a Área de Proteção Ambiental (APA) do rio Macacu que determina a proteção de terrenos na faixa complementar de $150 \mathrm{~m}$ de suas margens e seu principal afluente, o rio Guapiaçu (Rio de Janeiro, 2002).

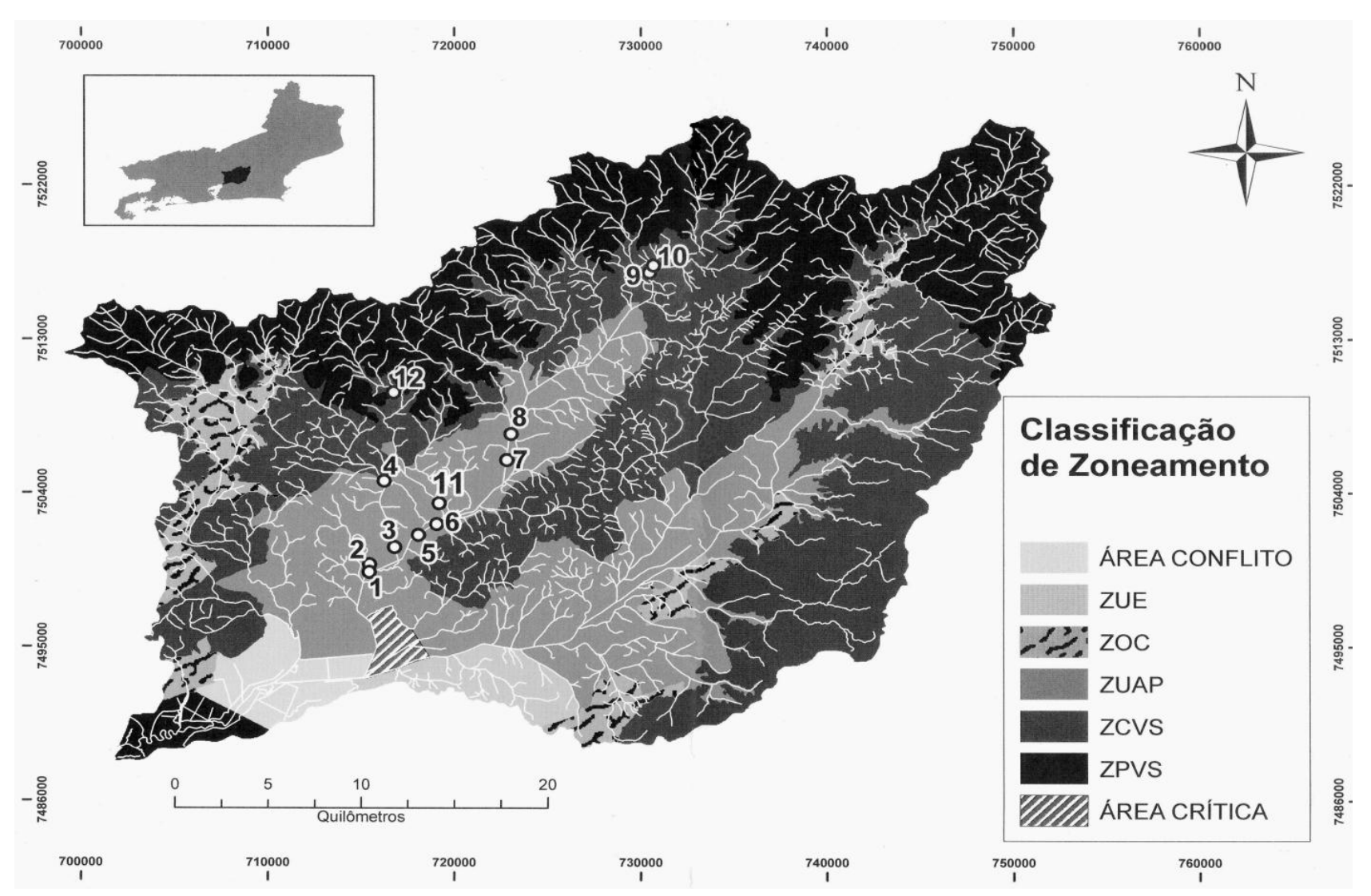

Figura 1. Zoneamento Ambiental da APA proposto pelo Instituto BioAtlântica (2009). Os pontos representam as coletas realizadas durante o projeto, onde ZPVS - Zona de Preservação da Vida Silvestre, ZUAP - Zona de Uso Agropecuário, ZCVS - Zona de Conservação da Vida Silvestre, ZOC Zona de Ocupação Controlada, ZUE - Zona de Uso Especial.

\subsection{Coleta de águas superficiais}

Foram realizadas amostragens bimestrais da água superficial no período de maio de 2008 até junho de 2009 em 12 diferentes pontos, totalizando 72 amostragens em 6 campanhas (Figura 1). A Tabela 1 mostra a localização geográfica dos trechos de rios dentro da área de estudo. 
PEREIRA, P. S.; FERNANDES, L. A. C.; OLIVEIRA, J. L. M.; BAPTISTA, D. F. Avaliação da integridade ecológica de rios em áreas do zoneamento ecológico econômico do complexo hidrográfico Guapiaçu-Macacu, RJ, Brasil. Ambi-Agua, Taubaté, v. 7, n. 1, p. 157-168, 2012. (http://dx.doi.org/10.4136/ambi-agua.762)

Para as análises físicas e químicas foram utilizados frascos de polipropileno e para análise microbiológica, sacos estéreis Whirl-Pak (Nasco). As amostras foram acondicionadas a $4^{\circ} \mathrm{C}$ e transportadas até o laboratório para análise imediata.

Tabela 1. Localização geográfica dos 12 diferentes estações de coleta em 12 estações de coleta, na sub-bacia do rio Guapiaçu.

\begin{tabular}{|c|c|c|c|c|}
\hline Pontos & Nome do rio & ZEE & \multicolumn{2}{|c|}{ Coordenadas geográficas } \\
\hline P1 & Rio Portinho & \multirow{8}{*}{ ZUAP } & W 715478 & S 7499815 \\
\hline $\mathbf{P 2}$ & Rio Portinho & & W 715460 & S 7499369 \\
\hline P3 & Rio Iconha & & W 716820 & S 7500820 \\
\hline P4 & Rio Iconha & & W 716258 & S 7504708 \\
\hline P5 & Rio Guapiaçu* & & W 718102 & S 7501532 \\
\hline P6 & Rio Guapiaçu* & & W 719085 & S 7502164 \\
\hline P7 & Rio Guapiaçu** & & W 722832 & S 7505919 \\
\hline P8 & Rio Guapiaçu** & & W 723057 & S 7507448 \\
\hline P9 & Rio Guapiaçu**** & & W 730483 & S 7516884 \\
\hline P10 & Rio Gato ${ }^{* * * *}$ & ZCVS & W 730695 & S 7517321 \\
\hline P11 & Rio Paraíso & ZUAP & W 736359 & S 7503135 \\
\hline P12 & Rio Paraíso & ZCVS & W 716771 & S 7509880 \\
\hline
\end{tabular}

\subsection{Análises físico-químicas e microbiológicas}

As medições de $\mathrm{pH}$, condutividade, sólidos totais dissolvidos (STD) e oxigênio dissolvido (OD) foram executadas no local da coleta utilizando as sondas MPA 210p e MCA 150p (LabConte) e a 550A (YSI). As análises de alcalinidade, dureza e o teor de cloretos foram realizados de acordo com APHA (2005). Para as análises de coliformes totais e termotolerantes foi utilizado o kit Colilert (Idexx).

\subsection{Protocolo de Avaliação Visual (PAV)}

A avaliação visual da área de amostragem foi efetuada por meio do preenchimento do Protocolo de Avaliação Visual (PAV) criado pela agência de proteção ambiental americana (EPA) durante a década de 1980 (Plafkin et al., 1989). O PAV é uma das ferramentas que compõem o Protocolo de Avaliação Rápida que agregam indicadores dos aspectos físicos e biológicos referente à avaliação dos recursos hídricos (Barbour et al., 1999). No PAV são avaliados 10 parâmetros ambientais divididos em caracterização do substrato, condição do canal de água corrente, estabilidade da margem, cobertura e extensão da mata ciliar, substratos disponíveis para fauna bentônica. 
Cada parâmetro recebeu uma pontuação de 0 a 20 para uma condição de ruim a ótima, respectivamente. $\mathrm{O}$ valor final do protocolo de cada trecho foi determinado pela média aritmética dos 10 parâmetros verificados. Assim, foi obtida uma classificação entre as 4 categorias: ótimo, bom, regular ou ruim. As áreas com médias menores que 6,0 foram consideradas como impactadas, ou seja, com uma condição ecológica ruim; as que tiveram médias entre 6,0 e 10,0 foram classificadas como regulares ou intermediárias; as que tiveram médias entre 10,0 e 15,0 estavam boas pelo ponto de vista ambiental; enquanto que as de excelente ou ótima condição tiveram médias superiores a 15,0 pontos.

\subsection{Análise de dados}

Foram realizadas análises estatísticas no Programa Past (Hammer et al., 2001) para a avaliação dos resultados físicos, químicos, microbiológicos e do Protocolo de Avaliação Visual. O teste $U$ de Mann-Whitney $(\mathrm{p}<0,05)$ foi utilizado para avaliar o grau de significância de distinção entre os resultados. A análise multivariada de agrupamento por correlação foi aplicada para comparar os trechos de rios estudados nas duas diferentes Zonas Econômicas Ecológicas.

\section{RESULTADOS E DISCUSSÃO}

A Tabela 2 apresenta os resultados físicos, químicos e microbiológicos entre a Zona de Conservação da Vida Silvestre (ZCVS) e a Zona de Uso Agropecuário (ZUAP). Na área mais restritiva quanto à ocupação e ao uso do solo (ZCVS) foram verificadas concentrações significativamente diferentes desses parâmetros em relação à ZUAP. A ZCVS é caracterizada como uma área que serve como zona de amortização dos impactos à Zona de Preservação da Vida Silvestre (ZPVS) e que juntas devem manter a qualidade de suas águas para o equilíbrio do ecossistema. Em geral, os locais com maior restrição quanto à ocupação e ao uso do solo apresentaram uma melhor qualidade de suas águas.

A Figura 2 indica que houve variação nos valores da condutividade e de sólidos totais dissolvidos (STD) entre a ZUAP e ZCVS. O teste U de Mann-Whitney confirmou a diferença significativa $(\mathrm{p}<0,00001)$ para ambos os parâmetros. A condutividade está relacionada à presença de partículas carregadas eletricamente, logo pode contribuir para a identificação de trechos impactados de uma bacia de drenagem. Este impacto provavelmente é devido ao lançamento de resíduos agrícolas e a entrada de dejetos orgânicos (Pereira et al., 2006). O aumento da concentração de STD normalmente está associado à entrada de partículas inorgânicas na água. Uma das possíveis origens dessas partículas é o uso inadequado da terra como a atividade agropecuária o que leva ao desmatamento e, consequentemente, à erosão das margens dos rios (Custódio e Llamas, 1983).

Os pontos 1 e 2 localizados no rio Portinho (ZUAP) apresentaram os menores valores de oxigênio dissolvido, como mostrado a Figura 3. Esses valores observados estão fora do recomendado para água doce Classe II segundo a resolução Conama 357 (Brasil, 2005). As zonas ZCVS e ZUAP foram significativamente diferentes em relação ao teor de OD e a concentração de coliformes termotolerantes com um valor de "p" igual a 0,001 e 0,004 , respectivamente (Figura 3). O ponto 5 (ZUAP) obteve o maior valor de coliformes termotolerantes provenientes de pastagens em seu entorno e de um assentamento rural local. No entanto neste mesmo trecho foi medida uma concentração OD maior que $6 \mathrm{mg} / \mathrm{L}$ provavelmente devido à declividade do rio. $\mathrm{O}$ uso inadequado do solo para agropecuária reduz a proteção da mata ciliar, o que também acarreta no aumento do processo erosivo das margens, provocando assoreamento e alterações no perfil vertical e na calha do rio. 
PEREIRA, P. S.; FERNANDES, L. A. C.; OLIVEIRA, J. L. M.; BAPTISTA, D. F. Avaliação da integridade ecológica de rios em áreas do zoneamento ecológico econômico do complexo hidrográfico Guapiaçu-Macacu, RJ, Brasil. Ambi-Agua, Taubaté, v. 7, n. 1, p. 157-168, 2012. (http://dx.doi.org/10.4136/ambi-agua.762)

Tabela 2. Estatística descritiva dos parâmetros de qualidade da água analisados em 12 estações amostrais na sub-bacia do rio Guapiaçu.

\begin{tabular}{|c|c|c|c|c|}
\hline Parâmetros & $\begin{array}{c}\text { Áreas da } \\
\text { ZEE }^{1} \\
\end{array}$ & $\operatorname{Min}^{2}$ & $\operatorname{Max}^{3}$ & Média \\
\hline \multirow{2}{*}{ Oxigênio Dissolvido (mg/L) } & ZUAP $^{4}$ & 3,3 & 7,6 & 5,9 \\
\hline & $\mathrm{ZCVS}^{5}$ & 5,6 & 8,3 & 6,6 \\
\hline \multirow{2}{*}{$\mathrm{pH}$} & ZUAP & 5,9 & 7,4 & 6,7 \\
\hline & ZCVS & 6,5 & 7,7 & 7,1 \\
\hline \multirow{2}{*}{ Condutividade $(\mu \mathrm{S} / \mathrm{cm})$} & ZUAP & 20,3 & 56,4 & 33,7 \\
\hline & ZCVS & 13,1 & 37,1 & 24,3 \\
\hline \multirow{2}{*}{ Sólidos Totais Dissolvidos (mg/L) } & ZUAP & 9,2 & 26,5 & 16,1 \\
\hline & ZCVS & 5,8 & 17,2 & 11,6 \\
\hline \multirow{2}{*}{ Alcalinidade Total (mg/l CaCO3) } & ZUAP & 9,3 & 20,6 & 16,2 \\
\hline & ZCVS & 9,3 & 16,8 & 14,1 \\
\hline \multirow{2}{*}{ Teor de Cálcio (mg/L) } & ZUAP & 1,6 & 5,5 & 3,1 \\
\hline & ZCVS & 1,6 & 3,3 & 2,6 \\
\hline \multirow{2}{*}{ Teor de Magnésio (mg/L) } & ZUAP & 0,5 & 3,7 & 1,5 \\
\hline & ZCVS & 0,5 & 1,9 & 0,8 \\
\hline \multirow{2}{*}{ Dureza Total (mg/L) } & ZUAP & 6,8 & 21,5 & 13,8 \\
\hline & ZCVS & 6,0 & 14,0 & 9,5 \\
\hline \multirow{2}{*}{ Dureza de $\mathrm{Mg}(\mathrm{mg} / \mathrm{L})$} & ZUAP & 2,0 & 15,6 & 6,1 \\
\hline & ZCVS & 1,9 & 8,0 & 3,3 \\
\hline \multirow{2}{*}{ Dureza Ca (mg/L) } & ZUAP & 2,0 & 13,7 & 7,5 \\
\hline & ZCVS & 1,9 & 8,0 & 3,3 \\
\hline \multirow{2}{*}{ Teor de Cloretos (mg/L) } & ZUAP & 4,3 & 16,6 & 8,9 \\
\hline & ZCVS & 3,9 & 16,6 & 8,2 \\
\hline \multirow{2}{*}{ Coliformes Termotolerantes (NMP/100 mL) } & ZUAP & 0 & 241 & 62,6 \\
\hline & ZCVS & 0 & 58 & 17,5 \\
\hline
\end{tabular}

Nota: ${ }^{1}$ ZEE-zoneamento ecológico-econômico; ${ }^{2}$ Min-mínimo; ${ }^{3}$ Max-máximo; ${ }^{4}$ ZUAP-zona de uso agropecuário; ${ }^{5}$ ZCVS-zona de conservação da vida selvagem.

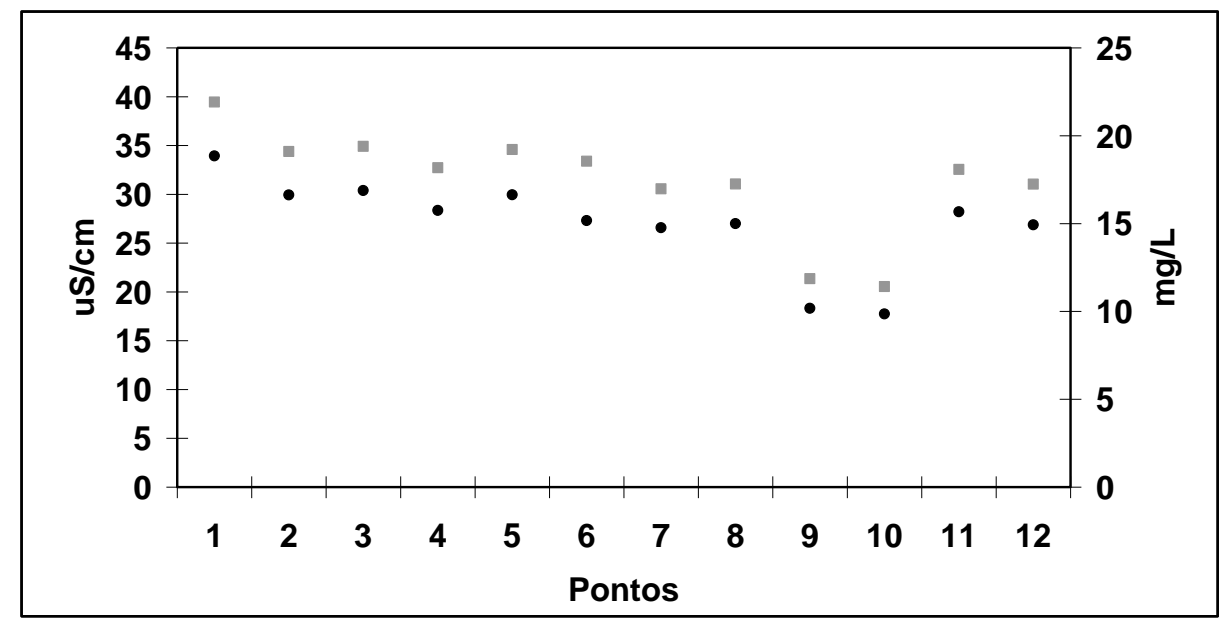

Figura 2. Resultados da condutividade $(\mu \mathrm{S} / \mathrm{cm})$ ( $\square$ ) e sólidos totais dissolvidos $(\mathrm{mg} / \mathrm{L})(\bullet)$ nos doze diferentes trechos de rios amostrados, no período de maio de 2008 até junho de 2009. 


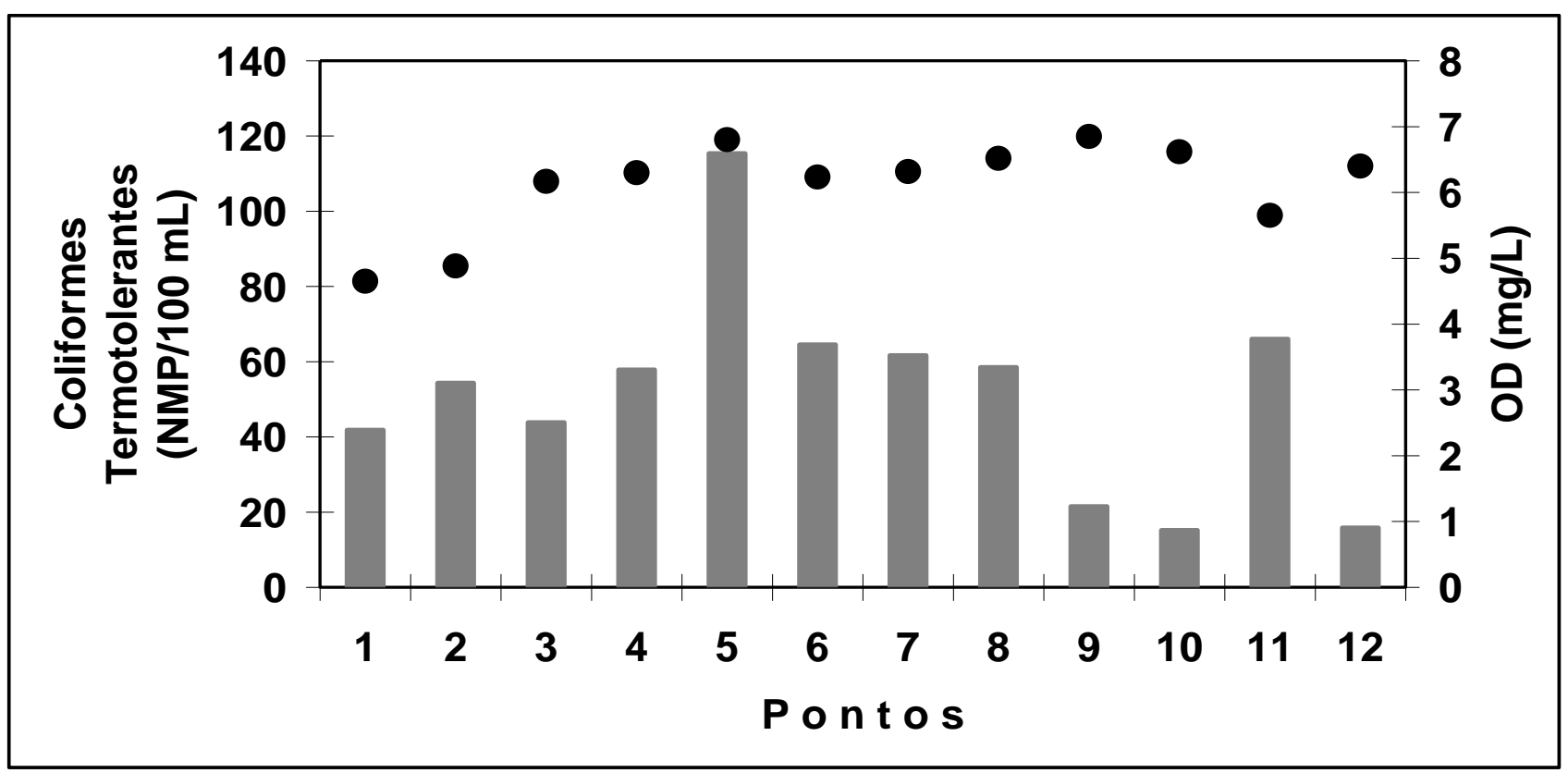

Figura 3. Resultados de oxigênio dissolvido $(\bullet)$ e de coliformes termotolerantes (barra) em doze diferentes trechos de rios amostrados, no período de maio de 2008 até junho de 2009.

A classificação da paisagem que foi realizada usando-se o Protocolo de Avaliação Visual (PAV) enquadrou a ZUAP em duas diferentes categorias paisagísticas. Os pontos de 1 a 6 obtiveram uma classificação ruim, enquanto que os pontos 7,8 e 11 apresentaram uma condição ecológica regular conforme a Tabela 3. Esta condição de subdivisão da característica da qualidade ambiental do rio não pode ser detectada por meio das análises físicas, químicas e microbiológicas embora estes trechos estejam dentro de uma mesma zona (ZUAP). Este resultado sugere que os trechos de rios que ainda se encontram em um estágio devam receber uma atenção especial pelos gestores da APA, pois são zonas de transição ecológica tendendo a atingir um estágio ruim. Os trechos de rios localizados na ZCVS (9, 10 e 12) apresentaram uma boa integridade ecológica pelo PAV. Estes resultados corroboraram com o modelo proposto de ZEE pelo Instituto Bioatlântica. Portanto, o PAV pode ser uma ferramenta útil no diagnóstico da integridade ecológica da paisagem como foi sugerido por outros autores (Callisto et al., 2002; Rodrigues et al., 2008, 2010).

Segundo o PAV, na ZCVS foram encontrados substratos favoráveis para colonização da biota aquática, indicando a presença de microhabitats que fornecem suporte alimentar e abrigo para manutenção da vida aquática, conforme previsto para está área. A alteração desses substratos pode prejudicar a formação de microhabitats e, com isso, organismos como macroinvertebrados bentônicos podem ser afetados, pois dependem desses microambientes. Este elemento fisiográfico é um fator importante para a manutenção da diversidade biológica do rio e da qualidade de suas águas.

$\mathrm{Na}$ ZUAP, os pontos 3, 4 e 6 encontravam-se em áreas retificadas dos rios. Esta característica difere da condição natural de um rio que forma meandros característicos desta área de planície costeira. A retificação de um rio acarreta no aumento da velocidade de sua correnteza provocando a homogeneização de seu leito devido ao assoreamento de material particulado. 
PEREIRA, P. S.; FERNANDES, L. A. C.; OLIVEIRA, J. L. M.; BAPTISTA, D. F. Avaliação da integridade ecológica de rios em áreas do zoneamento ecológico econômico do complexo hidrográfico Guapiaçu-Macacu, RJ, Brasil. Ambi-Agua, Taubaté, v. 7, n. 1, p. 157-168, 2012. (http://dx.doi.org/10.4136/ambi-agua.762)

Com isso estes trechos podem ser facilmente inundados, o que facilita seu uso no plantio, mas piora a sua qualidade ambiental e, consequentemente, reduz a qualidade de suas águas e altera a sua diversidade biológica (Lucas e Cunha, 2007).

Os valores atribuídos para mata ciliar na ZCVS foram acima de 10 pontos (exceto o ponto 12) mostrando uma boa integridade ecológica, diferente dos trechos da ZUAP. A ZUAP quase não apresentou áreas com extensão de mata ciliar, com exceção do ponto 7 que mantinha cerca de 30 metros de largura e uma vegetação arbórea em estágio de recuperação. A redução de mata ciliar reduz a retenção de sedimentos que são arrastados ao rio pelo escoamento superficial do seu entorno (Curvello et al., 2008; Santos e Cardoso, 2007; Coelho et al., 2011). Com isso, esses trechos ficam assoreados, reduzindo sua profundidade e, portanto, a qualidade de suas águas.

Pelos resultados físicos, químicos, microbiológicos e os aspectos visuais da integridade da paisagem (PAV) foi feita uma análise de agrupamento mostrada na Figura 4. Este dendrograma indica que existe uma similaridade de $60 \%$ entre as áreas estudadas (ZUAP e ZCVS) desta sub-bacia pelo índice de correlação. Oliveira (2009) que fez um estudo nesta mesma área incluindo a Zona de Preservação da Vida Silvestre (ZPVS) e a Zona de Ocupação Controlada (ZOC) e encontrou padrões semelhantes aos nossos. Portanto, os resultados obtidos estão coerentes com o modelo de zoneamento proposto para esta região.

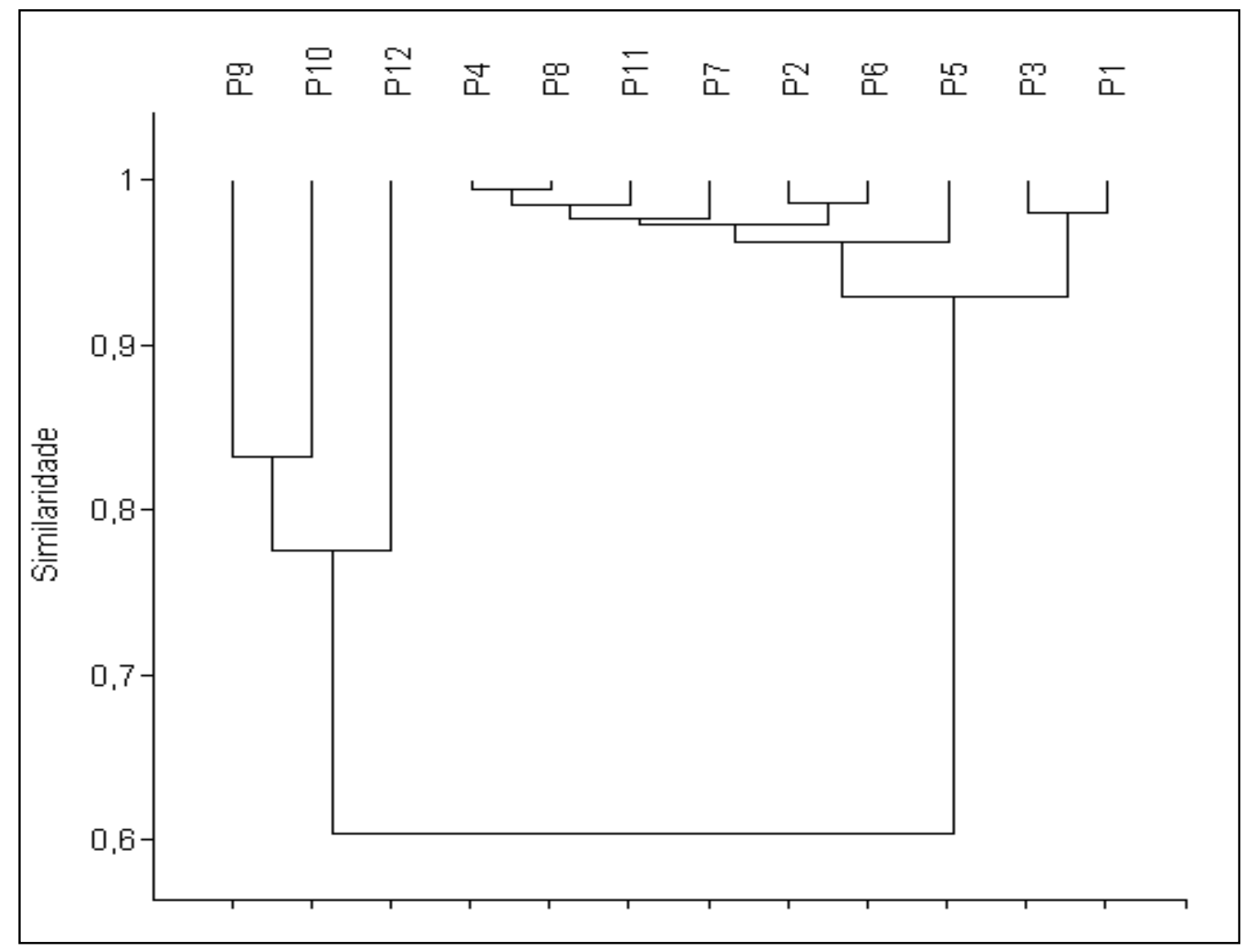

Figura 4. Dendrograma mostrando o agrupamento dos doze diferentes trechos de rios amostrados. 
PEREIRA, P. S.; FERNANDES, L. A. C.; OLIVEIRA, J. L. M.; BAPTISTA, D. F. Avaliação da integridade ecológica de rios em áreas do zoneamento ecológico econômico do complexo hidrográfico Guapiaçu-Macacu, RJ, Brasil. Ambi-Agua, Taubaté, v. 7, n. 1, p. 157-168, 2012. (http://dx.doi.org/10.4136/ambiagua.762)

Tabela 3. Resultado do Protocolo de Avaliação Visual (PAV) dos diferentes trechos de rios.

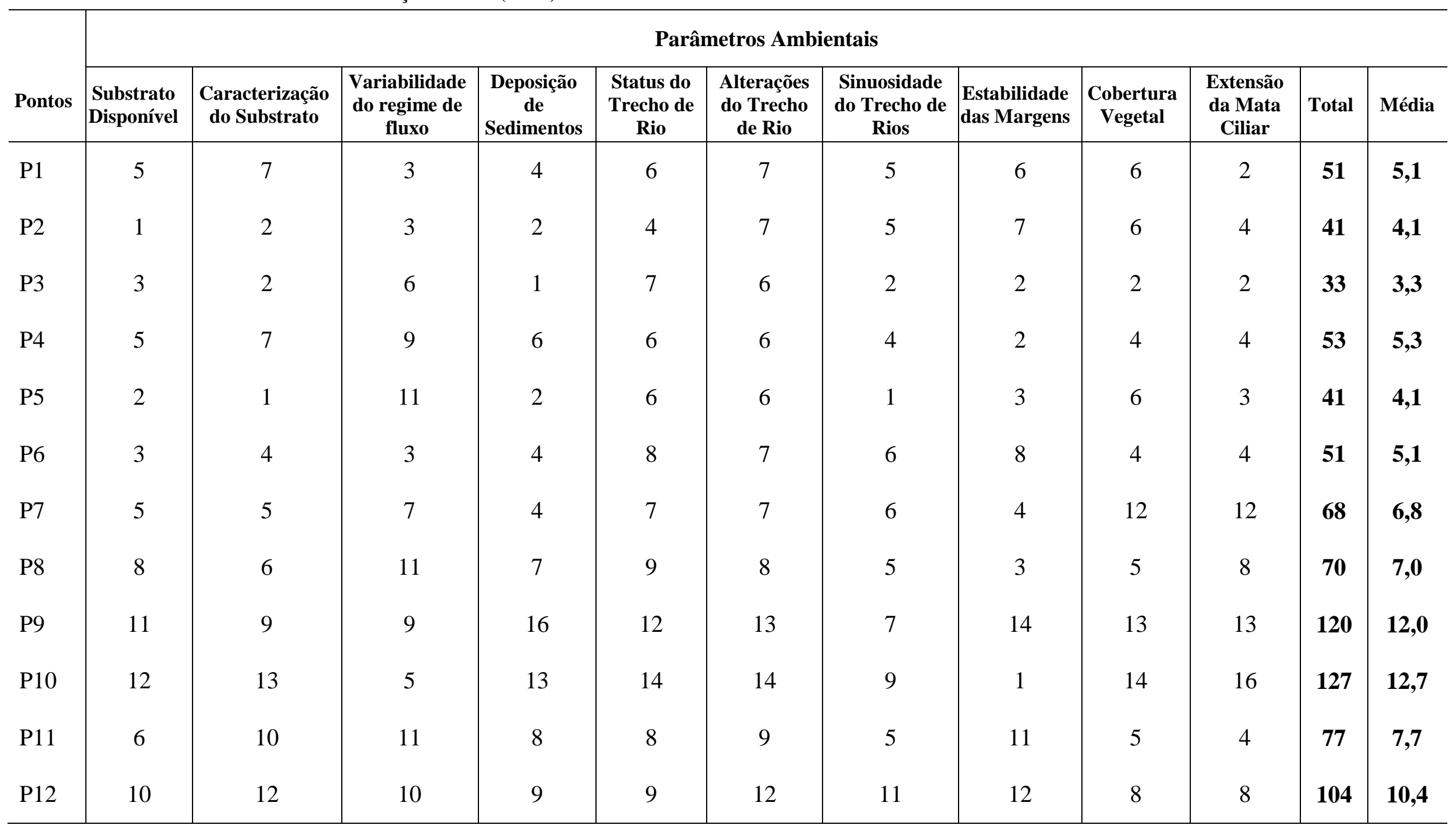

Nota: Escalas de Classificação: 0 a 6,0 - ruim (impactado); 6,0 a 10,0 - regular; 10,0 a 15,0 - boa; 15,0 a 20,0 - ótima. 


\section{CONCLUSÕES}

Este estudo permitiu as seguintes conclusões:

As áreas mais restritivas quanto à ocupação e ao uso do solo (ZCVS) tiveram uma melhor qualidade da água do que os trechos das áreas menos restritivas (ZUAP) em função dos parâmetros físicos, químicos e microbiológicos avaliados.

O PAV corroborou como os parâmetros físicos, químicos e microbiológicos na avaliação dos trechos da ZCVS, no entanto somente a avaliação fisiográfica foi capaz de distinguir as áreas de transição das impactadas da ZUAP.

O PAV foi mais sensível na avaliação da integridade ecológica de uma área do que os métodos de avaliação físicos, químicos e microbiológicos.

\section{AGRADECIMENTOS}

Os autores gostariam de agradecer a ONG Instituto BioAtlântica, pelo financiamento do projeto e confecção do mapa, o apoio financeiro do CNPq (PROEP/FIOCRUZ) e a FAPERJ pela bolsa de estudo. Os colegas do LAPSA/IOC/FIOCRUZ pela realização deste estudo, em especial aos técnicos Valdinei Valin e Denise Borges do Laboratório de Avaliação e Promoção da Saúde Ambiental pela realização das análises.

\section{REFERÊNCIAS}

AB'SABER, A. Zoneamento ecológico e econômico da Amazônia: questões de escala e método. Revista Estudos Avançados, v.3, n. 5, p. 4-20, 1989.

ACSELRAD, H. Zoneamento ecológico-econômico e a multiplicidade de ordens socioambientais na Amazônia. Novos Cadernos Naea, v. 3, n. 2, p. 5-15, 2000.

AMERICAN PUBLIC HEALTH ASSOCIATION - APHA. Standard methods for the examination of water and wastewater. $20^{\text {th }}$ ed. Washington, DC, 2005.

BARBOUR, M. T.; GERRITSEN, J.; SNYDER, B. D.; STRIBLING, J. B. Rapid bioassessment protocols for use in streams and wadeable rivers: periphyton, benthic macroinvertebrates and fish. 2. ed. Washington: EPA, 1999. $339 \mathrm{p}$.

BRASIL. Ministério do Meio Ambiente. Resolução Conama no 357 de 17 de março de 2005. Dispõe sobre a classificação dos corpos de água e diretrizes ambientais para o enquadramento, bem como estabelece as condições e padrões de lançamento de efluentes, e dá outras providências. Disponível em: <http://www.mma.gov.br/ port/conama/res/res05/res35705.pdf>. Acesso em: 19 mar. 2012.

CABRAL, D. C.; FISZON, J. T. Padrões sócio-espaciais de desflorestamento e suas implicações para a fragmentação florestal: estudo de caso na Bacia do Rio Macacu, RJ. Scientia Florestalis, n. 66, p. 13-24, 2004.

CALLISTO, M. et al. Aplicação de um protocolo de avaliação rápida da diversidade de habitats em atividades de ensino e pesquisa (MG-RJ). Acta Limnologica Brasiliensis, v. 14, n. 1, p. 91-98, 2002. 
CAMPANHA, M. B.; MELO, C. A., MOREIRA, A. B.; FERRARESE, R. F. M. S.; TADINI, A.M.; GARBIN, E. V. et al. Variabilidade espacial e temporal de parâmetros físicoquímicos nos rios Turvo, Preto e Grande no estado de São Paulo, Brasil. Revista Química Nova, v. 33, n. 9, p. 1831-1836, 2010.

CARVAlHO, A. R.; SCHLITTLE, F. H. M.; TORNISIELO, V. L. Relações da atividade agropecuária com parâmetros físicos químicos da água. Revista Química Nova, v. 23, p. $618-622,2000$.

COELHO, R. C. T. P.; BUFFON, I.; GUERRA, T.; Influência do uso e ocupação do solo na qualidade da água: um método para avaliar a importância da zona ripária. Revista Ambiente \& Água, v. 6, n. 1, p. 104-117, 2011. http://dx.doi.org/10.4136/ambiagua. 178

CORADI, P. C.; FIA R.; PEREIRA-RAMIREZ, O. Avaliação da qualidade da água superficial dos cursos de água do município de Pelotas-RS, Brasil. Revista Ambiente \& Água, v. 4, n. 2, p. 46-56, 2009. http://dx.doi.org/10.4136/ambi-agua.86

CURVELlO, R. T.; BATISTA, G. T.; TARGA, M. S. Estudo dos impactos da ocupação humana na microbacia do rio Batedor na Serra da Mantiqueira no município de Cruzeiro, SP, Brasil. Revista Ambiente \& Água, v. 3, n. 1, p. 91-107, 2008. http://dx.doi.org/10.4136/ambi-agua.45

CUSTÓDIO, E.; LLAMAS, M. R. Hidrologia Subterrânea. Tomo I e II. Barcelona: Ómega, 1983. $2350 \mathrm{p}$.

HAMMER, O.; HARPER, D. A. T.; RYAN, P. D. PAST: paleontological statistics software package for education and data analysis. Palaeontologia Electronica, v. 4, n. 1, p. 9, 2001.

HELDER, C. Subsídios para gestão dos recursos hídricos das bacias hidrográficas dos rios Macacu, São João, Macaé e Macabu. Rio de Janeiro: Secretaria do Meio Ambiente, 1999.

INSTITUTO BIOATLÂNTICA. Plano de manejo: APA da bacia do rio Macacu: proposta. In: Projeto entre Serras e Águas. Rio de Janeiro: 2009. Disponível em: <http://pib.socioambiental.org/anexos/6658_20091117_095531.pdf>. Acesso: 19 mar. 2012.

JAPAN INTERNACIONAL COOPERATION AGENCY - JICA. The study of recuperation of the Guanabara Bay ecosystem. Supporting Report. Tokyo: Kokusai Kogyo, 1994. Vol. 1-4.

LUCAS, L. M.; CUNHA, S. B. Rede de drenagem urbana em área tropical: mudanças na morfologia do canal e níveis de poluição das águas - Rio dos Macacos, Rio de Janeiro. GEOUSP - Espaço e Tempo, n. 22, p. 39-64, 2007.

MACHADO, C. J. S.; KLEIN, H. E. Água, doença, saúde e arcabouço institucional-legal: por uma gestão integrada das águas do Estado do Rio de Janeiro. Revista Rio de Janeiro, n. 11, p. 13-38, 2003. 
OLIVEIRA, R. B. Desenvolvimento de um índice multimétrico rápido baseado na comunidade de macroinvertebrados bentônicos para avaliação da integridade ecológica de riachos do complexo Guapiaçu-Macacu, RJ. 2009. 107f. Dissertação (Mestrado em Ecologia) - PPGE, Universidade Federal do Rio de Janeiro, Rio de janeiro, 2009.

PEDREIRA, B. C. C. G.; FIDALGO, E. C. C.; ABREU, M. B. Mapeamento do uso e cobertura da terra da bacia hidrográfica do rio Guapi-Macacu, RJ. In: SIMPÓSIO BRASILEIRO DE SENSORIAMENTO REMOTO, 14., 25-30 abril 2009, Natal. Anais... São José dos Campos: INPE, 2009. p. 2111-2118.

PEREIRA, M. R, ALVES, C., MARTINS, F., MACHADO, M., LOPES, S. A Qualidade da Água na Bacia Hidrográfica do Rio Sôrdo (Norte de Portugal). Geonovas, n. 20, p. 8793, 2006.

PLAFKIN, J. L.; BARBOUR, M. T.; PORTER, K. D.; GROSS, S. K.; HUGHES, R. M. Rapid bioassessment protocols for use in streams and rivers: benthic macroinvertebrates and fish. Washington: U.S. Environmental Protection Agency, EPA444/4-89-001, 1989.

RIO DE JANEIRO (Estado). Lei Estadual no 4018 de 05 de dezembro de 2002. Cria a área de proteção ambiental da bacia do rio macacu e determina providências para a defesa da qualidade da água. Disponível em: <http://www.inea.rj.gov.br/legislacao/docs/ 4018.pdf>. Acesso em: 19 mar. 2012.

RODRIGUES, A. S. L.; MALAFAIA, G.; CASTRO, P. T. A. Protocolos de avaliação rápida de rios e a inserção da sociedade no monitoramento dos recursos hídricos. Revista Ambiente \& Água, v. 3, n. 3, p. 143-155, 2008. http://dx.doi.org/10.4136/ambi-agua.68

RODRIGUES, A. S. L.; MALAFAIA, G.; CASTRO, P. T. A. A importância da avaliação do habitat no monitoramento da qualidade dos recursos hídricos: uma revisão. Revista Saúde e Biologia, v. 5, n.1, p. 26-42, 2010.

SANTOS, A. F.; CARDOSO, L. G. Delimitação das áreas de preservação Permanente (Mata ciliar) da microbacia hidrográfica do Ribeirão Faxinal, Botucatu-SP. In: SEMINÁRIO DE RECURSOS HÍDRICOS DA BACIA HIDROGRÁFICA DO PARAÍBA DO SUL, 1., 2007, Taubaté. O eucaplipto e o ciclo hidrológico. Anais... Taubaté: IPABHi, 2007. p. 231-235.

SARCINELLI, O.; MARQUES, J. F.; ROMEIRO A. R. Custo de adequação ambiental das áreas de vegetação ripária: estudo de caso na microbacia do Córrego Oriçanguinha, SP. Revista Informações Econômicas, v. 38, n. 10, p. 70-79, 2008.

TUCCI, C. E. M. Hidrologia: ciência e aplicação. Porto Alegre: UFRGS, 2002. 248 p.

TUNDISI, J. G. Água no século XXI: enfrentando a escassez. São Carlos: RIMA, 2003. $247 \mathrm{p}$.

VASCO, A. N.; BRITTO, F. B.; PEREIRA, A. P. S.; MÉLLO JÚNIOR, A. V. M.; GARCIA, C. A. B.; NOGUEIRA, L. C. Avaliação espacial e temporal da qualidade da água na sub-bacia do rio Poxim, Sergipe, Brasil. Revista Ambiente \& Água, v. 6, n. 1, p. 118130, 2011. http://dx.doi.org/10.4136/ambi-agua.178 


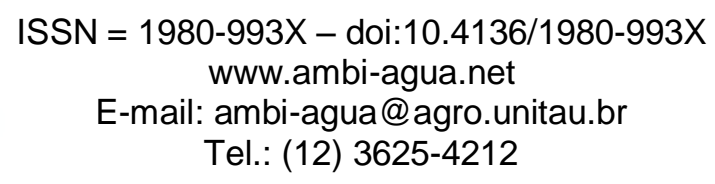

\title{
Caracterização geo-pedológica das áreas de nascentes na bacia hidrográfica do rio Piauitinga, Sergipe, Brasil
}

\author{
(http://dx.doi.org/10.4136/ambi-agua.767)
}

\author{
Leila Thais Soares Magalhães ${ }^{1}$; João Bosco Vasconcelos Gomes ${ }^{3}$; Anderson Nascimento \\ do Vasco'; Antenor de Oliveira Aguiar Netto ${ }^{1}$; Robério Anastácio Ferreira ${ }^{2}$ \\ ${ }^{1}$ Departamento de Engenharia Agronômica da Universidade Federal de Sergipe, São Cristovão, SE \\ ${ }^{2}$ Departamento de Engenharia Florestal da Universidade Federal de Sergipe, SE \\ ${ }^{3}$ Pesquisador da Empresa Brasileira de Pesquisa Agropecuária, Embrapa Florestas - Colombo - PR \\ e-mail: anderovasco@yahoo.com.br; antenor.ufs@gmail.com; \\ leilath24@gmail.com; raf@infonet.com.br; jbvgomes@cnpf.embrapa.br
}

\section{RESUMO}

Os estudos para recuperação e manutenção de áreas de nascentes têm papel fundamental na conservação dos recursos hídricos. Considerando a necessidade de recuperação das áreas do entorno das nascentes da bacia hidrográfica do rio Piauitinga (Lagarto, SE), foram caracterizados os solos de diferentes tipos de nascentes para servir como referencial entre áreas degradadas e em processo de recuperação. As nascentes foram classificadas quanto à sua recarga e quanto ao seu estado de conservação. Para o estudo dos solos locais, foram selecionadas as áreas de revegetação de cada nascente. Realizou-se a caracterização geopedológica dos sítios de estudo pela observação da paisagem local, pela abertura de microtrincheiras e por amostragem dos solos. Os solos foram descritos e classificados morfologicamente pelo Sistema Brasileiro de Classificação de Solos. Observou-se que de um total de 22 nascentes analisadas, apenas duas (9\%) foram consideradas como difusas, em relação à recarga e vinte $(91 \%)$ como pontuais. Em relação ao estado de conservação, cinco nascentes (22\%) foram identificadas como perturbadas e as demais como degradadas (88\%). Os sítios do entorno das nascentes do alto curso da bacia hidrográfica do rio Piauitinga foram distribuídos em posições erosicionais, baixadas e um único caso de sopé de encosta suave de tabuleiros costeiros. As características mais marcantes dos solos locais são o forte hidromorfismo (Gleissolos e Cambissolos gleissólicos) e, ou, o baixo grau de desenvolvimento (Cambissolos e Plintossolos, ambos com muito material esquelético, muitos com fase erodida).

Palavras-chave: Solos; Recuperação de áreas degradadas; Gestão ambiental.

\section{Soil classification of the Piauitinga river basin spring areas, Sergipe, Brazil}

\section{ABSTRACT}

The study of regeneration and maintenance of spring areas is fundamentally important for the conservation of water resources. Considering the need for restoration of the surrounding areas of the springs of the sub-basin of the Piauitinga River, in Lagarto-Sergipe, this study aimed to characterize the soils in their local environment which will serve as a benchmark for future comparisons between areas of springs already degraded and in the recovering process. The springs were classified according to their origin and their stage of 
preservation. For the study of the local soil, reforested areas of each spring were selected and grouped according to their position in the landscape. The soil classification of the study sites was performed based on local landscape observation, description of opened micro-trenches and analyses of soil samples. The soils were described and classified morphologically. It was observed that from 22 analyzed spring areas, only two (9\%) were considered according to their origin as diffuse and the remaining twenty (91\%) as punctual. Considering the preservation stage five spring areas (22\%) were identified as disturbed and the other ones as degraded (88\%). The sites around the springs' headwaters of the upper course of the Piauitinga river basin are located in erosion spots, depressions and a single case in the foothills coastal tablelands. The most striking characteristics of local soils are the strong hydromorphic (Gleissolos and gleic Cambisols) and, or, the low level of development (Cambisols and Plinthosols, both with much skeletal material, many of them in eroded phase).

Keywords: Soils; Recovery of degraded areas; Environmental management.

\section{INTRODUÇÃO}

O reconhecimento da importância da preservação ambiental não tem impedido que as necessidades humanas continuem sendo, muitas das vezes, satisfeitas em decorrência da exploração inadequada do meio ambiente. O processo de desmatamento é um dos expoentes dessa improfícua constatação, que acompanha sociedades atuais e passadas (Foley et al., 2005).

No caso das florestas fluviais, ações de desmatamento são extremamente impactantes, considerando que essas cumprem importantes serviços ambientais, principalmente o de proteger o solo e corpos de água e todos os reflexos disso na vida da população, inclusive da população urbana.

A bacia hidrográfica do rio Piauitinga, localizada na porção centro-sul do estado de Sergipe e responsável pelo abastecimento de água de alguns dos municípios do estado (Estância, Salgado, Lagarto e Boquim) não foge dessa realidade, com suas terras, inclusive aquelas enquadradas conforme Lei ${ }^{\circ} 4.771 / 65$ que instituiu o Código Florestal, quase em sua totalidade desmatadas (Moreira, 2008). Este desmatamento tem causado problemas ambientais que comprometem o volume e a qualidade das águas geradas pela unidade de planejamento em questão.

Nascentes são locais onde a água subterrânea aflora através da superfície do solo, formando um curso d'água (Pinto et al., 2004), ou seja, um ponto de recarga dos canais de drenagem das sub-bacias. Essas características tornam comum a presença de hidromorfismo nos solos que envolvem as nascentes. A presença de hidromorfismo à jusante das nascentes é uma constante nas bacias de inundação dos vales fluviais (Curcio, 2006) e de outras superfícies rebaixadas que constituem a ligação entre rios, córregos e lagoas (Martins et al., 2006). De forma pontual, se o canal de drenagem que começa em uma nascente for muito encaixado, o vale fluvial pode não ocorrer localmente, ou ser muito estreito. À montante das nascentes, posições de paisagem erosicionais convivem com solos de regime hídrico saturado e não-saturado, mas ganham importantes características de jovialidade (baixo grau de desenvolvimento) dos solos locais (Motta et al., 2002a).

Tendo em vista a necessidade de recuperação das áreas do entorno das nascentes da bacia hidrográfica do rio Piauitinga, em Lagarto, SE, o presente trabalho objetivou agrupar e caracterizar as paisagens e solos locais em diferentes nascentes, para servir como um referencial em futuras comparações, entre áreas de nascentes degradadas e em processo de recuperação ambiental. 
MAGAlHÃES, L. T. S.; GOMES, J. B. V.; VASCO, A. N.; AGUIAR NETTO, A. O.; FERREIRA, R. A. Caracterização geo-pedológica das áreas de nascentes na bacia hidrográfica do rio Piauitinga, Sergipe, Brasil. Ambi-Agua, Taubaté, v. 7, n. 1, p. 169-181, 2012. (http://dx.doi.org/10.4136/ambi-agua.767)

\section{MATERIAIS E MÉTODO}

A bacia hidrográfica do rio Piauitinga, afluente do rio Piauí, está situada no centro-sul do estado de Sergipe, compreendendo os municípios de Boquim, Estância, Lagarto, Salgado e Itaporanga D'Ájuda. Ela integra a meso-região geográfica do Agreste Sergipano (microrregião de Lagarto) e do Leste Sergipano (microrregiões de Boquim e Estância) e está localizada entre as coordenadas geográficas de $10^{\circ} 34^{\prime}$ e $10^{\circ} 45^{\prime} \mathrm{S}$ e $37^{\circ} 22^{\prime}$ e $37^{\circ} 34^{\prime} \mathrm{W}$. Compreende uma área de $411,98 \mathrm{~km}^{2}$ e seu perímetro é de $121,22 \mathrm{~km}$. A nascente do principal curso d'água desta bacia está localizada no povoado Brasília, pertencente ao município de Lagarto. Este curso recebe contribuição de 1.724 canais, com destaque para os riachos Grotão, Capivara, Riachão e Grilo. O rio Piauitinga possui 59,28 km de extensão e sua foz localiza-se próximo à sede do município de Estância, desembocando no rio Piauí (Moreira, 2008).

O clima da região do município de Lagarto é classificado como Megatérmico Subúmido, sendo que o valor médio anual da precipitação para o período de 1985 a 2005 foi de $1.182,8 \mathrm{~mm}$ (Sergipe, 2011). A temperatura média anual é de $28^{\circ} \mathrm{C}$, variando entre $22,3^{\circ} \mathrm{C}$, para os meses mais chuvosos e frios (julho a agosto), e $26^{\circ} \mathrm{C}$ para o período mais seco e quente (dezembro a março).

A região escolhida para o desenvolvimento da pesquisa concentrou-se no alto curso do rio Piauitinga entre as coordenadas $37^{\circ} 32^{\prime}$ e $37^{\circ} 36^{\prime} \mathrm{W}$ e $10^{\circ} 54^{\prime}$ e $10^{\circ} 57^{\prime} \mathrm{S}$, estando contida em sua totalidade no município de Lagarto. A área de estudo englobou 22 nascentes, que também estão inseridas no projeto "Adote um Manancial" (Figura 1), coordenado pelo Ministério Público, por meio da Promotoria de Meio Ambiente da Comarca de Lagarto, e pela Universidade Federal de Sergipe. Essas 22 nascentes encontram-se cercadas e nelas foi realizado o plantio de mudas nos meses de junho e julho de 2007 visando à recuperação ambiental. As espécies utilizadas na recomposição florestal foram: Angelim (Andira fraxinifolia Benth.), Angico (Anadenanthera colubrina (Vell.). Brenan), Aroeira (Schinus terebinthifolius Raddi.), Caju (Anacardium occidentali L.), Canafístula (Cassia grandis L. f.), Cedro (Cedrela fissilis Vell.), Ingá (Inga uruguensis Hook. et Arn.), Jatobá (Hymenaea courbaril L.), Jenipapo (Genipa americana L.), Maria-preta (Vitex polygama Cham.), Mauvizinho (Machaerium aculeatum Raddi), Mulungu (Erythrina velutina Willd.), Pau-brasil (Caesalpinia echinata Lam.), Pau-ferro (Caesalpinia leiostachya Benth.), Pau-pombo (Tapirira guianensis Aubl.), Saboneteria (Sapindus saponaria L.), Tamboril (Enterolobium contortisiliquum (Vell). Morong.).

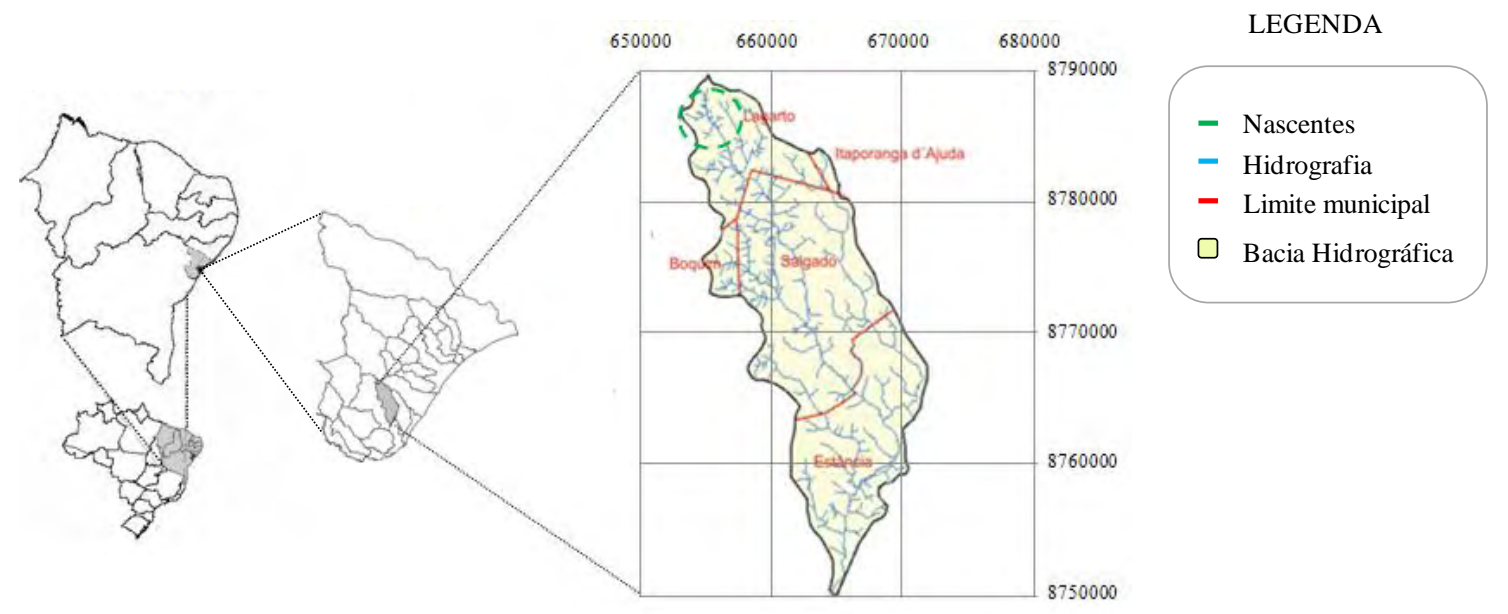

Figura 1. Nascentes do alto curso da bacia hidrográfica do rio Piauitinga, Lagarto-SE, englobadas pelo estudo. Fonte: Sergipe (2011). 
Parte das áreas de plantio abrangeram mais de uma nascente pela proximidade de seus vales de origem, podendo ocorrer a presença de nascentes em dupla ou tripleto dentro dessas áreas. Assim, tem-se 18 áreas de estudo, sendo três delas formadas por duas nascentes e uma por três nascentes.

As nascentes foram classificadas de acordo com Pinto et al. (2004) no que se refere a sua recarga como pontuais ou difusas, ou seja, pontuais aquelas que surgem na superfície em um único ponto e difusas as que surgem na superfície em vários pontos diferentes. As nascentes também foram classificadas em relação ao seu estado de conservação em conservadas (presença de pelo menos $50 \mathrm{~m}$ de vegetação natural em seu entorno, a partir do olho d'água), perturbadas (quando não apresenta $50 \mathrm{~m}$ de vegetação natural em seu entorno, mas apresenta bom estado de conservação) e degradadas (alto grau de perturbação, muito pouco vegetada, solo compactado, presença de gado, erosões e voçorocas).

Para o estudo dos solos locais foram selecionadas as áreas de revegetação de cada nascente (sítio). Se a nascente (de forma isolada, dupla ou tripleto) apresentou áreas de plantio de mudas à montante e à jusante da nascente em si, ela foi subdividida em parte alta e parte baixa (caso das nascentes 3-4, 10, 12 e 19-20-21).

A caracterização ambiental e pedológica dos sítios de estudo foi realizada pela observação da paisagem local, pela abertura de micro-trincheiras $(0,5 \times 0,5 \times 0,5 \mathrm{~m})$ e por tradagem dos solos de $0 \mathrm{~m}$ a $0,4 \mathrm{~m}$. Os solos foram descritos morfologicamente conforme (Santos et al., 2005) e classificados conforme EMBRAPA (2006), a partir das observações de campo. Para cinco pontos, amostras de solo foram coletadas e a fração argila separada por sedimentação após dispersão com $\mathrm{NaOH}\left(1 \mathrm{~mol} \mathrm{~L}^{-1}\right)$, confeccionando-se lâminas para a difração de raios-x, procurando definir a mineralogia dos solos locais nas encostas e nas áreas de baixada.

\section{RESULTADOS E DISCUSSÃO}

Os valores obtidos para a classificação das nascentes, bem como as atividades desenvolvidas nas suas áreas e/ou proximidades podem ser vistas na Tabela 1. Verificou-se que de um total de 22 nascentes analisadas, apenas duas $(9 \%)$ são consideradas em relação à recarga como difusas e vinte $(91 \%)$ como pontuais. Em relação ao estado de conservação foram identificadas cinco nascentes $(22 \%)$ como perturbadas e as demais como degradadas $(88 \%)$. Isto significa que no alto curso da bacia hidrográfica do rio Piauitinga não há registro de nascentes conservadas.

Uma situação um pouco mais branda, porém, não menos preocupante, foi observada em numa bacia hidrográfica próxima da região. Observou-se que as 20 principais nascentes dos rios e tributários que compõem a sub-bacia hidrográfica do rio Poxim, apresentam alterações decorrentes da acelerada antropização (90\%), a maioria delas (65\%) com elevada degradação (sem raio mínimo de $50 \mathrm{~m}$ de vegetação) e ocupadas por agricultura $(50 \%)$ e pastagens $(35 \%)$. Somente duas nascentes encontram-se preservadas (Ferreira et al., 2011). A conservação da vegetação nas áreas de nascentes assegura a conservação de sua perenidade e a qualidade de suas águas por propiciar maior infiltração das águas das chuvas no solo e, consequentemente, a recarga do lençol freático e alimentação das nascentes, ajudando a conservação dos recursos hídricos. Pinto et al. (2004) ao realizarem análise das vazões das nascentes observaram que as classificadas como preservadas apresentaram, em média, os maiores valores de vazão, destacando-se as nascentes pontuais. 
MAGAlhães, L. T. S.; GOMES, J. B. V.; VASCO, A. N.; AGUIAR NETTO, A. O.; FERREIRA, R. A. Caracterização geo-pedológica das áreas de nascentes na bacia hidrográfica do rio Piauitinga, Sergipe, Brasil. Ambi-Agua, Taubaté, v. 7, n. 1, p. 169-181, 2012. (http://dx.doi.org/10.4136/ambi-agua.767)

Tabela 1. Classificação das nascentes do alto curso do rio Piauitinga, Lagarto-SE, quanto ao tipo de recarga, ao estado de conservação e uso e/ou ocupação do solo das respectivas áreas e ou proximidades.

\begin{tabular}{clll}
\hline Nascentes & Recarga & $\begin{array}{c}\text { Estado de } \\
\text { conservação }\end{array}$ & \multicolumn{1}{c}{ Uso e/ou ocupação do solo } \\
\hline 1 & Pontual & Degradada & Cultivo de cana-de-açúcar \\
2 & Pontual & Degradada & Cultivo de cana-de-açúcar \\
3 & Pontual & Degradada & Extração de areia e pastagem \\
4 & Pontual & Degradada & Extração de areia e pastagem \\
5 & Difusa & Perturbada & Pastagem \\
6 & Pontual & Degradada & Área em regeneração natural \\
7 & Pontual & Degradada & Pastagem \\
8 & Difusa & Degradada & Pastagem \\
9 & Pontual & Degradada & Área em regeneração natural \\
10 & Pontual & Degradada & Cultivo de coco e pastagem \\
11 & Pontual & Degradada & Cultivo de coco, macaxeira, banana, maracujá e pastagem \\
12 & Pontual & Degradada & Pastagem \\
13 & Pontual & Degradada & Agricultura, pastagem e ocupação urbana \\
14 & Pontual & Degradada & Agricultura, pastagem e ocupação urbana \\
15 & Pontual & Degradada & Pastagem e ocupação urbana \\
16 & Pontual & Degradada & Pastagem \\
17 & Pontual & Degradada & Cultivo de cana-de-açúcar e pastagem \\
18 & Pontual & Degradada & Área em regeneração natural \\
19 & Pontual & Perturbada & Área em regeneração natural \\
20 & Pontual & Perturbada & Área em regeneração natural \\
21 & Pontual & Perturbada & Área em regeneração natural \\
22 & Pontual & Perturbada & Cultivo de coco, laranja, limão, tangerina e banana \\
\hline
\end{tabular}

As áreas de estudo foram reagrupadas a partir de suas posições na paisagem e das características dos solos locais em cinco grupos: baixada (BA), encosta com horizonte A (na superfície do solo) (EA), encosta sem horizonte A (ES), encosta com hidromorfismo (EH) e sopé de encosta (SE), conforme as Tabelas 2 e 3.

O sítio (SE) destaca-se tanto por sua posição na paisagem, sopé de encosta suave de uma elevação de topo amplo de tabuleiros costeiros cultivada com citrus (Figura 2A), como do ponto de vista da drenagem associada à nascente local. A drenagem aparece encaixada (depósito de canal), caracterizando uma ruptura abrupta entre a área de estudo (sopé da encosta) e o leito do riacho originado na nascente, que é do tipo vertical, indicativa da juventude do riacho, não ocorrendo localmente um vale fluvial. As outras nascentes ocorrem após quebras de relevo de elevações de tabuleiros costeiros. As encostas dessas quebras de relevo ocorrem em relevo ondulado a forte ondulado, podendo ocorrer níveis intermediários planos a quase planos (Figuras 2B e 2C). Os sítios dos grupos EA, ES e EH localizam-se nessas escarpas erosivas, à montante das nascentes. Os sítios BA estão em vales fluviais abertos, que ocorrem à jusante das nascentes estudadas. São depósitos nas bacias de decantação dos vales fluviais locais, com elevado grau de hidromorfia. Assim, à exceção da nascente do sítio SE, as demais são cabeceiras de drenagem de vales formados por processos de erosão areolar (lateral) e com drenagens de maior senelidade, dominantes na região de estudo. 
MAGAlhãeS, L. T. S.; GOMES, J. B. V.; VASCO, A. N.; AGUIAR NETTO, A. O.; FERREIRA, R. A. Caracterização geo-pedológica das áreas de nascentes na bacia hidrográfica do rio Piauitinga, Sergipe, Brasil. Ambi-Agua, Taubaté, v. 7, n. 1, p. 169-181, 2012. (http://dx.doi.org/10.4136/ambi-agua.767)

Tabela 2. Agrupamento dos pontos de amostragem das áreas do entorno das nascentes de acordo com suas posições na paisagem e características morfológicas dos solos das nascentes do alto curso do rio Piauitinga, Lagarto, SE.

\begin{tabular}{l|c|c}
\hline \multicolumn{1}{c|}{ Grupo } & Sítios & Nascentes \\
\hline \multirow{3}{*}{ Baixada (BA) } & BA1 & 3 e 4 (parte baixa) \\
& BA2 & 5 e 6 \\
& BA3 & 10 (parte baixa) \\
& BA4 & 11 \\
& BA5 & 12 (parte baixa) \\
Encosta com Horizonte A & BA6 & 19,20 e 21 (parte baixa) \\
(EA) & EA1 2 \\
& EA2 & 10 (parte alta) \\
& EA3 & 15 e 16 \\
Encosta com & EH1 & 7 \\
Hidromorfismo (EH) & EH2 & 8 e 9 \\
& EH3 & 17 \\
\hline & EH4 & 3 e 4 (parte alta) \\
Encosta sem Horizonte A & ES1 & 12 (parte alta) \\
(ES) & ES2 & 13 e 14 \\
& ES3 & 19,20 e 21 (parte alta) \\
\hline Sopé de Encosta (SE) & ES4 & SE \\
\hline
\end{tabular}

Tabela 3. Características ambientais das áreas agrupadas de acordo com suas posições geormorfológicas, dos solos das nascentes do alto curso do rio Piauitinga, Lagarto, SE.

\begin{tabular}{c|c|l}
\hline Áreas & Código & \multicolumn{1}{c}{ Características } \\
\hline Baixada & BA & Vale com forte presença de hidromorfismo. \\
\hline $\begin{array}{c}\text { Encosta com presença de } \\
\text { horizonte A }\end{array}$ & EA & $\begin{array}{l}\text { Encosta em quebra de relevo de tabuleiros, com } \\
\text { presença de vegetação suficiente para sustentar } \\
\text { horizonte superficial escurecido por C orgânico. }\end{array}$ \\
\hline $\begin{array}{c}\text { Encosta sem presença de } \\
\text { horizonte A }\end{array}$ & ES & $\begin{array}{l}\text { Encostas em quebra de relevo de tabuleiros, em áreas } \\
\text { com ausência de cobertura vegetal e solos destituídos } \\
\text { de horizonte A (cores denotam baixos teores de C } \\
\text { orgânico). Solos naturalmente erodidos (grotas) ou } \\
\text { decapitados por atividade antrópica (retirada de } \\
\text { material de empréstimo). }\end{array}$ \\
\hline $\begin{array}{c}\text { Encosta com presença de } \\
\text { hidromorfismo }\end{array}$ & EH & $\begin{array}{l}\text { Encostas em quebra de relevo de tabuleiros com } \\
\text { presença de hidromorfismo nos solos locais. Os solos } \\
\text { variam quanto a presença ou ausência de horizonte A } \\
\text { e de cobertura vegetal. }\end{array}$ \\
\hline $\begin{array}{c}\text { Sopé de encosta } \\
\text { final de encosta suave em tabuleiro extenso, com } \\
\text { nascente pontual surgindo de forma abrupta (pequeno } \\
\text { vale encaixado). }\end{array}$ \\
\hline
\end{tabular}



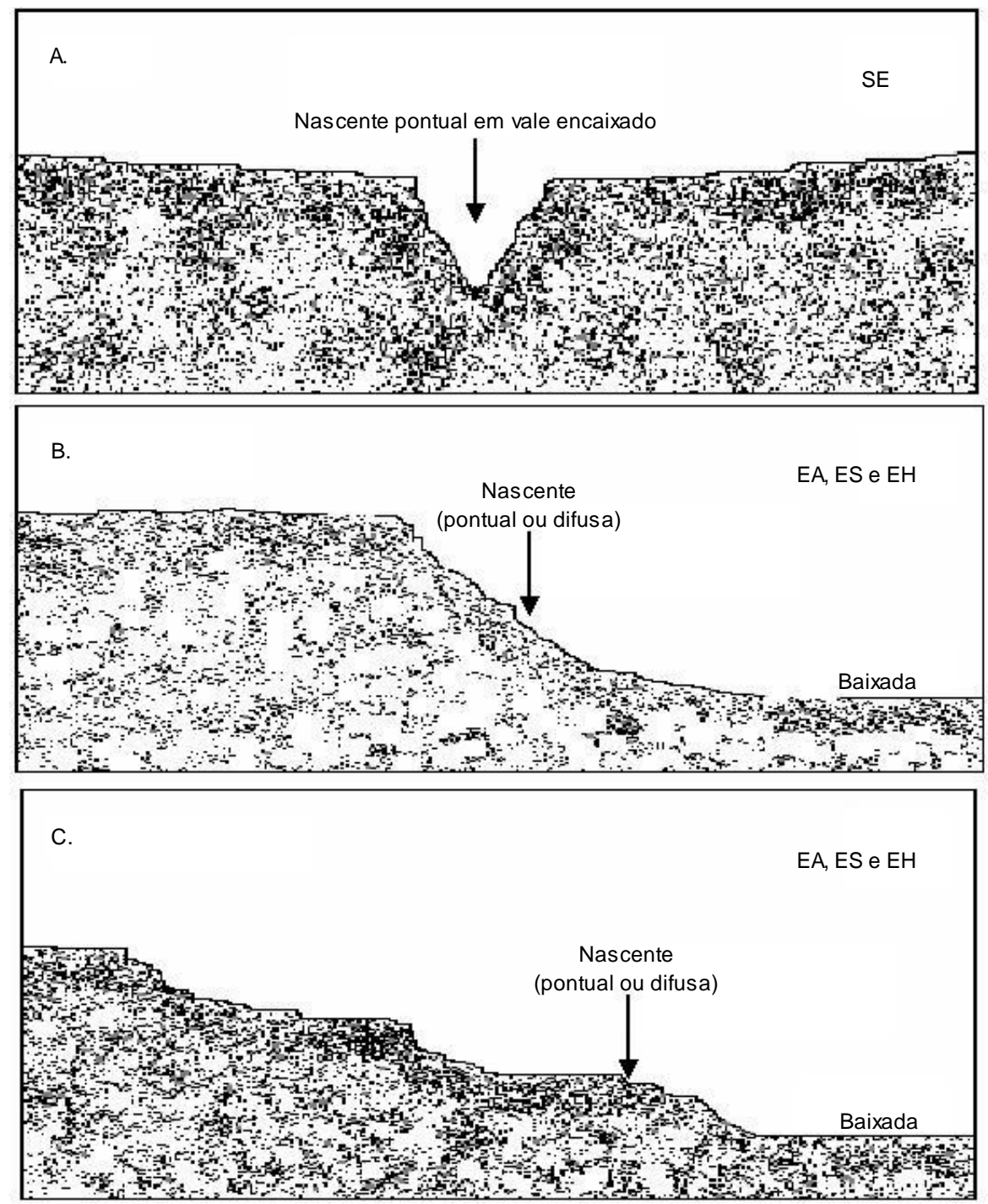

Figura 2. Esquemas mostrando as diferentes posições de amostragem na bacia hidrográfica do rio Piauitinga, Lagarto-SE, conforme a superfície geomorfológica. (A) Vale encaixado, que se origina em encosta suave de um topo amplo de elevação. (B) Vale aberto (com baixada), que se origina a partir de encosta que alcança o topo de elevação. (C) Vale aberto (com baixada), que se origina a partir de encosta que alcança nível intermediário entre o topo da paisagem e a baixada.

Como uma característica geral dos solos estudados, difrações de raios-X da fração argila mostraram uma mineralogia amplamente dominada por caulinita na fração argila, aparecendo ainda algum quartzo (Figura 3). Essa mineralogia é típica de materiais do Barreiras (Ferreira et al., 1999; Duarte et al., 2000) e se repetiu mesmo nas amostras das encostas após quebras de relevo (ES1, EH2 e EA2) e na baixada (BA6), descartando a presença de argilo-minerais do tipo 2:1 que representassem algum diferencial na reserva de nutrientes dos solos locais. $\mathrm{O}$ grupo Barreiras é constituído por sedimentos terrígenos (cascalho, conglomerados, areia finas e grossa e níveis de argila), sendo esses pouco consolidados e estratificados irregularmente, com a fração grosseira do sedimento basicamente constituída de quartzo (Duarte et al., 2000). No caso dos sítios BA, formados por sedimentos holocênicos, estes repetiram a composição mineralógica dos materiais à montante. 


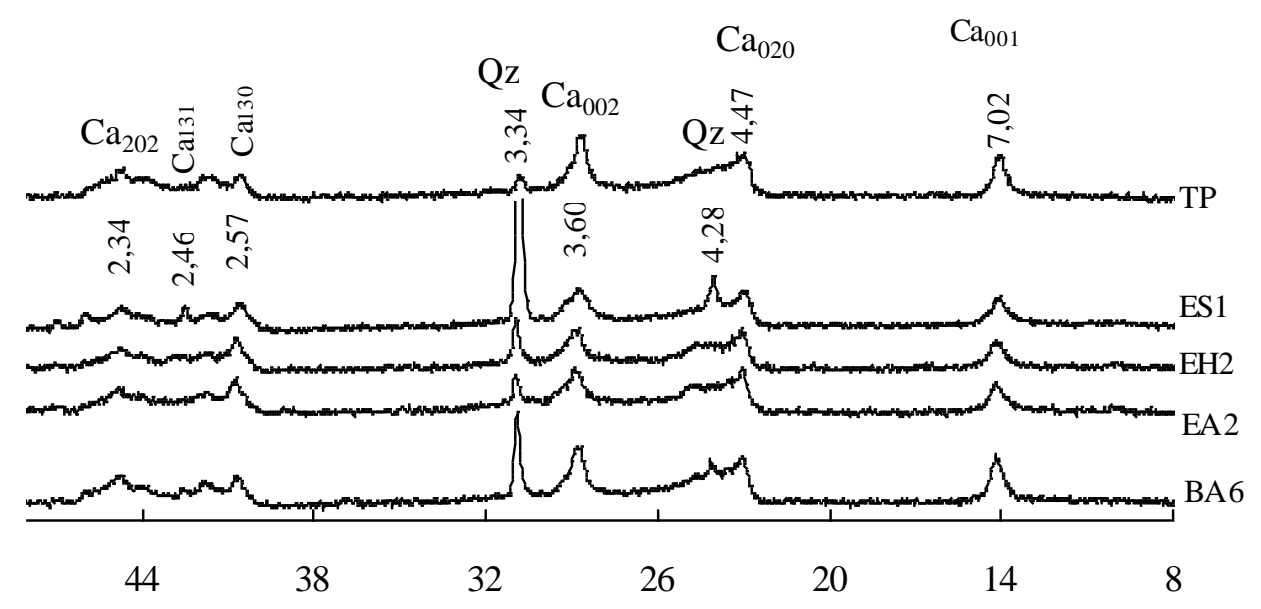

Graus $2 \theta$

Figura 3. Difratogramas de raios-X de amostras em pó da fração argila de solos do entorno de nascentes do alto rio Piauitinga, Lagarto-SE. Amostras de 0,1 a $0,3 \mathrm{~m}$ de profundidade. TP - sopé de encosta, ES1 - encosta sem horizonte A, $\mathrm{EH} 2$ - encosta com hidromorfismo, EA2 - encosta com horizonte A e BA6 Baixada.

Duas características são marcantes nos solos dos sítios BA. O excesso de água (hidromorfismo), expressado morfologicamente pelas cores do solo neutras, ou de cromas baixos (Guertal e Hall, 1990), e o relevo plano a quase plano. A proximidade das cabeceiras de drenagem não permitiu o aparecimento de depósitos de margem, com Neossolos Flúvicos relativamente mais bem drenados.

As alturas relativas dos depósitos locais em relação ao nível freático determinaram poucas diferenças no grau de desenvolvimento pedogenético e nos níveis de hidromorfia. Apenas BA5 não foi classificado como Gleissolo (Tabela 4), sendo classificado como um Cambissolo Háplico Tb Distrófico gleissólico. Nele, o lençol freático apresenta-se um pouco mais rebaixado, embora a vegetação atual mantenha-se como campo úmido.

Nesse sentido, é necessária uma melhor caracterização dos regimes hídricos locais, atentando para que solos com saturação hídrica plena por longos períodos dificultam, ou mesmo impedem (Curcio, 2006) as coberturas arbóreas. A presença ou ausência de árvores em ambientes com hidromorfia ainda pode conter variáveis locais que fazem a diferença. Motta et al. (2002b) postularam que a vegetação de campo pode ser favorecida por uma sazonalidade hídrica local, que por sua vez desfavoreceria o aparecimento de indivíduos lenhosos. Nessa hipótese, a presença de florestas em áreas mal a muito mal drenadas seria muito sensível a sucessão de períodos com deficiência e excesso de água no solo, mais do que a presença do hidromorfismo em si.

Os autores consideraram a existência de indivíduos lenhosos adaptados ao excesso de água, caso das espécies com estruturas especializadas em trocas gasosas, mas que não suportam conviver com estresses antagônicos e que exigem de sua parte estratégias de sobrevivência também antagônicas (Motta et al., 2002b). Considerando-se as características discutidas, é difícil prever as taxas de sobrevivência das espécies arbóreas em revegetação nos solos das baixadas locais, mas deve-se considerar que a predominância de hidromorfia a semihidromorfia restringe amplamente a entrada de espécies mesófilas, possibilitando maior espaço para plantas arbóreas hidrófilas e higrófilas (Curcio, 2006).

Os sítios dos grupos EA, ES e EH estão em posições de paisagem erosicionais (escarpas erosivas). Essas posições, quando relacionadas às coberturas sedimentares, no caso 
MAGAlhães, L. T. S.; GOMES, J. B. V.; VASCO, A. N.; AGUIAR NETTO, A. O.; FERREIRA, R. A. Caracterização geo-pedológica das áreas de nascentes na bacia hidrográfica do rio Piauitinga, Sergipe, Brasil. Ambi-Agua, Taubaté, v. 7, n. 1, p. 169-181, 2012. (http://dx.doi.org/10.4136/ambi-agua.767)

sedimentos do grupo Barreiras, apresentam exposição muito frequente de corpos de petroplintita, como os aqui observados (Tabela 4). Esses corpos ajudam a frear o processo erosivo a montante (Motta et al., 2002a), desacelerando a dissecação da paisagem. Também é comum a ocorrência de pavimento pedregoso na superfície dos solos locais. Independente da presença de vegetação, esses pavimentos são importantes na desaceleração de processos erosivos de maior amplitude (Poesen e Ingelmo-Sanchez, 1992).

A diferença entre os solos (Cambissolos e Plintossolos) dos sítios EA e ES ocorre pela presença ou ausência de horizonte A, como observado no campo. Nos sítios EA, a presença local de cobertura vegetal foi suficiente para incorporar ao solo biomassa e atividade biológica em sua superfície, formando um horizonte A de fraco a moderado (EMBRAPA, 2006). Em ES, todos os solos são fase erodida. A ausência de horizonte A nos solos de ES pode ser por características das paisagens locais, que por vezes formam pavimentos desérticos (ES2, ES3 e ES4), ou pela ação antrópica, como em ES1. A presença de material esquelético nos solos dos dois grupos é uma constante, como já comentado. Esse material é composto, basicamente, de corpos de quartzo e petroplintita.

Tabela 4. Características do solo em sua ambiência nos pontos de amostragem das nascentes do alto curso da bacia hidrográfica do rio Piauitinga, Lagarto-SE.

\begin{tabular}{|c|c|c|c|c|c|c|c|}
\hline Sítios & $\begin{array}{l}\text { Classe de } \\
\text { solo }^{(1)}\end{array}$ & Textura $^{(2)}$ & $\begin{array}{l}\text { Cor superficial e } \\
\text { subsuperficial }\end{array}$ & $\begin{array}{l}\text { Mosquea } \\
\text { do (e, ou, } \\
\text { plintita) }\end{array}$ & $\begin{array}{c}\text { Presença de } \\
\text { impedimento } \\
\text { (lençol freático e } \\
\text { material } \\
\text { esquelético) } \\
\end{array}$ & Relevo & $\begin{array}{l}\text { Cobertura } \\
\text { atual }\end{array}$ \\
\hline \multicolumn{8}{|c|}{ BAIXADA } \\
\hline BA1 & GX & FRA/RA & $10 \mathrm{YR} 3 / 2$ e $4 / \mathrm{N}$ & - & $\begin{array}{l}\text { faixa cascalhenta aos } \\
0,15 \mathrm{~m} \text { e lençol aos } \\
0,6 \mathrm{~cm} \text {. }\end{array}$ & $\begin{array}{l}\text { plano a } \\
\text { quase plano }\end{array}$ & campo úmido \\
\hline BA2 & GM & $\mathrm{R} / \mathrm{RR}$ & $3,5 / \mathrm{N}$ e $5 / \mathrm{N}$ & 7,5YR 5/5 & $\begin{array}{l}\text { lençol freático a } \\
0,5 \mathrm{~m} .\end{array}$ & $\begin{array}{l}\text { plano a } \\
\text { quase plano }\end{array}$ & campo úmido \\
\hline BA3 & GX & $\mathrm{R} / \mathrm{RR}$ & $2,5 / \mathrm{N}$ e $5 / \mathrm{N}$ & - & $\begin{array}{l}\text { lençol freático a } \\
0,65 \mathrm{~m}\end{array}$ & $\begin{array}{l}\text { plano a } \\
\text { suave } \\
\text { ondulado }\end{array}$ & campo úmido \\
\hline BA4 & GX & FRA/RA & & - & $\begin{array}{l}\text { lençol freático a } \\
0,7 \mathrm{~m} \text {. }\end{array}$ & $\begin{array}{l}\text { plano a } \\
\text { quase plano }\end{array}$ & campo úmido \\
\hline BA5 & CXg & $\mathrm{FS} / \mathrm{F} / \mathrm{FR}$ & $\begin{array}{l}\text { 10YR 4/3, 10YR } 5 / 2 \mathrm{e} \\
10 \mathrm{YR} 5 / 4\end{array}$ & 7,5YR 5/6 & $\begin{array}{l}\text { até } 1,5 \mathrm{~m} \text { de } \\
\text { profundidade } \\
\text { (tradagem) }\end{array}$ & $\begin{array}{l}\text { plano a } \\
\text { quase plano }\end{array}$ & campo úmido \\
\hline BA6 & GX & FA/FRA/RA & $10 \mathrm{YR} 4 / 2$ e $10 \mathrm{YR} 5 / 2$ & 7,5 YR 5/6 & $\begin{array}{l}\text { lençol freático a } \\
0,75 \mathrm{~m} \text {. }\end{array}$ & $\begin{array}{l}\text { plano a } \\
\text { quase plano }\end{array}$ & campo úmido \\
\hline \multicolumn{8}{|c|}{ ENCOSTA COM PRESENÇA DE HORIZONTE A } \\
\hline EA1 & FX & $\mathrm{RA} / \mathrm{R} / \mathrm{RR}$ & $\begin{array}{l}\text { 7,5YR 4/2, 7,5YR5/4 e } \\
\text { 7,5YR 5/5 } \\
\text { 7,5YR 4/4, 7,5YR 5/5, } \\
\text { 7,5YR 5/6 e 10YR 5/5 }\end{array}$ & \begin{tabular}{l}
\multicolumn{1}{c}{-} \\
(plintita \\
$2,5 \mathrm{YR} 4 / 5$ ) \\
$2,5 / \mathrm{Ne}$ \\
$2,5 \mathrm{YR} \mathrm{5/5}$ \\
(plintita \\
2,5YR 4/6)
\end{tabular} & $\begin{array}{l}\text { faixa cascalhenta de } \\
0 \text { a } 0,1 \mathrm{~m} . \\
\text { pavimento } \\
\text { pedregoso }\end{array}$ & $\begin{array}{l}\text { plano a } \\
\text { suave } \\
\text { ondulado } \\
\text { ondulado }\end{array}$ & $\begin{array}{l}\text { pousio com } \\
\text { capoeira } \\
\text { aberta } \\
\text { pastagem } \\
\text { nativa e } \\
\text { degradada }\end{array}$ \\
\hline EA3 & $\begin{array}{l}\text { CX } \\
\text { petroplín } \\
\text { tico }\end{array}$ & $\mathrm{RA} / \mathrm{R} / \mathrm{RR}$ & $\begin{array}{l}10 \text { YR } 4 / 5,7,5 \text { YR } 4 / 2 \\
7,5 \text { YR } 5 / 6 \text { e } 6 \text { YR } 5 / 6\end{array}$ & $\begin{array}{l}\text { petroplintit } \\
\text { a } 10 \mathrm{R} 5 / 5\end{array}$ & $\begin{array}{l}\text { pavimento } \\
\text { pedregoso } \\
\text { (dominância de } \\
\text { calhaus, com alguns } \\
\text { matacões de } \\
\text { petroplintita) e corpo } \\
\text { do solo com } \\
\text { cascalho }\end{array}$ & $\begin{array}{l}\text { forte } \\
\text { ondulado }\end{array}$ & $\begin{array}{l}\text { pastagem } \\
\text { nativa e } \\
\text { degradada }\end{array}$ \\
\hline
\end{tabular}


MAGAlhães, L. T. S.; GOMES, J. B. V.; VASCO, A. N.; AGUIAR NETTO, A. O.; FERREIRA, R. A.

Caracterização geo-pedológica das áreas de nascentes na bacia hidrográfica do rio Piauitinga, Sergipe, Brasil.

Ambi-Agua, Taubaté, v. 7, n. 1, p. 169-181, 2012. (http://dx.doi.org/10.4136/ambi-agua.767)

\section{ENCOSTA COM PRESENÇA DE HIDROMORFISMO}

\begin{tabular}{|c|c|c|c|c|c|c|c|}
\hline EH1 & GX & FRA/FA/RA & $10 \mathrm{YR} 4 / 1,4 / \mathrm{N}$ e $6 / \mathrm{N}$ & 10YR6/7 & $\begin{array}{l}\text { pavimento } \\
\text { pedregoso } \\
\text { (calhaus), linha de } \\
\text { pedra a } 0,18 \mathrm{~m} \\
\text { (entre horizontes } \\
\text { A e AC) e lençol } \\
\text { freático a } 1 \mathrm{~m} \text { de } \\
\text { profundidade }\end{array}$ & $\begin{array}{l}\text { forte } \\
\text { ondulado } \\
\text { a suave } \\
\text { ondulado }\end{array}$ & $\begin{array}{l}\text { campo } \\
\text { úmido }\end{array}$ \\
\hline EH2 & $\mathrm{CXg}$ & RA/RR/R & $\begin{array}{l}\text { 10YR 4/2,5, 10YR 4/3, } \\
10 \mathrm{YR} 6 / 1 \text { e } 8 / \mathrm{N}\end{array}$ & $\begin{array}{l}2,5 \text { YR } 4 / 8 \\
7,5 \text { YR } 5 / 6\end{array}$ & $\begin{array}{l}\text { superfície com } \\
\text { algum calhau }\end{array}$ & ondulado & $\begin{array}{l}\text { pousio com } \\
\text { poacea e } \\
\text { partes sem } \\
\text { vegetação }\end{array}$ \\
\hline EH3 & $\mathrm{CXg}$ & $\mathrm{RA} / \mathrm{R}$ & $10 \mathrm{YR} 4 / 3,5$ e $6 / \mathrm{N}$ & \begin{tabular}{l}
\multicolumn{1}{c}{-} \\
(plintita \\
2,5YR 4/5)
\end{tabular} & $\begin{array}{l}\text { pavimento } \\
\text { pedregoso com } \\
\text { matacões de } \\
\text { petroplintita }\end{array}$ & $\begin{array}{l}\text { forte } \\
\text { ondulado }\end{array}$ & $\begin{array}{l}\text { capoeira } \\
\text { aberta }\end{array}$ \\
\hline EH4 & GX & FRA & $3 / \mathrm{N}$ e $7 / \mathrm{N}$ & - & $\begin{array}{l}\text { cascalhento (aos } \\
0,55 \mathrm{~m} \text { ) e lençol } \\
\text { freático a } 1,10 \mathrm{~m}\end{array}$ & ondulado & $\begin{array}{l}\text { pousio com } \\
\text { capoeira } \\
\text { aberta }\end{array}$ \\
\hline Sítios & $\begin{array}{c}\text { Classe } \\
\text { de solo }\end{array}$ & Textura $^{(2)}$ & $\begin{array}{l}\text { Cor superficial e } \\
\text { subsuperficial }\end{array}$ & $\begin{array}{l}\text { Mosqueado } \\
\text { (e, ou, } \\
\text { plintita) }\end{array}$ & $\begin{array}{l}\text { Presença de } \\
\text { impedimento (lençol } \\
\text { freático e material } \\
\text { esquelético) }\end{array}$ & Relevo & $\begin{array}{l}\text { Cobertura } \\
\text { atual }\end{array}$ \\
\hline
\end{tabular}

ENCOSTA SEM PRESENÇA DE HORIZONTE A

\begin{tabular}{|c|c|c|c|c|c|c|c|}
\hline ES1 & $\begin{array}{l}\text { C fase } \\
\text { erodida } \\
\text { (solo } \\
\text { raspado) }\end{array}$ & FRA/FR & 2,5YR 4/6 e $10 \mathrm{YR} 6 / 8$ & - & $\begin{array}{l}\text { superfície e corpo do } \\
\text { solo com calhau, que } \\
\text { é cascalhento a } \\
\text { muito cascalhento }\end{array}$ & $\begin{array}{l}\text { plano } \\
\text { (paisagem } \\
\text { alterada } \\
\text { pela } \\
\text { extração de } \\
\text { material) } \\
\end{array}$ & ausente \\
\hline ES2 & $\begin{array}{l}\text { F fase } \\
\text { erodida } \\
\text { (solo } \\
\text { raspado) }\end{array}$ & $\begin{array}{l}\text { (grande } \\
\text { predominância } \\
\text { de material } \\
\text { esquelético) }\end{array}$ & $5 Y R 5 / 6$ & $\begin{array}{l}\text { - } \\
\text { (plintita } \\
\text { 10R } 3 / 6 \text { e } \\
\text { 7N entre } 10 \\
\text { e } 30 \mathrm{~cm} \text { ) }\end{array}$ & $\begin{array}{l}\text { superfície com muito } \\
\text { calhau, cascalho de } \\
\text { quartzo e } \\
\text { petroplintita e alguns } \\
\text { matacões, sulcos de } \\
\text { erosão }\end{array}$ & $\begin{array}{l}\text { forte } \\
\text { ondulado a } \\
\text { suave } \\
\text { ondulado }\end{array}$ & ausente \\
\hline ES3 & $\begin{array}{l}\mathrm{F} \text { fase } \\
\text { erodida }\end{array}$ & $\mathrm{RA} / \mathrm{R} / \mathrm{RR}$ & 8,5 YR $5 / 5$ e $10 Y R 7 / 6$ & $\begin{array}{l}5 Y R 5 / 8 \\
\text { (plintita e } \\
\text { petroplintit } \\
\text { a 10R 3/5) }\end{array}$ & $\begin{array}{l}\text { pavimento } \\
\text { pedregoso com } \\
\text { presença de } \\
\text { matacões de } \\
\text { petroplintita }\end{array}$ & $\begin{array}{l}\text { forte } \\
\text { ondulado }\end{array}$ & $\begin{array}{l}\text { pousio com } \\
\text { vegetação } \\
\text { muito rala }\end{array}$ \\
\hline ES4 & $\begin{array}{l}\text { F fase } \\
\text { erodida } \\
\text { (solo } \\
\text { raspado) }\end{array}$ & $\begin{array}{l}\mathrm{FRA} / \mathrm{F} \text { e } \\
\mathrm{FR} / \mathrm{RS} / \mathrm{R}\end{array}$ & $\begin{array}{l}10 \mathrm{YR} 4 / 4,5 \mathrm{YR} 4 / 3 \mathrm{e} \\
8 / \mathrm{N}\end{array}$ & $\begin{array}{l}8 / \mathrm{N} \text { e } \\
10 \mathrm{R} 4 / 6\end{array}$ & $\begin{array}{l}\text { superfície com } \\
\text { calhaus e matacões } \\
\text { de petroplintita }\end{array}$ & $\begin{array}{l}\text { plano a } \\
\text { quase } \\
\text { plano }\end{array}$ & ausente \\
\hline
\end{tabular}

\section{SOPÉ DE ENCOSTA}

\begin{tabular}{c|l|l|l|l|l|l|l}
\hline SE & PAC & A/AF/FA/FRA & $\begin{array}{l}\text { 10YR 4/2, 10YR4/2,5 } \\
\text { e 10YR 5/1 }\end{array}$ & $\begin{array}{l}\text { 10YR 5/2 } \\
\text { e 10YR } \\
6 / 8\end{array}$ & $\begin{array}{l}\text { ausência de lençol } \\
\text { freático até 1,35 m }\end{array}$ & $\begin{array}{l}\text { plano de } \\
\text { sopé de } \\
\text { encosta } \\
\text { poacea } \\
\text { (capetinga } \\
\text { e carrapicho) }\end{array}$ \\
\hline
\end{tabular}

${ }^{(1)}$ GX: Gleissolo Háplico; GM: Gleissolo Melânico; CXg: Cambissolo Háplico gleissólico; FX: Plintosolo Háplico; CXpetroplíntico: Cambissolo Háplico petroplíntico; C fase erodida: Cambissolo fase erodida; F fase erodida: Plintossolo fase erodida; PAC: Argissolo Acinzentado.

${ }^{(2)}$ A: arenosa; AF: areia-franca; FA: franco-arenosa; F: franca; FR: franco-argilosa; FRA: franco-argilo-arenosa;

RA: argila-arenosa; R: argila; RR: muito argilosa; FS: franco-siltosa; RS: argilo-siltosa. 
Os solos EH também representam posições de encosta, mas localizam-se no entorno de áreas de surgência, onde o hidromorfismo é uma constante. Como nos solos de baixada, cores neutras aparecem, mesmo em relevo predominantemente ondulado a forte ondulado. A vegetação atual volta a ser campo úmido. A presença de mosqueado é mais frequente que nos solos BA, pois aqui a flutuação entre o excesso e a ausência de água no perfil apresenta maior número de ciclos ao longo do ano, permitindo que zonas de oxidação apresentem mosqueados com maior frequência (Motta et al., 2002a).

A posição abaciada do sítio SE (relevo plano no entorno de nascente vertical) originou Argissolos Acinzentados, caracterizados por cores de valores relativamente altos e cromas baixos se comparados a outros Argissolos (EMBRAPA, 2006). Ocorre algum excesso de água sazonal, mas não deve ser suficiente para que ocorram problemas com o desenvolvimento das mudas locais. A posição dos solos em final de encosta melhora o regime de umidade desses solos, diminuindo a deficiência de água ao longo do ano relativamente aos solos à montante (Argissolos Amarelos), bem como diminuindo a expressão da coesão, comum aos solos dos tabuleiros costeiros (Gomes et al., 2008; Lima Neto et al., 2009) e que poderia dificultar o desenvolvimento de mudas plantadas na restauração da área.

\section{CONCLUSÃO}

Os sítios do entorno das nascentes do alto curso da bacia hidrográfica do rio Piauitinga estão distribuídos em posições erosicionais (quebra-de-relevo), baixadas e um único caso de sopé de encosta suave de topo de tabuleiros costeiros.

Para os sítios de escarpas erosivas em encostas sem hidromorfismo (EA e ES) a principal preocupação é o relevo e a quantidade de material esquelético do solo, com as áreas chegando a formar pavimentos desérticos induzidos pela ação antrópica ou pela condição natural local.

Para os sítios de escarpas erosivas com hidromorfismo $(\mathrm{EH})$, além do relevo e da quantidade de material esquelético, o excesso de água sazonal pode ser um fator ambiental limitante ao manejo e, ou, regeneração da vegetação local.

Para os sítios de baixada, o forte hidromorfismo é o principal fator de limitação ambiental à introdução de espécies arbóreas.

O sítio SE, por apresentar solos de relevo plano, profundos e com excesso de água não muito acentuado ao longo do ano, apresenta o maior potencial de taxa de sucesso da regeneração ambiental com espécies arbóreas entre os sítios estudados.

\section{REFERÊNCIAS}

BRASIL. Lei $n^{0}$ 4.771, de 15 de setembro de 1965. Institui o novo Código Florestal Brasileiro. Brasília, 1965. Disponível em: <http://www.jusbrasil.com.br/legislacao/ 91627/codigo-florestal-lei-4771-65>. Acesso em: 19 abr. 2012.

CURCIO, G. R. Relações entre geologia, geomorfologia, pedologia e fitossociologia nas planícies fluviais do rio Iguaçu, Paraná, Brasil. 2006. 488f. Tese (Doutorado em Engenharia Florestal) - Universidade Federal do Paraná, Curitiba, 2006.

DUARTE, M. N.; RAMOS, D. P.; LIMA, P. C. Mineralogia, química e micromorfologia de solos de uma microbacia nos Tabuleiros Costeiros do Espírito Santo. Pesquisa agropecuária brasileira, Brasília, v. 35, n. 6, p. 1237-1250, 2000.

EMPRESA BRASILEIRA DE PESQUISA AGROPECUÁRIA - EMBRAPA. Sistema brasileiro de classificação de solos. 2. ed. Brasília: Embrapa-SPI, 2006. 306p. 
MAGAlhãeS, L. T. S.; GOMES, J. B. V.; VASCO, A. N.; AGUIAR NETTO, A. O.; FERREIRA, R. A. Caracterização geo-pedológica das áreas de nascentes na bacia hidrográfica do rio Piauitinga, Sergipe, Brasil. Ambi-Agua, Taubaté, v. 7, n. 1, p. 169-181, 2012. (http://dx.doi.org/10.4136/ambi-agua.767)

FERREIRA, M. M.; FERNANDES, B.; CURI, N. Mineralogia da fração argila e estrutura de Latossolos da região Sudeste do Brasil. Revista brasileira de Ciência do Solo, Viçosa, MG, v. 23, p. 507-514, 1999.

FERREIRA, R A.; AGUIAR NETTO, A. O.; SANTOS, T. I. S.; SANTOS, B. L; MATOS, E. L. Nascentes da sub-bacia hidrográfica do rio Poxim, estado de Sergipe: da degradação à Restauração. Revista Árvore, v. 35, n. 2, p. 265-277, 2011 http://dx.doi.org/10.1590/S0100-67622011000200011

FOLEY, J. A.; DeFRIES, R.; ASNER, G. P.; BARFORD, C.; BONAN, G.; CARPENTER, S. R. et al. Global consequences of land use. Science, v. 309, p. 570-574, 2005. http://dx.doi.org/10.1126/science.1111772

GOMES, J. B. V.; BOLFE, E. L.; CURI, N.; FONTES, H. R.; BARRETO, A. C.; VIANA, R. D. Variabilidade espacial de atributos de solos em unidades de manejo em área piloto de produção integrada de coco. Revista brasileira de Ciência do Solo, v. 32, p. 24712482, 2008. http://dx.doi.org/10.1590/S0100-06832008000600024

GUERTAL, W. R.; Hall, G. F. Relating soil color to soil water table levels. The Ohio Journal of Science, v. 90, n. 4, p.118-124, 1990.

LIMA NETO, J. de A.; RIBEIRO, M. R.; CORRÊA, M. M.; SOUZA JÚNIOR, V. S .; LIMA, J. F. W. F.; FERREIRA, R. F. A. L. Caracterização e gênese do caráter coeso em latossolos amarelos e argissolos dos tabuleiros costeiros do estado de Alagoas. Revista brasileira de Ciência do Solo, Viçosa, MG, v. 33, n. 4, p. 1001-1011, 2009.

MARTINS, A. K. E.; SCHAEFER, C. E. G. R.; SILVA, E.; SOARES, V. P.; CORREA, G. R.; MENDONCA, B. A. F. Relações solo-geoambiente em áreas de ocorrência de ipucas na planície do Médio Araguaia - estado de Tocantins. Revista Árvore, Viçosa, MG, v. 30, n. 2, p. 297-310, 2006.

MOREIRA, F. D. Geotecnologia aplicada à sub-bacia hidrográfica do rio Piauitinga e suas relações ambientais. 2008. Dissertação (Mestrado em Geografia) - Núcleo de Pós-Graduação em Geografia (NPGEO), Universidade Federal de Sergipe, São Cristóvão, 2008.

MOTTA, P. E. F.; CARVALHO FILHO, A.; KER, J. C.; PEREIRA, N. R.; CARVALHO JUNIOR, W.; BLANCANEAUX, P. Relações solo-superfície geomórfica e evolução da paisagem em uma área de Planalto Central Brasileiro. Pesquisa agropecuária brasileira, Brasília, v. 37, n. 6, p. 869-878, 2002a.

MOTTA, P. E. F.; CURI, N.; OLIVEIRA FILHO, A. T.; GOMES, J. B. V. Ocorrência da macaúba em Minas Gerais: relação com atributos climáticos, pedológicos e vegetacionais. Pesquisa agropecuária brasileira, Brasília, v. 37, n. 7, p. 1023-1031, $2002 b$.

PINTO, L. V. A.; BOTELHO, S. A.; DAVIDE, A. C.; FERREIRA, E. Estudos das nascentes da bacia hidrográfica do Ribeirão Santa Cruz, Lavras, MG. Scientia Forestalis, Piracicaba, n. 65, p. 197-206, 2004.

POESEN, J.; INGELMO-SANCHEZ, F. Runoff and sediment yield from topsoils with different porosity as affected by rock fragment cover and position. Catena, v. 19, n. 5, p. 451-474, 1992. http://dx.doi.org/10.1016/0341-8162(92)90044-C 
MAGAlHÃES, L. T. S.; GOMES, J. B. V.; VASCO, A. N.; AGUIAR NETTO, A. O.; FERREIRA, R. A. Caracterização geo-pedológica das áreas de nascentes na bacia hidrográfica do rio Piauitinga, Sergipe, Brasil. Ambi-Agua, Taubaté, v. 7, n. 1, p. 169-181, 2012. (http://dx.doi.org/10.4136/ambi-agua.767)

SANTOS, R. D.; LEMOS, R. C.; SANTOS, H. G.; KER, J. C.; ANJOS, L. H. C. Manual de descrição e coleta de solos no campo. 5. ed. Viçosa, MG: SBCS, 2005. 92 p.

SERGIPE (Estado). Secretaria de Estado do Planejamento e da Ciência e Tecnologia. Superintendência de Recursos Hídricos. Sergipe: atlas digital sobre recursos hídricos. Aracajú, 2011. 


ISSN = 1980-993X - doi:10.4136/1980-993X
www.ambi-agua.net
E-mail: ambi-agua@agro.unitau.br
Tel.: (12) 3625-4212

\title{
Conservação e reúso de águas usando o método Diagrama de Fontes de Água para processos em batelada: estudo de casos
}

\author{
(http://dx.doi.org/10.4136/ambi-agua.565)
}

\author{
Reinaldo Coelho Mirre ${ }^{1}$; Shaula Christine Leal Ferreira ${ }^{2}$; \\ Aline Rodrigues Dias ${ }^{3}$; Fernando Luiz Pellegrini Pessoa ${ }^{4}$ \\ Universidade Federal do Rio de Janeiro, Escola de Química \\ ${ }^{1}$ e-mail: reinaldomirre@ hotmail.com; ${ }^{2}$ e-mail: shaula.leal@gmail.com; \\ ${ }^{3}$ e-mail: ninedias1@gmail.com; ${ }^{4}$ e-mail: pessoa@eq.ufrj.br
}

\section{RESUMO}

O gerenciamento de recursos hídricos tem sido um fator importante para a sustentabilidade dos processos industriais, visto que há uma necessidade crescente pelo desenvolvimento de metodologias voltadas para conservação e uso racional da água. $\mathrm{O}$ objetivo deste trabalho foi aplicar o método Diagrama de Fontes de Água (DFA), usado na definição de metas de mínimo consumo de água, a processos que operam em regime batelada. Foram gerados e avaliados cenários de reúso de correntes obtidos pela aplicação do método a partir de dados de quantidade de água e concentração de contaminantes nas operações. Foram apresentados dois estudos de caso com o objetivo de demonstrar a redução de consumo de água e da geração de efluentes, além de custos de tratamento final e de investimento em tanques de estocagem, em relação à configuração inicial. Os cenários mostraram-se bastante promissores, com reduções que alcançam $45 \%$, em termos de consumo hídrico e geração de efluentes, e $37 \%$, em termos de custos de tanques, sem a necessidade de processos de regeneração. Com isso, a técnica empregada mostrou-se relevante e flexível como alternativa às ferramentas sistemáticas voltadas para a minimização do consumo de água em processos industriais, exercendo importante papel em um programa de gerenciamento de recursos hídricos.

Palavras-chave: reúso de efluentes; tanque de estocagem; síntese de redes de transferência de massa.

\section{Water conservation and reuse using the Water Sources Diagram method for batch process: case studies}

\begin{abstract}
The water resources management has been an important factor for the sustainability of industrial processes, since there is a growing need for the development of methodologies aimed at the conservation and rational use of water. The objective of this work was to apply the heuristic-algorithmic method called Water Sources Diagram (WSD), which is used to define the target of minimum water consumption, to batch processes. Scenarios with reuse of streams were generated and evaluated with application of the method from the data of water quantity and concentration of contaminants in the operations. Two case studies aiming to show the reduction of water consumption and wastewater generation, and final treatment costs besides investment in storage tanks, were presented. The scenarios showed great promising, achieving reduction up to $45 \%$ in water consumption and wastewater generation, and a
\end{abstract}


MIRRE, R. C.; FERREIRA, S. C. L.; DIAS, A. R.; PESSOA, F. L. P. Conservação e reúso de águas usando o método Diagrama de Fontes de Água para processos em batelada: estudo de casos. Ambi-Agua, Taubaté, v.7, n. 1, p. 182-203, 2012. (http://dx.doi.org/10.4136/ambi-agua.565)

reduction of around $37 \%$ on cost of storage tanks, without the need to allocate regeneration processes. Thus, the WSD method showed to be a relevant and flexible alternative regarding to systemic tools aimed at minimizing the consumption of water in industrial processes, playing an important role within a program of water resources management.

Keywords: wastewater reuse; storage tank; mass exchange networks synthesis.

\section{INTRODUÇÃO}

Nas últimas décadas, os custos com tratamento de efluentes industriais vêm aumentando gradativamente. No meio industrial, a água é empregada para consumo humano, como matéria prima, como fluido auxiliar, na geração de energia, como fluido de aquecimento e/ou resfriamento, dentre outros. A quantidade e a qualidade da água necessárias ao desenvolvimento das atividades industriais dependem das características do setor, dados os diferentes níveis de qualidade e da capacidade de produção que podem ser empregados. A cobrança pelo uso da água irradia um cenário de aumento nos custos de produção, tornando-se importante adotar medidas para conservação e uso racional, adequação de tratamento e aplicação de técnicas de reúso.

No campo da Integração de Processos Químicos, uma das primeiras contribuições voltadas para minimizar a vazão total de efluentes aquosos surgiu com o trabalho de ElHalwagi e Manousiouthakis (1989), que introduziram o conceito de redes de transferência de massa. A ideia consiste na transferência de contaminantes das correntes ricas para um conjunto de correntes pobres, a partir da rede gerada, com um procedimento similar ao de uma rede de transferência de energia. Entretanto, a maior contribuição ocorreu com os trabalhos de Wang e Smith (1994a,b; 1995a,b), apresentando uma metodologia que possibilite minimizar as metas de consumo de água em sistemas com um e múltiplos contaminantes, fazendo uso dos conceitos básicos de curva composta e transferência vertical. A metodologia foi estendida para casos de regeneração, restrição de vazão, taxa de perda fixa e múltiplas fontes de água. Castro et al. (1999) desenvolveram uma metodologia para o alcance da meta do consumo mínimo de água de modo simultâneo à síntese da rede de transferência de massa, considerando situações de reúso e regeneração, para um contaminante.

Gomes et al. (2007) estenderam os trabalhos de Castro et al. (1999) e Wang e Smith (1994a,b) por meio do algoritmo Diagrama de Fontes de Água (DFA). Foram testadas várias situações a partir do exemplo de Wang e Smith (1994a) para um contaminante, em opções como máximo reúso, múltiplas fontes de água, perdas de vazão referentes ao processo, restrições de vazão, regeneração com reúso, e regeneração com reciclo. Constatou-se que o consumo mínimo de água primária foi alcançado para o caso de máximo reuso, mesmo com restrição de vazão. A necessidade de fontes externas de água pode ser reduzida com o uso de processos regenerativos; porém, neste caso, há um trade-off ("conflito de escolha") entre a redução do consumo de água da fonte externa e o processo de regeneração mais adequado.

Os processos industriais que operam em regime de batelada têm sido alvo de estudos voltados para a necessidade de se desenvolver metodologias que busquem minimizar os efluentes gerados. A grande maioria das metodologias encontradas na literatura destina-se aos processos contínuos, as quais empregam técnicas de programação matemática para a resolução de problemas (Alva-Argáez et al., 1998; Doyle e Smith, 1997). Tais técnicas facilitam a abordagem de correntes com múltiplos contaminantes, em função da maior complexidade envolvida. Uma outra parcela dos trabalhos disponíveis envolve o uso de métodos gráficos (Wang e Smith, 1995a,b; Majozi et al., 2006), cuja abordagem é mais propícia à análise para um contaminante. Considerando a sua potencialidade, as técnicas 
MIRRE, R. C.; FERREIRA, S. C. L.; DIAS, A. R.; PESSOA, F. L. P. Conservação e reúso de águas usando o método Diagrama de Fontes de Água para processos em batelada: estudo de casos. Ambi-Agua, Taubaté, v.7, n. 1, p. 182-203, 2012. (http://dx.doi.org/10.4136/ambi-agua.565)

matemáticas são superiores às técnicas gráficas, mesmo para processos em batelada, em que a dimensão do tempo é um fator relevante.

Wang e Smith (1995b) iniciaram o estudo sobre síntese de redes de transferência de massa em processos em batelada, apresentando um método gráfico em que o tempo é tratado como uma restrição primária, enquanto que a força motriz concentração como restrição secundária (Time Pinch Analysis).

Almató et al. (1997) estabeleceram uma metodologia baseada em regras heurísticas e otimização matemática para minimização do consumo de água limpa em processos em batelada, onde introduziram o conceito de tanques de estocagem, a fim de oportunizar maiores possibilidades de reúso. A função objetivo seleciona o tanque que atenderá a demanda de cada corrente, indicando aquele para o qual o efluente deve ser enviado. O método foi aplicado aos processos de uma fábrica de sucos, alcançando-se uma reutilização de até $37 \%$. Os tanques de estocagem atuam como estações de mistura e distribuição para outros pontos da planta, proporcionando um aumento nas oportunidades de reúso de água entre as operações que permitem a relaxação de restrições dependentes do tempo. Almató et al. (1999) e Puigjaner et al. (2000) desenvolveram um programa computacional de interface gráfica que permite reduzir o consumo de água em processos batelada, a partir do reúso de efluentes aquosos utilizando tanques de estocagem de água.

Jödicke et al. (2001) empregaram um modelo de programação linear, em que os custos totais, operacionais (água limpa, tratamento de efluentes, bombeamento) e de investimento (tubulação, tanques) foram minimizados em um dado período de tempo. A síntese de redes de transferência de massa para processos em batelada também foi gerada por Foo et al. (2004; 2005a), a partir de uma tabela de intervalo de composição dependente do tempo; também apresentaram um procedimento voltado para a síntese de redes considerando a presença de um tanque de estocagem para reúso (Foo et al., 2005b), sem, no entanto, realizar estimativas de custos para as redes estruturadas.

Majozi (2005) apresentou uma formulação matemática baseada numa superestrutura que engloba todas as possibilidades de reciclo e reúso em plantas batelada multipropósito, considerando casos de presença e ausência de um tanque central de estocagem; com isso, alcançaram economias superiores a 50\% com o uso do tanque. Majozi et al. (2006) apresentaram uma técnica gráfica que inclui a identificação de oportunidades de reúso e reciclo de água dentro do processo e entre processos. As redes consideraram a inclusão de vasos de processos voltados para estocagem de água.

Muitos dos trabalhos que envolvem a síntese de redes de reúso de águas em sistemas batelada são tratados a partir de problemas de otimização matemática. Méndez et al. (2006) realizaram uma revisão dos métodos de otimização empregados para programação da produção de processos em batelada. Além dos trabalhos já mencionados, têm-se recentes contribuições, dentre os quais: Chang e Li (2006), que estudaram a equalização ótima de vazão de efluentes e concentração de contaminantes em plantas batelada; Shoaib et al. (2008) e Oliver et al. (2008), que combinaram programação matemática com análise Pinch para sintetizar redes de água em processos em batelada; Gouws et al. (2008), que estenderam o modelo de Majozi (2005) para minimização de água em plantas multipropósito utilizando tanque central de estocagem; Rabie e El-Hawagi (2008), que minimizaram o custo anual total a partir de um procedimento hierárquico para a síntese e planejamento de redes de reciclo de água em processos em batelada.

Tokos e Pintarič (2009) apresentaram uma aplicação industrial para a otimização de uma rede de água, em uma cervejaria. Vários modelos matemáticos foram desenvolvidos a fim de reduzir o uso de água limpa. Os modelos foram baseados no projeto desenvolvido por Kim e Smith (2004). Como resultado, os custos com tratamento de água sofreram redução de $27 \%$. Chen et al. (2009) também utilizaram programação matemática para a síntese de redes com o 
MIRRE, R. C.; FERREIRA, S. C. L.; DIAS, A. R.; PESSOA, F. L. P. Conservação e reúso de águas usando o método Diagrama de Fontes de Água para processos em batelada: estudo de casos. Ambi-Agua, Taubaté, v.7, n. 1, p. 182-203, 2012. (http://dx.doi.org/10.4136/ambi-agua.565)

uso de tanque central de estocagem. Majozi e Gouws (2009a,b) utilizaram programação não linear para redução da captação de água e da geração de efluentes em processos em batelada com múltiplos contaminantes, aplicável a situações sem o uso de tanque central. Vale ainda destacar as contribuições de Zhou et al. (2009) e Gouws e Majozi (2009).

Immich et al. (2007) apresentaram uma adaptação do método DFA para um processo em batelada. O procedimento foi comparado à técnica gráfica empregada por Majozi et al. (2006). Os resultados encontrados foram semelhantes aos da literatura, porém ficou evidente a simplicidade da aplicação do DFA na consideração de problemas deste tipo. Amim et al. (2007) também aplicaram o método DFA para um processo em batelada, cujos resultados foram praticamente similares aos da literatura.

Chen e Lee (2008) utilizaram um método gráfico para aplicá-lo a um processo batelada simples e batelada em ciclo, alcançando reduções de $40 \%$ e $60 \%$ nos custos do processo, respectivamente. Como a maioria dos métodos gráficos, o trabalho se restringe a um único contaminante.

O método DFA (Gomes et al., 2007) é um procedimento algorítmico-heurístico baseado em equações de balanço material e em regras heurísticas que procuram estabelecer conexões ótimas entre fontes e sumidouros de água, dentro do processo industrial. O procedimento divide o problema em intervalos de concentração, cujos limites são considerados como fontes internas de água, enquanto que a água primária e a água regenerada são definidas como fontes externas. As concentrações são ordenadas e representadas em um diagrama de concentrações. As regras heurísticas adotadas estabelecem que: i) as fontes externas são utilizadas somente na indisponibilidade de fontes internas; ii) é necessário que a maior quantidade de massa seja transferida dentro do intervalo de concentração; e iii) quando uma operação é dividida em vários intervalos, a prioridade de alocação provém da corrente da mesma operação. A metodologia gera fluxogramas de processos em diferentes situações de reúso e regeneração, incluindo reciclo. Possui ainda a vantagem da geração simultânea de fluxogramas alternativos para o processo.

Este trabalho teve como objetivo aplicar o método DFA, originalmente desenvolvido para processos contínuos, na síntese de fluxogramas hídricos em processos que operam sob o regime de batelada. Procurou-se gerar redes em cenários que visam o uso racional da água. A metodologia foi apresentada simultaneamente com o desenvolvimento de um problema da literatura, detalhando sua resolução utilizando-se o método. Com isso, dois estudos de caso foram apresentados, sendo avaliados cenários que incluem a necessidade de se empregar tanques de estocagem de água, os quais contribuem para as oportunidades de máximo reúso no processo.

\section{METODOLOGIA}

A abordagem de problemas em batelada envolve a disponibilidade de informações relativas à massa de cada contaminante presente, à quantidade de água requerida, ao tempo inicial e final de cada batelada para alcance do efeito desejado, à massa (estocagem) de água disponível para o reúso, e às concentrações máximas de entrada e saída das respectivas operações (Majozi, 2005). Em problemas dessa natureza, o emprego de tanques de estocagem representa fonte adicional para reúso, tornando-se um depósito para cada operação. Em configurações em que inexiste um tanque de estocagem, a água necessária para cada operação é suprida por correntes de entrada de água limpa, correntes de reúso e/ou reciclo, ou ainda uma combinação destas correntes.

O procedimento algorítmico-heurístico DFA desenvolvido para processos contínuos é apresentado passo a passo em Gomes et al. (2007), sendo cada restrição (vazão fixa, múltiplas fontes e perda de vazão) discutida separadamente. 
MIRRE, R. C.; FERREIRA, S. C. L.; DIAS, A. R.; PESSOA, F. L. P. Conservação e reúso de águas usando o método Diagrama de Fontes de Água para processos em batelada: estudo de casos. Ambi-Agua, Taubaté, v.7, n. 1, p. 182-203, 2012. (http://dx.doi.org/10.4136/ambi-agua.565)

O procedimento apresentado neste trabalho para processos em batelada segue a abordagem de Immich et al. (2007), e é ilustrado pela aplicação aos dados do estudo de caso tratado por Foo et al. (2005b), conforme mostrado na Tabela 1.

Tabela 1. Dados do processo em batelada (Foo et al., 2005b).

\begin{tabular}{|c|c|c|c|c|c|}
\hline $\begin{array}{c}\text { Demanda, } \\
D_{j}\end{array}$ & $\begin{array}{c}\text { Vazão limite } \\
(\mathbf{t} / \mathbf{h})\end{array}$ & $\begin{array}{c}\text { Concentração } \\
(\text { ppm })\end{array}$ & $\begin{array}{c}\text { Tempo } \\
\text { inicial }(h)\end{array}$ & $\begin{array}{c}\text { Tempo } \\
\text { final }(h)\end{array}$ & $\begin{array}{c}\text { Carga mássica } \\
\text { limite }(\mathbf{t})\end{array}$ \\
\hline D1 & 20 & 0 & 0 & 1,0 & 20 \\
\hline D2 & 100 & 50 & 1,0 & 3,5 & 250 \\
\hline D3 & 40 & 50 & 3,0 & 5,0 & 80 \\
\hline D4 & 10 & 400 & 1,0 & 3,0 & 20 \\
\hline Fonte, $S_{i}$ & $\begin{array}{c}\text { Vazão limite } \\
(\mathbf{t} / \mathbf{h})\end{array}$ & $\begin{array}{c}\text { Concentração } \\
(\mathbf{p p m})\end{array}$ & $\begin{array}{c}\text { Tempo } \\
\text { inicial (h) }\end{array}$ & $\begin{array}{c}\text { Tempo } \\
\text { final (h) }\end{array}$ & $\begin{array}{l}\text { Carga mássica } \\
\text { limite (t) }\end{array}$ \\
\hline S1 & 20 & 100 & 0 & 1,0 & 20 \\
\hline $\mathrm{S} 2$ & 100 & 100 & 1,0 & 3,5 & 250 \\
\hline $\mathrm{S} 3$ & 40 & 800 & 3,0 & 5,0 & 80 \\
\hline $\mathrm{S} 4$ & 10 & 800 & 1,0 & 3,0 & 20 \\
\hline
\end{tabular}

A estrutura do problema pode ser dividida em intervalos de tempo de batelada, em que cada qual apresentam as operações, em estados terminais ou intermediários. Para adaptação à abordagem do DFA, o problema original pode ser tratado como uma operação na qual se incorpora sua respectiva fonte e demanda, conforme os dados representados na Tabela 2.

Tabela 2. Nova representação do conjunto de dados do processo.

\begin{tabular}{c|ccccc}
\hline Operação & $\begin{array}{c}\text { Vazão } \\
\text { limite (t/h) }\end{array}$ & $\begin{array}{c}\text { Concentração } \\
(\mathbf{p p m})\end{array}$ & $\begin{array}{c}\text { Tempo } \\
\text { inicial (h) }\end{array}$ & $\begin{array}{c}\text { Tempo } \\
\text { final (h) }\end{array}$ & $\begin{array}{c}\text { Carga } \\
\text { mássica limite } \\
\text { (t) }\end{array}$ \\
\hline D1/S1 (OP1) & 20 & 0 & 0 & 1,0 & 20 \\
D2/S2 (OP2) & 100 & 50 & 1,0 & 3,5 & 250 \\
D3/S3 (OP3) & 40 & 50 & 3,0 & 5,0 & 80 \\
D4/S4 (OP4) & 10 & 400 & 1,0 & 3,0 & 20 \\
\hline
\end{tabular}

Para cada operação envolvida, tem-se a estrutura segmentada do intervalo de tempo de batelada, de acordo com a Figura 1.

A estrutura do reúso de correntes aquosas deve atender ao intervalo sequencial de tempo, em que o reúso só é permitido ao término das operações inseridas nos intervalos de tempo subsequentes. Neste caso, o conjunto dos intervalos de tempo de batelada para reúso sequencial é dado por $\{0-1,0 \mathrm{~h} ; 1,0-3,0 \mathrm{~h} ; 3,0-3,5 \mathrm{~h} ; 3,5-5,0 \mathrm{~h}\}$, de tal modo que o método DFA é aplicado em cada intervalo de tempo. Assim, no primeiro intervalo $(0-1,0 \mathrm{~h})$, a operação 1 se inicia e finaliza, tornando disponível a quantidade de 20 t para eventual reúso em período posterior. 
MIRRE, R. C.; FERREIRA, S. C. L.; DIAS, A. R.; PESSOA, F. L. P. Conservação e reúso de águas usando o método Diagrama de Fontes de Água para processos em batelada: estudo de casos. Ambi-Agua, Taubaté, v.7, n. 1, p. 182-203, 2012. (http://dx.doi.org/10.4136/ambi-agua.565)
Tempo $(\mathrm{h}) \Rightarrow \quad 0$
1,0
3,0
3,5
5,0

OP1
OP2
OP3
OP4

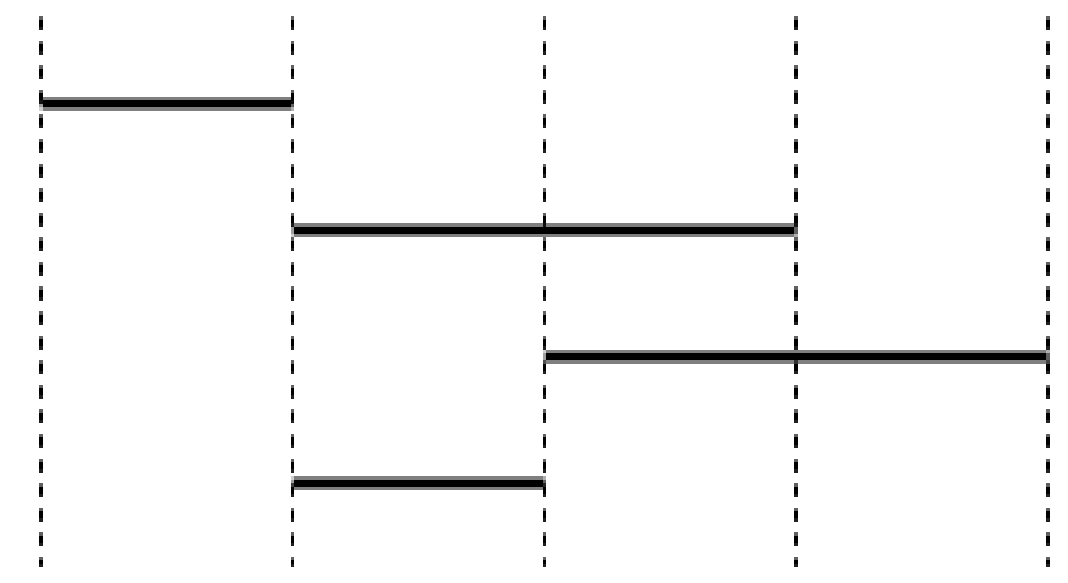

Figura 1. Representação das operações em cada intervalo de tempo da batelada.

No segundo intervalo $(1,0-3,0 \mathrm{~h})$, a quantidade de água necessária para suprir a necessidade da operação 2 pode ser proveniente da operação 1 , uma vez que, no período considerado, já encontra-se finalizada e disponível para reúso. Deve-se, portanto, calcular, por meio de um balanço no ponto de mistura, a quantidade necessária de água para minimizar a contribuição da água limpa $(0 \mathrm{ppm})$. O problema consiste em encontrar a vazão $\mathrm{F}$, ou melhor, a quantidade que ajuste o mínimo consumo de água limpa, maximizando o reúso da corrente efluente da operação 1 pela combinação das correntes a montante do misturador, conforme a Figura 2.

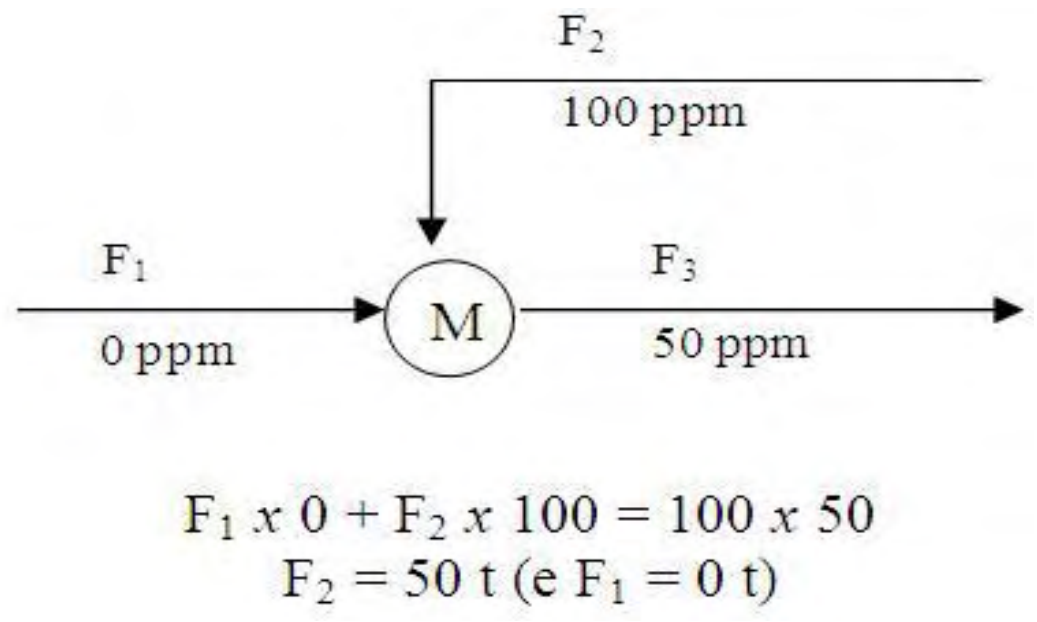

Figura 2. Balanço material para cálculo da menor quantidade de água $\left(\mathrm{F}_{3}\right)$ a jusante do misturador $\mathrm{M}$.

Como a quantidade calculada proveniente da operação 1 para o reúso de modo que minimize o emprego da água limpa corresponde a $50 \mathrm{t}$ e, somente encontram-se disponíveis $20 \mathrm{t}$, procura-se aproveitar essa máxima quantidade disponível para recalcular, a partir de $20 \mathrm{t}$ de $\mathrm{F}_{2}$, a contribuição de $\mathrm{F}_{1}$ (água limpa) para este caso, ou seja, quando há a máxima contribuição possível do reúso de da operação 1 . Neste caso, o valor encontrado para $F_{1}$ é de $20 \mathrm{t}$, totalizando $\mathrm{F}_{3}$ equivalente a $40 \mathrm{t}$. 
MIRRE, R. C.; FERREIRA, S. C. L.; DIAS, A. R.; PESSOA, F. L. P. Conservação e reúso de águas usando o método Diagrama de Fontes de Água para processos em batelada: estudo de casos. Ambi-Agua, Taubaté, v.7, n. 1, p. 182-203, 2012. (http://dx.doi.org/10.4136/ambi-agua.565)

Da mesma forma, o efluente da operação 2 pode ser prontamente reutilizado na operação 4, onde são necessárias 5,7 t para assimilar a carga desta operação dentro do intervalo de 100 ppm (de onde se busca o efluente para reúso) a 800 ppm.

No terceiro intervalo $(3,0-3,5 \mathrm{~h})$, a parcela remanescente da operação 2 , e que não foi reutilizada na operação 4, é então destinada em 20 t para a operação 3, entre 100 ppm e 400 ppm.

No quarto e último intervalo $(3,5-5,0 \mathrm{~h})$, encontra-se apenas a operação 3 , e a quantidade necessária para assimilação do contaminante já se torna suficiente.

Após a realização do DFA em cada intervalo de tempo de batelada, procede-se à união destes sub-DFA's gerados em um único diagrama, permitindo visualizar e auxiliar a montagem da configuração alternativa gerada, conforme mostra a Figura 3. O reúso da operação 2 nas operações 3 e 4 é simbolizado por um triângulo e um círculo, respectivamente, indicando a ordem na qual se estabeleceu a sequência do reúso.

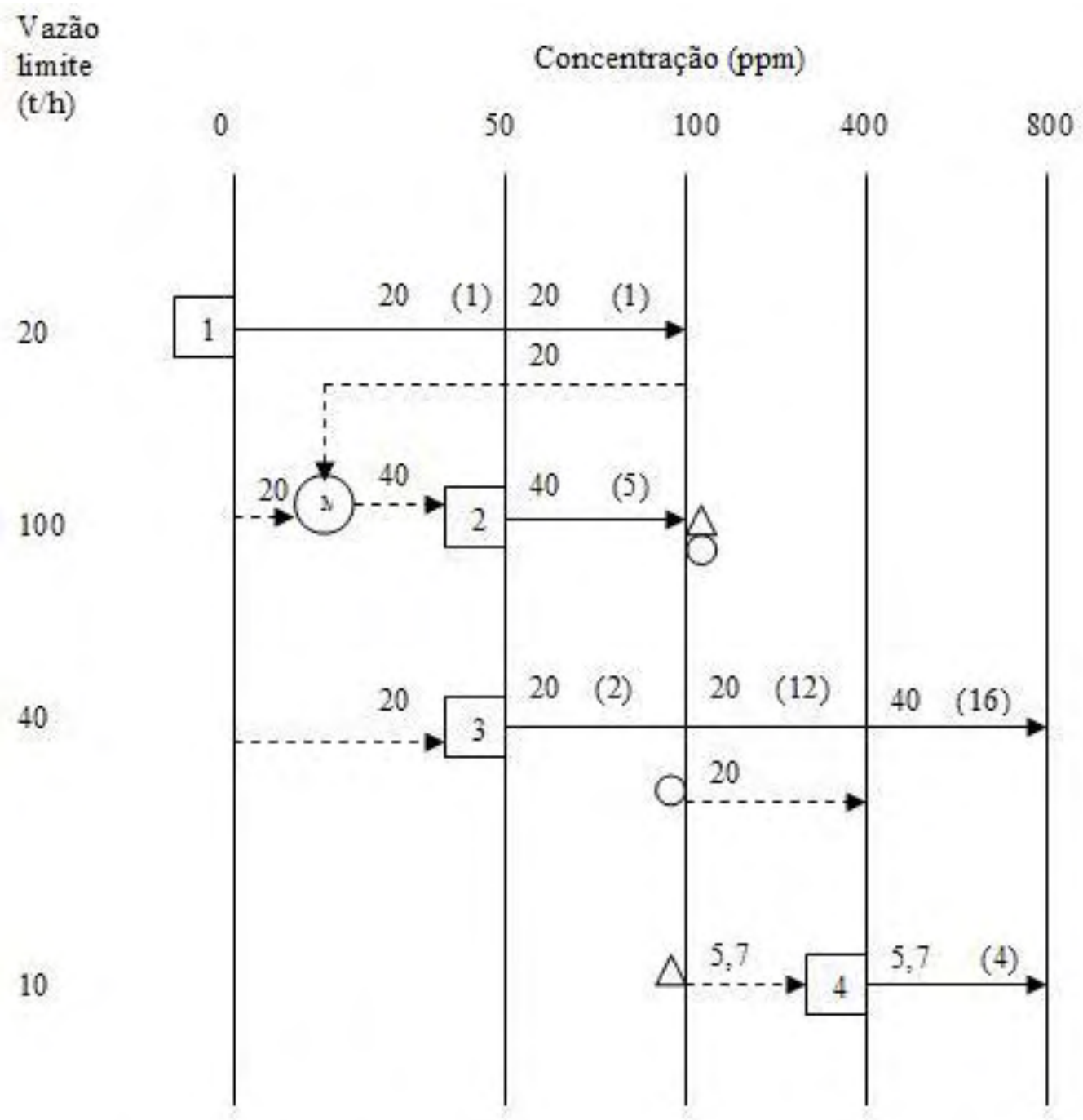

Figura 3. Esquema final da aplicação do método DFA.

A partir da estrutura unificada do DFA, torna-se possível construir um fluxograma representativo do processo hídrico, incluindo a configuração alternativa de reúso sugerida pela metodologia, conforme apresentado na Figura 4. 
MIRRE, R. C.; FERREIRA, S. C. L.; DIAS, A. R.; PESSOA, F. L. P. Conservação e reúso de águas usando o método Diagrama de Fontes de Água para processos em batelada: estudo de casos. Ambi-Agua, Taubaté, v.7, n. 1, p. 182-203, 2012. (http://dx.doi.org/10.4136/ambi-agua.565)

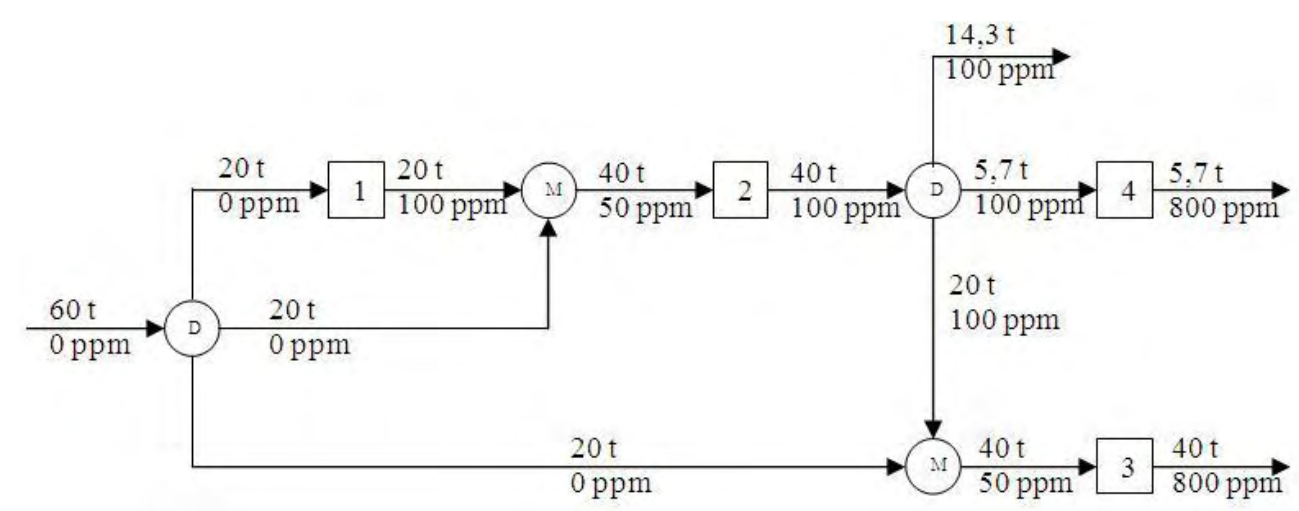

Figura 4. Fluxograma do processo hídrico.

A quantidade de água limpa utilizada no problema após a aplicação do DFA foi de 60 t, enquanto que a técnica empregada no trabalho de Foo et al. (2005b) utiliza uma quantidade de 211,25 t de água limpa, o que equivale a uma redução superior a $71 \%$.

Vale observar, entretanto, que o cenário estudado não inclui a existência de um tanque de estocagem, o que facilitaria a distribuição em qualquer intervalo subsequente para as operações dentro de um limite de armazenamento, além de não considerar a restrição de vazão fixa nas operações, permitindo obter valores menores de quantidade disponibilizada.

Um outro cenário pode ser analisado, em que se faz necessária a inclusão de um tanque de estocagem para a redestinação dos efluentes para as operações receptoras de reúso, desconsiderando a restrição de vazão fixa nas respectivas operações.

O procedimento adotado neste caso é similar ao anterior, em que se aplica o método DFA para cada intervalo de tempo. Ao final do primeiro intervalo de tempo de batelada $(0-1,0 \mathrm{~h})$, a operação 1 torna-se finalizada, tendo disponíveis 20 t para eventual reúso. Esta quantidade pode ser então armazenada em um tanque de estocagem (simbolizado pelo círculo contendo pela letra E), com uma capacidade predeterminada (aqui não tratado) para redestinação a outras operações.

No segundo intervalo $(1,0-3,0 \mathrm{~h})$, a quantidade de água necessária para suprir a necessidade da operação 2 pode ser proveniente da operação 1 que, no período considerado, já se encontra finalizada e disponível para reúso. Trata-se da mesma situação anterior, em que se deve calcular, por meio de um balanço material no ponto de mistura, a quantidade necessária de água que apresente a menor contribuição da água limpa $(0 \mathrm{ppm})$. Por ser o mesmo problema já abordado, a quantidade encontrada foi de 20 t de contribuição de água limpa e de $20 \mathrm{t}$ de água reutilizada do tanque de estocagem.

Similarmente ao primeiro cenário, o efluente da operação 2 pode ser prontamente reutilizado na operação 4 , onde são necessários 5,7 t para assimilar a carga desta operação dentro do intervalo de $100 \mathrm{ppm}$ (de onde se busca o efluente para reúso) a $800 \mathrm{ppm}$.

No terceiro intervalo $(3,0-3,5 \mathrm{~h})$, a parcela remanescente da operação 2 , não reutilizada na operação 4, é agora destinada na quantidade de 20 t na operação 3, no intervalo entre 100 ppm e 400 ppm.

No quarto e último intervalo $(3,5-5,0 \mathrm{~h})$, está presente apenas a operação 3 e a quantidade necessária para assimilação do contaminante já se torna suficiente.

Como no primeiro cenário, procede-se à união dos sub-DFA's, de acordo com o diagrama da Figura 5. O reúso da operação 2 nas operações 3 e 4 é simbolizado por um triângulo e um círculo, respectivamente, indicando a ordem na qual se estabeleceu a sequência de reúso. $\mathrm{O}$ círculo maior que envolve as figuras geométricas menores ao término da operação 2 indica a existência de um tanque de estocagem; entretanto, o fato de se utilizar água limpa para diluir a concentração de entrada na operação 1 a 50 ppm dificulta a localização de um 
MIRRE, R. C.; FERREIRA, S. C. L.; DIAS, A. R.; PESSOA, F. L. P. Conservação e reúso de águas usando o método Diagrama de Fontes de Água para processos em batelada: estudo de casos. Ambi-Agua, Taubaté, v.7, n. 1, p. 182-203, 2012. (http://dx.doi.org/10.4136/ambi-agua.565)

único tanque para receber as correntes de ambos, o que poderia ser sugerido caso todas estivessem na mesma concentração de entrada do tanque (100 ppm), sem influenciar a qualidade do reúso.

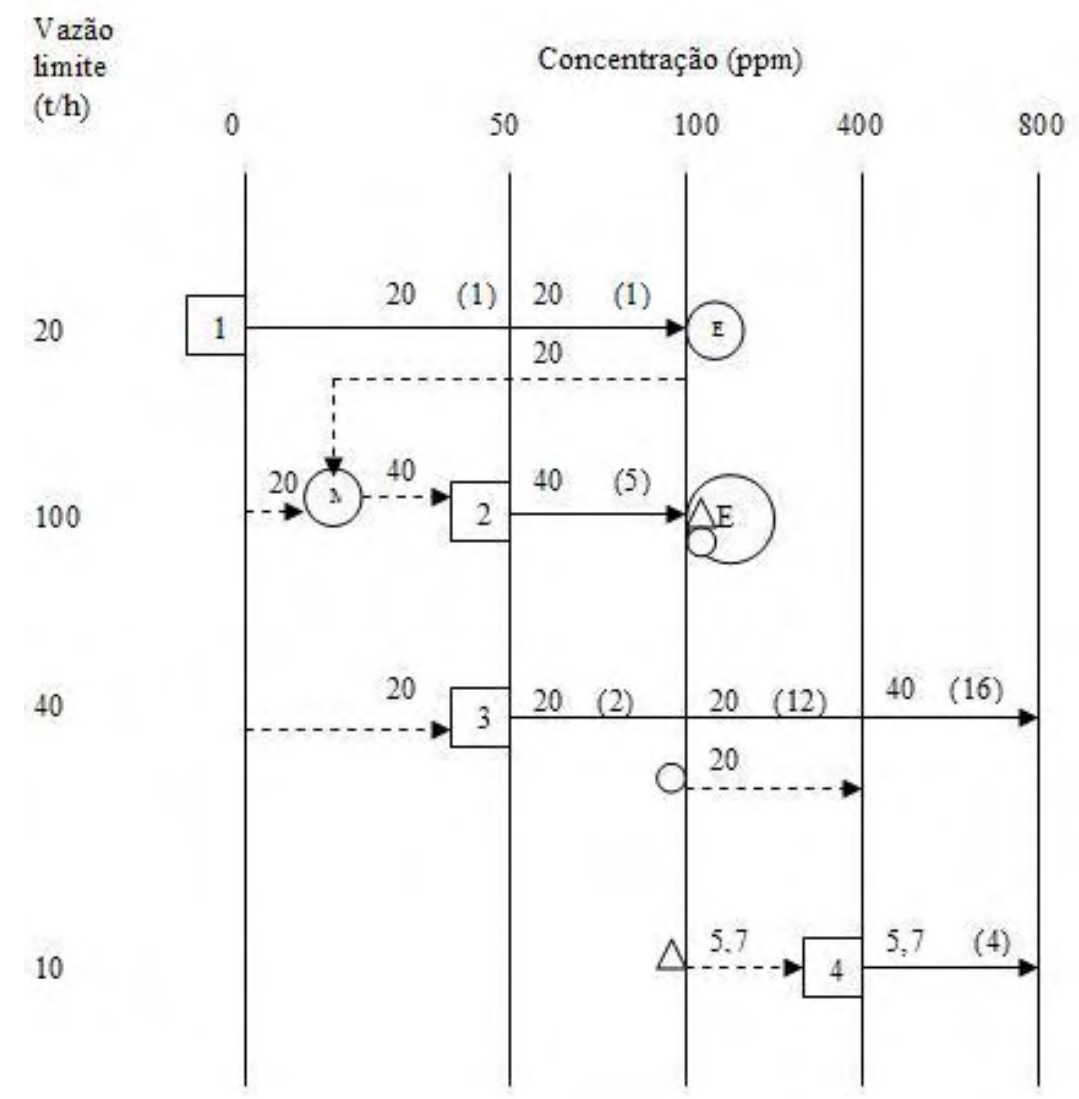

Figura 5. Esquema final do DFA para o novo cenário.

A partir da estrutura unificada do DFA, torna-se possível construir um fluxograma representativo do processo hídrico, incluindo a configuração alternativa de reúso sugerida pela metodologia, conforme apresentado na Figura 6.

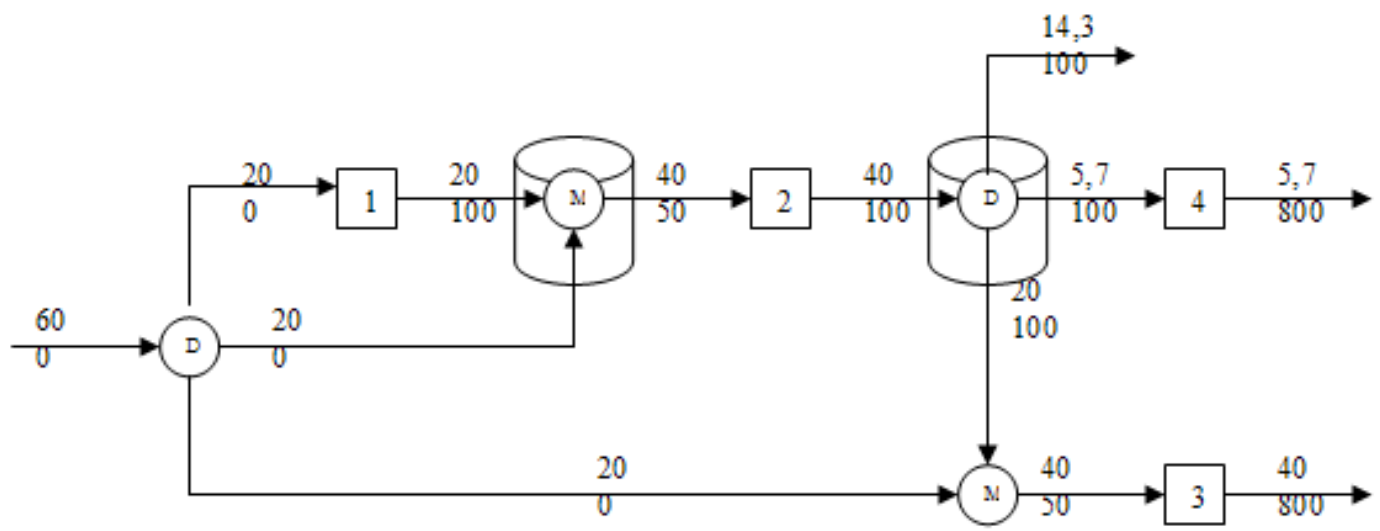

Figura 6. Fluxograma do processo hídrico para o novo cenário considerando a presença de tanque de estocagem. 
MIRRE, R. C.; FERREIRA, S. C. L.; DIAS, A. R.; PESSOA, F. L. P. Conservação e reúso de águas usando o método Diagrama de Fontes de Água para processos em batelada: estudo de casos. Ambi-Agua, Taubaté, v.7, n. 1, p. 182-203, 2012. (http://dx.doi.org/10.4136/ambi-agua.565)

Este exemplo ilustrou a necessidade de se estocar apenas a quantidade de água necessária para reúso. Esta quantidade armazenada no tanque servirá como fonte para as operações dos intervalos posteriores de tempo, de acordo com a lógica estabelecida para o primeiro cenário. Com o tanque de estocagem, a operação 1 pode enviar o efluente tanto para a operação 2 como para as operações 3 e 4. Diante de tal situação, optou-se por destiná-la integralmente para a operação 2, combinando-o à parcela de água limpa, permitindo a comparação com os resultados do primeiro cenário.

Neste trabalho, a metodologia apresentada para aplicação do método DFA a processos em batelada foi adotada para a realização de dois estudos de caso, de modo a auxiliar na minimização do consumo de água limpa. Foram apresentados dois casos existentes na literatura, em que o DFA é tratado como uma opção de técnica sistemática voltada para o reúso, avaliando oportunidades de nova configuração para o processo e de diminuição da quantidade de água limpa requerida para cada batelada. Assim, a Figura 7 sintetiza os cenários utilizados neste trabalho, tornando clara a divisão entre os casos.

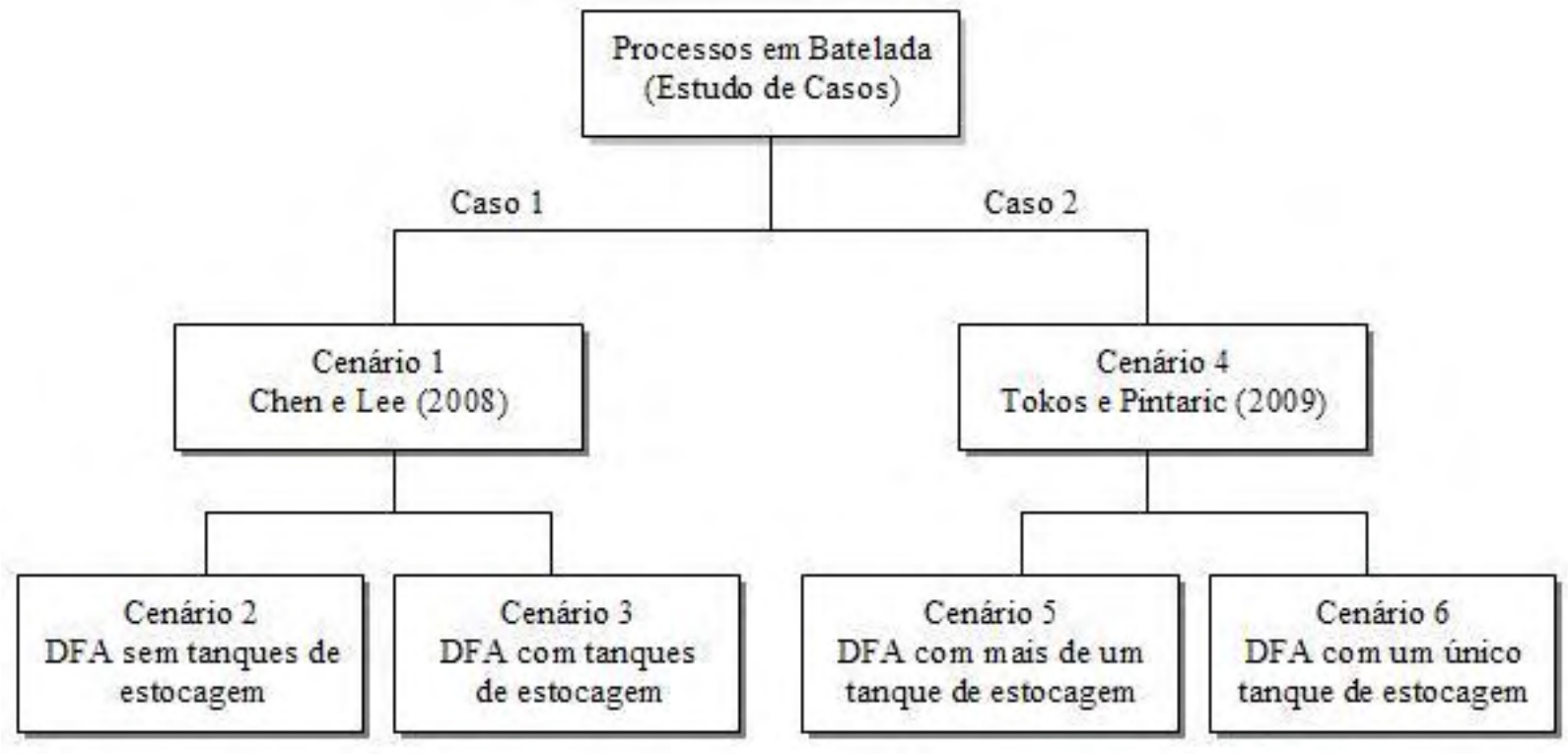

Figura 7. Estruturação dos cenários apresentados.

\subsection{Caso 1: apresentação do cenário 1}

O primeiro caso estudado refere-se a uma unidade hipotética apresentada por Chen e Lee (2008), na qual possui cinco operações que utilizam água e operam em regime de batelada. Para cada operação, têm-se as concentrações máximas de entrada (Ce,max) e saída (Cs,max) e a massa trocada de contaminante $(\Delta \mathrm{m})$. São também apresentados os intervalos de tempo de input (abastecimento) e output (descarregamento). Esses dados encontram-se relacionados na Tabela 3.

Tabela 3. Dados para a unidade hipotética (Chen e Lee, 2008).

\begin{tabular}{c|ccccc}
\hline Operação & $\begin{array}{c}\text { Intervalo de } \\
\text { input }(\mathbf{h})\end{array}$ & $\begin{array}{c}\text { Intervalo de } \\
\text { output }(\mathbf{h})\end{array}$ & $\begin{array}{c}\text { Ce,max (kg } \\
\text { sal / kg água) }\end{array}$ & $\begin{array}{c}\text { Cs,max (kg } \\
\text { sal / kg água) }\end{array}$ & $\Delta \mathbf{m}(\mathbf{t})$ \\
\hline 1 & $0-1,0$ & $4,0-5,0$ & 0 & 0,20 & 4 \\
2 & $0-0,5$ & $4,5-5,0$ & 0,25 & 0,50 & 4 \\
3 & $5,06,5$ & $5,0-6,5$ & 0,10 & - & 0 \\
4 & $2,02,5$ & $6,5-7,0$ & 0,25 & 0,40 & 3,6 \\
5 & $7,08,5$ & $7,0-8,5$ & 0,10 & - & 0,3 \\
\hline
\end{tabular}


MIRRE, R. C.; FERREIRA, S. C. L.; DIAS, A. R.; PESSOA, F. L. P. Conservação e reúso de águas usando o método Diagrama de Fontes de Água para processos em batelada: estudo de casos. Ambi-Agua, Taubaté, v.7, n. 1, p. 182-203, 2012. (http://dx.doi.org/10.4136/ambi-agua.565)

Nas operações 3 e 5, as massas de contaminantes trocadas são desprezíveis, e possuem uma quantidade mínima requerida de $15 \mathrm{t}$, para cada uma delas.

Para este caso são consideradas bateladas não-cíclicas sem reciclo, ou seja, a água que sai ao final de uma operação não pode ser retornada para o início da mesma operação e, se um tanque de estocagem for utilizado, a água que sai do tanque de estocagem não pode retornar para o mesmo tanque. No estudo de Chen e Lee (2008), o consumo de água limpa para bateladas não-cíclicas sem reciclo foi de $44,50 \mathrm{t}$, para cada batelada.

A aplicação do método DFA para este caso requer a determinação da quantidade de água necessária, expressa em toneladas, ao invés de vazão limite de cada operação. Assim, como a massa de contaminante trocada é desprezível para as operações 3 e 5, não são informadas as concentrações de saída para estas operações. Na implementação do DFA, a quantidade de água necessária é tratada como vazão para estas operações: 15 t cada uma delas.

Para as operações 1, 2 e 4, calcula-se a quantidade de água necessária para cada operação, de acordo com a Equação 1.

$$
\mathrm{f}_{\mathrm{k}}=\Delta \mathrm{m}_{\mathrm{i}} /\left(\mathrm{C}_{\mathrm{s}, \mathrm{i}}-\mathrm{C}_{\mathrm{e}, \mathrm{i}}\right)
$$

em que $f_{k}$ representa a quantidade de água para cada operação.

A Tabela 4 apresenta os valores calculados para as respectivas operações.

Tabela 4. Dados de concentração e quantidade de água para cada operação.

\begin{tabular}{c|cccccc}
\hline Operação & $\begin{array}{c}\text { Intervalo de } \\
\text { input (h) }\end{array}$ & $\begin{array}{c}\text { Intervalo de } \\
\text { output (h) }\end{array}$ & $\begin{array}{c}\text { Ce,max (kg sal } \\
\text { / kg água) }\end{array}$ & $\begin{array}{c}\text { Cs,max (kg sal } \\
\text { / kg água) }\end{array}$ & $\Delta \mathbf{m}(\mathbf{t})$ & $\mathbf{f}_{\mathbf{k}}(\mathbf{t})$ \\
\hline 1 & $0-1,0$ & $4,0-5,0$ & 0 & 0,20 & 4 & 20 \\
2 & $0-0,5$ & $4,5-5,0$ & 0,25 & 0,50 & 4 & 16 \\
3 & $5,0-6,5$ & $5,0-6,5$ & 0,10 & - & 0 & 15 \\
4 & $2,0-2,5$ & $6,5-7,0$ & 0,25 & 0,40 & 3,6 & 24 \\
5 & $7,0-8,5$ & $7,0-8,5$ & 0,10 & - & 0,3 & 15 \\
\hline
\end{tabular}

Em um sistema não-contínuo, a aplicação do DFA leva em conta os intervalos de tempo em que as operações são iniciadas e finalizadas, a fim de analisar a possibilidade de reúso. Neste caso, a corrente de saída de uma operação só pode ser reutilizada em outra se a primeira operação já estiver finalizada.

Outro fator a ser considerado refere-se à possibilidade de se manter tanques de estocagem. A ausência de tanques de estocagem implica o descarte de efluente ao final do processo. Assim, se não houver um tanque onde a água que sai do processo possa ser estocada, o efluente de uma operação só pode ser reutilizado em outra caso a primeira finalize exatamente no momento em que a outra se inicia. Na presença de um ou mais tanques de estocagem no processo, o efluente de uma operação pode ser estocado no momento em que a operação termina e, como a água pode ser armazenada, esta pode ser reutilizada em um processo que se inicie horas depois.

Duas oportunidades foram avaliadas neste estudo de caso: (i) ausência de tanques de estocagem, e (ii) considerando o uso de tanques de estocagem. 
MIRRE, R. C.; FERREIRA, S. C. L.; DIAS, A. R.; PESSOA, F. L. P. Conservação e reúso de águas usando o método Diagrama de Fontes de Água para processos em batelada: estudo de casos. Ambi-Agua, Taubaté, v.7, n. 1, p. 182-203, 2012. (http://dx.doi.org/10.4136/ambi-agua.565)

\subsection{Caso 2: apresentação do cenário 4}

O segundo caso aqui estudado é tratado por Tokos e Pintarič (2009), que propuseram uma estratégia de reúso utilizando um modelo matemático desenvolvido por Kim e Smith (2004), para diversos setores de uma cervejaria. Neste estudo, considerou-se apenas o setor de produção, que possui operações em regime de batelada. Este setor é constituído por seis processos não-contínuos e que consomem no total 1.076 t de água limpa por dia. Os dados limites de cada operação, divididos em intervalos de tempo, são apresentados na Tabela 5.

Tabela 5. Dados limite para as operações da unidade de produção (Tokos e Pintarič, 2009).

\begin{tabular}{|c|c|c|c|c|c|}
\hline \multirow{2}{*}{ Processo } & \multirow{2}{*}{$\begin{array}{l}\text { Tempo de } \\
\text { intervalo }\end{array}$} & \multicolumn{2}{|c|}{ Concentração limite (ppm) } & \multirow{2}{*}{$\mathbf{f}_{\mathbf{k}}(\mathbf{t})$} & \multirow{2}{*}{$\begin{array}{c}\text { Tempo de } \\
\text { operação (h) }\end{array}$} \\
\hline & & Ce,max & Cs,max & & \\
\hline \multirow{4}{*}{1} & $1(\mathrm{P} 1)$ & 24,25 & 425 & 41 & 4 \\
\hline & $2(\mathrm{P} 2)$ & 24,25 & 425 & 41 & 4 \\
\hline & $3(\mathrm{P} 3)$ & 24,25 & 425 & 41 & 4 \\
\hline & $4(\mathrm{P} 4)$ & 24,25 & 425 & 41 & 4 \\
\hline \multirow[t]{2}{*}{2} & $4(\mathrm{P} 5)$ & 100 & 299 & 261 & 4 \\
\hline & $1(\mathrm{P} 6)$ & 100 & 980 & 47,20 & 4 \\
\hline \multirow{3}{*}{3} & $2(\mathrm{P} 7)$ & 100 & 980 & 47,20 & 4 \\
\hline & $3(\mathrm{P} 8)$ & 100 & 980 & 47,20 & 4 \\
\hline & $4(\mathrm{P} 9)$ & 100 & 980 & 47,20 & 4 \\
\hline \multirow{4}{*}{4} & $1(\mathrm{P} 10)$ & 100 & 330 & 46,20 & 4 \\
\hline & $2(\mathrm{P} 11)$ & 100 & 330 & 46,20 & 4 \\
\hline & $3(\mathrm{P} 12)$ & 100 & 330 & 46,20 & 4 \\
\hline & $4(\mathrm{P} 13)$ & 100 & 330 & 46,20 & 4 \\
\hline \multirow{2}{*}{5} & $2(\mathrm{P} 14)$ & 24,25 & 56 & 46,90 & 4 \\
\hline & $4(\mathrm{P} 15)$ & 24,25 & 56 & 46,90 & 4 \\
\hline 6 & $2(\mathrm{P} 16)$ & 100 & 329 & 115,30 & 4 \\
\hline
\end{tabular}

O processo 1 é uma unidade de fervura de mosto; os processos 2 e 5 são sistemas de limpeza; já nas operações 3 e 4 , a água é utilizada para verter materiais no processo de batelada; e a operação 6 é uma unidade de filtração.

\section{RESULTADOS E DISCUSSÃO}

\subsection{Caso 1: DFA sem o uso de tanques de estocagem - cenário 2}

Aplicando-se o método DFA aos dados do problema, tem-se o diagrama representado pela Figura 8. Os intervalos de concentrações foram definidos, e as operações foram dispostas no diagrama de acordo com as concentrações limites de entrada e saída para o contaminante em cada operação. 
MIRRE, R. C.; FERREIRA, S. C. L.; DIAS, A. R.; PESSOA, F. L. P. Conservação e reúso de águas usando o método Diagrama de Fontes de Água para processos em batelada: estudo de casos. Ambi-Agua, Taubaté, v.7, n. 1, p. 182-203, 2012. (http://dx.doi.org/10.4136/ambi-agua.565)

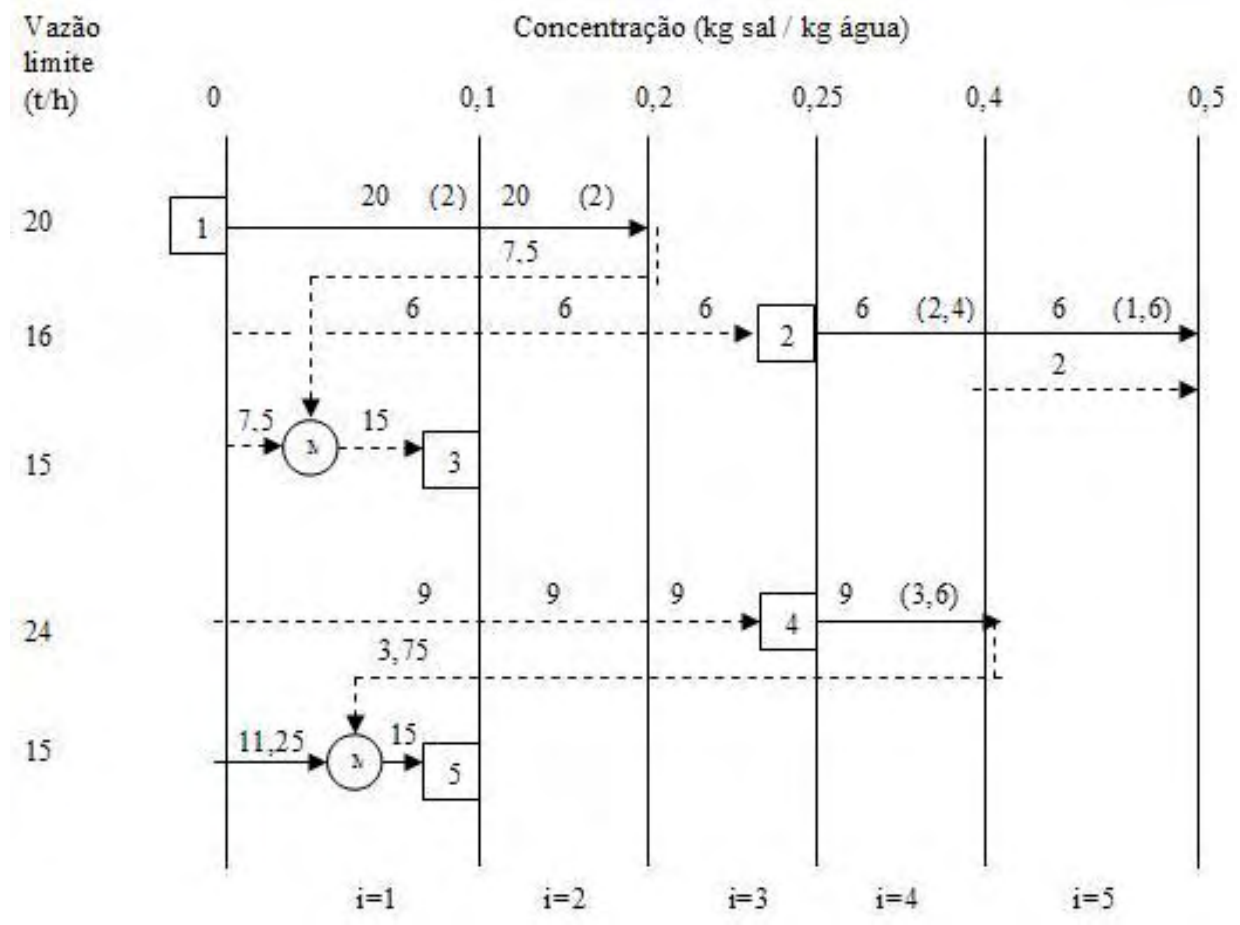

Figura 8. DFA gerado para caso 1 - sem tanques de estocagem.

Após esta etapa, o reúso foi avaliado de acordo com os intervalos de tempo das respectivas operações. O diagrama de blocos (fluxograma) do sistema está representado pela Figura 9.

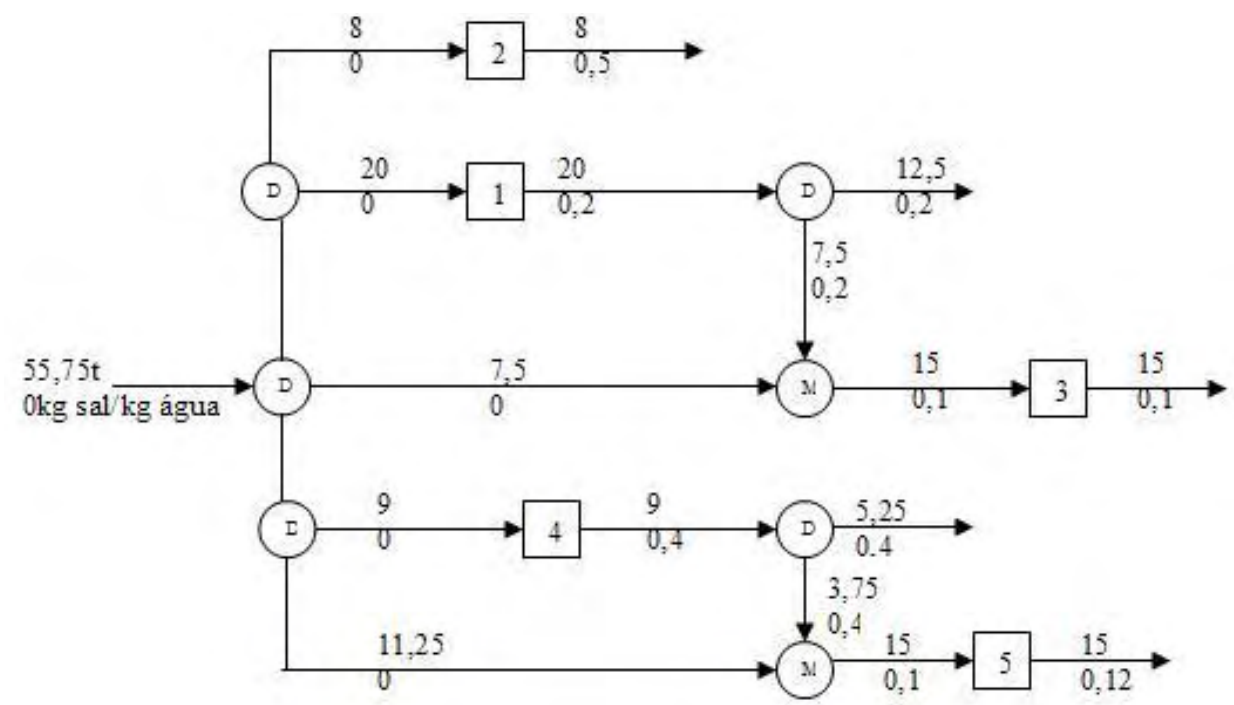

Figura 9. Fluxograma gerado - sem tanque de estocagem.

O consumo de água é de 55,75 t de água, superior ao do cenário 1, o que torna a proposta não recomendável para esta situação, sem o emprego de tanque de estocagem. 
MIRRE, R. C.; FERREIRA, S. C. L.; DIAS, A. R.; PESSOA, F. L. P. Conservação e reúso de águas usando o método Diagrama de Fontes de Água para processos em batelada: estudo de casos. Ambi-Agua, Taubaté, v.7, n. 1, p. 182-203, 2012. (http://dx.doi.org/10.4136/ambi-agua.565)

\subsection{Caso 1: DFA com o uso de tanques de estocagem - cenário 3}

Diante do alcance de uma configuração cujo consumo de água é maior que o problema inicial, considera-se neste caso a possibilidade de utilização de tanques de estocagem (T1). A aplicação do método resulta no diagrama da Figura 10.

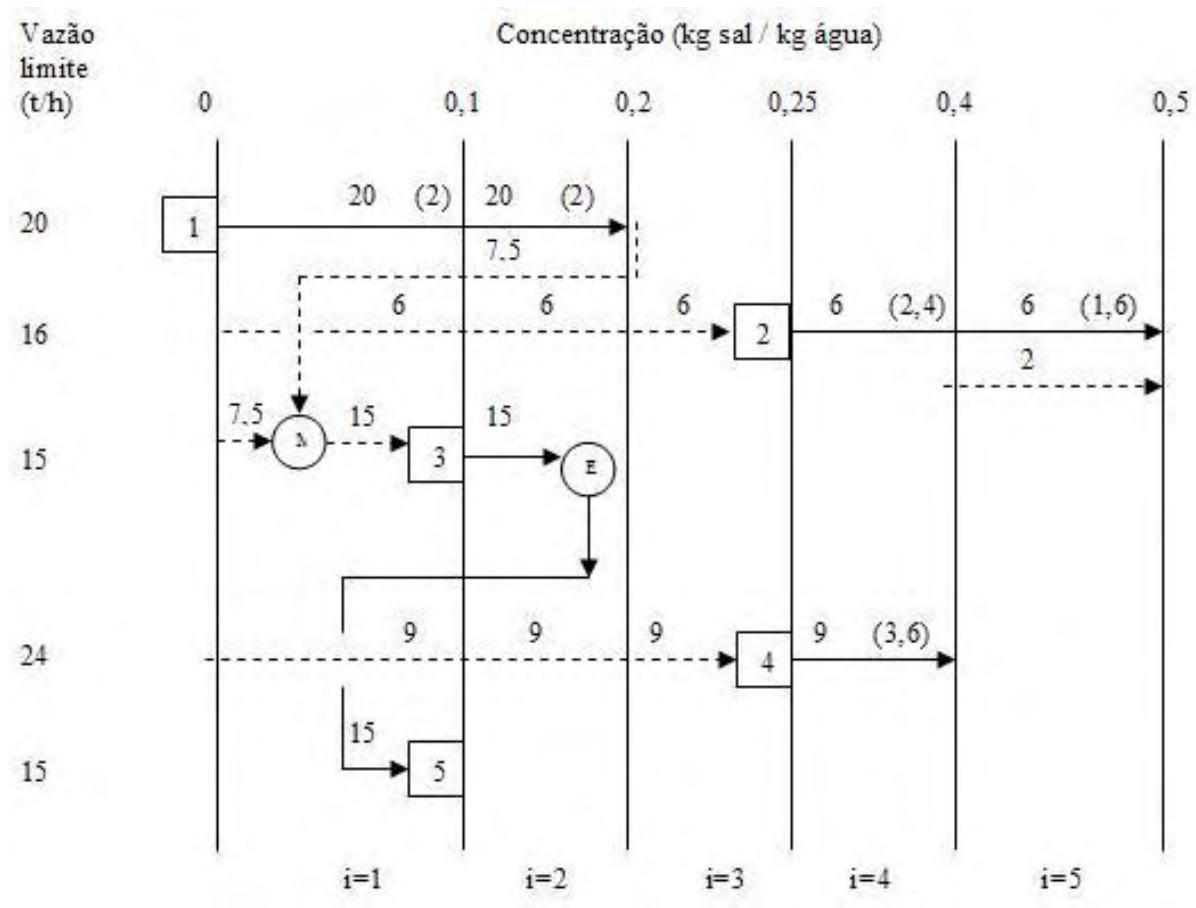

Figura 10. DFA gerado para o caso 1 - com uso de tanques de estocagem.

A Figura 11 apresenta uma proposta de fluxograma decorrente da aplicação do método. O consumo de água limpa é de 44,50 t por batelada, idêntico ao valor da proposta inicial apresentada por Chen e Lee (2008) (cenário 1).

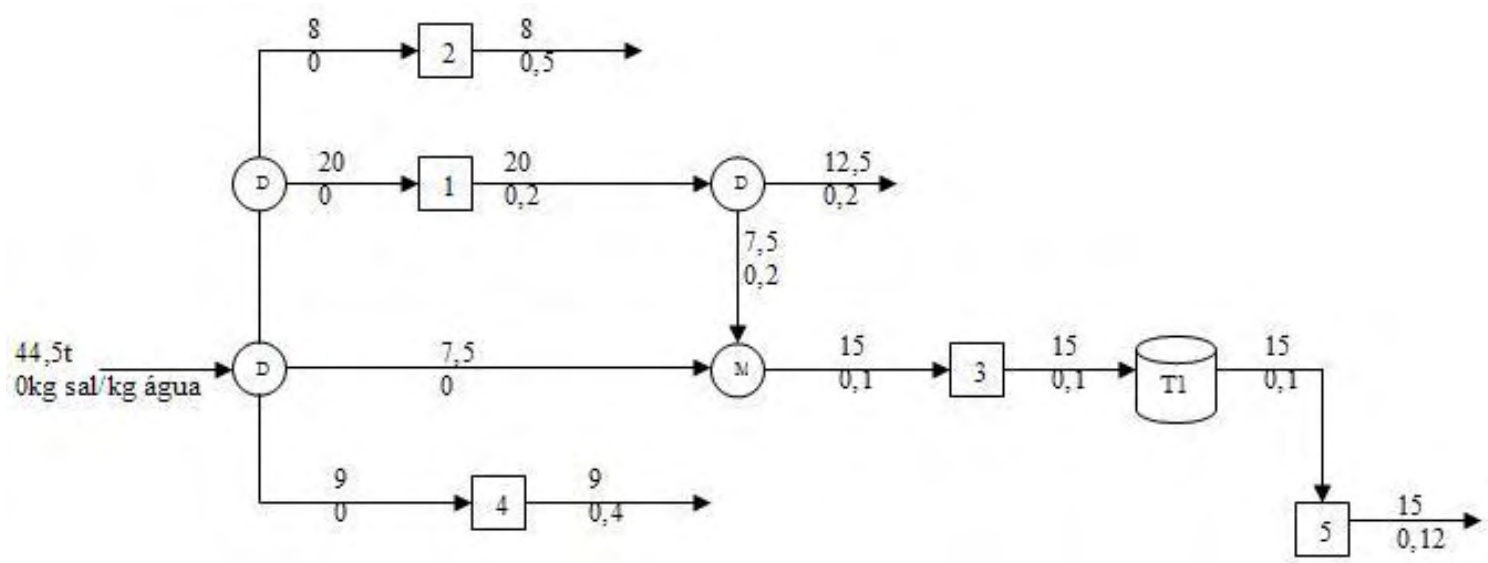

Figura 11. Fluxograma gerado - com tanque de estocagem (T1).

A metodologia aplicada em Tokos e Pintarič (2009) reduziu o consumo de água a 774,33 t/dia, gerando a mesma quantidade de efluente, destinado ao tratamento final de linha. Além disso, este procedimento requer o uso de unidades de tratamento da água. Foram regenerados neste processo 130,38 t de água, sendo necessário utilizar um tanque com capacidade para 
MIRRE, R. C.; FERREIRA, S. C. L.; DIAS, A. R.; PESSOA, F. L. P. Conservação e reúso de águas usando o método Diagrama de Fontes de Água para processos em batelada: estudo de casos. Ambi-Agua, Taubaté, v.7, n. 1, p. 182-203, 2012. (http://dx.doi.org/10.4136/ambi-agua.565)

43,46 t. Os dados limites para aplicação do método DFA encontram-se relacionados na Tabela 6.

Tabela 6. Dados limites do problema de Tokos e Pintarič (2009).

\begin{tabular}{c|cccc}
\hline Operação & Ce,max (ppm) & Cs, max (ppm) & $\mathbf{f}_{\mathbf{k}}(\mathbf{t})$ & Intervalo de tempo, ti (h) $-\mathbf{t f}(\mathbf{h})$ \\
\hline 1 & 24,25 & 425 & 41 & $0-16,0$ \\
2 & 100 & 299 & 261 & $12,0-16,0$ \\
3 & 100 & 980 & 47,20 & $0-16,0$ \\
4 & 100 & 330 & 46,20 & $0-16,0$ \\
5 & 24,25 & 56 & 46,90 & $4,0-8,0 \mathrm{e} 12,0-16,0$ \\
6 & 100 & 329 & 115,30 & $4,0-8,0$ \\
\hline
\end{tabular}

A operação 5 é uma operação de limpeza que ocorre em dois intervalos de tempo distintos. Por essa razão, visando à aplicação do método, a operação foi dividida em duas: (i) a operação 5', que ocorre no intervalo de 4 h a 8 h; e (ii) a operação 5', que ocorre no intervalo de $12 \mathrm{~h}$ a $16 \mathrm{~h}$. A Tabela 7 inclui os dados com essa adaptação.

Tabela 7. Dados adaptados para o cenário 4.

\begin{tabular}{c|cccc}
\hline Operação & Ce, $\mathbf{m a x}(\mathbf{p p m})$ & $\mathbf{C s ,} \mathbf{m a x}(\mathbf{p p m})$ & $\mathbf{f}_{\mathbf{k}}(\mathbf{t})$ & Intervalo de tempo, ti $(\mathbf{h})-\mathbf{t f}(\mathbf{h})$ \\
\hline 1 & 24,25 & 425 & 41 & $0-16,0$ \\
2 & 100 & 299 & 261 & $12,0-16,0$ \\
3 & 100 & 980 & 47,20 & $0-16,0$ \\
4 & 100 & 330 & 46,20 & $0-16,0$ \\
5, & 24,25 & 56 & 46,90 & $4,0-8,0$ \\
5, & 24,25 & 56 & 46,90 & $12,0-16,0$ \\
6 & 100 & 329 & 115,30 & $4,0-8,0$ \\
\hline
\end{tabular}

Neste problema, não existem operações que terminam no mesmo instante em que outras se iniciam, sendo necessário utilizar tanques de estocagem para que sejam levantadas oportunidades de reúso. Assim, avaliaram-se duas opções neste caso: na primeira, o método foi aplicado considerando a possibilidade de se utilizar mais de um tanque de estocagem; na segunda opção, utilizou-se somente um tanque de estocagem, recebendo as correntes de saída de todas as operações passíveis de reúso.

\subsection{Caso 2: DFA com mais de um tanque de estocagem - cenário 5}

O método foi aplicado considerando a possibilidade de se utilizar um tanque de estocagem para a saída de cada operação, de tal modo que pudesse ser reutilizada em outra que se inicie em um instante posterior. $O$ procedimento foi similar ao adotado no caso 1.

Para as operações $1,3,4,5$ ' e 6 , não existem outras fontes de água disponíveis, além da fonte externa. No momento em que estas operações se iniciam, nenhuma outra está finalizada, o que inviabiliza o reúso.

No instante $\mathrm{t}=12 \mathrm{~h}$ iniciam-se as operações 2 e 5". Como os intervalos de tempo são os mesmos, avalia-se primeiro a operação 5", pois seu início ocorre em um intervalo menor de concentração $(i=1)$.

Quando a operação 5" se inicia têm-se disponíveis duas fontes de água, provenientes das operações 5 ' e 6 , que terminaram em $t=8$ h. A saída de ambas viola a concentração 
MIRRE, R. C.; FERREIRA, S. C. L.; DIAS, A. R.; PESSOA, F. L. P. Conservação e reúso de águas usando o método Diagrama de Fontes de Água para processos em batelada: estudo de casos. Ambi-Agua, Taubaté, v.7, n. 1, p. 182-203, 2012. (http://dx.doi.org/10.4136/ambi-agua.565)

máxima de entrada da operação 5". Então, a operação selecionada para o reúso é a operação 5', já que possui menor concentração de saída que a operação 6 , e por isso menos água limpa terá que ser misturada a essa corrente, para que se alcance a concentração de entrada máxima na operação 5'. Assim, pode-se calcular a quantidade de água oriunda da operação 5', que requer a mínima quantidade de água limpa a ser misturada para o reúso, calculada em 26,59 t. O fluxograma obtido para este cenário encontra-se apresentado na Figura 12.

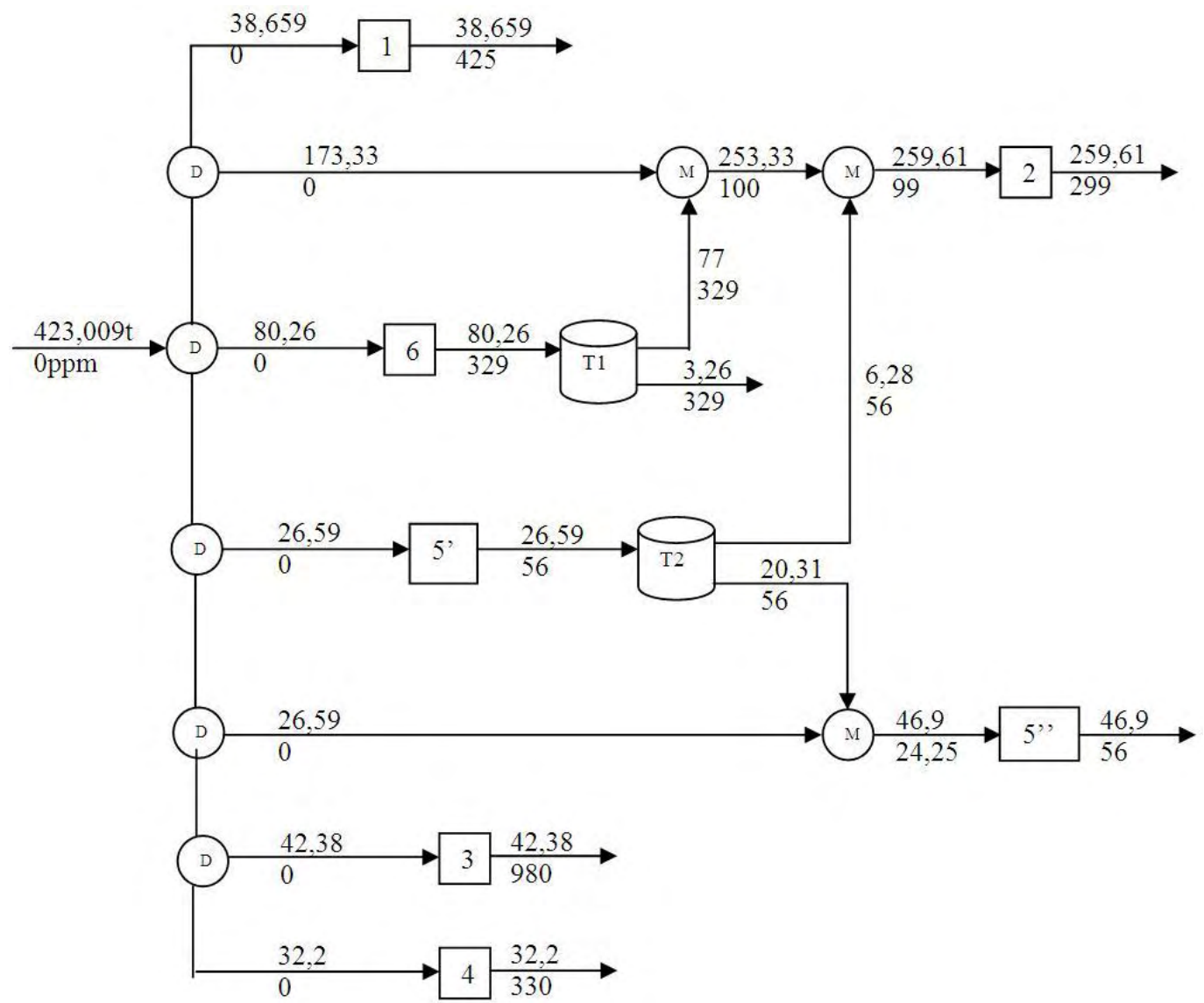

Figura 12. Fluxograma gerado - dois tanques de estocagem (T1 e T2).

Este cenário apresenta um consumo de água limpa de 423,01 t/dia. O consumo de água é $45,40 \%$ menor do que o consumo requerido para o cenário 4.

\subsection{Caso 2: DFA com apenas um tanque de estocagem - cenário 6}

Considerou-se aqui a possibilidade de se utilizar apenas um tanque de estocagem, para a aplicação do método.

Assim como no item anterior, as operações 1, 3, 4, 5' e 6 recebem água da fonte externa, e as saídas das operações 5' e 6 são reutilizadas nas operações 2 e 5'. No entanto, as saídas das operações 5' e 6 não são estocadas em diferentes tanques, sendo direcionadas para um mesmo tanque. Foram combinadas 26,59 t de água a 56 ppm com 80,26 t de água a 329 ppm, permitindo obter um tanque para recebimento de 106,85 t de água a $261 \mathrm{ppm}$. Com isso, a água estocada neste tanque em $\mathrm{t}=8 \mathrm{~h}$ é utilizada para alimentar as operações 2 e 5 ", que se iniciam em instantes posteriores; como a concentração de $261 \mathrm{ppm}$ é superior às concentrações limites de entrada de ambas operações, é necessário adicionar água limpa a estas correntes. 
MIRRE, R. C.; FERREIRA, S. C. L.; DIAS, A. R.; PESSOA, F. L. P. Conservação e reúso de águas usando o método Diagrama de Fontes de Água para processos em batelada: estudo de casos. Ambi-Agua, Taubaté, v.7, n. 1, p. 182-203, 2012. (http://dx.doi.org/10.4136/ambi-agua.565)

As quantidades de água limpa e de água proveniente do tanque a serem utilizadas para o reúso foram determinadas por meio de balanço material, como nos casos anteriores, e suas quantidades são descritas no fluxograma da Figura 13.

A demanda de água para este cenário foi de 423,63 t, representando uma redução de 45,20\% em relação à proposta inicial (cenário 4). Foram geradas 423,63 t de efluentes a serem destinados ao tratamento final.

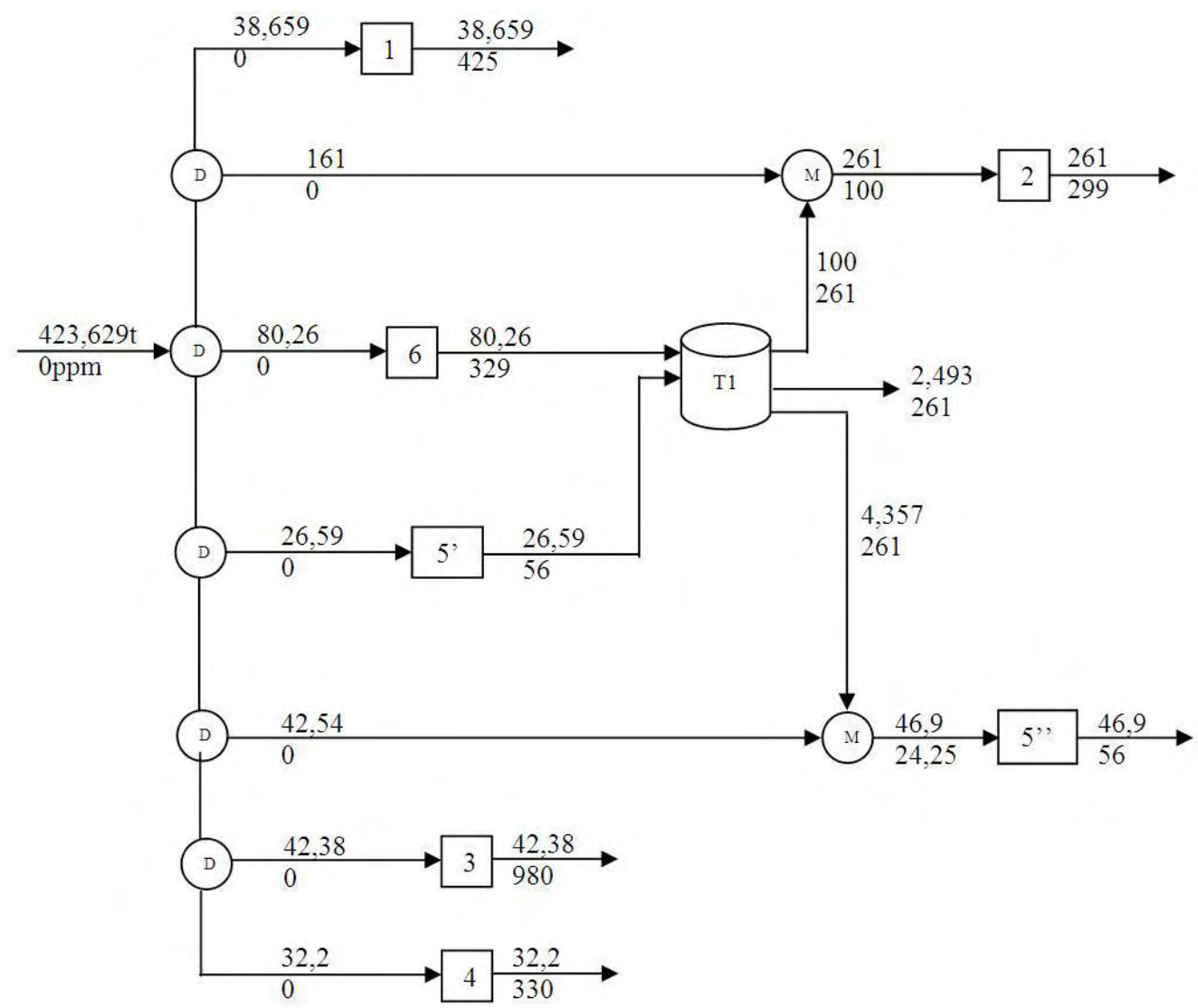

Figura 13. Fluxograma gerado - um tanque de estocagem (T1).

\subsection{Análise preliminar de custos}

As propostas de cenários promissores devem ser analisadas quanto à viabilidade econômica de sua implantação. Uma análise preliminar envolvendo a determinação de custos de investimento, que incorpora a parcela fixa, o capital de giro e a partida da planta, foi realizada.

As correlações para o cálculo dos custos de investimento e operacional relativos ao tratamento final de linha (end-of-pipe) e ao processo regenerativo disponível (stripping), adotado para fins comparativos, foram obtidas do trabalho de Wang e Smith (1994a). A depreciação anual do custo de capital é de 0,1 .

Para o caso 1, considerou-se como custo de investimento o custo da unidade de tratamento final e o custo dos tanques $\left(\mathrm{C}_{\mathrm{t}}\right)$, quando existem. Neste trabalho, utilizou-se uma correlação (Equação 2) obtida a partir de dados de Tokos e Pintarič (2009), relacionando um tanque cuja capacidade é de 43,36 t ao custo de 4.036,00 $€$, ou cerca de US\$ 5.560,00 (considerando $1,00 €=>$ US\$ 1,377), supondo que o tanque seja fabricado em aço inoxidável. A expressão torna-se válida para valores de capacidade de mesma ordem de grandeza.

$$
\mathrm{C}_{\mathrm{t}}=397,3 \cdot \mathrm{Q}^{0,7}
$$

em que Q é a capacidade de estocagem de água do tanque, em toneladas. 
MIRRE, R. C.; FERREIRA, S. C. L.; DIAS, A. R.; PESSOA, F. L. P. Conservação e reúso de águas usando o método Diagrama de Fontes de Água para processos em batelada: estudo de casos. Ambi-Agua, Taubaté, v.7, n. 1, p. 182-203, 2012. (http://dx.doi.org/10.4136/ambi-agua.565)

Assim, para um tanque com capacidade de $15 \mathrm{t}$, o investimento estimado foi da ordem de US\$ 2.673,00. Como cada batelada dura 8,5 h, admite-se que a unidade realize duas bateladas por dia, a fim de se estimar o custo anual.

Os resultados relativos a cada cenário obtido, em termos de vazão de água captada, efluente e água regenerada, encontram-se sintetizados na Tabela 8; já a Tabela 9 apresenta os custos estimados para cada cenário. Considera-se que o sistema opere 310 dias por ano, ou $5.270 \mathrm{~h} / \mathrm{ano}$, e que o custo da água tratada (0 ppm) seja de $0,3 \mathrm{US} \$ / \mathrm{t}$.

Tabela 8. Vazão de água captada, efluente e água regenerada para os cenários estudados.

\begin{tabular}{|c|c|c|c|c|}
\hline \multicolumn{5}{|c|}{ Caso 1} \\
\hline Cenário & $\begin{array}{l}\text { Consumo de } \\
\text { água por } \\
\text { batelada (t) }\end{array}$ & $\begin{array}{l}\text { Efluente para } \\
\text { tratamento } \\
\text { final }(\mathbf{t})\end{array}$ & $\begin{array}{c}\text { Água } \\
\text { regenerada }(t)\end{array}$ & $\begin{array}{l}\text { Tanques de } \\
\text { estocagem }\end{array}$ \\
\hline 1 & 44,50 & 44,50 & - & $\begin{array}{c}01 \text { tanque: capacidade } \\
\text { de } 15 \mathrm{t}\end{array}$ \\
\hline 2 & 55,75 & 55,75 & - & - \\
\hline 3 & 44,50 & 44,50 & - & $\begin{array}{c}01 \text { tanque: capacidade } \\
\text { de } 15 \mathrm{t}\end{array}$ \\
\hline \multicolumn{5}{|c|}{ Caso 2} \\
\hline Cenário & $\begin{array}{l}\text { Consumo de } \\
\text { água por } \\
\text { batelada (t) }\end{array}$ & $\begin{array}{l}\text { Efluente para } \\
\text { tratamento } \\
\text { final }(\mathbf{t})\end{array}$ & $\begin{array}{c}\text { Água } \\
\text { regenerada }(t)\end{array}$ & $\begin{array}{l}\text { Tanques de } \\
\text { estocagem }\end{array}$ \\
\hline 4 & 774,33 & 774,33 & 180,38 & $\begin{array}{c}03 \text { tanques: capacidades } \\
\text { de } 43,36 \text { t cada }\end{array}$ \\
\hline 5 & 423,01 & 423,01 & - & $\begin{array}{l}02 \text { tanques: capacidades } \\
\text { de } 80,26 \text { t e } 26,59 \mathrm{t}\end{array}$ \\
\hline 6 & 423,63 & 423,63 & - & $\begin{array}{c}01 \text { tanque: capacidade de } \\
106,85 \mathrm{t}\end{array}$ \\
\hline
\end{tabular}

Tabela 9. Custos estimados para os cenários estudados.

\begin{tabular}{|c|c|c|c|c|}
\hline \multicolumn{5}{|c|}{ Caso 1} \\
\hline Cenário & $\begin{array}{l}\text { Custo de } \\
\text { água limpa } \\
\text { (US\$/a) }\end{array}$ & $\begin{array}{c}\text { Custo de } \\
\text { tratamento final } \\
\text { do efluente (US\$/a) }\end{array}$ & $\begin{array}{c}\text { Custo de } \\
\text { investimento em } \\
\text { regeneração } \\
\text { (US\$/a) }\end{array}$ & $\begin{array}{c}\text { Custo de } \\
\text { investimento em } \\
\text { tanques (US\$/a) }\end{array}$ \\
\hline 1 & $8.277,00$ & $76.514,02$ & - & $2.644,74$ \\
\hline 2 & $10.369,50$ & $91.865,22$ & - & - \\
\hline 3 & $8.277,00$ & $76.514,02$ & - & $2.644,74$ \\
\hline \multicolumn{5}{|c|}{ Caso 2} \\
\hline Cenário & $\begin{array}{l}\text { Custo de } \\
\text { água limpa } \\
\text { (US\$/a) }\end{array}$ & $\begin{array}{c}\text { Custo de } \\
\text { tratamento final } \\
\text { do efluente (US\$/a) }\end{array}$ & $\begin{array}{c}\text { Custo de } \\
\text { investimento em } \\
\text { regeneração } \\
\text { (US\$/a) }\end{array}$ & $\begin{array}{c}\text { Custo de } \\
\text { investimento em } \\
\text { tanques (US\$/a) }\end{array}$ \\
\hline 4 & $144.025,38$ & $843.277,84$ & $175.609,23$ & $16.680,24$ \\
\hline 5 & $78.679,86$ & $499.784,16$ & - & $12.504,35$ \\
\hline 6 & $78.795,18$ & $500.412,97$ & - & $10.453,48$ \\
\hline
\end{tabular}


MIRRE, R. C.; FERREIRA, S. C. L.; DIAS, A. R.; PESSOA, F. L. P. Conservação e reúso de águas usando o método Diagrama de Fontes de Água para processos em batelada: estudo de casos. Ambi-Agua, Taubaté, v.7, n. 1, p. 182-203, 2012. (http://dx.doi.org/10.4136/ambi-agua.565)

Observa-se que a aplicação do método considerando o uso de tanque de estocagem constitui uma alternativa promissora, uma vez que o custo do caso base foi alcançado com o uso de metodologia mais simples do que a apresentada pela proposta inicial. Em relação ao caso 2, observa-se que a utilização do método levou a configurações de menores custos nesse processo, especialmente caso se adote um único tanque de estocagem para toda a unidade.

\section{CONCLUSÕES}

Este trabalho procurou contribuir para o desenvolvimento do método DFA, originalmente proposto para processos contínuos, para o caso de processos em batelada. $\mathrm{O}$ procedimento foi apresentado na forma de um exemplo da literatura, o que facilitou a discussão dos estudos de caso. Para cada intervalo de tempo de batelada foi aplicado um DFA, gerando sub-DFA's que se integram ao final, para que seja possível visualizar a elaboração do fluxograma hídrico. Dois estudos de caso foram realizados para estender a aplicação da metodologia. Os cenários gerados permitiram reduzir o consumo de água e a geração de efluentes em até $45 \%$, em relação à configuração inicial, com o uso de tanques de estocagem. Uma análise preliminar de custos também foi conduzida, em que o custo de investimento em tanques de estocagem reduziu em torno de $37 \%$, sem necessidade de processos regenerativos. Neste sentido, este trabalho procurou assinalar o potencial da metodologia aqui empregada, como uma alternativa flexível para o auxílio de ferramentas sistemáticas voltadas para a minimização do consumo de água e da geração de efluentes industriais, exercendo importante papel em um programa de gerenciamento de recursos hídricos.

\section{AGRADECIMENTOS}

Os autores agradecem ao Conselho Nacional de Desenvolvimento Científico e Tecnológico $(\mathrm{CNPq})$, pelo suporte financeiro.

\section{REFERÊNCIAS}

ALMATÓ, M.; ESPUÑA, A.; PUIGJANER, L. Optimisation of water use in batch process industries. Computers and Chemical Engineering, Oxford, v. 23, n. 10, p. 1427-1437, 1999. http://dx.doi.org/10.1016/S0098-1354(99)00302-6

ALMATÓ, M.; SANMARTÍ, E.; ESPUÑA, A.; PUIGJANER, L. Rationalizing the water use in the batch process industry. Computers and Chemical Engineering, Oxford, v. 21, Supplement, S971-S976, 1997.

ALVA-ARGÁEZ, A.; KOKOSSIS, A. C.; SMITH, R. Wastewater minimization of industrial systems using an integrated approach. Computers and Chemical Engineering, Oxford, v. 22, Supplement, S741-S744, 1998. http://dx.doi.org/10.1016/S00981354(98)00138-0

AMIM, R. S.; HASEGAWA, F. A.; LEITE, D. C.; PESSOA, F. L. P.; ULSON DE SOUZA, A. A. Aplicação do diagrama de fonte de água em processos em batelada - definição de metas. In: WORKSHOP GESTÃO E REÚSO DE ÁGUA NA INDÚSTRIA, 3., 22-24 nov. 2007, Florianópolis. Anais... Florianópolis: FEESC, 2007. 1 CD-ROM.

CASTRO, P.; MATOS, H.; FERNANDES, M. C.; PEDRO NUNES, C. Improvements for mass-exchange networks design. Chemical Engineering Science, Oxford, v. 54, n. 11, p. 1649-1665, 1999. http://dx.doi.org/10.1016/S0009-2509(98)00526-0 
MIRRE, R. C.; FERREIRA, S. C. L.; DIAS, A. R.; PESSOA, F. L. P. Conservação e reúso de águas usando o método Diagrama de Fontes de Água para processos em batelada: estudo de casos. Ambi-Agua, Taubaté, v.7, n. 1, p. 182-203, 2012. (http://dx.doi.org/10.4136/ambi-agua.565)

CHANG, C-T.; LI, B-H. Optimal design of wastewater equalization systems in batch processes. Computers and Chemical Engineering, Oxford, v. 30, n. 5, p.797-806, 2006. http://dx.doi.org/10.1016/j.compchemeng.2005.12.003

CHEN, C.; LEE, J. A graphical technique for the design of water-using networks in batch processes. Chemical Engineering Science, Oxford, v. 63, n. 14, p. 3740-3754, 2008. http://dx.doi.org/10.1016/j.ces.2008.04.047

CHEN, C-L.; LEE, J-Y.; TANG, J-W.; CIOU, Y-J. Synthesis of water-using network with central reusable storage in batch processes. Computers and Chemical Engineering, Oxford, v. 33, n. 1, p. 267-276, 2009.

http://dx.doi.org/10.1016/j.compchemeng.2008.09.013

DOYLE, S. J.; SMITH, R. Targeting water reuse with multiple contaminants. Process Safety and Environmental Protection, London, v. 75, n. 3, B, p. 181-189, 1997.

EL-HALWAGI, M. M.; MANOUSIOUTHAKIS, V. Synthesis of mass exchange networks. American Institute of Chemical Engineering Journal, New York, v. 35, n. 8, p. 1233-1244, 1989. http://dx.doi.org/10.1002/aic.690350802

FOO, C. Y.; MANAN, Z. A.; YUNUS, R. M.; AZIZ, R. A. Synthesis of mass exchange network for batch processes - Part I: utility targeting, Chemical Engineering Science, Oxford, v. 59, n. 5, p. 1009-1026, 2004. http://dx.doi.org/10.1016/j.ces.2003.09.043

FOO, C. Y.; MANAN, Z. A.; YUNUS, R. M.; AZIZ, R. A. Synthesis of mass exchange network for batch processes - Part II: minimum units target and batch network design, Chemical Engineering Science, Oxford, v. 60, n. 5, p. 1349-1362, 2005a. http://dx.doi.org/10.1016/j.ces.2004.10.008

FOO, D. C. Y.; MANAN, Z. A.; TAN, Y. L. Synthesis of maximum water recovery network for batch process systems, Journal of Cleaner Production, Knoxville, v. 13, n. 15, p. 1381-1394, 2005b. http://dx.doi.org/10.1016/j.jclepro.2005.04.013

GOMES, J. F. S.; QUEIROZ, E. M.; PESSOA, F. L. P. Design procedure for water/wastewater minimization: single contaminant. Journal of Cleaner Production, Knoxville, v. 15, n. 5, p. 474-485, 2007. http://dx.doi.org/10.1016/j.jclepro.2005.11.018

GOUWS, J. F.; MAJOZI, T. Usage of inherent storage for minimisation of wastewater in multipurpose batch plants. Chemical Engineering Science, Oxford, v. 64, n. 16, p. 3545-3554, 2009. http://dx.doi.org/10.1016/j.ces.2009.04.038

GOUWS, J. F.; MAJOZI, T.; GADALLA, M. Flexible mass transfer model for water minimization in batch plants. Chemical Engineering and Processing, New York, v. 47, n. 12, p. 2323-2335, 2008. http://dx.doi.org/10.1016/j.cep.2008.01.008

IMMICH, A. P. S.; GUSATTI, M.; MELLO, J. M. M.; GUELLI U.; SOUZA, S. M. A.; PESSOA, F. L. P. et al. Application of the water source diagram (WSD) procedure to water use minimization in a batch process. In: EUROPEAN CONGRESS OF CHEMICAL ENGINEERING, 6., 16-20 set. 2007, Copenhagen Proceedings... Copenhagen: EFCE, 2007. 1 CD-ROM.

JÖDICKE, G.; FISCHER, U.; HUNGERBÜHLER, K. Wastewater reuse: a new approach to screen for designs with minimal total costs. Computers and Chemical Engineering, Oxford, v. 25, n. 2/3, p. 203-215, 2001. 
MIRRE, R. C.; FERREIRA, S. C. L.; DIAS, A. R.; PESSOA, F. L. P. Conservação e reúso de águas usando o método Diagrama de Fontes de Água para processos em batelada: estudo de casos. Ambi-Agua, Taubaté, v.7, n. 1, p. 182-203, 2012. (http://dx.doi.org/10.4136/ambi-agua.565)

KIM, J. K.; SMITH, R. Automated design of discontinous water systems. Process Safety and Environmental Protection, London, v. 82, B3, p. 238-248, 2004. http://dx.doi.org/10.1205/095758204323066000

MAJOZI, T. Wastewater minimisation using central reusable water storage in batch plants. Computers and Chemical Engineering, Oxford, v. 29, n. 7, p. 1631-1646, 2005. http://dx.doi.org/10.1016/j.compchemeng.2005.01.003

MAJOZI, T.; BROUCKAERT, C. J.; BUCKLEY, C. A. A graphical technique for wastewater minimisation in batch processes. Journal of Environmental Management, New York, v. 78, n. 4, p. 317-329, 2006.

MAJOZI, T.; GOUWS, J. F. A mathematical optimisation approach for wastewater minimisation in multipurpose batch plants: multiple contaminants. Computers and Chemical Engineering, Oxford, v. 33, n. 11, p. 1826-1840, 2009a. http://dx.doi.org/10.1016/j.compchemeng.2009.06.008

MAJOZI, T.; GOUWS, J. F. Reliable method for water reuse in multicontaminant batch plants: NIS policy. Applied Mathematical Modelling, London, v. 33, n. 10, p. 37923800, 2009b. http://dx.doi.org/10.1016/j.apm.2008.12.005

MÉNDEZ, C. A.; CERDÁ, J.; GROSSMANN, I. E.; HARJUNKOSKI, I.; FAHL, M. Stateof-the-art review of optimization methods for short-term scheduling of batch processes. Computers and Chemical Engineering, Oxford, v. 30, n. 6/7, p. 913-946, 2006.

OLIVER, P.; RODRÍGUEZ, R.; UDAQUIOLA, S. Water use optimization in batch process industries. Part 1: design of the water network. Journal of Cleaner Production, Knoxville, v. 16, n. 12, p. 1275-1286, 2008. http://dx.doi.org/10.1016/j.jclepro.2007.06.012

PUIGJANER, L.; ESPUÑA, A.; ALMATÓ, M. A software tool for helping in decisionmaking about water management in batch process industries. Waste Management, New York, v. 20, n. 8, p. 645-649, 2000.

RABIE, A. H.; EL-HALWAGI, M. M. Synthesis and scheduling of optimal batch waterrecycle networks. Chinese Journal of Chemical Engineering, Beijing, v. 16, n. 3, p. 474-479, 2008.

SHOAIB, A. M.; ALY, S. M.; AWAD, M. E.; FOO, D. C. Y.; EL-HALWAGI, M. M. A hierarchical approach for the synthesis of batch water network. Computers and Chemical Engineering, Oxford, v. 32, n. 3, p. 530-539, 2008.

http://dx.doi.org/10.1016/j.compchemeng.2007.03.015

TOKOS, H.; PINTARIČ, Z. N. Synthesis of batch water network for a brewery plant. Journal of Cleaner Production, Knoxville, v. 17, n. 16, p. 1465-1479, 2009. http://dx.doi.org/10.1016/j.jclepro.2009.06.009

WANG, Y. P.; SMITH, R. Wastewater minimisation. Chemical Engineering Science, Oxford, v. 49, n. 7, p. 981-1006, 1994a. http://dx.doi.org/10.1016/0009-2509(94)80006-5

WANG, Y. P.; SMITH, R. Desing of distributed effluent treatment systems. Chemical Engineering Science, Oxford, v. 49, n. 18, p. 3127-3145, 1994b. http://dx.doi.org/10.1016/0009-2509(94)E0126-B 
MIRRE, R. C.; FERREIRA, S. C. L.; DIAS, A. R.; PESSOA, F. L. P. Conservação e reúso de águas usando o método Diagrama de Fontes de Água para processos em batelada: estudo de casos. Ambi-Agua, Taubaté, v.7, n. 1, p. 182-203, 2012. (http://dx.doi.org/10.4136/ambi-agua.565)

WANG, Y. P.; SMITH, R. Wastewater minimization with flowrate constraints. Transactions of the Institution of Chemical Engineers, London, v. 73 (A), p. 889-904, 1995a.

WANG, Y. P.; SMITH, R. Time pinch analysis. Transactions of the Institution of Chemical Engineers, London, v. 73 (A), p. 905-914, 1995 b.

ZHOU, R-J.; LI, L-J.; XIAO, W.; DONG, H-G. Simultaneous optimization of batch process schedules and water-allocation network. Computers and Chemical Engineering, Oxford, v. 33, n. 6, p. 1153-1168, 2009. http://dx.doi.org/10.1016/j.compchemeng.2008.11.008 


ISSN = 1980-993X - doi:10.4136/1980-993X
www.ambi-agua.net
E-mail: ambi-agua@agro.unitau.br
Tel.: (12) 3625-4212

\title{
Tratamento do lixiviado de aterro sanitário usando destilador solar
}

(http://dx.doi.org/10.4136/ambi-agua.815)

\author{
Lidiane Freire de Sá; José Fernando Thomé Jucá; \\ Maurício A. da Motta Sobrinho \\ Universidade Federal de Pernambuco, \\ Programa de Pós-Graduação em Engenharia Civil, Recife - PE \\ e-mails: lidifs@hotmail.com; jucah@ufpe.br; mottas@ufpe.br
}

\section{RESUMO}

Com o intuito de prover uma solução alternativa para o tratamento de lixiviados de aterros de pequeno porte, este trabalho apresenta os resultados do desenvolvimento, avaliação e otimização de um sistema de tratamento, baseado na evaporação natural. Para a avaliação foram monitorados parâmetros físico-químicos e microbiológicos, tais como a DQO, DBO, cor, turbidez, condutividade, sólidos totais e coliformes. Estudou-se também a influência da radiação solar, assim como a pluviometria/evaporação. Foi constatada uma redução de aproximadamente $100 \%$ na turbidez, cor e sólidos totais. Foi ainda observado que os resultados da DBO e DQO, assim como dos coliformes totais e fecais do destilado estiveram dentro dos padrões de lançamento do CONAMA 357/2005. Concluiu-se assim que este sistema é eficiente e viável para aterros de pequeno porte.

Palavras-chave: Destilador solar; Lixiviado; Evaporação.

\section{Treatment of landfill leachate using a solar destillar}

\section{ABSTRACT}

The subject of this research was to build, develop, evaluate and optimize a system of natural evaporation of leachate, to reduce the organic loads. Physical and chemical microbiological parameters were monitored during the experiment to evaluate the system performance. The solar radiation and rainfall influence on the evaporator was investigated. The results showed $100 \%$ reduction of the turbidity, color and total solids. The values of BOD, COD, thermotolerants and total coliforms in the treated effluent had concentrations that meet the Brazilian Federal Environmental Council (CONAMA) standards. Based on the results, it was concluded that the natural solar system was adequate for small landfills.

Keywords: Solar distillation; Leachate; Evaporation.

\section{INTRODUÇÃO}

Com o crescimento populacional nas cidades e aumento do consumo, está ocorrendo uma produção exacerbada de resíduos sólidos em todo mundo. Mesmo com avanços tecnológicos, o processamento do lixo não é eficiente, havendo um insignificante reaproveitamento e reciclagem do material, e uma grande quantidade de resíduos sendo lançados sem um tratamento adequado na natureza, formando os lixões. 
As consequências adversas da disposição de resíduos sólidos é um importante problema da atualidade que envolve a análise de migração de contaminantes a partir dos locais onde esses resíduos são dispostos, bem como garantia de estabilidade e impermeabilização dos locais usados para disposição dos mesmos. Dentre os contaminantes ou poluentes destes resíduos destacam-se os: cloretos, nitratos, metais pesados e compostos orgânicos de difícil degradabilidade (Oliveira, 1999).

No Brasil são produzidas aproximadamente 260 mil toneladas de Resíduos Sólidos Urbanos por dia, os quais representam um dos mais graves problemas de saneamento ambiental uma vez que apenas $27,7 \%$ são destinados a aterros sanitários e 50,8\% vão para vazadouros a céu aberto (IBGE, 2008). Estima-se que, em média, 55\% (em peso) dos Resíduos Sólidos Urbanos produzidos são constituídos de matéria orgânica putrescível, sendo imprescindível a busca de alternativas tecnológicas adequadas para o tratamento dos resíduos sólidos, líquidos e gasosos gerados na sua decomposição.

O resíduo líquido gerado da decomposição do material putrescível presente no lixo é denominado chorume, sendo também conhecido por lixiviado ou percolado. O chorume é somente o líquido proveniente da decomposição da matéria orgânica, e os lixiviados e/ou percolados são a solução do chorume e água, de origem superficial (chuva ou escoamento) ou subterrânea (infiltração), carreando materiais dissolvidos ou suspensos, proveniente da digestão anaeróbia da matéria orgânica por ação das exoenzimas produzidas pelas bactérias. Este líquido flui pela massa de lixo após atingir sua capacidade de campo ou de retenção (Rocha, 2005).

O Lixiviado ou percolado de aterros sanitários é originário de quatro diferentes fontes:

Da umidade natural do lixo, aumentando no período chuvoso;

Do líquido de constituição da matéria orgânica, que se origina durante o processo de decomposição;

Das bactérias existentes no lixo, que expelem enzimas e as mesmas dissolvem a matéria orgânica com formação de líquido;

De fontes de águas naturais existentes na área de disposição dos resíduos.

Os resíduos líquidos percolados representam a principal fonte de poluição em aterros sanitários, sendo os mesmos gerados pela infiltração de água das chuvas que percolam através da massa de resíduos, carreando os produtos da decomposição biológica e os elementos minerais em dissolução. Estes efluentes representam um problema de poluição potencial para as águas superficiais e principalmente, para as águas subterrâneas (Souza, 2005).

O impacto produzido pelo lixiviado sobre o meio ambiente está diretamente relacionado com a sua fase de decomposição. O lixiviado de aterro novo, quando recebe boa quantidade de água pluvial é caracterizado por $\mathrm{pH}$ ácido, altas concentrações de Demanda Bioquímica de Oxigênio $\left(\mathrm{DBO}_{5}\right)$ e de Demanda Química de Oxigênio (DQO) e diversos compostos potencialmente tóxicos, além de microorganismos patogênicos. Com o passar dos anos há uma redução significativa da biodegradabilidade devido à conversão em gás metano e $\mathrm{CO}_{2}$ de parte dos componentes biodegradáveis.

Pessin et al. (2000) relatam que o desenvolvimento da atividade microbiana no interior das células de aterramento, associado aos fatores ambientais, é capaz de promover a percolação de quantidades significativas do lixiviado. Em função da elevada concentração de matéria orgânica e de metais, o lixiviado constitui-se como um poluente extremamente agressivo ao ambiente, necessitando de tratamento anterior ao seu lançamento no corpo receptor.

Os processos de tratamento de efluentes se dividem em dois grandes grupos. Os que concentram o poluente (processos de separação e adsorção) e os que destroem os poluentes (basicamente os processos oxidativos químicos ou biológicos e pirolíticos). Como exemplos 
de processos que concentram o poluente têm-se a adsorção, filtração, processos com membrana (ultrafiltração, osmose inversa, etc.), decantação e evaporação, dentre outros.

A fim de obter um lixiviado de baixas concentrações, reduzindo principalmente amônia e DQO, o tratamento de lixiviado por evaporação se apresenta como uma nova tecnologia de baixo custo (Etalla, 1998). A Global Methane (Global Methane, 2010), cita na palestra intitulada "Controle de Lixiviado (Chorume) \& Tecnologias de Controle o sistema de lagoas de evaporação como uma unidade de tratamento para o lixiviado em grande escala.

A destilação solar utiliza a radiação solar (direta e difusa) para promover o aquecimento e mudança de fase do líquido, em um sistema extremamente simples, permitindo assim a remoção de contaminantes. O processo natural de purificação do líquido, por meio de evaporação, condensação e precipitação, é reproduzido em pequena escala. Esse equipamento, chamado de destilador solar, consiste basicamente em um tanque raso com um tampo de vidro transparente, formando um sistema estanque.

$O$ processo se realiza da seguinte forma: a radiação solar atravessa o vidro e aquece o líquido, promovendo a sua evaporação. $\mathrm{O}$ vapor sobe e condensa ao entrar em contato com o vidro mais frio. O líquido condensado escorre pela superfície interna do vidro até ser coletado nas canaletas, deixando para trás os sais, outros minerais e a maioria das impurezas, incluindo microorganismos nocivos à saúde (Figura 1).

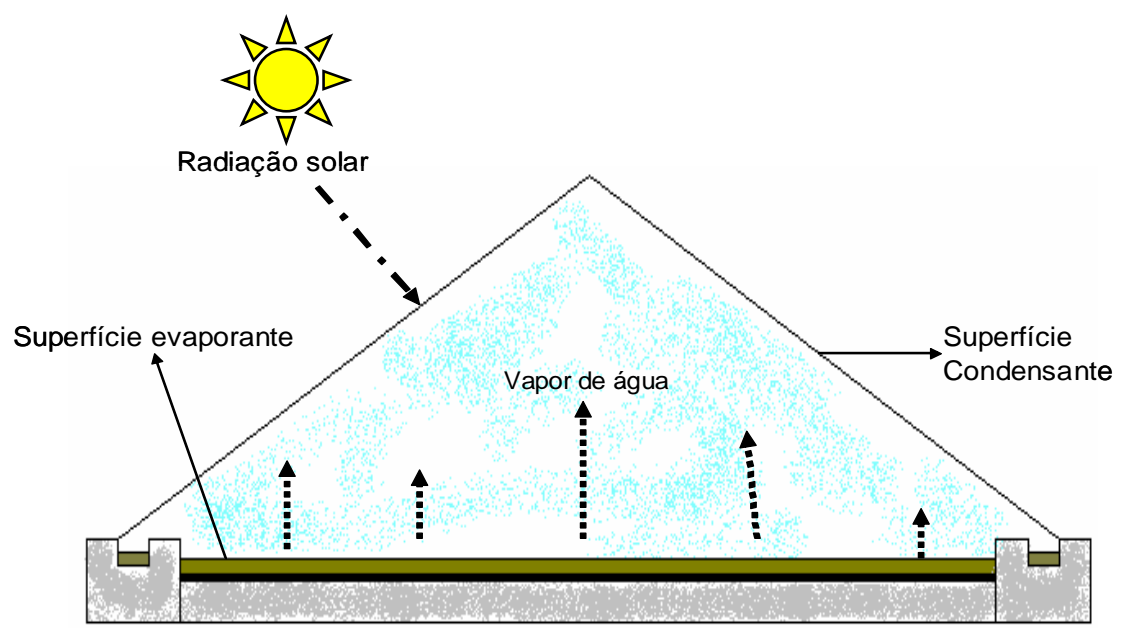

Figura 1. Esquema de um destilador solar.

Uma unidade piloto experimental foi montada com o objetivo de avaliar o processo de evaporação como uma nova alternativa para eliminar os impactos ambientais causados pelo lixiviado, concentrando as substâncias contidas no lixiviado como um resíduo sólido e eliminado os voláteis, como a amônia, por "stripping", diluindo-a no ar atmosférico. Desta forma, este estudo visa assim avaliar o processo de evaporação natural para tratar o lixiviado oriundo de um aterro sanitário. Essa tecnologia foi escolhida pela localização da região na qual foi realizado o experimento, ou seja, uma área que apresenta altas taxas de insolação, mas também apresentam médios a altos níveis de precipitação pluviométrica.

Existem ainda unidades de tratamento de lixiviados que utilizam o gás gerado nos aterros para promoverem a evaporação do lixiviado (Catanhede et al., 2009; Silva e Segato, 2002). O Sistema desenvolvido no aterro de Bauru, prevê uma evaporação de cerca de $5500 \mathrm{~kg} / \mathrm{h}$ de lixiviado considerando-se uma captação de $90 \%$ do metano gerado no aterro (Silva e Segato, 2002). Vários sistemas de tratamento de lixiviado por evaporação são apresentados por Birchler et al. (1994), mostrando inclusive sistemas de múltiplo estágio. Sistemas como estes, que utilizam o metano gerado no aterro, são aplicável para aterros de grande porte, que não são o foco deste trabalho. 


\section{MATERIAIS E MÉTODO}

\subsection{Amostragem}

O lixiviado utilizado para a realização dos experimentos proveio do Aterro da Muribeca, o qual recebe diariamente em média, 3.000 t/dia de resíduos dos municípios de Jaboatão dos Guararapes e Recife, sendo o maior do Estado de Pernambuco. Ele ocupa uma área de 60 hectares e localiza-se na zona rural do município de Jaboatão dos Guararapes (PE), à uma distância de $16 \mathrm{Km}$ do centro do Recife. O lixo que chega ao aterro é composto por $60 \%$ de matéria orgânica, $15 \%$ de papel, $8 \%$ de plástico, $2 \%$ de metais e $13 \%$ de outros materiais (Lins, 2003).

$\mathrm{O}$ aterro da Muribeca produz, diariamente $3 \pm 2 \mathrm{~L} / \mathrm{s}$ de líquidos lixiviados, dependendo da precipitação pluviométrica diária. Esse lixiviado é drenado e encaminhado para Estação de Tratamento do Lixiviado (ETC), que utiliza o processo de Sistema de Lagoas de Estabilização que, neste caso, é constituído por uma lagoa de decantação, uma lagoa anaeróbia e três lagoas facultativas.

Estudos realizados nesta estação (Rocha, 2005) mostraram que a concentração média de matéria orgânica (DQO) foi de $7.863 \mathrm{mgO}_{2} / \mathrm{L}$ e de matéria orgânica biodegradável (DBO) de $3.655 \mathrm{mgO}_{2} / \mathrm{L}$. Estes valores são altos comparados a um efluente doméstico, sobretudo quando se sabe que a vazão média situa-se em torno de $400 \mathrm{~m}^{3} /$ dia, o que dá uma carga orgânica de $1.462 \mathrm{~kg} \mathrm{DBO}_{5} /$ dia. Por outro lado, o sistema de lagoas, utilizado na ETC da Muribeca, não vem sendo eficiente na remoção da poluição, apresentando baixas eficiências de remoção e descarte fora dos limites estabelecidos pela resolução CONAMA 357/2005 (Brasil, 2005).

\subsection{A Unidade Piloto (Evaporador solar)}

O evaporador que funciona como um destilador solar (Figura 2) foi construído com as seguintes características: o tanque raso que é a base do destilador foi confeccionado em aço galvanizado, onde possui uma cobertura de vidro, que é inclinada do centro até as bordas para que o líquido se condense na superfície interior e escoe por gravidade até a calha. Para vedação entre os cantos do vidro e o tanque, foi utilizado silicone. As dimensões da unidade piloto são as seguintes: caixa de base: $1,00 \mathrm{~m}$ de largura $\mathrm{x} 1,50 \mathrm{~m}$ de comprimento $\mathrm{x} 0,30 \mathrm{~m}$ de altura; altura da base para o solo: $0,90 \mathrm{~m}$; calhas: $0,15 \mathrm{~m}$ de largura $\mathrm{x} 1,5 \mathrm{~m}$ de comprimento; vidro: 1,30 m de largura x 1,5 m de comprimento; inclinação da placa de vidro: $45^{\circ}$. A Figura 2 mostra uma foto do evaporador solar. As dimensões desta unidade foram baseadas no trabalho de Bezerra (2004) e nas discussões informais com o Grupo Fontes Alternativas de Energia (FAE) da UFPE. O aumento na escala do referido sistema implica na utilização de vários sistemas em paralelo, assim como ocorre para a produção de água potável por destilação solar. O aumento no porte de cada unidade está limitada por esforços mecânicos e resistência dos materiais, sobretudo do vidro de cobertura

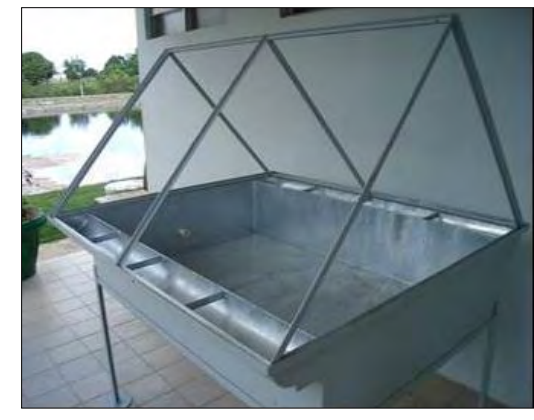

Figura 2. Foto da unidade piloto de tratamento do Lixiviado por evaporação. 


\subsection{Local de Estudo}

O Evaporador solar foi instalado na área de testes do grupo Fontes Alternativas de Energia (FAE) do Departamento de Energia Nuclear (DEN) na UFPE, no sentido norte-sul, com uma das faces voltadas ao nascente e a outra ao poente, de modo melhor aproveitar a incidência dos raios solares. O Grupo FAE forneceu dados de radiação solar, de modo estudar a influência da radiação solar na produção de efluente tratado. Além disso, a facilidade de acesso ao experimento, uma vez que o mesmo, sendo realizado dentro do campus, viabilizou a coleta de uma maior variedade de dados e um monitoramento mais intenso do experimento.

\subsection{Pontos de Amostragem e Procedimento de Coleta}

O preenchimento do evaporador foi realizado com o lixiviado coletado na saída da lagoa de decantação do sistema de tratamento da Muribeca (Jaboatão doa Guararapes/PE). Para avaliar a eficiência do sistema, em função da qualidade do efluente tratado, foram coletadas amostras do efluente tratado na calha que recebe o líquido evaporado que foi condensada na cobertura de vidro (Figura 3).
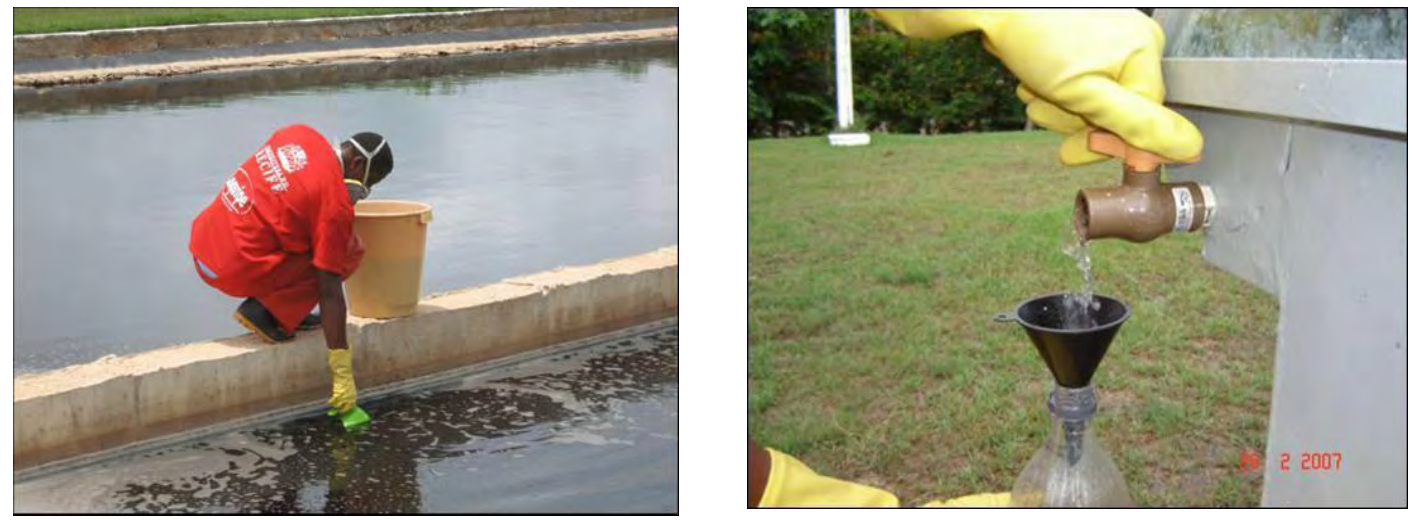

Figura 3. Coleta do lixiviado na lagoa de decantação e coleta do destilado.

\subsection{Coletas dos dados}

O monitoramento da operação do destilador para determinação de sua eficiência na remoção de contaminantes foi realizado de 04 de julho a 14 de novembro de 2007, divididos em três Fases. A Fase I foi realizada de 04 de julho a 12 de setembro de 2007, perfazendo um total de 70 dias. Fase II iniciou dia 13 de setembro sendo finalizada 02 de outubro tendo uma duração de vinte dias, já a Fase III teve duração de quatorze dias iniciando-se 01 de novembro e finalizando no dia 14 de novembro. As análises Físico - Químicas foram realizadas segundo o Standart Methods (APHA et al., 1995). Também foi monitorada a radiação solar e os dados pluviométricos foram fornecidos pelo ITEP (Instituto de Tecnologia de Pernambuco). Estes dados são fundamentais para se estimar o rendimento da evaporação do lixiviado, ou seja, o quanto de efluente tratado foi produzido a cada dia.

\section{RESULTADOS E DISCUSSÃO}

\subsection{Análise do Destilado}

A Figura 4 apresenta os valores de $\mathrm{pH}$ do efluente tratado. Pode-se observar que os valores variaram entre 8,5 e 9,7, indicando assim um $\mathrm{pH}$ levemente alcalino. $\mathrm{O}$ valor do $\mathrm{pH}$ do lixiviado nas três fases (respectivamente 8,14, 8,52 e 8,63) manteve-se praticamente constante. $\mathrm{O}$ fato do $\mathrm{pH}$ ser levemente alcalino, está associado à presença principalmente da amônia, que é transferida por stripping do lixiviado bruto para o efluente tratado. 


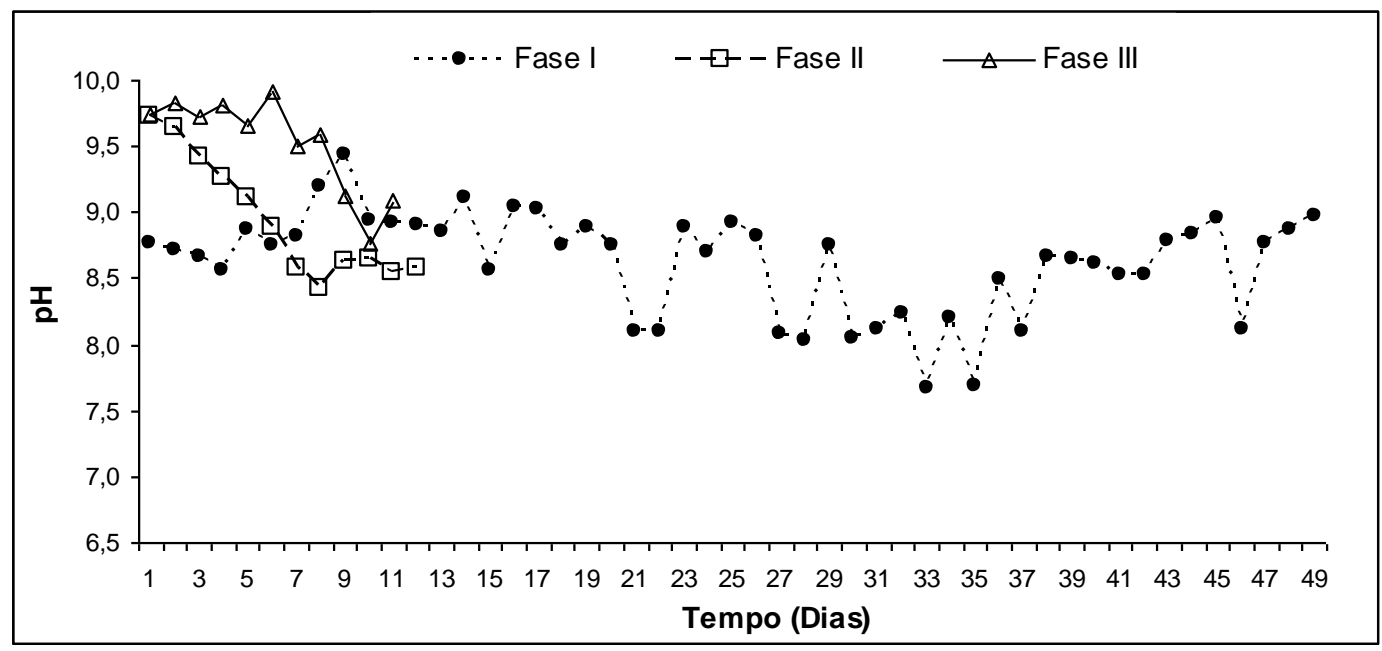

Figura 4. Variação do pH do efluente tratado.

Na Figura 5 encontram-se os resultados para condutividade, através dos quais pode-se observar a redução de condutividade no destilado, haja vista que a destilação solar fornece um condensado (efluente tratado) quase isento de sais, que conferem condutividade à mesma.

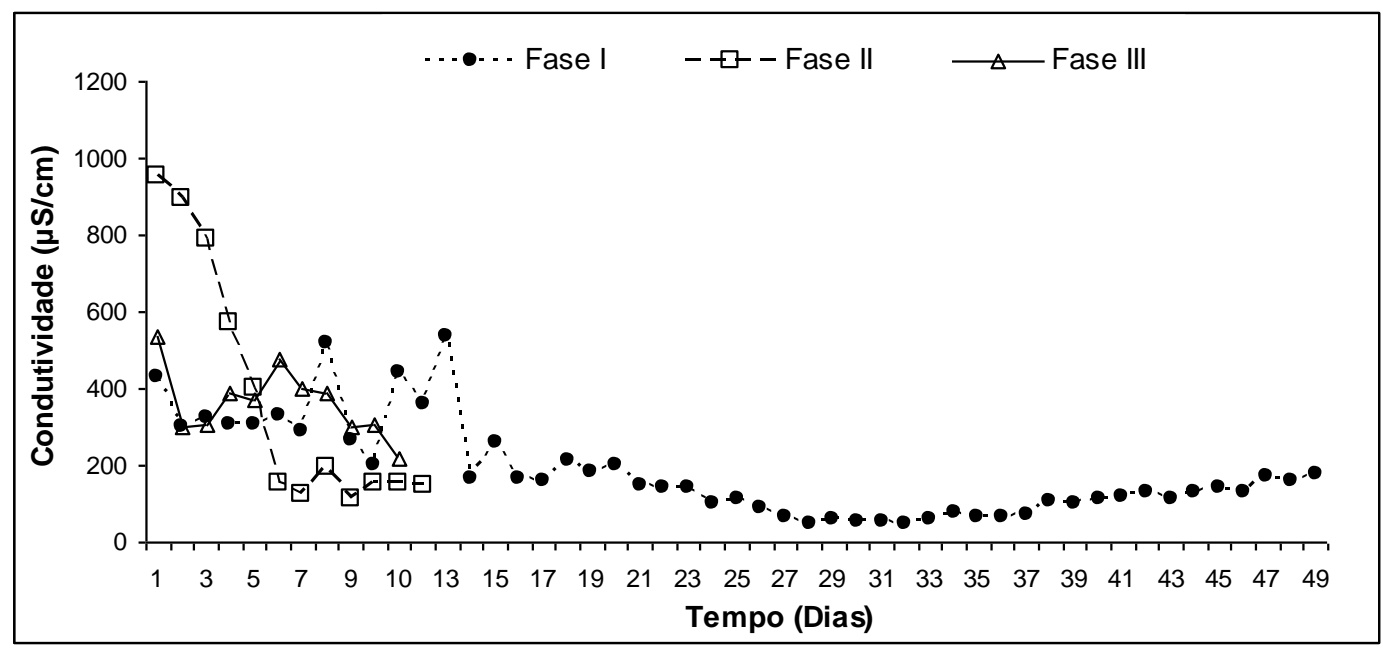

Figura 5. Variação da Condutividade Elétrica do efluente tratado.

As Figuras 6, 7 e 8 apresentam os resultados para as determinações da turbidez, cor e sólidos totais, respectivamente, do efluente tratado. Observa-se que a turbidez, cor e sólidos totais no Lixiviado nas Fases I, II e III são de 288, 613 e 170,4 UNT, 6115, 7180 e 11160 Hazen e 7760, 7702 e $11456 \mathrm{mg} / \mathrm{L}$ respectivamente. Essa redução ocorre porque o efluente tratado (de qualidade próxima à uma água destilada) é obtido por evaporação condensação e, portanto, livre de material em suspensão (principal causador da turbidez e cor). $\mathrm{O}$ acréscimo nos valores da turbidez, cor, e sólidos totais, no efluente tratado no início dos experimentos deve-se principalmente ao arraste de pequenas partículas em suspensão e de substâncias voláteis.

Pode-se observar que ocorreram aumentos nos valores de cor e turbidez e principalmente nos de sólidos totais. Esse fato sugere duas hipóteses: os recipientes para a coleta não estavam devidamente lavados, ou ocorreu infiltração de partículas pela vedação dos vidros durante as chuvas. 
SÁ, L. F.; JUCÁ, J. F. T.; MOTTA SOBRINHO, M. A. Tratamento do lixiviado de aterro sanitário usando destilador solar. Ambi-Agua, Taubaté, v. 7, n. 1, p. 204-217, 2012. (http://dx.doi.org/10.4136/ambi-agua.815)

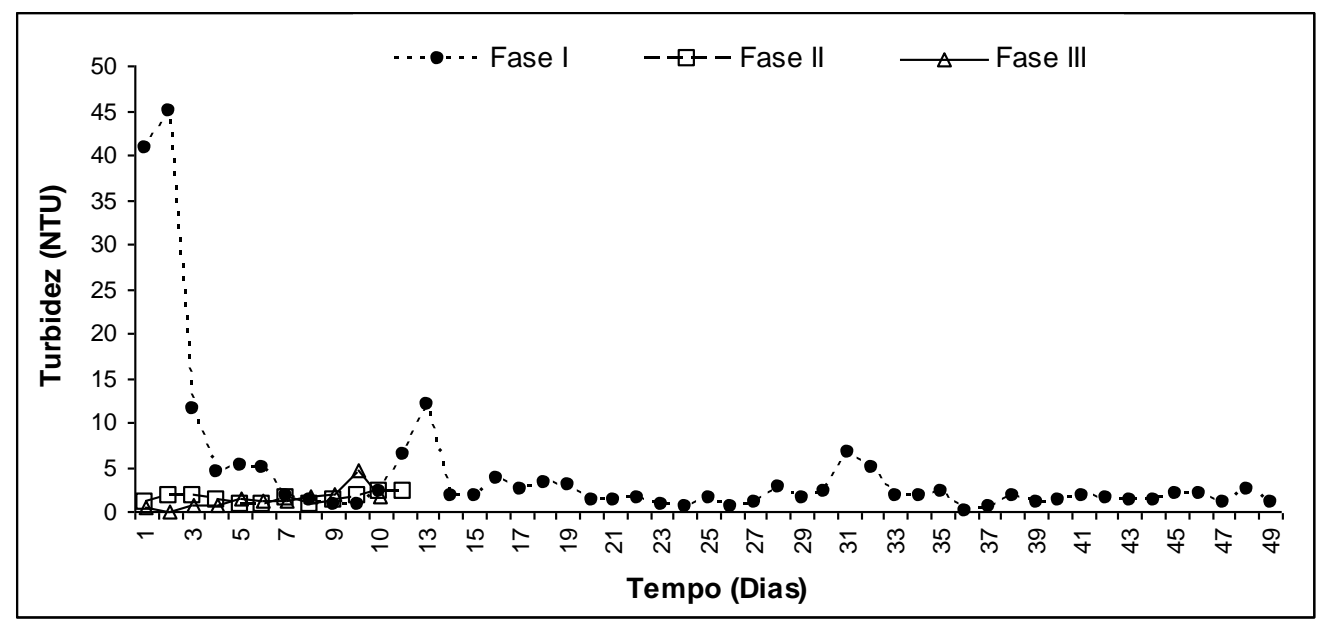

Figura 6. Variação da turbidez do efluente tratado.

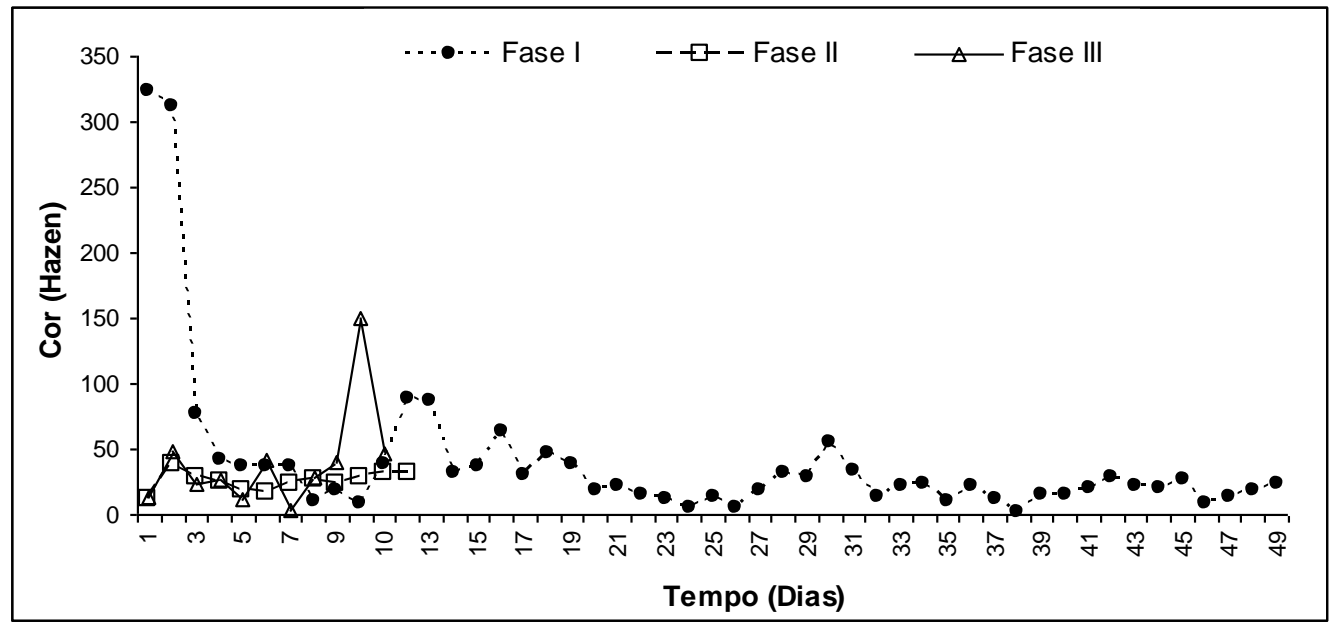

Figura 7. Variação da cor do efluente tratado.

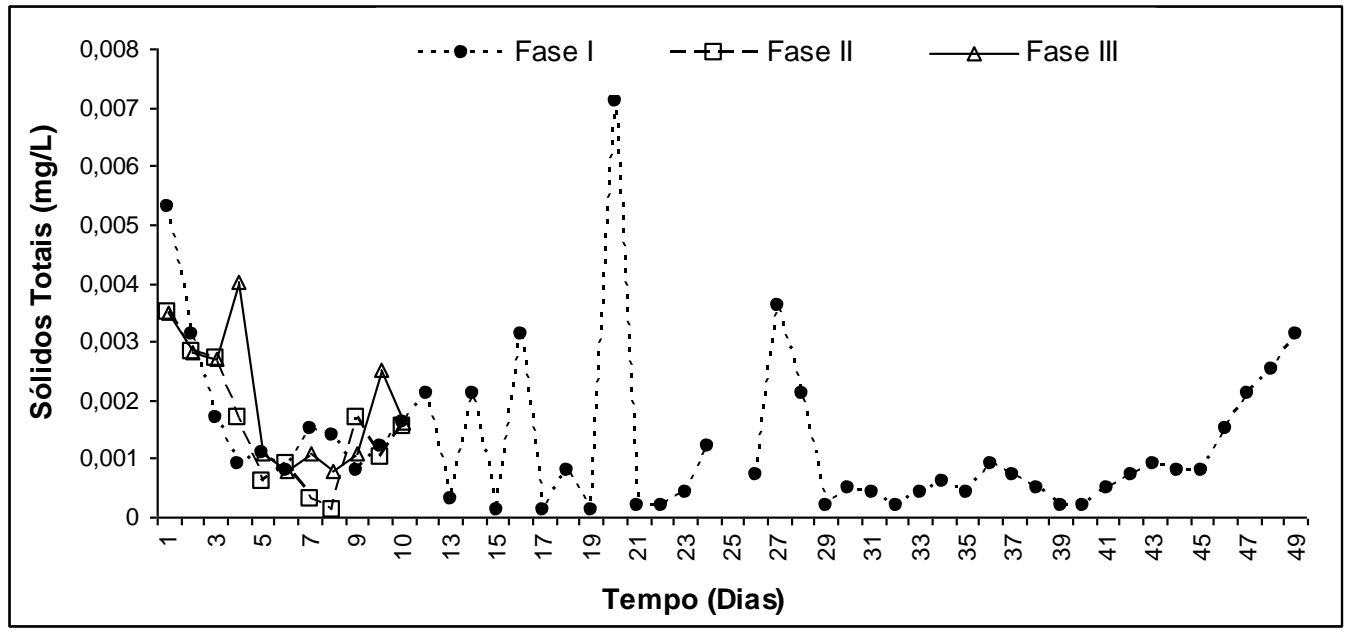

Figura 8. Variação dos Sólidos Totais do efluente tratado.

Na Figura 9 são apresentados os resultados das análises da DQO. Observa-se que nas três fases estudadas, no primeiro dia sempre ocorrem os maiores valores. Pode ocorrer que no início, os orgânicos voláteis sejam transferidos inicialmente da fase líquida (lixiviado) para o vapor e em seguida para a líquida (efluente tratado). 
SÁ, L. F.; JUCÁ, J. F. T.; MOTTA SOBRINHO, M. A. Tratamento do lixiviado de aterro sanitário usando destilador solar. Ambi-Agua, Taubaté, v. 7, n. 1, p. 204-217, 2012. (http://dx.doi.org/10.4136/ambi-agua.815)

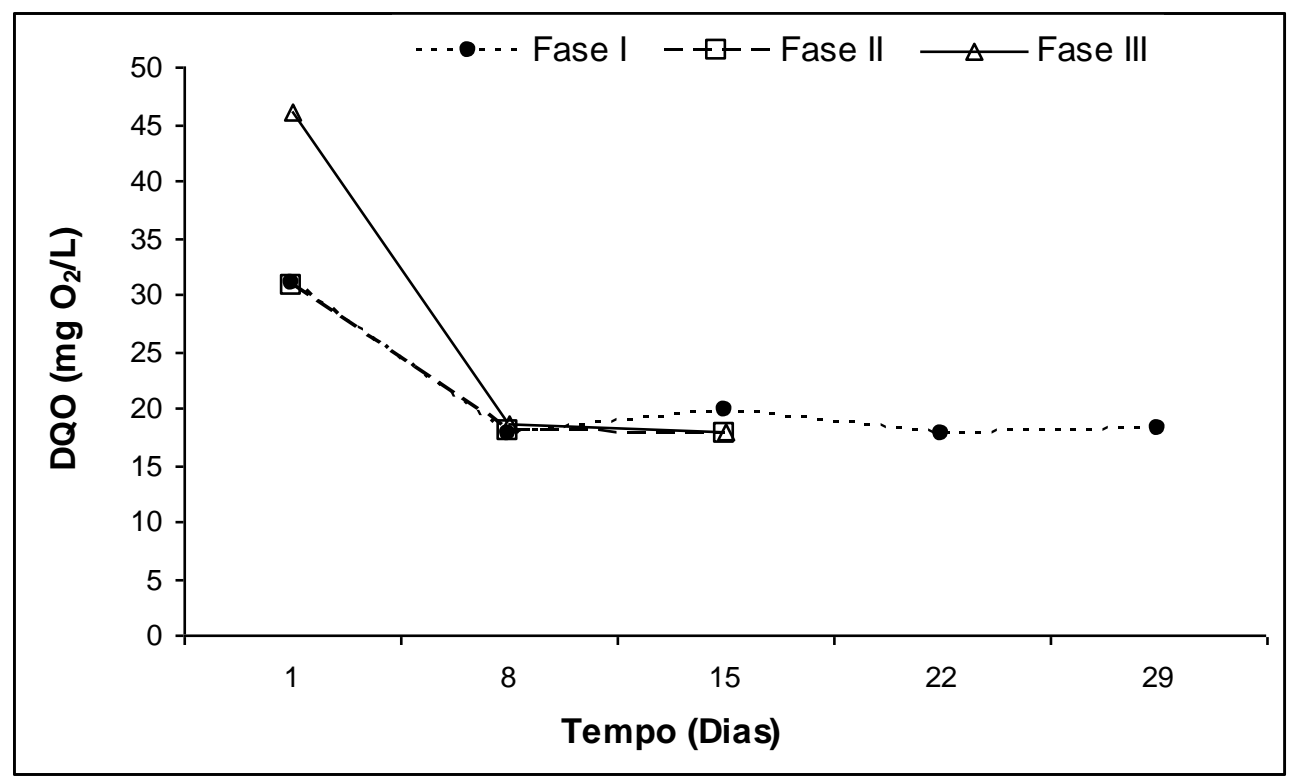

Figura 9. Variação do DQO do efluente tratado.

O fato acima pode também explicar os elevados valores obtidos para a DBO, que foram de 29, 27, e 21mg $\mathrm{O}_{2} / \mathrm{L}$ para as Fases I, II e III, respectivamente. Comparando estes, com os valores de DBO do lixiviado, 2164, 3644 e $4308 \mathrm{mg} \mathrm{O} / \mathrm{L}$, observam-se reduções acima de 98\%. A Figura 10 mostra que não ocorre muita variação da DBO, entre os experimentos, ao final da primeira semana. Desta forma fica claro que o Evaporador Solar cumpre a função de tratar o lixiviado, ou seja, obter um efluente tratado. Todavia o valor obtido da DBO para este efluente tratado está acima do permitido pela resolução 357/05 do CONAMA. Vale frisar que assim como a concentração da DQO foi reduzida ao longo do experimento, o mesmo deve ter acontecido para a DBO, de forma que se assumirmos a relação DBO/DQO como constante e adotarmos os valores da Fase III, temos uma relação DBO/DQO de 0,46 e como a partir da segunda semana a DQO que está um pouco abaixo de $20 \mathrm{mgO}_{2} / \mathrm{L}$, logo a DBO estar abaixo de $10 \mathrm{mgO}_{2} / \mathrm{L}$, respeitando assim a legislação.

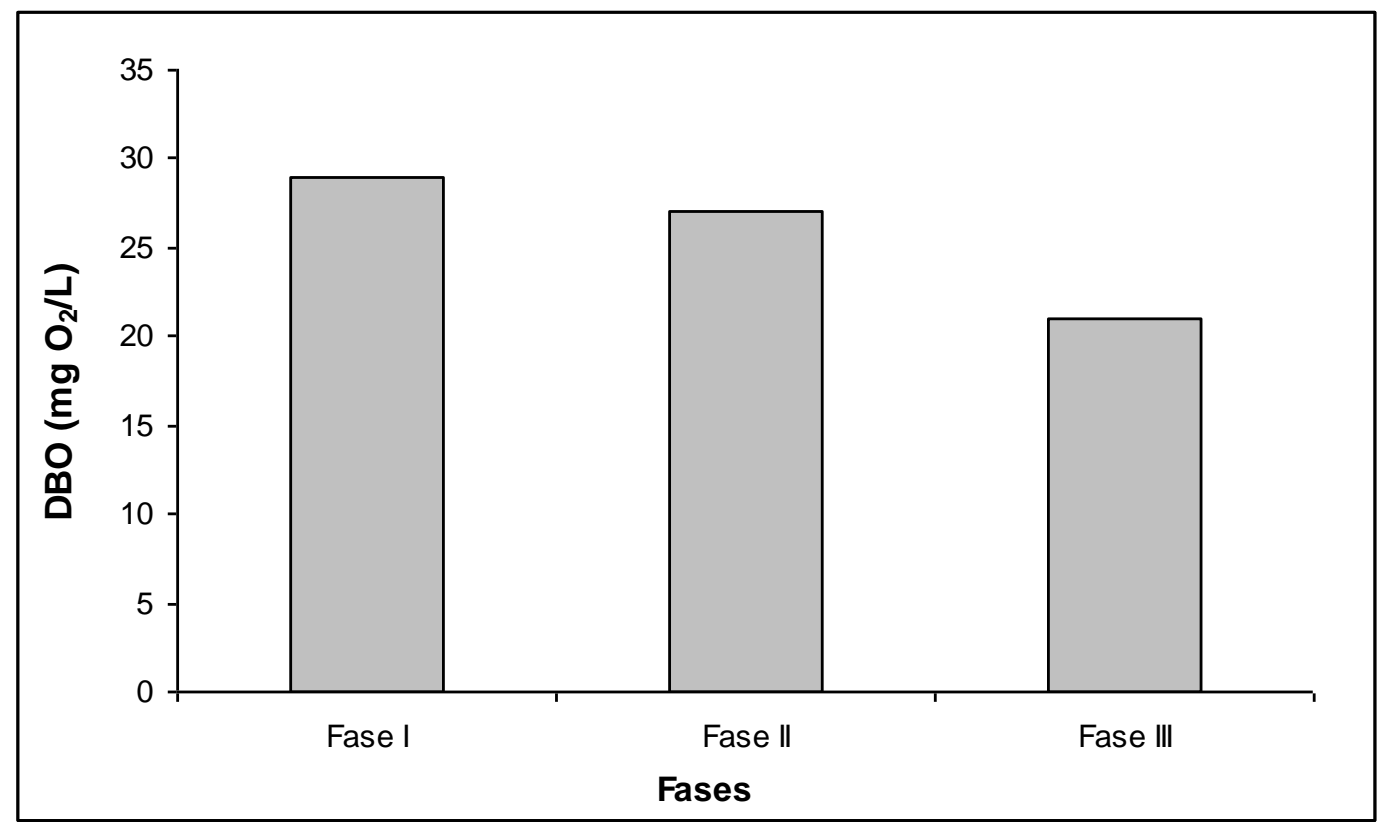

Figura 10. DBO do efluente tratado nas fases I, II e III, após a $1^{\circ}$ semana do experimento. 
Os valores de coliformes totais e termotolerantes determinados foram de $1,6 \times 10^{6}$ e 9,0 x $10^{4}$ respectivamente, para Fase I, nota-se que seus valores apresentaram elevação quando comparados com a Fase II e III, apresentados na Tabela 1. O motivo desse aumento para as análises de coliforme pode ter sido contaminação durante a coleta.

Para as Fases II e III, o resultado de coliformes totais e termotolerantes foi de ausência. Com base nos resultados obtidos nos experimentos, foi possível observar que o evaporador solar tem capacidade para reduzir a contaminação fecal a níveis compatíveis com o padrão de qualidade sanitária recomendado para lançamento de efluentes em corpos receptores naturais. Brandão (2000 apud PROSAB, 2001) afirma que para um elevado grau de contaminação, a eliminação total de coliformes pode ser conseguida com um tempo de exposição de duas horas a uma temperatura do líquido de $50^{\circ} \mathrm{C}$. As temperaturas observadas no interior do equipamento (no ar) foram iguais ou superiores a este valor, indicando que o líquido estava a uma temperatura acima desta, garantindo assim a eliminação dos coliformes.

A Tabela 1 apresenta os resultados obtidos através da destilação solar, sendo que esses valores são valores médios. Através da observação da Tabela verifica-se que todos os parâmetros apresentaram índices de remoção.

Tabela 1. Resumo dos resultados das análises estudadas e suas remoções.

\begin{tabular}{|c|c|c|c|c|c|c|c|c|c|}
\hline \multirow{3}{*}{$\begin{array}{l}\text { PARÂMETROS } \\
\text { Cor (Hazen) }\end{array}$} & \multicolumn{3}{|c|}{ FASE I } & \multicolumn{3}{|c|}{ FASE II } & \multicolumn{3}{|c|}{ FASE III } \\
\hline & LIX & DES & $\%$ & LIX & DES & $\%$ & LIX & DES & $\%$ \\
\hline & 6115 & 39,39 & 99,35 & 7180 & 25,08 & 99,65 & 11160 & 39,45 & 99,64 \\
\hline Turbidez (UNT) & 288,1 & 4,10 & 98,57 & 613 & 1,37 & 99,77 & 170,4 & 1,46 & 99,14 \\
\hline $\begin{array}{l}\text { Condutividade } \\
\qquad(\mu \mathrm{S} / \mathrm{cm})\end{array}$ & 12800 & 135,77 & 98,93 & 14945 & 345,1 & 97,69 & 22310 & 363,2 & 98,37 \\
\hline $\begin{array}{c}\text { Sólidos Totais } \\
(\mathrm{mg} / \mathrm{L})\end{array}$ & 7760 & 0,0012 & 99,99 & 7702 & 0,01 & 99,99 & 11456 & 0,0017 & 99,99 \\
\hline DBO (mg/L) & 2164 & 29 & 98,65 & 3644 & 27 & 99,25 & 2430 & 21 & 99,13 \\
\hline DQO (mg/L) & 4308 & 31 & 99,28 & 4380 & 30,72 & 99,29 & 3967,3 & 46 & 98,84 \\
\hline $\begin{array}{c}\text { Coliformes } \\
\text { Termotolerante } \\
\text { (NPJM/100ml) }\end{array}$ & $3 \times 10^{6}$ & $9 \times 10^{4}$ & 97 & $5 \times 10^{5}$ & 0 & 100 & $5 \times 10^{5}$ & 0 & 100 \\
\hline $\begin{array}{l}\text { Coliformes Totais } \\
\text { (NPJM/100ml) }\end{array}$ & $3 \times 10^{6}$ & $16 \times 10^{4}$ & 94 & $9 \times 10^{5}$ & 0 & 100 & $13 \times 10^{5}$ & 0 & 100 \\
\hline
\end{tabular}

em que: LIX - Lixiviado, DES- Destilado, \% - Remoção.

A comprovação da eficiência da remoção da contaminação microbiológica pode ser feita ao se observar os valores obtidos para os coliformes totais e termotolerante, que apresentação uma redução de aproximadamente 100\%. Para análises- físico-químicas houve um decréscimo dos valores de condutividade, turbidez, cor e sólidos totais. Estes valores estão dentro de padrões estabilizados pela norma CONAMA 357/2005. Como se pode perceber, a destilação solar apresenta-se como uma alternativa viável para tratamento do lixiviado. 
A análise de amônia só foi realizada na Fase III. O efluente tratado apresenta um forte odor de amônia, no início do experimento, devido ao "stripping" da amônia. A amônia é transferida do lixiviado para o destilado (absorção da amônia no líquido). A Figura 11 mostra a diminuição do nitrogênio amoniacal, com o decorrer dos dias, no efluente tratado. Com o passar do tempo o nitrogênio amoniacal do lixiviado foi sendo eliminado gradativamente através do efluente tratado.

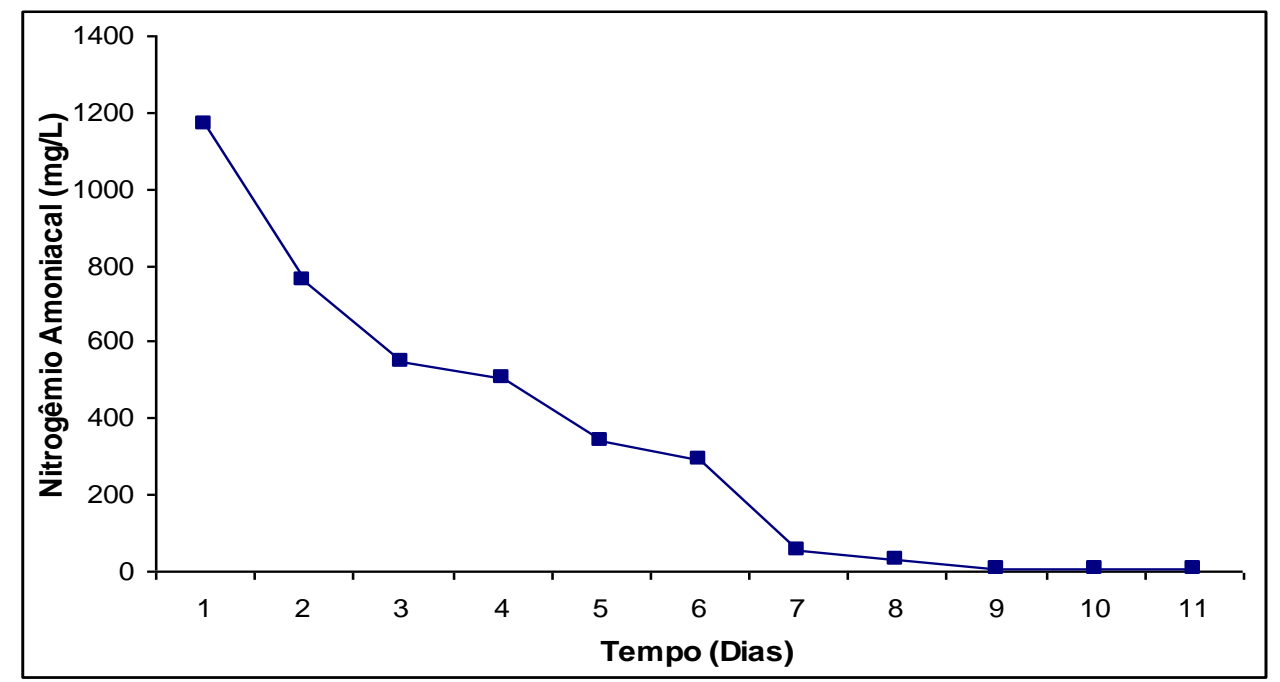

Figura 11. Variação dos valores do nitrogênio amoniacal da Fase III.

\subsection{Análise da Radiação solar e da precipitação}

Nessa parte do trabalho buscou-se estudar o comportamento da radiação solar e os dados pluviométricos, de forma que se possa avaliar o rendimento da evaporação do lixiviado, ou seja, o quanto de efluente tratado foi gerado a cada dia.

A evaporação dentro do evaporador solar é muito rápida e após cinco minutos de operação já pode ser visualizado o vapor devido à radiação solar. Entretanto a condensação só começa a ser percebida aproximadamente uma hora depois de iniciado o experimento. A Figura 12 apresenta os dados de radiação solar total e de efluente produzido (volume evaporado) em função do tempo nas três Fases estudadas. Pode-se assim observar a influência da radiação solar na evaporação do lixiviado e, por conseguinte, na produção de efluente tratado (observar elipses na Figura 12). Pode-se constatar que a cada queda da radiação solar, ocorre também uma redução no volume do efluente tratado. Também pode se perceber que no decorrer dos dias existem picos que chegam acima de $20 \mathrm{~mL}$. Contudo estes valores correspondem ao volume evaporado durante todo o fim de semana (que não se tem acesso ao sistema - destaque quadrado na Figura12). Desta forma este pico deve ser dividido por três pra se ter uma idéia mais realista.

Também pode se observar na Figura 12, que na Fase I a radiação apresentou valores mais baixos. A razão é que essa época do ano é mais chuvosa. Devido a isso, esta fase teve uma duração maior. Já nas Fases II e III houve um aumento no valor da radiação solar, ou seja, é nos meses de setembro a fevereiro que são observados os maiores índice de insolação.

Marcelo (1996 apud Bezerra, 2004) comenta que as perdas de energia dependem das condições meteorológicas, com irradiação, temperatura do ar, velocidade dos ventos e do projeto evaporador. Incluindo nesse item tipo de material, forma e orientação do evaporador e profundidade da camada a evaporar, que afeta a variação diária da temperatura do líquido, o que tem influência decisiva nas perdas. Estes aspectos podem ser claramente observados ao se comparar a Fase I com a II e III. Ressalta-se ainda que a temperatura muito elevada não favorece a destilação solar, uma vez que o vidro também fica quente e não favorece assim a 
SÁ, L. F.; JUCÁ, J. F. T.; MOTTA SOBRINHO, M. A. Tratamento do lixiviado de aterro sanitário usando destilador solar. Ambi-Agua, Taubaté, v. 7, n. 1, p. 204-217, 2012. (http://dx.doi.org/10.4136/ambi-agua.815)

condensação. Por esta razão, as maiores eficiências do destilador solar estão no início da manhã e do meio para o fim da tarde.
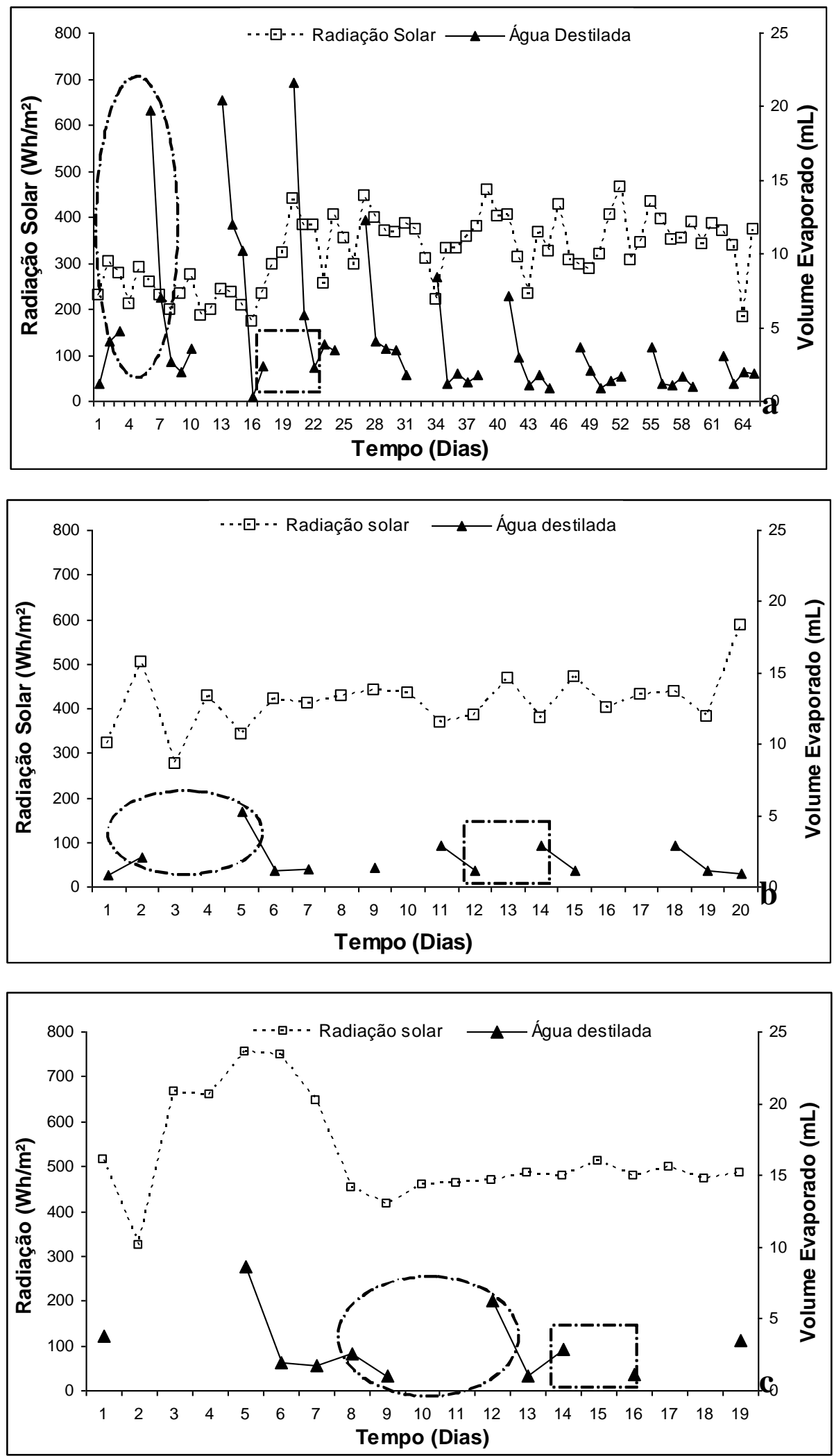

Figura12. Comportamento da radiação solar e do volume evaporado:

a) Fase I; b) Fase II ; c) Fase III. 
SÁ, L. F.; JUCÁ, J. F. T.; MOTTA SOBRINHO, M. A. Tratamento do lixiviado de aterro sanitário usando destilador solar. Ambi-Agua, Taubaté, v. 7, n. 1, p. 204-217, 2012. (http://dx.doi.org/10.4136/ambi-agua.815)

Na Figura 13 é apresentado o comportamento da radiação solar e da precipitação função do tempo.
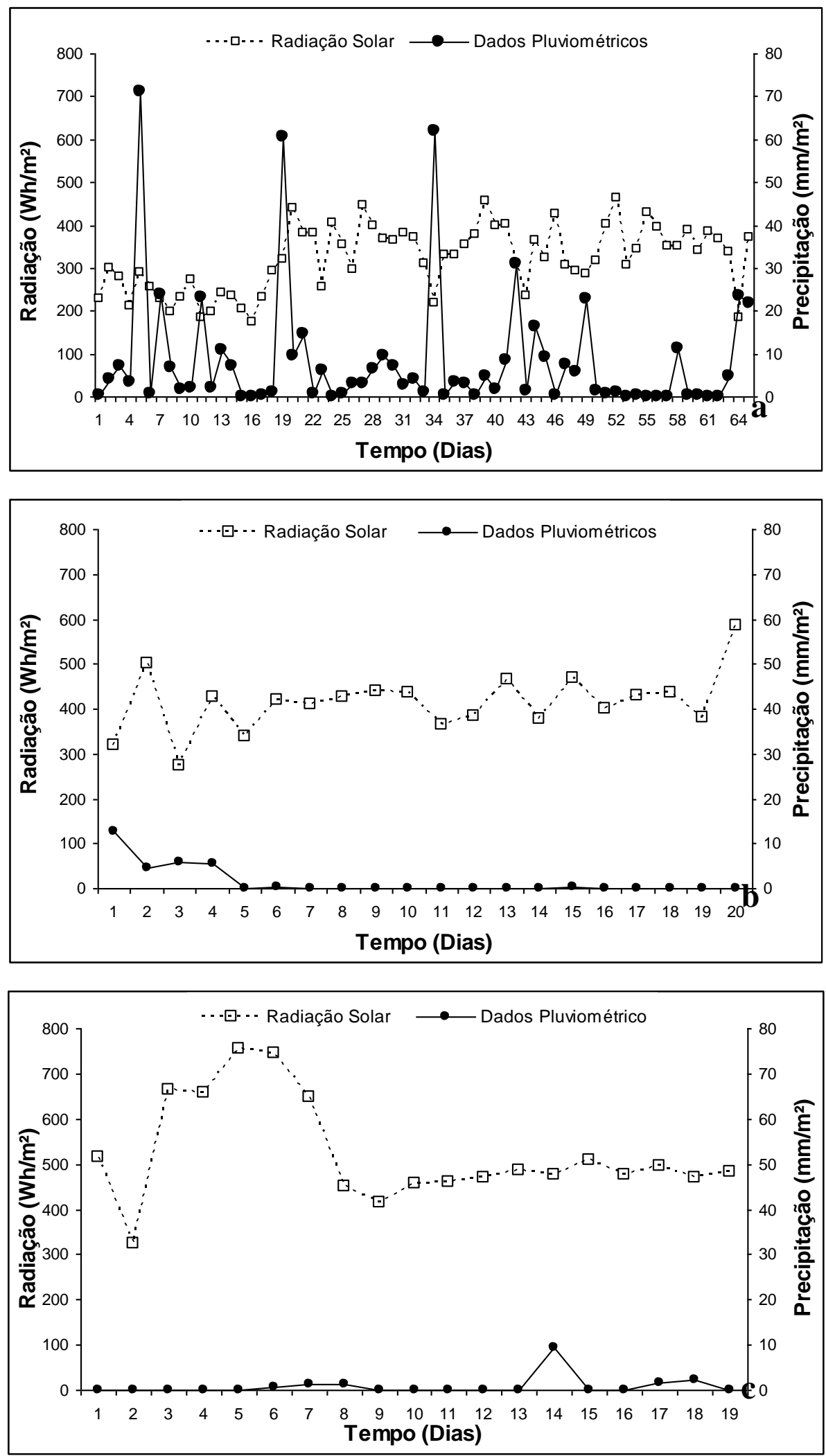

Figura13. Comportamento da radiação solar e Precipitação:

a) Fase I; b) Fase II; c) Fase III. 
Percebe-se que nos dias que houve uma grande precipitação, ocorreu, na maioria das vezes uma queda na radiação solar, porém isso não é regra. Há dias em que ocorreu precipitação e a radiação solar foi alta. Isso pode ser explicado pelo fato de que a precipitação ocorreu no período noturno. Percebe-se que nas Fases II e III o volume de precipitação diminui conforme fora explicado para a radiação solar.

Para os dias com altas nebulosidades, a radiação solar diminui. Isto é justificável pelo fato de que as nuvens são responsáveis por 25 a $30 \%$ (em média) da reflexão da radiação solar que chega ao planeta. As nuvens variam continuamente de forma e tamanho e são grandes moduladoras da energia solar que chega a superfície (INPE, 2003)

\section{CONCLUSÃO}

O sistema conseguiu tratar o lixiviado, produzindo água que pode ser empregada em sistemas de irrigação, apesar de ter uma baixa taxa de evaporação devido ao sistema estar fechado. Dessa forma, pode-se aproveitar o efluente tratado para um reuso. Desta forma podese constatar que este trabalho vai além de um simples tratamento, fornece também efluente de boa qualidade para possível aplicação na agricultura. Mostra-se assim a contribuição de um destilador solar, relativamente simples, para tratamento de lixiviados oriundos de aterros sanitários. Tendo em vista os volumes gerados, prevê-se sua aplicação para aterros de pequeno porte.

\section{AGRADECIMENTOS}

Os autores agradecem ao edital PROSAB-5 FINEP/MCT/CT-HIDRO pelo apoio financeiro e aos revisores deste artigo.

\section{REFERÊNCIAS}

American Public Heath Association; American Water Works Association; Water Enviroment Federation - APHA - AWWA - WEF. Standard methods for the examinations of water and wastewater. 19th ed. Washington, 1995.

BEZERRA, M. A. S. Desenvolvimento de um destilador solar para tratamento de águas de produção de petróleo com vistas a sua utilização na agricultura e geração de vapor. 2004. 106f. Dissertação (Mestrado em Engenharia Química) - Universidade Federal do Rio Grande do Norte, Natal, 2004.

BIRCHLER, D. R.; MILKE, M. W.; MARKS, A. L.; LUTHY, R. G. Landfill leachate treatment by evaporation. Journal of Environmental Engineering, New York, v. 120, n. 5, p. 1109-1131, 1994.

BRASIL. Conselho Nacional do Meio Ambiente - CONAMA. Resolução no 357 de 17 de março de 2005. Dispõe sobre a classificação dos corpos de água e diretrizes ambientais para o seu enquadramento, bem como estabelece as condições e padrões de lançamento de efluentes, e dá outras providências. Disponível em: <http://www.cetesb.sp.gov.br/ Agua/praias/res_conama_357_05.pdf>. Acesso em: 07 mar. 2012.

CATANHEDE, A.; JUCÁ, J. F. T.; FIGUEIREDO, I. C.; SILVA, F. M. S.; MOTTA SOBRINHO, M.; SÁ, L. F. et al. Tratamento de lixiviados por evaporação. In: PROSAB. Estudos de caracterização e tratabilidade de lixiviados de aterros sanitários para as condições brasileiras. Rio de Janeiro: ABES, 2009. p. 332-358. 
ETTALA, M. Full-scale leachate treatment using new evaporation technology. Practice Periodical of Hazardous, Toxic, and Radioactive Waste Management, Reston, v. 2, n. 2, p. 86-87, 1998. http://dx.doi.org/10.1061/(ASCE)1090-025X(1998)2:2(86)

GLOBAL METHANE. Controle de Lixiviado (Chorume) \& Tecnologias de Controle. In: Methane to markets. 2010. Disponível em: <www.globalmethane.org/ documents/events_land_20091027_wietting3.pdf>. Acesso em: 05 abr. 2011.

INSTITUTO BRASILEIRO DE GEOGRAFIA E ESTATÍSTICA - IBGE. Pesquisa nacional de saneamento: 2008. Rio de Janeiro, 2008. Disponível em: <http://www.ibge.gov.br/

home/presidencia/noticias/noticia_visualiza.php?id_noticia=1691\&id_pagina=1>. Acesso em: 20 dez. 2008.

INSTITUTO NACIONAL DE PESQUISAS ESPACIAIS - INPE. Radiação solar e terrestre. 2003. Disponível em: < http://satelite.cptec.inpe.br/radiacao/\#/>. Acesso em: 17 fev. 2008.

LINS, E. A. M. A utilização da capacidade de campo na estimativa do percolado gerado no aterro da Muribeca. 2003. 142f. Dissertação (Mestrado em Engenharia Civil) Universidade Federal de Pernambuco, Recife, 2003.

OLIVEIRA, R.; SILVA, J. B. P.; ATHAYDE JR., G. B. et al, Velocidade de remoção de coliformes fecais em um reservatório de estabilização alimentado com esgoto doméstico bruto. In: CONGRESSO BRASILEIRO DE ENGENHARIA SANITÁRIA E AMBIENTAL, 15-20 set. 1999, Rio de Janeiro. Anais... Rio de Janeiro: ABES, 1999. 1 CD-ROM

PESSIN, N.; BRUSTOLIN, I.; FINKLER, R. Determinação da eficiência de tratabilidade de reatores biológicos para atenuação de carga orgânica presente no chorume proveniente de aterros sanitários. In: SIMPÓSIO LUSO-BRASILEIRO DE ENGENHARIA SANITÁRIA E AMBIENTAL, 9., 9-14 abr. 2000, Porto Seguro. Anais... Rio de Janeiro: ABES, 2000. 1 CD ROM.

PROGRAMA DE PESQUISAS EM SANEAMENTO BÁSICO - PROSAB. Processo de desinfecção e desinfetantes alternativos na produção de água potável. São Carlos: ABES, 2001. 149p.

ROCHA, E. M. R. Desempenho de um sistema de lagoas de estabilização na redução da carga orgânica do percolado gerado no aterro da Muribeca - PE. 2005. 151f. Dissertação (Mestrado em Engenharia Civil) - Universidade Federal de Pernambuco, Recife, 2005.

SILVA, C. L.; SEGATO, L. M. Tratamento de líquidos percolados por evaporação através do aproveitamento de gás de aterros sanitários. In: CONGRESSO INTERAMERICANO DE INGENIERIA SANITÁRIA Y AMBIENTAL, 28., 27-31 de out. 2002, Cancún. Anais... Cancun: [s.n.], 2002.

SOUZA, G. Monitoramento de parâmetros qualitativos e quantitativos de líquidos percolados de aterros sanitários: estudo em piloto experimental. 2005. 86f. Dissertação (Mestrado em Engenharia Ambiental) - Universidade Federal de Santa Catarina, Florianópolis, 2005. 


ISSN = 1980-993X - doi:10.4136/1980-993X
www.ambi-agua.net
E-mail: ambi-agua@agro.unitau.br
Tel.: (12) 3625-4212

\title{
Uso del modelado de nicho ecológico como una herramienta para predecir la distribución potencial de Microcystis sp (cianobacteria) en la Presa Hidroeléctrica de Aguamilpa, Nayarit, México
}

\author{
(http://dx.doi.org/10.4136/ambi-agua.607)
}

\author{
José L. Ibarra-Montoya ${ }^{1}$; Gabriel Rangel-Peraza ${ }^{1}$; Fernando A. González-Farias ${ }^{2}$; \\ José De Anda ${ }^{1}$; Enrique Martínez-Meyer ${ }^{3}$ y Humberto Macias-Cuellar ${ }^{4}$ \\ ${ }^{1}$ Centro de Investigación y Asistencia en Tecnología y Diseño del Estado de Jalisco, México \\ e-mail: jibarra@ecologia.unam.mx; jgrp2000@hotmail.com; janda@ ciatej.net.mx; \\ ${ }^{2}$ Instituto de Ciencias del Mar y Limnología, Universidad Nacional Autónoma de México \\ e-mail: gfarias@servidor.unam.mx; \\ ${ }^{3}$ Instituto de Biología, Universidad Nacional Autónoma de México \\ e-mail: emm@ibunam2.ibiologia.unam.mx; \\ ${ }^{4}$ Departamento de Investigación Acción Participativa y Planeación Territorial Comunitaria, \\ Chakaan Buulaan, A. C. \\ e-mail: maciascuellar@chakaan.org
}

\section{RESUMEN}

El modelado de nicho ecológico es una herramienta importante para la evaluación de la distribución espacial de especies terrestres, sin embargo, su aplicabilidad ha sido poco explorada en el medio acuático. Microcystis sp., es una especie de cianobacteria con frecuencia conocida por la producción de toxinas del tipo microcistinas, cuya ingestión en altas concentraciones ocasiona la muerte de animales, desde pequeñas aves hasta el ganado. Como cualquier grupo taxonómico, ésta cianobacteria presenta umbrales ambientales, es decir; un nicho ecológico idóneo que va a delimitar su distribución. El presente estudio se realizó en la Presa Hidroeléctrica Aguamilpa, un ecosistema artificial que entró en operación en 1994. En este sistema se evaluó la distribución potencial de Microcystis sp., mediante la generación de un modelo de predicción basado en el concepto de nicho ecológico MAXENT; empleando un Modelo Digital de Elevación en celdas de 100 m x 100 m (1 ha) de resolución espacial y once variables físicas, químicas y biológicas del agua. La elaboración de los mapas de distribución, se realizó con ArcMap 9.2 ${ }^{\circledR}$. Los resultados indican que Microcystis sp., se distribuye principalmente en la cuenca alta del afluente del río Huaynamota, tanto en el estiaje frío, como en el cálido. Sin embargo, existe una menor probabilidad de encontrarla en todo el sistema de la presa durante el estiaje frío, mientras que durante el estiaje cálido también se localiza en la confluencia de ambos ríos. Para la época de lluvias no se tienen reportes de la presencia de ésta cianobacteria. Esta especie, generalmente está asociada a procesos tróficos derivados de la presencia de contaminantes de origen antropogénico. Las actividades humanas en la cuenca (por ejemplo, agricultura tradicional, ganadería, actividades industriales) y los escurrimientos, han afectado la distribución de Microcystis sp., dados los efectos deletéreos de la contaminación. Se requerirá atención en las áreas específicas que se han identificado en este trabajo, así como medidas de manejo y restauración de las cuencas. También se documenta una interacción entre fósforo y nitrógeno que determina la distribución de Microcystis sp. El modelado de nicho ecológico es una herramienta adecuada para la evaluación de la distribución espacial de microalgas en ambientes dulceacuícolas.

Palabras clave: Microcystis sp.; cianobacteria; modelo de nicho ecológico; presas; MAXENT. 


\title{
Use of ecological niche modeling as a tool for predicting the potential distribution of Microcystis sp (cyanobacteria) in the Aguamilpa Dam, Nayarit, Mexico
}

\begin{abstract}
Ecological niche modeling is an important tool to evaluate the spatial distribution of terrestrial species, however, its applicability has been little explored in the aquatic environment. Microcystis sp., a species of cyanobacteria, is widely recognized for its ability to produce a group of toxins known as microcystins, which can cause death of animals as fish, birds and mammals depending on the amount of toxin absorbed. Like any taxonomic group, cyanobacteria has environmental thresholds, therefore, a suitable ecological niche will define their distribution. This study was conducted in Aguamilpa Hydroelectric Reservoir, an artificial ecosystem that started operations in 1994. In this system we evaluated the potential distribution of Microcystis sp., by generating a prediction model based on the concept of ecological niche MAXENT, using a Digital Elevation Model in cells of $100 \mathrm{~m}$ x $100 \mathrm{~m}$ (1 ha) spatial resolution and monitoring eleven physicochemical and biological variables and nutrients in water. The distribution maps were developed using ArcMap 9.2 ${ }^{\circledR}$. The results indicated that Microcystis sp., is distributed mainly in the upper tributary basin (Huaynamota basin) during the dry season. There was less chance to find cyanobacteria in the entire system during the cold dry season, while during the warm dry season cyanobacteria was recognized at the confluence of two rivers. During the rainfall season there were no reports of cyanobacteria presence. This species is often associated with arising trophic processes of anthropogenic origin; therefore, attention is required in specific areas that have been identified in this work to improve Aguamilpa's watershed management and restoration. It was also recognized the importance of phosphorus and nitrogen interaction, which determines the distribution of Microcystis sp., in the Aguamilpa Reservoir. The results of this study demonstrated that ecological niche modeling was a suitable tool to assess the spatial distribution of microalgae in freshwater environments.
\end{abstract}

Keywords: Micocystis sp.; cyanobacteria; ecological niche model; reservoir; MAXENT.

\section{Uso de modelagem de nicho ecológico como ferramenta para previsão da distribuição potencial de Microcystis sp (cyanobacteria), na Usina Hidrelétrica de Aguamilpa, Nayarit, México}

\section{RESUMO}

Modelagem de nicho ecológico é uma ferramenta importante para se avaliar a distribuição espacial das espécies terrestres, no entanto, sua aplicabilidade tem sido pouco explorada no ambiente aquático. Microcystis sp., uma espécie de cianobactérias, é amplamente reconhecida pela sua capacidade de produzir um grupo de toxinas conhecidas como microcistinas, o que pode causar a morte de animais como peixes, aves e mamíferos, dependendo da quantidade de toxina absorvida. Como qualquer grupo taxonômico, as cianobactérias têm limites ambientais, portanto, um nicho adequado ecológico define sua distribuição. Este estudo foi realizado no reservatório da usina hidroelétrica Aguamilpa, um ecossistema artificial que iniciou suas operações em 1994. Neste sistema, foi avaliada a distribuição potencial de Microcystis sp., para se gerar um modelo de previsão baseado no conceito do nicho ecológico MAXENT, utilizando um Modelo de Elevação Digital com 

predecir la distribución potencial de Microcystis sp (cianobacteria) en la Presa Hidroeléctrica de Aguamilpa, Nayarit, México. Ambi-Agua, Taubaté, v. 7, n. 1, p. 218-234, 2012. (http://dx.doi.org/10.4136/ambiagua.607)

células de 100 m x 100 m (1 ha) de resolução espacial e o monitoramento de 11 variáveis físico-químicas, biológicas e nutrientes na água. Os mapas de distribuição foram desenvolvidos utilizando o ArcMap 9.2 ${ }^{\circledR}$. Os resultados indicaram que a Microcystis sp. Distribui-se principalmente na parte superior da bacia afluente (bacia Huaynamota) durante a estação seca. Houve menos chances de se encontrar cianobactérias no sistema durante a estação fria e seca, enquanto que durante a estação quente e seca, cianobactérias foram reconhecidas na confluência de dois rios. Durante o período chuvoso não houve relatos da presença de cianobactérias. Esta espécie é frequentemente associada com processos tróficos decorrentes de origem antropogênica, portanto, atenção é necessária em áreas específicas que foram identificadas neste trabalho para melhorar a gestão e a restauração de bacias hidrográficas em Aguamilpa. Foi também reconhecida a importância da interação entre o fósforo e nitrogênio, na distribuição de Microcystis sp., no reservatório Aguamilpa. Os resultados deste estudo demonstraram que a modelagem de nicho ecológico foi uma ferramenta adequada para se avaliar a distribuição espacial de microalgas em ambientes de água doce.

Palavras-chave: Microcystis sp.; cyanobacteria; o modelo de nicho ecológico; reservatório; MAXENT.

\section{INTRODUCCIÓN}

El modelado de nicho ecológico (MNE) es probablemente el método más adecuado que actualmente existe para estimar la distribución geográfica real y potencial de las especies (Guisan y Thuiller, 2005). Este enfoque se utiliza cada vez más en la toma de decisiones en materia de conservación, restauración y contaminación ambiental (Pearce y Lindenmayer, 1998; Ferrier, 2002). A pesar de la probada eficacia de este método para la delimitación de las distribuciones geográficas de las especies terrestres, su aplicabilidad en el ámbito acuático ha sido poco explorada (Wiley et al., 2003). Esto es particularmente cierto para los ecosistemas de agua dulce, donde la escala geográfica es grande, y la información de los datos ambientales, para la mayor parte del mundo no es de calidad; esta información es necesaria para la generación de los modelos de nicho (Iguchi et al., 2004; McNyset, 2005). Tal es el caso de los ecosistemas limnológicos en México, donde los datos normalmente están incompletos y no se cuenta con bases de datos geográficos, regionales o nacionales, de las características físicas, químicas y biológicas de las aguas continentales.

La Presa Hidroeléctrica (P. H.) de Aguamilpa, se ubica en el borde sureste de la Sierra Madre Occidental, con la presencia de terrenos con relieves accidentados de origen volcánico. Sus características principales son dos sistemas de topoformas: la sierra alta, ubicada en la subcuenca del río Huaynamota, formada por altas mesetas interrumpidas de manera abrupta por cañadas; y la del tipo cañón, en la subcuenca Santiago-Aguamilpa, donde el relieve se conforma de cadenas montañosas de formas volcánicas escarpadas y cañones con perfiles en "V", que llegan a alcanzar una altura por arriba de los 1,000 m en algunos sitios (INEGI, 2006a).

En el embalse de la P. H. de Aguamilpa, se ha registrado una gran diversidad de especies de fitoplancton, que incluyen a Microcystis, Anabaena y Aulacoseira como los géneros más abundantes durante el estiaje cálido y algunas especies de Clorofitas durante el estiaje frío (Zamudio y González-Farias, 2009). Uno de los grupos más representativos de la comunidad de fitoplancton del embalse es el de las cianobacterias, entre las que se tiene a Microcystis sp., una especie que crece preferentemente en ambientes con alta concentración de nutrientes, principalmente fósforo y nitrógeno (Lampert y Sommer, 1997; Bernal-Brooks et al., 2003; 
Dávalos et al., 1989), por lo que es común encontrarla en cuerpos de agua eutrofizados (Roset et al., 2001), y puede producir potentes toxinas del tipo de las microcistinas, capaces de originar efectos agudos y crónicos en el hombre y en las diversas especies de animales (Cood et al., 1999).

A nivel mundial se tiene gran interés en el estudio del género Microcystis, debido a las numerosas intoxicaciones letales en diversas especies de fauna silvestre y doméstica, y en el número de casos de enfermedades causadas a los humanos por la exposición prolongada a las toxinas, situación que ha llamado la atención de la Organización Mundial de la Salud (OMS) de la sociedad en general y de la comunidad científica en particular (Chorus, 2001).

Dada la importancia de Microcystis sp., en este trabajo se presenta un análisis espacial, basado en un modelo de nicho ecológico que permite generar mapas predictivos de las zonas de presencia de esta especie en el embalse de Aguamilpa, en función de los parámetros ambientales, las variables físico-químicas y biológicas del agua y los parámetros hidrológicos. Se considera una excelente oportunidad para establecer estrategias que permitan conocer la distribución potencial de Microcystis sp., en el ecosistema acuático y contrastarlo con las actividades propias del uso de suelo y vegetación de las subcuencas.

\section{2. Área de Estudio}

La P. H. de Aguamilpa se localiza en la región central del estado de Nayarit, México, y comprende los municipios del Nayar, la Yesca, Santa María del Oro y Tepic. Está localizada entre los meridianos $104.39^{\circ}$ y $104.74^{\circ}$ de longitud oeste y los paralelos $21.51^{\circ}$ y $21.9^{\circ} \mathrm{de}$ latitud norte (Figura 1). Se ubica en el borde sureste de la Sierra Madre Occidental, con la presencia de terrenos con relieves accidentados de origen volcánico. Presenta dos ramas, una de $50 \mathrm{~km}$ de largo y la otra de $20 \mathrm{~km}$ aproximadamente, que son los cauces originales de los ríos Santiago y Huaynamota, respectivamente. Exhibe además un cuerpo de agua amplio e irregular que se forma desde la cortina de la presa hasta el punto de confluencia de ambas ramas (Figura 1).

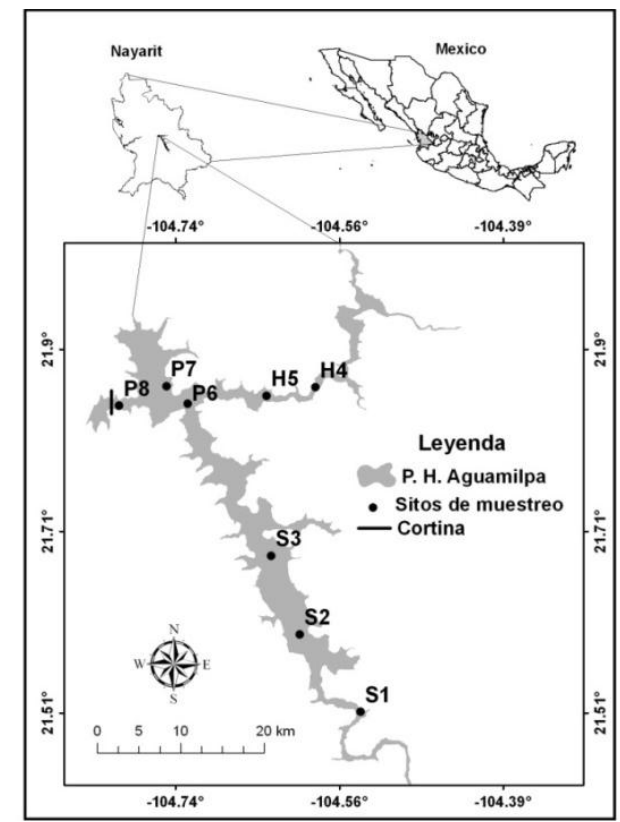

Figura 1. Mapa de localización del área de estudio. La "S" corresponde al río Santiago; la " $\mathrm{H}$ " al río Huaynamota; y la "P" a la Presa (Fuente: Ibarra-Montoya et al., 2010). 
IBARRA-MONTOYA, J. L.; RANGEL-PERAZA, G.; GONZÁLEZ-FARIAS, F. A.; ANDA, J.; MARTÍNEZMEYER, E.; MACIAS-CUELLAR, H. M. Uso del modelado de nicho ecológico como una herramienta para predecir la distribución potencial de Microcystis sp (cianobacteria) en la Presa Hidroeléctrica de Aguamilpa, Nayarit, México. Ambi-Agua, Taubaté, v. 7, n. 1, p. 218-234, 2012. (http://dx.doi.org/10.4136/ambiagua.607)

La P. H. de Aguamilpa tiene un clima cálido subhúmedo, se ubica en la categoría Awo (W), que corresponde al clima más seco de los cálidos subhúmedos (García, 1973). Según Rangel-Peraza et al. (2009) presenta un régimen hidrológico estacional, con lluvias en verano y dos épocas de estiaje, uno frío en los meses de noviembre a febrero y uno cálido de marzo a mayo. Respecto al clima de la cuenca del río Santiago, éste es variado, va desde semiseco y semicálido en las regiones más altas, hasta semicálido y subhúmedo en la parte central, y templado, semifrío y frío en las serranías. La temperatura media anual oscila entre 24 y $26^{\circ} \mathrm{C}$, con una máxima de $40{ }^{\circ} \mathrm{C}$ y mínima de $-2{ }^{\circ} \mathrm{C}$ (INEGI, 2006b). Por su parte la cuenca del río Huaynamota presenta una temperatura media anual que va de $\operatorname{los} 18^{\circ} \mathrm{C}$ a $\operatorname{los} 26^{\circ} \mathrm{C}$ (INEGI, 2006b).

\section{MATERIAL Y MÉTODOS}

\subsection{Modelo de Nicho Ecológico}

Se utilizó el enfoque de Máxima Entropía (MAXENT) para modelar el nicho ecológico y predecir la distribución de Microcystis sp. Para este trabajo se utilizó la versión de escritorio 3.3.0. de noviembre 2011 (Phillips et al., 2006). En general, este algoritmo detecta las relaciones no aleatorias entre dos conjuntos de datos: a) los registros georeferenciados de la presencia de la especie, y b) un conjunto de coberturas tipo "raster", de datos digitales que representan a las variables físico-químicas y biológicas pertinentes para determinar la distribución de la especie en una escala particular de análisis (Phillips et al., 2006).

MAXENT ha sido utilizado ampliamente para estimar la distribución potencial de los grupos terrestres con una gran precisión (Anderson et al., 2002; Peterson et al., 2002a, 2002b), y los pocos resultados que se han obtenido de las exploraciones en donde se ha usado para especies acuáticas han sido prometedores (Ibarra-Montoya et al., 2010).

Una explicación detallada de los aspectos técnicos de MAXENT se puede revisar en Phillips et al. (2006), sin embargo el procedimiento general aplicado para construir los modelos de nicho en el embalse de Aguamilpa es el siguiente:

1. Selección de las estaciones de muestreo. Se eligieron ocho estaciones de muestreo, según Rangel-Peraza et al. (2009), tres se ubican en la Presa: P6, P7 y P8; tres sobre el río Santiago: S1, S2 y S3; y dos en el curso del río Huaynamota: H4 y H5 (Figura 1). Todas las estaciones fueron georeferenciadas con un geoposicionador satelital (GPS map, 178C Sounder, marca GARMIN).

En cada una de las estaciones se registraron, a nivel superficial $(1 \mathrm{~m})$, once parámetros físicos, químicos y biológicos del agua, utilizando una sonda multiparámetro YS1 (Modelo 6600D), que fue calibrada in situ antes de cada muestreo. Los parámetros medidos fueron: temperatura, conductividad, sólidos disueltos totales, oxígeno disuelto, $\mathrm{pH}$, potencial de óxido reducción, turbidez, concentración de algas verde-azules, clorofila total, fósforo y nitrógeno (Tabla 1).

La selección de las estaciones de muestreo, tanto para los parámetros ambientales como para las colectas de fitoplancton, se basa en encontrar los lugares adecuados para generar un mapa de interpolación. Por lo tanto, las estaciones fueron seleccionadas según los siguientes criterios: i) ubicación longitudinal sobre los cauces de los ríos Santiago y Huaynamota; ii) ubicación en el área de confluencia donde se interconectan ambos afluentes de los ríos y iii) ubicación cercana a la cortina de la presa para incluir todo el embalse.

2. Colecta e identificación de la especie. Se tomaron muestras superficiales en botellas plásticas de 1 litro de capacidad, que fueron fijadas con acetato de lugol al 1 \% (Ferrario et al., 1995). Las muestras fueron analizadas con ayuda de un microscopio invertido de acuerdo al 
IBARRA-MONTOYA, J. L.; RANGEL-PERAZA, G.; GONZÁLEZ-FARIAS, F. A.; ANDA, J.; MARTÍNEZMEYER, E.; MACIAS-CUELLAR, H. M. Uso del modelado de nicho ecológico como una herramienta para predecir la distribución potencial de Microcystis sp (cianobacteria) en la Presa Hidroeléctrica de Aguamilpa, Nayarit, México. Ambi-Agua, Taubaté, v. 7, n. 1, p. 218-234, 2012. (http://dx.doi.org/10.4136/ambiagua.607)

método de Utermmohl (Hasle, 1978). En cada muestra se identificó a Microcystis sp., con ayuda de las claves taxonómicas.

3. Generación de las coberturas de los parámetros físico-químicos y biológicos. Utilizando los datos anuales registrados de cada parámetro (muestreos bimensuales), se obtuvieron los promedios por cada una de las épocas climáticas presentes en el embalse de Aguamilpa (Tabla 1); estiaje frío (diciembre 2008-febrero 2009) y estiaje cálido (abril-junio 2009). Cabe mencionar que para la época de lluvias (agosto-octubre 2008) no se registro la presencia de esta especie.

Se generaron las coberturas con los promedios de las épocas climáticas, éstas se construyeron utilizando un polígono que delimita al cuerpo de agua del embalse, el cual fue creado a una cota de 300 metros sobre el nivel del mar (msnm), a partir de las Curvas de Nivel y el Modelo Digital de Elevación (Escala 1:250,000) de CONAGUA (México, 2006). Estas coberturas, mapas tipo "raster", se generaron utilizando la técnica IDW de interpolación (Distancia Inversa Ponderada) (Delaney, 1999), en el Sistema de Información Geográfica ArcMap 9.2. ${ }^{\circledR}$ (GIS, ESRI, 1999-2001), enmascarando el análisis solo para el cuerpo de agua de la Presa. La resolución definitiva (tamaño de píxel) de todas las coberturas fue de $1 \mathrm{~m}^{2}$ (Zambrano et al., 2006).

4. Modelo de nicho ecológico. Utilizando las coberturas de los parámetros y los datos de presencia de Microcystis sp., se llevó a cabo el modelaje con MAXENT. El $75 \%$ de los registros de presencia fueron utilizados como puntos de entrenamiento y el $25 \%$ como puntos de validación. Se utilizó un umbral de convergencia de $10^{-5}$ con 1000 iteraciones como límite superior para cada corrida. Para estimar la capacidad de predicción de cada modelo, se analizó el área bajo la curva (AUC), salida gráfica donde se observa la capacidad de discriminación de una presencia (sensitividad) versus la capacidad de discriminación de una ausencia (especificidad) (Phillips y Dudik, 2008). El formato de salida analizado es el acumulativo (rango de 0 a 100), el cual indica una idoneidad de hábitat relativa de cada píxel más no una probabilidad de ocurrencia de la especie (salida logística). Se usó la prueba de Jackknife (Sokal y Rohlf, 1995; Phillips et al., 2006) para calcular la contribución relativa de cada variable al modelo, los resultados de esta evaluación se expresan con una medida conocida como "ganancia". Esta información es de suma importancia para evidenciar los requerimientos ecológicos de la especie, y que probablemente determinen el área de distribución potencial propia. Ambos análisis, el AUC y la prueba de Jackknife están implementados en MAXENT.

5. Desarrollo de los modelos de predicción. Debido a que MAXENT produce resultados de alguna manera diferentes de una corrida a la siguiente, utilizando la misma entrada de datos, se desarrollaron 100 modelos de predicción independientes para la especie, y se eligieron un subconjunto de los mejores 10 modelos basado en dos criterios: i) fue seleccionado un primer conjunto de 20 modelos con menos del $10 \%$ de error por omisión y; ii) de ellos, se seleccionaron los 10 modelos más cercanos a la media en las zonas donde la especie fue predicha como presente (Anderson et al., 2003). Estos 10 modelos fueron examinados en un Sistema de Información Geográfica (SIG), y se generó un mapa de consenso con los valores de píxel de 0 a 10, donde el 0 representa las áreas en las que todos los modelos predicen la ausencia de la especie y el 10 representa las zonas donde todos los modelos están de acuerdo en la predicción de la presencia de la especie. 
IBARRA-MONTOYA, J. L.; RANGEL-PERAZA, G.; GONZÁLEZ-FARIAS, F. A.; ANDA, J.; MARTÍNEZMEYER, E.; MACIAS-CUELLAR, H. M. Uso del modelado de nicho ecológico como una herramienta para predecir la distribución potencial de Microcystis sp (cianobacteria) en la Presa Hidroeléctrica de Aguamilpa, Nayarit, México. Ambi-Agua, Taubaté, v. 7, n. 1, p. 218-234, 2012. (http://dx.doi.org/10.4136/ambiagua.607)

\section{RESULTADOS}

En el modelo la capacidad de predicción para los datos de prueba generó un AUC de 0.903, lo que indica que la habilidad del modelo para clasificar las presencias fue bueno (Parolo et al., 2008). Así mismo, las variables que tuvieron el mayor poder de predicción cuando fueron analizadas independientemente son: en el estiaje frío, el fósforo (AUC $=0.93$ ), las algas verde-azules $(\mathrm{AUC}=0.78)$ y la turbidez $(\mathrm{AUC}=0.65)$; mientras que la variable con el menor poder de predicción fue el potencial de óxido reducción ( $\mathrm{AUC}=0.23$ ); en el estiaje cálido las variables con mayor poder de predicción fueron: el nitrógeno (AUC=0.87), el fósforo $(\mathrm{AUC}=0.74)$ y la temperatura $(\mathrm{AUC}=0.73)$; mientras que la variable con menor poder de predicción fue también el potencial de óxido reducción (AUC=0.46) (Tabla 2).

Tabla 1. Valores promedio de los parámetros físicos, químicos y biológicos que se usaron para generar las coberturas del cuerpo de agua de los diferentes sitios de muestreo, durante el periodo de agosto 2008 a junio 2009. Loc=localidad; T=temperatura del agua; Cond=conductividad; $\mathrm{SDT}=$ sólidos disueltos totales; $\mathrm{OD}=$ oxígeno disuelto; $\mathrm{ORP}=$ potencial de óxido reducción; Tur=turbidez; F=fósforo; N=nitrógeno.

\begin{tabular}{|c|c|c|c|c|c|c|c|c|c|c|c|}
\hline \multicolumn{12}{|c|}{ Estiaje Frío } \\
\hline Loc & $\begin{array}{c}\mathrm{T} \\
\left({ }^{\circ} \mathrm{C}\right)\end{array}$ & $\begin{array}{c}\text { Cond } \\
\left(\mu \mathrm{S} \mathrm{cm} \mathrm{cm}^{-1}\right)\end{array}$ & $\begin{array}{l}\text { SDT } \\
\left(\mathrm{g} \mathrm{l}^{-1}\right)\end{array}$ & $\begin{array}{c}\text { OD } \\
\left(\mathrm{mg} \mathrm{l}^{-1}\right)\end{array}$ & pH & ORP & $\begin{array}{c}\text { Tur } \\
\text { (NTU) }\end{array}$ & $\begin{array}{c}\text { Algas } \\
\left(\text { cel ml }^{-1}\right)\end{array}$ & $\begin{array}{c}\text { Clorofila } \\
\left(\mu \mathrm{g} \mathrm{l}^{-1}\right)\end{array}$ & $\begin{array}{c}F \\
\left(\mathrm{mg} \mathrm{l}^{-1}\right)\end{array}$ & $\begin{array}{c}\mathrm{N} \\
\left(\mathrm{mgl}^{-1}\right)\end{array}$ \\
\hline $\mathrm{S} 1$ & 25.06 & 0.259 & 0.168 & 3.92 & 7.6 & 52.43 & 52.72 & 525 & 5.36 & 2.22 & 0.24 \\
\hline $\mathrm{S} 2$ & 24.94 & 0.254 & 0.165 & 4.02 & 7.7 & 45.97 & 54.00 & 488 & 5.19 & 2.21 & 0.26 \\
\hline $\mathrm{S} 3$ & 25.00 & 0.257 & 0.167 & 4.00 & 7.6 & 40.55 & 54.45 & 558 & 5.23 & 2.24 & 0.20 \\
\hline $\mathrm{H} 4$ & 24.52 & 0.173 & 0.112 & 2.65 & 7.3 & 56.11 & 42.61 & 842 & 3.83 & 0.71 & 0.13 \\
\hline H5 & 24.96 & 0.168 & 0.110 & 3.20 & 7.3 & 51.08 & 51.22 & 398 & 4.54 & 0.69 & 0.16 \\
\hline P6 & 24.92 & 0.230 & 0.149 & 5.29 & 7.6 & 46.34 & 55.69 & 373 & 5.03 & 2.39 & 0.27 \\
\hline P7 & 24.73 & 0.231 & 0.150 & 6.31 & 7.6 & 55.51 & 46.20 & 757 & 5.39 & 2.43 & 0.28 \\
\hline P8 & 24.72 & 0.229 & 0.149 & 6.12 & 7.6 & 48.26 & 49.66 & 352 & 4.41 & 2.37 & 0.25 \\
\hline
\end{tabular}

\begin{tabular}{|c|c|c|c|c|c|c|c|c|c|c|c|}
\hline \multicolumn{12}{|c|}{ Estiaje Cálido } \\
\hline Loc & $\begin{array}{c}\mathbf{T} \\
\left({ }^{\circ} \mathbf{C}\right)\end{array}$ & $\underset{\left(\mu S \text { cm }^{-1}\right)}{\text { Cond }}$ & $\begin{array}{l}\text { SDT } \\
\left(\mathrm{g} \mathrm{l}^{-1}\right)\end{array}$ & $\underset{\left(\mathrm{mg} \mathrm{l}^{-1}\right)}{\text { OD }}$ & pH & ORP & $\begin{array}{c}\text { Tur } \\
\text { (NTU) }\end{array}$ & $\underset{\left(\text { cel } \mathbf{m l}^{-1}\right)}{\text { Algas }}$ & $\begin{array}{c}\text { Clorofila } \\
\left(\mu \mathrm{g} \mathrm{l^{-1 }}\right)\end{array}$ & $\underset{\left(\mathrm{mg} \mathrm{l}^{-1}\right)}{\mathbf{F}}$ & $\underset{\left(\mathbf{m g l}^{-\mathbf{1}}\right)}{\mathbf{N}}$ \\
\hline $\mathrm{S} 1$ & 27.89 & 0.289 & 0.188 & 7.32 & 8.6 & 91.50 & 27.63 & 1605 & 6.7 & 0.77 & 0.78 \\
\hline $\mathrm{S} 2$ & 28.81 & 0.280 & 0.182 & 8.06 & 8.7 & 87.65 & 26.79 & 1376 & 6.4 & 0.75 & 0.72 \\
\hline S3 & 28.96 & 0.278 & 0.181 & 8.46 & 8.6 & 88.65 & 27.80 & 1566 & 7.3 & 0.74 & 0.74 \\
\hline $\mathrm{H} 4$ & 27.47 & 0.288 & 0.187 & 3.73 & 7.5 & 120.82 & 19.46 & 1092 & 5.5 & 0.28 & 1.02 \\
\hline H5 & 27.90 & 0.261 & 0.169 & 7.41 & 8.0 & 54.01 & 21.28 & 1170 & 3.3 & 0.26 & 1.05 \\
\hline P6 & 27.74 & 0.261 & 0.167 & 8.58 & 8.3 & 108.49 & 28.28 & 968 & 6.2 & 0.73 & 0.65 \\
\hline P7 & 27.03 & 0.256 & 0.166 & 9.23 & 8.2 & 90.85 & 33.71 & 7416 & 6.7 & 0.71 & 0.63 \\
\hline P8 & 26.32 & 0.264 & 0.172 & 8.15 & 8.2 & 126.02 & 29.29 & 1507 & 7.5 & 0.73 & 0.64 \\
\hline
\end{tabular}

Las predicciones del modelo para Microcystis sp., durante el estiaje frío, muestran que tiene una distribución en todo el sistema de Aguamilpa (Figura 2), aunque el modelo predice una mayor probabilidad de encontrarse en el afluente del río Huaynamota y en la cortina de la Presa. Durante el estiaje cálido esta especie tiene una mayor probabilidad de encontrase en la cuenca alta del río Huaynamota y en la Confluencia (P6), así mismo, aunque con menor probabilidad en la cuenca alta del río Santiago.

Las zonas que el modelo predijo como más probables para la distribución de Microcystis $s p$., están asociadas principalmente con la presencia de nutrientes como el fósforo y nitrógeno (Tabla 2). 
Tabla 2. Valores de AUC, para las variables analizadas, en las distintas épocas del año, según el modelo de nicho ecológico. $\mathrm{T}=$ =temperatura del agua; Cond=conductividad; SDT=sólidos disueltos totales; $\mathrm{OD}=$ =xígeno disuelto; ORP=potencial de óxido reducción; Tur=turbidez; F=Fósforo; N=Nitrógeno.

\begin{tabular}{c|cc}
\hline Variable & Estiaje Frío & Estiaje Cálido \\
\hline T & 0.64 & $\mathbf{0 . 7 3}$ \\
Cond & 0.56 & 0.36 \\
SDT & 0.60 & 0.65 \\
OD & 0.54 & 0.57 \\
pH & 0.63 & 0.69 \\
ORP & 0.23 & 0.46 \\
Tur & $\mathbf{0 . 6 5}$ & 0.72 \\
Algas & $\mathbf{0 . 7 8}$ & 0.64 \\
Clorofila & 0.67 & 0.68 \\
F & $\mathbf{0 . 9 3}$ & $\mathbf{0 . 7 4}$ \\
N & 0.61 & $\mathbf{0 . 8 7}$ \\
\hline
\end{tabular}

Por ejemplo, durante el estiaje frío, todo el sistema Aguamilpa tiene probabilidad de ser un nicho idóneo para la distribución de Mycrocystis sp. Es muy probable que este fenómeno se deba al aumento de flujo de agua que se da en la época de lluvias y que se mantiene hasta el estiaje frío, dicho aumento estará dado por los escurrimientos, particularmente desde las cuencas altas de los ríos Santiago y Huyanamota que traen consigo diferentes nutrientes, principalmente fósforo y nitrógeno al cuerpo de agua del sistema. Lo anterior, ocasiona que la mayor parte del cuerpo de agua del embalse mantenga condiciones ambientales adecuadas para el crecimiento y desarrollo de esta especie.

Durante el estiaje cálido, se observan dos zonas de mayor probabilidad de distribución de Microcystis sp: i) en la cuenca alta del río Huaynamota; y ii) en la confluencia de ambos ríos. Este fenómeno es probable que se deba a que estas áreas mantienen altas concentraciones de nitrógeno y fósforo, como una consecuencia del poco movimiento que presenta el agua en esta época. Lo anterior genera un ambiente ideal para el crecimiento y abundancia de esta especie.

Es posible que dichos nutrientes sean producto de las actividades antropogénicas, agrícolas, industriales y urbanas, principalmente por la cuenca del río Santiago y las actividades de tala, y la creciente deforestación en la cuenca alta del río Huaynamota, lo cual induce erosión de suelos, transporte de nutrientes y descomposición de los ciclos biogeoquímicos naturales de la cuenca, durante la época de lluvias, a los arroyos y ríos que forman la red hidrográfica del sistema Aguamilpa. 
IBARRA-MONTOYA, J. L.; RANGEL-PERAZA, G.; GONZÁLEZ-FARIAS, F. A.; ANDA, J.; MARTÍNEZMEYER, E.; MACIAS-CUELLAR, H. M. Uso del modelado de nicho ecológico como una herramienta para predecir la distribución potencial de Microcystis sp (cianobacteria) en la Presa Hidroeléctrica de Aguamilpa, Nayarit, México. Ambi-Agua, Taubaté, v. 7, n. 1, p. 218-234, 2012. (http://dx.doi.org/10.4136/ambiagua.607)

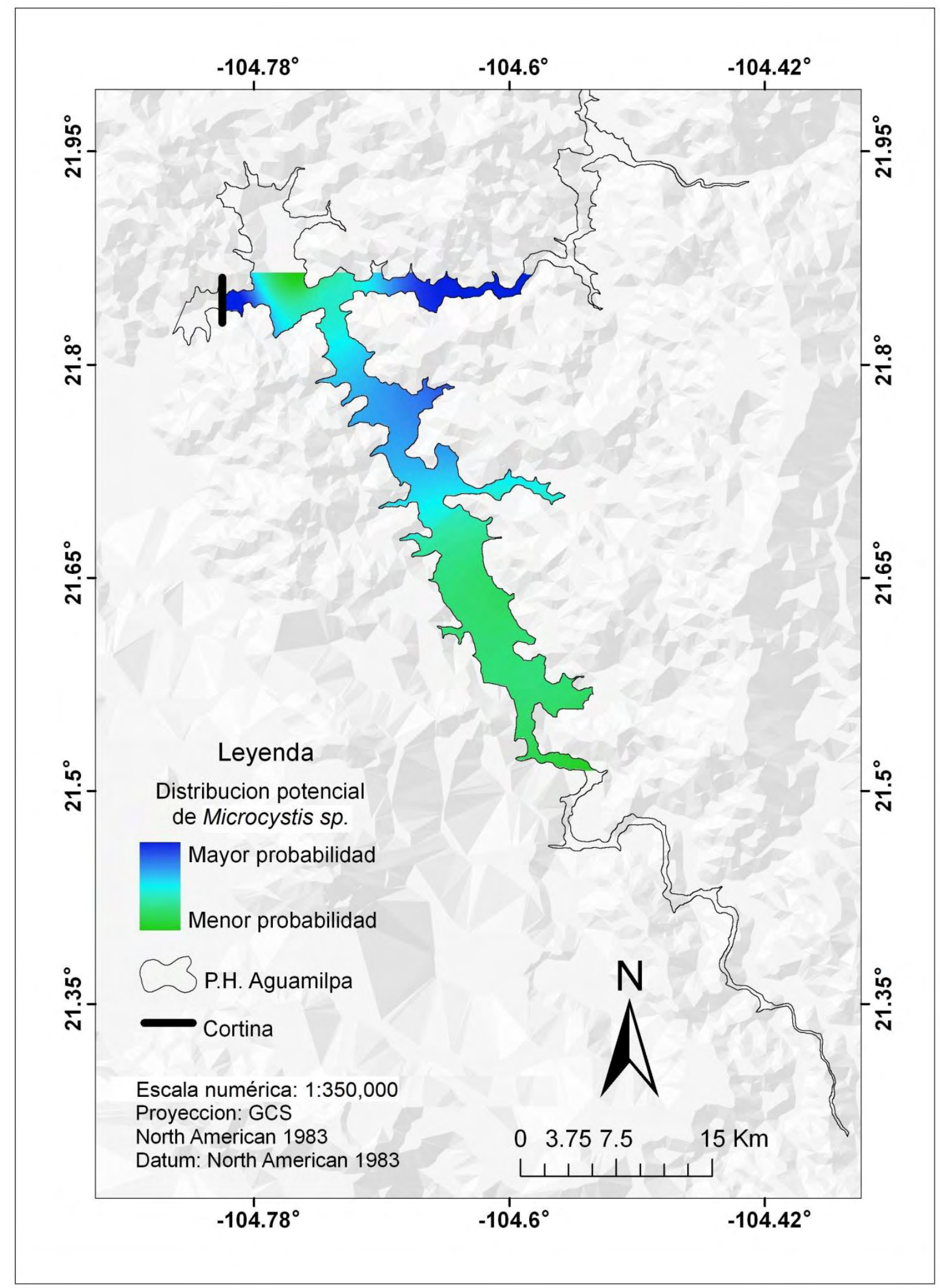

Figura 2. Zonas potenciales de distribución de Microcystis sp., en el embalse de Aguamilpa, durante el estiaje frío. Las probabilidades fueron las predichas por el modelo de nicho ecológico. 
IBARRA-MONTOYA, J. L.; RANGEL-PERAZA, G.; GONZÁLEZ-FARIAS, F. A.; ANDA, J.; MARTÍNEZMEYER, E.; MACIAS-CUELLAR, H. M. Uso del modelado de nicho ecológico como una herramienta para predecir la distribución potencial de Microcystis sp (cianobacteria) en la Presa Hidroeléctrica de Aguamilpa, Nayarit, México. Ambi-Agua, Taubaté, v. 7, n. 1, p. 218-234, 2012. (http://dx.doi.org/10.4136/ambiagua.607)

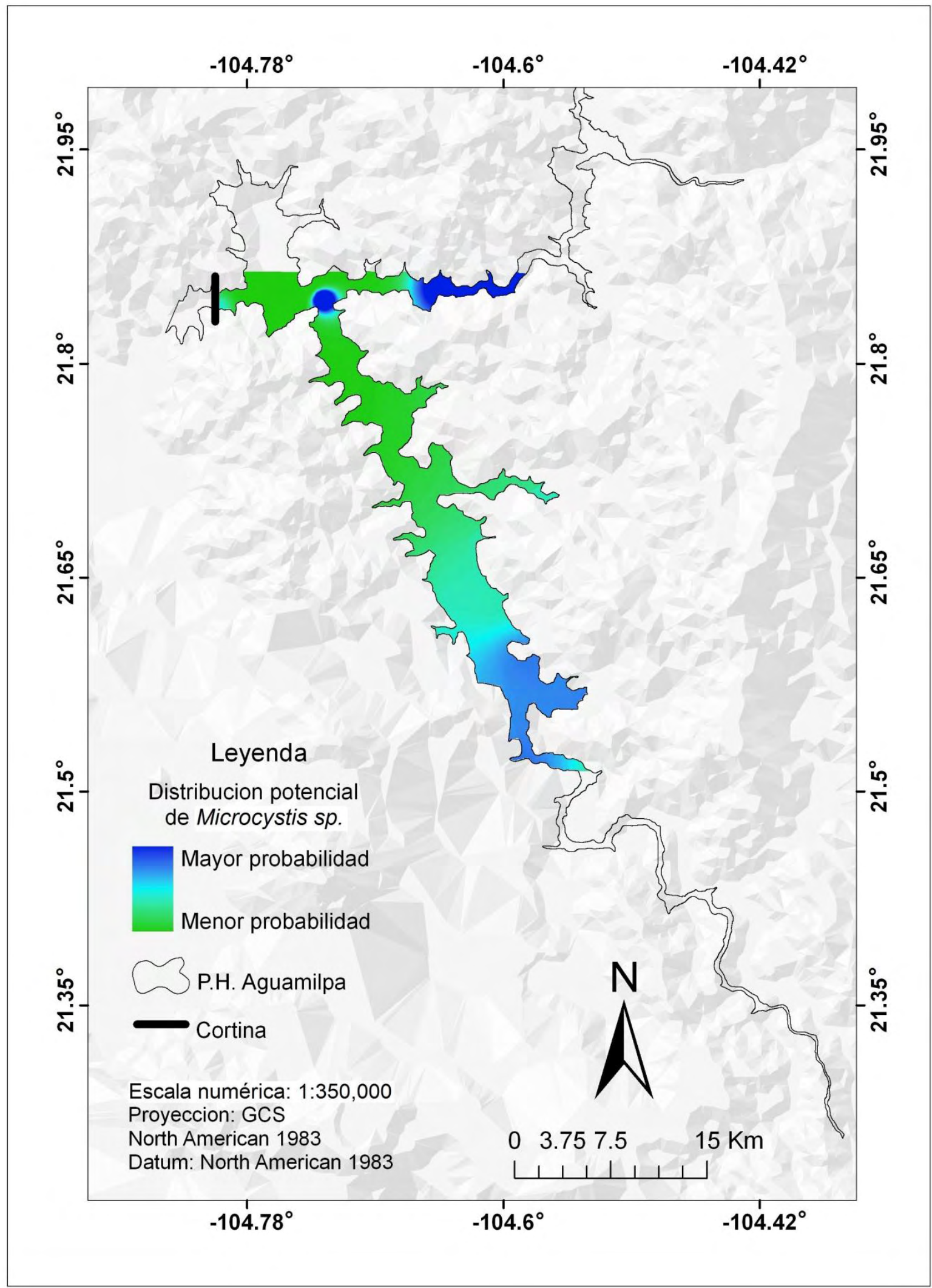

Figura 3. Zonas potenciales de distribución de Microcystis sp., en el embalse de Aguamilpa, durante el estiaje cálido. Las probabilidades fueron las predichas por el modelo de nicho ecológico. 

predecir la distribución potencial de Microcystis sp (cianobacteria) en la Presa Hidroeléctrica de Aguamilpa, Nayarit, México. Ambi-Agua, Taubaté, v. 7, n. 1, p. 218-234, 2012. (http://dx.doi.org/10.4136/ambiagua.607)

\section{DISCUSIÓN}

El modelado de nicho ecológico (junto con otras herramientas de análisis espacial, sobre todo los SIG, Sistemas de Información Geográfica) es un enfoque útil para futuros estudios en los sistemas terrestres (Chen y Peterson, 2002; Anderson y Martínez-Meyer, 2004; Chefauri et al., 2005). Sin embargo, este enfoque ha sido poco utilizado en los sistemas acuáticos (Wiley et al., 2003; McNyset, 2005; Ibarra-Montoya et al., 2010), en gran parte, debido a la falta de información ambiental (Iguchi et al., 2004). A pesar de esta limitación, la predicción de ocurrencia de la especie con base en las localidades incluidas para la construcción de este modelo, fue bastante bueno. El análisis de la AUC obtuvo una predicción el $90 \%$, lo que sugiere que MAXENT generó un buen desempeño en la predicción de la distribución potencial de Microcystis sp.

En otros estudios donde se utilizan modelos de nicho ecológico es frecuente que se presenten sobreestimaciones, éstas pueden tener varias causas, algunas son algorítmicas y otras son conceptuales y metodológicas: (1) Estudios recientes de la comparación de modelos con MAXENT y GARP (Genetic Algorithm for Rule-Set Prediction) muestran una frecuente sobreestimación (clasificar erróneamente las ausencias) con respecto a otros métodos (Elith, 2006; Pearson et al., 2006). Sin embargo, estos análisis se centraron en la capacidad de los algoritmos para interpolar (en vez de extrapolar) analizando los modelos construidos con puntos de presencia-ausencia seleccionados al azar de un conjunto de datos más grande. En los estudios diseñados explícitamente para poner a prueba la capacidad de extrapolación (predicción de las presencias en las zonas donde no hay datos de muestreo) MAXENT ha funcionado bien (Peterson, 2001). (2) La sobreestimación también se debe a la naturaleza del enfoque en relación con la historia natural del grupo. El enfoque del modelado de nicho ecológico se centra en las condiciones ambientales donde una especie puede persistir (es decir, su nicho ecológico) y no incluye los factores históricos y ecológicos que provocan que las especies ocupen en su totalidad la extensión espacial de sus nichos ecológicos (por ejemplo, las barreras biogeográficas y las interacciones) (Soberón y Peterson, 2005). Por lo tanto, la ausencia de una especie de un lugar determinado no significa necesariamente la ausencia de su nicho ecológico. Esto es particularmente importante para Microcystis sp., porque el elevado número de individuos en general, indican una historia muy dinámica de aislamiento y su posterior abundancia bajo condiciones físico-químicas, biológicas y de nutrientes del agua. (3) Por último, la falta de información ambiental de cuerpos de agua representa una importante limitación metodológica que pudiera influir en los resultados.

Claramente, la producción y la incorporación de la información ambiental específicamente en relación con los sistemas de agua (por ejemplo, profundidad, $\mathrm{pH}$, nutrientes y contenido de oxígeno) mejoran en gran medida la calidad de los modelos.

Dentro del grupo de cianobacterias la especie Microcystis sp., es de las más distintivas en los cuerpo de agua dulce. Varias poblaciones de esta especie poseen rasgos biológicos y ecológicos únicos, como la producción de sustancias alelopáticas, para eliminar la competencia de otros organismos del medio, y para evitar ser depredadas por otros organismos (Shapiro, 1973).

Al igual que los demás miembros de las cianobacterias, requieren de la energía luminosa para realizar la fotosíntesis, sin embargo, Microcystis sp., tiene la capacidad de sintetizar diversos pigmentos que le permiten capturar la luz de manera muy eficiente, absorbiendo la radiación electromagnética en longitudes de onda de 500 hasta $600 \mathrm{~nm}$, que difícilmente son empleadas por otros organismos del fitoplancton, incluso pueden vivir en ambientes con solo luz verde (Mur et al., 1977). 

predecir la distribución potencial de Microcystis sp (cianobacteria) en la Presa Hidroeléctrica de Aguamilpa, Nayarit, México. Ambi-Agua, Taubaté, v. 7, n. 1, p. 218-234, 2012. (http://dx.doi.org/10.4136/ambiagua.607)

Microcystis sp., presenta vesículas de gas, las cuales le permiten migrar y posicionarse verticalmente en la columna de agua (Walsby, 1997). De acuerdo a Reynolds (1999), la tasa de crecimiento de las cianobacterias, particularmente de Microcystis sp., es mucho menor que la de microalgas, debido a esto, se requiere de tiempos de retención del agua prolongados para permitir así las floraciones algales. Se pensaba que esta especie al igual que otras cianobacterias dependían del nitrógeno y fósforo en altas concentraciones, sin embargo, se ha visto que pueden crecer incluso cuando estos dos elementos están en condiciones limitantes; ya que esta especie tienen la capacidad de almacenar fósforo, lo cual le permite hasta cuatro divisiones celulares, lo que correspondería a un incremento sustancial en biomasa (Downing et al., 2005). Presentan una estabilidad poblacional, que les permite prevalecer por más tiempo una vez establecidas (Chorus y Bartram, 1999).

La temperatura óptima para el crecimiento es mayor que la necesaria $\left(15-30{ }^{\circ} \mathrm{C}\right)$, lo cual explicaría porque en cuerpos de agua templados y boreales se dan los florecimientos durante el verano, mientras que en un sistema con clima tropical como el caso de Aguamilpa, están presentes en ambos estiajes, el frío y el cálido. Por otro lado, Microcystis sp., forma scums, (colonias) de células cocoides o filamentos, lo que le proporciona la capacidad de flotar y posicionarse en la parte más alta de la columna de agua, hasta hallar la intensidad luminosa favorable para su crecimiento. Esto significa que la presencia de esta especie no esta relacionada solo al nivel de eutrofización del medio, por lo que puede encontrarse en aguas mesotróficas, eutróficas e hipertróficas, pero la cantidad de biomasa estará relacionada con la cantidad de nutrientes disponibles (Mur et al., 1999).

Además de sus diferentes estrategias ecofisiológicas, su diversidad poblacional y dominancia en el sistema Aguamilpa, tiene un papel de importancia ecológica para las demás especies del fitoplancton. Sin embargo, y a pesar de su importancia se ha hecho poco para evaluar su presencia en el sistema, y la amenaza de que esta especie provoque "blooms" y daños a la biota es probable.

\subsection{Presencia de Microcystis sp., en la P. H. Aguamilpa}

En el modelo se identificaron zonas muy extensas en donde es probable que se distribuya Microcytis sp. Tanto en la cuenca del río Huaynamota como en la del río Santiago, se predice una distribución continua durante el estiaje frío, mientras que durante el estiaje cálido la zona de distribución potencial se reduce a tres áreas dentro del sistema Aguamilpa. Estos resultados pueden deberse a dos factores: (1) una sobreestimación del modelo, y (2) a que en estos ambos estiajes, el nicho ecológico de Microcystis sp., es todo el sistema Aguamilpa.

Ambas situaciones son posibles. Como ya se menciono anteriormente, la sobreestimación (es decir, error de omisión) es común en modelos de nicho ecológico. Por otra parte, y aunque se hizo el esfuerzo por contar con los estudios de campo (colectas en más estaciones), todavía siguen siendo incompletos, por lo que varias estaciones más aún pueden producir nuevos registros de esta especie. Este fenómeno podría ser la respuesta al hecho de que en la época de lluvias no se encontraran registros de esta especie.

\subsection{Uso de suelo}

Microcystis sp., es sensible a los cambios en la calidad de agua (Chorus, 2001). Por lo tanto, para mantener sus poblaciones bajo un esquema "normal" (es decir, sin producir toxinas), es importante tener en cuenta la calidad de agua. Sin embargo, las zonas con mayor probabilidad de presencia de la especie, como el río Santiago y la cuenca alta del río Huaynamota, han sufrido durante el siglo pasado, importantes transformaciones de la cubierta vegetal, utilizando el suelo para terrenos agrícolas, para las actividades de pastoreo, urbanas e industriales (Mercado-Silva et al., 2002). Estos usos de la tierra modifican directamente la 
IBARRA-MONTOYA, J. L.; RANGEL-PERAZA, G.; GONZÁLEZ-FARIAS, F. A.; ANDA, J.; MARTÍNEZMEYER, E.; MACIAS-CUELLAR, H. M. Uso del modelado de nicho ecológico como una herramienta para predecir la distribución potencial de Microcystis sp (cianobacteria) en la Presa Hidroeléctrica de Aguamilpa, Nayarit, México. Ambi-Agua, Taubaté, v. 7, n. 1, p. 218-234, 2012. (http://dx.doi.org/10.4136/ambiagua.607)

calidad de agua e incrementan los nutrientes (principalmente fósforo y nitrógeno) a través de la contaminación, la eutrofización (por la entrada de fertilizantes), y la erosión del suelo.

De a cuerdo con los análisis, la mayoría de las áreas en donde habita Microcystis sp., son zonas continuas dentro del cuerpo de agua (Figuras 2 y 3) y las áreas que el modelo predice con una mayor probabilidad de presencia de la especie han sido transformadas drásticamente por la actividad humana. En esta áreas Microcystis sp., sobrevive principalmente, donde las tasas de renovación de agua son altas y la contaminación y otros factores de perturbación se amortiguan (García-Cabrera, 2006). El uso de suelo, en torno a la transformación de los cuerpo de agua con certeza ha afectado directa o indirectamente a la biota acuática, probablemente incluso causando que otras especies de fitoplancton sean eliminadas del cuerpo de agua en Aguamilpa.

Por ultimo, con estos análisis se argumenta que el elemento limitante para el crecimiento de las cianobacterias, en especial para Microcystis sp., en ambientes tropicales, es además del nitrógeno, el fósforo (Henry et al., 1985; Dávalos et al., 1989). Con esto, se tiene información de que en los cuerpos de agua dulce ubicados en zonas tropicales son ambos nutrientes los que en gran medida determinan la distribución de las cianobacterias, y no solo el nitrógeno como se pensaba (Philips et al., 1993).

\section{CONCLUSIÓN}

El modelo de nicho ecológico demostró ser una metodología confiable para la predicción de la distribución potencial de Microcystis sp., en el cuerpo de agua de la P. H. Aguamilpa. El estudio se caracterizó por presentar áreas aisladas de mayor probabilidad de presencia de esta especie durante el estiaje cálido, mientras que en el estiaje frió, Microcystis sp., se puede encontrar en casi todo el sistema Aguamilpa. Se sugiere que la presencia de esta especie se encuentra asociada al cambio en el uso de suelo y vegetación y a los procesos tróficos derivados de las actividades antropogénicas que se llevan a cabo en la cuenca del sistema. Por ejemplo, en la cuenca alta del rio Huaynamota principalmente la agricultura y la ganadería, y por el río Santiago las actividades industriales.

Por otro lado, el estudio documenta que existe una dinámica entre los nutrientes (fósforo y nitrógeno) que en gran medida determina la distribución de Microcystis $s p$.

Esta metodología se recomienda para ser utilizada tanto en este sistema como en otros, para ayudar a identificar las zonas potenciales de distribución de Microcystis sp, y con esto localizar a lo largo de la cuenca las áreas geográficas donde se recomiende realizar acciones de restauración y conservación, principalmente del uso de suelo y vegetación, y que tales esfuerzos puedan orientarse en una estrecha coordinación entre las poblaciones locales, autoridades y la academia.

\section{AGRADECIMIENTOS}

Al Dr. José de Anda, del Centro de Investigación y Asistencia en Tecnología del Estado de Jalisco, y al Dr. Fernando González-Farias, del Instituto de Ciencias del Mar y Limnología, Universidad Nacional Autónoma de México, por su asesoría y orientación, A todos los colaboradores de este trabajo, especialmente a la Biol. Karla Gutiérrez, por su auxilio y ayuda en el desarrollo y aplicación de SIG. Al proyecto Aguamilpa, clave: CB-CONACYT-200658119 por la beca otorgada y al Consejo Mexiquense de Ciencia y Tecnología (COMECYT), del Estado de México, por la beca otorgada. 
IBARRA-MONTOYA, J. L.; RANGEL-PERAZA, G.; GONZÁLEZ-FARIAS, F. A.; ANDA, J.; MARTÍNEZMEYER, E.; MACIAS-CUELLAR, H. M. Uso del modelado de nicho ecológico como una herramienta para predecir la distribución potencial de Microcystis sp (cianobacteria) en la Presa Hidroeléctrica de Aguamilpa, Nayarit, México. Ambi-Agua, Taubaté, v. 7, n. 1, p. 218-234, 2012. (http://dx.doi.org/10.4136/ambiagua.607)

\section{REFERENCIAS}

ANDERSON, R. P.; LEW, D.; PETERSON, A. Evaluating predictive models of species' distributions: criteria for selecting optimal models. Ecological Modelling, v. 162, n. 3, p. 211-32, 2003. http://dx.doi.org/10.1016/S0304-3800(02)00349-6

ANDERSON, R. P.; PETERSON, A. T.; GÓMEZ-LAVERDE, M. Using niche-based GIS modelinh to test geographic predictions of competitive exclusion and competitive release in South American pocket mice. Oikos, v. 98, n. 1, p. 3-16, 2002. http://dx.doi.org/10.1034/j.1600-0706.2002.t01-1-980116.x

ANDERSON, R. P.; MARTÍNEZ-MEYER, E. Modeling species' geographic distributions for preliminary conservation assessments: an implementation with the spiny pocket mice (Heteromys) of Ecuador. Biological Conservation, v. 116, p. 167-76, 2004. http://dx.doi.org/10.1016/S0006-3207(03)00187-3

BERNAL-BROOKS, F. W.; DÁVALOS-LIND, L.; LIND, O. T. Seasonal and spatial variation in algal growth potential and growth-limiting nutrients in a shallow endorheic lake: Lake Pátzcuaro (México). Lakes \& Reservoirs: Research and Management, v. 8, n. 2, p. 83-93, 2003. http://dx.doi.org/10.1046/j.1320-5331.2003.00217.x

COOD, G. A.; BELL, S. G.; KAYA, K.; WARD, C.; BEATTIE, K.; METCALF, S. J. Cyanobacterial toxins, exposure routes and human health. European Journal of Phycology, v. 34, n. 4, p. 405-15, 1999. http://dx.doi.org/10.1080/09670269910001736462

CHEFAURI, R. M.; HORTAL, J.; LOBO, M. Potential distribution modeling, niche characterization and conservation status assessment using GIS tools: a case study of Iberian Copris species. Biological Conservation, v. 122, p. 327-38, 2005. DOI:10.1016/j.biocon.2004.08.005 http://dx.doi.org/10.1016/j.biocon.2004.08.005

CHEN, G.; PETERSON, A. T. Prioritization of areas in China for the conservation of endangered birds using modelled geographical distributions. Bird Conservation International, v. 12, p. 197-209, 2002. DOI: 10.1017/S0959270902002125 http://dx.doi.org/10.1017/S0959270902002125

CHORUS, I. Cyanotoxins - occurrence, causes, consequences. New York: Springer, 2001. $357 \mathrm{p}$.

CHORUS, I.; BARTRAM, J. (Ed.) Toxic cyanobacteria in water: a guide to their public health consequences, monitoring and management. London: Spon, 1999. p. 1-14.

DÁVALOS, L.; LIND, O. T.; DOYLE, R. D. Evaluation of phytoplankton limiting factors in Lake Chapala, Mexico: turbidity and spatial and temporal variations in algal assay response. Lake Reservoir Management, v. 5, n. 2, p. 99-104, 1989. http://dx.doi.org/10.1080/07438148909354404

DELANEY, J. Geographical information systems an introduction. Oxford: University Press, 1999. 194 p. ISBN 019550789-4.

DOWNING, T. G.; MEYER, C.; GEHRINGER, M. M.; VAN DE VENTER, M. Microcystin content of Microcystis aeruginosa is modulated by nitrogen uptake rate relative to specific growth rate or carbon fixation rate. Environmental Toxicology, v. 20, n. 3, p. 257-62, 2005. http://dx.doi.org/10.1002/tox.20106 
IBARRA-MONTOYA, J. L.; RANGEL-PERAZA, G.; GONZÁLEZ-FARIAS, F. A.; ANDA, J.; MARTÍNEZMEYER, E.; MACIAS-CUELLAR, H. M. Uso del modelado de nicho ecológico como una herramienta para predecir la distribución potencial de Microcystis sp (cianobacteria) en la Presa Hidroeléctrica de Aguamilpa, Nayarit, México. Ambi-Agua, Taubaté, v. 7, n. 1, p. 218-234, 2012. (http://dx.doi.org/10.4136/ambiagua.607)

ELITH, J. Novel methods improve prediction of species' distributions from occurrence data. Ecography, v. 29, n. 2, p. 129-51, 2006. http://dx.doi.org/10.1111/j.2006.0906-7590.04596.x

FERRARIO, M. E.; SAR, E.; SALA, S. E. Metodología básica para el estudio del fitoplancton con especial referencia a las diatomras. In: ALVEAL, K.; FERRARIO, M. E.; OLVEIRA, E. C.; SAR, E. (Ed.). Manual de métodos ficológicos. Concepción: Editorial Aníbal Pinto, 1995. p. 1-24.

FERRIER, S. Mapping spatial pattern in biodiversity for regional conservation planning: where to from here? Systematic Biology, v. 51, n. 2, p. 331-63, 2002. http://dx.doi.org/10.1080/10635150252899806

GARCÍA-CABRERA, J. Plancton como indicador de calidad del agua en la presa Aguamilpa. Ingeniería Hidráulica en México, v. 22, n. 1, p. 103-16, 2006.

GARCÍA, E. Modificaciones al sistema de clasificación climática de Köppen (para adaptarlo a las condiciones de la República Mexicana). Ciudad de México: Universidad Nacional Autónoma de México, Instituto de Geografía, 1973. 246 p. ISBN 75553596.

GUISAN, A.; THUILLER, W. Predicting species distribution: offering more than simple habitat models. Ecology Letters, v. 8, n. 9, p. 993-1009, 2005.

http://dx.doi.org/10.1111/j.1461-0248.2005.00792.x

HASLE, G. R. The inverted-microscope method. In: SOURNIA, A. (Ed.). Phytoplankton manual. Paris: UNESCO, 1978. p. 191-96.

HENRY, R.; HINO, K.; TUNDISI, J. G.; RIBEIRO, J. S. B. Responses of phytoplankton in lake Jacaretinga to enrichment with nitrogen and phosphorus in concentrations similar to tose of the River Solimoes (Amazon, Brazil). Archiv für Hydrobiologie, v. 103, p. 453-77, 1985.

IBARRA-MONTOYA，J. L.; RANGEL-PERAZA， G.; GONZÁLEZ-FARIAS， F.; DE ANDA, J.; ZAMUDIO-RESENDIZ, M. E.; MARTÍNEZ-MEYER, E. et al. Ecological niche model to predict the potential distribution of phytoplankton in the Aguamilpa Dam, Nayarit. México. Ambiente \& Agua - An Interdisciplinary Journal of Applied Science, v. 5, n. 3, p. 60-75, 2010. http://dx.doi.org/10.4136/ambi-agua.154

IGUCHI, K.; MATSUURA, K.; MCNYSET, K. M.; PETERSON, A. T.; SCACHETTIPEREIRA, R.; POWERS, K. A. et al. Predicting invasions of North American basses in Japan using native range data and a genetic algorithm. Transactions of the American Fisheries Society, v. 133, n. 4, p. 845-54, 2004.

http://dx.doi.org/10.1577/T03-172.1

INSTITUTO NACIONAL DE ESTADISTICA Y GEOGRAFIA - INEGI. Continuo nacional del conjunto de datos geográficos de la carta topográfica, 1:250 000, serie II. Aguascalientes, 2006a.

INSTITUTO NACIONAL DE ESTADISTICA Y GEOGRAFIA - INEGI. Conjunto nacional del conjunto de datos geográficos de la carta de climas, 1:1 000 000, serie I. Aguascalientes, 2006b. 
IBARRA-MONTOYA, J. L.; RANGEL-PERAZA, G.; GONZÁLEZ-FARIAS, F. A.; ANDA, J.; MARTÍNEZMEYER, E.; MACIAS-CUELLAR, H. M. Uso del modelado de nicho ecológico como una herramienta para predecir la distribución potencial de Microcystis sp (cianobacteria) en la Presa Hidroeléctrica de Aguamilpa, Nayarit, México. Ambi-Agua, Taubaté, v. 7, n. 1, p. 218-234, 2012. (http://dx.doi.org/10.4136/ambiagua.607)

LAMBERT, W.; SOMMER, U. Limnoecology: the ecology of lakes and streams. Oxford: University Press, 1997. 382 p. ISBN 01888897.

MAXENT. Disponible en: 〈http://www.cs.princeton.edu/ schapire/maxent>. Acceso en: nov. 2011.

MERCADO-SILVA, N.; LYONS, J. D.; SALGADO MALDONADO, G.; MEDINA NAVA, M. Validation of a fish-based index of biotic integrity or streams and rivers of central Mexico. Reviews in Fish Biology and Fisheries, v. 12, n. 2/3, p. 179-91, 2002. http://dx.doi.org/10.1023/A:1025099711746

MÉXICO. Comision Nacional Del Agua - CONAGUA. Modelo digital de elevación, escala 1:250,000. Ciudad de México: Departamento de Sistemas de Información Geográfica del Agua, 2006.

MCNYSET, K. M. Use of ecological niche modeling to predict distributions of freswater fish species in Kansas. Ecology of Freshwater Fish, v. 14, n. 3, p. 243-55, 2005. http://dx.doi.org/10.1111/j.1600-0633.2005.00101.x

MUR, L. R.; GONS, H. J.; VAN LIERE, L. Some experiments on the competition of the green algae and blue-green bacteria in light-limited environments. FEMS Microbiology Letters, v. 1, n. 6, p. 335-38, 1977.

http://dx.doi.org/10.1111/j.1574-6968.1977.tb00646.x

MUR, L. R.; SKULBERG, O. M.; UTKILEN, H. Cyanobacteria in the environment. In: CHORUS, I.; BARTRAM, J. (Ed.). Toxic cyanobacteria in water: a guide to their public health consequences, monitoring and management. London: Spon, 1999. p. 1440. ISBN 1402030223.

PAROLO, G.; ROSSI, G.; FERRARINI, A. Toward improved species niche modelling: Arnica montana in the Alps as a case study. Journal of Applied Ecology, v. 45, n. 5, p. 1410-18, 2008. http://dx.doi.org/10.1111/j.1365-2664.2008.01516.x

PEARCE, J.; LINDENMAYER, D. Bioclimatic analysis to enhance reintroduction biology of the endangered helmeted honeyeater (Lichenostomus melanops cassidix) in Southeastern Australia. Restoration Ecology, v. 6, n. 3, p. 238-43, 1998. http://dx.doi.org/10.1046/j.1526-100X.1998.00636.x

PEARSON, R. G.; THUILLER,W.; ARAÚJO, M. B.; MARTINEZ-MEYER, E.; BROTONS, L.; McCLEAN, C. et al. Model-based uncertainty in species range prediction. Journal of Biogeography, v. 33, n. 10, p. 1704-11, 2006. http://dx.doi.org/10.1111/j.13652699.2006.01460.x

PETERSON, A. T. Predicting species' geographic distributions based on ecological niche modeling. The Condor, v. 103, n. 3, p. 599-605, 2001.

http://dx.doi.org/10.1650/0010-5422(2001)103[0599:PSGDBO]2.0.CO;2

PETERSON, A.T.; BALL, L. G.; COHOON, K. P. Predicting distributions of Mexican birds using ecological niche modeling methods. Ibis, v. 144, n. 1, p. 27-32, 2002 a. http://dx.doi.org/10.1046/j.0019-1019.2001.00031.x

PETERSON, A. T.; ORTEGA-HUERTA, M. A.; BARTLEY, J.; SANCHEZ-CORDERO, V.; SOBERÓN, J.; BUDDEMEIER, R. H. et al Future projections for Mexican faunas under global climate change scenarios. Nature, v. 416, p. 626-29, 2002 b.

http://dx.doi.org/10.1038/416626a 
IBARRA-MONTOYA, J. L.; RANGEL-PERAZA, G.; GONZÁLEZ-FARIAS, F. A.; ANDA, J.; MARTÍNEZMEYER, E.; MACIAS-CUELLAR, H. M. Uso del modelado de nicho ecológico como una herramienta para predecir la distribución potencial de Microcystis sp (cianobacteria) en la Presa Hidroeléctrica de Aguamilpa, Nayarit, México. Ambi-Agua, Taubaté, v. 7, n. 1, p. 218-234, 2012. (http://dx.doi.org/10.4136/ambiagua.607)

PHILIPS, E. J.; ALDRIDGE, F. J.; HANSEN, P. Spatial and temporal variability of trophic state parameters in a shallow subtropical lake (Lake Okeechobee, Florida, USA). Archiv für Hydrobiology, v.128, p. 437-58, 1993.

PHILLIPS, S. J.; ANDERSON, R. P.; SCHAPIRE, R. E. Maximum entropy modeling of species geographic distributions. Ecological Modelling, v. 190, n. 3/4, p. 231-59, 2006. http://dx.doi.org/10.1016/j.ecolmodel.2005.03.026

PHILLIPS, S. J.; DUDIK, M. Modeling of species distributions with Maxent: new extensions and a comprehensive evaluation. Ecography, v. 31, n. 2, p. 161-75, 2008. http://dx.doi.org/10.1111/j.0906-7590.2008.5203.x

RANGEL-PERAZA, J. G.; DE ANDA, J.; GONZALEZ-FARIAS, F.; ERICKSON, D. Statistical assessment of water quality seasonality in large tropical reservoirs. Lakes \& Reservoirs: Research and Management, v. 14, n. 4, p. 315-23, 2009. http://dx.doi.org/10.1111/j.1440-1770.2009.00412.x

REYNOLDS, C. S. Cyanobacterial water blooms. In: CALLOW, P. (Ed.). Advances in botanical research. 13. ed. London: Academic Press, 1999. 143p. ISBN 0-419-23930-8.

ROSET, J.; AGUAYO, S.; MUÑOZ, M. J. Detección de cianobacterias y sus toxinas: una revisión. Revista de Toxicología, v. 18, n. 2, p. 65-71, 2001.

SOBERÓN, J.; PETERSON, A. T. Interpretation of models of fundamental ecological niches and species' distributional areas. Biodiversity Informatics, v. 2, p. 1-10, 2005.

SHAPIRO, J. Blue-green algae: why they become dominant. Science, v. 179, n. 4071, p. 38284, 1973. http://dx.doi.org/10.1126/science.179.4071.382

SOKAL, R. R.; ROHLF, F. J. Biometry: the principles and practice of statistics in biological research. New York: State University of New York; Stony Brook, 1995. 887 p. ISBN 0-7167-2411-1

WALSBY, A. E. Mechanisms of buoyancy regulation by planktonic cyanobacteria with gas esicles. In: FAY, P.; VAN BAALEN, C. (Ed.). The cyanobacteria. Amsterdan: Elsevier, 1997. 414 p.

WILEY, E. O.; MCNYSET, K. M.; PETERSON, A. T.; ROBINS, C. R.; STEWART, A. M. Niche modeling and geographic range predictions in the marine environment using a machine-learning algorithm. Oceanography, v. 16, n. 3, p. 120-7, 2003.

http://dx.doi.org/10.5670/oceanog.2003.42

ZAMBRANO, L.; MARTINEZ-MEYER, E.; MENEZES, N.; PETERSON, A. T. Invasive potential of common carp (Cyprinus carpio) and Nile tilapia (Oreochromis niloticus) in American freshwater systems. Canadian Journal of Fisheries and Aquatic Sciences, v. 63 , n. 9, p. 1903-10, 2006. http://dx.doi.org/10.1139/f06-088

ZAMUDIO, R. M.; GONZÁLEZ-FARIAS, F. Informe de fitoplancton del embalse de Aguamilpa. Mérida: Centro de Investigación y Asistencia en Tecnología y Diseño del Estado de Jalisco, A.C., 2009. 


ISSN = 1980-993X - doi:10.4136/1980-993X
www.ambi-agua.net
E-mail: ambi-agua@agro.unitau.br
Tel.: (12) 3625-4212

\title{
Bacterias resistentes a antibióticos en aguas grises como agentes de riesgo sanitario
}

\author{
(http://dx.doi.org/10.4136/ambi-agua.638)
}

\author{
Lidia Nuñez ${ }^{1}$; Carina Tornello ${ }^{2}$; Noel Puentes ${ }^{3}$; Juan Moretton ${ }^{4}$ \\ Cátedra de Higiene y Sanidad, Facultad de Farmacia y Bioquímica, \\ Universidad de Buenos Aires, Argentina \\ 'e-mail: lidian@ ffyb.uba.ar; ${ }^{2}$ carinatornello@yahoo.com.ar; \\ 3noelsonik@hotmail.com; ${ }^{4}$ jamorett@ffyb.uba.ar
}

\section{RESUMEN}

La eliminación y disposición final de las aguas residuales originadas por las actividades domésticas constituye un importante problema sanitario en áreas urbanas densamente pobladas. En muchas zonas del Gran Buenos Aires las aguas grises se eliminan en zanjas a cielo abierto cuyo riesgo potencial no ha sido adecuadamente cuantificado. El objetivo de este trabajo fue evaluar la prevalencia de bacterias resistentes y el perfil de resistencia a antibióticos, en muestras de aguas grises de canales localizados en la zona de Ingeniero Budge Provincia de Buenos Aires. Se determinó por el método de dilución en agar la prevalencia de bacterias heterotróficas, bacterias Gram-negativas resistentes a antibióticos betalactámicos y enterococos vancomicina resistentes en aguas grises. Se determinó el género y la especie y se estableció el perfil de resistencia frente a otros antibióticos. De todos los antibióticos ensayados, la mayor prevalencia de bacterias heterotróficas resistentes se detectó con la cefalotina (19\%) y ampicilina (8\%). Con respecto, a las bacterias Gram-negativas, la mayor prevalencia de resistencia está dada por los coliformes frente a ampicilina (34\%) y cefalotina (17\%). Se detectó un 38\% de enterococos con bajo nivel de resistencia a vancomicina. Los aislamientos multirresistentes se identificaron como Escherichia coli, Alcaligenes faecalis y Stenotrophomonas maltophilia. Estos resultados indican que las aguas grises pueden considerarse como un reservorio de bacterias resistentes a los antibióticos, aumentando así su riesgo sanitario

Palabras-clave: resistencia a antibióticos; agua gris; antibióticos $\beta$ lactámicos.

\section{Health risks associated with the presence of antibiotic resistant bacteria in greywater}

\begin{abstract}
The removal and disposal of waste from domestic activities is a major health problem in densely populated urban areas. In many areas of Greater Buenos Aires, greywater is disposed in open ditches and risk potential of this has not been adequately quantified. The aim of this study was to evaluate the prevalence of antibiotic-resistant bacteria and its resistance profile present in raw greywater obtained from a channel located in the area of Ingeniero Budge Buenos Aires Province. Thus, the prevalence of heterotrophic bacteria, Gram-negative bacteria resistant to beta-lactam antibiotics and vancomycin-resistant enterococci in greywater, their typing, and resistance to other antibiotics were determined. The prevalence of resistant bacteria was determined by the agar dilution method. Of all the antibiotics tested, the
\end{abstract}


NUÑEZ, L; TORNELlO, C.; PUENTES, N.; MORETTON, J. Bacterias resistentes a antibióticos en aguas grises como agentes de riesgo sanitario. Ambi-Agua, Taubaté, v. 7, n. 1, p. 235-243, 2012. (http://dx.doi.org/10.4136/ambi-agua.638)

highest prevalence of resistant heterotrophic bacteria was detected with cephalothin (19\%) and ampicillin (8\%). With regard to Gram-negative bacteria, the highest prevalence of resistance was given by coliforms ampicillin (34\%) and cephalothin (17\%). A total of 38\% of enterococci with low level resistance to vancomycin was detected. The multiresistant isolates were identified as Escherichia coli, Alcaligenes faecalis y Stenotrophomonas maltophilia. These results indicate that greywater can be considered as a reservoir of bacteria resistant to antibiotics, thus increasing their health risk.

Keywords: antibiotic- resistance; greywater; $\beta$-lactamic antibiotic.

\section{Riscos à saúde associados com a presença de bactérias resistentes a antibióticos em águas cinzas}

\section{RESUMO}

A remoção e eliminação dos resíduos resultantes da atividade doméstica é um grave problema de saúde em áreas urbanas densamente povoadas. Em muitas áreas dos subúrbios de Buenos Aires, as águas cinzas são depositadas em canais abertos, cujo risco sanitário potencial não tem sido devidamente quantificado. O objetivo deste estudo foi avaliar a prevalência de bactérias resistentes a antibióticos presentes em águas cinzas brutas obtidas de um canal localizado na área de Ingeniero Budge, Província de Buenos Aires, bem como seu perfil de resistência. Para isso, determinou-se a prevalência de bactérias heterotróficas, bactérias Gram-negativas resistentes a antibióticos beta-lactâmicos e enterococos resistentes a vancomicina em águas cinzas, a sua tipificação, e resistência a outros antibióticos. A prevalência de bactérias resistentes foi determinada pelo método de diluição em agar. De todos os antibióticos testados, a maior prevalência de resistência de bactérias heterotróficas, foi detectada com cefalotina (19\%) e ampicilina (8\%). Com relação às bactérias Gramnegativas, a maior prevalência de resistência é dada por coliformes ampicilina (34\%) e cefalotina (17\%). Foram detectados $38 \%$ dos enterococos com baixo nível de resistência à vancomicina. As bactérias multirresistentes foram identificadas como Escherichia coli, Alcaligenes faecalis y Stenotrophomonas maltophilia. Estes resultados indicam que a água cinza pode ser considerada como um reservatório de bactérias resistentes aos antibióticos, aumentando o risco microbiológico.

Palavras-chave: resistência a antibióticos; água cinza; antibióticos $\beta$ - lactámicos.

\section{INTRODUCCIÓN}

El desarrollo y diseminación de bacterias resistentes a antimicrobianos está generando una preocupación creciente ya que las bacterias resistentes producen infecciones difíciles de tratar y de controlar. La farmacoterapia para dichas infecciones es costosa y en muchos casos no disponible para un gran grupo de población. En consecuencia, estas propiedades de resistencia bacteriana se están convirtiendo en un problema sanitario, ecológico y económico (Gomez et al., 2007).

La incidencia de bacterias resistentes a antibióticos en el medio acuático se ha incrementado como consecuencia de la utilización a gran escala de los antibióticos. La resistencia a los antibióticos se ha detectado en bacterias presentes en líquidos clocales urbanos (Heuer et al., 2002; Tennstedt et al., 2003), en líquidos residuales hospitalarios (Reinthaler et al., 2003; Schwartz et al., 2003), en barros cloacales (Guillaume et al., 2000; Reinthaler et al., 2003), en aguas subterráneas (Gallert et al., 2005), en ríos contaminados con descargas cloacales (Costanzo et al., 2005). Pocos estudios se han realizado con los efluentes 
conocidos como aguas grises a pesar de ser una de las formas clásicas de eliminación de aguas residuales en las grandes zonas periurbanas de Latinoamérica.

Las aguas grises pueden definirse como los líquidos residuales domiciliarios provenientes de duchas, lavado de ropa, alimentos y vajilla. Por su origen esta agua transportan una significativa carga microbiana cuyas características dependerán de las actividades domésticas desarrolladas en la comunidad (Gross et al., 2007; Casanova et al., 2001). La carga contaminante es menor que la de los líquidos cloacales pero la detección de microorganismos de contaminación fecal indica la potencial presencia de enteropatógenos. Diferentes estudios aislaron agentes patógenos oportunistas como Pseudomonas aeruginosa y Staphylococcus aureus (Birks and Hills, 2007; Gilboa and Friedler, 2008). El agua gris también puede contener patógenos introducidos por la manipulación de los alimentos como Salmonella y bacterias resistentes a antibióticos, de origen humano o animal (Nuñez et al., 2010).

El objetivo de este trabajo fue evaluar la prevalencia de bacterias resistentes a antibióticos presentes en las aguas grises crudas obtenidas de canales localizados en la zona de Ingeniero Budge, Provincia de Buenos Aires, como así también su perfil de resistencia. Para esto se determinó la prevalencia de bacterias heterotróficas, bacterias Gram-negativas resistentes a antibióticos betalactámicos y enterococos vancomicina resistentes en aguas grises, su tipificación y perfil de resistencia frente a otros antibióticos.

La zona seleccionada presenta características de eliminación de aguas similar a otras de la Provincia sumada a una serie de dificultades que la transforman en el escenario más complejo de la región. Los canales a cielo abierto que drenan las aguas grises hacia otros canales mayores que a su vez desembocan en la cuenca Matanza Riachuelo están construidos en terrenos bajo la cota de este río, como consecuencia, el desagüe es dificultoso y durante temporadas de lluvias los canales desbordan cubriendo las zonas habitables de casas y aceras. Estos desbordes incrementan el contacto de los habitantes con las aguas grises y como consecuencia, producen un riesgo que debe ser cuantificado.

\section{MATERIAL Y MÉTODOS}

\subsection{Muestreo}

Se tomaron muestras mensuales durante un año, de mayo de 2008 a abril de 2009 en un canal en Ingeniero Budge, Provincia de Buenos Aires. Todas las muestras se recogieron en una sola toma en bidones de polietileno de 5 litros. Las muestras se conservaron refrigeradas a $4^{\circ} \mathrm{C}$, y fueron procesadas el mismo día de la toma de muestra.

\subsection{Determinación del porcentaje de bacterias resistentes}

Las bacterias son cuantificadas por el método de recuento en placa. De alícuotas de las muestras se prepararon diluciones decimales seriadas $10^{-1}$ a $10^{-4}$ en solución fisiológica y se sembraron por duplicado en placas con medios de cultivo con y sin antibióticos en superficie $(0,1 \mathrm{~mL})$ que se incubaron $24 \mathrm{~h}$ a $35^{\circ} \mathrm{C}$.

Diferentes medios selectivos se utilizaron: agar Slanetz-Bartley para enterococos, y Violeta rojo bilis lactosa agar, como medio de cultivo selectivo, para bacilos Gram negativos. Para el recuento de bacterias heterotróficas se utilizó Mueller-Hinton agar.

Para evaluar el porcentaje de bacterias resistentes se agregaron los siguientes antibióticos:

En Mueller-Hinton agar se utilizaron: $\beta$-lactamicos: ampicilina $(32 \mu \mathrm{g} / \mathrm{mL})$, ceftriaxona $(64 \mu \mathrm{g} / \mathrm{mL})$, cefalotina $(32 \mu \mathrm{g} / \mathrm{mL})$, ceftazidima $(32 \mu \mathrm{g} / \mathrm{mL})$; aminoglucósidos: gentamicina (16 $\mu \mathrm{g} / \mathrm{mL})$; quinolonas: ciprofloxacina $(4 \mu \mathrm{g} / \mathrm{mL})$, 
NUÑEZ, L; TORNELlO, C.; PUENTES, N.; MORETTON, J. Bacterias resistentes a antibióticos en aguas grises como agentes de riesgo sanitario. Ambi-Agua, Taubaté, v. 7, n. 1, p. 235-243, 2012. (http://dx.doi.org/10.4136/ambi-agua.638)

En Violeta rojo bilis lactosa agar: $\beta$-lactámicos: ampicilina, ceftriaxona, cefalotina, ceftazidima .

El agar Slanetz-Bartley se suplementó con $6 \mu \mathrm{g} / \mathrm{mL}$ de vancomicina.

La prevalencia de bacterias resistentes se ha calculado como el número de bacterias que crecen en los medios que contiene antibióticos, dividido por el número de bacterias que crecen en medios que no contienen antibióticos. Las pruebas de sensibilidad a los antibióticos se han realizado por duplicado.

Las cepas aisladas en los medios de cultivo con antibiótico se tipificaron.

Los enterococos se identificaron mediante los ensayos de catalasa, la hidrólisis de esculina y hemólisis en agar sangre. Todos los aislamientos de enterococos vancomicina resistentes son confirmados utilizando API 20 Strep (Biomerieux). Los bacilos Gram negativos se tipificaron mediante la coloración de Gram, el ensayo triple azúcar hierro (TSI), la reacción de oxidasa, la reducción de nitratos y el sistema de identificación de bacterias API 20E y API 20NE (Biomereux). A los cocos Gram positivos aislados de Mueller-Hinton agar se les realizó la prueba de catalasa. En el caso de ser catalasa positivos se efectuó el ensayo de óxido-fermentación, se sembró en caldo con $6.5 \%$ de $\mathrm{ClNa}$, y se confirmó con el sistema API Sth.

\subsection{Ensayos de susceptibilidad antimicrobiana}

Para determinar el perfil de resistencia de los bacilos Gram negativos aislados de los medios de cultivo con antibióticos se utilizó la técnica de difusión en agar Mueller- Hinton. Se utilizaron discos con los siguientes antibióticos: imipenen, meropenen, gentamicina, amicacina, ciprofloxacina, trimetoprima-sulfametoxazol, ampicilina-sulbactan, cefalotina, cefepime, ceftazidima, cefotaxima, piperacilina-tazobactan.

A los enterococos vancomicina resistentes se les determinó la concentración inhibitoria mínima (CIM) por el método de dilución en agar. Se realizó frente a los siguientes antibióticos: vancomicina (V), ampicilina (AMP), gentamicina (GM), tetraciclina.

Cuando se aislaron cocos Gram positivos de los medios de cultivo con antibiótico, se determinó la resistencia a cefoxitina, oxacilina, vancomicina, eritromicina, teicoplamina, clindamicina mediante el método de difusión.

Las pruebas de sensibilidad se han realizado siguiendo las normas del Clinical and Laboratory Standards Institute (CLSI, 2008).

\section{RESULTADOS}

En la Tabla 1 se observan la concentración de las bacterias detectadas en las muestras de agua gris.

Tabla 1. Concentración bacteriana en las muestras de agua gris.

\begin{tabular}{l|c|c|c|c}
\hline & Bacterias heterotróficas & Coliformes & Bacilos & Enterococos \\
\hline Média & $9.8 \times 10^{5}$ & $4.1 \times 10^{5}$ & $3.4 \times 10^{5}$ & $3.2 \times 10^{3}$ \\
Mínimo & $3.3 \times 10^{5}$ & $2.0 \times 10^{4}$ & $4.0 \times 10^{4}$ & $1.4 \times 10^{3}$ \\
Máximo & $9.8 \times 10^{6}$ & $4.5 \times 10^{6}$ & $2.5 \times 10^{6}$ & $2.0 \times 10^{4}$ \\
\hline
\end{tabular}


NUÑEZ, L; TORNELlO, C.; PUENTES, N.; MORETTON, J. Bacterias resistentes a antibióticos en aguas grises como agentes de riesgo sanitario. Ambi-Agua, Taubaté, v. 7, n. 1, p. 235-243, 2012. (http://dx.doi.org/10.4136/ambi-agua.638)

\subsection{Bacterias heterotróficas}

Se han aislado bacterias heterotróficas resistentes a los antibióticos ensayados en todas las muestras. La Figural muestra el porcentaje de bacterias heterotróficas resistentes a los antibióticos. De todos los antibióticos ensayados, la mayor prevalencia de resistencia se detectó con la cefalotina (19\%) y ampicilina (8\%) con valores máximos de 52 y $30 \%$ y con valores mínimos de 0,2 y 0,5\%, respectivamente Entre los antibióticos no betalactámicos, se observó una mayor resistencia a tetraciclina $(1,4 \%)$.

Los aislamientos resistentes fueron predominantemente bacilos Gram-negativos no fermentadores como la Stenotrophomonas maltophilia, Acinetobacter spp, Alcaligenes faecalis. y Psychrobacter phenylpyruvicus. En los perfiles de resistencia observamos que la resistencia a algunos antibióticos es natural como la resistencia de $S$ maltophilia a meropenen y Alcaligenes faecalis a gentamicina. (Tabla 2).

También se aislaron cocos Gram+ resistente a ampicilina y a cefalotina.Estos se identificaron como estafilococos coagulasa negativa. Todos los aislamientos fueron resistentes a cefoxitina y se observó resistencia a vancomicina en el $50 \%$ de dichos aislamientos. Además entre los cocos Gram+ se han aislado cepas identificadas principalmente como Alloiococcus spp y Gemella spp resistentes a cefalosporinas (cefoxitina, ceftazidima y oxacilina).

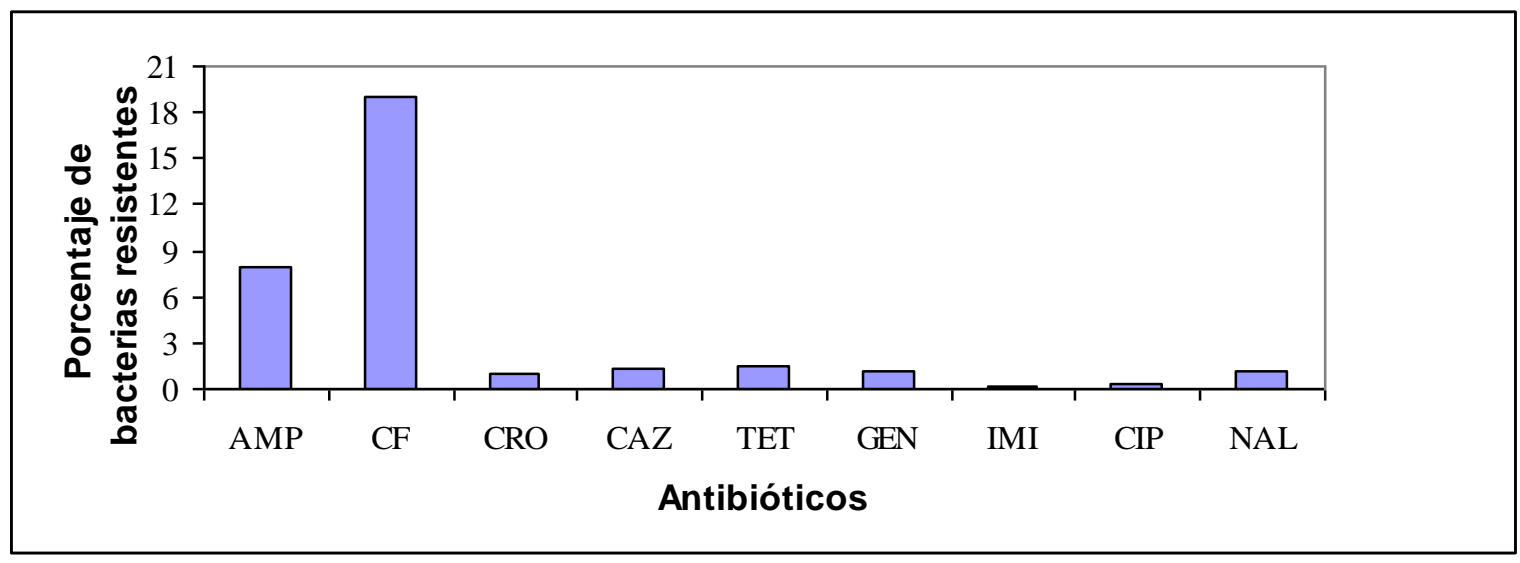

Figura 1. Prevalencia de bacterias heterotróficas resistentes a antibióticos.

\subsection{Bacterias Gram-negativas}

En todas las muestras se detectaron coliformes resistentes a cefalotina y ceftazidima, y con respecto a ampicilina y ceftriaxona, se observaron la presencia de coliformes resistentes en el $90 \%$ de las muestras. Se detectó bacilos Gram negativos no fermentadores de lactosa resistentes a ceftazidima en todas las muestras ensayadas. En cambio, frente a los demás antibióticos se observó resistencia en 80.0 a $90.0 \%$ de las muestras ensayadas.

Se observó una mayor resistencia a ampicilina con un $34.0 \%$ de bacterias coliformes resistentes, seguida por las bacterias resistentes a cefalotina (17.0\%) y alcanzando valores máximos de $100.0 \%$ y $37.0 \%$ y mínimos de 0.1 y $1.1 \%$ respectivamente. Con respecto a los bacilos Gram negativos no coliformes, también se detectó una mayor resistencia a ampicilina, seguida por la cefalotina (valores medios de 20.0 y $12.0 \%$ ) y alcanzando valores máximos de $87.0 \%$ y $40.0 \%$ y mínimos de 3.0 y $2.0 \%$ respectivamente (Figura 2 ).

Los aislamientos de coliformes resistentes fueron identificados como Escherichia coli, los cuales presentaron multirresistencia (Tabla 2).

Con respecto a los aislamientos no fermentadores de lactosa, todos fueron resistentes a cefalotina, ampicilina, ampicilina-sulbactan y a trimetoprima-sulfametoxazol. El 10\% de estos aislamientos fue también resistente a meropenen. 
NUÑEZ, L; TORNELlO, C.; PUENTES, N.; MORETTON, J. Bacterias resistentes a antibióticos en aguas grises como agentes de riesgo sanitario. Ambi-Agua, Taubaté, v. 7, n. 1, p. 235-243, 2012. (http://dx.doi.org/10.4136/ambi-agua.638)

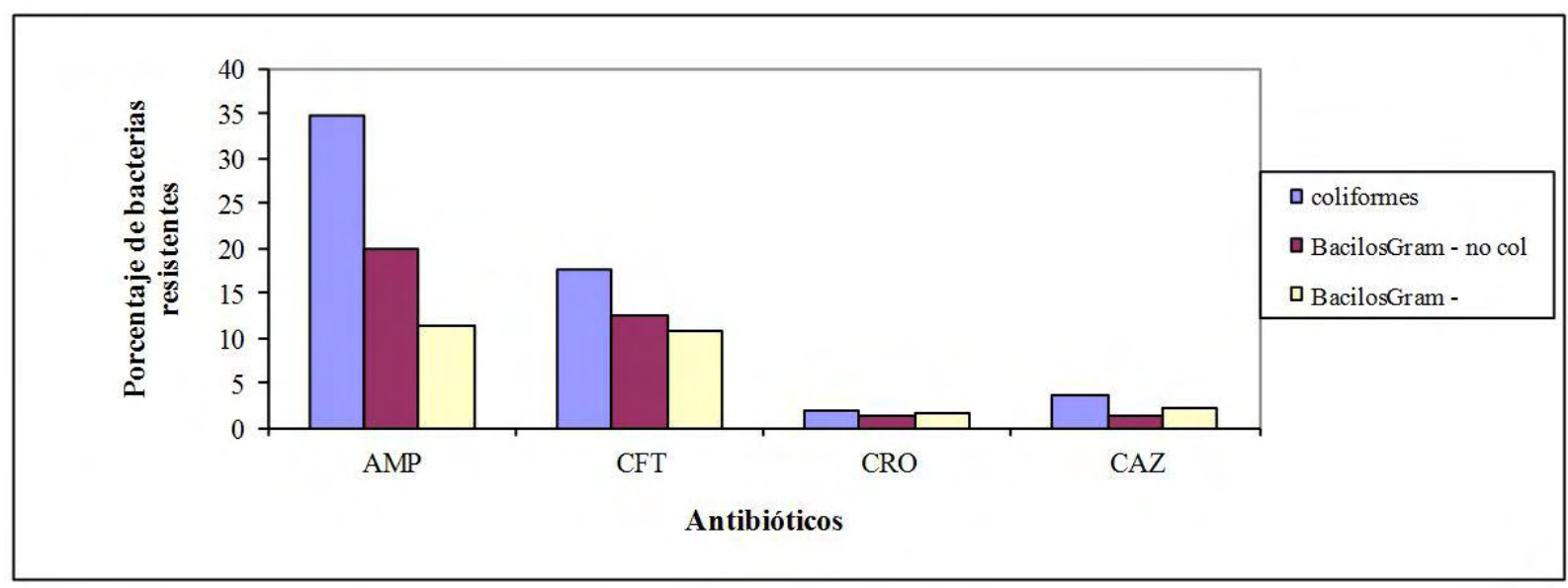

Figura 2. Prevalencia de bacilos Gram negativos resistente a antibióticos $\beta$ - lactámicos.

Tabla 2. Perfil de resistencia de los principales aislamientos.

\begin{tabular}{c|c}
\hline MICROORGANISMOS & PERFIL DE RESISTENCIA \\
\hline Stenotrophomonas maltophilia & MEN-CF-TMS-AMS-FEP \\
Acinetobacter spp & MEN-CIP-CF-AKN-AMS \\
Acinetobacter spp & MEN-CF-CTX-TMS-CAZ-AMS \\
Alcaligenes faecalis & CIP-FEP-TMS-GEN-CAZ \\
Psychrobacter phenylpyruvicus & MEN-TAZ-FEP-CF-CTX-TMS-GEN-CAZ-AMS \\
Escherichia coli & MEN-TAZ-FEP-CF-CAZ-AMS-CTX \\
\hline
\end{tabular}

\subsection{Enterococos resistentes}

Se obsevaron valores medios de $58.6 \%$ enterococos vancomicina resistentes (EVR) con valores mínimo de $38.4 \%$ y un máximo de $71.7 \%$. Los EVR fueron identificados como Enterococcus durans. Los enterococos son resistentes a bajo niveles de vancomicina (8mg/L) pero con alta y constante prevalencia. Son también resistentes a tetraciclina (16 mg/L) y a ciprofloxacina $(32 \mathrm{mg} / \mathrm{L})$.

\section{DISCUSIÓN}

Las aguas grises reciben bacterias previamente expuestas a antibióticos provenientes de tratamientos ambulatorios (contaminación fecal) y las presentes en alimentos frescos. En la actividad agrícola ganadera los antibióticos son usados para tratamiento, profilaxis y promoción del crecimiento.

Estudios reportados por Manaia et al. (2010) realizados en plantas de tratamiento de residuos líquidos municipales detectaron mayor prevalencia de bacterias resistentes a ciprofloxacina (1.7-4.4\%) que la encontrada en este trabajo.

Se observó una mayor prevalencia de bacterias resistentes a tetraciclina que en los líquidos residuales hospitalarios (Nuñez, 2010). Si bien algunos estudios como el de CheeSanford et al. (2001) demostraron que la resistencia a tetraciclina en el ambiente proviene principalmente de la actividad agrícola ganadera escasa es la información acerca de la situación en zonas urbanas densamente pobladas de nuestra región. Los datos de prevalencia de resistencia de bacilos Gram negativos resistentes a betalactámicos fueron similares a la detectada en el sistema cloacal de la ciudad de Buenos Aires. 
NUÑEZ, L; TORNELlO, C.; PUENTES, N.; MORETTON, J. Bacterias resistentes a antibióticos en aguas grises como agentes de riesgo sanitario. Ambi-Agua, Taubaté, v. 7, n. 1, p. 235-243, 2012. (http://dx.doi.org/10.4136/ambi-agua.638)

Los estafilococos coagulasa negativos ( $\mathrm{SCN}$ ) meticilina resistentes predominaron entre los aislamientos analizados. En cambio, Faria et al. (2009) en líquidos residuales urbanos, en Portugal, detectó una alta prevalencia de SCN resistentes a eritromicina y no observó la presencia de meticilina resistentes.

Un estudio en Florida también detectó enterococos resistentes a bajas concentraciones de vancomicina $(5 \mathrm{mg} / \mathrm{L})$ en líquidos residuales domiciliarios. En cambio, en líquidos residuales hospitalarios, diferentes autores observaron la presencia de EVR con resistencia a concentraciones notablemente más altas (480 mg/ L) (Harwood et al., 2001; Nuñez, 2010).

Los coliformes presentaron una mayor prevalencia de resistencia a antibióticos $\beta$ lactámicos que las bacterias no fermentadoras de lactosa. Esto resultados sugieren que las bacterias resistentes provienen de la contaminación fecal de las aguas grises.

\section{CONCLUSIONES}

En las aguas grises, la presencia de bacterias no patógenas resistentes representa un riesgo para los seres humanos y el medio ambiente en que pueden actuar como reservorios de resistencia, contribuir al almacenamiento y difusión de los genes de resistencia a los antibióticos.

Los resultados de este trabajo sugieren que las aguas grises pueden contribuir a la diseminación de bacterias resistentes a los antibióticos. Las aguas grises al contener bacterias multirresistentes presentan un riesgo potencial para la salud pública.

Si bien la eliminación de aguas negras o grises por sistemas de canales a cielo abierto es una práctica poco adecuada desde lo sanitario, la situación socio económica que se presenta tanto en asentamientos precarios como en zonas urbanizadas de América Latina indica que continuará siendo una práctica prevalente durante los próximos años.

A pesar de esta situación poco es lo que se ha estudiado acerca del riesgo sanitario que implica esta práctica y menos aún acerca de la resistencia a antibióticos. El presente trabajo es un aporte para un plan de investigación más amplio relacionado con el riesgo sanitario poblacional que realiza este grupo.

\section{REFERENCIAS}

BIRKS R, HILLS S. Characterization of indicator organisms and pathogens in domestic greywater for recycling. Environmental Monitoring Assessment, v.129, p.61-69, 2007. http://dx.doi.org/10.1007/s10661-006-9427-y

CLINICAL AND LABORATORY STANDARDS INSTITUTE (CLSI). Performance standards for antimicrobial susceptibility testing. 18th edn. Approved standard M100-S18. Wayne, 2008.

CASANOVA, L.; LITTLE, V.; FRYE, R.J.; GERBA, C.P. A survey of the microbial quality of recycled household graywater. Journal of the American Water Resources Association, v. 37, p. 1313-1319, 2001. http://dx.doi.org/10.1111/j.1752-1688.2001.tb03641.x

COSTANZO, S.D.; MURBY, J.; BATES, J. Ecosystem response to antibiotics entering the aquatic environmental. Marine Pollution Bulletin, v. 51, p. 218-223, 2005.

http://dx.doi.org/10.1016/j.marpolbul.2004.10.038 
NUÑEZ, L; TORNELlO, C.; PUENTES, N.; MORETTON, J. Bacterias resistentes a antibióticos en aguas grises como agentes de riesgo sanitario. Ambi-Agua, Taubaté, v. 7, n. 1, p. 235-243, 2012. (http://dx.doi.org/10.4136/ambi-agua.638)

CHEE-SANFORD, J. C.; AMINOV, R. I.; KRAPAC, I. J.; GARRIGUES-JEANJEAN, N.; MACKIE, R. I. Occurrence and diversity of tetracycline resistance genes in lagoon and groundwater underlying two swine production facilities. Applied and Environmental Microbiology, v. 67, p. 1494-1502, 2001. http://dx.doi.org/10.1128/AEM.67.4.1494-1502.2001

FARIA, C.; VAZ-MOREIRA, I.; SERAPICOS, E.; NUNES, O. C.; MANAIA, C. M. Antibiotic resistance in coagulase negative staphylococci isolated from wastewater and drinking water. Science of the Total Environment, v.407, p. 3876-3882, 2009. http://dx.doi.org/10.1016/j.scitotenv.2009.02.034

GALLERT, C.; FUND, K. L.; WINTER, J. Antibiotic resistance of bacteria in raw and biologically treated sewage and in groundwater below leaking sewers. Applied Microbiology and Biotechnology, v. 69, p. 106-112, 2005. http://dx.doi.org/10.1007/s00253-005-0033-7

GILBOA, Y.; FRIEDLER, E. UV disinfection of RBC- treated light light greywater effluent: Kinetics, survival and regrowth of select microorganisms. Water research, v. 42, p. 1043-1050, 2008. http://dx.doi.org/10.1016/j.watres.2007.09.027

GUILlAUME, G., VERBRUGGE, D., CHASSEUR-LIBOTTE, M., MOENS, W. AND COLLARD, J. PCR typing of tetracycline resistance determinants (Tet A-E) in Salmonella enterica serotype Hadar and in the microbial community of activated sludges from hospital and urban wastewater treatment facilities in Belgium. FEMS Microbiology Ecology, v.32, p. 77-85, 2000.

GÓMEZ LÓPEZ, M.; ARAUJO PRADO, M.; DÍAZ DÍAZ, M. T.; GARRIDO VÁZQUEZ, J.; SUEIRO, R.; SUÁREZ, S. El tratamiento secundario de aguas residuales comomecanismo redistribuidor de genes de resistencia en bacterias: análisis y evaluación de riesgo. Higiene y Sanidad Ambiental, v. 7, p. 238-250, 2007.

GROSS, A.; KAPLAN, D.; BAKER, B. Removal of chemical and microbiological contaminants from domestic greywater using a recycled vertical flor biorreactor (RVFB). Ecological engineering, v. 31, p. 107-114, 2007.

http://dx.doi.org/10.1016/j.ecoleng.2007.06.006

HARWOOD, V. J.; BROWNELL, M.; PERUSEK, W.; WHITLOCK, J. E. Vancomycinresistant Enterococcus spp. isolated from wastewater and chicken feces in the United States. Applied Environmental Microbiology, v. 67, p. 4930-4933, 2001.

http://dx.doi.org/10.1128/AEM.67.10.4930-4933.2001

HEUER, H.; KROGERRECKLENFORT, E.; WELLINGTON, E. M. H.; EGAN, S.; VAN ELSAS, J. D.; VAN OVERBEEK, L. et al. Gentamicin resistance genes in environmental bacteria: prevalence and transfer. FEMS Microbiology Ecology, v. 42, p. 289-302, 2002. http://dx.doi.org/10.1111/j.1574-6941.2002.tb01019.x

MANAIA, C. M.; NOVO, A.; COELHO, B.; NUNES, O.C. Ciprofloxacin Resistance in Domestic Wastewater Treatment Plants. Water Air Soil Pollution, v. 208, p 335-343, 2010. http://dx.doi.org/10.1007/s11270-009-0171-0

NUÑEZ, L. Riesgo sanitario asociado a líquidos residuales hospitalarios. Disertación (Máster en Investigación y avances en Medicina Preventiva y Salud Pública)Universidad de Granada, Granada, 2010. 
NUÑEZ, L; TORNELlO, C.; PUENTES, N.; MORETTON, J. Bacterias resistentes a antibióticos en aguas grises como agentes de riesgo sanitario. Ambi-Agua, Taubaté, v. 7, n. 1, p. 235-243, 2012. (http://dx.doi.org/10.4136/ambi-agua.638)

NUÑEZ, L.; PAZ, M.; TORNELlO, C.; MANTOVANO, J.;MOLINARI, C.; MORETTON, J. Caracterización microbiológica de aguas grises bajo distintas condiciones de disposición final en Ingeniero Budge (Buenos Aires, Argentina). Higiene y Sanidad Ambiental, v. 10, p. 569$574,2010$.

PATERSON, D. L. Resistance in gram-negative bacteria: Enterobacteriaceae. American Journal of Medicine, v. 119, p. S20-S28, 2006.

http://dx.doi.org/10.1016/j.amjmed.2006.03.013

REINTHALER F.F.,. POSCH J., FEIERL G., WUST G., HAAS D., RUCKENBAUER G., MASCHER F., MARTH E. Antibiotic resistance of E. coli in sewage and sludge. Water Research, v. 37, p.1685-1690, 2003. http://dx.doi.org/10.1016/S0043-1354(02)00569-9

SCHWARTZ, T.; KOHNEN, W.; JANSEN, B.; OBST, U. Detection of antibiotic-resistant bacteria and their resistance genes in wastewater, surface water, and drinking water biofilms. FEMS Microbiology Ecology, v. 43, p. 325-335, 2003. http://dx.doi.org/10.1111/j.1574-6941.2003.tb01073.x

TENNSTEDT, T.; SZCZEPANOWSKI, R.; BRAUN, S.; PUHLER, A.; SCHLUTER, A. Occurrence of integron-associated resistance gene cassetes located on antibiotic resistance plasmids isolated from a wastewater treatment plant. FEMS Microbiology Ecology, v. 45, p. 239-252, 2003. http://dx.doi.org/10.1016/S0168-6496(03)00164-8 


ISSN = 1980-993X - doi:10.4136/1980-993X
www.ambi-agua.net
E-mail: ambi-agua@agro.unitau.br
Tel.: (12) 3625-4212

\title{
Qualidade da água de chuva armazenada em cisterna utilizada na dessedentação de suínos e bovinos de corte
}

\author{
(http://dx.doi.org/10.4136/ambi-agua.822) \\ Julio Cesar Pascale Palhares ${ }^{1}$; Antônio Lourenço Guidoni ${ }^{2}$ \\ ${ }^{1}$ Embrapa Pecuária Sudeste, São Carlos, São Paulo, Brasil \\ ${ }^{2}$ Embrapa Clima Temperado, Pelotas, Rio Grande do Sul, Brasil \\ e-mails: palhares@cppse.embrapa.br; antlogui@gmail.com
}

\section{RESUMO}

Na região do Meio Oeste Catarinense tem-se incentivado a utilização de cisternas como tecnologia capaz de ofertar água aos rebanhos. A região é caracterizada por secas severas nos meses de verão. Os objetivos da pesquisa foram: monitorar variáveis físicas, químicas e microbiológicas de qualidade da água de chuva de uma cisterna; avaliar se a água armazenada possuía qualidade para dessedentação de suínos e bovinos de corte. As concentrações de nitrato, nitrito e amônia mantiveram-se de acordo com os padrões para o consumo animal. A E. coli esteve presente em algumas amostras. A quantidade de chuva e velocidade do vento influenciaram as concentrações dos elementos nitrogenados. Investigações a fim de aprofundar esse conhecimento devem ser conduzidas para que as fontes emissoras agrícolas e pecuárias não representam alto impacto negativo para a qualidade da água. A água armazenada na cisterna apresentou qualidade satisfatória para o uso na dessedentação de suínos e bovinos de corte o que corrobora a utilização da tecnologia, visando o uso eficiente da água pelas produções pecuárias.

Palavras-chave: coliformes; legislação; nitrato; nitrogênio amoniacal.

\section{Rain water quality of a cistern used for pigs and beef cattle}

\begin{abstract}
Santa Catarina State has encouraged the use of cisterns as a technology to offer water in quantity and quality to livestock. The region is characterized by severe droughts in the summer months. The aims of the study were: to monitor physical, chemical and microbiological rain water quality parameters of a cistern; to evaluate if water had quality for pigs and beef cattle water consumption. Concentrations of nitrate, nitrite and ammonia were in accordance with the standards for animal consumption. E. coli was present in some samples. The rainfall and speed of wind influenced the concentrations of nitrogen. Investigations of the relations between these environmental parameters and water quality must be conducted to avoid agricultural and livestock emission sources to have a negative impact on water quality. The water stored in the cistern showed satisfactory quality for use of pigs and beef cattle drinking. This gives support to the utilization of this technology to improve the water use efficiency for livestock.
\end{abstract}

Keywords: ammonium nitrogen; coliforms; legislation; nitrate. 
PALHARES, J. C. P.; GUIDONI, A. L. Qualidade da água de chuva armazenada em cisterna utilizada na dessedentação de suínos e bovinos de corte. Ambi-Agua, Taubaté, v. 7, n. 1, p. 244-254, 2012. (http://dx.doi.org/10.4136/ambi-agua.822)

\section{INTRODUÇÃO}

A disponibilidade de água em quantidade e qualidade para os rebanhos é uma preocupação dos produtores rurais devido às constantes ameaças antrópicas a esse recurso natural. Essas ameaças são intensificadas em regiões nas quais a concentração de animais por unidade de área é elevada, a ocorrência de secas é um fator inerente aos ciclos produtivos, há conflitos pelo uso da água e o atendimento ao saneamento urbano e rural são precários.

O uso de cisterna para o armazenamento de água da chuva é uma tecnologia que pode atenuar as ameaças citadas bem como dispor água para os rebanhos. Essa tecnologia tem sido utilizada desde as primeiras organizações humanas e seu uso é fomentado por governos e instituições ao redor do mundo, principalmente, nas regiões onde a disponibilidade de água é escassa em quantidade e qualidade. A captação da água da chuva e seu armazenamento em cisternas, além de promover a segurança hídrica, promovem a segurança alimentar e econômica de produtores rurais e territórios.

O armazenamento de água da chuva é prática comum em muitas nações há milhares de anos, especialmente nas zonas áridas ou remotas, onde o fornecimento de água encanada ou através de redes não é rentável ou tecnicamente viável (Simmons et al., 2001; Ngigi, 2003; Prado et al., 2007). A colheita de água da chuva inclui todas as etapas relacionadas a captação, armazenamento, utilização e gestão da água para finalidades produtivas (agricultura, pastagem, silvicultura, pecuária e abastecimento de água doméstica, etc.). Os componentes de um sistema de aproveitamento de água pluvial variam de acordo com o uso que se pretende fazer, da qualidade da água desejada, do espaço para as instalações e dos recursos financeiros disponíveis (Mantovan et al., 1995).

Estudos relacionando o armazenamento de água em cisternas com as variáveis físicas, químicas e microbiológicas da água são escassos, bem como programas de monitoramento a fim de estabelecer relações entre as condições climáticas e de captação e armazenamento com as exigências qualitativas dos diversos usos.

Há uma ausência de informações científicas quanto à qualidade da água coletada dos telhados, com isso tem-se assumido que está é uma fonte relativamente segura, até mesmo para o consumo humano (Lye, 2009).

O tipo de uso que se pretende fazer da água irá determinar à qualidade que essa deve ter e consequentemente a gestão da tecnologia. A utilização da água de cisterna para dessedentação de animais é um uso nobre. O referencial de qualidade para esse tipo de uso são as Resoluções 357 (Brasil, 2005) e 396 (Brasil, 2008) do CONAMA. Também deve ser considerada a ABNT NBR 15527 (ABNT, 2007).

A qualidade da água da chuva captada em cisternas depende da pureza da atmosfera e do entorno desta, da época do ano, da duração e intensidade da chuva, das condições regionais, dos materiais usados para construir a área de captação, das impurezas depositadas na superfície do telhado, das calhas que conduzem a água para a cisterna, da "ecologia da cisterna", da maneira como se tira a água, do contato humano e do tipo de tratamento antes do consumo .

Normalmente a qualidade química e física de água de chuva armazenada nas cisternas é boa, mas é difícil atingir, sem cuidados específicos, um padrão de qualidade com ausência de coliformes (Brito e Gnadlinger, 2006). A água da chuva é naturalmente livre de organismos patogênicos, mas pode tornar-se contaminada devido ao contato com as superfícies de captação e armazenamento. Portanto, a qualidade microbiológica da água irá depender das condições de armazenamento, fatores como temperatura e tempo, manutenção e práticas sanitárias relacionadas ao sistema (WHO, 2008). A coleta de água da chuva insere potenciais riscos a saúde devido à presença de possíveis contaminantes microbiológicos e químicos. Patógenos podem ter origem fecal de aves, mamíferos e répteis que têm acesso as áreas de 
PALHARES, J. C. P.; GUIDONI, A. L. Qualidade da água de chuva armazenada em cisterna utilizada na dessedentação de suínos e bovinos de corte. Ambi-Agua, Taubaté, v. 7, n. 1, p. 244-254, 2012. (http://dx.doi.org/10.4136/ambi-agua.822)

captação ou armazenamento. A contaminação química pode ocorrer devido às emissões do tráfego e da poluição industrial em áreas urbanas ou devido ao uso agrícola de adubos e pesticidas nas áreas rurais (Sazaklia, 2007).

A região do Meio Oeste Catarinense é uma tradicional produtora de suínos, aves de corte e bovinos de leite, sendo historicamente caracterizada por uma das maiores concentrações de animais do país. A região também apresenta um período de severa estiagem na época do verão o que tem condicionado perdas agrícolas e dos rebanhos por falta de água. Esse cenário tem sido utilizado como motivador para implantação de cisternas nas propriedades rurais a fim de reduzir o impacto da estiagem, principalmente, quanto à oferta de água para os animais. A literatura indica a possibilidade do uso dessa água para a dessedentação de animais, mas não há pesquisas no país que tenham como foco essa avaliação.

A validação do uso de água de chuva armazenada em cisternas para a dessedentação de animais pode promover a segurança hídrica das propriedades rurais em três dimensões: ambiental, conservando o recurso natural devido à menor extração das fontes superficiais e subterrâneas, promovendo o uso racional da água e consequentemente maior eficiência hídrica das produções, reduzindo a pegada hídrica das criações; social, auxiliando na manutenção do homem no campo por contribuir para a independência hídrica da propriedade e reduzir sua dependência a fontes externas, promovendo o bem estar de humanos e animais, facilitando o cumprimento da legislação ambiental; econômica, reduzindo o impacto do custo da água no custo de produção das atividades.

A pesquisa constituísse em um estudo de caso de caráter descritivo no qual o pesquisador não interveio no manejo da tecnologia e apresentou os seguintes objetivos: monitorar variáveis físicas, químicas e microbiológicas de qualidade da água de uma cisterna que armazena água de chuva; avaliar se a água armazenada possuía qualidade para dessedentação de suínos e bovinos de corte.

\section{MATERIAL E MÉTODOS}

O estudo de caso foi conduzido entre os meses de novembro de 2008 a maio de 2010 em propriedade rural localizada no município de Concórdia, Santa Catarina, Brasil. As coordenadas geográficas são: latitude $-27.270075^{\circ}$ e longitude $-51.960881^{\circ}$. A propriedade situa-se a uma altitude de $691 \mathrm{~m}$.

$\mathrm{O}$ clima do município é temperado, com temperaturas médias de $17,9^{\circ} \mathrm{C}$ a $19,8^{\circ} \mathrm{C}$, máximas variando de $25,8^{\circ} \mathrm{C}$ a $27,5^{\circ} \mathrm{C}$ e mínimas de $12,9^{\circ} \mathrm{C}$ a $14,0^{\circ} \mathrm{C}$. A precipitação anual varia entre $1.430 \mathrm{~mm}$ e $2.020 \mathrm{~mm}$, com dias de chuva que variam de 108 a 150 dias.

A propriedade denominada como de agricultura familiar, apresentava o perfil produtivo, econômico e social típico das propriedades rurais localizadas nas regiões do Meio-Oeste e Oeste de Santa Catarina. A área total era de 34 ha, 22 ha eram ocupados com culturas (milho, 16 ha; pastagem, 5 ha; uva, 0,5 ha; erva-mate, 0,5 ha) e 7 ha com mata nativa. As atividades comercialmente desenvolvidas eram a suinocultura (610 animais em terminação); bovinocultura de corte (seis vacas e 39 bezerros); milho; uva.

Como principais características sociais da propriedade destacam-se: possuía uma unidade residencial com quatro adultos e uma criança; os adultos tinham baixo nível de escolaridade (três adultos não possuíam o ensino fundamental completo e um possui até a primeira série do ensino médio), havia contratação de mão-de-obra temporária nos momentos de intensificação das atividades agrícolas.

Quanto às condições ambientais, na propriedade existia uma fonte permanente de água que era utilizada para consumo humano e animal; a fonte estava protegida de acordo com as exigências da legislação ambiental; possuía licença ambiental somente para atividade 
PALHARES, J. C. P.; GUIDONI, A. L. Qualidade da água de chuva armazenada em cisterna utilizada na dessedentação de suínos e bovinos de corte. Ambi-Agua, Taubaté, v. 7, n. 1, p. 244-254, 2012. (http://dx.doi.org/10.4136/ambi-agua.822)

suinícola; os dejetos animais eram utilizados como fertilizantes em todas as áreas sem orientação técnica.

A cisterna foi construída em agosto de 2008 devido aos recorrentes eventos de falta de água na estação da seca o que obrigava o proprietário adquirir de duas a quatro cargas de água por dia $(8.000 \mathrm{~L} /$ carga) para dessedentação dos animais. A cisterna estava localizada a $150 \mathrm{~m}$ de uma rodovia federal que apresentava intenso tráfego de veículos pesados.

O sistema foi dimensionado pelos técnicos da Prefeitura Municipal. A cisterna era escavada revestida com manta de polietileno e coberta com estrutura metálica e lona, evitando assim a entrada de insetos e sujeira. A lona de cobertura tinha sua parte externa na cor azul e parte interna na cor preta.

A capacidade de armazenamento era de $500 \mathrm{~m}^{3}$. A captação da água era feita de dois telhados de instalações para suínos e bovinos, totalizando $621 \mathrm{~m}^{2}$ de superfície de captação, por sistema de calhas de alumínio que ficavam junto ao beiral destes. Canos de PVC conduziam a água até o sistema de filtragem. Em ambos os galpões as telhas eram de fibrocimento, sendo que as partes metálicas tinham contato com a água captada. Telhados e o interior da cisterna nunca foram lavados.

Antes da água captada nos telhados entrar na cisterna ela passava por um sistema de filtração em série composto por três filtros. Os filtros eram feitos de caixas d'água plástica com capacidade de $2.000 \mathrm{~L}$ e tinham como meio filtrante basalto e britas. O primeiro filtro possuía rocha tipo basalto, sendo que no segundo e terceiro havia brita tipo 2 . O descarte da água das primeiras chuvas era realizado, mas essa passava pelo sistema de filtragem antes do descarte, o que proporcionava a rápida saturação do meio filtrante, demandando lavagem das britas de forme frequente. Durante o período de monitoramento ocorreram duas lavagens do meio filtrante.

As águas das primeiras chuvas eram descartadas de acordo com a percepção dos proprietários. Eles relataram que em alguns eventos esse descarte não ocorria, pois a chuva se dava a noite ou eles não tinham disponibilidade para fazer no momento necessário. A captação da água da cisterna era feita superficialmente e não havia sistema de cloração.

$\mathrm{O}$ monitoramento ocorreu com periodicidade mensal. As coletas para análise da qualidade da água ocorreram em dois pontos de amostragem, superfície da cisterna (coletas realizadas $20 \mathrm{~cm}$ abaixo da superfície da água) e fundo. As coletas para análise dos elementos nitrogenados (nitrato, nitrito e amônia) ocorreram somente na superfície.

No momento das coletas utilizou-se Sonda Multiparâmetro Modelo Hanna HI 9828 para monitorar a temperatura $\left({ }^{\circ} \mathrm{C}\right)$, oxigênio dissolvido $\left(\mathrm{mg} . \mathrm{L}^{-1}\right)$, potencial hidrogeniônico, potencial redox $(\mathrm{mV})$, Sólidos Dissolvidos Totais $(\mathrm{ppm})$ e condutividade elétrica $(\mu \mathrm{S} / \mathrm{cm})$.

Para cada ponto de amostragem foram coletados dois litros de amostra as quais eram acondicionadas em garrafas plásticas e armazenadas a $4^{\circ} \mathrm{C}$. Imediatamente após a coleta, as amostras eram levadas para o Laboratório de Análises Ambientais da Embrapa Suínos e Aves para determinação de nitrato $\left(\mathrm{N}-\mathrm{NO}_{3}\right)$, nitrito $\left(\mathrm{N}-\mathrm{NO}_{2}\right)$ e nitrogênio amoniacal $\left(\mathrm{N}_{-} \mathrm{NH}_{3}\right)$. O protocolo de amostragem, estabilização da amostra e análise estavam de acordo com os procedimentos da American Public Health Association (1995).

$\mathrm{Na}$ determinação do nitrito e do nitrato utilizou o método colorimétrico em um sistema de análise por injeção de fluxo. Foi utilizado um sistema multicanal FIAlab- 2500. Cabos de fibra ótica SMA $200 \mathrm{~mm}$ que ligam a célula de reação ao espectrofotômetro (Ocean-Optics S2000). Para determinação do nitrato foi utilizada coluna com $5 \mathrm{~g}$ de cádmio. A determinação do nitrogênio amoniacal foi realizada com eletrodo de íon seletivo da marca Thermo pelo método potenciométrico.

As análises microbiológicas foram realizadas no Centro de Diagnóstico de Sanidade Animal - Cedisa a partir de amostras de $200 \mathrm{~mL}$ coletadas em garrafas plásticas esterilizadas. 
PALHARES, J. C. P.; GUIDONI, A. L. Qualidade da água de chuva armazenada em cisterna utilizada na dessedentação de suínos e bovinos de corte. Ambi-Agua, Taubaté, v. 7, n. 1, p. 244-254, 2012. (http://dx.doi.org/10.4136/ambi-agua.822)

Analisou-se o número de Coliformes Totais (CT), Coliformes Termotolerantes (CF) e Escherichia coli $(\mathrm{Ec})$ em UFC $\mathrm{mL}^{-1}$ utilizando-se a metodologia de Placa Petrifilm.

O protocolo de amostragem para avaliação da qualidade da água também conteve: entrevista aberta com o produtor a fim de avaliar os eventos e manejos ocorridos no período anterior; relato dos resultados da amostragem do mês anterior; observação da cisterna e entorno.

As informações relacionadas a quantidade de chuva e a velocidade do vento foram geradas na Estação Meteorológica da Embrapa Suínos e Aves a qual faz parte da rede estadual de monitoramento meteorológico. A estação está localizada na unidade da Embrapa e a $5 \mathrm{~km}$ da propriedade de estudo.

O Brasil não dispõe de legislação ou normativa técnica que determine a qualidade que a água armazenada em cisterna deve ter para dessedentação de animais. Portanto, o referencial utilizado para verificar se a água da cisterna possuía qualidade para uso na dessedentação foi a Resolução Conama 357 que classifica as águas superficiais. A Resolução determina que águas superficiais destinada a esse uso deva cumprir os padrões Classe 3.

Por ser um estudo de caso, o trabalho gerou dados observacionais, portanto se enquadra na categoria dos delineamentos quase-experimentais em que as datas de amostragem são usadas como repetições no tempo e cada data é entendida como um fator aleatório do tipo bloco. Para fins de análise a condição de independência entre as datas é assumida e o modelo de análise é do tipo blocos (datas de amostragem) com dois tratamentos (profundidades da cisterna, superfície e fundo). Por se tratar de dados observacionais o nível de significância adotado chegou até a $15 \%$ de probabilidade. As comparações entre as profundidades foram feitas pelo Teste F. Calculou-se a correlação de Pearsosn entre cada variável de qualidade da água e as variáveis meteorológicas. As análises estatísticas foram realizadas com o programa SAS (2003).

\section{RESULTADOS E DISCUSSÃO}

$\mathrm{Na}$ discussão dos resultados irá se fazer a generalização analítica, ou seja, irá se generalizar a partir dos aspectos da unidade de estudo a qual pode ser caracterizada como representativa do modelo agrário familiar vigente no Estado e na região Sul do Brasil. Portanto, a validade externa da generalização foi estabelecida a partir das características socioeconômicas, produtivas e ambientais da propriedade o que garante a confiabilidade desse estudo de caso.

As maiores médias de chuvas concentraram-se entre agosto de 2009 e fevereiro de 2010 , o que corresponde às estações de primavera e verão. Neste período as médias de velocidade do vento também foram elevadas (Tabela 1). Chuva e vento são dois fatores que irão influenciar na qualidade da água armazenada na cisterna. $O$ vento carreará partículas em suspensão no ar, sendo que muitas destas irão ser depositadas na superfície de captação do telhado. Dependendo da orientação dos ventos e da posição das fontes emissoras, esse fator poderá depreciar a qualidade da água armazenada. Na região de estudo as maiores fontes de emissão de gases e partículas são a produção animal, potencial emissora de amônia e outros gases, e a agricultura, via manejo dos solos. A emissão de gases pelas produções animais é uma fonte de emissão constante, mas a contribuição da agricultura compreende um perfil sazonal, pois as maiores emissões ocorrerão no período de preparo da terra para o plantio e colheita do milho, entre os meses de julho e setembro e fevereiro, respectivamente.

Estudos demonstram a relação entre a composição química da água da chuva e a proximidade de fontes emissoras de poluição, padrões climáticos, transporte e disposição de partículas (Evans et al., 2007). Em regiões agrícolas as populações microbianas estão mais 
PALHARES, J. C. P.; GUIDONI, A. L. Qualidade da água de chuva armazenada em cisterna utilizada na dessedentação de suínos e bovinos de corte. Ambi-Agua, Taubaté, v. 7, n. 1, p. 244-254, 2012. (http://dx.doi.org/10.4136/ambi-agua.822)

presentes na atmosfera durante a época de colheita das culturas, há relatos de amostras de chuva com aspecto turvo nessas regiões durante esses meses (Agrios, 1997).

Tabela 1. Quantidade total de chuva, médias de chuva e velocidade do vento e valores mínimos e máximos entre o período de coletas.

\begin{tabular}{l|c|c|c|c}
\hline \multicolumn{1}{c|}{$\begin{array}{c}\text { Mês de } \\
\text { Coleta }\end{array}$} & $\begin{array}{c}\text { Dias } \\
\text { entre } \\
\text { coletas }\end{array}$ & $\begin{array}{c}\text { Total de chuva no } \\
\text { período entre as coletas } \\
\text { e valores mínimos e } \\
\text { máximos (mm) }\end{array}$ & $\begin{array}{c}\text { Média de Chuva } \\
\text { por dia (mm) }\end{array}$ & $\begin{array}{c}\text { Velocidade média do } \\
\text { vento por dia e valores } \\
\left.\text { mínimos e máximos (m.s } \mathbf{s}^{-1}\right)\end{array}$ \\
\hline novembro & - & - & - & - \\
dezembro & 21 & $60(8-20)$ & 2,8 & $1,70(1,7-2,3)$ \\
janeiro & 35 & $149(1-31)$ & 4,2 & $1,42(0,0-2,3)$ \\
fevereiro & 18 & $18(5-13)$ & 1,0 & $1,67(1,0-2,3)$ \\
março & 31 & $172(1-34)$ & 5,5 & $1,36(0,0-2,3)$ \\
abril & 32 & $41(1-22)$ & 1,3 & $1,45(1,0-2,5)$ \\
maio & 28 & $35(1-34)$ & 1,2 & $1,45(1,0-2,0)$ \\
junho & 21 & $162(1-76)$ & 7,7 & $1,21(1,0-3,5)$ \\
julho & 35 & $72(4-39)$ & 2,1 & $1,26(1,0-3,5)$ \\
agosto & 45 & $390(1-68)$ & 8,6 & $1,28(0,0-2,5)$ \\
setembro & 27 & $253(5-90)$ & 9,4 & $1,48(1,0-2,5)$ \\
outubro & 33 & $341(2-75)$ & 10,3 & $1,59(1,0-2,5)$ \\
novembro & 28 & $199(1-62)$ & 7,1 & $1,59(1,0-3,5)$ \\
dezembro & 36 & $247(1-45)$ & 6,8 & $1,58(1,0-3,0)$ \\
janeiro & 30 & $168(1-48)$ & 5,6 & $1,53(1,0-3,0)$ \\
fevereiro & 34 & $379(1-118)$ & 11,1 & $1,51(0,0-3,0)$ \\
março & 26 & $161(2-53)$ & 6,2 & $1,01(0,0-2,5)$ \\
abril & 29 & $45(3-11)$ & 11,3 & $\mathrm{~s} / 1$ \\
maio & 42 & $476(3-87)$ & & \\
\hline sion & & &
\end{tabular}

$\mathbf{s} / \mathbf{l}=$ sem leitura.

A chuva transporta os gases e partículas dissolvidos e em suspensão na atmosfera, bem como promove a lavagem do telhado. Esses dois eventos poderão depreciar a qualidade da água armazenada, portanto o correto manejo da água antes do armazenamento é fundamental para conservação dos padrões de qualidade exigidos para os diversos usos. Deverá ser feita a drenagem do excesso da água da chuva provocado por chuvas intensas e eliminação da água da chuva inicial que lava os telhados. No período inicial da chuva são carregados alguns detritos e contaminantes que ficam no telhado e calhas, assim alguns minutos de chuva farão a limpeza do telhado (Fendrich e Oliynik, 2002).

Os proprietários declararam que a água da primeira chuva era descartada, mas que em alguns momentos esse manejo não era feito. $O$ descarte era feito de forma manual, o que insere alto potencial de risco. Portanto, em certos momentos, a água da primeira chuva foi armazenada o que acarretaria impactos nas variáveis químicas e microbiológicas da água. $\mathrm{O}$ impacto do não descarte da primeira chuva será potencializado pela falta de limpeza da cisterna. Durante o período de monitoramento a cisterna não foi limpa, bem como o telhado e as calhas, portanto a matéria orgânica carreada pela chuva acumulou-se na cisterna. 
PALHARES, J. C. P.; GUIDONI, A. L. Qualidade da água de chuva armazenada em cisterna utilizada na dessedentação de suínos e bovinos de corte. Ambi-Agua, Taubaté, v. 7, n. 1, p. 244-254, 2012. (http://dx.doi.org/10.4136/ambi-agua.822)

Observou-se diferença significativa entre as amostras coletadas na superfície e fundo da cisterna somente para as variáveis de oxigênio dissolvido e temperatura (Tabela 2). Baixas concentrações de oxigênio no fundo da cisterna estão relacionadas a ausência de troca gasosa nesta região, pois na superfície há troca entre esta e a coluna de ar. As baixas concentrações também podem ser produto do acúmulo de matéria orgânica no fundo da cisterna o que provoca a consumo do gás na sua degradação aeróbia.

Tabela 2. Médias e erros-padrão das variáveis de qualidade da água na cisterna.

\begin{tabular}{|c|c|c|c|c|}
\hline \multirow{3}{*}{ Variáveis } & \multicolumn{4}{|c|}{ Profundidade } \\
\hline & \multicolumn{2}{|c|}{ Médias sem Correção ${ }^{1}$} & \multicolumn{2}{|c|}{ Médias com Correção $^{2}$} \\
\hline & Superfície & Fundo & Superfície & Fundo \\
\hline Oxigênio Dissolvido $\left(\mathrm{mg} . \mathrm{L}^{-1}\right)$ & $3,2 \pm 0,28 \mathrm{a}$ & $1,6 \pm 0,30 \mathrm{~b}$ & $3,4 \pm 0,27 \mathrm{a}$ & $1,7 \pm 0,28 b$ \\
\hline Temperatura $\left({ }^{\circ} \mathrm{C}\right)$ & $21,5 \pm 0,47 \mathrm{a}$ & $19,5 \pm 0,50 \mathrm{~b}$ & $21,6 \pm 0,83 \mathrm{a}$ & $19,3 \pm 0,87 \mathrm{~b}$ \\
\hline $\mathrm{pH}$ & $6,8 \pm 0,07 \mathrm{a}$ & $6,9 \pm 0,08 \mathrm{a}$ & $6,9 \pm 0,10 \mathrm{a}$ & $6,9 \pm 0,10 \mathrm{a}$ \\
\hline $\begin{array}{l}\text { Sólidos Dissolvidos Totais } \\
\left(\mathrm{mg} . \mathrm{L}^{-1}\right)\end{array}$ & $24,19 \pm 0,66 \mathrm{a}$ & $25,47 \pm 0,71 \mathrm{a}$ & $24,62 \pm 2,29 \mathrm{a}$ & $23,42 \pm 2,39 \mathrm{a}$ \\
\hline $\begin{array}{l}\text { Condutividade Elétrica } \\
\left(\mu \mathrm{S} . \mathrm{cm}^{-1}\right)\end{array}$ & $0,06 \pm 0,00 \mathrm{a}$ & $0,06 \pm 0,00 \mathrm{a}$ & $0,06 \pm 0,01 \mathrm{a}$ & $0,05 \pm 0,01 \mathrm{a}$ \\
\hline Potencial Redox (mV) & $-42,83 \pm 4,98 \mathrm{a}$ & $-52,25 \pm 5,36 \mathrm{a}$ & $-48,49 \pm 26,93 \mathrm{a}$ & $-45,25 \pm 28,13 \mathrm{a}$ \\
\hline $\begin{array}{l}\text { Coliformes Totais (UFC } 100 \\
\mathrm{~mL}^{-1} \text { ) }\end{array}$ & $659 \pm 189 \mathrm{a}$ & $947 \pm 189 \mathrm{a}$ & $653 \pm 309 a$ & $970 \pm 309 a$ \\
\hline $\begin{array}{l}\text { Coliformes Termotolerantes } \\
\text { (UFC } 100 \mathrm{~mL}^{-1} \text { ) }\end{array}$ & $632 \pm 187 \mathrm{a}$ & $932 \pm 187 \mathrm{a}$ & $624 \pm 302 \mathrm{a}$ & $958 \pm 302 \mathrm{a}$ \\
\hline $\begin{array}{l}\text { Escherichia coli } \\
\left(\text { UFC } 100 \mathrm{~mL}^{-1}\right)\end{array}$ & $27 \pm 10 \mathrm{a}$ & $21 \pm 10 \mathrm{a}$ & $29 \pm 14 \mathrm{a}$ & $18 \pm 14 \mathrm{a}$ \\
\hline Amônia (N-NH$\left.H_{3} \mathrm{mg} \cdot \mathrm{L}^{-1}\right)$ & $0,11 \pm \mathrm{a}$ & & $0,10 \pm 0,02 \mathrm{a}$ & \\
\hline Nitrito $\left(\mathrm{N}-\mathrm{NO}_{2} \mathrm{mg} \cdot \mathrm{L}^{-1}\right)$ & $0,02 \pm \mathrm{a}$ & & $0,02 \pm 0,00 \mathrm{a}$ & \\
\hline Nitrato $\left(\mathrm{N}-\mathrm{NO}_{3} \mathrm{mg} . \mathrm{L}^{-1}\right)$ & $1,18 \pm \mathrm{a}$ & & $1,18 \pm 0,07 \mathrm{a}$ & \\
\hline
\end{tabular}

${ }^{1}$ médias sem correção para as variáveis de quantidade de chuva e velocidade do vento.

2 médias com correção para as variáveis de quantidade de chuva e velocidade do vento.

Médias seguidas por letras distintas, nas linhas, diferem significativamente pelo Teste $\mathrm{F}(\mathrm{p}<0,05)$.

O padrão de consumo para concentração de oxigênio estipulado pela Resolução $\mathrm{n}^{0} .357$ para águas Classe 3 é não inferior a $4,0 \mathrm{mg} . \mathrm{L}^{-1}$. Durante todo monitoramento, somente em quatro meses a concentração na superfície esteve de acordo com esse padrão. No fundo isso ocorreu apenas em uma coleta. Concentrações mínimas de $2,0 \mathrm{mg} . \mathrm{L}^{-1}$ e $0,3 \mathrm{mg} . \mathrm{L}^{-1}$ foram observadas na superfície e fundo, respectivamente. Apesar dessa realidade não foi detectado nenhum impacto negativo no desempenho zootécnico dos animais.

A temperatura da água apresentou média de $20,5{ }^{\circ} \mathrm{C}$, portanto em condições ideais para o consumo dos animais. As maiores temperaturas da água foram observadas entre os meses de novembro de 2009 e março de 2010 na superfície da cisterna, variando de $22,0^{\circ} \mathrm{C}$ a $26,6^{\circ} \mathrm{C}$, portanto mesmo no verão a cisterna demonstrou possuir a capacidade de manter a temperatura da água em valores satisfatórios para a dessedentação.

$\mathrm{O} \mathrm{pH}$ da água destinada ao consumo de animais pode variar de 6,0 a 9,0 (Brasil, 2005). Observou-se maior freqüência de valores básicos no fundo da cisterna, atingindo o máximo de 
PALHARES, J. C. P.; GUIDONI, A. L. Qualidade da água de chuva armazenada em cisterna utilizada na dessedentação de suínos e bovinos de corte. Ambi-Agua, Taubaté, v. 7, n. 1, p. 244-254, 2012. (http://dx.doi.org/10.4136/ambi-agua.822)

7,6. Isso se deve a natureza ácida das águas pluviais, ressaltando que a entrada de água da chuva na cisterna ocorria pela superfície.

As concentrações de Sólidos Dissolvidos Totais (SDT) sempre estiveram abaixo do padrão da Resolução que é $500 \mathrm{mg} . \mathrm{L}^{-1}$. A concentração máxima $\left(84 \mathrm{mg} . \mathrm{L}^{-1}\right)$ ocorreu em dezembro de 2008 na superfície da cisterna. No período entre essa coleta e a anterior observou-se uma das menores quantidades de chuva $(60 \mathrm{~mm})$ e a média de velocidade do vento foi a mais alta do estudo $(1,70 \mathrm{~m} / \mathrm{s})$. A concentração de SDT é um indicador importante, pois esses são potenciais carreadores de elementos poluentes que possuam características hidrofóbicas. As baixas concentrações de SDT demonstram que apesar do sistema de descarte da água da primeira chuva não ser o ideal, da proximidade da superfície de captação a uma rodovia com tráfego pesado e da presença de várias fontes emissoras de partículas no entrono, o sistema de filtragem se mostrou eficiente.

Altas correlações foram observadas entre a concentração de SDT e a velocidade do vento para ambas as profundidades (Figura 1). Isso atesta a influência do vento no transporte de partículas e o potencial impacto que esse transporte significa para conservação da qualidade da água armazenada. Em regiões agrícolas, como a desse estudo de caso, o uso de barreiras físicas (cercas vivas), a lavagem do telhado e o descarte das primeiras chuvas, devem ser práticas inerentes ao manejo da cisterna.

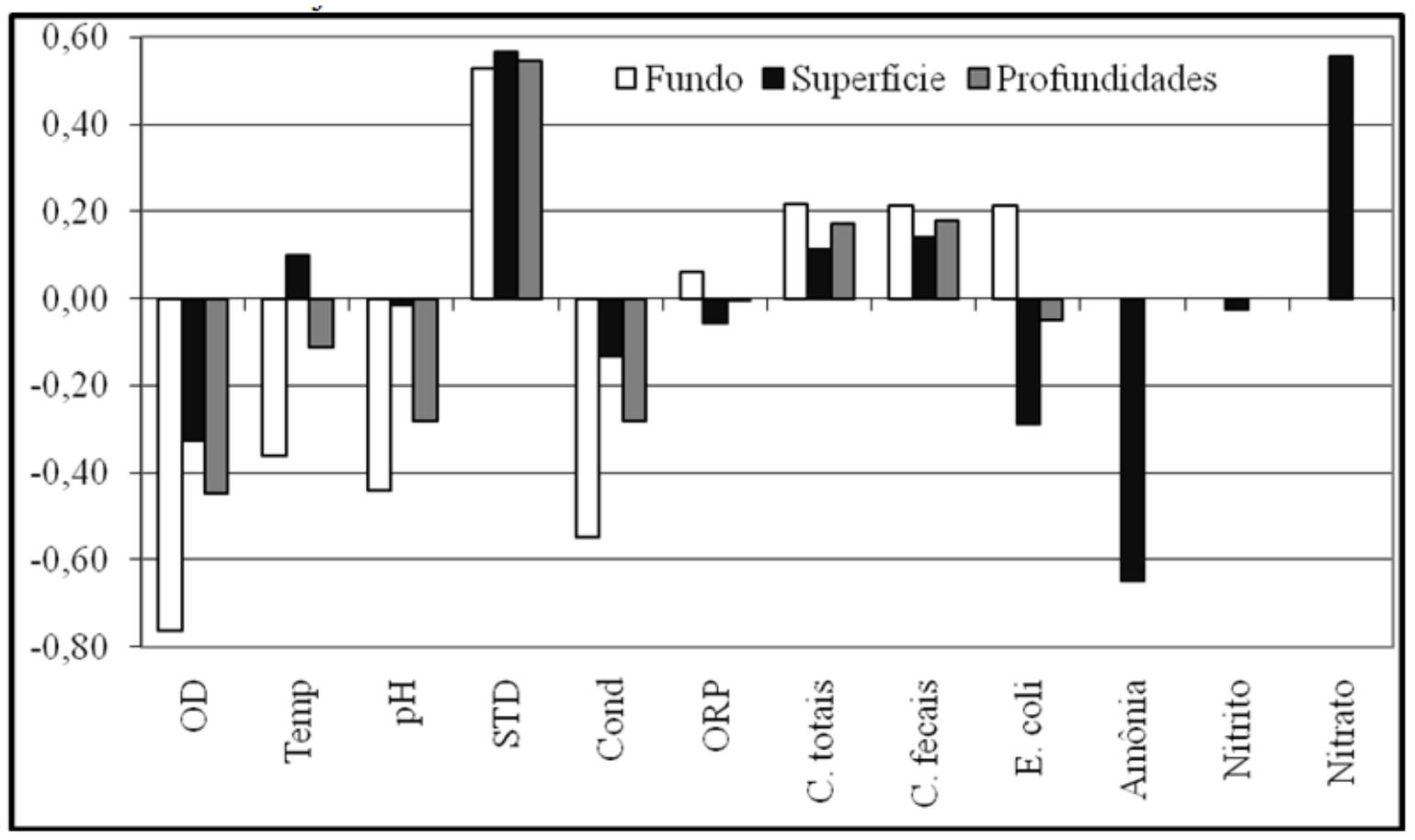

Figura 1. Correlação das variáveis de qualidade da água com a velocidade do vento.

Condutividade elétrica e potencial redox são duas variáveis que não apresentam padrão de qualidade para o consumo de animais. A Tabela 2 demonstra que não houve diferença significativa para ambas as variáveis entra as profundidades. Os baixos potenciais redox no fundo da cisterna são reflexo das baixas concentrações de oxigênio nessa profundidade.

Os padrões constantes na Resolução $\mathrm{n}^{0}$. 357 para amônia, nitrato e nitrito são respectivamente: 13,3 mg. $\mathrm{L}^{-1}, 10 \mathrm{mg} . \mathrm{L}^{-1}$ e 1,0 mg. $\mathrm{L}^{-1}$ (Brasil, 2005). Essas concentrações não foram atingidas em nenhuma das amostras coletadas, sendo as concentrações observadas muito baixas.

Entre os meses de fevereiro e maio de 2010 a amônia não foi detectada e as menores concentrações foram observadas entre outubro de 2009 e janeiro de 2010 . No caso da área de 
PALHARES, J. C. P.; GUIDONI, A. L. Qualidade da água de chuva armazenada em cisterna utilizada na dessedentação de suínos e bovinos de corte. Ambi-Agua, Taubaté, v. 7, n. 1, p. 244-254, 2012. (http://dx.doi.org/10.4136/ambi-agua.822)

estudo as principais áreas-fonte seriam as propriedades rurais devido a concentração de resíduos animais na forma de dejetos de suínos e camas de aviário. No período em que a amônia não foi detectada observou-se menores médias de velocidade do evento, portanto não foi verificada correlação entre as duas variáveis. Também foi baixa a correlação entre a concentração de amônia e a quantidade de chuva (Figura 2).

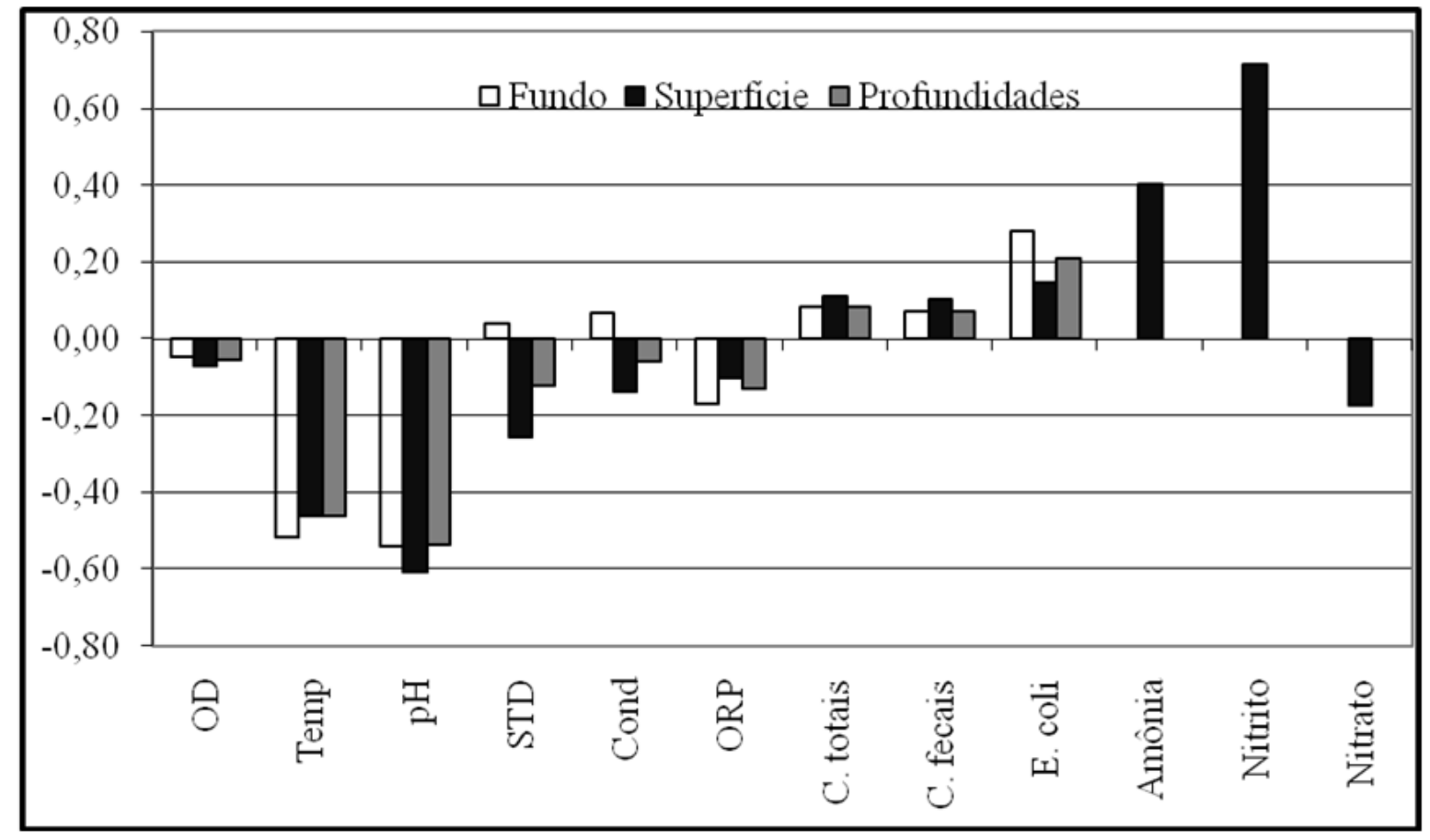

Figura 2. Correlação das variáveis de qualidade da água com a quantidade de chuva.

As mais altas concentrações de nitrato foram observadas entre junho e setembro de 2009, meses em que a movimentação do solo na região é intensa devido ao preparo deste para o plantio do milho. O nitrato apresentou alta correlação com a velocidade do vento (Figura 1). Os resultados demonstram que em propriedades ou regiões nas quais se pretende implantar cisternas o manejo do solo para o plantio e colheita das culturas agrícolas deve ser feito, considerando seu potencial impacto na qualidade da água armazenada. As menores concentrações de nitrato ocorreram entre janeiro e maio de 2010. Neste período se teve o maior acumulado de chuva e menores médias de velocidade do vento. Isso demonstra o poder de diluição que a chuva tem sobre a concentração do elemento.

Conforme a Resolução $n^{\circ} .357$ para dessedentação de animais confinados não deverá ser excedido o número de 1.000 Coliformes termotolerantes por $100 \mathrm{~mL}^{-1}$ em $80 \%$ ou mais de pelo menos seis amostras, coletadas durante o período de um ano, com frequência bimestral. Durante o monitoramento esse número só foi excedido em quatro amostras da superfície $(21 \%)$ e três amostras de fundo (16\%). Portanto, a água apresentou qualidade microbiológica para o consumo de animais.

Na cisterna monitorada os coliformes totais foram detectados em $79 \%$ (superfície) e $89 \%$ (fundo) e a $E$. coli em $26 \%$ (superfície) e $11 \%$ (fundo). Essas presenças não apresentaram um padrão identificado com as condições climáticas ou de manejo.

Segundo Schets et al. (2010), presença elevada de E. coli foi detectada em cisternas que tiveram suas águas amostradas em dias precedidos por chuvas intensas. Correlações de moderada a alta foram observadas entre a intensidade da chuva e a contagem de microrganismos. Esse tipo de correlação na foi observada neste estudo para a presença de $E$. coli. 
PALHARES, J. C. P.; GUIDONI, A. L. Qualidade da água de chuva armazenada em cisterna utilizada na dessedentação de suínos e bovinos de corte. Ambi-Agua, Taubaté, v. 7, n. 1, p. 244-254, 2012. (http://dx.doi.org/10.4136/ambi-agua.822)

Em janeiro de 2010, amostras de água dos três filtros foram coletadas. As análises demonstraram a presença de $E$. coli nos três filtros, sendo a concentração mais elevada no primeiro 700 UFC $100 \mathrm{~mL}^{-1}$ e no último $600 \mathrm{UFC} 100 \mathrm{~mL}^{-1}$. Esses resultados corroboram a teoria de que o sistema de filtragem compreendia uma fonte de contaminação para água da cisterna devido ao seu dimensionamento que possibilitava o acúmulo de água no fundo de cada um dos três filtros. Acredita-se que essa água foi carreada para dentro da cisterna, provavelmente devido a chuvas intensas e ao não descarte das primeiras chuvas, contaminando a água.

\section{CONCLUSÃO}

A água armazenada na cisterna apresentou qualidade satisfatória para o uso na dessedentação de animais de produção.

A presença de E. coli em algumas amostras esteve relacionada ao incorreto manejo da cisterna, estando estas ausentes na maior parte das coletas, conclui-se que a tecnologia apresenta viabilidade para o uso proposto desde que as boas práticas de manejo, as fontes de emissão do entorno e as condições climáticas sejam consideradas.

A quantidade de chuva e velocidade do vento influenciaram as concentrações dos elementos nitrogenados. Investigações a fim de aprofundar esse conhecimento devem ser conduzidas para que as fontes emissoras agrícolas e pecuárias não representam alto impacto negativo para a qualidade da água.

\section{REFERÊNCIAS}

AGRIOS, G. N. Plant pathology. San Diego: Academic Press, 1997.

\section{AMERICAN PUBLIC HEALTH ASSOCIATION. Standard methods for the examination of water and wastewater. Washington, 1995.}

ASSOCIAÇÃO BRASILEIRA DE NORMAS TÉCNICAS. NBR 15257: água da chuva aproveitamento de coberturas em áreas urbanas para fins não potáveis: requisitos. Rio de Janeiro, 2007. 8 p.

BRASIL. Conselho Nacional do Meio Ambiente. Resolução no $\mathbf{n}^{\mathbf{0}} 357$ de 17 de março de 2005. Dispõe sobre a classificação dos corpos de água e diretrizes ambientais para o seu enquadramento, bem como estabelece as condições e padrões de lançamento de efluentes, e dá outras providências. Disponível em: <http://www.mma.gov.br/ port/conama/legiabre.cfm?codlegi=459>. Acesso em: 8 fev. 2010.

BRASIL. Conselho Nacional do Meio Ambiente. Resolução nº 396 de 03 de abril de 2008. Dispõe sobre a classificação e diretrizes ambientais para o enquadramento das águas subterrâneas e dá outras providências. Disponível em: < http://www.mma.gov.br/ port/conama/legiabre.cfm?codlegi=562>. Acesso em: 12 abr. 2012.

BRITO, L. T. L.; GNADLINGER, J. Relatório sobre a oficina: avanços nos estudos sobre cisternas: qualidade de água e cisterna de alambrado. Petrolina: ABCMAC, 2006.

EVANS, C. A.; COOMBES, R. H.; DUNSTAM, R. H.; HARRISON, T. Identifying the major influences on the microbial composition of roof harvested rainwater and the implications for water quality. Water Science and Technology. v. 55, p. 245-253, 2007. http://dx.doi.org/10.2166/wst.2007.115 
PALHARES, J. C. P.; GUIDONI, A. L. Qualidade da água de chuva armazenada em cisterna utilizada na dessedentação de suínos e bovinos de corte. Ambi-Agua, Taubaté, v. 7, n. 1, p. 244-254, 2012. (http://dx.doi.org/10.4136/ambi-agua.822)

FENDRICH, R.; OLIYNIK, R. Manual de utilização de águas pluviais (100 maneiras práticas). Curitiba: Chain, 2002.

LYE, D. J. Rooftop runoff as a source of contamination: a review. Science of the Total Environment, v. 407, p. 5429-5434, 2009. http://dx.doi.org/10.1016/j.scitotenv.2009.07.011

MANTOVAN, P.; PASTOREA, A.; SZPYRKOWICZ, L.; ZILIO-GRANDI, F. Characterization of rainwater quality from the Venice region network using multiway data analysis. Science of the Total Environment, v. 164, p. 27-43, 1995. http://dx.doi.org/10.1016/0048-9697(95)04432-Z

NGIGI, S. What is the limit of up-scaling rainwater harvesting in a river basin? Physics and Chemistry of the Earth, v. 28, p. 944-956, 2003.

PRADO, G. S.; MULLER, M.S. K. Sistema de aproveitamento de água para edifícios. Revista Téchne, São Paulo, p. 77-80, 2007. Disponível em: <http://www.revistatechne. com.br/engenharia-civil/128/artigo66612-4.asp>. Acesso em: 22 jun. 2008.

SAS INSTITUTE INC. System for microsoft windows: release 9.1. Cary, 2003.

SAZAKLIA, E.; ALEXOPOULOSB, A.; LEOTSINIDISA, M. Rainwater harvesting, quality assessment and utilization in Kefalonia Island, Greece. Water Research, v. 41, p. 2039-2047, 2007. http://dx.doi.org/10.1016/j.watres.2007.01.037

SCHETS, F. M.; ITALIAANDER, R.; VAN DEN BERG, H. H. J. L.; RODA, A. M. H. de. Rainwater harvesting: quality assessment and utilization in The Netherlands. Journal Water and Health, v. 8, p. 224-235, 2010. http://dx.doi.org/10.2166/wh.2009.037

SIMMONS, G.; HOPE, V.; LEWIS, G.; WHITMORE, J.; GAO, W. Contamination of potable roof collected rainwater in Auckland. New Zealand. Water Resource, v. 35, p. 1518-1524, 2001.

WORLD HEALTH ORGANIZATION. Guidelines for drinking-water quality: recommendations. 3. ed. 2008. Vol 1. Disponível em: <http://www.who.int/ water_sanitation_health/dwq/gdwq3rev/en/>. Acesso em: 11 abril 2012. 


ISSN = 1980-993X - doi:10.4136/1980-993X
www.ambi-agua.net
E-mail: ambi-agua@agro.unitau.br
Tel.: (12) 3625-4212

\title{
Avaliação de eventos de inundação na Região Norte Fluminense, Rio de Janeiro, utilizando imagens de sensores remotos
}

\author{
(http://dx.doi.org/10.4136/ambi-agua.817) \\ José Carlos Mendonça ${ }^{1}$; Ramon Morais de Freitas ${ }^{2}$; \\ Yosio Edemir Shimabukuro ${ }^{2}$; \\ Valdo da Silva Marques ${ }^{3}$ \\ ${ }^{1}$ Laboratório de Engenharia Agrícola - LEAG/UENF - Campos dos Goytacazes, RJ \\ e-mail: mendonca@uenf.br; \\ ${ }^{2}$ Instituto Nacional de Pesquisas Espaciais - INPE São José dos Campos, SP \\ e-mail: yosio@dsr.inpe.br; ramon@dsr.inpe.br; \\ ${ }^{3}$ Laboratório de Meteorologia - LAMET/UENF-Macaé, RJ \\ e-mail: valdo@lenep.uenf.br
}

\section{RESUMO}

O presente trabalho teve por objetivo identificar e quantificar, por meio de imagens de sensoriamento remoto, as áreas atingidas pelas inundações ocorridas no período do verão de 2008/2009 na região Norte Fluminense, Rio de Janeiro. Para isso, foram utilizadas imagens dos sensores TM Landsat-5 e CCD CBERS-2B adquiridas antes e após a ocorrência das inundações. Nessas imagens foram aplicadas o Modelo Linear de Mistura Espectral - MLME para realçar as áreas ocupadas com os corpos d’água. Concluiu-se que, após comparar a imagem TM do dia 26/07/2007 (sem inundação) com as imagens TM (17/11/2008) e CCD (20/01/2009) tomadas depois do período chuvoso na região, o espelho d’água da região sofreu um incremento de 2,61 vezes, correspondendo a área total de 99.000 ha atingida pelas águas.

Palavras-chave: Sensoriamento remoto; Modelo Linear de Mistura Espectral; recursos hídricos; inundações.

\section{Evaluation of floodings events in the Norte Fluminense, Rio de Janeiro, using remote sensing imagery}

\begin{abstract}
This study aimed to identify and to quantify the flooded area in the 2008/2009 summer period in the Norte Fluminense region, Rio de Janeiro state using remote sensing images. For this, Landsat-5 TM and CBERS-2B CCD images acquired before and after flooding occurrence were used. In these images, the Linear Spectral Mixture Model - LSMM was applied in order to highlight the areas occupied by water bodies. It was concluded that the water bodies in the region suffered an increment of 2.61 times corresponding to 99,000 ha of total area of water surface based on the comparison of the TM image acquired on July 26, 2007 (without flooding) with TM acquired on November 17, 2008 and with the CCD image of January 20, 2009 acquired after the rainy season in this region.
\end{abstract}

Keywords: Remote sensing; Linear Spectral Mixture Model; water resources; floodings. 
MENDONÇA, J. C.; FREITAS, R. M. ; SHIMABUKURO, Y. E.; MARQUES, V. S. Avaliação de eventos de inundação na Região Norte Fluminense, Rio de Janeiro, utilizando imagens de sensores remotos. Ambi-Agua, Taubaté, v. 7, n. 1, p. 255-267, 2012. (http://dx.doi.org/10.4136/ambi-agua.817)

\section{INTRODUÇÃO}

A Baixada Campista se localiza na região Norte Fluminense, Rio de Janeiro, às margens do trecho final do Rio Paraíba do Sul, abrangendo os municípios de Campos dos Goytacazes, São João da Barra, São Francisco de Itabapoana e Quissamã. Segundo Lamego (1955) essa região se caracteriza por uma vasta várzea originária de uma antiga baía que, após regressão marinha e ascensão continental, ocasionou uma planície de grande extensão.

O clima da região pela classificação de Köppen é considerado como tropical úmido (Aw), com verão chuvoso e inverno seco, sendo a normal climatológica da precipitação pluviométrica igual a 1.055,3 mm (Ramos et al., 2009). No entanto, a ocorrência de episódios extremos de precipitação tem gerado diversos problemas ambientais, dos quais se destacam cinco grandes inundações, somente na década de 2000.

Cataldi et al. (2010) citam que as principais teleconexões diretas entre o regime pluviométrico e hidrológico do sudeste da América do Sul são associadas às variações na Temperatura da Superfície do Mar (TSM) do Oceano Pacífico Equatorial e aos fenômenos do tipo El Niño-Oscilação Sul (ENOS), ficando as influências das anomalias na TSM do Oceano Atlântico Sul com papel secundário.

Gerólamo e Kayano (2010) citam que a TSM tem um papel preponderante na variabilidade climática interanual e interdecenal e que os padrões anômalos da circulação atmosférica associados às anomalias de TSM, hoje conhecidos como parte dos ciclos do fenômeno ENOS, conduzem a padrões climáticos anômalos em várias áreas do globo que se manifestam em diversas variáveis como a precipitação, temperatura do ar, pressão ao nível médio do mar, entre outras.

A disponibilidade atual de diversos dados de sensoriamento remoto, notadamente as imagens de satélites com diferentes resoluções espaciais, espectrais e temporais, muitas delas disponíveis gratuitamente na rede mundial de computadores, propiciou a crescente utilização desses dados nos trabalhos de monitoramento da superfície terrestre.

A técnica do Modelo Linear de Mistura Espectral (MLME) tem por base a análise subpixel e considera que a formação de um pixel é a mistura linear da resposta espectral das frações água/sombra, solo e vegetação em imagens multiespectrais (Shimabukuro e Smith, 1991). As imagens fração geradas realçam áreas de interesse para interpretação das imagens multiespectrais. Essa técnica vem sendo comumente utilizada em estudos da cobertura vegetal (Shimabukuro et al., 1998; Sabol et al., 2002; Silva et al., 2007; Shimabukuro et al., 2009; Lima et al., 2009; Moura et al., 2009). No entanto, apenas nos anos mais recentes, a técnica passou a ser empregada, com sucesso, em estudos hidrológicos por meio da análise da imagem fração água/sombra gerada pelo modelo.

Mendonça et al. (2007) avaliaram a aplicação do MLME com imagens MODIS/Terra e MODIS/Aqua, analisando o impacto de eventos de precipitações pluviométricas sobre a região Norte Fluminense, Rio de Janeiro, concluindo ser esta uma técnica eficiente e de baixo custo, podendo ser adotada operacionalmente como ferramenta de auxílio à política de gestão dos recursos hídricos.

Silva (2008) aplicou a técnica do MLME para mapear os diferentes tipos de água no rio Solimões e no lago de Coari utilizando imagens do TM Landsat-5 e concluiu que o MLME permitiu mapear as diferentes fases do ciclo hidrológico e os fluxos de água preta originários do lago de Coari no interior do rio Solimões.

Renó et al. (2009) avaliaram o desempenho de duas estratégias de classificação baseadas em regiões, com aplicação do MLME para o mapeamento das classes de água da bacia do alto Paraná.

Padovani et al. (2009) estudaram as inundações do Pantanal Mato-grossense para quantificar a dinâmica das inundações na área de influência do rio Paraguai e concluíram que 
MENDONÇA, J. C.; FREITAS, R. M. ; SHIMABUKURO, Y. E.; MARQUES, V. S. Avaliação de eventos de inundação na Região Norte Fluminense, Rio de Janeiro, utilizando imagens de sensores remotos. Ambi-Agua, Taubaté, v. 7, n. 1, p. 255-267, 2012. (http://dx.doi.org/10.4136/ambi-agua.817)

o emprego do MLME em imagens MODIS mostraram-se muito úteis no mapeamento e na caracterização da dinâmica das inundações do Pantanal, podendo ser usados para o monitoramento quantitativo das inundações desse bioma. Os mesmos autores citam ainda que os métodos convencionais de classificação de imagens limitam-se à classes qualitativas, porém, com o emprego do MLME é possível quantificar a proporção de determinado alvo de interesse e dessa forma, nas imagens fração água/sombra, cada pixel representa uma estimativa da proporção de água na superfície do terreno, sendo possível relacionar cada pixel da imagem com os dados de superfície e obter um mapa dessa relação.

Evans et al. (2010) utilizaram imagens multi-temporais de radar ALOS/PALSAR e RADARSAT-2 para mapear o uso e a cobertura da terra e a dinâmica das inundações do Panantal Matogrossense, concluindo que os mapas gerados são um recurso valioso para a definição de habitats necessários para conservar a biodiversidade do Pantanal e para mitigar os impactos do desenvolvimento humano na região.

Dessa forma, o presente trabalho teve por objetivo identificar e quantificar, com o uso de imagens de sensoriamento remoto, as áreas atingidas pelas inundações ocorridas no período do verão dos anos de 2008/2009 na região Norte Fluminense, Rio de Janeiro.

\section{MATERIAL E MÉTODOS}

\subsection{Caracterização da Área de Estudo}

A área objeto deste trabalho localiza-se às margens do trecho final do Rio Paraíba do Sul, abrangendo os municípios de Campos dos Goytacazes, São Francisco de Itabapoana, São João da Barra e Quissamã, todos na região norte do Estado do Rio de Janeiro (Figura 1). Segundo Lamego (1955), essa região caracteriza-se por uma vasta várzea originária de uma antiga baía que, após regressão marinha e ascensão continental, ocasionou uma planície de grande extensão onde é comum a ocorrência de solos com camadas argilosas, cuja distribuição é aleatória. Mendonça et al. (2007) citam que a explicação para a distribuição heterogênea dos solos na planície fluvial pode ser a história geológica da região, formada por aportes de sedimentos marinhos e fluviais da era Quaternária, na margem direita, e Terciária, na margem esquerda do trecho final do rio Paraíba do Sul.

Segundo a classificação climática de Köeppen, a região Norte Fluminense insere-se na classe Aw, isto é, tropical úmido, com verão chuvoso, inverno seco e temperatura do mês mais frio superior a $18{ }^{\circ} \mathrm{C}$. A temperatura média anual situa-se em torno de $24{ }^{\circ} \mathrm{C}$, sendo a amplitude térmica pequena e a normal climatológica da precipitação pluviométrica igual a 1.055,3 mm (Ramos et al., 2009).

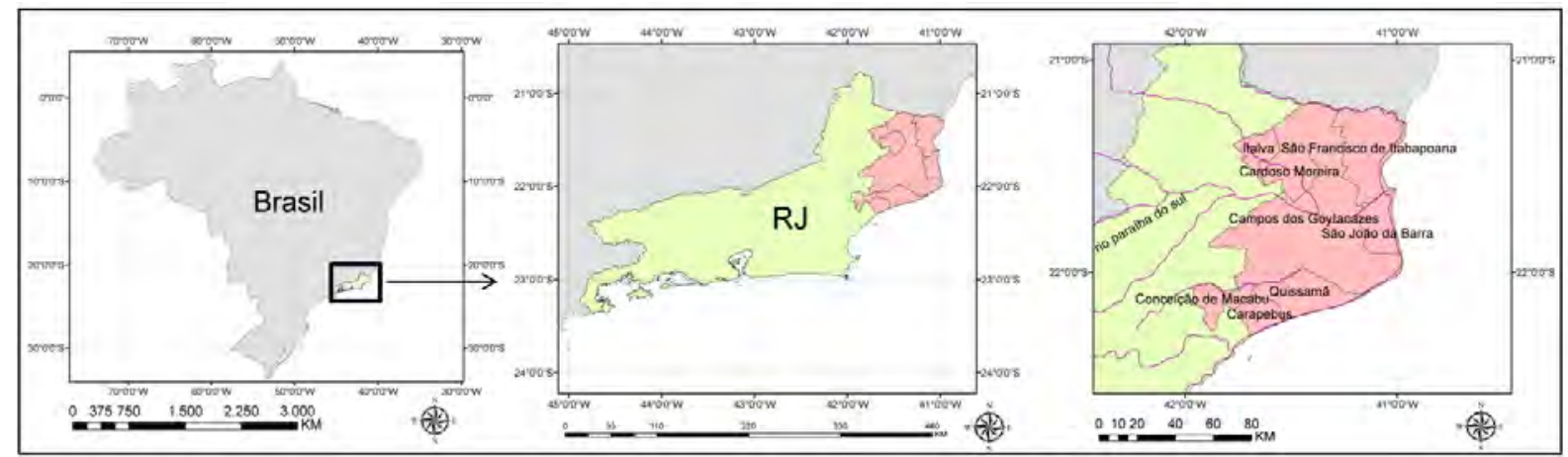

Figura 1. Localização da área de estudo em referência ao Estado do Rio de Janeiro e ao Brasil. 
MENDONÇA, J. C.; FREITAS, R. M. ; SHIMABUKURO, Y. E.; MARQUES, V. S. Avaliação de eventos de inundação na Região Norte Fluminense, Rio de Janeiro, utilizando imagens de sensores remotos. Ambi-Agua, Taubaté, v. 7, n. 1, p. 255-267, 2012. (http://dx.doi.org/10.4136/ambi-agua.817)

Na Figura 2 é apresentada a rede hidrográfica existente na área de estudo, com destaque para a lagoa Feia e a localização das estações meteorológicas onde foram coletados parte dos dados pluviométricos utilizados neste estudo.

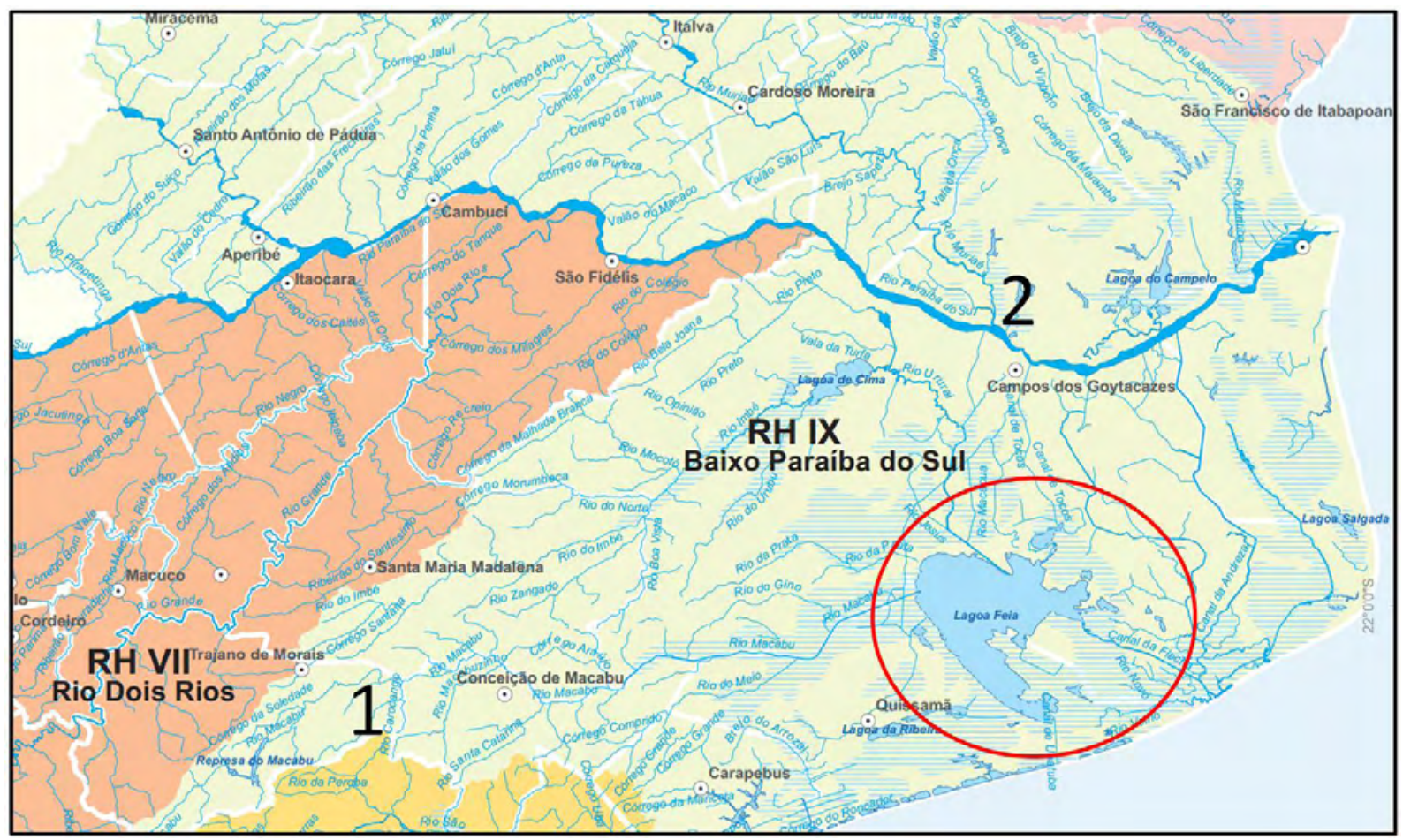

Figura 2. Rede hidrográfica existente na área de estudo. 1. Plataforma de Coleta de Dados do SIMERJ/CPTEC e 2. Estação do INMET.

Fonte: Adaptado de INEA (2008).

\subsection{Imagens de Sensores Remotos}

$\mathrm{Na}$ elaboração deste trabalho foram utilizadas imagens adquiridas pela câmera CCD CBERS-2B no dia 02/12/2008 referentes a órbita 146 e pontos 124 e 125 que possuem resolução espacial de $20 \mathrm{~m}$ x $20 \mathrm{~m}$ e imagens do sensor TM Landsat-5 adquiridas nos dias 26/07/2007 e 20/01/2009 referentes a órbita/ponto 216/75 cuja resolução espacial é de $30 \mathrm{~m} \mathrm{x}$ $30 \mathrm{~m}$, sendo todas essas imagens obtidas gratuitamente no site do Instituto Nacional de Pesquisas Espaciais - INPE. Os recortes utilizados envolveram a área compreendida pelas coordenadas geográficas $21^{\circ} 10^{\prime}$ e $22^{\circ} 25^{\prime}$ de latitude Sul e $40^{\circ} 45^{\prime}$ e $42^{\circ} 10^{\prime}$ de longitude Oeste.

Para as etapas de pré-processamento, recortes, aplicação do MLME e geração dos mapas temáticos foi utilizado o software Environment for Visualizing Images - ENVI, ver. 4.3.

\subsection{Dados Pluviométricos e Batimétricos}

Os dados pluviométricos foram coletados por uma estação meteorológica automática modelo Vaisalla, pertencente ao Instituto Nacional de Meteorologia - INMET, instalada no Colégio Estadual Agrícola Antônio Sarlo situada no município de Campos dos Goytacazes, RJ (Coordenadas $21^{\circ} 71,47^{\prime}$ de latitude Sul e $41^{\circ} 34,41^{\prime}$ de longitude Oeste; Altitude de 25 $\mathrm{m})$, na Plataforma de Coleta de Dados - PCD, da rede do Sistema de Meteorologia do Estado do Rio de Janeiro - SIMERJ/CPTEC, instalada no município de Santa Maria Madalena, RJ (Coordenadas $21^{\circ} 95^{\prime}$ de latitude Sul e $42^{\circ} 00^{\prime}$ de longitude Oeste; Altitude de $615 \mathrm{~m}$ ) e na série de dados pluviométricos da Companhia Açucareira Paraíso (Coordenadas $21^{\circ} 53,88^{\prime}$ de latitude Sul e $41^{\circ} 17,28^{\prime}$ de longitude Oeste; Altitude de $8 \mathrm{~m}$ ). 
MENDONÇA, J. C.; FREITAS, R. M. ; SHIMABUKURO, Y. E.; MARQUES, V. S. Avaliação de eventos de inundação na Região Norte Fluminense, Rio de Janeiro, utilizando imagens de sensores remotos. Ambi-Agua, Taubaté, v. 7, n. 1, p. 255-267, 2012. (http://dx.doi.org/10.4136/ambi-agua.817)

Os dados batimétricos foram coletados na régua de monitoramento da lagoa Feia instalada pelo Instituto Estadual do Ambiente - INEA na localidade de Ponta Grossa dos Fidalgos, município de Campos dos Goytacazes, RJ (Coordenadas 21 $56^{\circ}$ de latitude Sul e $41^{\circ} 20^{\prime}$ de longitude Oeste; Altitude de $5 \mathrm{~m}$ ).

\subsection{Modelo Linear de Mistura Espectral (MLME)}

O MLME faz a suposição de que a resposta de um pixel em cada banda espectral é a combinação linear ponderada das respostas espectrais das componentes selecionadas. $\mathrm{O}$ fator de ponderação é dado pela fração da área do pixel ocupada pela respectiva componente (endmember). Para cada pixel individual, o modelo linear de mistura pode ser expresso por:

$$
R_{k}=\sum_{j=1}^{m} r_{j, k} f_{j}+v_{k}(k=1, \ldots, p)
$$

Em que, $R_{k}$ representa a resposta espectral de um pixel na banda espectral $k, r_{j, k}$ a resposta espectral da componente $j$ na banda espectral $k, f_{j}$ a fração da área total do pixel ocupada pela componente $j, m$ o numero de componentes, $v_{k}$ o valor do resíduo em (1) para a banda espectral $k$ e $p$ o número de bandas espectrais dos sensores remotos em consideração. As respostas espectrais $R_{k}$ e $r_{j, k}$ podem ser expressas em termos de refletância espectral, radiância espectral ou número digital. Neste estudo, optou-se por número digital, uma vez que o interesse é somente na classificação da imagem.

\subsection{Procedimento Metodológico}

Neste trabalho o MLME foi aplicado nas bandas espectrais dos sensores TM (b1-azul, b2-verde, b3-vermelho, b4-infravermelho próximo, b5-infravermelho médio e b7infravermelho médio) e CCD CBERS-2B (b1-azul, b2-verde, b3-vermelho e b4infravermelho próximo) utilizando três componentes, solo, água/sombra e vegetação. A fração solo ressalta as áreas de solo exposto, a fração vegetação se assemelha aos índices de vegetação ressaltando o vigor da vegetação, e a fração água/sombra ressalta bem os corpos d'água e valores com baixa refletância espectral. A seleção dos pixels puros (endmember) baseou-se na experiência do foto-intérprete. Foram selecionados pixels de vegetação uniforme e densa para a fração vegetação, solo exposto para a fração solo e água sem sedimentos para a fração água/sombra.

A imagem fração água/sombra gerada a partir do MLME foi utilizada para estimar a área total ocupada pelo espelho d`água da área de estudo. Para esse cálculo, após supervisão do foto-intérprete, considerou-se para fatiamento, o limiar de $70 \%$ da imagem fração água/sombra obtendo-se uma imagem binária de espelho d'água. Os valores contaminados por sombras de nuvens foram editados, a fim de se evitar confusão entre as classes, o que em alguns casos poderia gerar uma super-estimativa das áreas inundadas.

\section{RESULTADOS E DISCUSSÃO}

\subsection{Cronologia dos Eventos}

O período chuvoso na Região Norte Fluminense se iniciou em meados do mês de outubro/2008 estando à cota batimétrica da lagoa Feia em níveis controlados e relativamente baixos para o período. Em 01/11/2008 o nível da lagoa observado na localidade de Ponta Grossa dos Fidalgos era de 3,20 m e em 17/11/2008 de 3,25 m. Em Santa Maria Madalena, RJ, à montante da lagoa de Cima foi registrado no dia 15/11/2008 um evento de precipitação de $360,25 \mathrm{~mm}$ e entre as $21 \mathrm{~h}$ do dia $17 / 11$ e as $9 \mathrm{~h}$ do dia 18/11 foi registrado em Campos 
MENDONÇA, J. C.; FREITAS, R. M. ; SHIMABUKURO, Y. E.; MARQUES, V. S. Avaliação de eventos de inundação na Região Norte Fluminense, Rio de Janeiro, utilizando imagens de sensores remotos. Ambi-Agua, Taubaté, v. 7, n. 1, p. 255-267, 2012. (http://dx.doi.org/10.4136/ambi-agua.817)

dos Goytacazes, RJ, a ocorrência de 189,8 mm totais de chuvas. Esses eventos pluviométricos contribuíram para o transbordamento dos rios Macabú, Imbé e Preto, sendo esses dois últimos afluentes da lagoa de Cima e todos, afluentes da lagoa Feia.

De acordo com o Instituto Nacional de Meteorologia - INMET, a Normal Climatológica do mês de novembro, em Campos dos Goytacazes, RJ, é de 160,6 mm e a altura máxima de precipitação em 24 h, ocorreu no dia 20 de novembro do ano de 1972, no valor de 117,2 mm. No entanto os dados dessas Normais Climatológicas, por serem referentes ao período de 1961 a 1990, devem ser considerados apenas como valores de referência, pois ao deixar, nesse trabalho, uma lacuna de quase 20 anos de dados podem não representar a situação atual, o que em muito pode comprometer a avaliação de eventos climáticos extremos possivelmente relacionados com mudanças climáticas globais.

Na Figura 3 é apresentado o gráfico das médias mensais da precipitação pluviométrica ocorridas entre os meses de outubro a março dos anos de 2000 a 2009, bem como os totais acumulados nesses mesmos períodos.

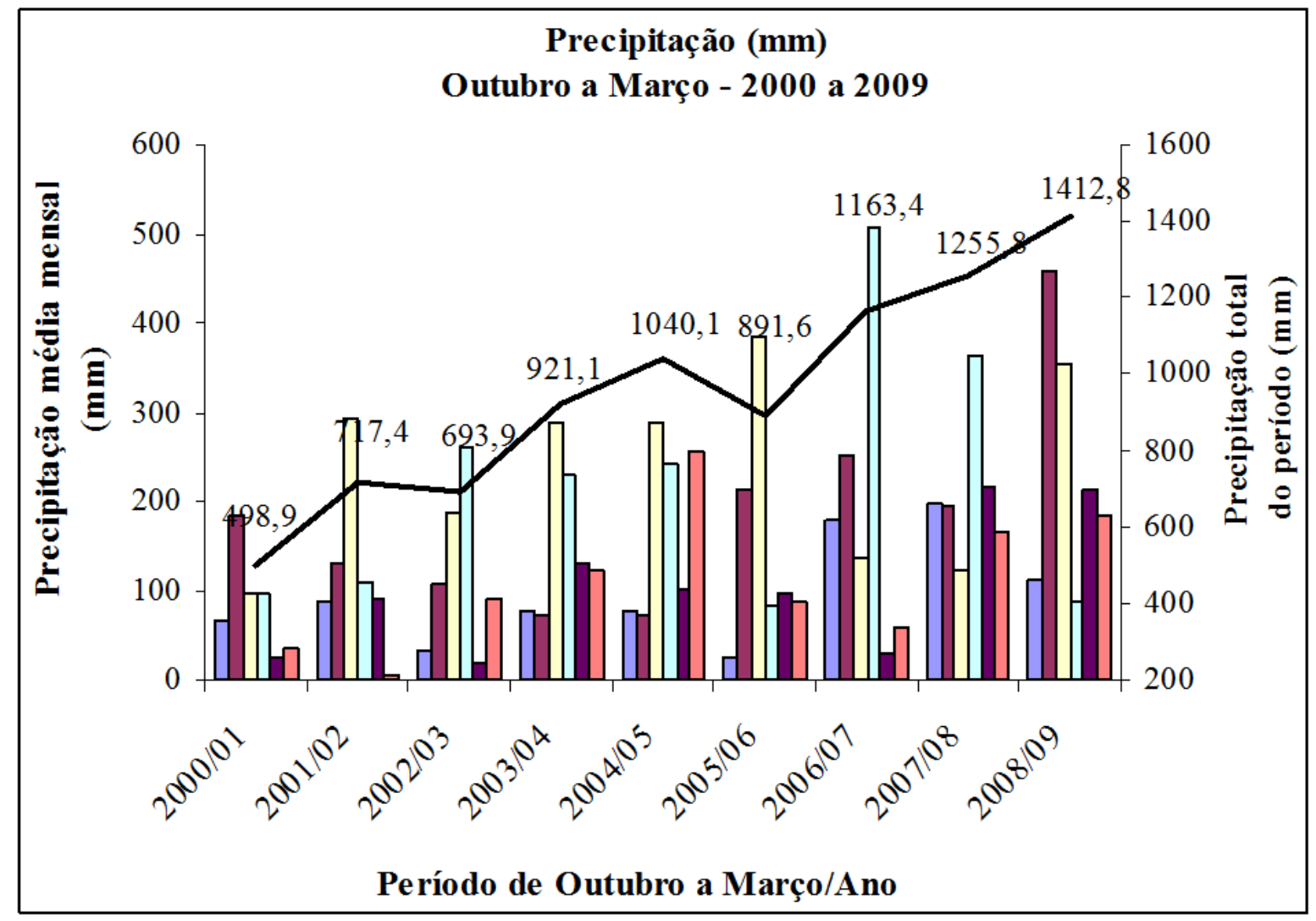

Figura 3. Gráfico das médias mensais da precipitação pluviométrica ocorridos entre os meses de outubro a março dos anos de 2000 a 2009, bem como os totais acumulados nesses períodos.

Fonte: Dados fornecidos por comunicação pessoal com a Companhia Açucareira Paraíso, Campos dos Goytacazes (2009).

Observando a Figura 3 pode-se perceber que os totais acumulados no período outubro a março sofreram um incremento progressivo nessa década de 2000, passando de pouco menos de $500 \mathrm{~mm}$ (2000/2001) para cerca de $1400 \mathrm{~mm}$ (2008/2009), sendo este incremento associado por Cataldi et al. (2010) às variações na Temperatura da Superfície do Mar (TSM) do Oceano Pacífico Equatorial e aos fenômenos ENOS. 
MENDONÇA, J. C.; FREITAS, R. M. ; SHIMABUKURO, Y. E.; MARQUES, V. S. Avaliação de eventos de inundação na Região Norte Fluminense, Rio de Janeiro, utilizando imagens de sensores remotos. Ambi-Agua, Taubaté, v. 7, n. 1, p. 255-267, 2012. (http://dx.doi.org/10.4136/ambi-agua.817)

Na Figura 4 é apresentado o gráfico da evolução da cota da lagoa Feia, medida na localidade de Ponta Grossa dos Fidalgos e dos eventos de precipitação durante o período de 01/11/2008 a 30/01/2009 medidos em Campos dos Goytacazes, RJ.

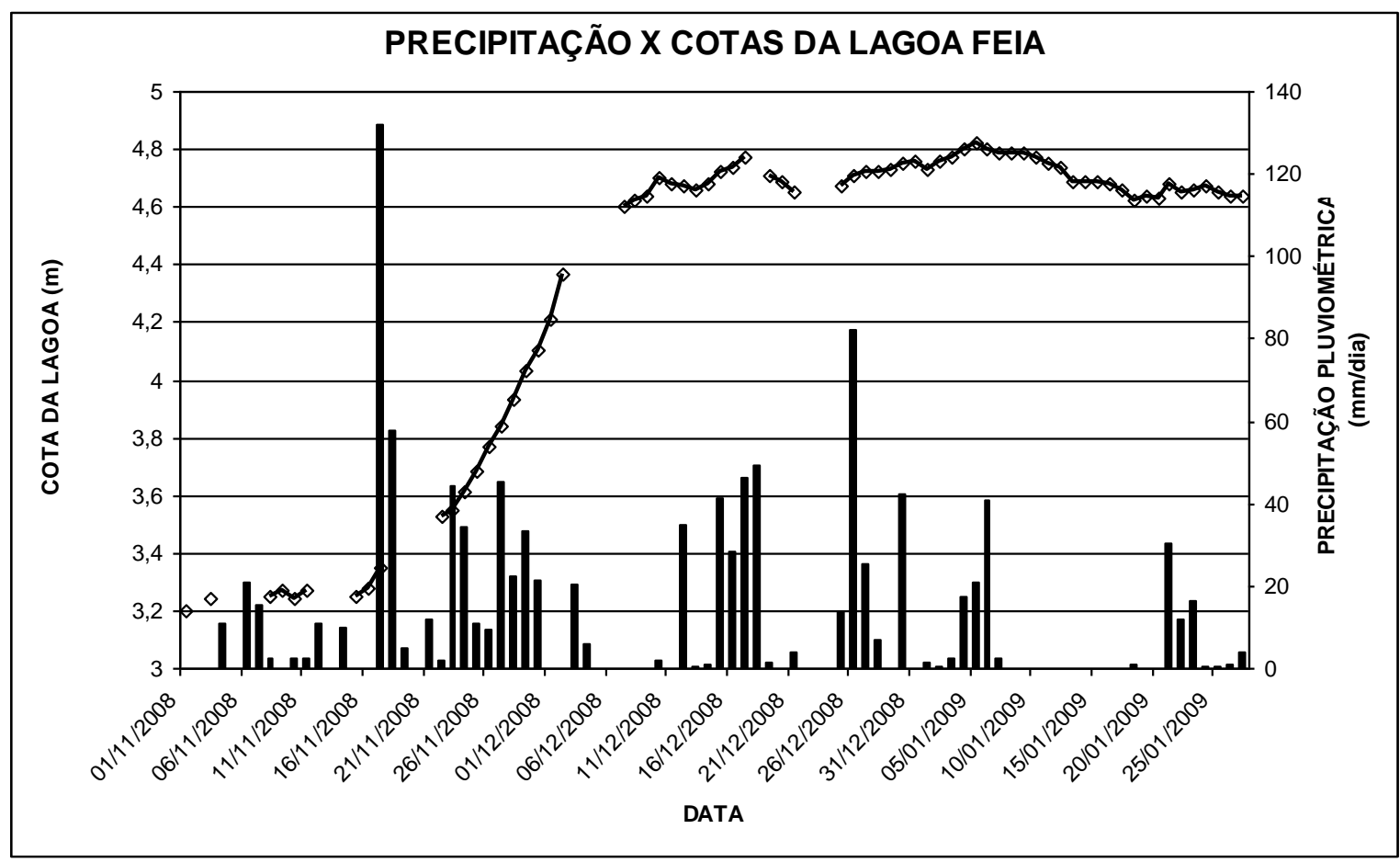

Figura 4. Gráfico da evolução da cota da lagoa Feia e dos eventos de precipitação durante o período de 01/11/2008 a 30/01/2009.

Observando a Figura 4 pode-se perceber que após as fortes chuvas ocorridas à montante da bacia da lagoa de Cima, a cota da lagoa Feia passou a se elevar bruscamente, passando da cota de 3,25 m em 17/11/2008 para 4,10 m em 02/12/2008, representando uma elevação de $0,85 \mathrm{~m}$ em apenas 15 dias.

\subsection{Analise das Imagens CCD CBERS-2B e TM Landsat-5}

Nesta análise aplicou-se a técnica do MLME para avaliar e quantificar a mancha de inundação da área estudada. Como parâmetro inicial utilizou-se uma cena do sensor TM Landsat-5, imageada em 26/07/2007, buscando representar a área do espelho d’água da região em estado de normalidade, ou seja, fora do período chuvoso.

Na Figura 5 são apresentadas as composições coloridas (R5 G4 B3) do TM adquirida no dia 26/07/2007 e das imagens fração derivadas do MLME (Água/sombra Solo Vegetação), evidenciando as áreas ocupadas pelos espelhos d'água.

Na Figura 5 pode-se perceber o comportamento do espelho d'água da região, devidamente em seus limites físicos. A coloração mais avermelhada na Figura 5B destaca as áreas da fração solo gerada pelo MLME. Essa evidência na fração solo se justifica por ser um período de baixa precipitação pluviométrica (inverno seco), coincidindo com a colheita da cana-deaçúcar, principal cultura agrícola local. A área dos corpos d’água extraída da fração água/sombra nesta mesma Figura 5B foi quantificada pela ferramenta "Contagem de pixels Estatística de Polígonos", do software ENVI ver. 4.3, em 27.400 ha.

Na Figura 6 é apresentada a imagem da fração água/sombra gerada pelo MLME aplicado sobre a imagem CCD CBERS-2B adquirida em 02/12/2008 evidenciando a mancha de inundação e fotografias aéreas de alguns trechos dessa área inundada. 
MENDONÇA, J. C.; FREITAS, R. M. ; SHIMABUKURO, Y. E.; MARQUES, V. S. Avaliação de eventos de inundação na Região Norte Fluminense, Rio de Janeiro, utilizando imagens de sensores remotos. Ambi-Agua, Taubaté, v. 7, n. 1, p. 255-267, 2012. (http://dx.doi.org/10.4136/ambi-agua.817)

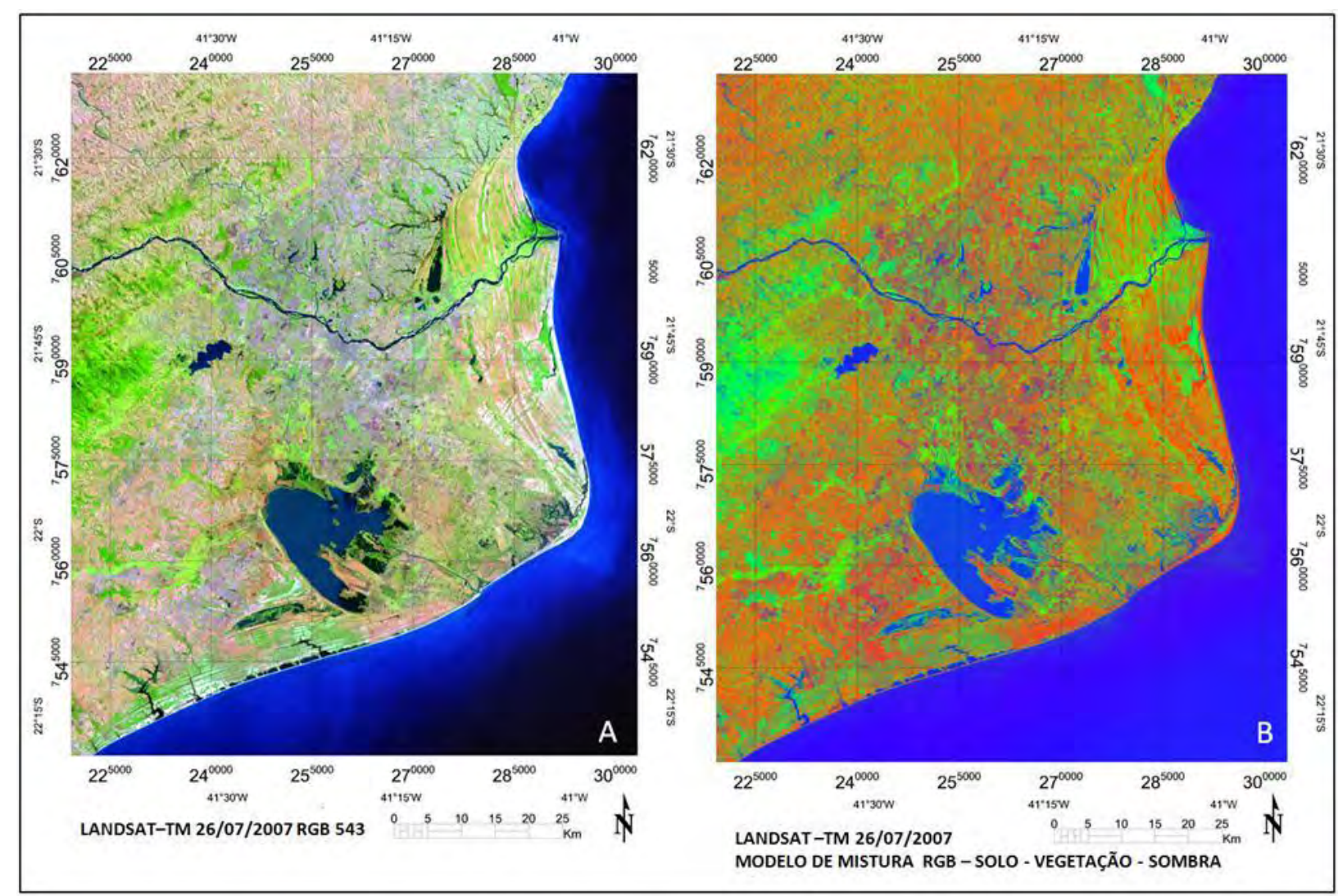

Figura 5. Imagem TM de 26/07/2007 da Região Norte Fluminense, RJ. Composição RGB 543 e composição colorida das frações RGB Solo-Vegetação-Água/Sombra.

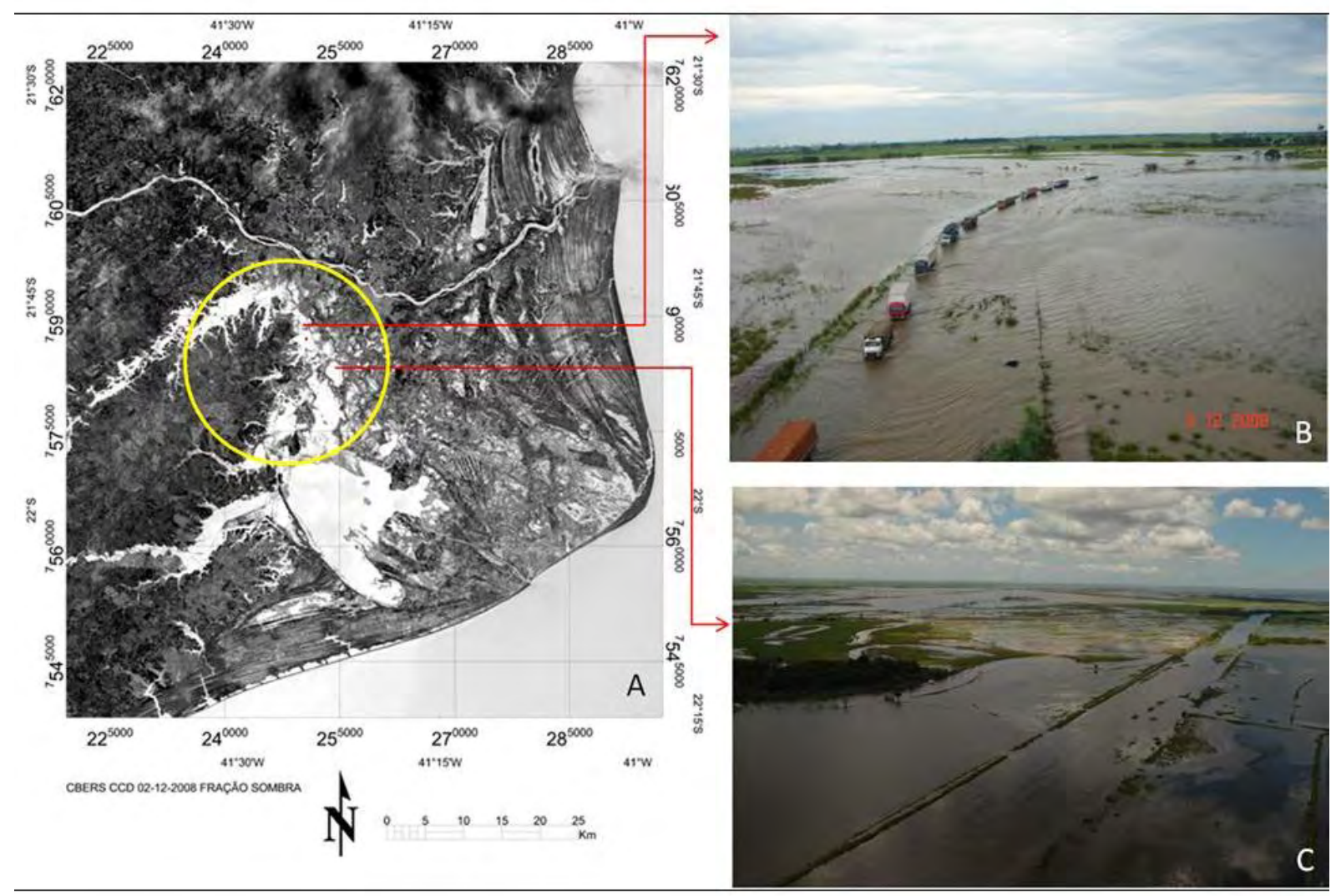

Figura 6. Imagem da fração água/sombra gerada pelo MLME aplicado sobre a imagem CCD CBERS2B (A), e fotografias aéreas de alguns trechos dessas áreas inundadas (B e C). 
MENDONÇA, J. C.; FREITAS, R. M. ; SHIMABUKURO, Y. E.; MARQUES, V. S. Avaliação de eventos de inundação na Região Norte Fluminense, Rio de Janeiro, utilizando imagens de sensores remotos. Ambi-Agua, Taubaté, v. 7, n. 1, p. 255-267, 2012. (http://dx.doi.org/10.4136/ambi-agua.817)

A região de maior magnitude de escoamento superficial (runoff) no Estado do Rio de Janeiro, desvia do leito do Rio Paraíba do Sul, entre as cidades de Campos dos Goytacazes e São Fidelis, em direção a Lagoa Feia (Costa et al., 2009), saindo das Escarpas e Reversos da Serra do Mar, Colinas e Maciços Costeiros para a Planície Costeira (Bergallo et al., 2009). Analisando a Figura 6 pode-se perceber que, em 02/12/2008 a mancha de inundação se concentra na direção deste fluxo, motivo pelo qual a cidade de Campos dos Goytacazes não sofreu maiores impactos decorrentes dos eventos extremos de precipitação. As sub-bacias mais impactadas foram as dos rios Imbé, Ururaí, Prata e Macabú.

Na Figura 7 é apresentada a imagem da fração água/sombra gerada pelo MLME aplicado sobre a imagem TM Landsat-5 de 20/01/2009 evidenciando a mancha de inundação e fotografias aéreas de alguns trechos da área inundada no entorno da lagoa Feia.

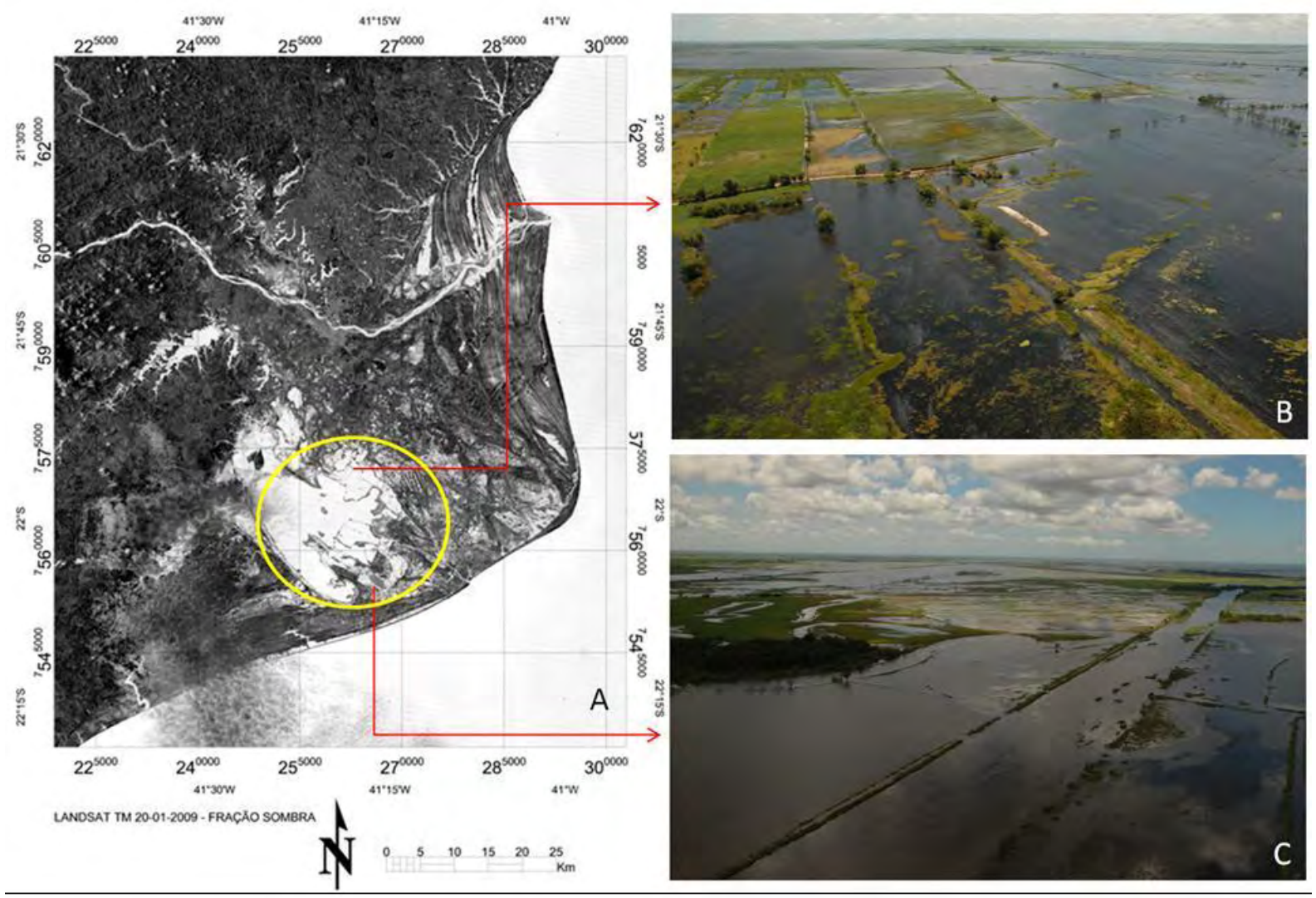

Figura 7. Imagem da fração água/sombra gerada pelo MLME aplicado sobre a imagem TM Landsat-5 de 20/01/2009 evidenciando a mancha de inundação em (A) e fotografias aéreas de alguns trechos das áreas inundadas (B e C).

Na análise da Figura 7 deve-se destacar a contaminação por nuvens sobre a sub-bacia do rio Macabú e lagoa da Ribeira (trecho sul da imagem). Mas a região leste da lagoa Feia se encontra devidamente evidenciada, sem contaminação de nuvens e sendo assim possível se fazer uma análise mais detalhada e perceber que a região a leste da lagoa Feia se encontra fortemente impactada pelo deslocamento da mancha de inundação. Sendo a Baixada Campista uma região muito ampla abrangendo todo o litoral Norte Fluminense, desde São Francisco de Itabapoana a Conceição de Macabu, a inundação a leste da Lagoa Feia representa apenas uma parte desta região, que foi alagada pelo fluxo proveniente da acomodação e distribuição do volume d'água à montante do escoamento e acumulo anterior, concordando com as afirmações de Costa et al. (2009) e Bergallo et al. (2009) quanto ao regime do escoamento superficial (runoff) para esta região do estado do Rio de Janeiro. 
MENDONÇA, J. C.; FREITAS, R. M. ; SHIMABUKURO, Y. E.; MARQUES, V. S. Avaliação de eventos de inundação na Região Norte Fluminense, Rio de Janeiro, utilizando imagens de sensores remotos. Ambi-Agua, Taubaté, v. 7, n. 1, p. 255-267, 2012. (http://dx.doi.org/10.4136/ambi-agua.817)

\section{3. Área Total Atingida Pelas Inundações}

Com a sobreposição das áreas da fração água/sombra obtidas pela aplicação da técnica do MLME extraídas das imagens CCD CBERS-2B de 02/12/08 e TM Landsat-5 de 20/01/09 foi possível estimar a área total atingida pelos eventos das inundações ocorridas neste período.

Na Figura 8 são apresentadas os espelhos d'águas extraídos das imagens TM Landsat-5 e CCD CBERS-2B que permitem a visualização e a quantificação da evolução da mancha de inundação sobre a região em análise, bem como as áreas que permaneceram inundadas por períodos mais prolongados.

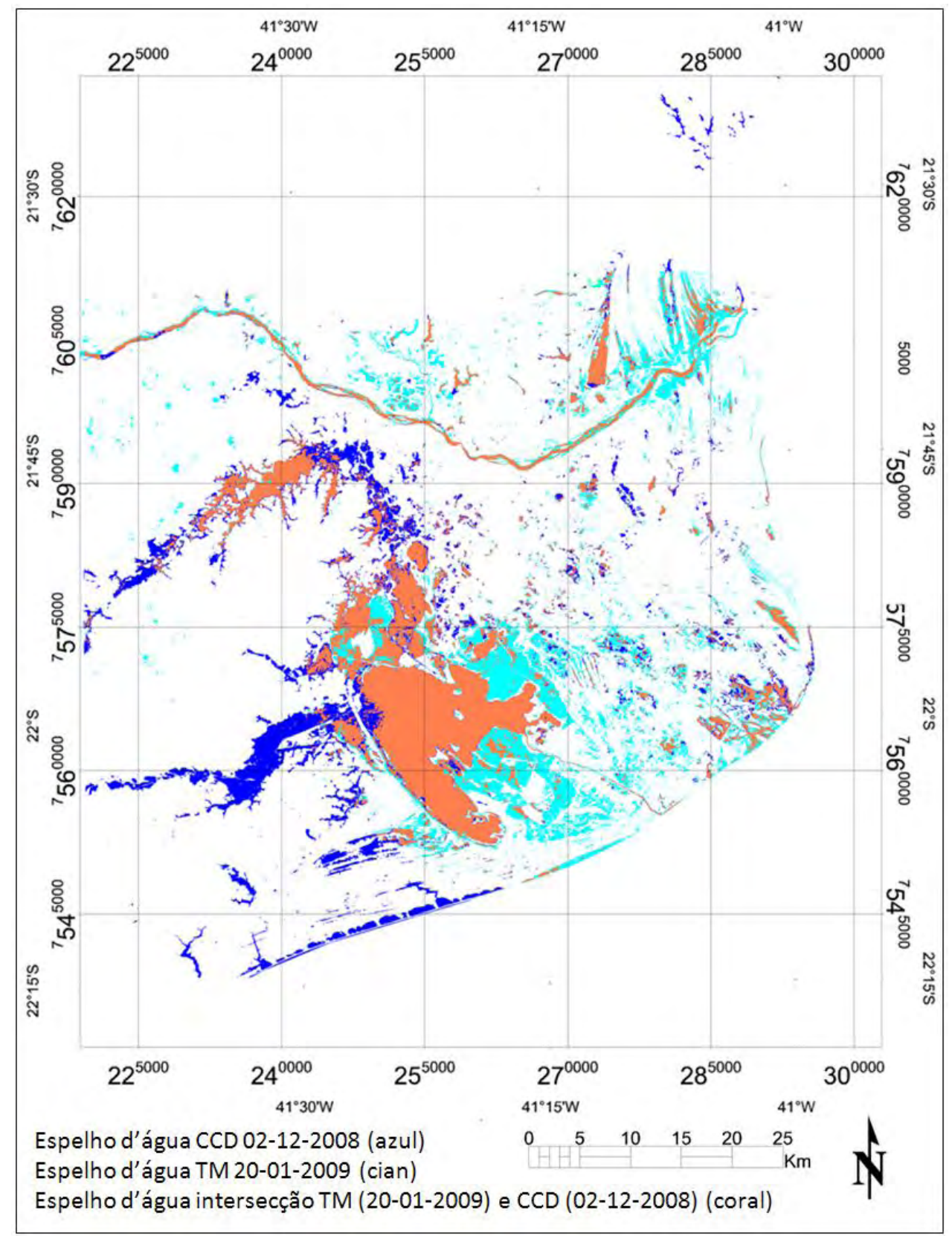

Figura 8. Espelho d’água da imagem CCD CBERS - 2B de 02/12/2008 (azul), da imagem TM Landsat-5 de 20/01/2009 (cian) e espelho d’água em comum entre às duas imagens (coral).

Observando a Figura 8 é possível verificar as áreas sobrepostas entre as imagens CCD CBERS-2B de 02/12/2008 e TM Landsat-5 de 20/01/2009 (coral) evidenciando as áreas do espelho d'água comum às duas imagens. Essas áreas em comum, com exceção do espelho 
MENDONÇA, J. C.; FREITAS, R. M. ; SHIMABUKURO, Y. E.; MARQUES, V. S. Avaliação de eventos de inundação na Região Norte Fluminense, Rio de Janeiro, utilizando imagens de sensores remotos. Ambi-Agua, Taubaté, v. 7, n. 1, p. 255-267, 2012. (http://dx.doi.org/10.4136/ambi-agua.817)

d’água da própria Lagoa Feia e da Lagoa de Cima (Figura 5), representam as áreas que permaneceram alagadas por um período mais prolongado que os demais, mesmo após o deslocamento e acomodação do escoamento para a região leste da área estudada (Figura 7). $\mathrm{O}$ total da área do espelho d'água existente na Figura 8 (azul + cian + coral) foi quantificada pela ferramenta "Contagem de pixels - Estatística de Polígonos", do software ENVI ver. 4.3, em 99.000 ha. Dessa maneira, pode-se observar que o espelho d'água da região sofreu um incremento de 2,61 vezes impactando uma área de 71.600 ha, quando comparada com o espelho d'água extraída da imagem TM de referência (26/07/2007).

\section{CONCLUSÃO}

Os mapas do espelho d’água gerados a partir das imagens fração água/sombra derivadas do MLME apresentam a evolução do deslocamento da mancha de inundação. Esses mapas são importantes para a identificação das áreas atingidas, podendo ser utilizados na avaliação sócio-econômica dos prejuízos ocorridos e nas atividades mitigatórias visando o controle de enchentes na região.

Com base na imagem do dia 26/07/2007 (período sem chuvas) e nas imagens dos dias 02/12/2008 e 20/01/2009, pode-se concluir que o espelho d'água da região sofreu um incremento de 2,61 vezes impactando uma área de 71.600 ha.

A metodologia adotada utilizando imagens TM Landsat-5 e CCD CBERS-2B, disponibilizadas gratuitamente na internet se mostrou eficiente para auxiliar a gestão dos recursos hídricos na região Norte Fluminense, Rio de Janeiro.

\section{REFERÊNCIAS}

BERGALlO, H. G.; FIDALGO, E. C.; ROCHA, C. F. D. et al. Estratégias e ações para a conservação da biodiversidade no Estado do Rio de Janeiro e outros. Rio de Janeiro: Instituto Biomas, 2009. 344 p.

CATALDI, M.; ASSAD, L. P. de F.; TORRES JÚNIOR, A. R.; ALVES, J. L. D. Estudo da influência das anomalias da TSM do Atlântico Sul extratropical na região da confluência Brasil Malvinas no regime hidrometeorológico de verão do sul e sudeste do Brasil. Revista Brasileira de Meteorologia, São José dos Campos, v.25, n.4, p. 513$524,2010$.

COSTA, T. C. C; FIDALGO, E. C. C.; NAIME, E. J.; GUIMARÃES, S. P.; ZARONI, M. J.; UZEDA, M. C. Vulnerabilidade de sub-bacias hidrográficas do estado do Rio de Janeiro por meio da equação universal da perda de solo e da integração de parâmetros morfométricos, topográficos, hidrológicos e de uso/cobertura da terra no estado do Rio de Janeiro, Brasil. Revista Ambiente \& Água, Taubaté. v. 4. n. 1. p. 93-116, 2009.

EVANS, T.; COSTA, M. P. F. ; TELMER, K.; SILVA, T. S. F. Using ALOS/PALSAR and RADARSAT-2 to map land cover and seasonal inundation in the Brazilian Pantanal. IEEE J-STARS, Piscataway, v. 3, p. 560-575, 2010.

GERÓLAMO, R. O. P.; KAYANO, M. T. Variações do ciclo anual da temperatura da superfície do mar no Pacífico Tropical. Revista Brasileira de Meteorologia, São José dos Campos, v. 25, n. 2, p. 237-245, 2010. 
MENDONÇA, J. C.; FREITAS, R. M. ; SHIMABUKURO, Y. E.; MARQUES, V. S. Avaliação de eventos de inundação na Região Norte Fluminense, Rio de Janeiro, utilizando imagens de sensores remotos. Ambi-Agua, Taubaté, v. 7, n. 1, p. 255-267, 2012. (http://dx.doi.org/10.4136/ambi-agua.817)

INSTITUTO ESTADUAL DO AMBIENTE - INEA (Rio de Janeiro). Divisão de Outorga. Núcleo de Geotecnologias. Mapa das regiões hidrográficas do Estado do Rio de Janeiro. Rio de Janeiro, 2008. Disponível em: <http://www.inea.rj.gov.br/ recursos/re_hidrograf.asp>. Acesso em: 10 mar. 2009.

LAMEGO, A. R. Geologia das quadrículas de Campos, São Tomé, Lagoa Feia e Xexé. Boletim 154. Rio de Janeiro: DNPM, 1955. 60 p.

LIMA, A.; SHIMABUKURO, Y. E.; ADAMI, M.; FREITAS, R. M.; ARAGÃO, L. E. O. C.; FORMAGGIO, A. R. et al. Mapeamento de cicatrizes de queimadas na amazônia brasileira a partir da aplicação do Modelo Linear de Mistura Espectral em imagens do sensor MODIS. In: SIMPÓSIO BRASILEIRO DE SENSORIAMENTO REMOTO SBSR, 14., 25 - 30 abril 2009, Natal. Proceedings... São José dos Campos: INPE, 2009. p. 5925-5932. 1 CD-ROM.

MENDONÇA, J. C.; FREITAS, R. M.; SOUSA, E. F. Avaliação temporal dos eventos de inundação da Baixada Campista, Região Norte Fluminense, RJ, pelo uso de imagens digitais orbitais do sensor MODIS. Revista Brasileira de Cartografia, Rio de Janeiro, v. 59, n. 03, p. 249/4-253, 2007.

MOURA, Y. M.; ARAI, E.; SHIMABUKURO, Y. E.; SANTOS, J. R.; FISCH, G. F.; NOVAES JUNIOR, R. A. et al. Aplicação do MLME em imagens MODIS para o estudo do comportamento de fitofisionomias da Floresta Atlântica e sua relação com a variabilidade pluviométrica. In: SIMPÓSIO BRASILEIRO DE SENSORIAMENTO REMOTO -SBSR, 14., 25 - 30 abril 2009, Natal. Proceedings... São José dos Campos: INPE, 2009. p. 2847-2854. 1 CD-ROM.

PADOVANI, C. R.; VETTORAZZI, C. A.; SHIMABUKURO, Y. E.; ADAMI, M.; FREITAS, R. M. Estudo das inundações do Pantanal a partir de imagens MODIS. In: SIMPÓSIO BRASILEIRO DE SENSORIAMENTO REMOTO - SBSR, 14., 25 - 30 abril 2009, Natal. Proceedings... São José dos Campos: INPE, 2009. p. 4805-4812. 1 CD-ROM.

RAMOS, A. M.; SANTOS, L. A. R.; FONTES, L. T. G. (Org.). Normais climatológicas do Brasil 1961-1990. Brasília, DF: INMET, 2009. 465 p.

RENÓ, V. F.; MORAES, L. E. S.; SAITO, E. A.; NASCIMENTO, R. F. F.; LOBO, F. L. SAMIZAVA, T. M. et al. Caracterização espectral das águas da Planície do Rio Paraná a partir de imagens Landsat TM. In: SIMPÓSIO BRASILEIRO DE SENSORIAMENTO REMOTO - SBSR, 14., 25 - 30 abril 2009, Natal. Proceedings... São José dos Campos: INPE, 2009. p. 4821-4828. 1 CD-ROM.

SABOL, D. E.; GILlESPIE, A. R.; ADAMS, J. B.; SMITH, M. O.; TUCKER, C. J. Structural stage in Pacific Northwest estimated using simple mixing models of multispectral images. Remote Sensing of Enviroment, v. 80, n. 1, p. 1-16, 2002. http://dx.doi.org/10.1016/S0034-4257(01)00245-0

SILVA, T. S. F.; FREITAS, R. M.; NOVO, E. M. L. M. Monitoramento de áreas alagáveis. In: BERNARDO F. T.; RUDORFF, B.; SHIMABUKURO, Y. E.; CEBALLOS, J. C. (Org.). O sensor Modis e suas aplicações ambientais no Brasil. 1. ed. São José dos Campos: Parêntese, 2007. v. 1. p. 255-263. 
MENDONÇA, J. C.; FREITAS, R. M. ; SHIMABUKURO, Y. E.; MARQUES, V. S. Avaliação de eventos de inundação na Região Norte Fluminense, Rio de Janeiro, utilizando imagens de sensores remotos. Ambi-Agua, Taubaté, v. 7, n. 1, p. 255-267, 2012. (http://dx.doi.org/10.4136/ambi-agua.817)

SILVA, W. C. S. Aplicação da técnica de Modelo Linear de Mistura Espectral (MLME) para o mapeamento de diferentes tipos de água no rio Solimões e no lago de Coari utilizando imagens Landsat-TM. 2008. 109f. Dissertação (Mestrado em Engenharia Civil) - Universidade Federal do Rio de Janeiro, Rio de Janeiro, 2008.

SHIMABUKURO, Y. E.; BATISTA, G. T.; MELLO, E. M. K.; MOREIRA, J.C.; DUARTE, V. Using shade fraction image segmentation to evaluate deforestation in Landsat Thematic Mapper images of the Amazon Region. International Journal of Remote Sensing, London, v. 19, n. 3, p. 535-541, 1998. http://dx.doi.org/10.1080/014311698216152

SHIMABUKURO, Y. E.; SMITH, J. A. The least-squares mixing models to generate fraction images derived from remote sensing multispectral data. IEEE Transactions on Geoscience and Remote Sensing, Piscataway, v. 29, n. 1, p. 16-20, 1991.

SHIMABUKURO, Y. E.; DUARTE, V.; ARAI, E.; FREITAS， R. M.; LIMA, A.; VALERIANO, D. M. et al. Fraction images derived from Terra MODIS data for mapping burnt areas in Brazilian Amazonia. International Journal of Remote Sensing, London, v. 30, n. 6, p. 1537-1546, 2009. http://dx.doi.org/10.1080/01431160802509058 


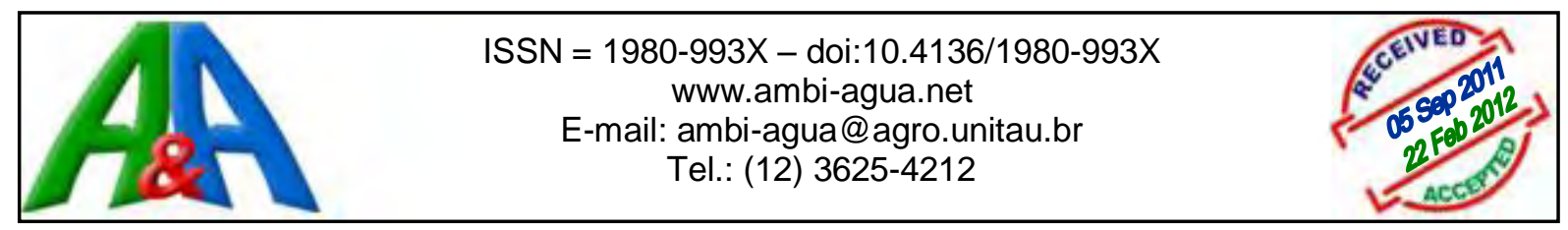

Modelagem do balanço hídrico em povoamentos de eucalipto sob diferentes manejos como auxílio ao gerenciamento do impacto hidrológico da atividade

(http://dx.doi.org/10.4136/ambi-agua.810)

\author{
Rosane Barbosa Lopes Cavalcante'; Carlos André Bulhões Mendes². \\ Instituto de Pesquisas Hidráulicas / UFRGS, Porto Alegre, \\ 1e-mail: rosanecavalcante@gmail.com; ${ }^{2}$ e-mail: mendes@iph.ufrgs.br
}

\title{
RESUMO
}

A busca de informações que possibilitem a incorporação das variáveis ambientais nos modelos de gestão florestal é um desafio atual. Para atingi-lo é importante conhecer os processos e componentes que atuam de forma efetiva no balanço de água. Neste contexto, o presente artigo visa estimar o impacto hidrológico de plantações de eucalipto e sua relação com as formas de manejo, a fim de identificar variáveis que auxiliem na integração do planejamento florestal e de recursos hídricos. Para tanto, utilizou-se um modelo de balanço hídrico simplificado que considerasse diferentes características do povoamento florestal para estimar a vazão resultante de diferentes manejos em uma bacia em Eldorado do Sul, RS. O índice de área foliar apresentou-se como um importante descritor do dossel florestal estando diretamente relacionado com a produção de água pela bacia. A vazão média ao longo da rotação obtida pelos diferentes manejos variou de $493 \mathrm{~mm} \cdot \mathrm{ano}^{-1}$ a $792 \mathrm{~mm}$.ano ${ }^{-1}$. A grande variação na vazão anual resultante enfatiza a necessidade da integração do gerenciamento dos recursos florestais com os recursos hídricos.

Palavras-chave: eucalipto; impacto hidrológico; manejo de plantações florestais; índice de área foliar.

\section{Modeling the water balance in eucalyptus stands under different managements as an aid to the hydrological impact management}

\begin{abstract}
The search for information that allows the incorporation of environmental variables in the forest management models is a current challenge. In this context, this article aimed to estimate the hydrological impact of eucalyptus plantations and its relation with management practices, considering a case study in Rio Grande do Sul, Brazil. Variables that may assist in the integration of forest planning and water resources were identified based on the results. A simplified water balance model was used, considering different forest stand characteristics to estimate the discharge resulting from different management practices. The leaf area index was presented as an important descriptor of the forest canopy and it is directly related to the production of water in the watershed. The average flow obtained by different managements ranged from $493 \mathrm{~mm} . \mathrm{yr}-1$ to $792 \mathrm{~mm}$.yr-1. The wide variation in annual discharge enhanced the need to integrate the management of forest resources and water resources.
\end{abstract}

Keywords: Eucalyptus; hydrological impact; management; leaf area index. 


\section{INTRODUÇÃO}

As altas taxas de crescimento do eucalipto e de outras espécies são normalmente acompanhadas de um alto uso dos recursos naturais locais, levantando questões sobre os impactos ecológicos de sua plantação em larga escala, em especial quanto ao consumo de água. No Rio Grande do Sul, a expansão da silvicultura foi acompanhada de discussões acaloradas sobre seus impactos ambientais (Binkowski, 2009), o que culminou no zoneamento ambiental da atividade (Rio Grande do Sul, 2010). A área com florestas plantadas apenas de eucalipto no estado cresceu $81,6 \%$ no período de 2004 a 2008, atingindo $277 \mathrm{mil}$ ha (ABRAF, 2009).

Diversos estudos apontam para a necessidade de considerar a possibilidade real de uma redução da vazão das bacias devido à mudança de cobertura vegetal de pequeno para maior porte (Lima e Zákia, 2006; Bruijnzeel, 1990; Brown et al., 2005; Tucci e Clarke, 1998). Muitos fatores são responsáveis por esta redução no deflúvio, entre os quais o aumento da energia disponível para evapotranspiração, aumento da interceptação e ao fato de que florestas retiram do solo mais água do que pastagens (Bruijnzeel, 1990; Lima, 1993).

É importante ressaltar, porém, que o consumo de água do eucalipto dependerá das condições locais, principalmente em termos de solo e da precipitação anual, além de ser fortemente dependente das práticas de manejo (Calder, 1986; Andréassian, 2004). Entretanto, conforme salienta Sun et al. (2008), poucos estudos examinam as mudanças na estrutura e composição florestal de modo associado a hidrologia da bacia. Os estudos que examinam utilizam dados de bacias experimentais que ainda não são disponíveis na maioria dos locais. Logo, a simulação hidrológica aparece como uma ferramenta bastante útil para estimar os impactos do florestamento sobre os recursos hídricos.

Apesar da conhecida relação entre o manejo florestal e as respostas hidrológicas da bacia, a busca de informações e resultados que possibilitem a incorporação das variáveis ambientais nos modelos de gestão florestal é um desafio atual (Lima e Zakia, 2006). Neste contexto, o presente artigo visa estimar o impacto hidrológico da implantação de plantações de eucalipto e sua relação com as formas de manejo, a fim de identificar variáveis que auxiliem na integração do planejamento florestal e de recursos hídricos, com estudo de caso no Rio Grande do Sul.

\section{MATERIAIS E MÉTODO}

\subsection{Modelo Hidrológico Simplificado}

Um modelo de balanço hídrico simplificado foi utilizado para estimar a vazão resultante de cada manejo considerado para a área de estudo e compará-las a situação anterior ao povoamento de eucalipto.

As alternativas de manejo foram geradas a partir dos dados fornecidos pela empresa responsável pela área de estudo de acordo com as características do local e objetivo da produção. Os dados combinados foram: unidade de manejo, idade mínima e máxima permitidas para o corte em cada rotação, número de rotações mínimo e máximo, densidade do povoamento, material genético e idade da plantação no início do período de análise, de modo a formar o mosaico da plantação. As unidades de manejo foram definidas como as áreas que apresentaram mesmo índice de sítio por ser este o método mais utilizado para definir a potencialidade dos sítios florestais (Tonini et al., 2006), além de fornecer subsídios para o manejo da área (Braga et al., 1999). O índice de sítio é uma variável que procura quantificar a qualidade do sítio por meio de parâmetros dendrométricos, sendo o mais utilizado a altura das árvores dominantes e codominantes de um povoamento numa idade base (Batista e Couto, 1986). 
Entre os diversos aspectos da mudança de uso do solo de vegetação de pequeno porte para florestas, a redução na vazão frequentemente observada deve-se, sobretudo, ao aumento da evapotranspiração. $\mathrm{O}$ modelo hidrológico utilizado calcula o balanço hídrico diário na zona radicular considerando as diferentes prescrições (Figura 1). Destaca-se que não são considerados no modelo a interação com o lençol freático e o processo de ascensão capilar, sendo necessário um estudo mais detalhado para utilização em locais onde esta influência seja significativa. Para a área de estudo, devido à localização das áreas de plantio e de observações pontuais da profundidade do lençol freático, foi assumido que estes processos não interferiam de forma significativa no balanço hídrico. Estudos realizados no Brasil com Eucalyptus grandis em Santa Bárbara/MG (Leite et al., 1999) e em Aracruz/ES (Almeida e Soares, 2003) observaram que o crescimento das plantas foi mais dependente da água retida até $2,5 \mathrm{~m}$ de profundidade, enquanto Almeida et al. (2006) observou sistemas de raízes variando de 0,8 m aos 2 anos a 1,6 $\mathrm{m}$ aos 7 anos.

Do total precipitado, parte é interceptado no dossel florestal. Para a determinação da interceptação, utilizou-se o modelo para áreas com vegetação esparsa proposto por Valente et al. (1997), desconsiderando as perdas por interceptação dos troncos. Este modelo divide a área total em duas distintas sub-áreas nas quais os cálculos são feitos separadamente: a área descoberta e a área coberta (onde ocorre a interceptação). O parâmetro que ajusta estas áreas é a fração de cobertura vegetal (c). Este parâmetro pode ser relacionado com o índice de área foliar (IAF) pela equação de Beer-Lambert conforme apresentado por Van Dijk e Bruijnzeel (2001):

$$
c=1-e^{-k \cdot I A F}
$$

em que c é a fração de cobertura vegetal [-]; IAF é o índice de área foliar $\left[\mathrm{m}^{2} . \mathrm{m}^{-2}\right]$; e k é o coeficiente de extinção luminosa [-].

O IAF corresponde à razão entre a área foliar do dossel e a unidade de superfície projetada no solo $\left(\mathrm{m}^{2}\right.$ de folha $/ \mathrm{m}^{2}$ de solo). Dessa forma, a fração de cobertura vegetal e a interceptação variam com o tipo e com o estágio de desenvolvimento da vegetação de acordo com as modificações no IAF. A exemplo de Dye et al. (2004), foi assumido neste trabalho $\mathrm{k}=0,45$.

$\mathrm{Na}$ área coberta, considera-se que toda a precipitação será interceptada pela copa até que esta se encontre saturada, ou seja, até que seja atingida a capacidade de armazenamento do reservatório do dossel em relação à área coberta. A capacidade de armazenamento do dossel foi considerada como o produto de um valor característico da capacidade de armazenamento das copas por unidade de área foliar pelo IAF. Dingman (2002) cita o valor de 0,15 para este valor característico, enquanto Valente et al. (1997) refere-se a valores de 0,2 a 1,0 mm. Neste trabalho foi utilizada uma capacidade de armazenamento do dossel de $0,2 \mathrm{~mm} *$ IAF.

O IAF é apontado como uma importante característica da vegetação a ser utilizada em modelos hidrológicos devido a sua influência nos processos de transpiração e interceptação (Soares e Almeida, 2001; Van Dick e Bruijnzeel, 2001; Collischonn et al., 2007). O IAF é também uma das variáveis mais apontadas para explicar a variação na vazão da bacia ao longo do período de rotação devido a sua grande variabilidade com a idade da árvore do povoamento (Cornish e Vertessy, 2001; Almeida et al., 2007).

$\mathrm{O}$ excesso de precipitação não interceptada na área coberta drena para a camada superficial do solo. Entretanto, apenas uma parcela da precipitação interna infiltra no solo. A parcela que não infiltra gera escoamento superficial. A separação deste escoamento foi feita utilizando o modelo SCS (Soil Conservation Service), conforme apresentado por Tucci (2004). 
O solo é considerado como um reservatório cuja capacidade é definida pela capacidade de água disponível (CAD) do solo. Valores de umidade do solo superiores a CAD são drenados para fora da zona radicular. A CAD representa o limite de água entre a capacidade de campo e o ponto de murcha permanente do solo para uma determinada profundidade do solo sendo, portanto, dependente do tipo de solo e da profundidade das raízes. Na ausência de medições diretas destes parâmetros na área de estudo, os valores das propriedades de retenção de água do solo foram estimados a partir da classificação do solo, enquanto o crescimento do sistema radicular foi definido como tendo variação linear.

O esvaziamento dos reservatórios do dossel e do solo se dá pelo processo de evapotranspiração calculada pela equação de Penman-Monteith conforme apresentado por Allen et al. (2006), com a resistência superficial calculada em função do IAF. Para a vegetação transpirante, a resistência superficial foi calculada conforme apresentado por Dingman (2002). A radiação global foi determinada utilizando a ferramenta Solar Radiation do ArcGis, a partir do modelo digital de elevação do terreno e de parâmetros atmosféricos. $\mathrm{O}$ modelo digital de elevação do terreno utilizado foi o ASTER GDEM (disponível em https://wist.echo.nasa.gov/api). Os parâmetros atmosféricos foram estimados utilizando dados de cobertura de nuvens provenientes da normal climatológica.

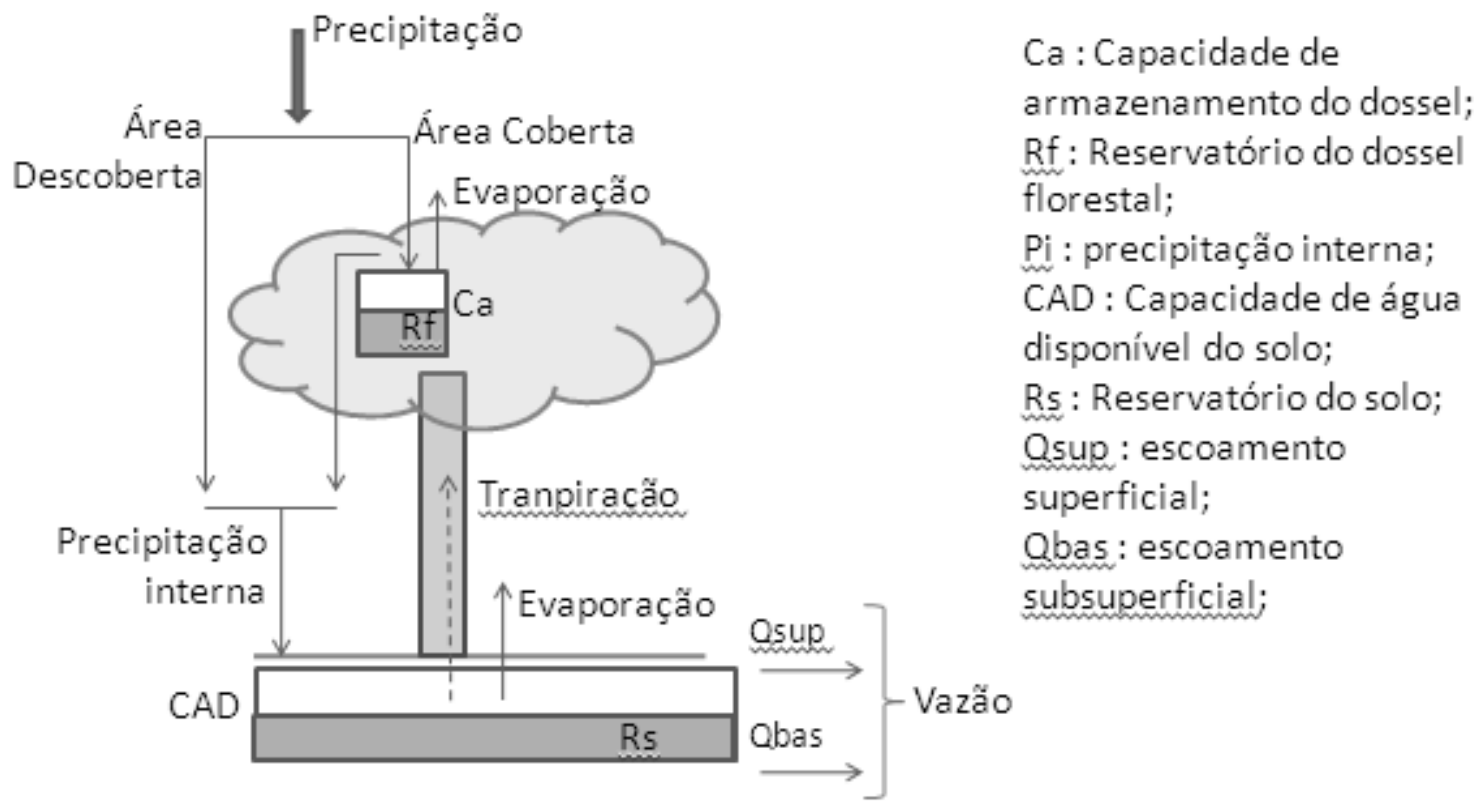

Figura 1. Esquema do modelo de balanço hídrico utilizado.

\section{2. Área de estudo}

A área de estudo corresponde a bacia inserida num horto florestal pertencente à empresa CMPC Celulose Riograndense no município de Eldorado do Sul/RS (Figura 2). A bacia possui $0,97 \mathrm{~km}^{2}$ da área da bacia, $84 \%$ são destinados ao plantio de eucalipto, $13 \%$ a áreas de preservação e o restante corresponde a demais usos do solo. Toda a produção é destinada a indústria de papel e celulose. A bacia está dividida em duas áreas com índices de sítio IS=30 e IS=32. Para a geração das alternativas de manejo para a área, considerou-se idades de corte entre 7 e 9 anos; 1 ou 2 rotações por ciclo; densidades de 1666, 1333 ou 1111 árvores/ha; e 4 diferentes espécies. Foi adotado ainda idades de 0, 3 e 6 anos no início da análise. 
CAVALCANTE, R. B. L.; MENDES, C. A. B. Modelagem do balanço hídrico em povoamentos de eucalipto sob diferentes manejos como auxílio ao gerenciamento do impacto hidrológico da atividade. Ambi-Agua, Taubaté, v. 7, n. 1, p. 268-280, 2012. (http://dx.doi.org/10.4136/ambi-agua.810)

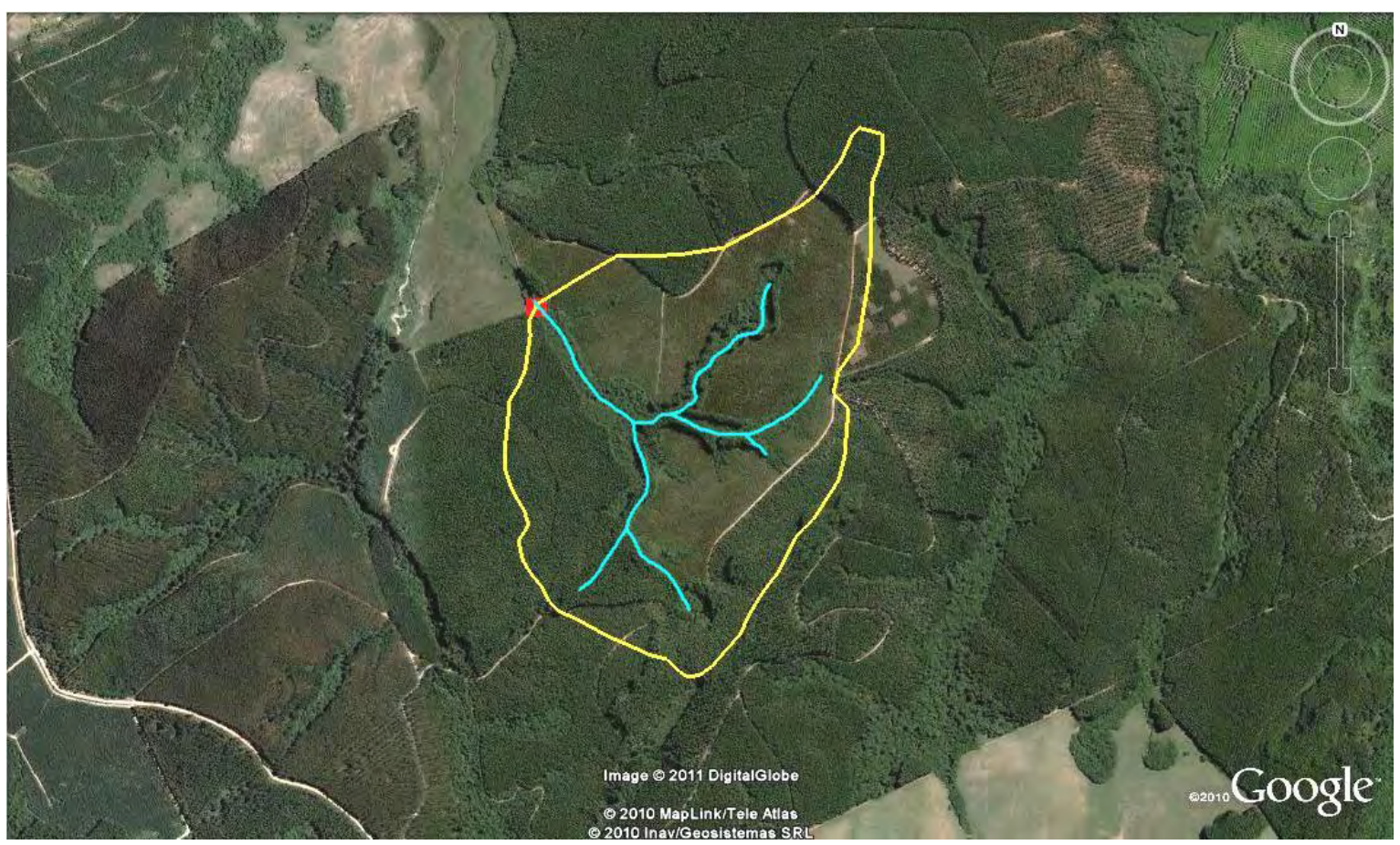

Figura 2. Área de estudo (Google Earth) com destaque para a delimitação da bacia.

A precipitação na região é distribuída durante todo o ano, sendo os meses mais chuvosos entre Junho e Agosto (Bermagaschi et al., 2003). O total precipitado anual é de aproximadamente $1450 \mathrm{~mm}$. A temperatura média apresenta comportamento sazonal (Figura 3 ), com temperatura média inferior a $14^{\circ} \mathrm{C}$ no mês mais frio (Junho), e superior a $24^{\circ} \mathrm{C}$ no mês mais quente (Janeiro). Os dados utilizados no modelo de balanço hídrico foram obtidos

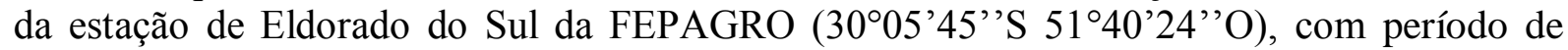
análise de setembro de 1975 a agosto de 1983. A precipitação anual média no período foi de $1317 \mathrm{~mm}$.

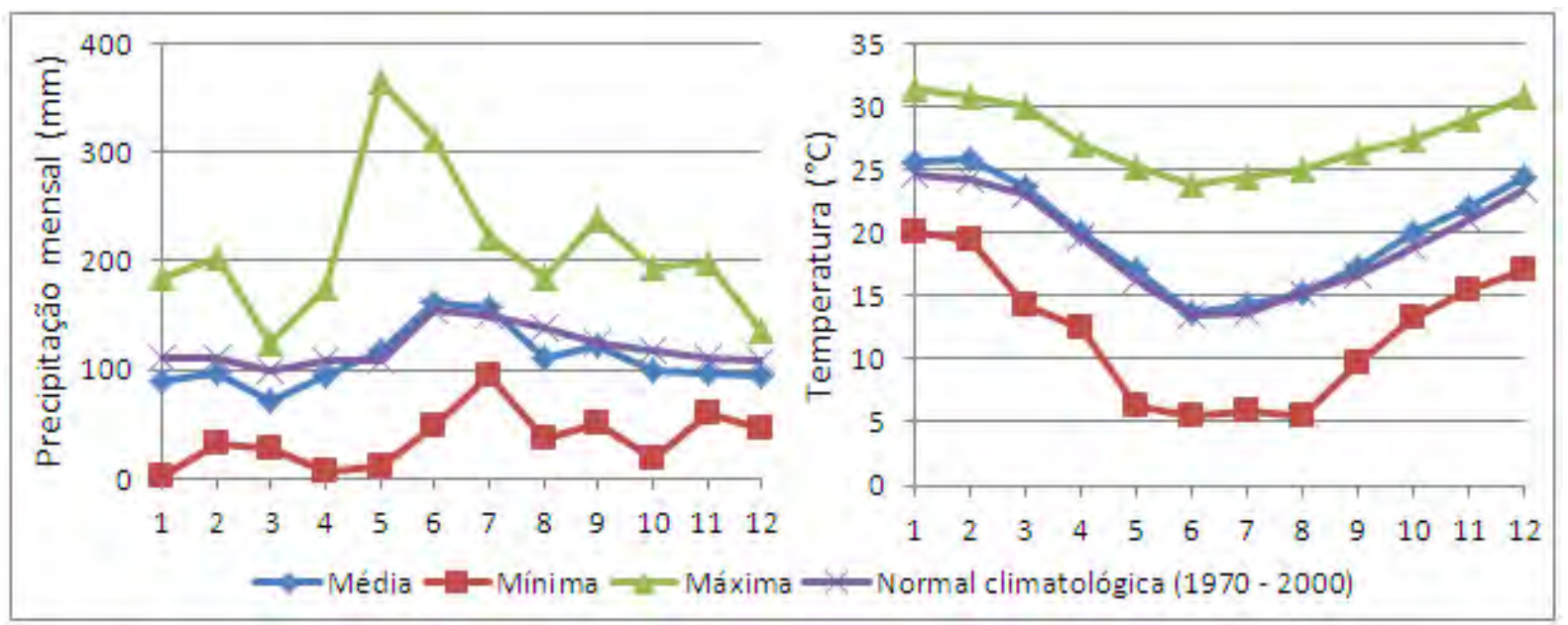

Figura 3. Dados mensais precipitação e temperatura de normais climatológicas da estação experimental da UFRGS (Bermagaschi et al., 2003) e da estação Eldorado do Sul da FEPAGRO (Setembro de 1975 a Agosto de 1984).

Para este estudo, assim como o índice de sítio e, consequentemente, os dados de produtividade, as características do solo também foram assumidas como constantes dentro de cada talhão. Para cada tipo de solo predominante em cada talhão foi obtida a distribuição 
CAVAlCANTE, R. B. L.; MENDES, C. A. B. Modelagem do balanço hídrico em povoamentos de eucalipto sob diferentes manejos como auxílio ao gerenciamento do impacto hidrológico da atividade. Ambi-Agua, Taubaté, v. 7, n. 1, p. 268-280, 2012. (http://dx.doi.org/10.4136/ambi-agua.810)

granulométrica a partir dos dados obtidos no mapeamento de solos realizado por Costa et al. (2009). A partir da classificação destes solos, os valores das propriedades de retenção de água de cada talhão foram definidos como sendo equivalentes aos valores médios de cada classe textural apresentados por Rawls et al. (1993).

Funções de variação do IAF (Tabela 1), da altura da vegetação e da profundidade da raiz ao longo do crescimento de cada espécie foram ajustadas para a estimativa do impacto hidrológico. Como apenas se dispunha de uma medição de IAF para cada espécie, as funções para simular a variação do IAF com a idade do povoamento foram estabelecidas baseadas na variação do IAF com a idade do povoamento observado em estudos realizados no Brasil (Xavier et al., 2002; Almeida et al., 2007). A Figura 4 apresenta os resultados.

Tabela 1. Equações estimadas para determinação do IAF (de 1,5 a 6 anos) e manejos, com parâmetros para as equações de cada espécie com base nas medições de junho de 2009.

\begin{tabular}{l|ccc|cccc}
\hline \multicolumn{7}{c}{${\mathbf{I A F}=\mathbf{A t}^{\mathbf{3}}+\mathbf{B t}^{\mathbf{2}}+\mathbf{C t}+\mathbf{D}}$} \\
\hline Manejo & IAF & Densidade & Idade (anos) $^{-} \mathbf{A}$ & $\mathbf{B}$ & $\mathbf{C}$ & D \\
\hline Espécie 1 & 2,88 & 1111 árv.ha $^{-1}$ & 3,34 & 0,1443 & $-1,9481$ & 7,7924 & $-6,7924$ \\
Espécie 2 IS 32 & 2,82 & 1111 árv.ha $^{-1}$ & 4,84 & 0,1793 & $-2,4661$ & 10,2734 & $-9,4665$ \\
Espécie 2 IS 30 & 3,01 & 1111 árv.ha $^{-1}$ & 4,84 & 0,1475 & $-2,0550$ & 8,7704 & $-8,0297$ \\
Espécie 3 & 2,01 & 1122 árv.ha $^{-1}$ & 8,00 & 0,1715 & $-2,3444$ & 9,6985 & $-8,8183$ \\
Espécie 4 & 2,88 & 1666 árv.ha $^{-1}$ & 18,93 & 0,1310 & $-1,8281$ & 7,9374 & $-7,2351$ \\
\hline
\end{tabular}

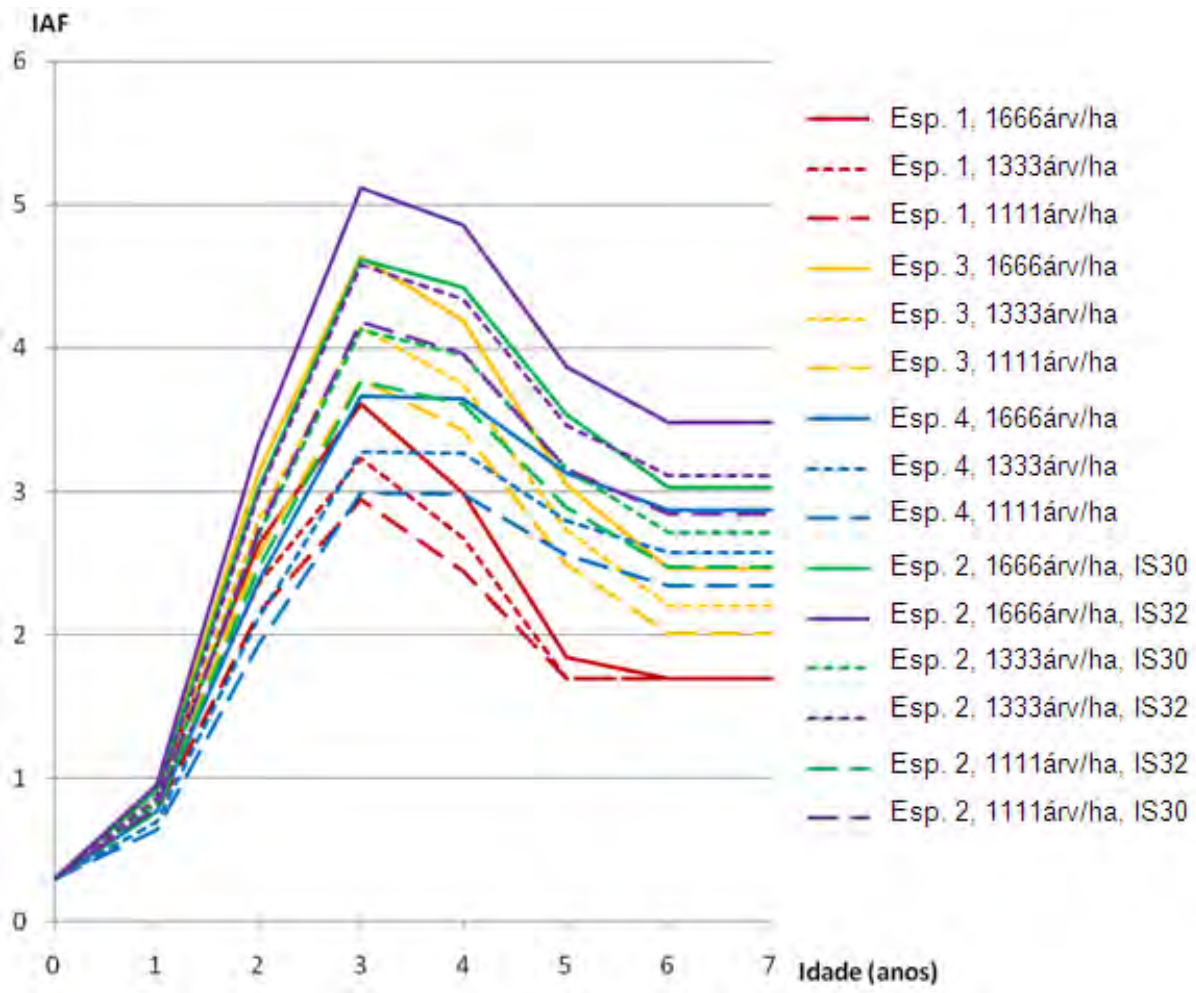

Figura 4. Variação da estimativa do IAF ao longo da idade da plantação para diferentes regimes de manejo.

É considerado ainda que o IAF varia linearmente do plantio aos 18 meses e que do sexto ano até o final da rotação o valor do IAF permanece constante. Na ausência de medições de IAF para diferentes espaçamentos de cada espécie, este foi estimado utilizando a equação sugerida por Allen et al. (2006): 


$$
\mathrm{IAF}_{\mathrm{dens} 1}=\mathrm{IAF}_{\mathrm{dens} 2} \cdot\left(\frac{\text { dens } 1}{\operatorname{dens} 2}\right)^{0,5}
$$

em que $\mathrm{IAF}_{\text {dens1 }}$ corresponde a vegetação com densidade dens1; e $\mathrm{IAF}_{\mathrm{dens} 2}$ corresponde a densidade dens2.

A profundidade do sistema radicular foi definida como variando linearmente entre $0,2 \mathrm{~m}$ no plantio, 2,5 m aos 9 anos e 3,5 $\mathrm{m}$ aos 20 anos. $O$ crescimento da vegetação foi determinado a partir de tabelas fornecidas pela empresa, sendo ajustada ao modelo de crescimento molecular (Tabela 2).

Tabela 2. Equações estimadas de crescimento das espécies do horto florestal.

\begin{tabular}{l|cccc}
\hline \multicolumn{5}{c}{ Eq. de ajuste: $\mathbf{h d o m = A} *(\mathbf{1 - e x p}(-\mathbf{a} 0 * \mathbf{I} * \mathbf{1 2}))$, onde A $=\mathbf{I S} /(\mathbf{1 - e x p}(-\mathbf{a} 0 * \mathbf{8 4}))$} \\
\hline \multicolumn{1}{c|}{ Manejo } & Altura (m) & Idade (anos) & IS & $\mathbf{a 0}$ \\
\hline Espécie 1, 3x2 & 26,86 & 5,17 & 32 & 0,0140 \\
Espécie 1, 3x3 & 26,28 & 5,17 & 32 & 0,0112 \\
Espécie 2, 3x2.5 & 17,87 & 3,34 & 30 & 0,0114 \\
Espécie 2, 3x3 & 30,39 & 6,67 & 30 & 0,0400 \\
Espécie 2, 3x3 & 31,68 & 6,67 & 32 & 0,0315 \\
Espécie 3 & 30,28 & 9,42 & 30 & 0,0530 \\
Espécie 4 & 46,55 & 20,35 & 30 & 0,0109 \\
\hline
\end{tabular}

Para a pastagem foi adotado uma profundidade do sistema radicular de $0,30 \mathrm{~m}$; altura de $0,15 \mathrm{~m}$; e IAF de $0,8 \mathrm{~m}^{2} \cdot \mathrm{m}^{-2}$. O IAF foi obtido pela média de valores encontrados na literatura para pastagens com altura entre 10 e 15 cm (Fagundes et al., 1999; Kelliher et al., 1993).

\section{RESULTADOS E DISCUSSÃO}

A fim de obter valores mais representativos da vazão anual média em cada ano de plantio, foi calculada a média dos valores obtidos considerando o início do plantio em cada um dos nove anos do período de simulação. As Figuras 5 e 6 ilustram o impacto hidrológico da mudança de cobertura florestal (de pastagem para plantações de eucalipto) ao longo de uma rotação. São apresentadas as parcelas das perdas (interceptação e evapotranspiração), do escoamento superficial e da vazão (escoamento superficial e escoamento subsuperficial) para a pastagem e para as rotações que apresentaram maior e menor média de vazão anual ao longo da rotação. A fim de facilitar a comparação dos valores de vazão independentemente da área sujeita ao manejo, os valores estão apresentados em mm.ano ${ }^{-1}$, o que corresponde a uma vazão em L.ano-1 ${ }^{-1}$ por unidade de área em $\mathrm{m}^{2}$.

Observa-se que a vazão é bastante reduzida entre o terceiro e quarto ano de plantio, onde ocorrem os maiores valores do IAF. As perdas são predominantemente devido à evapotranspiração da vegetação. A pequena redução observada no escoamento superficial é devido à utilização de valores relativos à floresta esparsa e solo com baixa capacidade de 
CAVAlCANTE, R. B. L.; MENDES, C. A. B. Modelagem do balanço hídrico em povoamentos de eucalipto sob diferentes manejos como auxílio ao gerenciamento do impacto hidrológico da atividade. Ambi-Agua, Taubaté, v. 7, n. 1, p. 268-280, 2012. (http://dx.doi.org/10.4136/ambi-agua.810)

infiltração. Após este período, a vazão anual aumenta, variando pouco após o sexto ano. Na análise do balanço hídrico mensal, observou-se também que a redução da vazão nos períodos secos foi tão significativa quanto à redução na estação chuvosa.
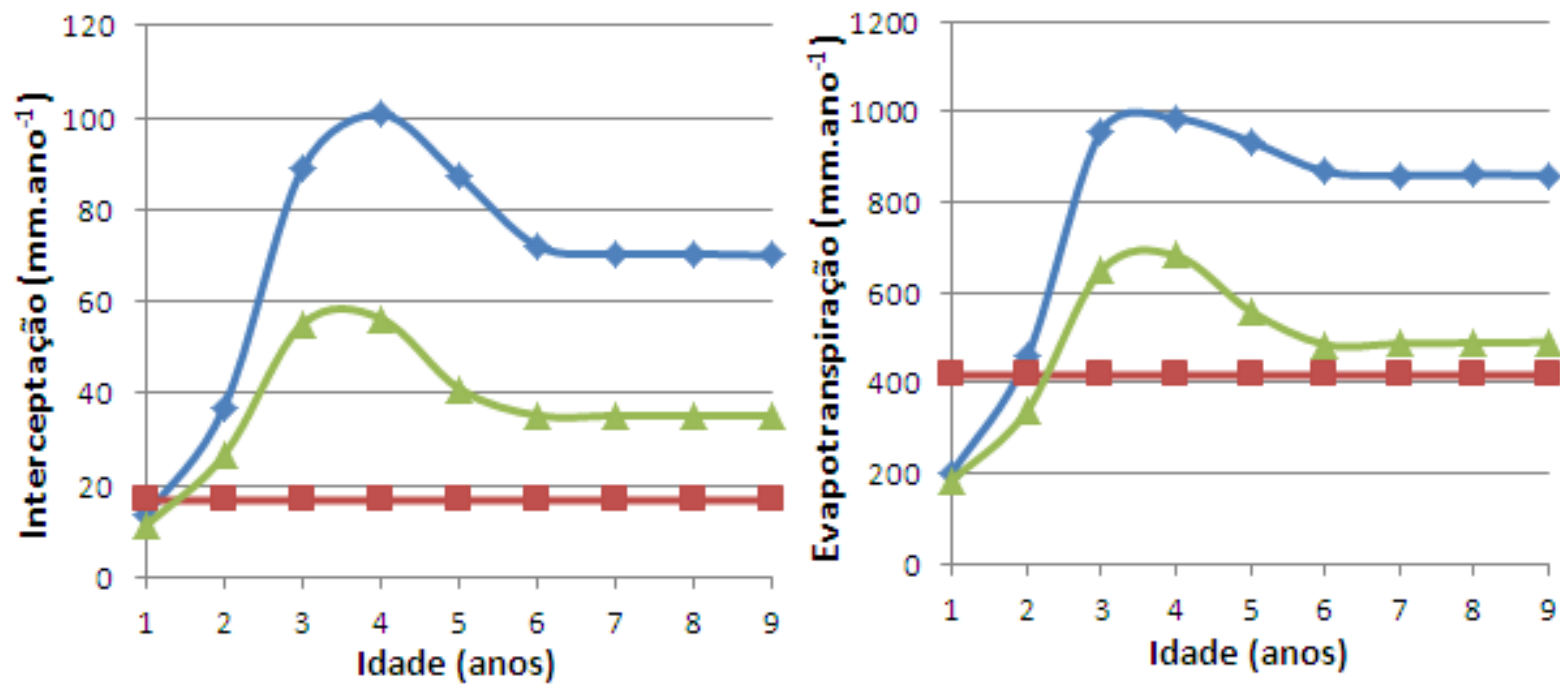

—Espécie 2,1666 árv/ha, IS 32, rebrota

Pasto

Espécie 1, 1111 árv/ha, IS 32, reforma

Figura 5. Interceptação e evapotranspiração anual para o pasto (vermelho) e para as rotações com maior (verde) e menor (azul) vazão média anual ao longo da rotação.
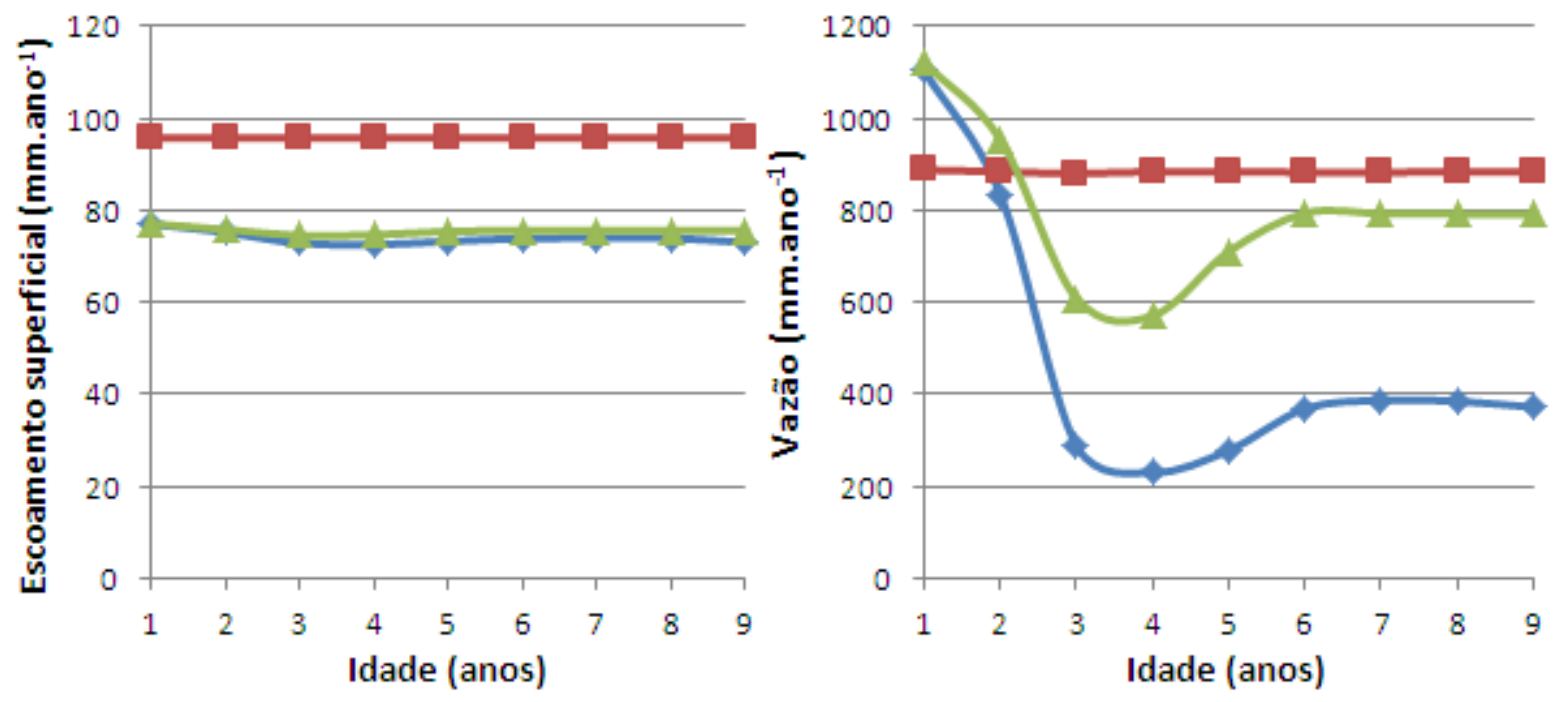

—Espécie 2,1666 árv/ha, IS 32, rebrota

Pasto

_-Espécie 1,1111 árv/ha, IS 32, reforma

Figura 6. Escoamento superficial e vazão anual para o pasto (vermelho) e para as rotações com maior (verde) e menor (azul) vazão média anual ao longo da rotação.

A escolha da espécie apareceu como o principal fator determinante do impacto hidrológico (Figura 7). Dentre as espécies, a que apresentou menor redução de vazão média foi o material genético 1 , com coeficientes de vazão anual $(\mathrm{Q} / \mathrm{P})$ variando entre 0,55 e 0,60 . A menor vazão média ao longo da rotação ocorre para o material 2 que apresenta coeficiente de vazão anual entre 0,36 e 0,50 . 
CAVAlCANTE, R. B. L.; MENDES, C. A. B. Modelagem do balanço hídrico em povoamentos de eucalipto sob diferentes manejos como auxílio ao gerenciamento do impacto hidrológico da atividade. Ambi-Agua, Taubaté, v. 7, n. 1, p. 268-280, 2012. (http://dx.doi.org/10.4136/ambi-agua.810)

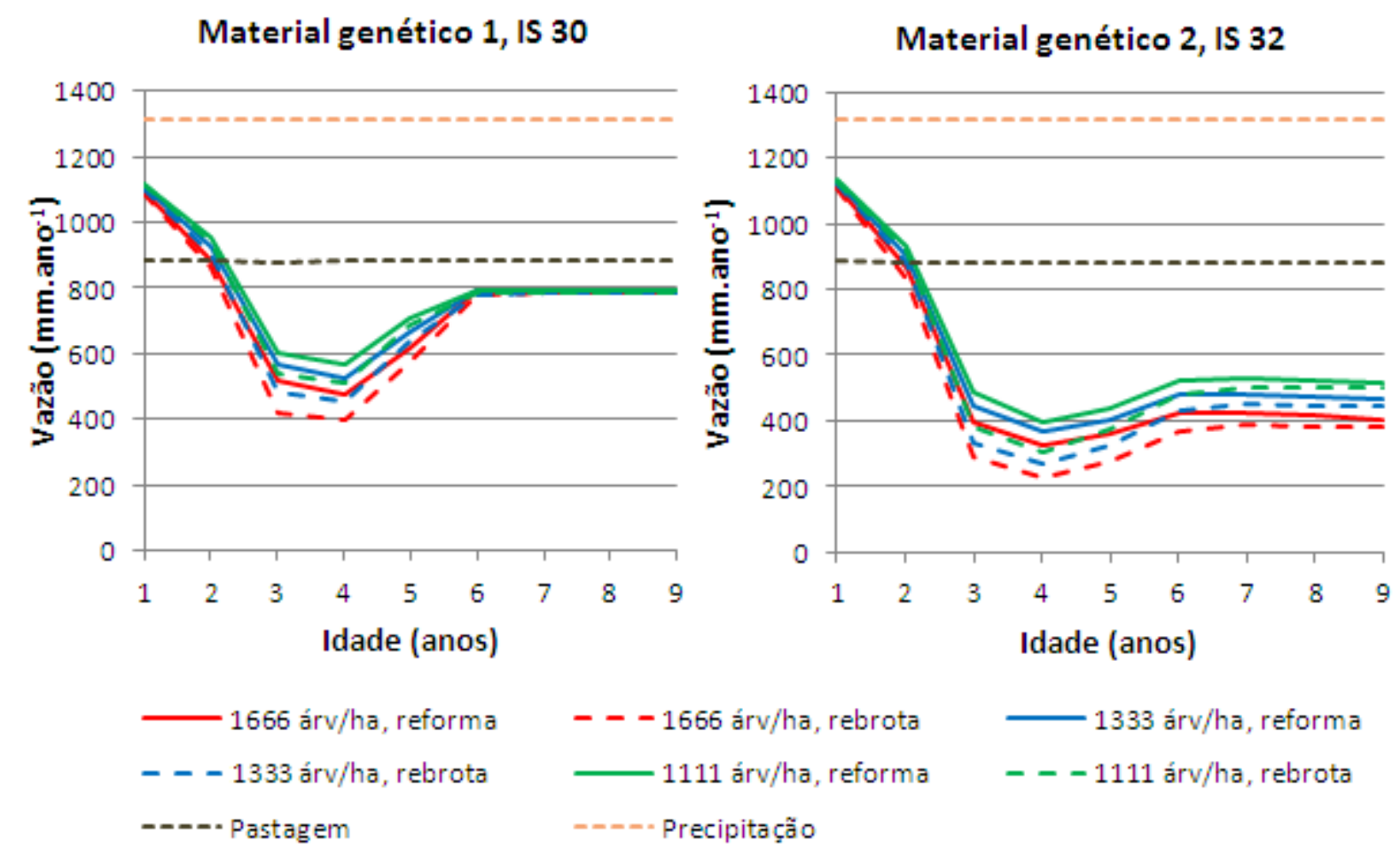

Figura 7. Vazões anuais obtidas para o material $2, I S=32$, sob diferentes condições de manejo ao longo do período de rotação.

Como esperado, para estes e os demais manejos, a vazão por unidade de área resultante para as plantações de eucalipto aumenta com a redução da densidade do plantio (aumento o espaçamento entre as árvores), devido à diminuição do IAF (Allen at al., 2006; Leite et al., 1999).

Verifica-se também que, mantendo-se as demais variáveis de manejo constantes, a vazão foi menor nas áreas de rebrota que nas áreas de reforma. Isto ocorreu em decorrência da maior profundidade do sistema radicular da plantação sob o regime de rebrota. Com mais água disponível, as perdas por evapotranspiração são maiores neste sistema, tornando a vazão menor.

$\mathrm{O}$ ano de menor vazão durante a rotação foi o quarto ano para todos os regimes de manejo considerados, indicando que esta se trata de uma idade crítica a ser considerada no planejamento dos povoamentos de eucalipto. Como consequência, trata-se de um dos principais períodos para análise do impacto hidrológico da bacia. Após este período o crescimento das árvores e o IAF diminuem, e a vazão anual começa a aumentar. Dessa forma, rotações mais longas tendem a ter um menor impacto hidrológico por rotação.

A vazão máxima obtida neste ano foi de $570,6 \mathrm{~mm}$ para o material genético 1 , densidade de 1111 árv.ha $^{-1}$, IS 32 e sistema de reforma. A vazão mínima neste ano foi obtida para o material genético 2, densidade de 1666 árv.ha $^{-1}$, IS 32 e sistema de rebrota e correspondeu a 229,4 mm.ano ${ }^{-1}$ (cerca de $40 \%$ menor que a máxima), ou seja, 654,2 mm.ano ${ }^{-1}$ a menos que para a situação de pastagem. A vazão média ao longo da rotação obtida pelos diferentes manejos variou de $493 \mathrm{~mm}$.ano ${ }^{-1}$ a $792 \mathrm{~mm}$. ano ${ }^{-1}$.

Outro valor importante a ser analisado é a vazão a partir do sexto ano de idade e a sua diferença em relação à vazão mínima, visto que a vazão anual pouco varia neste período. Em um manejo onde ocorre um significativo aumento de vazão anual do quarto ao sexto ano, a importância de se adotar rotações mais longas a fim de se reduzir o impacto hidrológico total é ainda maior. Critérios de manutenção da vazão podem, portanto, ser associados a critérios 
econômicos objetivando a obtenção de manejos que tenham menor impacto hidrológico sobre a bacia.

Observa-se que os resultados obtidos para vazão anual refletem bem o comportamento do IAF estimado para cada manejo. A Figura 8 apresenta esta relação, onde fica evidente a importância do IAF como descritor do dossel florestal no modelo utilizado. Para fins de comparação, para a pastagem foi definido um IAF de 0,8 e obtida uma vazão estimada de cerca de $883 \mathrm{~mm}$. ano $^{-1}$.

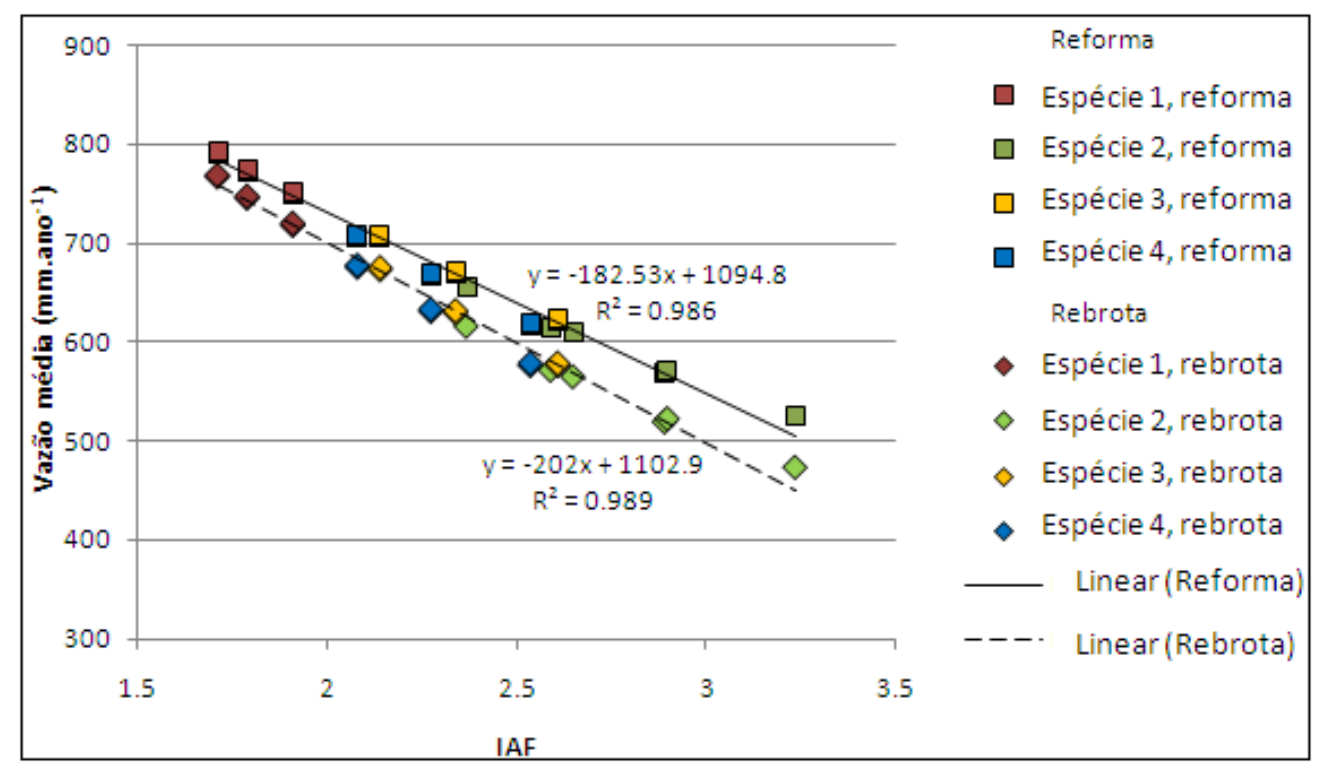

Figura 8. Relação entre IAF médio e vazão média (mm.ano-1) ao longo da rotação para cada espécie e tipo de condução adotado.

Esta influência do IAF na vazão também é apontada na literatura onde o IAF apresentase como uma importante característica da vegetação a ser utilizada em modelos hidrológicos devido a sua influência nos processos de transpiração e interceptação (Soares e Almeida, 2001; Van Dick e Bruijnzeel, 2001; Collischonn et al., 2007). O IAF é também uma das variáveis mais apontadas para explicar a variação na vazão da bacia ao longo do período de rotação devido a sua grande variabilidade com a idade da árvore do povoamento (Cornish e Vertessy, 2001; Almeida et al., 2007), conforme foi verificado neste trabalho.

\section{CONCLUSÃO}

O modelo utilizado apresentou diferença significativa das estimativas dos componentes do balanço hídrico obtidos para os diferentes manejos, o que ressalta que o impacto hidrológico de uma plantação de eucalipto pode ser fortemente dependente do manejo da área, conforme indicado na literatura. Também evidencia a necessidade da integração do gerenciamento dos recursos florestais com os recursos hídricos e de adoção da bacia hidrográfica como unidade de planejamento. Para tanto, é necessário o monitoramento dos aspectos hidrológicos para que se possa avaliar as práticas de manejo que menos impactam o balanço hídrico da bacia.

Para a área de estudo, o IAF apresentou-se como um importante descritor do dossel florestal estando diretamente relacionado com a produção de água pela bacia. Sua medição poderia, então, ser adicionada aos inventários florestais a fim de melhor analisar o impacto hidrológico. Medições de profundidade do sistema radicular também são importantes por definirem a quantidade de água disponível a evapotranspiração das plantas. 
Os resultados obtidos pelo modelo de balanço hídrico apontam para a possibilidade de uma grande variação no impacto ambiental da implantação de um povoamento de eucalipto dependendo do manejo adotado na área. Dessa forma, as políticas que visem reduzir este impacto devem considerar as diferenças entre manejos.

\section{AGRADECIMENTOS}

Agradecemos ao CNPQ pela concessão da bolsa de mestrado ao primeiro autor e à CMPC-Celulose Riograndense pela disponibilização de dados.

\section{REFERÊNCIAS}

Associação Brasileira de Produtores de Floresta Plantada - ABRAF. Anuário estatístico da ABRAF: ano base 2008. Brasília, 2009. [online] Disponível em: <www.abraflor.org.br/ estatisticas.asp>. Acesso em 20/12/09.

ANDRÉASSIAN, V. Water and forests: from historical controversy to scientific debate. Journal of Hidrology, Amsterdam, v. 291, n. 1/2, p. 1-27, 2004.

http://dx.doi.org/10.1016/j.jhydrol.2003.12.015

ALLEN, R. G.; PEREIRA, L. S.; RAES, D.; SMITH, M. Evapotranspiración del cultivo guias para la determinación de los requerimientos de água de los cultivos. Roma: FAO, 2006. Disponível em: <http://www.fao.org/docrep/009/x0490s/x0490s00.htm>. Acesso em: 26 abr. 2012.

ALMEIDA, A. C.; SOARES, J. V.; LANDSBERG, J. L.; REZENDE, G. D. Growth and water balance of Eucalyptus grandis hybrid plantations in Brazil during a rotation for pulp production. Forest Ecology and Management, Amsterdam, v. 251, n. 1/2, p. 1021, 2007. http://dx.doi.org/10.1016/j.foreco.2007.06.009

ALMEIDA, A. C.; SOARES, J. V.; LANDSBERG, J. L.; REZENDE, G. D. Water use and yields of Eucalyptus grandis hybrids plantations in Brazil during a rotation for pulp production. INPE ePrint: sid.inpe.br/ePrint@80/2006/07.25.19.29, 2006. Disponível em: <http://mtc-m18.sid.inpe.br/col/sid.inpe.br/ePrint@80/2006/07.25.19.29/doc/ v1.pdf $>$. Acesso em: 26 abr. 2012.

ALMEIDA, A. C.; SOARES, J. V. Comparação entre uso de água em plantações de Eucalyptus grandis e floresta ombrófila densa (Mata Atlântica) na costa leste do Brasil. Revista Árvore, Viçosa-MG, v. 27, n. 2, p.159-170, 2003.

BATISTA, J. L. F.; COUTO, H. T. Z. do. Escolha dos modelos matemáticos para a construção de curvas de índice de sítio para florestas implantadas de Eucalyptus sp no estado de São Paulo. IPEF, Piracicaba, n.32, p.33-42, abr.1986.

BERGAMASCHI, H.; GUADAGNIN, M. R.; CARDOSO, L. S.; SILVA, M. I. G. da. Clima da Estação Experimental da UFRGS (e Região de Abrangência). Porto Alegre: UFRGS, 2003.

BINKOWSKI, P. Conflitos ambientais e significados sociais em torno da expansão da silvicultura do eucalipto na "metade sul" do Rio Grande do Sul. Dissertação (Mestrado em Desenvolvimento Rural) - Pós-graduação em Desenvolvimento Rural Universidade Federal do Rio Grande do Sul, Porto Alegre, 2009. 
BRAGA, F. A.; BARROS, N. F.; SOUZA, A. L.; COSTA, L. M. Características ambientais determinantes da capacidade produtiva de sítios cultivados com eucalipto. Revista Brasileira de Ciência do Solo, Viçosa-MG, 23, p. 291-298, 1999.

BROWN, A. E.; ZHANG, L.; MCMAHON, T. A.; WESTERN, A. W.; VERTESSY, R. A. A review of paired catchment studies for determining changes en water yield resulting from alterations in vegetation. Journal of hydrology, Amsterdam, v. 310, n. 1/4, p. 28 61, 2005. http://dx.doi.org/10.1016/j.jhydrol.2004.12.010

BRUIJNZEEL, L. A. Hydrology of moist tropical forests and effects of conversion: a state of knowledge review. Amsterdam, Free University, 1990. Disponível em: <http:// unesdoc.unesco.org/images/0009/000974/097405eo.pdf>. Acesso em: 26 abr. 2012.

CALDER, I. D. Water use of eucalyptus - a review with special reference to south Índia. Agricultural Water Management, Amsterdam, v.11, n. 1/4, p. 333-342, 1986. http://dx.doi. org/10.1016/0378-3774(86)90049-1

COLLISCHONN, W.; ALLASIA, D.; SILVA, B. C.; TUCCI, C. E. M. The MGB-IPH model for large-scale rainfall-runoff modelling. Journal des Sciences Hydrologiques, Wallingford, v. 52, n. 5, 2007.

CORNISH, P. M.; VERTESSY, R. A. Forest age-induced changes in evapotranspiration and water yield in a eucalypt forest. Journal of Hydrology, Amsterdam, v. 242, n. 1/2, p. 43-63, 2001. http://dx.doi.org/10.1016/S0022-1694(00)00384-X

COSTA, A. M. da; CURI, N.; MENEZES, M. D.; ARAÚJO, E. F. de; MARQUES, J. J. Levantamento detalhado de solos da microbacia hidrográfica do horto florestal Terra Dura (RS) e considerações sobre escalas de mapeamento. Ciência e Agrotecnologia, Lavras, v. 33, n. 5, p. 1272-1279, 2009.

DINGMAN, S. L. Physical hydrology. 2nd ed. Upper Saddle River: Prentice Hall, 2002. $568 \mathrm{p}$.

DYE, P. J.; JACOBS, S.; DREW, D. Verification of 3-PG growth and water-use predictions in twelve Eucalyptus plantation stands in Zululand, South Africa. Forest Ecology and Management, Amsterdam, v.193, n. 1/2, p. 197-218, 2004. http://dx.doi.org/10.1016/j.foreco.2004.01.030

FAGUNDES, J. L.; DA SILVA, S. C.; PEDREIRA, C. G. S.; SBRISSIA, A. F.; CARNEVALLI, R. A.; CARVALHO, C. A. B. et al. Índice de área foliar, interceptação luminosa e acúmulo de forragem em pastagens de Cynodon spp. sob diferentes intensidades de pastejo. Scientia Agricola, Piracicaba, v. 56, n. 4, p. 1141-1150, 1999.

KELLIHER, F. M.; LEUNING, R., SCHULZE, E. D. Evaporation and canopy characteristics of coniferous forests and grasslands. Oecologia, Berlim, v. 95, n. 2, p.153-163, 1993.

LEITE, F. P.; BARROS, N. F.; NOVAIS, R. F.; SANS, L. M. A.; FABRES, A. S. Relações hídricas em povoamentos de eucalipto com diferentes densidades populacionais. Revista Brasileira de Ciência do Solo, Viçosa-MG, v. 23, p. 9-16, 1999.

LIMA, W. P. Impacto ambiental do eucalipto. São Paulo: EDUSP, 1993. 301 p.

LIMA, W. P.; ZÁKIA, M. J. B. (Org.). As florestas plantadas e a água: implementando o conceito da microbacia hidrográfica como unidade de planejamento. São Carlos: RiMa, 2006. 226 p. 
RAWLS, W. J.; AHULA, L. R.; BRAKENSIEK, D. L.; SHIRMOHAMMADI, A. Infiltration and soil water movement. In: Maidment, D. Handbook of hydrology. New York: McGraw-Hill, 1993.

RIO GRANDE DO SUL. Secretaria Estadual do Meio Ambiente. Zoneamento ambiental da silvicultura: diretrizes da silvicultura por unidade de paisagem e bacia hidrográfica. Porto Alegre, 2010. Disponível em: <http://www.fepam.rs.gov.br/biblioteca/ silvicultura/V2_ZAS\%20APROVADO\%20CONSOLIDADO\%20CORRIGIDO\%20V18-05-20101.pdf>. Acesso em: nov. de 2010.

SOARES, J. V.; ALMEIDA, A. C. Modeling the water balance and soil water fluxes in a fast growing Eucalyptus plantation in Brazil. Journal of Hydrology, Amsterdam, v. 253, n. 1/4, p.130-147, 2001. http://dx.doi.org/10.1016/S0022-1694(01)00477-2

SUN, G.; ZHUO, C.; LIU, S.; LIU, M.; MCNULTY, S. G.; VOSE, J. M. Watershed evapotranspiration increased due to changes in vegetation composition and structure under a subtropical climate. Journal of the American Water Resources Association. Middleburg, v. 44, n. 5, p. 1164-1175, 2008.

TONINI, H.; SCHNEIDER, P. R.; FINGER, C. A. G. Curvas de índice de sítio para povoamentos clonais de Eucalyptus saligna Smith para a depressão central e serra do sudeste, Rio grande do Sul. Ciência Florestal, Santa Maria, v. 16, n. 1, 2006.

TUCCI, C. E. M. Hidrologia: ciência e aplicação. 3. ed. Porto Alegre: Editora da UFRGS/ABRH, 2004.

TUCCI, C. E. M.; CLARKE, R. T. Impacto das mudanças da cobertura vegetal no escoamento: revisão. In: Anais... I Fórum Geo-Bio-Hidrologia: estudo em vertentes e microbacias hidrográficas. Curitiba, 1998.

VALENTE, F.; DAVID, J. S.; GASH, J. H. C. Modelling interception loss for two sparse eucalypt and pine forests in central Portugal using reformulated Rutter and Gash analytical models. Journal of Hydrology, Amsterdam, v. 190, n. 1/2, p. 141-162, 1997. http://dx.doi.org/10.1016/S0022-1694(96)03066-1

Van DIJK, A. I. J. M.; BRUIJNZEEL, L. A. Modelling rainfall interception by vegetation of variable density using an adapted analytical model. Part 1. Model description. Journal of Hydrology, Amsterdam, v. 247, n. 3/4, p. 230-238, 2001. http://dx.doi.org/10.1016/S0022-1694(01)00392-4

XAVIER, A. C.; SOARES, J. V.; ALMEIDA, A. C. Variação do índice de área foliar em clones de eucalipto ao longo de seu ciclo de crescimento. Revista Árvore, Viçosa-MG, v. 36, n. 4 , p. 421-427, 2002. 